\author{
Universidad Nacional de La Plata \\ Facultad de Humanidades y Ciencias de la Educación \\ Maestría en Escritura y Alfabetización
}

\title{
Los mediadores de lectura de la comunidad y sus estilos
}

Estudio de casos en Biblioteca Solidaria

Tesis presentada para la obtención del grado de magíster en Escritura y Alfabetización

Tesista: Sandra Mosca

Directora Dra. Ana María Margallo

Codirectora: Mag. María Noel Guidali

La Plata, junio de 2020 

[...] el sentido de la transmisión cultural es ayudar a cada uno a no tener miedo de precipitarse en un abismo, al final de la Tierra, aun cuando se sepa que no tiene la forma de un plato. A actuar de tal modo que el mundo esté en pie más allá de la fragilidad de nuestra condición, de las múltiples locuras a las que nos vemos confrontados día tras día en los medios, en la escuela, en el trabajo, en nuestra familia o en nuestros pensamientos. A forjar un arte de vivir.

Michèle PETIT, Leer el mundo 



\section{Agradecimientos}

Mi primer agradecimiento es para los protagonistas de este trabajo: Omar, Cecilia, Rosario y Patricia, quienes tanto me enseñaron sobre la mediación y los mediadores. De ellos aprendí, además, que la solidaridad todavía existe y que el "placer de la lectura» se enseña, en primer lugar, y fundamentalmente, compartiéndolo.

Agradezco muy especialmente a los niños que participaron de esta investigación, de quienes aprendí que cuando se les da la oportunidad de hablar de manera genuina, son capaces de opinar y argumentar con un tino extraordinario.

No olvido en este agradecimiento a las maestras de los grupos investigados que me abrieron las puertas de sus aulas, aun con recelo, a las directoras y demás integrantes del equipo comunitario de lectura de las escuelas en las que realicé la investigación.

Agradezco también a la Dra. Ana María Margallo y a la Mag. María Noel Guidali por acompañarme en este camino, por enseñarme, exigirme y, muy especialmente, por su infinita paciencia para conmigo; a la Maestría en Escritura y Alfabetización de la Universidad Nacional de La Plata y a todo su cuerpo académico por darme la oportunidad de crecer académicamente, y a Gabriela y Andrés por su grata compañía en La Plata, durante los largos periodos de cursada, que hizo más llevadero el estar fuera de casa.

Dedico este trabajo a mis hijos: Pilar, Emiliano y Cecilia, mis tres soles, y a Leo a quien además agradezco y reconozco su esfuerzo y superación, al hacerse cargo de la casa y de los niños durante mis ausencias. 

ÍNDICE

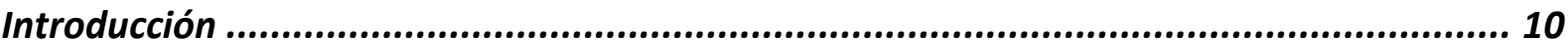

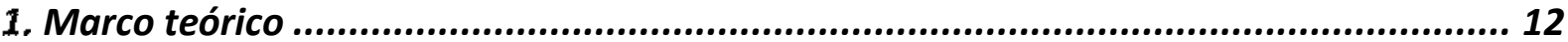

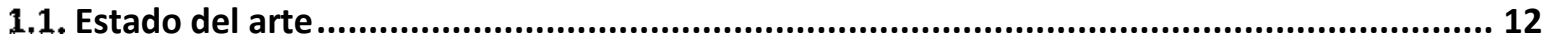

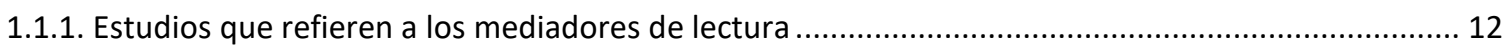

1.1.2. Estudios que refieren a los estilos de enseñanza ........................................................................ 15

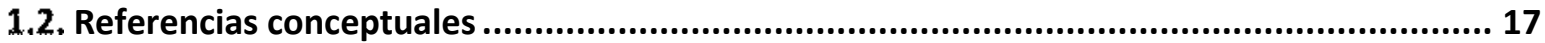

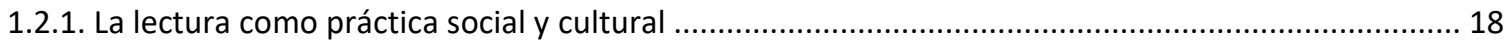

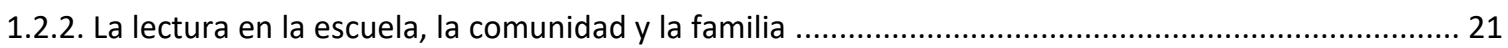

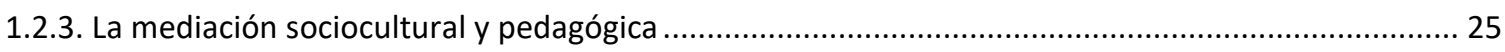

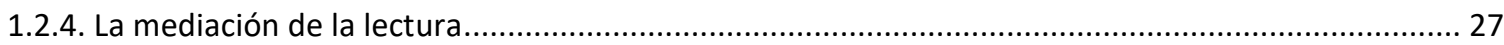

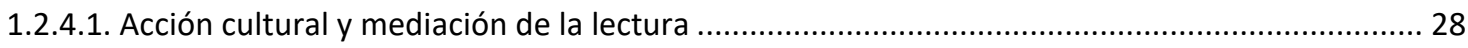

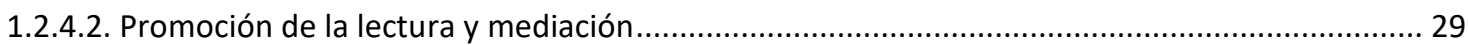

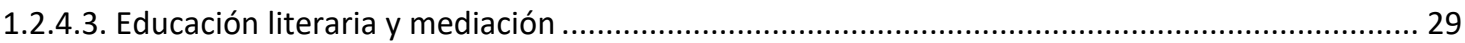

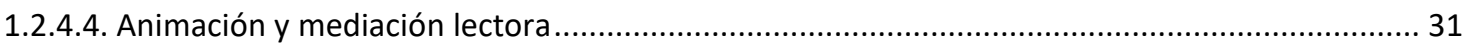

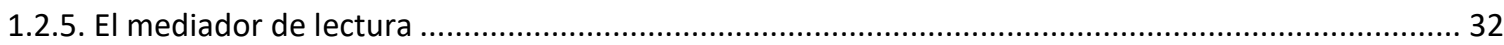

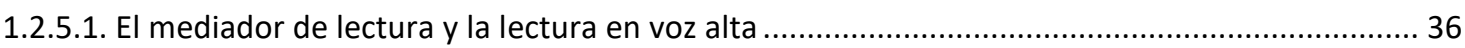

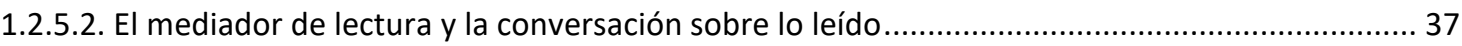

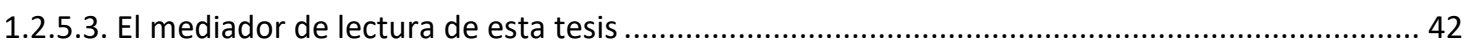

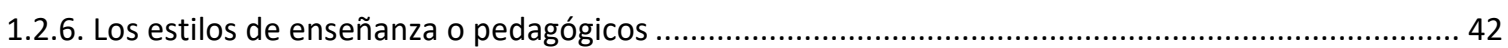

2. Marco metodológico ................................................................................. 49

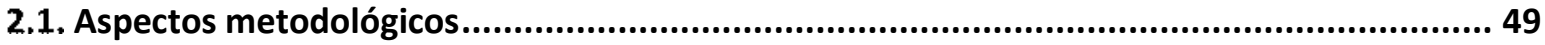

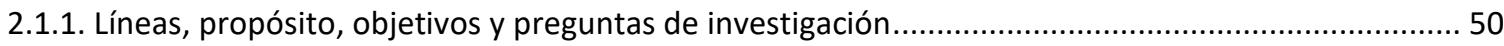

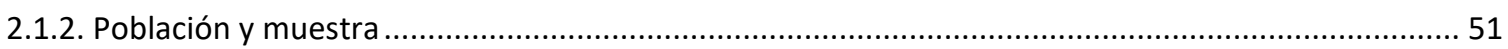

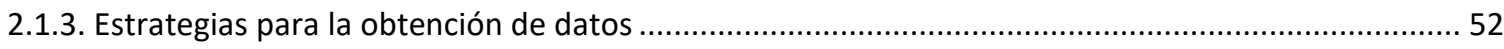

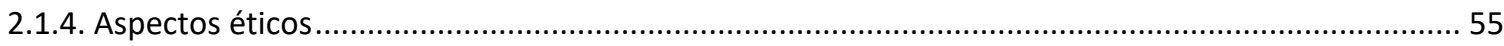

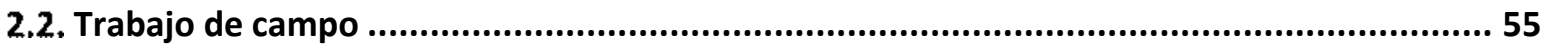

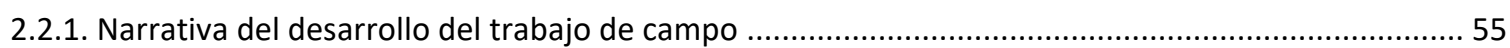

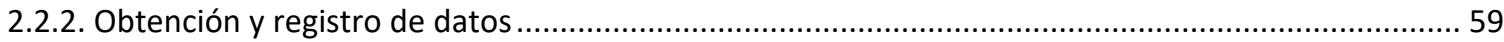

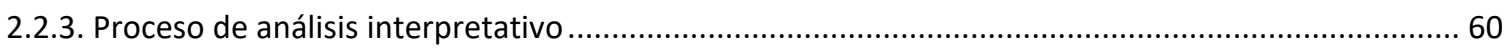

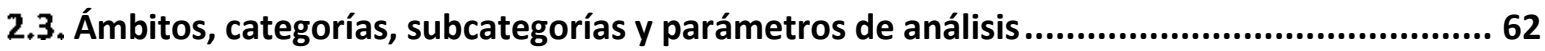

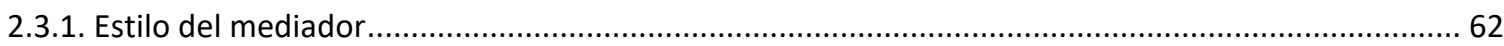

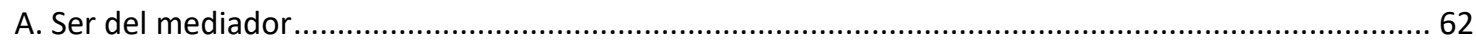

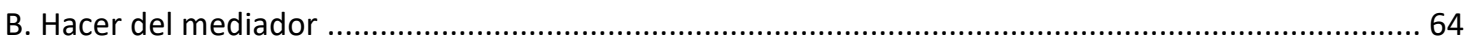

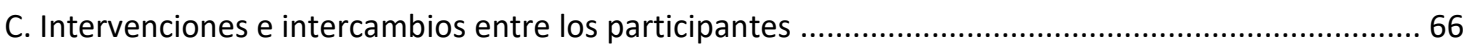

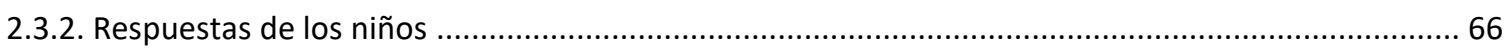

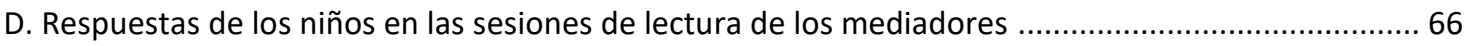

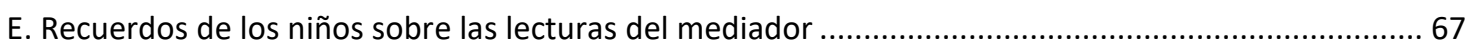

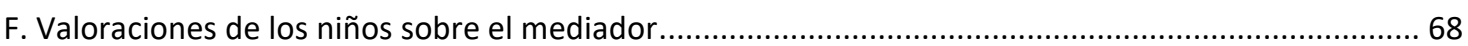

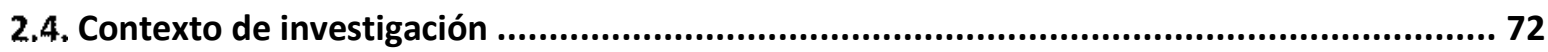

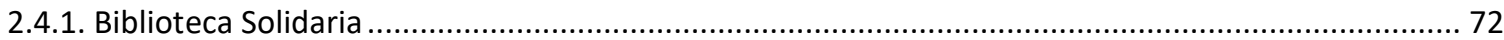

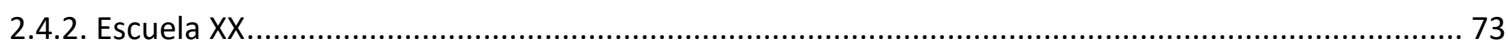

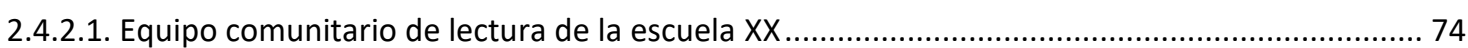

2.4.2.2. Reuniones del equipo comunitario de lectura de la escuela XX .......................................... 74 
2.4.2.3. Clases de la escuela XX que participaron de la investigación ................................................ 75

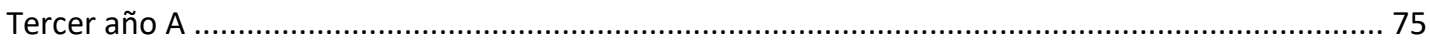

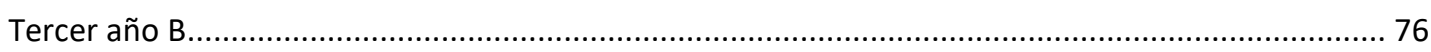

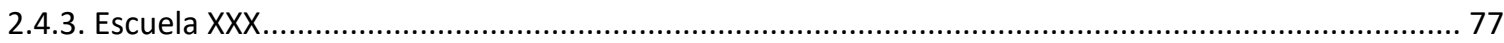

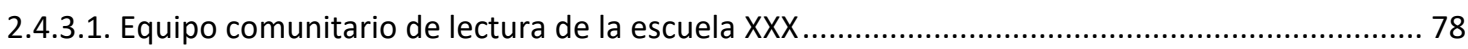

2.4.3.2. Reuniones del equipo comunitario de lectura de la escuela XXX ......................................... 80

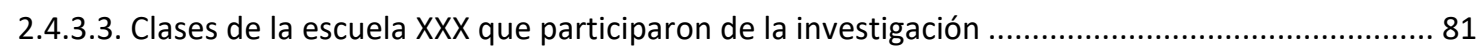

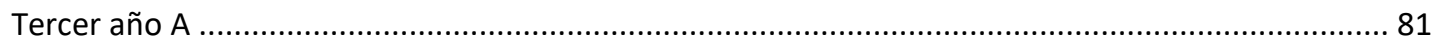

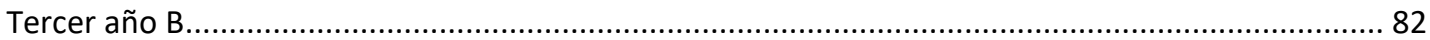

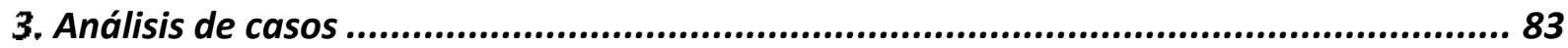

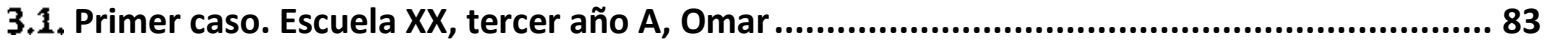

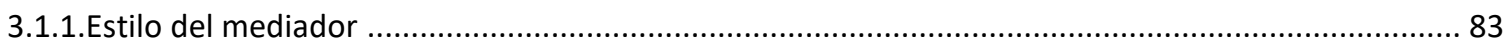

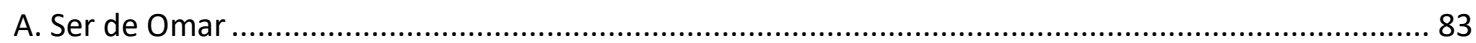

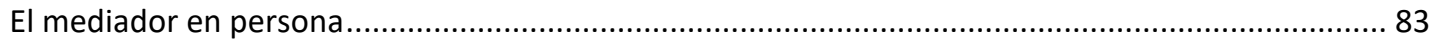

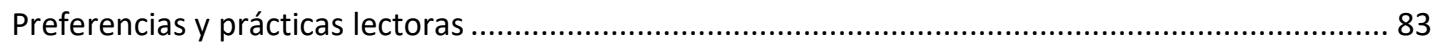

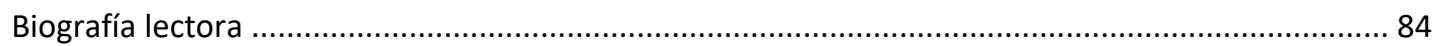

Motivaciones para ejercer el rol de mediador ..................................................................... 84

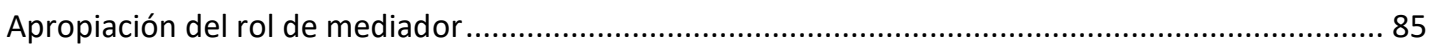

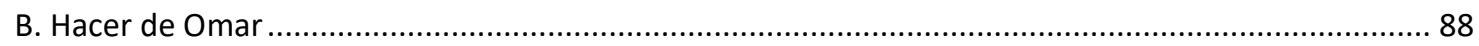

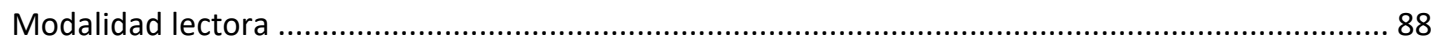

Acciones para organizar el espacio y el tiempo de lectura.......................................................... 89

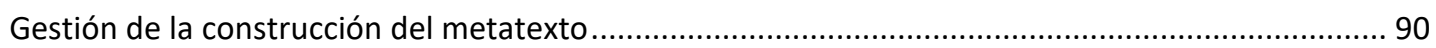

C. Intervenciones e intercambios entre los participantes ................................................................ 94

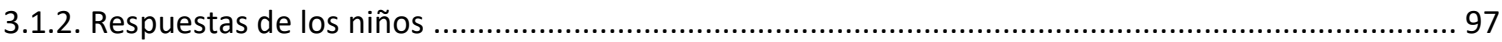

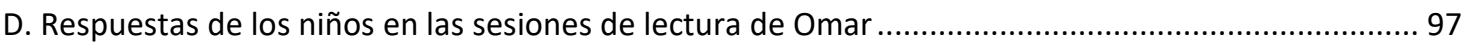

E. Recuerdos de los niños sobre La manta de las historias............................................................... 102

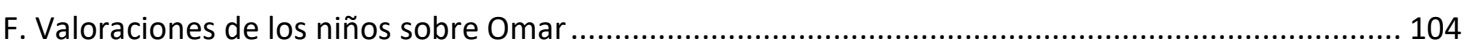

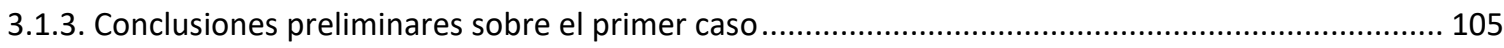

3.2. Segundo caso. Escuela XX, tercer año B, Cecilia ....................................................108

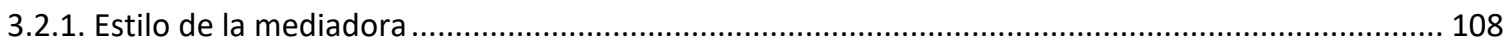

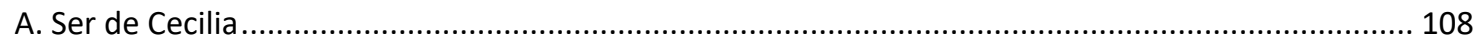

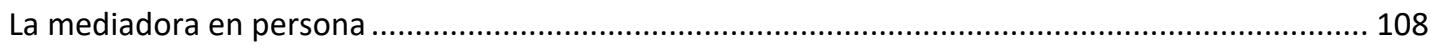

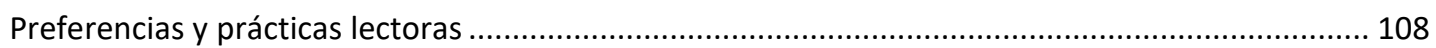

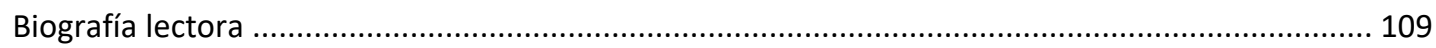

Motivaciones para ejercer el rol de mediadora .................................................................. 109

Apropiación del rol de mediadora ........................................................................................... 110

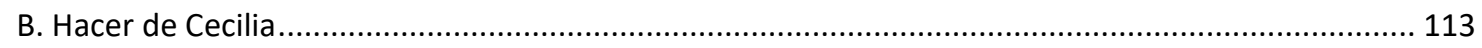

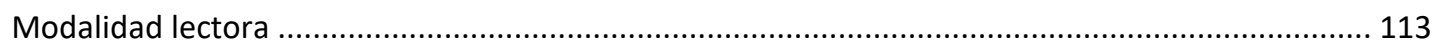

Acciones para organizar el espacio y tiempo de lectura ........................................................ 114

Gestión de la construcción del metatexto ................................................................................. 115

C. Intervenciones e intercambios entre los participantes ............................................................. 117

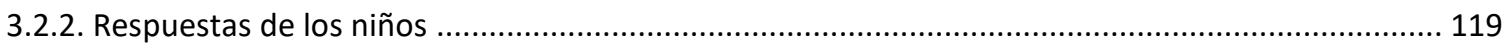

D. Respuestas de los niños en las sesiones de lectura de Cecilia................................................... 119

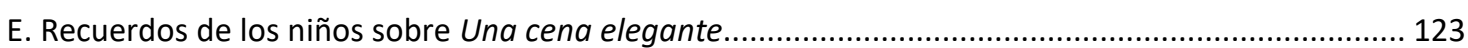

F. Valoraciones de los niños sobre Cecilia.................................................................................. 124

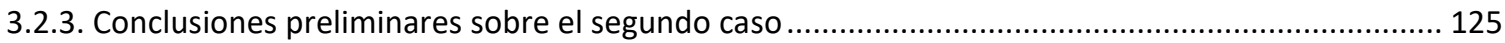




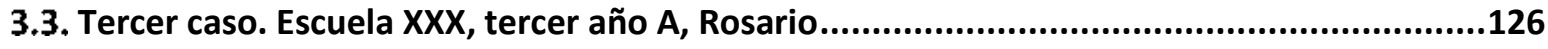

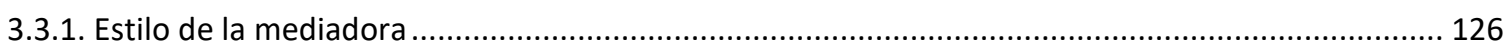

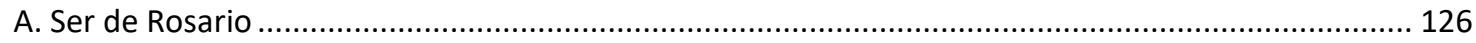

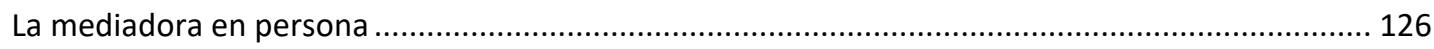

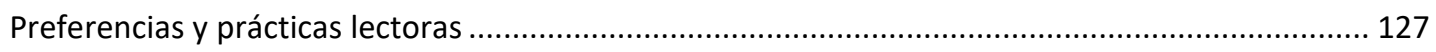

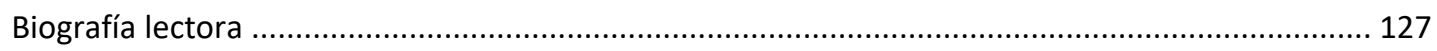

Motivaciones para ejercer el rol de mediadora ................................................................... 128

Apropiación del rol de mediadora ......................................................................................... 129

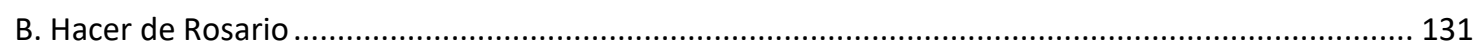

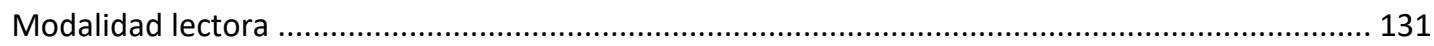

Acciones para organizar el espacio y tiempo de lectura .......................................................... 131

Gestión de la construcción del metatexto................................................................................. 132

C. Intervenciones e intercambios entre los participantes ............................................................. 134

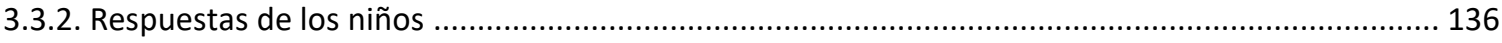

D. Respuestas de los niños en las sesiones de lectura de Rosario ...................................................... 136

E. Recuerdos de los niños sobre La manta de las historias.............................................................. 138

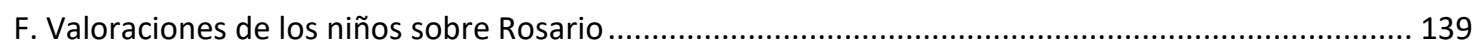

3.3.3. Conclusiones particulares sobre el tercer caso .................................................................... 140

3.4. Cuarto caso. Escuela XXX, tercer año B, Patricia ...................................................142

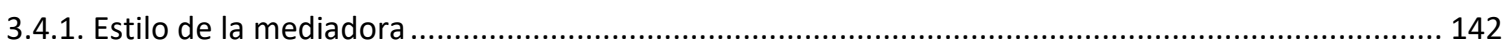

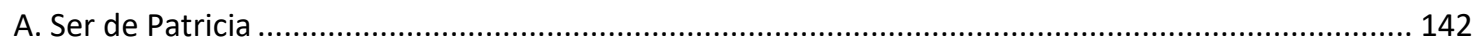

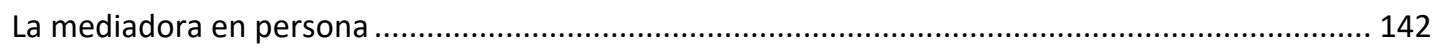

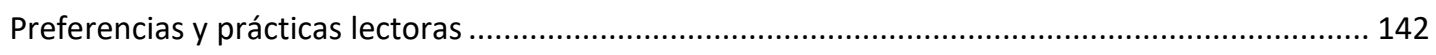

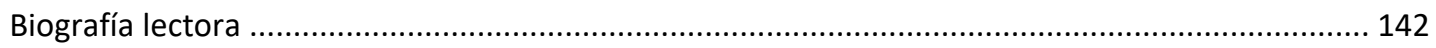

Motivaciones para ejercer el rol de mediadora ....................................................................... 143

Apropiación del rol de mediadora ......................................................................................... 144

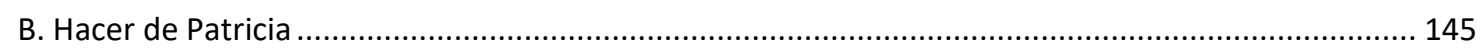

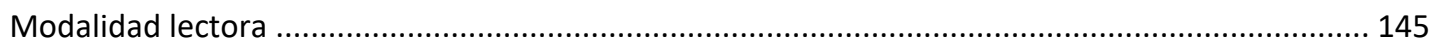

Acciones para organizar el espacio y el tiempo de lectura........................................................... 145

Gestión de la construcción del metatexto................................................................................... 147

C. Intervenciones e intercambios entre los participantes ............................................................... 149

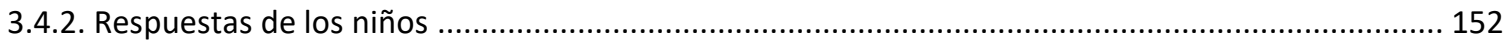

D. Respuestas de los niños en las sesiones de lectura de Patricia ..................................................... 152

E. Recuerdos de los niños sobre Una cena elegante........................................................................... 155

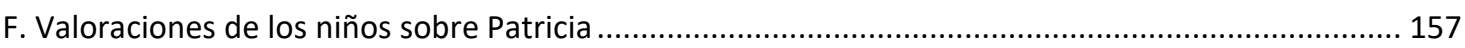

3.4.3. Conclusiones particulares sobre el cuarto caso ................................................................... 157

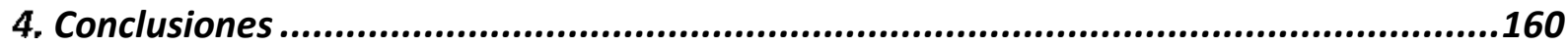

4.1. Comparativa de los cuatro casos investigados..................................................................160

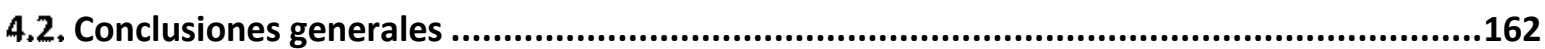

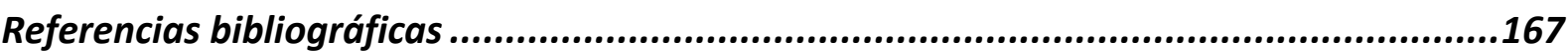




\section{INTRODUCCIÓN}

Tal como lo anuncia el título, esta investigación trata sobre mediadores de lectura de la comunidad que leen a los niños de las escuelas públicas uruguayas. El interés por estudiar a estos actores: familiares, exalumnos, vecinos... tiene sus orígenes - debo confesar - en el recelo que sentí cuando ingresaron a las escuelas. ¿Por qué estas personas querrían, en un mundo de individualidades y urgencias cotidianas, ir a leer a los niños? ¿Qué pueden querer hacer que ya no se esté haciendo? ¿Cómo leerán? ¿Cómo serán recibidos? ¿Tendrán algo que aportar?

Sobre esta preocupación, el primer paso consistió en indagar sobre las experiencias desarrolladas en el ámbito latinoamericano que otorgan protagonismo a los integrantes de la comunidad en torno a la lectura. Fue así como conocí la existencia del proyecto Agentes de Leitura, impulsado por los Ministerios de Educación y de Cultura de Brasil (Instituto Interdisciplinario de Leitura PUC-Rio Cátedra Unesco de Leitura PUC Rio 2013), y de los programas Abuelas Cuentacuentos, promovido por la Fundación Mempo Giardinelli en Argentina (FMG-Abuelas Cuentacuentos s.d), y Cuenta Quien Cuenta, desarrollado en Uruguay (Guidali 2014).

De esta manera, di con una expresión que hasta ese momento era novedosa para mí: mediador de lectura. El segundo paso consistió en asignar a esa expresión una caracterización, un «universo semántico», al decir de Felipe Munita (2014), que me permitiera establecer un punto de partida y señalara el norte hacia el cual dirigir la indagación. En este camino constaté la centralidad que las nociones de mediación y mediador de lectura poseen en muchos proyectos y programas desarrollados en distintos ámbitos: estatales y privados, nacionales o locales, que han dado origen a diversas publicaciones. En muchas de ellas, sin embargo, estas nociones aparecen explicadas con ambigüedad o desde un deber ser, con escaso sustento empírico o teórico. Encontré también, para mi complacencia, una importante cantidad de investigaciones que, aunque no están centradas en la figura del mediador de lectura comunitario, aportan evidencias sobre ellos, e investigaciones que profundizan sobre los docentes como mediadores ( $\rightarrow$ 1.1.1. «Estudios que refieren a los mediadores de lectura»). Estos estudios evidencian la novedad y trascendencia que las nociones señaladas han ido adquiriendo en el campo de los estudios sobre la lectura. Por otra parte, tanto estas investigaciones como la bibliografía relevadas para la construcción del marco teórico destacan la incidencia de los mediadores en la formación de los lectores.

En consecuencia con lo expuesto, y al no haber podido constatar en Uruguay investigaciones centradas en la figura de los mediadores, este estudio intenta profundizar sobre los mediadores de la comunidad que leen a los niños en las escuelas públicas de Uruguay y sus estilos, constituyéndose este en el propósito de este trabajo.

Para concretar la indagación sobre los mediadores de lectura, opté en el marco de este trabajo por la noción de estilo de enseñanza ${ }^{1}$, considerando, al respecto, dos antecedentes. Por una parte, el desarrollo teórico que sugiere Estela Cols ( $\rightarrow$ 1.2.6. «Los estilos de enseñanza o pedagógicos»), por otra, su empleo en la investigación sobre el debate interpretativo, una modalidad de conversación sobre lo leído, que propone Ana Días-Chiaruttini ( $\rightarrow$ 1.1.2. «Estudios que refieren a los estilos de enseñanza»).

\footnotetext{
${ }^{1}$ En la bibliografía relevada las expresiones estilo (o estilos) de enseñanza, estilo pedagógico o estilos de enseñanza pedagógicos son sinónimas.
} 
En el sentido atribuido por Cols, los estilos de enseñanza constituyen configuraciones singulares e inéditas que no están dadas por una sumatoria de rasgos sino por una particular combinación y conexión entre ellos. Esta singular "alquimia" de los estilos de enseñanza es la que permite apreciar a través de una mirada holística la singularidad de cada mediador (2007).

De acuerdo con lo expuesto, la noción de estilos de enseñanza ha sido adoptada en el marco de este trabajo como herramienta teórica para ahondar sobre el ser y el hacer de los mediadores. Esta decisión se fundamenta, por un lado, en la tradición y amplitud de dicha noción, que brinda la oportunidad de hacerla extensiva a la indagación a los mediadores de lectura. Y por otro, en la consideración de su pertinencia para profundizar sobre los sentidos que estos atribuyen a sus acciones, estableciendo lazos entre las diferentes dimensiones que configuran su hacer; entre estas y las biografías lectoras de los actores indagados, y con la manera en que los niños perciben a los mediadores. En esa posibilidad de hacer inteligible un conjunto de elementos que se presentan heterogéneos y aun discordantes reside, justamente, siguiendo a Cols, la potencialidad de la noción de estilo (2007: 341).

Para el diseño de esta investigación, se optó por realizar una investigación sociocultural exploratoria de carácter cualitativo-interpretativa, con la intención de profundizar la comprensión del fenómeno estudiado in situ. Se planteó entonces una investigación observacional-participativa mediante el enfoque del estudio de caso $(\rightarrow$ 2.1. "Aspectos metodológicos»), sin pretensión alguna de generalización de las conclusiones a las que se arriban.

El trabajo que se presenta a continuación se organiza en cuatro partes:

La primera de ellas: el "Marco teórico», se subdivide a la vez en dos secciones: una aporta el estado del arte, que releva los estudios que ofician de antecedente de esta tesis; la otra desarrolla las referencias conceptuales que sustentan teóricamente la investigación realizada.

La segunda está dedicada al «Marco metodológico» $(\rightarrow 2$.) que pretende dar cuenta de la dialéctica del proceso de investigación y de las decisiones metodológicas tomadas; relata el proceso de trabajo de campo, los procedimientos seguidos para la obtención, registro de los datos y los criterios adoptados para su análisis. Brinda además información sobre el contexto en el que se desarrolló la investigación.

En la tercera parte: «Análisis de casos» $(\rightarrow 3$.) se presenta el resultado del análisis, organizado según los casos de estudio. Al cierre de cada caso, se exponen las conclusiones particulares sobre cada uno de ellos, en las que se intentará relacionar los aspectos analizados.

La cuarta y última parte expone las «Conclusiones» $(\rightarrow 4$.) de esta investigación, organizada en dos secciones: la primera dedicada a comparar los cuatro casos investigados y la segunda, a establecer las conclusiones generales. 


\section{MARCO TEÓRICO}

Esta primera parte se organiza en dos secciones: el «Estado del arte», en la que se releva aquellos estudios que ofician como antecedentes de esta tesis, y las «Referencias conceptuales» en la cual se desarrollan las nociones que sustentan teóricamente la investigación realizada.

\subsection{Estado del arte}

A la vez, el relevamiento en esta sección se organiza en dos apartados, y en cada uno de ellos las investigaciones se presentan en orden cronológico. En el primero, se compilan las investigaciones que reportan hallazgos significativos acerca de los mediadores de lectura, tanto docentes como de la comunidad, aunque algunos de estos trabajos no se centren específicamente en la figura del mediador. En el segundo, se describen los estudios sobre los estilos de enseñanza, que aportan a la construcción de la perspectiva epistemológica o al objeto de estudio de esta investigación.

\subsubsection{Estudios que refieren a los mediadores de lectura}

Lectura, escritura y desarrollo en la sociedad de la información es el título de la investigación dirigida por Jesús Martín-Barbero y coordinada por Gemma Lluch (2010)². Este estudio se centra en las políticas públicas desarrolladas en torno a la lectura y escritura como prácticas culturales en siete países: Argentina, Brasil, Colombia, Chile, España, México y Portugal. Entre sus objetivos se encuentran: formular líneas de trabajo para implementar proyectos de formación de lectores y escritores desde la perspectiva del desarrollo social; orientar políticas que transformen la lectura y la escritura en un espacio de aprendizaje solidario, culturalmente abierto y tolerante, y construir indicadores sobre el impacto de la lectura y la escritura en los participantes de las experiencias investigadas. La investigación analiza nueve experiencias ${ }^{3}$ innovadoras que incluyen la lectura, la escritura y el acceso a nuevas tecnologías. Entre otros aspectos, se indagó a los mediadores de lectura con perfil profesional, a quienes el proyecto define como actores y agentes de las experiencias de lectura. Desde un punto de vista interpretativo, del estudio emerge el protagonismo del mediador como orientador y la importancia de su contribución para madurar y transformar una práctica en una experiencia de lectura ${ }^{4}$. Da cuenta de la importancia del intercambio de ideas, conocimientos, metodologías con otros mediadores como parte constitutiva de la formación y del aprendizaje del rol. Reporta además la transformación de la mirada de los mediadores hacia su trabajo, hacia la lectura y hacia los grupos con los que interactúa con la reflexión sobre su hacer.

\footnotetext{
2 Esta investigación fue encargada por la CERLALC (Centro Regional para el Fomento del Libro en América Latina y el Caribe) y la AECID (Agencia Española de Cooperación Internacional para el Desarrollo).

${ }^{3}$ En este estudio, se diferencian las actividades de las experiencias de lectura. Mientras que la primera expresión denomina a aquellas prácticas, concretas, aisladas y sin continuidad temporal, por ejemplo, el Día del Libro, la segunda se reserva para aquellas otras prácticas que se caracterizan por constituirse en una experiencia vital para los sujetos implicados en ella, por su éxito, solidez y duración temporal, por dar visibilidad a los actores sociales, territorios y culturas y por una explícita utilidad del conocimiento que adquiere la comunidad (Martín-Barbero y Lluch 2011: 50-51).

${ }^{4}$ Estas experiencias son aquellas que por su propia definición tienen un fuerte anclaje en la comunidad, que entre sus objetivos se encuentra la necesidad de fortalecer el compromiso y el sentido de pertenencia (Martín-Barbero y Lluch 2011:110).
} 
La perseverancia, el compromiso y la permanencia en el rol surgen también como factores que inciden en el éxito de las experiencias que llevan a cabo.

El estudio revela, asimismo, cómo las experiencias de lectura mediada mejoran la convivencia en los grupos sociales involucrados e inciden en la construcción de las identidades de sus integrantes, quienes logran trascender lo cotidiano, construir expectativas de futuro, afianzar su autoestima, su capacidad creativa y acrecentar su capital cultural.

Desde un punto de vista prescriptivo, la investigación establece las funciones que los mediadores deben cumplir, cuál debe ser su perfil: actitud culturalmente abierta, compromiso social, perseverancia y continuidad en su rol; capacidad de liderazgo..., y qué características debe asumir su formación.

La tesis doctoral de Mery Cruz Calvo (Universidad de Barcelona), Lectura literaria en secundaria: Ia mediación de los docentes en la concreción de los repertorios lectores, dirigida por Antonio Mendoza Fillola (2013), tiene por propósito examinar en los discursos de los docentes sus interpretaciones sobre las estrategias que utilizan para enseñar literatura, en contraste con las valoraciones de los estudiantes sobre la lectura de obras literarias narrativas. Entre los objetivos de este estudio, que se llevó a cabo en un grupo de seis docentes de literatura del nivel secundario de la ciudad de Cali, Colombia, se encuentra el de determinar el papel del docente como mediador de lectura y su impacto sobre los repertorios lectores de sus estudiantes. Con respecto a este punto, la investigación concluye en que la mediación docente es determinante en el desarrollo de la capacidad receptora de los estudiantes en cuanto dinamiza y contextualiza los repertorios lectores, especialmente el de las obras clásicas.

María Noel Guidali (Universidad Nacional de La Plata), en su tesis de maestría: Incidencia de un programa de alfabetización familiar: evaluación de actitudes y conocimientos sobre el mundo letrado en niños de sectores populares, dirigida por Ana María Kaufman (2014), investigó por una parte, la incidencia del programa de alfabetización familiar cac (Cuenta Quien Cuenta)5, en la inclusión de los niños de las familias participantes en el mundo letrado, y por otro, los conocimientos que estos niños poseen sobre el lenguaje escrito al ingresar a primer año de escuela. Con relación a los participantes de CQC, quienes se forman como mediadores de lectura de sus familias, la investigación concluyó que todos ellos revalorizaron la lectura como una práctica cultural importante a ser desarrollada en sus hogares y generaron nuevos escenarios y momentos para leer a sus niños. Esta revalorización constituye el factor que desencadenó que estos referentes familiares desarrollaran nuevas actitudes y comportamientos que redundaron en la relación que los niños establecieron con el lenguaje escrito. Al respecto, el estudio constató un aumento en la frecuencia con que los participantes de cac leen a sus niños; el incremento en la disponibilidad de materiales de lectura en sus hogares; la diversificación de las actividades de apoyo a los aprendizajes de sus niños y la disminución de las restricciones que tenían para leerles. El estudio evidencia además que en los hogares de los participantes de cac la lectura estrechó los vínculos familiares en torno a esta práctica y que brindó a los referentes la oportunidad de reflexionar sobre su vida cotidiana, a partir de la lectura de cuentos. La investigación de Guidali es pionera en Uruguay en cuanto refiere a la mediación de la lectura.

Felipe Munita, en su tesis doctoral El mediador escolar de lectura literaria. Un estudio del espacio de encuentro entre prácticas didácticas, sistemas de creencias y trayectorias personales de lectura,

${ }^{5}$ El programa CQC se inició en 2006 el departamento de Paysandú, pero posteriormente se extendió a otros departamentos del país (Naciones Unidas, CEPAL: en línea). 
dirigida por Teresa Colomer (2014), tuvo por propósito el análisis en profundidad de la figura del docente como mediador escolar de lectura literaria, con la intención de comprender cómo se construye la identidad docente en este ámbito. La elección de esta expresión para designar a los sujetos que investiga remite, en primer lugar, al rol que asume el docente como mediador de lectura; en segundo lugar, al ámbito en el que desarrolla su función (la educación formal) y, en tercer lugar, a su acción en el campo de la formación lectora de sus alumnos. Sobre esta definición inscribe entre sus funciones, a un mismo nivel tanto el enseñar los saberes disciplinares propios de la literatura como el compartir las distintas facetas de su comportamiento lector con sus estudiantes.

El estudio se realizó mediante la metodología cualitativa del estudio de caso y la indagación se centró sobre lo que piensan y hacen los docentes como mediadores de lectura literaria. Con respecto a ello, la investigación concluyó en la importancia de la figura del mediador en la formación lectora de las personas; la influencia de la propia formación que como lector posee el docente; el cuestionamiento al preconcepto de que si se es un buen lector también se es un buen mediador - pues no siempre la experiencia lectora se extrapola a la mediación- y la fuerte relación entre el sistema de creencias y las prácticas didácticas, sobre todo con aquellas que son compartidas por los equipos docentes.

En su investigación Los usos sociales de la lectura: del modo tradicional a otras formas colectivas de leer, Carmen Pérez Camacho y Andrés López Ojeda (2015: 39-104) analizaron, desde una perspectiva etnográfica, las prácticas lectoras de los usuarios de programas, proyectos y acciones de lectura desarrolladas en ámbitos no normativos (en contraposición a las prácticas normativas desarrolladas en las aulas), es decir, menos formalmente organizados y en espacios no convencionales: parques, hospitales..., con mayor antigüedad y trayectoria de la Ciudad de México. Los investigadores indagaron a los agentes intermediarios de lectura que tipificaron como proveedores -que proporcionan las condiciones de acceso a la lectura: infraestructura, acervos, difusión, información como parte de sus atribuciones -; cómplices - personas que cooperan en la promoción de la lectura de una manera creativa, en redes sociales digitales y con un sentido de camaradería-, y mediadores - participantes ciudadanos que promueven la lectura y vinculan las acciones del gobierno con los intereses de los lectores-, estos últimos como responsable de centros de lectura. Con respecto a los mediadores, el estudio constató:

- la valoración de sí mismos y la obtención de prestigio social de quienes desempeñan el rol; la «intensidad» (2015: 68) que adquieren los vínculos entre los mediadores y su público, y el reconocimiento de las cualidades personales de los primeros: desprendimiento, capacidades lectoras, entre otras, por parte de los segundos;

- el tono mesiánico «de rescate, mejoramiento, reconciliación y tono moral» (2015: 67) en los discursos del mediador cuando se refiere a su labor;

- su incidencia, especialmente en aquellas comunidades con mayor problemática social y económica, en la creación del sentido de solidaridad y servicio a la comunidad; de cohesión colectiva y comunitaria, y su influjo en la creación de relaciones de confianza y vínculos personales;

- que las prácticas de lectura mediada dependen en gran medida del perfil del mediador y de los entornos en que las desarrollan. Asimismo, que los diversos modos de leer que aquellos promueven producen distintos perfiles de lectores y viceversa; 
- la influencia de los mediadores en la creación del sentido social de la lectura en las comunidades en las que actúan, en las prácticas de lectura que impulsan, en los modos de leer y la significación que los involucrados atribuye a dichas prácticas.

\subsubsection{Estudios que refieren a los estilos de enseñanza}

La tesis de doctorado de Estela Cols: Estilos de enseñanza. Sentidos personales y configuraciones de acción, tras la semejanza de la palabra, dirigido por Lidia Fernández (2007), asume el estudio de los estilos de enseñanza ( $\rightarrow$ 1.2.6.) desde la complejidad e interrelación de sus componentes, desde una perspectiva interpretativa y relacional.

Esta investigación, que se desarrolló sobre la metodología de estudio de caso, a diferencia de otras que le precedieron y que le sucedieron, no partió de categorías de análisis obvias o prestablecidas ni derivó categorías de estilos posteriores al análisis; en este sentido, y por la perspectiva heurística asumida por Cols, constituye un antecedente valioso para la investigación que aquí se presenta.

El propósito de la investigación fue describir los estilos de enseñanza de los docentes en relación con los marcos simbólicos compartidos, establecidos por los modelos de enseñanza, por una parte, y las experiencias biográficas del sujeto, reconstruidas a partir de su relato autobiográfico, por otro. La indagación se planificó en dos instancias: en la primera se apuntó a identificar y definir las concepciones modélicas de enseñanza de un grupo de docentes a partir de entrevistas; en la segunda, a analizar en profundidad las prácticas de aula de dos maestras a quienes se entrevistó también en profundidad.

El estudio señala la potencialidad del binomio modelo-estilo como herramienta de análisis: «[...] los sujetos interpretan su práctica y construyen sus modelos personales de entender la enseñanza en el marco de estas referencias. Pero interpretándolas y asignando un sentido personal a la acción» (Cols 2007: 335). Destaca asimismo la productividad de la noción de estilo desde una perspectiva heurística en cuanto posibilita describir los diferentes planos de la acción pedagógica del sujeto (decisiones, gestión, instrumentación, relación con sus alumnos) y establecer conexiones con sus concepciones previas; con los sentidos que construye a partir de su acción; con las demás dimensiones de su acción, y con su historia académica y profesional.

El estudio aporta, además, evidencias sobre la relación entre el estilo y la identidad de los indagados, la recurrencia e incidencia de los aspectos biográficos (figuras de referencia escolar y experiencias académicas...) con los modos de pensar y llevar a cabo la enseñanza, con las motivaciones personales, el sentido de ser docente y las imágenes acerca de sí mismos. Identifica además ciertas relaciones de consistencia o inconsistencia entre las concepciones manifiestas de los docentes y su hacer.

Por último, la investigación de Ana Dias-Chiaruttini Le debat interprétatif dans l'enseignement de la lecture y de la littérature, dirigida por Bertrand Daunay e Yves Reuter (2010), interesa a este marco teórico por su empleo de la noción de estilos de enseñanza en función del estudio del debate interpretativo ( $\rightarrow 1$.2.5.2.) como dispositivo de discusión literaria en las clases de Francés.

Esta investigación constituye un referente para el estudio que aquí se presenta en la medida que centra su indagación en las conversaciones que se producen en las aulas entre estudiantes y docentes como mediadores para construir sentido en la lectura de textos literarios. 
El propósito de Dias-Chiaruttini es indagar la emergencia y formalización del debate interpretativo como género prescripto en los currículos franceses, considerado emblemático en la renovación de la enseñanza de la literatura en la escuela (2015: 4).

La noción de estilos de enseñanza constituye para esta investigadora, junto con la noción de gestos profesionalizantes ${ }^{6}$, una herramienta para describir y comprender, por una parte, la estilización del debate interpretativo, al permitir la caracterización del género efectivamente realizado, que se concreta en prácticas de enseñanza contextualizadas. Es precisamente a través de estas últimas que el género formalizado (en los modelos didácticos, en las prescripciones curriculares, en las transposiciones de los libros de texto...) se desarrolla y evoluciona (2010: 262).

Por otra, la investigación también indaga sobre la incidencia de los estilos de enseñanza de cada docente sobre las performances metatextuales ${ }^{7}$ de los alumnos, en el entendido de que dichos estilos habilitan o restringen la construcción de sentido durante la elaboración del metatexto.

Dias-Chiaruttini adopta la noción de estilos de enseñanza propuesta por Altet $(\rightarrow$ 1.2.6.) en tanto designa una construcción individual, no transferible, propone tres dimensiones organizativas de los estilos y comparte vínculos intrínsecos con las de estilo de Bajtín y Clot y Faïta (2010: 279)8.

La autora concluye que los estilos de enseñanza singularizan cada gesto de los docentes durante la práctica del debate interpretativo y explican las diferencias en las performances de los estudiantes, habilitándolas o constriñéndolas. Los gestos didácticos que los docentes despliegan se relacionan con la historia singular de cada uno de ellos, sus concepciones sobre la enseñanza de la literatura e inciden en los aprendizajes disciplinares y la forma en que llevan a cabo el debate interpretativo en sus clases. La singularidad de cada estilo explica la variedad de prácticas de este género, la tensión entre las prescripciones, la actividad real y las transformaciones que en él se producen. Las modalidades de lectura observadas son plurales y permiten comprender los efectos de los estilos de enseñanza sobre la configuración del género a través de sus prácticas (Dias-Chiaruttini 2015:217-223).

Sobre el análisis de los estilos de enseñanza y su relación con las performances de los estudiantes, la autora identifica cuatro modalidades características de debate interpretativo - que se complementan y articulan según lo exija la situación de lectura:

-una modalidad con finalidad realista por la cual los profesores planifican la actividad de lectura, esperando que sus estudiantes identifiquen los elementos del texto. En función de sus estilos de gestión

\footnotetext{
${ }^{6}$ Las nociones de gestos y estilos provienen de enfoques teóricos diferentes, pero, a criterio de Días-Chiaruttini, pueden complementarse.

${ }^{7}$ El término performance es una construcción abstracta que alude en la investigación de Dias-Chiarutini a lo que los estudiantes hacen y dicen en situación de la conversación metatextual. Estas, que se traducen en niveles de participación que, de ninguna manera pueden relacionarse con sus aprendizajes. (2015:143). Por otra parte, la autora adopta la noción de metatexto de Daunay (1993: 101 en Dias-Chiaruttini 2010: 8), que es comprendida como el texto dentro de otro texto. En el marco de su estudio, aborda el metatexto oral u escrito que se produce en forma colectiva en el ámbito escolar, mediante el debate interpretativo que le da forma.

8 Dias-Chiaruttini construye la noción de género disciplinar a partir de las referencias a las de género de discurso, de Bajtín, género de actividad, de Clot y Faïta y los aportes de Reuter y Daunay.
} 
de las interacciones, pueden dejar poco espacio para la interpretación de los estudiantes e incluso a veces para la cooperación prevista por el texto;

-una modalidad distanciada, focaliza en el conocimiento del texto, por la cual las actividades escolares crean distancia con el material leído;

-una modalidad impresionista que favorece la reacción personal ante los hechos narrados y la expresión de las opiniones de los estudiantes sobre el texto;

-una modalidad cognitiva que tiende al desarrollo de la argumentación y la justificación sobre la lectura.

Estas modalidades se presentan y articulan en el hacer de cada docente de manera muy diferente, en función de los estilos de cada uno; les proponen a los estudiantes diversas formas de relacionarse con el texto y aportan a sus performances metatextuales de manera muy diferente, también (DiasChiaruttini 2011:en línea).

\subsection{Referencias conceptuales}

Esta sección aborda aquellos conceptos que sustentan teóricamente este trabajo. La exposición se organiza en seis apartados: los tres primeros pretenden brindar un marco general a este estudio mientras que los tres últimos atienden específicamente las nociones sobre las que trata esta investigación.

El apartado «La lectura como práctica social y cultural» $(\rightarrow 1.2 .1)$ ahonda en el marco interpretativo que sustenta las nociones de mediación y mediador de lectura. Explicita, además, otros conceptos que se articulan dentro del marco de referencia, y que resultan operativos para este estudio.

En el apartado "La lectura en la escuela, la comunidad y la familia» ( $\rightarrow$ 1.2.2.) se profundiza sobre las relaciones que se establecen, en torno a la lectura, en los contextos implicados en esta investigación. Hace referencia al proceso histórico por el cual la escuela se constituyó como ámbito alfabetizador y a las particularidades que asumen las prácticas de lectura en las instituciones involucradas, para dilucidar los puntos de contacto y controversias que entre ellas se suscitan y considerar los aportes específicos de cada una a la formación de los lectores.

El apartado «La mediación sociocultural y pedagógica» ( $\rightarrow$ 1.2.3.) acopia y relaciona aportes teóricos provenientes de la pedagogía y psicología, considerados relevantes para la construcción de una noción de mediación, funcional al campo educativo, que dé sustento al estudio que aquí se presenta.

La discusión en el apartado "La mediación de la lectura» ( $\rightarrow$ 1.2.4.) asume el desafío de delinear el «universo semántico» (Munita 2014: 36) que convoca la expresión mediación de la lectura (o mediación lectora) sobre el que se construirá la noción central de esta tesis: la de mediador de lectura.

Al ser el mediador de lectura el protagonista de este estudio, el apartado «El mediador de lectura» $\rightarrow$ 1.2.5.) intentará profundizar en su caracterización, en un primer momento, desarrollando las dimensiones de su figura, sus roles o funciones y perfiles. Luego, describiendo las herramientas a las que recurre en las instancias de lectura mediada: la lectura en voz alta y la conversación sobre lo leído. Y, por último, intentando conceptualizar con amplitud al mediador de lectura al que refiere esta tesis. 
Por último, en el apartado dedicado a «Los estilos de enseñanza o pedagógicos» ( $\rightarrow$ 1.2.6.) se profundiza sobre este concepto, proveniente del campo pedagógico, en función del propósito de su inclusión en esta investigación.

\subsubsection{La lectura como práctica social y cultural}

La concepción de la lectura como práctica social y cultural es sustentada por los marcos interpretativos de la historia y la sociología cultural.

Desde la historia cultural ${ }^{9}$, Roger Chartier establece que las prácticas culturales - la lectura es una entre tantas-, son invenciones de sentido limitadas por determinaciones múltiples (sociales, religiosas, institucionales...), que instituyen en cada comunidad normas y comportamientos legítimos (1995:137). Una práctica es la manera en que los individuos, comunidades o clases manejan los códigos, los textos y los objetos en el seno de sus comunidades ${ }^{10}$.

La sociología cultural, por otra parte, aporta el desarrollo teórico de la noción de práctica social que fundamenta numerosos estudios sobre la lectura en tanto consumo cultural, ligados a las problemáticas sociales y políticas (Lahire et ál. 2012; Bahloul 2002). Al respecto, Pierre Bourdieu concibe las prácticas sociales como productos de un sentido práctico, de un sentido de juego socialmente constituido, cuyo principio de construcción es el habitus ${ }^{11}$.

La noción de práctica de Bourdieu se opone tanto a la que la comprende como el producto objetivo de la acción, como reacción puramente mecánica, carente de agente, como a la que la considera como realización individual deliberada de una intención consciente y racional, producto del subjetivismo. Esta postura contempla, ante todo, cómo se construye y aprehende una práctica social, considerando su lógica específica y temporal, estableciendo una ruptura con el empirismo y con el idealismo intelectualista (Bourdieu y Wacquant 1995:83).

Pueden encontrarse en torno a las concepciones de práctica social y cultural reseñadas diversos puntos de contacto en cuanto a su origen, producción e historicidad. Pero frente a la noción de habitus, que se impone a los sujetos, constriñendo su margen de acción, Chartier propone la de apropiación, que designa los modos en que los sujetos se relacionan con los objetos culturales o normas sociales, que son recibidos, interpretados y manejados de acuerdo con sus determinaciones fundamentales. Los dispositivos de dominación sean de la índole que sean, aclara Chartier, nunca suprimen las posibilidades de apropiación de los sujetos, quienes puede desplazar, reformular o subvertir lo que se les impone. El concepto de apropiación opera en función del de práctica, y su pertinencia intenta dar cuenta de las múltiples formas de apropiación (algunas de ellas conflictivas) de códigos, reglas, y mensajes compartidos (Chartier, 2000).

\footnotetext{
${ }^{9}$ Corriente teórica desarrollada por un grupo de investigadores continuadores de la Escuela de los Annales francesa, cuyo mayor exponente es el historiador Roger Chartier.

${ }^{10}$ Elsie Rockwell destaca el vínculo de esta noción con la de práxis, comprendida como actividad productiva del ser humano, tanto en su sentido material como simbólico (Rockwell 2001:14).

${ }^{11}$ Pierre Bourdieu concibe al habitus como un sistema social de disposiciones estructuradas y estructurantes. Hablar de habitus, dice este autor, es plantear que lo individual, e incluso lo personal, lo subjetivo, es social, colectivo. El habitus es un producto de la historia, una subjetividad socializada un sistema abierto de disposiciones, que se enfrenta de continuo a experiencias nuevas y es afectado sin cesar por ellas $y$, en este sentido, es perdurable, pero no inmutable (1995: 83-87).
} 
Contra la concepción de la lectura como operación intelectual abstracta, la noción de lectura como práctica la concibe situada social e históricamente en una comunidad de lectores que conforman verdaderas comunidades interpretativas $(\rightarrow 1$.2.5.). Estas comunidades desarrollan prácticas de lectura reguladas por normas y convenciones que establecen los usos legítimos del libro, de los modos de leer y de los instrumentos y procedimientos de interpretación (Cavallo y Chartier 1998: 13-15).

En todas las épocas y sociedades, existen tres contrastes específicos que permiten caracterizar y diferenciar las comunidades de lectores, las tradiciones de lectura y los modos de leer: los que se establecen en función de las competencias individuales -lectores cultos o analfabetos-; las normas y convenciones que regulan los usos legítimos - de los textos, soportes de lectura y procedimientos de interpretación - y los que efectivamente se concretan en cada comunidad de lectores; y las esperanzas e intereses compartidos, con los particulares de cada lector (Cavallo y Chartier 1998: 15).

La historia de la lectura no concibe la existencia del texto separada de su materialidad y condiciones de legibilidad (tipos y tamaños de letra, apartados o párrafos, títulos y subtítulos, grabados e imágenes, etc.). Todo ello configura un protocolo de lectura que le indica al lector cómo debe ser leído un texto (Chartier 1996:114). Distingue además la distancia histórica, social, espacial y de propósitos que separan la producción de la recepción de los textos, al «mundo del texto» del «mundo del autor» ${ }^{12}$, que impide al autor imaginar cabalmente al lector que lo leerá. Este espacio, esta distancia, es la que hace de la recepción una actividad productiva. Contra la imagen de la lectura como consumo pasivo, Chartier, siguiendo a De Certau, la propone como una actividad intelectual inventiva, creadora (1995:130). Por todo ello, y en la medida que todo texto "es una construcción de su lector» (Chartier 1996:39), la historia de la lectura pretende dar cuenta de las formas de apropiación que de los textos hacen los lectores.

Por otra parte, para Bourdieu la lectura constituye una institución social resultante de la emergencia y autonomía del campo literario ${ }^{13}$, como campo específico de producción cultural, y al texto, el producto de un tipo particular de condiciones sociales de producción (2011:447).

Tanto Bourdieu como Chartier acuerdan en la complementariedad de las perspectivas histórica y sociológica para la inteligibilidad de la lectura como práctica y como forma específica de consumo cultural (Chartier 2000:164; Bourdieu y Chartier 2010:255).

\footnotetext{
12 Citan a Paul Ricoeur.

${ }^{13}$ Bourdieu propone pensar el concepto de campo como una red o configuración de relaciones. Estas poseen una existencia objetiva e imponen determinaciones a los agentes o instituciones que las ocupan (reales o potenciales) en una estructura de distribución de poder o capital. Dichas relaciones, que pueden ser de dominación, subordinación o analogía, se vinculan con la posesión de las ganancias que están en juego dentro del campo en cuestión. Cada campo (artístico, religioso, económico, etc.) es relativamente autónomo de los otros y se constituye en un microcosmos que funciona dentro de la estructura social en relación con otros. Los campos establecen las condiciones de entrada y pertenencia a ellos. En el interior del campo se configuran relaciones de fuerza entre los actores que participan en él y se entablan luchas, que son inmanentes a la existencia de los campos y constitutivas de su dialéctica. Estas luchas, que buscan incidir en la conservación o transformación de esas relaciones internas de fuerza, son las que confieren historicidad al campo en cuestión. Los campos preexisten; se imponen y construyen a los agentes (individuos o instituciones que lo integran). Los agentes existen en función del campo y están subordinados a él (no en un sentido determinista). En virtud de su posesión de capital y de su trayectoria dentro del campo, los agentes podrán asumir, o no, una orientación dentro de este (Bourdieu y Wacquant 1995:64-74).
} 
Ambos coinciden, además en su desacuerdo con la concepción de lectura que la caracteriza por sus efectos y postulados universales: la abstracción del lector; la lectura individual, silenciosa y desinteresada; el etnocentrismo que da por supuesto que las prácticas específicas de un lector especializado son comunes a todos los lectores y a todas las épocas, y la consideración de que todos los textos fueron hechos para ser leídos de la misma manera (Bourdieu, P. y Chartier, R. 2010).

Estos marcos interpretativos que se han venido reseñando han sustentado investigaciones en el campo de la educación, etnología, sociología... que, a la vez, han contribuido a ampliar las referencias de base. En este sentido, en el contexto de esta investigación, se hará referencia a las nociones de escenas de lectura, escenarios de lectura, acceso y disponibilidad, contexto y participación, funcionales a este estudio.

El programa Histelea (Historia Social de la Enseñanza de la Lectura y la Escritura en Argentina) ${ }^{14}$ propone la categoría escena de lectura, a la que define como «lugar donde se realiza /materializa la escritura como práctica social de comunicación» (Cucuzza y Pineau 2001:17) para estudiar las problemáticas de acceso, inclusión y exclusión de los sujetos en la cultura escrita que se producen en la institución escolar. Una escena de lectura se configura por seis variables, a saber: actores, espacio, tiempo, finalidad, modos de leer, soportes y tecnologías de la palabra, que al igual que una fotografía, establecen, en el devenir, un corte sincrónico. La noción de escena de lectura se vuelve útil en cuanto permite investigar las continuidades y rupturas experimentadas en las prácticas letradas.

En el marco de la sociología de la lectura, Jöelle Bahloul investiga los poco lectores a los que las investigaciones sociológicas cuantitativas definen por la cantidad de libros que leen anualmente. Hace énfasis en la necesidad de considerar la lectura como práctica social y no solamente como práctica cultural pues además de destacar su relación con la jerarquía, organización y condiciones sociales, señala su vínculo con la iniciativa, recepción, circulación y las representaciones del libro y de la lectura, que nunca se producen fuera del marco de las redes de socialización (2002: 22).

La autora estudia la forma en que los poco lectores llegan a serlo a partir del concepto de escenario de lectura, entendido como «el conjunto de las condiciones sociales producto de la historia familiar, socioprofesional y educativa de los lectores» (2002: 23). Para constituir su objeto de estudio, ahonda en las representaciones de los modelos de clasificación de los géneros, las concepciones sobre la lectura, el libro y su materialidad, y las prácticas de consumo en las biografías educativas y familiares, que poseen los poco lectores. Desde estos cruces, encuentra que los poco lectores no se conciben a sí mismos como lectores, pues no se identifican con el arquetipo del profesional intelectual, culto, que disfruta la lectura. El poco lector, dice esta investigadora, reconoce la debilidad de su trayectoria escolar en términos de fracaso, y se ve a sí mismo desprovisto de capital cultural. Se caracteriza, además, por la sustitución de las lecturas canónicas, luego de que salen del sistema escolar, por otras, acordes con sus prácticas culturales de origen; por la no planeación de sus lecturas; por su percepción del acto de

\footnotetext{
${ }^{14}$ El programa Histelea constituye un programa de la Universidad Nacional de Luján que investiga la enseñanza de la lectura y la escritura y la problemática del acceso e inclusión de cultura escrita en el ámbito escolar. Aborda la historia de la lectura y la escritura desde la perspectiva de su construcción como disciplinas escolares, buscando superar la mirada diacrónica de la didáctica y las miradas escolarizantes que reducen dichas prácticas a meras prácticas escolares. Las investigaciones de Histelea se inscriben en el ámbito de la historia social de la educación, en diálogo con otras disciplinas, que tienen como objeto de estudio la lectura y la escritura (antropología, lingüística, sociología, entre otras) (Cucuzza y Pineau 2001:101-102).
} 
leer como una actividad pasiva (física e intelectualmente) y por lo tanto marginada al ocio y por concebir al libro como un producto de consumo. Los poco lectores, además, no logran retener el título, el nombre del autor o la trama de los libros que leen, entre otros aspectos.

Para los que tienen dificultad para decodificar lo escrito, y para los que la lectura les exige un arduo esfuerzo de concentración, prosigue Bahloul, las imágenes constituyen un valioso apoyo para acceder al sentido del texto. Enfatiza, asimismo, el papel de la familia, cuyos miembros se proveen y recomiendan libros entre sí, en el acceso y sostenimiento de las prácticas de lectura. Por último, cabe señalar que esta investigadora observa que las rupturas en los escenarios de lectura se acompañan de cambios en las condiciones socioeconómicas de los lectores (movilidad social, geográficas, culturales...). Y de manera anecdótica, que los episodios vinculados con un quebranto de salud de los sujetos indagados también provocan rupturas en los escenarios de lectura (2002).

Para finalizar, cabe mencionar los aportes de la antropóloga Judith Kalman quien investiga, desde la etnografía, las prácticas de lectura y escritura de personas adultas, con escasa o nula escolaridad y sus procesos de apropiación, participación y acceso a la cultura escrita. A partir de una conceptualización amplia sobre la alfabetización, que abarca además del manejo del lenguaje escrito, el manejo discursivo, la autora establece que la interacción entre los individuos, mediada por la oralidad, es condición necesaria para aprender a leer y escribir y apropiarse de la cultura escrita.

En este marco, Kalman articula las nociones de acceso y disponibilidad, para diferenciar las condiciones materiales de las condiciones sociales presentes en los procesos de apropiación de la cultura escrita, y de contexto y participación para comprender la dinámica entre circunstancias y actores presentes en estos procesos (2003: 44).

Mientras que, por una parte, la disponibilidad alude a las condiciones materiales para la práctica de la lectura y la escritura, el acceso hace referencia a las oportunidades de participación en eventos de lengua escrita. Finalmente, la autora establece que si bien la disponibilidad de los materiales impresos influye sobre las oportunidades para acceder a prácticas de lectura y viceversa, no es condición suficiente para la apropiación de la cultura escrita (2003: 40).

\subsubsection{La lectura en la escuela, la comunidad y la familia}

No hay lugar a dudas de que es en la escuela donde los niños aprenden, hoy en día, a leer y a escribir. Desde el surgimiento de la escuela moderna y hasta ahora, este aprendizaje no puede concebirse separado de la escolarización (Chartier 2004:15; Meek 2004:51). Este hecho, tan naturalizado en nuestros días, es consecuencia de la consolidación de la escuela como «forma educativa hegemónica», que asumió como su principal propósito alfabetizar a las nuevas generaciones. Esta consolidación fue resultado de un proceso caracterizado por fuertes tensiones, que lejos de ser armónico, solo pudo concretarse sobre la confrontación y oposición con otros agentes o instituciones (Brito, Pineau y Southwell 2012:5).

La consagración de la hegemonía escolar, que se efectuó en un corto período -últimas décadas del siglo XIX y primeras del siglo XX-, se hizo posible graciasa la universalización de la educación, a partir del establecimiento de la obligatoriedad de la enseñanza y la expansión de la matrícula (Pineau 2001:28).

Hasta mediados del siglo XVIII la alfabetización estaba a cargo, principalmente, de las familias o de las instituciones religiosas y tenía como finalidad garantizar los saberes básicos que permitieran el acceso 
al conocimiento religioso o a otros estudios disciplinares (Hébrard 1989:63-64). A fines del siglo XVIII, la burguesía impulsora de la llustración estaba convencida de que el camino hacia el bien pasaba por la lectura (Reinhard 1998:471). Esta concepción terminó finalmente por concretarse en la cultura escolar; la lectura entonces pasó a ser considerada como la legítima vía de garantizar el ejercicio de la ciudadanía y la preeminencia de la civilización frente a la barbarie, convirtiéndose en el medio más efectivo de trasmisión ideológica. La educación trascendió entonces las necesidades de la familia y de la Iglesia para convertirse en un asunto de Estado (Chartier y Hébrard 1994:262).

En el nuevo escenario, la lectura se instauró como un componente esencial y fundacional de la cultura escolar, de concreción del mandato social y político de formar a los lectores, desde temprana edad, y consecuentemente, a los ciudadanos. Al adquirir este nuevo estatus, se convirtió, en una compleja dialéctica, al decir de Cucuzza: «[...] en consecuencia y causa, resultado y a la vez agente generador de los procesos sociohistóricos [...]» (2012:15).

De esta manera, el sistema escolar instituyó su voz de autoridad sobre la lectura, prescribiendo técnicas, modos, normas y lecturas "correctos» y por sobre otros. El discurso de la escuela, que se opuso y desplazó al de la Iglesia y la Biblioteca y sus cuerpos profesionales, no consiguió sin embargo anularlos. Tal como expresan Anne Marie Chartier y Jean Hébrard, estas voces desplazadas han perdurado hasta nuestros días, plasmándose en juicios que ponen en cuestión el rol alfabetizador de la institución escolar: «[...] la escuela fracasa en su tarea o no fracasa, traiciona o no traiciona sus compromisos, enseña o no enseña como hay que enseñar y lo que hay que enseñar. Hace leer o no hace leer, hace leer bien o hace leer mal.» Estos discursos foráneos «cargado de sedimentación» de otros discursos que le son ajenos se contraponen a los de los agentes escolares que naturalizan la vocación de la escuela como lugar en donde se aprende a leer y escribir (Chartier y Hébrard 1994: 250-251).

Los cruces de discursos sobre la lectura confrontan también a la escuela con la familia, quizás como resabio o apéndice del proceso por el cual esta última fue relegada de su rol alfabetizador. Al respecto, las voces son contradictorias: mientras la escuela aclama su responsabilidad en la alfabetización de las nuevas generaciones, reclama al entorno familiar el capital cultural ${ }^{15}$ necesario para que los niños aprendan a leer y escribir, y señala el origen de las dificultades de estos aprendizajes en las carencias que los niños traen de sus orígenes. En similar sentido, sobre la base de la teoría del aprendizaje significativo ${ }^{16}$, apela a los conocimientos previos de los estudiantes para la construcción de nuevos saberes. Y en contrapartida, la familia le confía a la escuela la tarea de enseñar a leer y escribir, pero manifiesta sus sospechas cuando los métodos de enseñanza difieren de aquellos por los cuales los adultos se alfabetizaron en otras épocas.

Estas posiciones confrontadas revelan la complejidad que, en términos de tensión, asume la relación escuela, comunidad y familia, cuya comprensión se hace necesaria para contribuir al encuentro entre instituciones y prácticas; entre la lectura en su dimensión de práctica sociocultural y su concreción en «práctica escolar» (Lerner 2001:49).

\footnotetext{
${ }^{15} \mathrm{Al}$ respecto, las teorías reproductivistas señalan la influencia del capital lingüístico en el rendimiento escolar (Bourdieu y Passeron 1998:115-116) y la teoría de los códigos sociolingüísticos indica que los niños que provienen de hogares donde se emplea un código restringido pueden presentar problemas de educabilidad (Bernstein 1988:160).

${ }^{16}$ La teoría del aprendizaje significativo postulada por Ausubel establece que el aprendizaje es producto de la interacción de un material o información nueva y una estructura cognitiva preexistente (Pozo 2010:215).
} 
Para ahondar sobre estas cuestiones, se debe volver sobre el concepto de lectura como práctica social y cultural arraigada en una comunidad de lectores, tradiciones y modos de leer -al que ya se hizo referencia en el apartado anterior - cuya apropiación solo es posible en convivencia con estas prácticas, con los objetos y sujetos implicados en ella y con los sentidos que estos les atribuyen. En consecuencia, la inmersión temprana de los niños en entornos letrados los predispondrá en mayor medida a constituirse en lector. Al respecto, son muchos los aportes que destacan esta relación. Desde los estudios sobre la alfabetización, Jenny Cook-Gumperz indica que las experiencias que los alumnos traen desde sus hogares y comunidades los prepara para la vida escolar (1998:21). Y en el mismo sentido, Teresa Colomer expresa:

[...] los niños y niñas de contextos culturalmente ricos se benefician de prácticas de lectura compartidas antes de "saber leer", lo que les permite extraer mayor rendimiento escolar de esas mismas prácticas; mientras que los niños que carecen de ellas tienen más dificultades para llevarlas a cabo y además no obtienen tanto beneficio de su escolarización (2004:17).

... y Margareth Meek afirma: "La mayoría de los niños descubren los inicios de su cultura escrita en el seno de su familia, que es su primer y vigoroso entorno de aprendizaje. La cultura escrita es familiar» (Meek, 2004:110).

En sintonía, Michèle Petit, antropóloga especializada en la lectura, opina que la relación con la lectura «es en gran parte una cuestión de familias» (1999:146). Refiere además a la importancia de que se establezca una relación temprana con la lectura, a través de la presencia física de libros en el hogar y de adultos que manifiestan interés por los libros y leen en voz alta a los niños. Son estos adultos quienes, precisamente, al crear «un clima familiar», transmiten una relación, una actitud hacia la lectura (1999: 146-147; 2005: 9-13; 2016: 150).

Esta investigadora refiere además a que el entorno familiar puede constituirse en obstáculo para la práctica de la lectura en medios desfavorables, en donde factores de índole económico, social o psíquicos obran en su contra: «En entornos desfavorables, a la crisis en la relación madre /hijo se suman a veces la falta de recursos materiales, lo precario de la vivienda, los trayectos escolares erráticos, la escasez de recursos culturales y los obstáculos de todo tipo que vuelven muy difícil la apropiación de los libros» (2005:15).

Petit señala además otros factores que pueden dificultar la práctica de la lectura, por ejemplo, en el medio rural, donde la afirmación de la singularidad y la soledad que aquella demanda es sentida como un alejamiento del grupo; cuando entra en conflicto con las costumbres y valores de la comunidad de pertenencia, cuando en esta se impone «lo útil» en desmedro de la inutilidad y ocio de la lectura; cuando es rechazada, al ser sentida como una actividad propia de otros grupos sociales o que la lengua de los libros es la lengua de quienes tienen el poder (Petit 1999: 109-129).

Para aquellos niños que provienen de entornos socialmente favorecidos -en los cuales la lectura es una práctica habitual y, además, valorada-, la familia es la puerta de acceso a la cultura escrita y la base de sus futuros aprendizajes. En este sentido, si bien la familia, en nuestros días, no es ya la encargada de enseñar a leer en forma explícita, establece las condiciones para que este aprendizaje suceda.

La escuela por otra parte, en sus más de dos siglos de existencia ha debido enfrentar diversos cuestionamientos, que sin poner en duda el mandato fundacional, interpelan la «naturalidad» de ese mandato. En este sentido, a los discursos foráneos «cargados de sedimentación» ya señalados, a los 
que refieren Chartier y Hébrard debe sumarse, entre otros factores, la constatación del abismo existente entre el éxito escolar de los niños procedentes de contextos sociales favorecidos y de aquellos que pertenecen a familias con bajos ingresos o de minorías étnicas, en las últimas décadas del siglo XX (Cook-Gumperz 1998:61). A ello deben añadirse que como consecuencia de los profundos cambios sociales y tecnológicos acaecidos en los últimos tiempos, se han ampliado las exigencias respecto al dominio de los usos escritos, instaurando la necesidad de educación permanente; se ha transformado además el concepto de alfabetización - que pasó de tener un sentido estricto, limitado a la enseñanza de los saberes básicos implicados en la lectura y la escritura, a adquirir un sentido amplio, expandiendo sus objetivos, espacios y formas de consumo cultural (Colomer 2004:14-15).

Pese a estos cuestionamientos, la escuela es quien detenta la responsabilidad social de enseñar a leer y a escribir a las nuevas generaciones. Al respecto, Cook-Gumperz afirma: «[...] la alfabetización como fenómeno definido socialmente se construye a través de un proceso de escolarización. Los sistemas escolares parece que se han convertido en uno de los principales caminos institucionales hacia muchas metas sociales y van a seguir siendo así» (1998:20).

En el mismo sentido, Emilia Ferreiro recuerda: «Los primeros lectores se forman en las familias, cuando hay libros y lectores a su alrededor. Por ahora, y hasta que seamos capaces de reducir la desigualdad social [...], la educación básica, la escuela pública, es el lugar donde se forman lectores de los otros grupos» (Ferreiro 2006:64).

Para cumplir cabalmente con el mandato de formar lectores, la escuela debe protagonizar, por lo menos, dos trasformaciones. La primera de ellas hacia adentro: para que se constituya en ámbito de apropiación de la cultura escrita la institución escolar debe comprenderse como lugar de intersección de las redes y los procesos que se producen más allá de sus límites. Lo fundamental, dice Elsie Rockwell, «es concebir las actividades del aula como prácticas culturales que integran no solo maneras de leer construidas para los propósitos de enseñanza escolar, sino también aquellas derivadas de otros ámbitos sociales» (2001:24; 2005:28). El desafío, señala Delia Lerner, es transformar las prácticas de lectura y escritura en objeto de enseñanza para formar seres críticos, capaces de adentrarse en los otros mundos que ofrece la literatura y de apropiarse de la escritura como instrumento de reflexión y reorganización del pensamiento (2001:25-42).

La segunda transformación, como consecuencia de la primera, es hacia afuera, estableciendo puentes entre la escuela y la comunidad en torno a la lectura. Debe considerarse que hoy en día los lectores y escritores se forman como tales en el entrecruce, y como resultado de su participación en instituciones y prácticas. Tal como expresan Pérez Camacho y López Ojeda: «[...] hay que reconocer que hoy las prácticas lectoras no se pueden considerar como el resultado de entornos claramente diferenciados. La lectura [...] es una serie de combinaciones e interacciones donde se van construyendo lectores con distintos grados de compromiso: con el entorno, con su desarrollo personal, con la vinculación con los otros» (2015:98-99).

Habiendo definido con claridad los objetivos de aprendizaje que le son propios, la escuela debe integrar los aportes de otros actores sociales. Al respecto, Colomer expresa: "[...] para la consecución de un entorno alfabetizado donde todo el mundo pueda incorporarse con naturalidad al uso del escrito, la familia y la sociedad tienen mucho que decir. Si definimos mejor lo que debe y puede esperarse de la escuela y lo que puede y debe esperarse del entorno, tal vez las reglas de juego serían más claras» (2004:17-18). 
Tal vez, en esta confluencia de propósitos, modos de leer y modelos lectores que la escuela, la comunidad y la familia puedan brindar, se den las «condiciones de posibilidad» para que los lectores en formación vivencien la «experiencia de la lectura» como un acontecimiento formador y transformador, que nos constituye y cuestiona lo que somos (Larrosa 2011).

\subsubsection{La mediación sociocultural y pedagógica}

Al intentar profundizar sobre la noción de mediación, es posible encontrarse con que esta es empleada en diferentes ámbitos: al respecto, Jean F. Six determina siete: la familia, la escuela, la empresa, la salud, la justicia, la ciudad y los usuarios (1997). Es posible también rastrear el uso del concepto en el campo de los estudios interculturales (Bermúdez Anderson et. ál s.d.), de la teoría de la comunicación (MartínBarbero 1987) y de educación para la paz (Cascón Soriano 2000).

De antemano, es necesario aclarar que en este marco teórico se ha priorizado el tratamiento del concepto en educación, dejándose de lado aquellos otros que comprenden la mediación como dinámica o proceso de resolución de conflictos.

Desde la psicología del aprendizaje, la noción de mediación asienta sus bases en la teoría sociocultural de Lev Vygotsky, quien postuló la naturaleza social e interpsicológica del aprendizaje: «[...] el aprendizaje humano presupone una naturaleza social específica y un proceso mediante el cual los niños acceden a la vida intelectual de aquellos que les rodean» (1979:133).

El psicólogo ruso destacó la interrelación, desde los primeros días de vida, entre aprendizaje y desarrollo, dos procesos que, sin ser idénticos, conforman una unidad. Para Vygotsky, el aprendizaje sucede en la zona de desarrollo próximo, comprendida entre el nivel real de desarrollo, determinado por la capacidad de resolver independientemente un problema, y el nivel de desarrollo potencial, definido por la capacidad de resolver un problema bajo mediación de un adulto u otro niño más capaz. La mediación, que se realiza por medio del lenguaje - concebido como instrumento de mediación semiótica-, es entonces, a la vez, la que da origen a esta zona de desarrollo próximo y la que desencadena los procesos de aprendizaje: «[...] lo que crea la zona de desarrollo próximo es un rasgo esencial de aprendizaje; es decir, el aprendizaje despierta una serie de procesos evolutivos internos capaces de operar solo cuando el niño está en interacción con las personas de su entorno y en cooperación con algún semejante» (1979:138-139).

En la psicología cultural de Jerome Bruner, instituida sobre los aportes vygotskianos, la función de mediación está contemplada implícitamente en la perspectiva culturalista (o culturalismo) ${ }^{17}$, que asigna un lugar fundamental a los procesos intersubjetivos en la aprehensión de la cultura. El culturalismo explica cómo los seres humanos crean y trasforman la cultura, entendida esta como una "caja de herramientas, de técnicas y procedimientos para entender y manejar el mundo» (2001: 116), y trasmiten los significados culturales en sus comunidades. Para el autor, la evolución de la mente no podría existir sin la cultura; lo que se constituye como 'realidad' para una comunidad cultural, se encuentra representado por un simbolismo compartido entre sus miembros, que además, es elaborado, conservado y transmitido entre generaciones, manteniendo de esta manera «la identidad y la forma de vida de la cultura» (2001:21). La intersubjetividad, definida como «la habilidad humana para entender

\footnotetext{
17 La hipótesis de este autor sobre el funcionamiento de la mente contempla dos perspectivas complementarias, la culturalista y la computacional, que explica cómo la mente humana procesa la información por medio de un mecanismo computacional (Bruner, 2001).
} 
las mentes de otros», es la base que permite que los individuos aprehendan su cultura, y la que, en definitiva, hace posible la mediación. Bruner agrega: "Somos la especie intersubjetiva por excelencia. Es esto lo que nos permite "negociar" los significados cuando las palabras pierden el mundo» (2001, 39). Desde esta perspectiva, la interacción constituye el mecanismo por el cual los individuos intercambian conocimientos y habilidades. Al respecto, Bruner afirma: «Nada está libre de cultura, pero tampoco son los individuos simples espejos de su cultura. Es la interacción entre ellos lo que da un carácter comunal al pensamiento individual», y más adelante agrega: «Es sobre todo a través de la interacción con otros que los niños averiguan de qué trata la cultura y cómo concibe al mundo» (2001:31-39).

Desde la psicología de la educación, y bajo la influencia de Vygotsky y Piaget, Reuven Feuerstein desarrolló la teoría de la experiencia del aprendizaje mediado (Mediated Learnig Experience, MLE), que considera la inteligencia como una capacidad dinámica del ser humano, abierta al cambio y pasible de ser modificada estructuralmente. El autor denomina a esta capacidad como modificabilidad estructural cognitiva. El potencial de aprendizaje de los sujetos se activa según sus posibilidades de interactuar con el medio que le provea de experiencias culturalmente ricas, pero para que estos estímulos se configuren en aprendizaje es necesaria la influencia de la mediación. El desarrollo cognitivo y el aprendizaje, según Feuerstein, mantienen un vínculo dialéctico y no dependen directamente ni de la maduración ni de la interacción individual con el objeto. La mediación en este modelo implica una interacción intencional, consciente y dirigida, voluntaria y recíproca, ejercida por un sujeto con mayor experiencia y conocimiento sobre otro. La experiencia de la mediación constituye una forma de interacción que acompaña el desarrollo y moldea la experiencia humana; es el factor que ensambla lo biológico con lo sociocultural y precipita el cambio. El ser humano es quien media la experiencia con los objetos y eventos del mundo y el portador de la cultura que se ha acumulado durante miles de generaciones. La MLE funciona intergeneracionalmente para enriquecer e intensificar la experiencia sociocultural. La mediación brinda a los seres humanos herramientas para reflexionar sobre los fenómenos y entender las conexiones entre ellos, así como para descubrir las regularidades que los rigen (Feuerstein, Feuerstein, y Falik 2010: 27-46).

En el contexto latinoamericano, la noción de mediación es resignificada por la pedagogía crítica de Paulo Freire: «[...] nadie educa a nadie - nadie se educa a sí mismo-, los hombres se educan entre sí con la mediación del mundo» (1978: 69). La mediación, en este contexto, se constituye en la herramienta de una educación problematizadora, liberadora de los oprimidos, opuesta a una concepción bancaria de la educación ${ }^{18}$. La acción mediatizadora ya no tendrá como fin la apropiación de un objeto; este se instaura en la dialéctica de la comunicación como parte constitutiva del proceso de conocimiento. Al decir de Paulo Freire: «[...] el mundo mediatiza las conciencias en comunicación», y agrega que en situación gnoseológica «el objeto cognoscible, en vez de ser el término del acto cognoscente de un sujeto, es el mediatizador de sujetos cognoscentes -educador por un lado; educandos por otro [...]» (Freire 1978 81-86). En el pensamiento freiriano, la lectura y la escritura son inherentes a la mediación pedagógica,

\footnotetext{
18 La educación bancaria constituye una concepción y una práctica que entiende el acto de educar como el depósito de saberes que, a modo de donación, realizan los educadores en los educandos. Esta concepción, que considera a estos últimos como objetos, seres pasivos, ignorantes, enfrenta a educadores y educandos. En definitiva, se instaura como un instrumento de opresión que busca anular, controlar y adaptar el poder de acción y creación de los oprimidos. En contrapartida, la concepción problematizadora de la educación responde a la esencia del ser y se basa en el diálogo sobre el mundo, en la comunicación entre educandos y educadores, buscando superar las oposiciones y contradicciones entre ellos (Freire 1978).
} 
en la medida que la palabra leída «implica siempre percepción crítica, interpretación y "reescritura" de lo leído» (Freire 1984: 107) y la apropiación de la palabra escrita permite a los sujetos «decir y escribir su mundo, su pensamiento» y «contar su historia» (Fiori 1978:9).

Sobre la base de los aportes de Feuerstein y Freire, entre otros, Lorenzo Tébar Belmonte propone la pedagogía de la mediación. Construida esta desde una perspectiva humanista, que considera la educación como motor de cambio social, caracteriza la mediación como un modo de intervención educativa para la formación de los educandos, un estilo de desempeño de la «misión educativa» (2016:14). Para este autor, la mediación constituye una pedagogía dialógica y concientizadora y destaca su papel en la formación de las personas: en autonomía, libertad y responsabilidad para enfrentar los cambios sociales mediante la reflexión y trascendencia; asentar principios éticos y valores; buscar el sentido de la existencia humana; vencer el miedo y la incertidumbre, y crear convicciones, vivencias positivas y confianza hacia los demás, entre otros aspectos. En su modelo de mediación pedagógica, destaca el encuentro con el otro, la continuidad, el desinterés y la confianza como valor a conquistar: «La función mediadora es de multitarea, incesante, pero cálida y gratuita, cordial y reflexiva, que se expresa en todas las tonalidades, con cuantas personas y situaciones nos encontremos. No debemos obviar el clima de confianza que debe presidir toda mediación, a sabiendas que la confianza no se impone, se conquista» (Tébar Belmonte 2016:20).

Por último, cabe referirse la caracterización de la mediación que Jean F. Six realiza para el sector escuela. Este autor, quien define la mediación como una función con múltiples dimensiones (1997: 32-33), destaca los dos sentidos que este término adquiere en educación: como enfoque o herramienta pedagógica que pone su acento en las interacciones sociales en torno a la enseñanza y el aprendizaje o como forma para la resolución de los conflictos que acaecen en la institución escolar. Con respecto al primer sentido referido, Six establece: «En pedagogía la mediación introduce lo terciario: ya no hay dos términos, sino tres; está el profesor, que debe ser activo y responsable, está el alumno, que debe ser activo y responsable a su vez, y está el saber, que es un puente y una herramienta [...]» (1997:66).

Los aportes reunidos hasta aquí contribuyen, de una manera u otra, a la construcción de una noción de mediación operativa a este estudio; en todos ellos confluyen algunas ideas que pueden considerarse en comunión, a saber: la intersubjetividad como esencia y fundamento del aprendizaje humano, y la interacción como mecanismo de su realización; la apropiación cultural como último fin, la cooperación y el diálogo como herramientas para lograrlo; el lenguaje como constituyente y constructo de los procesos de mediación y como mediación fundamental entre el mundo y la cultura, entre la cultura y los sujetos, entre los sujetos y el mundo.

\subsubsection{La mediación de la lectura}

En este recorrido teórico, se hace necesario, desde un principio, deslindar del conjunto de nociones relevadas aquellas que aportan en forma poco precisa a la construcción del concepto. A modo de ejemplo, puede destacarse la referencia a la «profunda convicción del poder de la mediación de lectura» (Programa La Escuela Lee Más 2007:17) o la alusión a que su finalidad es la de hacer vivenciar «el mundo encantado» de la lectura» (Mekis 2013:375).

En un segundo momento, se impone ordenar los aportes recopilados en función de los diferentes contextos teóricos de los cuales provienen, ya que la noción de mediación de la lectura adquiere su significado en función de estos marcos, que le confieren mayor o menor alcance, tanto conceptual como 
práctico. En consecuencia, el presente apartado se organiza en cuatro secciones, centradas cada una de ellas en una perspectiva sobre la mediación lectora.

\subsubsection{Acción cultural y mediación de la lectura}

Desde la perspectiva de la acción cultural, Didier Álvarez Zapata y Silvia Castrillón entienden la mediación de la lectura en su dimensión social y conexión intrínseca con la cultura escrita y las prácticas sociales que en torno a ellas se desarrollan. Los autores la definen como una práctica de intervención simbólica en la dimensión social de la cultura escrita, orientada a la «integración y promoción plena del derecho a vivir y construirse un lugar en la palabra». La mediación, agregan, constituye «una práctica de humanización», encaminada "no hacia la conformación de individuos, sino de personas (como sujetos de sí mismos) que se reconocen en las esferas de lo subjetivo y de lo ciudadano» (2009:89). Al situar la mediación de la lectura es esta esfera, inscriben su acción en el marco de las relaciones de poder, dominación y resistencia que en ella se suscitan. En este sentido, Álvarez Zapata y Castrillón develan la dimensión ideológica de dicha práctica, que se encuentra atravesada por enfoques, paradigmas e ideologías diversas que la colocan en medio de tensiones y confrontaciones simbólicas. Al respecto, advierten sobre los riesgos de reducir la mediación lectora a una mediación neutralizante, fundada "en una visión equivocada de la autonomía y el respeto por el otro, que lleva a obviar la intervención con el prurito de que la individualidad es intocable», y a una "animación de la lectura "liviana" e incidental, llena de juegos y olvidos de sí» (2009:88).

En un sentido amplio, y en sintonía con lo expuesto, Martín-Barbero y Lluch conciben las prácticas de lectoescritura como un espacio mediador, como ámbito de encuentro de «las diversas culturas que habitan hoy los ciudadanos -orales, letradas, audiovisuales-» (2010:85), constituido en espacio de acción social y ciudadana. En este entorno sitúan la acción de los mediadores de lectura.

Un punto de partida similar al señalado, asumen Julia Bonaccorsi y Dias-Chiaruttini en sus investigaciones didácticas sobre la mediación de la lectura en el entorno escolar. La primera de ellas la entiende como una forma específica de acción y mediación cultural en torno a la promoción de la práctica cultural de la lectura, en cuya expresión territorial y simbólica, y en relación dialéctica, operan los individuos y la sociedad, los sujetos y los colectivos que fortalecen y movilizan espacios y proyectos comunes (2003).

Por su parte, Dias-Chiaruttini, quien analiza las prácticas escolares extracurriculares ${ }^{19}$, analiza las mediaciones de la lectura dentro del conjunto de las mediaciones culturales que ponen en diálogo lo escolar con lo extraescolar. Esta investigadora adhiere a la idea de mediación de la lectura como forma específica de mediación cultural. En este sentido, señala que mientras la enseñanza de la lectura apunta a la formación de un sujeto humanista, alfabetizado, y privilegia un corpus y modos de lectura, y discrimina otros, las mediaciones de la lectura consideran prácticas y modos de leer diversos, creando vínculos entre las lecturas canónicas y la paraliteratura, entre los autores consagrados y los emergentes, y entre las lecturas intensivas y extensivas. Dias-Chiaruttini concluye que las mediaciones de la lectura además de diversificar los contenidos educativos, cambian la forma en que la escuela concibe al lector

\footnotetext{
${ }^{19}$ Dias-Chiaruttini entiende por prácticas extracurriculares aquellas que se realizan durante el horario escolar fuera de las paredes del aula o las intervenciones intramurales de agentes culturales externos a la escuela (artistas, escritores...).
} 
y la lectura, a la vez que refleja una apertura, un proceso de modernización y democratización de la enseñanza, expresa un rechazo a las formas tradicionales de enseñar y a lo que se enseña (2012).

\subsubsection{Promoción de la lectura y mediación}

La circunscripción de la mediación lectora a la promoción de la lectura, entendida como la acción que designa un conjunto diverso de experiencias, prácticas y proyectos desarrollados con el propósito de incluir a los ciudadanos en la cultura escrita (Bombini 2008: 19-25), puede rastrarse en el contexto de las políticas públicas, como por ejemplo la que impulsa el Ministerio de Educación de España con su III Plan de Fomento de la Lectura. En este ámbito, se define la mediación como «conjunto de actuaciones que tratan de poner en contacto a las personas con la práctica de la lectura en las mejores condiciones posibles» (LCFL s.d.: 7). La mediación tiene por propósito, según este punto de vista, colaborar en el proceso de construcción de competencias y criterios lectores, y ayudar a que los sujetos afronten las exigencias y dificultad del proceso lector, en consideración de las exigencias y complejidades que este implica.

Otros grupo de autores, provenientes de diversos campos interpretativos, adscriben también la mediación a la promoción de la lectura en su sentido de acción política que se concreta en diferentes niveles (Cerrillo, Larrañaga, y Yubero 2002; Cerrillo y Yubero 2003, Cerrillo y Cañamares 2008; Bombini 2008; Bajour 2009; Robledo s.d.).

En el campo de los estudios antropológicos, Petit, quien entiende la mediación de la lectura como una forma de transmisión cultural (2016), la sitúa también en el entorno de promoción de la lectura. En palabras de la investigadora, esta encuentra su sentido cuando apunta a garantizar los derechos culturales de aquellos quienes por obstáculos diversos: culturales, económicos, geográficos, sociales... no pueden acceder a los libros y a la lectura (Petit 2001).

\subsubsection{Educación literaria y mediación}

La promoción de la lectura y la mediación se vinculan también dentro de la educación literaria, un nuevo paradigma que transforma la enseñanza de la literatura, al extender su alcance a la formación cultural del individuo. La educación literaria, a la vez que cuestiona los fundamentos que históricamente sostuvieron la enseñanza de la literatura, desde el siglo XIX hasta fines de la década del setenta -la lectura de textos clásicos; la trasmisión de información sobre obras, autores, contextos y convenciones literarias, y la hegemonía del comentario del profesor - los ensambla con nuevos propósitos que atañen a la formación del lector. Este nuevo paradigma establece como centro para el diseño y selección de objetivos, contenidos y tareas de enseñanza las necesidades formativas de los alumnos y la función de la literatura, dentro de la cultura, como herramienta que da sentido a la experiencia humana, y posibilita comprender el presente, pasado y el futuro, aportando a la construcción de nuestra individualidad y del sentido de pertenencia a una comunidad (Colomer 1996; Mendoza Fillola 2008).

Con la mira puesta entonces en la formación del lector, la educación literaria establece una continuidad en la formación lectora de los estudiantes desde los primeros niveles de la escolaridad hasta los últimos. A la vez que reconsidera el valor de contenidos tradicionales de la enseñanza de la literatura, introduce líneas de renovación didáctica: el contacto directo con las obras como punto de partida; la introducción de un nuevo corpus más próximo a los intereses lectores de los estudiantes; la revalorización de las actividades de lectura en voz alta e interpretación, junto con la lectura individual y silenciosa; la frecuentación libre y autónoma de las obras en bibliotecas o salas de 
lectura; la familiarización de los estudiantes con el circuito social del fenómeno literario (visitas a bibliotecas, librerías, ferias del libro, por ejemplo), entre otras (Colomer 1996:136).

Dentro del paradigma de la educación literaria, Ana María Margallo discierne dos dimensiones de la formación del lector fuertemente interrelacionadas: la formación del hábito lector y la capacidad de profundizar en la interpretación de las lecturas que la escuela determina como obligatorias. Al respecto, la autora explica: "Nos situamos claramente en un espacio fronterizo que surge de la escuela pero que traspasa sus límites al aspirar a formar lectores que se integren en una comunidad lectora. Se ha de ser muy cuidadoso, por tanto, en mantener la naturaleza híbrida de este objetivo de manera que se atienda tanto a su dimensión social - que los estudiantes ingresen en una sociedad lectora - como a la escolar - que el hábito lector integre los objetivos de la educación literaria» (Margallo 2012: 2). Ambas dimensiones poseen también sus particularidades e implican modalidades de lectura diferentes. La construcción del hábito lector y el desarrollo del gusto por la lectura, específicamente, son propósitos del fomento de la lectura en los cuales la mediación encuentra un lugar preponderante. Y, en este sentido, Colomer destaca el lugar de la mediación: como forma de transmisión cultural por la cual los adultos introducen en la literatura a las nuevas generaciones; en el descubrimiento y contagio de la afición por la lectura, y como mecanismo de andamiaje frente a las lecturas difíciles, es decir, «seduciendo al lector para que acepte el esfuerzo» (Colomer 2004:12).

Continuando con el paradigma de la educación literaria, debe destacarse la contribución sustantiva de Munita a la construcción de la noción de mediación de la lectura. Este investigador, que sitúa esta acción en el contexto de la promoción, parte de una conceptualización amplia de la expresión. Según su punto de vista, los términos mediación y mediador refieren a un conjunto de experiencias y prácticas humanas que involucran los procesos de familiarización con el mundo de lo escrito» (Munita 2014: 36).

Munita propone realizar una «imagen holística» de la mediación de la lectura, que atienda a las diversas dimensiones de la noción. En primer término, invita a dejar de lado una concepción puramente técnica de esta actividad, asumiendo una perspectiva ideológica y el sistema de valores que esta implica; en segundo término, a reconocer su potencial transformador en los sujetos con quienes trabaja; por último, a considerar la mediación en su dimensión dialéctica, como un proceso que se inventa continuamente en la propia práctica y, por último, a admitir que, en cuanto práctica de apropiación cultural, la mediación es un proyecto a largo plazo.

Otro valioso aporte de Munita a la construcción de la noción de mediación lectora es la de ecosistema mediador, de utilidad para la investigación en el campo de la formación de lectores. Este concepto hace énfasis en la interrelación y en la unidad que componen los individuos y sus ambientes y en el flujo de energía que se moviliza entre ellos, en torno a la lectura. Al respecto el autor explica: "Si hasta ahora la cuestión de la mediación de la lectura ha estado muy enfocada en la reflexión sobre los mediadores individuales, la visualización de un concepto como este podría ayudar a desplazar el interés hacia los entornos en los cuales esos mediadores actúan» (2014: 524). A nuestro entender, este concepto constituye una interesante herramienta teórica en cuanto permite relacionar, dar sentido y unidad a las nociones de mediación y mediador, que tanto en el campo de la acción cultural como en el de la enseñanza de la lectura aún se encuentran dispersas teóricamente, así como articular actores, funciones y contextos de acción en torno a ellas. 


\subsubsection{Animación y mediación lectora}

Por último, cabe referirse a la mediación de la lectura en el ámbito de la animación lectora, entendida como conjunto de actividades para «animar a leer en diversos contextos y con objetivos concretos, pero que pueden ser diferentes: leer un libro, leer libros de un tema concreto, leer libros de un autor, etc.» (Cerrillo y Cañamares 2008:78). Sobre el sentido que dicha expresión implica, Beatriz Robledo esclarece: "Animar, dar ánima, dar alma ${ }^{20}$. Es decir, dar vida. Quien anima infunde soplo vital a los libros, pero también anima al lector a entablar una relación más personal con los materiales de lectura» (s.d.:21).

En este marco, la mediación de la lectura es comprendida como una «intervención» (Yubero 2001 en Cerrillo, Larrañaga, y Yubero 2007:30), cuya finalidad radica en facilitar el encuentro entre los buenos libros y los lectores en formación, especialmente los niños y adolescentes; incidir en la creación de hábitos lectores y contribuir a la interpretación de los textos (Sehringer y Griotti 2002; Cerrillo, Larrañaga y Yubero 2007; Cerrillo y Cañamares 2008; Cerrillo 2009; Robledo s.d.).

Cabe aclarar que el escenario de la animación de la lectura es el de la lectura recreativa. A propósito de ello, algunos autores que adhieren a dicho modelo contraponen la lectura obligatoria - la lectura escolar - a la lectura voluntaria que se efectúa en otros contextos: bibliotecas, clubes de lectura, etc. Al respecto, Pedro Cerrillo y Elisa Cañamares explican: «Las lecturas obligatorias -las lecturas escolares - hay que aceptarlas y realizarlas. [...] Son lecturas que exigen esfuerzo, disciplina, tiempo y dedicación». Ambas lecturas deben estar en «necesaria convivencia»y, más adelante, los autores agregan: "La lectura escolar puede lograr que los niños asuman que leer es importante, pero difícilmente podrá conseguir que la lectura sea una alternativa de ocio para ellos. [...] No es extraño que esos escolares huyan de la lectura [...]» (Cerrillo y Cañamares 2008: 79).

La animación de la lectura ha recibido múltiples críticas; puede mencionarse, entre ellas, la que objeta su reducción a un conjunto de actividades de espectacularización de la lectura (Bajour 2009), y la que la acusa de «pedagogía incitativa», que al ocultar el modelo liberal que le subyace, en definitiva, no hacen más que transmitir el sentido de una práctica en forma difusa, confusa y selectiva (Privat 2001:49). Dentro de estas críticas se reportan también las que cuestionan la dicotomía lectura por placer-lectura por obligación en la que la escuela «carga con la culpa de obligar a leer, lo que estaría en flagrante contradicción con las prácticas sociales de lectura desarrollada en contextos extraescolares» (Bombini 2002:29), y las que critican la desescolarización de la lectura que el modelo propone, promoviendo una relación ingenua o una renuncia de la educación a la mediación de la lectura (Díaz Sunico 2005; Álvarez Zapata y Castrillón 2009).

Para dar un cierre a la discusión que se sostuvo en este apartado, solo resta sintetizar los aportes que de las diferentes concepciones sobre mediación de la lectura surgen a la luz de la indagación realizada. Esta síntesis permitirá prefigurar el sentido de dicha expresión con la amplitud teórica que esta merece, si la intención es la de contribuir a dar sentido a la figura, roles y perfiles de los mediadores sobre quienes se centrará el próximo apartado.

Frente a la concepción de mediación de la lectura propuesta desde el paradigma de la animación lectora, de alcance más concreto, en este trabajo se opta, sobre la base de los aportes teóricos

\footnotetext{
${ }^{20}$ Cecilia Bajour discute el sentido del término animación y, por consiguiente, la concepción que le subyace. Al respecto afirma que es «[...] una palabra que a mi juicio esconde o sugiere la idea de que hay algo, la lectura y los lectores, en este caso, a lo que le falta ánimo o hay que reanimar.» (2009: en línea).
} 
reseñados, por la que la considera una práctica de intervención simbólica, de acción y promoción cultural y política, orientada a la humanización y construcción de ciudadanía a través de su acción en el espacio mediador de la cultura escrita.

\subsubsection{El mediador de lectura}

En un primer momento, este apartado ahonda en la figura, roles y perfiles que definen al mediador de lectura. A continuación, en las secciones «El mediador de lectura y la lectura en voz alta» $(\rightarrow 1.2 .5 .1$.) y «El mediador de lectura y la conversación sobre lo leído» ( $\rightarrow 1.2 .5 .2$.) se abordan las herramientas a las que estos recurren en las instancias de lectura mediada. Por último, en la tercera sección: «El mediador de lectura de esta tesis» $(\rightarrow 1.2 .5 .3$.) se configura la especificidad de los mediadores protagonistas de este estudio.

Como señala Six, el rol que cumplen los sujetos a los que refiere este trabajo es de índole pedagógico (1997). En tal sentido, tienen vigencia la generalización que Tébar Belmonte realiza sobre la figura del mediador, para el caso específico del mediador de lectura como intermediario, amplificador, adaptador y diseñador en y del proceso formativo de una persona (2011: 20).

Al igual que sucede con la noción de mediación de la lectura, al explorar la de mediador para esta práctica específica, salta a la vista, desde un primer momento, la «indeterminación conceptual» constatada por Munita (2014: 45). En consecuencia, quien desee profundizar sobre el concepto en la literatura de referencia encontrará que, ya desde el inicio, acontecen nominaciones diversas para designar lo que, en esencia, es una misma función: la de facilitador (Chambers 2007b), patrocinador de la cultura escrita (Kalman 2008), iniciador (Petit 2001), animador (Robledo s.d.), entre otras.

Cabe aclarar, además, que si bien algunos autores hacen extensiva la expresión mediador de lectura a las instituciones e incluso a las herramientas tecnológicas ${ }^{21}$, en el marco de este trabajo su significado quedará acotado al de personas concretas.

Desde la perspectiva de la acción cultural a la que ya se hizo referencia, el mediador de lectura es comprendido como actor social que inscribe su práctica en el marco más amplio de la cultura escrita. En ese sentido, Álvarez Zapata y Castrillón enfatizan las dimensiones ética, política y pedagógica y el rol simbólico, emancipador y humanizante que otorgan sentido a su figura, advirtiendo, además, sobre la necesidad de profundizar la reflexión en torno al su rol (2009).

Kalman, en sintonía con lo expuesto, establece el rol dialógico de quienes se encargan de introducir a otros en la cultura escrita, en hacer que los sujetos con quienes interactúan se involucren en las prácticas letradas que se desarrollan en su comunidad. El acceso a la cultura escrita, indica la autora, es un proceso social en que la participación e interacción con otras personas que la conocen y utilizan se vuelve indispensable (2003). Sostiene, además: «Los lectores y escritores demuestran a otros cómo

\footnotetext{
${ }^{21}$ Al respecto, García Canclini establece: «No solo las personas —o sea los padres, los maestros, los libreros, los escritores - son mediadores entre los textos y los lectores. No solo las instituciones: bibliotecas, salas de lectura, editoriales, ferias. También las herramientas tecnológicas [...]» (2015: 21). También A. M. Chartier incluye en la definición de mediador de lectura a las personas o instituciones (la escuela, familia, y la biblioteca, entre otras), [...] que actúan como intermediarias o se interponen para conseguir que los niños accedan a la lectura en general y al mundo de los libros en particular» (2009:30).
} 
interpretar y usar los textos; cómo leer el mundo con la experiencia personal y los textos como referencia, y cómo la cultura escrita puede lograr un lugar en la vida personal y social» (Brice Heath y Mangiola, 1991 en Kalman 2008:124).

En su investigación, Martín-Barbero y Lluch $(\rightarrow$ 1.1.1.) configuran al mediador de lectura en la dualidad de su rol como agente y actor: a la vez que su participación da forma a la práctica de lectoescritura, su gestión y acompañamiento permiten madurar y transformar esta práctica en una experiencia de lectoescritura y vida para sí mismos (2010). Estos autores determinan para los sujetos que investigan tres tipos o perfiles, entendidos estos como el conjunto de rasgos peculiares que los caracterizan, en función de las prácticas que desarrollan, del contexto y los recursos con los que cuentan:

-El mediador que proviene del ámbito familiar, no profesional, formado en la experiencia (padres u otros agentes comunitarios), que acaba transformándose en gestor de sus actividades y las de su grupo;

-El mediador de una práctica de lectura, relacionado con la biblioteca o el centro escolar, quien está directamente vinculado con los usuarios de la práctica, pero no necesariamente forma parte de su grupo social;

-El gestor político o cultural quien diseña, evalúa, propone y ejecuta cambios en las prácticas para su mejora. Este mediador crea las condiciones económicas y sociales para que la práctica encuentre un terreno adecuado para su desarrollo.

Entre las funciones de los mediadores a quienes investigan, Martín-Barbero y Lluch establecen la de coordinar, dinamizar y crear un espacio de comunicación en torno a una historia o libro. Revelan, asimismo, la complejidad de su tarea: el mediador de lectura trabaja con seres humanos, «diversos y complejos» a los que tiene que entusiasmar, estimular, coordinar, acompañar, hacer que se integren y formen parte de las prácticas de lectura que se desarrollan en su comunidad (2010: 108-109).

Entre las cualidades del mediador, destacan las que inciden directamente en el éxito de las experiencias que lideran: su actitud abierta, su compromiso social con la comunidad, la perseverancia y permanencia en su rol (2010: 91-96).

En otro orden, desde los estudios antropológico, Petit inscribe la labor del mediador de lectura en el universo de la transmisión cultural. Destaca su papel para iniciar a otros en la lectura, sobre todo a aquellos que, por motivos sociales, culturales y hasta geográficos se encuentran alejados de la cultura escrita. Entre las funciones del mediador, cita la de compartir sin imponer; acompañar; revelar y legitimar el deseo de leer; ampliar el acceso a los libros, y la de motivar a «traspasar umbrales» (1999, 2011, 2016). La tarea del mediador, expresa la autora, "es un arte de acogida y disponibilidad» que pone en juego la escucha; la observación; la apertura hacia los otros; la propia relación con los libros y le lectura. Implica además hacer un trabajo sobre sí mismo, ya que para transmitir el amor por esta práctica hay que haberlo experimentado $(2011,2016)$.

En sintonía con lo expuesto, Ani Siro destaca la función pedagógica de los mediadores de lectura en la inclusión en la cultura escrita en general, y en una comunidad de lectores, en particular, especialmente de quienes provienen de sectores sociales desfavorecidos. El mediador, acota: «[...] puede ser un puente de pertenencia y experiencia simbólica que alivie la exclusión» (Siro, 2005: 47).

Y en contrapartida, Kalman advierte que no siempre la figura de los mediadores es aceptada positivamente por sus destinatarios. El vínculo entre ambos, que se instaura en la complejidad de las relaciones intersubjetivas, los sujetos a quienes va dirigida la acción del mediador pueden asumir 
posturas de resistencia o rechazo, y agrega: «En ciertos contextos esto puede ser la regla y no la excepción. La resistencia y el rechazo constituyen también una relación entre el agente y un mediador e inclusive impactan en el desarrollo del agente de manera importante» (Wertsch 1998:144-145 en Kalman 2003).

En el campo de la educación literaria, y al igual que lo hace con la de mediación lectora, Munita propone una perspectiva holística sobre el mediador de lectura, en la que hace confluir las caracterizaciones que sobre su figura se efectúan desde diferentes marcos teóricos:

[...] nos parece que una definición integral del mediador de lectura sería pensarlo como un actor que, premunido de habilidades y saberes de diversos ámbitos ligados al campo cultural y al trabajo social, interviene intencionadamente con el propósito de construir condiciones favorables para la apropiación cultural y la participación en el mundo de lo escrito por parte de sujetos que no han tenido la posibilidad de disfrutar de esas condiciones (2014: 46).

Con la impronta ya señalada, Munita establece entre las funciones del mediador la creación de situaciones de lectura en las que intención y propósitos son compartidos por los participantes, la puesta en juego de la literatura y lo escrito como una forma de diálogo con la vida personal del sujeto y con la vida sociocultural de su comunidad (2014: 43).

Por otra parte, Mirta Castedo (2011) y Robledo (s.d.) caracterizan al mediador como un intérprete de la cultura escrita. Al respecto, la primera indica: «[...] un mediador es un intérprete, como tal, se encuentra en una zona de intersección entre la cultura escrita y quien se introduce en ella. El mediador ofrece su voz, sus gestos, sus trazos, su postura... para construir una interpretación y representación posibles del mundo» (2011:30).

Robledo establece entre las funciones del animador-mediador, a quien define como «lector agudo» y «experimentado», la función de seleccionar los libros de acuerdo con su calidad estética, orientar la exploración de los textos y ofrecer claves para descubrir significados a los que los destinatarios no podrían acceder por sí mismos. Apunta además que su intervención es fundamental para que los lectores encuentren caminos personales para la apropiación de los textos (s.d.: 21-30).

En este panorama, queda aludir a la postura asumida por otro grupo de autores quienes caracterizan al mediador enfatizado su rol de enlace o puente entre los libros y los lectores (Cerrillo, Larrañaga y Yubero 2002; Fittipaldi 2009). Este nexo también es destacado por Montes en una peculiar metáfora que, además, destaca el protagonismo del mediador en la formación de los lectores: «Los lectores no se encuentran con los textos en el vacío, sino -siempre- en situaciones históricas concretas, en determinado lugar y determinada hora del día, en determinado momento de su historia personal, en ciertas circunstancias, mediando ciertos vínculos [...] Y los mediadores, que hacen de nexo, de casamenteros entre el lector y el texto, quedan ligados a la experiencia misma» (Montes 2006: 17).

Otra constatación que surge en la indagación realizada es la referencia prescriptiva a la figura, funciones y perfiles que el mediador de lectura debe cumplir, tanto desde las políticas públicas (Martín-Barbero y Lluch 2010; LCFL s.d.) como desde algunos ámbitos profesionales. En este orden, Constanza Mekis caracteriza al «buen mediador» como "un profesional preparado que, abierto al azar de los descubrimientos de los lectores, es capaz de responder a sus dudas e inquietudes; de ser una presencia que dirija y encauce su navegar [...] (2013: 378) o como sujeto que activa "en su hábitat el bien cultural del buen leer» (s.d. 11) de otros lectores». Este mediador, acota la autora, debe desarrollar prácticas «llenas de simpatía y consideración por el otro, suficientemente abiertas para que acojan a los niños y 
jóvenes en su propia realidad, con sus problemas, dilemas e intereses y sueños» o generar un espacio acogedor para que se produzca el encuentro entre los niños, los jóvenes y los libros (s.d. 11).

Por otra parte, Mekis establece una relación entre el tipo de mediador que se es y las experiencias y preferencias de lectura personales, ya que estas inciden en la configuración de su estilo. Es así como puede identificarse al mediador sobrio: quien no necesitan elementos externos que acompañen su función; al equilibrista, cuya principal preocupación es dar a conocer distintos tipos de lectura a sus destinatarios; el investigador, que se preocupa de fomentar la curiosidad entre quienes lo rodean y generar interrogantes; el buen conversador; el empático, que posee una sensibilidad especial para recomendar libros, y el tecnológico, entre otros (2013).

Con la misma impronta, Cerrillo y Cañamares señalan entre las funciones del mediador la de crear y fomentar hábitos lectores; ayudar a leer por leer, diferenciando la lectura obligatoria de la lectura voluntaria; orientar la lectura extraescolar; seleccionar las lecturas; preparar, desarrollar y evaluar las animaciones a la lectura y transmitir el gozo por la lectura. Entre las cualidades que debe poseer el mediador para realizar con éxito su función se encuentran la de ser un lector habitual, convencido de las bondades de la lectura; el tener conocimiento del grupo y del contexto donde desarrolla su función y capacidad de generar la participación con compromiso y entusiasmo; contar con formación literaria, psicológica y didáctica, y manejar técnicas y estrategias de animación lectora, entre otras (2008:81).

Como bien señala Colomer al referirse al mediador de lectura: «En cualquier cultura los adultos “intervienen" para hacer que las nuevas generaciones aprendan lo que se necesita para vivir [...]» (2004: 9). En este orden, si bien la figura del mediador ha adquirido importancia en los últimos tiempos, tiene presencia y continuidad histórica. Al respecto, A. M. Chartier, analiza las transformaciones que se han sucedido en torno a ella a lo largo del tiempo, enfatizando, además, la esencialidad de esta función para perpetuar el diálogo entre los libros y la infancia y para hacer «que el mundo de los textos entre en el mundo del lector» (A. M. Chartier 2009:48).

Con perspectiva diacrónica, esta investigadora explica cómo a comienzos del siglo XX los adultos abandonaron su papel prescriptor y se asumieron como guías en la función de acompañar a los jóvenes lectores a descubrir en los textos los valores de fraternidad y respeto que estos les transmitían. En la década de 1930, estos adultos-mediadores asumieron un doble papel: el de ayudar a aquellos niños a quienes les costaba leer solos a descubrir las obras maestras de la literatura infantil, prevalenciendo la función transmisora y, en los cincuenta, se convirtieron en defensores del libro frente a las historietas y la literatura de mala calidad. Finalmente, en la década de 1970, cuando el «placer de leer» se transformó en «eslogan consensuado» (2009: 46), todas las acciones de los adultos destinadas a favorecer la lectura fueron validadas.

En las escenas de lectura protagonizadas por los mediadores que se investigan en esta tesis, la lectura en voz alta (o a viva voz) y la conversación sobre lo leído se convierten en herramientas esenciales para la creación de comunidades de lectores que se configuren en comunidades interpretativas (Colomer 2005; Silva-Díaz 2006). Al respecto, este concepto acuñado por Stanley Fish adquiere centralidad al enfatizar en que los lectores perciben los significados de los textos dentro de una estructura normativa de impronta social. En este marco, las actividades interpretativas no quedan libradas a la individualidad, sino que están acotadas por estrategias, prácticas y sobreentendidos comunes que se comparten entre los integrantes de una comunidad y se deducen de la precomprensión de intereses y metas compartidas (2008). 
En consideración con lo expuesto, se dedicará las dos próximas secciones a analizar la incidencia de la lectura en voz alta y la conversación sobre lo leído en la construcción de sentido, en las escenas de lectura protagonizada por los mediadores.

\subsubsection{El mediador de lectura y la lectura en voz alta}

Varios son los autores que acuerdan, aportando diferentes argumentos, con lo que Colomer sintetiza en estas palabras: la lectura compartida es la base de la formación de lectores $(2004,2005)$. El compartir lecturas posibilita vivenciar la dimensión socializadora de la lectura y sienta las bases, como ya se mencionó, para la conformación de una comunidad de lectores (Colomer 2005).

En la investigación psicológica, Enrique Riquelme destaca el componente afectivo implícito en la lectura mediada: esta hace posible que los niños exploren y reconozcan las emociones y contribuye a la creación de comunidades saludables desde el punto de vista afectivo. En la lectura mediada, el lenguaje literario; la narración visual; las pausas, tono y ritmo de lectura; la expresión facial y los movimientos del mediador, convergen en un «mismo andamiaje» que permite «adentrarse en los universos emocionales del texto» (2013: 139).

También en la lectura compartida se origina el deseo de leer; leer con los demás «es el puente para leer en solitario» (Colomer 2005: 195) y, a la vez, el inicio a la lectura personal (Chambers 2007; Patte 2011).

El escuchar leer una y otra vez la misma historia permite acceder al lenguaje escrito y comprender que la escritura «fija las palabras de tal manera que no se desorganizan ni se confunden (2006:62). Contribuye también al desarrollo del vocabulario, a la incorporación de los modos de decir propios de la literatura, a la comprensión de conceptos y a «pensar solo con palabras» (Colomer 2004).

Existe, por otra parte, una estrecha relación entre escuchar leer en voz alta y la comprensión de la lectura. Leer con otros, además, hace posible beneficiarse de la competencia de lectores más expertos para construir sentido sobre lo leído (Colomer 2005). Esta constatación es válida también para el ámbito escolar en el que la lectura en voz alta permite la convivencia, el intercambio y la conversación sobre lo leído entre los alumnos, independientemente de la capacidad lectora de cada uno de ellos (A. Chartier en Poulain 2010). Con similar impronta, Ana María Kaufman establece en su modelo didáctico22 la lectura por parte del maestro, que permite a los niños conectarse, apropiarse del lenguaje escrito y comprender el texto a través de la voz del docente (2009).

Es también conocida la relación entre la lectura en voz alta y la creación de referencias culturales compartidas. Escuchar historias en compañía asienta las bases de una cultura común que enriquece la comunicación y genera, en las alusiones a ese patrimonio en común, un sentimiento de pertenencia y participación (Patte 2011). Por otra parte, el compartir historias leídas colabora en la construcción de la biblioteca mental, entendida como el conjunto de referencias culturales que hace posible la comprensión de la cultura escrita (Hébrard 2006:4). Contribuye asimismo a la creación de cohesión social en un doble sentido: como instancia de socialización en sí misma, de fortalecimiento de una comunidad lectora, al crear lazos de convivencia en torno a una lectura que despierta motivación y emociones compartidas (Beuchat 2013), y como medio de establecimiento de redes sociales verticales,

\footnotetext{
22 Este modelo integra cuatro situaciones didácticas fundamentales centradas en el protagonismo del niño: leer a través del maestro, escribir a través del maestro, leer por sí mismo y escribir por sí mismo (Kaufman et ál. 2009).
} 
que conectan a sujetos pertenecientes a distintas generaciones (abuelos, padres, hijos) y tradiciones culturales (Colomer 2005).

La lectura en voz alta constituye la puerta de ingreso a la literatura y al lenguaje literario. Revela a sus destinatarios el aspecto lúdico y ficcional de la literatura (Munita y Riquelme 2009) y los ayuda a familiarizarse con los encadenamientos de palabras cada vez más ricos y complejos, propios de la literatura (Patte 2011).

Por último, la lectura en voz alta del mediador acerca a los sujetos destinatarios de la mediación un modelo de lectura fluida que aporta ritmo, pronunciación, entonación, acorde con la obra leída, y enseña a escuchar en forma apreciativa y analítica (Beuchat 2013).

Munita y Riquelme indican que para lograr una lectura mediada eficaz, el mediador debe recurrir a elementos paralingüísticos tales como la entonación, el tono y el ritmo; estos se convierten en fundamentales «para canalizar en forma verosímil y atractiva la trama de la narración» (2011: 273). En sintonía, Meek y Robledo consideran la importancia de estos elementos en la lectura en voz alta. Al respecto, la primera establece: «El ritmo y el tono de la voz que nos leyó un cuento puede haber sido más importante que las palabras» (2004:104); la segunda compara al mediador con «el intérprete de una partitura» quien «toca los libros con su voz y los llena de sentido» (s.d. 22).

La modalidad de lectura descrita por los autores referidos encuentra coincidencias con la que Cerrillo y Yubero denominan lectura expresiva ${ }^{23}$, a la que definen como un "arte del lenguaje» y describen de esta manera: «Trate de dar expresión a la voz, para que se comprenda el sentido de la lectura. Dramatice un poquito los diálogos, Ajuste el ritmo a la acción de la historia. Subraye ligeramente los sentimientos expresados. Siga el sentido que marcan los signos de puntuación. En los momentos más emocionantes, lea más despacio o más deprisa para crear una atmósfera de suspenso y acrecentar el interés. Ajuste el ritmo, el tono y el volumen a las necesidades del relato» (2003:225).

\subsubsection{El mediador de lectura y la conversación sobre lo leído}

La conversación sobre lo leído, antes, durante o después de la lectura en voz alta, realizada en forma espontánea o planificada, es también constitutiva de la acción del mediador.

Desde la perspectiva más general que brinda la investigación educativa, Gordon Wells destaca el papel mediador del diálogo en la construcción del conocimiento y del aprendizaje que se produce en la interacción comunicativa. El aprendizaje es un proceso activo de creación de significado, orientado a incrementar la comprensión y que, en esencia, es intrapersonal y colaborativo. El autor representa este proceso dialógico con una espiral continua que, partiendo de la experiencia personal, crece y se expande en la interrelación con el discurso y la comprensión (2003). En el mismo sentido, Joan Tough señala la importancia de la conversación como recurso para estimular el aprendizaje y alcanzar los objetivos educativos (1979).

Ya con el foco puesto en la mediación lectora, debe precisarse que en la indagación bibliográfica efectuada para este trabajo se constató que lo que aquí se denomina genéricamente conversación sobre

\footnotetext{
${ }^{23}$ Los autores dividen al proceso lector en tres niveles: el de la lectura mecánica (el lector domina la correspondencia fonema, grafema), el de la lectura comprensiva (el lector construye sentido a partir del texto escrito) y el de la lectura expresiva (el lector interpreta el texto y lo transmite a otro por vía oral). Se consideran niveles de lectura porque uno precede al otro y lo incluye (Cerrillo y Yubero 2003).
} 
lo leído asume distintas denominaciones y significados según el marco teórico en el que se inscriba: discusión literaria (Colomer 2012; Munita y Manresa 2012) discusión sobre lo leído (Kaufman, Lerner y Castedo 2015), conversación literaria (Bajour 2010), lectura dialógica (Molina Iturrondo 2001; Soler 2003; Valls, Soler y Flecha 2008) o debate interpretativo (Días-Chiaruttini 2010; 2011; 2014; 2015) son algunas de ellas.

Todas estas expresiones se aplican al diálogo y a las interacciones que se suceden en torno a la lectura en voz alta, entre niños y adultos mediadores. Mientras que las cuatro primeras expresiones se reservan para las prácticas que se realizan en el aula, de carácter planificado, el de lectura dialógica abarca además las que acaecen en otros ámbitos: hogar, bibliotecas o espacios educativos no formales, que puede adquirir, además, una impronta de comunicación espontánea entre los niños y los adultos allegados (Molina Iturrondo 2001). La elección de la expresión conversación sobre lo leído, por la que se optó en este marco de referencia, pretende incluir todas las modalidades de conversación en torno a los textos que leen los mediadores que aquí se investigan, sean estas planificadas o no.

La discusión literaria constituye una situación dialógica de co-construcción del sentido del texto, gestionada por el mediador. Munita y Manresa (2012) establecen que es el instrumento mediador (en el sentido vygotskiano) con mayor potencial para la formación del lector literario en cuanto permite construir en comunidad el sentido de los textos.

Como herramienta para la educación literaria (Colomer 2012), se caracteriza por la interacción entre pares y con el profesor, por la exposición de múltiples puntos de vista y la extensión de las interacciones verbales en torno a la lectura de libros.

Por otra parte, la expresión debate interpretativo $(\rightarrow$ 1.2.5.2.) designa en el sistema escolar francés a una modalidad institucionalizada de desarrollar la conversación o discusión literaria, surgida en la renovación de las prácticas de enseñanza del Francés y de la jerarquización de la enseñanza de la literatura en la escuela primaria. El debate interpretativo como tal es considerado un género disciplinar con estatus propio que se diferencia de otros géneros escolares (por ejemplo, del debate en otras disciplinas) o extraescolares (es el caso del debate social) y se asemeja al de otros discursos disciplinares (por ejemplo, la disertación filosófica). El debate interpretativo implica el aprendizaje del habla metatextual, y la reflexión y el dominio de herramientas propias de esta modalidad de discusión: saber expresar varias interpretaciones posibles, discutir la validez de una interpretación, interpretar un implícito o completar una ausencia del texto. No es reductible a una invitación a hablar del texto o a aplicar saberes de la lengua (gramaticales o de otra índole) ya aprendidos (Diaz-Chiaruttini 2011; 2015). Por otra parte, la lectura dialógica ${ }^{24}$ se centra el aprendizaje de la lectura en el contexto sociocultural. Este aprendizaje no se concibe como un proceso cognitivo individual, sino que se engloba dentro de un proceso más amplio de socialización en el que la lectura crea sentido acerca de la cultura escrita. La lectura dialógica implica el aumento de las interacciones alrededor de las actividades de lectura, multiplicando los espacios más allá de la escuela, donde tradicionalmente se realiza, y abriéndolos a personas muy diversas, e incluye la variedad de prácticas de lectura extraescolares, que se realizan en

\footnotetext{
${ }^{24}$ La lectura dialógica se basa en la perspectiva del aprendizaje dialógico. Por medio del diálogo las personas intercambian ideas, aprenden y producen conocimiento en forma conjunta y, como resultado de estos procesos, encuentran nuevos sentidos y transforman sus vidas. Esta perspectiva se basa en la noción de comunidad de aprendizaje, la teoría de la acción comunicativa de Habermas, la teoría sociocultura de Vygotsky y la concepción de dialogicidad de Bajtin, entre otras (Valls, Soler y Flecha 2008).
} 
las bibliotecas, en el hogar, en centros culturales, y con todas las personas que interactúan en las vidas de los niños (Soler 2001).

Finalmente, la lectura dialógica desplaza el foco de la construcción de significado, entendida como un proceso interactivo entre el lector y el texto, hacia su consideración como proceso intersubjetivo por el cual las personas profundizan sus interpretaciones y reflexionan críticamente sobre lo leído por medio de la interacción entre ellas, abriendo así posibilidades de transformación como ser humano y como lector. De esta manera, el proceso de interpretación, construcción de significado y creación de sentido en relación con lo escrito deja de ser individual y se torna colectivo (Soler 2001; Valls, Soler y Flecha 2008).

La conversación sobre lo leído posee una dimensión ética que debe ser considerada especialmente por el mediador. Al respecto, Álvarez Zapata y Castrillón destacan entre las cualidades que este debe desarrollar la disponibilidad, la empatía y la habilidad para abrir el diálogo y convocar la palabra, pero también para dar lugar al silencio que propicia la reflexión.

Particularmente, la confianza que depositan en el mediador los sujetos mediados constituye una condición para que estos aprendan a discutir literatura, con el convencimiento de que sus intervenciones van a ser tenidas en cuenta Bajour (2011). Esta disposición de acogida y de escucha remite a la dimensión afectiva de la mediación lectora, y es constitutiva de una comunidad de lectores (Munita y Manresa 2012).

Al igual que sucede con la lectura en voz alta, varios autores señalan la incidencia de la conversación en la construcción de sentido sobre lo leído.

Desde la investigación etnográfica, Rockwell, quien indaga sobre la mediación docente en las interacciones orales que se suceden en el aula en torno a los textos escolares ${ }^{25}$; establece: «En el contexto escolar, las interpretaciones posibles del texto se construyen en la interacción, no están dadas de antemano ni son inherentes al texto» (Rockwell 2001b: 222). Indica asimismo que cuando las interacciones no se producen, el texto permanece ajeno, y es más lejana la posibilidad de apropiación de su contenido (Rockwell 1991:41).

Destaca que la mediación docente se concreta en dos modalidades: la mediación conceptual - la que establece asociaciones entre el texto y otro tipo de conocimientos y el contexto - y la instrumental -que permite evitar digresiones y seguir el hilo del texto-, y ofrece a la vez que un esquema de interpretación los andamiajes necesarios para su comprensión (2001b).

Rockwell indica asimismo que cuando algún texto escrito aparece en la clase la relación bipolar maestro alumno se convierte en triádica, estableciéndose, además, un vínculo dialéctico entre lo oral y lo escrito: la presencia del texto obliga a modificar las pautas de interacción y la dinámica oral incide en la interpretación del texto (1991: 32). Las mediaciones del discurso docente, continúa diciendo la investigadora, no solo proporcionan una representación alternativa de los contenidos del texto; señalan

\footnotetext{
${ }^{25}$ Rockwell señala la especificidad de los eventos de habla que se producen en el aula: la necesidad de transmitir conocimientos le da un carácter asimétrico a la interacción; el maestro posee un estatus de autoridad que determina el desarrollo de la interacción; marca los ritmos cambios y cierres; el cambio de turnos es de maestro a alumno y no de alumno a alumno; el maestro pregunta y los niños contestan; las preguntas son hechas por quien conoce la respuesta en lugar de por quien busca nueva información. Se da la respuesta a coro, la recitación y el dictado. Las clases escolares establecen un continuo oral-escrito y limitan la negociación de significado entre los participantes (Tannen, 1982 en Rockwell 1991:31).
} 
diversas formas de relacionarse con la lengua escrita o de entender el acto de leer, al privilegiar determinadas maneras de interpretar y de atender selectivamente al texto (Rockwell 2001b:199).

También, desde los estudios antropológicos, Petit indica la influencia positiva «si el libro vive con la familia y en particular si se vuelve objeto de conversación» (Petit 2005:10) en el surgimiento del gusto por la lectura y en establecimiento de vínculos afectivos, emotivos con este objeto cultural.

Hébrard, por su parte, destaca la importancia de socializar las lecturas y conversar sobre lo leído en la escuela como forma de crear intercomprensión; indica que lo importante no es dar libros a los niños, sino enseñarles que no hay lecturas fuera de las comunidades (2000), y agrega:

Yo no estoy tan seguro de que la lectura sea algo tan bueno, quizás sea algo muy malo, pero la discusión, eso sí que es algo importante, y si no logramos compartir, ¿entonces para qué leer un libro? [...] lo importante en nuestras sociedades es crear intercomprensión entre hombres y mujeres, entre generaciones. [...] la representación que tuvimos de la lectura desde los años setenta, ochenta y noventa es la de monjes cistersianos, es decir gente que no hablaba con nadie, que se pasaba la vida adentro de los libros. Pero nuestras sociedades modernas no son monasterios de monjes, sino lugares donde la intercomprensión es algo absolutamente decisivo, porque es la base misma de la democracia (2006: 6.).

Desde el campo educativo, Meek establece también la interrelación entre el hablar sobre lo leído y la comprensión del mundo: «En sus interacciones cotidianas con los adultos, los niños descubren que pueden hablar sobre lo que sucede en los libros, y también pueden aplicar su comprensión cotidiana del mundo para interpretar lo que leen» (Meek 2004:144).

En esa misma dirección, Chambers señala ${ }^{26}:$ «Hablar sobre literatura es compartir una forma de contemplación. Es una manera de dar forma a los pensamientos y emociones excitados por el libro y los significados que construimos juntos a partir del texto [...]» (Chambers: 2007a:27). Este autor propone que las situaciones de lectura compartidas se realicen en torno a tres ejes: compartir el entusiasmo, compartir el desconcierto y compartir las conexiones entre los textos, y acota que la interpretación del sentido de una obra no es una tarea individual. Comienza en el compartir lo que cada uno sabe, que se negocia y construye colectivamente, para luego avanzar hacia la construcción cooperativa de un saber compuesto por diferentes entendimientos. (Chambers: 2007a: 69). Destaca además la importancia de la relectura y de la conversación recursiva, pues el sentido sobre lo que se lee no se construye en una única vez.

Siro destaca la importancia de conversar sobre lo leído para generar la autonomía de los lectores: «Leer, escuchar leer y ver, dejarse impactar, interpretar, compartir con otros las impresiones, volver sobre la obra, buscar indicios que sostengan las interpretaciones, confirmar y /o reformular, compartir y /o confrontar con otros las interpretaciones, volver nuevamente sobre la obra en busca de nuevos indicios... son prácticas que consolidan la formación de un lector que en adelante pueda ser capaz de llevar a cabo con autonomía ese proceso en nuevos contextos, con otras obras y autores.» (2005: 8687).

\footnotetext{
${ }^{26}$ Al respecto, Chambers propone el enfoque Dime, una propuesta dirigida a los educadores sobre cómo intervenir para ayudar a los niños a hablar sobre lo leído. Este es una propuesta abierta, que sugiere maneras de formular preguntas promotoras del intercambio entre los niños a propósito de la lectura literaria (2007a).
} 
Desde la educación literaria, Cecilia Silva-Díaz aporta que, en las prácticas de aula, la discusión literaria, además de incidir en la interpretación sobre lo leído, contribuye a enseñar las normas de funcionamiento de estas conversaciones entre los lectores. Asimismo, advierte sobre las particularidades que impone el contexto escolar en las respuestas lectoras de los alumnos en las discusiones colectivas sobre lo leído, en la medida que inhibe aquellas que podrían expresarse en ámbitos informales y favorece otras que no se producirían sin la mediación de los profesores (2006).

Munita y Manresa destacan también la importancia de hablar sobre lo leído para elaborar inferencias sobre las narraciones y poner en juego los saberes literarios aprendidos (Munita y Manresa 2012:134), además de la construcción compartida y dialógica de la comprensión e interpretación sobre lo leído. En el mismo sentido, Vanesa Amat indica que la reflexión conjunta sobre las obras literarias es necesaria para aprender a expresar juicios propios acerca de estas. Esta autora estudia además cómo a partir de conversar sobre lo leído las opiniones de los niños avanzan desde las valoraciones personales hacia otras más críticas y reflexivas y ganan progresiva autonomía. La verbalización de las dificultades de comprensión o desconcierto generan respuestas en los compañeros, que además de ayudar a la comprensión general, hace que pongan en juego sus propias reflexiones. El contraste de opiniones durante la conversación sobre lo leído posibilita el descubrimiento, la elaboración y la profundización de las reflexiones individuales (2010).

Desde la investigación situada en el paradigma de la educación literaria, Colomer y Margallo confirman la potencialidad de la discusión literaria para el desarrollo de la capacidad interpretativa: "Tan pronto como se presentan los libros a los niños, se inicia una búsqueda de sentido de las historias a través de la conversación. [...] De inmediato se aprecia cómo los niños se valen de distintas estrategias para adentrarse en la comprensión del texto a partir del diálogo cruzado entre la obra, la discusión y sus propias experiencias de vida (2013: 37).

Por otra parte, Munita y Riquelme destacan la incidencia del diálogo como espacio de interacción para que los niños expresen las representaciones que construyen sobre la función de la emoción, tanto en el contexto de la ficción como en el real: «[...] en la lectura mediada, el aprendizaje vicario de emociones no se da solo en el encuentro con el libro en sí mismo, sino que esto se acompaña por la lectura que el mediador hace del texto. En otras palabras, es en el contexto de lectura y diálogo en donde la emoción se sitúa. [...] allí el adulto lector entrega la seguridad en la exploración de mundos, que constituyen los conjuntos de narraciones de una serie de interacciones sociales acaecidas en la ficción» (Riquelme y Munita 2011: 274).

Son tres las variables fundamentales que en la bibliografía de referencia emergen como incidentes, en el entorno de la conversación de la lectura mediada, en la construcción de sentido y en el crecimiento del lector. En primer lugar, la práctica continuada de la discusión, que contribuye a hacer progresar la complejidad de las respuestas y la autonomía de los lectores (Amat 2010; Colomer y Margallo 2012); el tiempo que se dedica a hablar y escuchar hablar sobre los libros, y la construcción de un ambiente de confianza que favorezca la dimensión socializadora de la lectura (Munita y Manresa 2012). Este contexto es el que Chambers conceptualiza en la expresión ambiente de la lectura como entorno social favorable en donde esta se desarrolla. Este abarca la disposición (actitudes mentales y emocionales que involucran nuestras acciones); circunstancias (entorno físico y su pertinencia para determinada actividad); la disponibilidad y accesibilidad de los materiales; y el tiempo que se le dedica a la lectura. 


\subsubsection{El mediador de lectura de esta tesis}

Al llegar aquí, sobre la base de los aportes teóricos recogidos, se hace necesario caracterizar al mediador de lectura que protagoniza este estudio.

En primer lugar, cabe inscribir su acción en el universo de la cultura escrita de la cual forma parte, y en un plano más concreto, en el entorno de la comunidad situada sociohistóricamente en la que desarrolla sus prácticas de lectura y en la que, siguiendo a Castedo (2011) y Robledo (s.d.) oficia de intérprete.

Debe señalarse además el carácter dual de su figura: en primer lugar, en cuanto es actor y agente de los procesos sociales y culturales que promueve, pues, de manera dialéctica, impulsa transformaciones sobre las prácticas letradas y modos de leer de los sujetos a los que dirige su acción, a la vez que se transforma con ellas. Y, en segundo lugar, en cuanto su figura se sitúa en el cruce de dos ámbitos: el familiar de origen (Martín Barbero y Lluch 2010) y el de la institución escolar. En este sentido, en el marco de este trabajo, los mediadores de lectura se conciben como un nexo entre estos dos ámbitos señalados.

La figura del mediador de lectura de este estudio comparte con el mediador escolar de lectura literaria de Munita ( $\rightarrow 1$ 1.1.2.) (2014) el contexto en el que desarrolla su función (la educación formal) y el hecho de constituir un modelo de comportamiento lector $^{27}$ para los niños a quienes lee.

Para la labor que desarrollan los sujetos que aquí se investigan, es pertinente la complejidad señalada por Álvarez Zapata y Castrillón 2009 y Martín-Barbero y Lluch 2010: 108-109, prefigurada por la dimensión ética, política y pedagógica que asume su rol; por desarrollar su trabajo con seres humanos «diversos y complejos», y porque su hacer, además, está condicionado por la gramática escolar que impone horarios, la clasificación de los niños por edades y capacidad para aprender en clases, etc., y el grado de disposición y apertura de cada docente a recibirlos, entre otros aspectos.

Por último, debe destacarse la dialogicidad presente en la figura de los mediadores de lectura, quienes contribuyen -en forma intencional o no- a la inclusión de los sujetos con los que interactúan en la cultura letrada y promueven su crecimiento dentro de esta.

\subsubsection{Los estilos de enseñanza o pedagógicos}

Como ya se adelantó ( $\rightarrow$ Introducción) la noción de estilo de enseñanza ${ }^{28}$ ha sido adoptada como herramienta teórica en este trabajo en función de su potencial para describir e interpretar, con perspectiva heurística, el ser y hacer de los mediadores de lectura de la comunidad.

Al pretender elaborar el marco interpretativo que dé cuenta de una noción operativa a este estudio, es posible encontrarse, en primer lugar, con la larga tradición que la noción de estilos de enseñanza posee en educación y, en segundo lugar, con la amplitud y profusión con que dicho constructo teórico ha sido empleado en el campo de la investigación educativa (psicología y filosofía de la educación, pedagógicos y didáctica, pensamiento del profesor, trabajo docente...) para caracterizar la singularidad de los

\footnotetext{
${ }^{27}$ El comportamiento lector se define como la forma en que una persona representa y practica la lectura en el contexto de la cultura escrita que lo acoge (Álvarez, D. 2006 en CERLALC-Unesco 2011).

${ }^{28}$ En la bibliografía relevada las expresiones estilo (o estilos) de enseñanza, estilo pedagógico o estilos de enseñanza pedagógicos son sinónimas; en cada caso se respetó la terminología empleada por cada autor para hacer referencia a ellas.
} 
enseñantes (De León 2005; Rendón Uribe 2013). Estas investigaciones, realizadas en diferentes épocas y contextos, fueron confiriendo y transformando el significado de la noción de estilo de enseñanza, conforme a sus propósitos, objetos y dimensiones de análisis particulares.

Es la tradición y amplitud de uso de la noción de estilos de enseñanza la que brinda, precisamente, la oportunidad de hacerla extensiva en esta indagación a los mediadores de lectura de la comunidad sobre los que trata esta tesis.

En consecuencia con lo señalado, este apartado propone efectuar una mirada diacrónica y panorámica que recomponga el contexto de emergencia y transformación de la noción de estilos de enseñanza, deteniéndose, en este recorrido, en aquellos estudios que surgen como paradigmáticos o son valiosos en cuanto se configuran como hitos para la construcción de la noción en cuestión.

La singularidad de los docentes fue objeto de consideración, desde muy temprano, por la pedagogía. Las primeras líneas de investigación en torno a los estilos del profesor surgieron con el fin de contrastar empíricamente los postulados de la Escuela Nueva y enfrentarlos a los de la escuela tradicional. Estos primeros estudios, centrados sobre el efecto maestro, se llevaron a cabo en Estados Unidos, entre las décadas del cuarenta y sesenta, orientados por la premisa de que si algunos docentes obtenían mejores resultados que otros en relación con los aprendizajes de sus alumnos, era debido a alguna característica de su personalidad. Este postulado se concretó, en un primer momento, en las investigaciones en torno a los estilos de liderazgo del profesor, que tuvieron como propósito identificar aquellas variables (variables presagio) que podían incidir en el desempeño de los alumnos (variables producto). En esta perspectiva, el estilo de enseñanza, constituido por la personalidad del profesor, era la variable independiente de la que dependía el factor alumno (Cols 2007: 28).

Las investigaciones presagio-producto intentaron identificar estilos globales de docentes; partían del postulado de que al poder establecer los estilos de los mejores profesores, es decir, de quienes lograban un mayor impacto en el aprendizaje de sus estudiantes, podrían introducirse mejoras en la enseñanza y alcanzarse mejores resultados en las evaluaciones. Los estilos sobre los cuales se investigaba constituían categorías preexistentes y se configuraron desde la teoría con escaso apoyo empírico. Como resultado, estas investigaciones propusieron tipologías de estilos pedagógicos bastante similares, que modelizaban los comportamientos de los docentes sobre parámetros contrapuestos, por ejemplo, la del docente autoritario versus democrático, de Lewin; autocrático, democrático, laissez-faire, de Lippit y White, o dominador versus integrador, de Anderson, pero no lograron establecer un vínculo entre los estilos de los profesores y los aprendizajes de los estudiantes (Montero 1990: 273-276; Bressoux et ál. 1999: 98; Cols 2007: 27).

Las investigaciones presagio-producto derivaron, en la década del setenta, en las de proceso-producto; estas, si bien mantuvieron el enfoque prescriptivo, y el propósito de impulsar mejoras en la enseñanza para elevar los aprendizajes de los alumnos, a diferencias del primer grupo de estudios, intentaron determinar estilos personales de los profesores, identificando empíricamente sus comportamientos (variables de proceso) y relacionándolos con los rendimientos de los estudiantes (variables producto). Estos trabajos se efectuaron mediante metodología cuantitativa e incluyeron el análisis de otras variables vinculadas con el comportamiento de los profesores tales como su formación y experiencia profesional (Montero 1990: 276; Bressoux et ál. 1999: 98; Cols 2007:28).

Dentro de este grupo de investigaciones debe destacarse el trabajo de Neville Bennet. La investigación que este y su equipo desarrollaron tuvo por propósito confrontar los estilos de enseñanza con el 
progreso de los alumnos. Si bien partió de la teoría para determinar los estilos sobre la base de la dicotomía progresista y tradicional, construyó las categorías de análisis a partir de tres dimensiones: los objetivos, las opiniones y su relación con las formas de enseñar de los profesores, que expresó en un haz de rasgos constitutivos, multidimensionales, obtenidos en forma empírica en una muestra representativa de profesores (Montero 1990: 281).

El paradigma proceso-producto se concretó en un amplio corpus de trabajos sobre los estilos de los docentes que, al igual que los estudios que les precedieron, concluyeron con el establecimiento de estilos «mejores» que otros y de tipologías que servían de base para la comparación y clasificación de los profesores. Estas investigaciones, al igual que las de presagio-producto, recibieron numerosas críticas por la pobreza de sus conceptualizaciones, la limitación de sus variables a los aspectos comportamentales, pasibles de ser observados mediante un conjunto de técnicas, y por la idea de causalidad que les daba sustento, ya que establecían un paralelismo entre el comportamiento de los profesores y los logros de los alumnos. Por otra parte, no pudieron explicar cómo un mismo comportamiento del profesor podía tener diferente impacto en el rendimiento de un alumno a otro (Cols 2007:28-46).

En el contexto francés, en los años ochenta y noventa, bajo la influencia de las investigaciones procesoproducto, y además para rebatir los resultados de los estudios realizados en el ámbito anglosajón, se efectuaron una serie de trabajos sobre los procesos de mediación que, de alguna manera, atenuaban el efecto del factor maestro. Si bien este continuó siendo relevante, ya no era un determinante para el aprendizaje de sus alumnos; el comportamiento del profesor pasó a ser entonces un estímulo del rendimiento del alumno, que se tornó en una variable a ser tenida en cuenta al igual que los aspectos estructurales del contexto de enseñanza. Las prácticas pedagógicas, y particularmente los procesos de mediación maestro-alumno, se constituyeron entonces en el centro de un corpus de investigaciones que se propuso ahondar en las diferencias de las prácticas de los docentes, sin intención prescriptiva; se abandonó además la pretensión de establecer correlación alguna entre el factor maestro y el rendimiento de los alumnos. El análisis de las interacciones entre los actores educativos, del uso del tiempo pedagógico, de la organización de la clase, adquirieron así protagonismo. Otra innovación que introdujo este conjunto de investigaciones fue el empleo de metodologías cualitativas, que se combinaron con las cuantitativas (Bressoux et ál. 1999:98-107).

Dentro de este grupo de trabajos, debe destacarse el de Marguerite Altet, quien a comienzos de los noventa investigó sobre la figura de los profesores y sus prácticas reales de enseñanza, resignificando la noción de estilo pedagógico al que definió como la manera dominante, personal, de ser, de relacionarse y de hacer del enseñante (Altet, 1985: 9 en Altet 1993:92).

Esta investigadora asumió el concepto de estilos pedagógicos para categorizar las relaciones y acciones del profesor realmente implementadas, que hacen posible que los estudiantes transformen la información en conocimiento. La fuerza del concepto, según Altet, reside en su potencialidad descriptiva y explicativa, en cuanto constituye una herramienta operativa para la formación de los enseñantes. Los saberes sobre los estilos de enseñanza son saberes útiles para aquellos, en la medida que le permiten objetivar sus prácticas, identificar sus regularidades y sus variedades para hacerlas más eficientes. También ponen en evidencia que cada maestro participa de acuerdo con su estilo tanto en el proceso de enseñanza como en el de capacitación. Este conocimiento es un elemento clave en la construcción del profesionalismo docente. En palabras de Altet, si los docentes quieren cambiar sus prácticas de enseñanza, primero deben tomar conciencia de su estilo dominante en todas sus 
dimensiones, para que se adapten a las situaciones cambiantes y diversas con las que se encuentren (1993: 100).

La autora propuso, a la vez, un modelo de análisis multidimensional y multicategorial para caracterizar y describir los estilos de los docentes, a los efectos de identificar qué es lo que cambia y qué permanece invariable en sus prácticas (Altet 1993:89-90).

Para su análisis, Altet recurrió a la identificación y cruce de tres dimensiones constitutivas de los estilos pedagógicos: el estilo personal, el relacional y el didáctico, que se encuentran en interdependencia. El estilo personal y relacional corresponden al campo de las condiciones. La dimensión personal es la ligada al ser del docente; abarca las opiniones, actitudes, representaciones, concepciones y valoraciones pedagógicas, concepciones sobre los alumnos, su aceptación de los demás, su relación con el conocimiento, sus teorías implícitas. El estilo relacional refiere a la manera en que el maestro se comunica (en forma verbal y no verbal) e interactúa con sus alumnos, la manera de generar las interacciones, de crear un clima, de desarrollar ciertas formas y modos de comunicación, de utilizar más o menos los mensajes no verbales, su habilidad de entrar en contacto y de percibir la realidad del grupo clase. Por último, el estilo didáctico implica el campo de las decisiones y abarca las modalidades didácticas, estrategias y métodos puestos en juego por cada docente en sus prácticas de enseñanza.

Para cada dimensión analizada, la autora propuso, a su vez, un haz de categorías organizadas en torno a ejes con extremos polarizados. En el siguiente cuadro se observa la interrelación de las dimensiones, ejes y categorías propuestas por Altet:

\begin{tabular}{|c|c|c|c|c|}
\hline \multirow[t]{3}{*}{ Dimensiones } & & & Eje & Categorías \\
\hline & EL ESTILO PERSONAL & & & \\
\hline & Factores personales & & & \\
\hline \multirow{4}{*}{$\begin{array}{l}\text { Espacio } \\
\text { cognitivo }\end{array}$} & - Estilo cognitivo & & Estimulante & \\
\hline & - Estructura cognitiva & & Estructurante & \\
\hline & - Actitudes & & & \\
\hline & - Factores motivacionales & Campo & & \\
\hline \multirow[t]{11}{*}{ Espacio social } & EL ESTILO RELACIONAL & de las & Ordenador & \\
\hline & Factores sociopsicológicos & condiciones: & & Instructivo \\
\hline & - Interacción, formas de & Variables & & Interrogador de \\
\hline & interactuar & personales e & & clase \\
\hline & - Relaciones maestro-alumnos & institucionales & & Cuestionador de los \\
\hline & - Clima socioemocional & & & alumnos-individuos \\
\hline & - Representaciones & & & Cuestionador de \\
\hline & - Tácticas & & & intercambio mixto \\
\hline & & & & Monitor guía \\
\hline & & & Consintiente & \\
\hline & EL ESTILO DIDÁCTICO & & Guía & \\
\hline \multirow{7}{*}{$\begin{array}{l}\text { Espacio } \\
\text { organizacional }\end{array}$} & Factores operacionales & & & Expositivo \\
\hline & - Modalidades didácticas, & Campo & & Interrogativo \\
\hline & - comunicativas & de las & & Incitativo \\
\hline & - Métodos, técnicas, estrategias & decisiones: & & Animación \\
\hline & - Estructuración de los contenidos & variables & & Guía \\
\hline & - Formas de agrupamiento & decisionales & & Mixto-flexible \\
\hline & - Planificación & & Líder & \\
\hline
\end{tabular}

(Altet, 1993: 90; adaptado) 
La investigación desarrollada por Altet concluyó en que algunos enseñantes presentan un estilo pedagógico mixto. La autora conceptualizó los estilos de los docentes como una configuración de rasgos y los caracterizó por su modo dominante, pues encontró en la multiplicidad de sus combinaciones posibles una dificultad para definirlos (Altet 1993: 100).

La mayor potencialidad del concepto de estilos de enseñanza propuesto por esta autora reside justamente en la idea de configuración, que remite a una forma peculiar de composición. Altet, al advertir este aspecto, le asignó un carácter problemático (Cols 2007: 338). Esta investigación, a diferencia de las de proceso-producto, al asumir una perspectiva interpretativa marcó un hito en los estudios sobre los estilos de enseñanza.

En el contexto latinoamericano, debe destacarse la contribución de Cols a la resignificación de esta noción. Esta investigadora dirigió su análisis, realizado desde una perspectiva descriptiva y comprensiva, hacia el docente y sus prácticas de enseñanza; hacia las diversas maneras en que aquellos llevan a cabo su acción pedagógica y los procesos de construcción de sentido que la acompañan.

En su punto de partida, Cols concibe la enseñanza como práctica social realizada dentro de un campo de actividad, en el sentido asignado por Bourdieu; como acción interactiva dialógica, orientada hacia otros y para otros, y como mediación entre saberes y estudiantes. Dentro de esta práctica, sitúa la acción docente - acción contextualizada y compleja, definida como conjunto de actividades sobre las cuales se interviene sobre la realidad-, y al docente como actor (Cols 2011:57-98).

En el entendido de que las diferencias entre los enseñantes existen y son significativas (2011:98), la autora integra la noción de estilo de enseñanza, al que define, a grandes rasgos, como «los modos personales de enseñar» para indagar sobre esta singularidad. Con mayor precisión, los estilos son, desde su perspectiva, «las modalidades singulares e idiosincráticas según las cuales cada maestro concibe y lleva a cabo su tarea»; los estilos aluden, así, a «un "modo de ser" docente, a una impronta o sello propio» (2011:77: 81).

Con respecto a la potencialidad de la noción de estilos de enseñanza, Cols enfatiza:

[...] desde una perspectiva heurística, el estilo opera como una herramienta para describir los patrones de acción del sujeto y sus modos de enfrentar lo "real", para elucidar los sentidos que el actor atribuye a experiencia y su acción, para establecer lazos entre las configuraciones de actividad y las concepciones del sujeto acerca de la acción y para buscar articulaciones entre las diferentes dimensiones de la acción (relaciones entre intervención didáctica, gestión y relación pedagógica, entre intención e instrumentación, entre las decisiones relativas a los distintos componentes de la enseñanza). En esa posibilidad de volver inteligible al observador un conjunto de elementos heterogéneos y aun discordantes reside, justamente, la potencialidad de la noción de estilo.» (2007: 341).

Son dos las dimensiones seleccionadas por esta investigadora para constituir el estilo de enseñanza: por una parte, los modos particulares que despliega el docente para llevar a cabo las actividades de enseñanza, es decir, todo lo que hace antes, durante y después de enseñar, sus decisiones, su planificación, la organización y gestión de la clase, la evaluación... Y por otra, por los modos de concebir su tarea - las representaciones acerca del entorno, del currículum, de sus alumnos, del aprendizaje y a su propia acción como docente (2011: 87). 
Cols se planteó el desafío de comprender los estilos de los docentes, insertos en el marco de las significaciones contextualizadas dentro de una cultura y tradición pedagógicas determinadas. En este sentido, empleó, a la par de la noción de estilo, la de modelo, concebido como la trama de concepciones de carácter político e ideológico acerca de lo que debe ser una «buena enseñanza» (2011:175). Ambas herramientas, estilo y modelo, precisa la autora: «[...] permiten explorar la diversidad de maneras de pensar y llevar a cabo la tarea de enseñanza» (2011: 81). Los modelos ofrecen puntos de identificación y anclaje (la inscripción de lo social en lo individual), regulan, pero no determinan el estilo de los docentes.

Pero si bien Cols asume una perspectiva situacional para dar cuenta del «aquí y del ahora del ser docente» (2011: 77-98), introduce la perspectiva biográfica para indagar en esa construcción personal que cada docente expresa en su estilo de enseñanza. La adopción de la perspectiva biográfica permite dar cuenta de las experiencias que lo constituyeron y situar el momento actual en el horizonte de la vida profesional del sujeto. La reconstrucción biográfica, al decir de la autora: «Posibilita la emergencia de nuevas significaciones a partir de la búsqueda de elementos operantes en la génesis del estilo, situaciones y temas recurrentes, rupturas, experiencias críticas y puntos de inflexión» (2007: 341).

Al nuestro entender, Cols realizó interesantes contribuciones a la noción de estilos de enseñanza. En primer lugar, al considerar su carácter multidimensional, integrando las maneras particulares de ser y actuar de los docentes - en sintonía con Altet-, con sus percepciones y valoraciones -idea que adopta de la filosofía de la educación (Jackson, P., Boostrom, R. y Hansen, D. 2003 en Cols 2007:36). En segundo lugar, al entender al estilo como la integridad de una configuración personal, adoptando y extendiendo la noción de configuraciones didácticas de Litwin (1997 en Cols 2007: 44). Al respecto Cols precisa:

Esta investigación sugiere, además, otra faceta de la idea de configuración, en tanto lo singular e inédito no está dado solo por el tipo de atributos, sino por la particular conexión entre ellos, por el modo en que estos se engarzan unos con otros [...] el estilo no se aprehende como la sumatoria de rasgos independientes referidos a distintos aspectos o criterios sino por la particular combinación o la pregnancia de algunos de ellos. La singular «alquimia» que constituye el estilo de enseñanza de un docente se aprecia a través de una mirada holística (2007: 339).

En tercer lugar, a establecer la relación entre el estilo e identidad, siguiendo a Barbier, para quien la acción se encuentra ligada al problema de la identidad del actor, en la medida en que el sujeto es transformado por su acción, y que esta pone en juego representaciones identitarias (Cols 2007: 350).

En cuarto lugar, al incorporar la perspectiva biográfica a la que ya se hizo referencia, idea que adopta de la línea de estudios acerca de los conocimientos del profesor (Cols 2007: 93). Y por último, al renunciar a establecer categorías de clasificación de los estilos de enseñanza, pretensión que caracterizó a los estudios que le antecedieron.

En las últimas décadas, en el contexto latinoamericano, la noción de estilos de enseñanza puede rastrearse en diversas investigaciones que la incorporaron como marco conceptual para caracterizar a los docentes de acuerdo con variables relacionadas con su personalidad, comportamiento, conocimientos o concepciones acerca de la enseñanza y el aprendizaje (Rendón Uribe 2013: 181). Muchos de estos estudios poseen el común denominador de definir los estilos en forma ad hoc y, por lo tanto, al querer establecer lo que singulariza a cada docente deben dar cuenta del mestizaje de sus prácticas o de la disonancia entre estas y las creencias de cada uno. La mayoría de estos trabajos, también, recurren al concepto en cuestión como herramienta potencial para que los docentes tomen 
consciencia de sus propias prácticas, e incorporen insumos para el cambio y mejoramiento de sus procesos de formación (Callejas y Corredor 2002; Burgos et. ál 2002; Callejas et ál. 2008; Suárez Mantilla 2008; Moreno et ál. 2014; Pastor de Jones 2017). 


\section{MARCO METOdOLÓGICO}

Esta segunda parte de la tesis pretende dar cuenta de la dialéctica del proceso de investigación y de las decisiones metodológicas tomadas. En consecuencia, se organiza en cuatro apartados: el primero: «Aspectos metodológicos» $(\rightarrow$ 2.1.) considera el tipo de metodología empleada; las líneas; los propósitos; los objetivos y las preguntas de investigación; los instrumentos para la obtención de datos; la población y muestra, y los aspectos éticos tomados en cuenta para el ingreso al campo de estudio.

En el segundo apartado: «Trabajo de campo» ( $\rightarrow 2.2$.) se describe el proceso del trabajo de campo, los procedimientos seguidos para la obtención y registro de los datos y el proceso de análisis interpretativo.

El tercer apartado: «Ámbitos, categorías, subcategorías y parámetros de análisis» ( $\rightarrow$ 2.3.) se centra en la explicitación de los aspectos seleccionados para la construcción y análisis de los datos y su organización y jerarquía en función del propósito, objetivos y preguntas de investigación.

El cuarto y último apartado: "Contexto de investigación» ( $\rightarrow 2.4$.) describe, a modo panorámico, los distintos ámbitos en los que se efectuó la indagación que aquí se presenta, con el propósito de situar a quien lee este trabajo en el marco institucional y territorial de acción de los mediadores, protagonistas de este estudio.

\subsection{Aspectos metodológicos}

Se optó por realizar una investigación sociocultural exploratoria de carácter cualitativo-interpretativa (Wittrock 1997), con la intención de profundizar la comprensión del fenómeno estudiado in situ. Este enfoque contempla el involucramiento y compromiso del investigador en la investigación como parte constitutiva del proceso de investigación y en la construcción del conocimiento que se genere, ya que no puede obviarse el hecho de que esta tesista se desempeña laboralmente en el Programa de Lectura y Escritura en Español de la Administración Nacional de Educación Pública de Uruguay desde 2011.

Se planteó entonces una investigación observacional-participativa mediante el enfoque de estudio de caso (Simons 2011) en cuanto:

-se encuentra en sintonía con la orientación metodológica seleccionada;

-permite estudiar la unicidad y naturaleza distintiva de cada mediador, pero también los aspectos comunes a todos ellos;

-valora las múltiples perspectivas de los sujetos investigados, la observación de los acontecimientos en las circunstancias que se producen y su interpretación dentro de ese contexto;

-cada caso se considera un sistema integrado cuyos diversos aspectos se encuentran en interacción;

-se orienta a obtener un conocimiento cualitativo y exhaustivo del fenómeno estudiado;

-tiene en cuenta la complejidad de cada caso y la interrelación de los aspectos investigados;

-contempla el papel interactivo del investigador y la relación que este entabla con los sujetos investigados;

-considera el compromiso del investigador y su implicancia con la realidad investigada en la medida que esta no puede ser comprendida de modo aséptico, neutral o abstracto (Martínez Bonafé 1988; Simons 2011; Stake 2013). 
A partir del análisis en profundidad de la información obtenida y de su puesta en relación con la bibliografía e investigaciones relevadas, este estudio pretende aportar en forma heurística a conocer en profundidad a los mediadores de los equipos comunitarios de lectura que leen a los niños de las escuelas públicas de Uruguay y sus estilos.

\subsubsection{Líneas, propósito, objetivos y preguntas de investigación}

Como ya se mencionó, este estudio refiere a los mediadores de los equipos comunitarios de lectura que se desempeñan en un contexto escolar. Por una parte, en cuanto investiga los estilos pedagógicos o de enseñanza particulares de estos mediadores, se vincula en el campo educativo con el paradigma de la educación literaria, en su vertiente del fomento de la lectura.

Por otra parte, en cuanto refiere a las prácticas de la lectura desarrolladas por actores comunitarios, esta investigación apela a campos teóricos diversos tales como la sociología, historia y antropología de la lectura, la investigación etnográfica en educación y la psicología, entre otros.

En consideración con lo expuesto, el propósito general de este trabajo se enuncia entonces así:

Profundizar el conocimiento sobre los mediadores de la comunidad que leen a los niños en las escuelas públicas de Uruguay y sus estilos.

A partir del panorama realizado sobre la noción de estilos de enseñanza en el apartado «Los estilos de enseñanza o pedagógicos» ( $\rightarrow$ 1.2.6.) se decidió, por una parte, indagar sobre el ser y el hacer de los mediadores en cuanto estos ámbitos configuran sus estilos. Por otra, se optó por investigar cómo responden los niños al mediador, analizando las respuestas de estos en las sesiones de lectura, sus recuerdos sobre lo leído y sus valoraciones sobre el mediador, con la intención de conocer, a grandes rasgos, la incidencia de esta figura en la formación lectora de los niños, sin ambición alguna de exhaustividad o de establecer relaciones de causalidad o determinismos. En relación con el propósito enunciado más arriba, se determinaron los siguientes objetivos de investigación:

I. Caracterizar la singularidad del ser y el hacer de los mediadores de lectura de la comunidad que leen a los niños en las escuelas públicas uruguayas.

II. Explorar las respuestas de los niños en las sesiones de lectura de los mediadores y los recuerdos sobre sus lecturas.

III. Indagar las valoraciones de los niños sobre los mediadores.

Con respecto al objetivo I, se formularon las siguientes preguntas:

1. ¿Cuáles son las preferencias y prácticas lectoras del mediador, su biografía lectora, motivaciones, y cómo construye y se apropia de su rol?

2. ¿Qué caracteriza el hacer de cada mediador: modalidad lectora, organización del espacio y administración del tiempo en las sesiones de lectura, gestión de la construcción del metatexto?

3. ¿Cómo son los intercambios e interacciones que generan los mediadores?

En relación con el objetivo II, se concretaron las siguientes preguntas:

4. ¿Cómo responden los niños a la lectura del mediador?

5. ¿Qué recuerdan los niños de las lecturas con el mediador? 
A propósito del objetivo III, se plasmó esta pregunta:

6. ¿Cómo valoran los niños la figura y lectura del mediador?

Sobre estas preguntas de investigación se establecieron los siguientes ámbitos de análisis: el ser del mediador, el hacer del mediador, las intervenciones e intercambios entre los participantes, las respuestas de los niños en las sesiones de lectura, los recuerdos de los niños sobre las lecturas del mediador y las valoraciones de los niños sobre el mediador.

En el siguiente cuadro puede observarse la relación entre las preguntas y los ámbitos de análisis establecidos:

\begin{tabular}{|c|c|c|}
\hline & Preguntas & Ámbitos de análisis \\
\hline \multirow{3}{*}{ 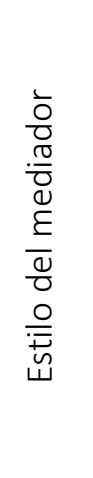 } & $\begin{array}{l}\text { 1. ¿Cuáles son las preferencias y prácticas lectoras del } \\
\text { mediador, su biografía lectora, motivaciones, y cómo } \\
\text { construye y se apropia de su rol? }\end{array}$ & A. Ser del mediador \\
\hline & $\begin{array}{l}\text { 2. ¿Qué caracteriza el hacer de cada mediador: modalidad } \\
\text { lectora, organización del espacio y administración del } \\
\text { tiempo en las sesiones de lectura, gestión de la } \\
\text { construcción del metatexto? }\end{array}$ & B. Hacer del mediador \\
\hline & $\begin{array}{l}\text { 3. ¿Cómo son los intercambios e interacciones que } \\
\text { generan los mediadores? }\end{array}$ & $\begin{array}{l}\text { C. Intervenciones e intercambios } \\
\text { entre los participantes }\end{array}$ \\
\hline \multirow{3}{*}{ 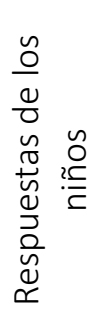 } & 4. ¿Cómo responden los niños a la lectura del mediador? & $\begin{array}{l}\text { D. Respuestas de los niños en las } \\
\text { sesiones de lectura }\end{array}$ \\
\hline & $\begin{array}{l}\text { 5. ¿Qué recuerdan los niños de las lecturas con el } \\
\text { mediador? }\end{array}$ & $\begin{array}{l}\text { E. Recuerdos de los niños sobre } \\
\text { las lecturas del mediador }\end{array}$ \\
\hline & $\begin{array}{l}\text { 6. ¿Cómo valoran los niños la figura y lectura del } \\
\text { mediador? }\end{array}$ & $\begin{array}{l}\text { F. Valoraciones de los niños } \\
\text { sobre el mediador }\end{array}$ \\
\hline
\end{tabular}

\subsubsection{Población y muestra}

En relación con el propósito de investigación ya enunciado, se decidió realizar el trabajo de campo en dos escuelas primarias públicas de Montevideo que participaran de Biblioteca Solidaria desde 2014, cuyos equipos comunitarios de lectura tuvieran como mínimo cinco integrantes y la mayoría de ellos permanecieran en el equipo desde el inicio del proyecto De esta manera se contaba con mayores probabilidades de que los mediadores a investigar contaran con experiencia en su rol.

Se optó por realizar la investigación en tercer grado, en consideración de que los niños de estos grupos (8-9 años) ya han transitado por cuatro años de escolaridad obligatoria en los que, por una parte, ya han frecuentado contenidos literarios ${ }^{29} \mathrm{y}$, por otra, aún no suelen haber «saltado al otro lado de la barrera de la lectura» (Colomer, 2004: 10) cuando manifiestan que ya no les gusta leer. Poseen además

\footnotetext{
${ }^{29}$ La obligatoriedad de la enseñanza en Uruguay está establecida en la Ley General de Educación nro. 18437, a partir de los cuatro años. El Programa de Educación Inicial y Primaria 2008 establece la enseñanza de la Literatura (área del Conocimiento Artístico) desde Nivel Inicial 4 hasta $6 .^{\circ}$ año.
} 
mayor capacidad para verbalizar sus opiniones, tanto en forma oral como escrita, al tener, como es de prever, mayor conocimiento del sistema de escritura y del lenguaje escrito ${ }^{30}$.

En función de estas decisiones, se estableció que cada caso de estudio se correspondería con un mediador que concurriera a leer en todos o en algunos de los grupos mencionados de las escuelas participantes de la investigación, con un máximo de uno por clase.

\subsubsection{Estrategias para la obtención de datos}

De acuerdo con el propósito, objetivos y preguntas enunciados más arriba se decidió recurrir a las siguientes estrategias para la obtención de datos:

- Participar y observar las reuniones de los equipos comunitarios de lectura convocadas por las maestras referentes de Biblioteca Solidaria durante 2015, relacionadas con la preparación de la tarea de los mediadores, y las sesiones de lectura de quienes se desempeñaban como tales en los grupos y clases participantes, desde las primeras instancias, para el mutuo conocimiento y la generación de confianza con los protagonistas de la investigación.

- Seleccionar, en forma posterior a la finalización del trabajo de campo, dos reuniones de los equipos comunitarios de lectura, con el propósito de analizar los tópicos emergentes de la conversación y los títulos sugeridos por los mediadores para leer.

- Participar y observar las sesiones de lectura protagonizadas por los mediadores a investigar (de libros seleccionados por el mediador o las maestras) y seleccionar posteriormente una de estas instancias en función de los intercambios suscitados durante ellas, con el propósito de observar cómo el mediador organiza las sesiones de lectura, gestiona la construcción del metatexto, cómo se producen los intercambios e interacciones entre los actores participantes de la mediación y cómo responden los niños al mediador.

- Participar y observar una sesión de lectura de un libro de cuento propuesto ad hoc para esta investigación por cada mediador. Este sería elegido por el mediador con mayor experiencia de cada escuela, entre un conjunto de títulos propuestos por la investigadora, mientras que el mediador con menor experiencia en cada escuela leería el título seleccionado por el de mayor experiencia de la otra escuela. Esta decisión fue tomada con la intención de comparar el hacer de los mediadores y los intercambios e interacciones durante las sesiones de lectura, en función de su experiencia en el rol y, a la vez, asegurar la lectura de un título novedoso para los niños, (descartando posibles situaciones de relectura), adecuado al nivel escolar. Se tuvo en cuenta que la elección de estos cuentos no podía realizarse de antemano sin conocer las colecciones bibliográficas de las escuelas, las lecturas previas de los actores involucrados y sus preferencias en materia lectora.

- Realizar entrevistas semiestructuradas a las directoras de las escuelas XX y XXX, a los efectos de obtener información sobre el centro escolar, las características de Biblioteca Solidaria y de los equipos comunitarios en cada escuela.

- Realizar entrevistas semiestructuradas a los mediadores para obtener insumos para reconstruir el ser del mediador (preferencias y prácticas lectoras del mediador, motivaciones para ejercer su rol, biografía

\footnotetext{
30 El Programa de Educación Inicial y Primaria 2008 uruguayo establece que hacia fines del segundo año escolar los niños deben haber adquirido el conocimiento del sistema de escritura y escribir por sí mismos.
} 
lectora, experiencia en el rol, valoración sobre su tarea y su aporte a los niños). Se planeó realizar estas entrevistas al finalizar las observaciones de las sesiones de lectura, con el propósito de que no incidieran en el hacer de los mediadores.

- Realizar entrevistas semiestructuradas a las maestras para obtener su percepción sobre el accionar de los mediadores, sobre el vínculo que establecen con los niños y sus aportes a la formación de estos como lectores.

- Realizar una encuesta a todos los niños de los grupos investigados, y entrevistas semiestructurada a seis niños por cada clase, con la intención de recuperar los recuerdos sobre sus lecturas y sus valoraciones sobre los mediadores. Se proyectó llevar a cabo la encuesta, en un primer momento, y con posterioridad a esta, la entrevista, a continuación de la finalización de la observación de las sesiones de lectura. Ambas instancias se concibieron como complementarias. Para seleccionar a los niños que participasen de la entrevista se previó contar con el consejo de las maestras, tener en cuenta los diferentes niveles de participación que aquellos evidenciaran en las sesiones de lectura y que en la encuesta expresaran diferentes opiniones sobre los mediadores.

En la siguiente página, se presenta un cuadro que resume la relación entre los objetivos, las preguntas, estrategias metodológicas y la población involucrada en esta investigación: 


\begin{tabular}{|c|c|c|c|c|c|}
\hline & Objetivos & Preguntas & Estrategias & Instancias & Población \\
\hline \multirow{4}{*}{ 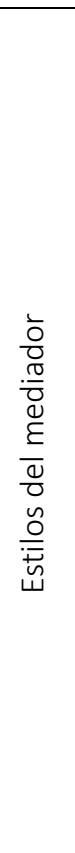 } & \multirow{4}{*}{$\begin{array}{l}\text { I. Caracterizar la singularidad ser y el } \\
\text { hacer de los mediadores de lectura } \\
\text { de la comunidad que leen a los niños } \\
\text { en las escuelas públicas uruguayas. }\end{array}$} & \multirow{2}{*}{$\begin{array}{l}\text { 1. ¿Cuál son las } \\
\text { preferencias y prácticas } \\
\text { lectoras del mediador, su } \\
\text { biografía lectora, } \\
\text { motivaciones, y cómo } \\
\text { construye y se apropia de } \\
\text { su rol? }\end{array}$} & Observación participante & $\begin{array}{l}\text { Reuniones de los equipos } \\
\text { comunitarios de lectura }\end{array}$ & $\begin{array}{l}\text { Integrantes de los equipos comunitarios de } \\
\text { lectura }\end{array}$ \\
\hline & & & \multicolumn{2}{|c|}{ Entrevistas semiestructuradas } & $\begin{array}{l}\text { Mediadores investigados } \\
\text { Maestras de tercer año de las escuelas XX y } \\
\text { XXX }\end{array}$ \\
\hline & & $\begin{array}{l}\text { 2. ¿Qué caracteriza el } \\
\text { hacer de cada mediador: } \\
\text { modalidad lectora, } \\
\text { organización del espacio y } \\
\text { administración del tiempo } \\
\text { en las sesiones de lectura, } \\
\text { gestión de la construcción } \\
\text { del metatexto? }\end{array}$ & Observación participante & \begin{tabular}{|l} 
Dos sesiones de lectura de \\
los mediadores de los \\
grupos de tercero
\end{tabular} & Mediadores investigados \\
\hline & & $\begin{array}{l}\text { 3. ¿Cómo son los } \\
\text { intercambios e } \\
\text { interacciones que generan } \\
\text { los mediadores? }\end{array}$ & Observación participante & \begin{tabular}{|l} 
Dos sesiones de lectura de \\
los mediadores de los \\
grupos de tercero
\end{tabular} & $\begin{array}{l}\text { Mediadores investigados } \\
\text { Niños de tercer año de las escuelas XX y XXX } \\
\text { presentes en cada sesión de lectura }\end{array}$ \\
\hline \multirow{3}{*}{ 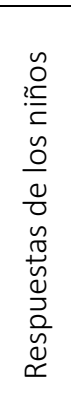 } & \multirow{2}{*}{$\begin{array}{l}\text { II. Explorar las respuestas de los } \\
\text { niños en las sesiones de lectura de } \\
\text { los mediadores y los recuerdos sobre } \\
\text { sus lecturas. }\end{array}$} & $\begin{array}{l}\text { 4. ¿Cómo responden los } \\
\text { niños a la lectura del } \\
\text { mediador? }\end{array}$ & Observación participante & \begin{tabular}{|l|} 
Dos sesiones de lectura de \\
los mediadores de los \\
grupos de tercero
\end{tabular} & $\begin{array}{l}\text { Niños de tercer año de las escuelas XX y XXX } \\
\text { presentes en cada sesión de lectura }\end{array}$ \\
\hline & & $\begin{array}{l}\text { 5. ¿Qué recuerdan los } \\
\text { niños de las lecturas con el } \\
\text { mediador? }\end{array}$ & \multicolumn{2}{|c|}{ Entrevistas semiestructuradas } & $\begin{array}{l}\text { Muestra acotada de niños de cada clase de } \\
\text { tercer año }\end{array}$ \\
\hline & $\begin{array}{l}\text { III. Indagar las valoraciones de los } \\
\text { niños sobre los mediadores. }\end{array}$ & $\begin{array}{l}\text { 6. ¿Cómo valoran los niños } \\
\text { la figura y lectura del } \\
\text { mediador? }\end{array}$ & \multicolumn{2}{|l|}{ Encuesta } & $\begin{array}{l}\text { Niños de tercer año de las escuelas XX y XXX } \\
\text { presentes en la clase el día de la entrevista }\end{array}$ \\
\hline
\end{tabular}




\subsubsection{Aspectos éticos}

Según los principios éticos recomendados en la bibliografía consultada (Wittrock, 1997, Achilli, 2005) se previó:

- Informar desde un comienzo a docentes y mediadores de los propósitos de la investigación, realizada en el marco de la Maestría en Escritura y Alfabetización de la Universidad Nacional de La Plata y del vínculo laboral de esta tesista con el Programa de Lectura y Escritura en Español de la ANEP. Se asumió además el compromiso de mantener en reserva la identidad de los participantes y de emplear la información recabada únicamente para la investigación. Cabe aclarar que hasta el momento del ingreso al campo la investigadora no había tenido contacto alguno con las escuelas ni con los mediadores que participaron de la investigación.

- Ingresar en el campo de estudio en forma progresiva, solicitando autorización a todos los involucrados para presenciar todas las instancias y registrar lo vivido.

- Realizar encuentros iniciales con las directoras, maestras y equipos comunitarios de las escuelas y grupos seleccionados para la investigación para presentar y explicar el proyecto, tomar contacto con el contexto de investigación y conocer sus características.

- Participar y observar las reuniones de los equipos comunitarios de lectura convocadas por las maestras referentes de Biblioteca Solidaria durante 2015, relacionadas con la preparación de la tarea de mediador, y las sesiones de lectura de los mediadores en los grupos de tercero, desde las primeras instancias, para el mutuo conocimiento y la generación de confianza con los participantes de la investigación.

- Dar un cierre formal al trabajo de campo una vez que este finalizara, agradeciendo a los actores su participación e informándoles que una vez que se concluyera la investigación, se le comunicarán sus conclusiones.

\subsection{Trabajo de campo}

\subsubsection{Narrativa del desarrollo del trabajo de campo}

En este apartado, la relatoría del desarrollo del trabajo de campo asume la modalidad de narrativa, y por tal motivo, opto por emplear la primera persona en el devenir del relato.

Luego de identificar las escuelas que podrían participar potencialmente del estudio tomé contacto con sus equipos de dirección para consultarlos sobre la posibilidad de investigar en dichos centros. En un inicio, consulté a una escuela del oeste de Montevideo que funciona en el turno matutino (escuela XX) y a otra escuela del este de la capital, que funciona en el turno vespertino. La dirección de esta última se rehusó amablemente a dar cabida a mi investigación por una situación particular que en ese momento estaban atravesando. Consulté entonces sobre la posibilidad de realizar la investigación en otra escuela del oeste de la ciudad, también del turno matutino, pero de distinto contexto socioeconómico y alejada geográficamente de la primera (escuela XXX). Una vez que conté con el aval de las directoras de ambos centros educativos, les solicité que hicieran extensiva la consulta a los equipos docentes y a los equipos comunitarios de lectura, quienes finalmente me habilitaron a ingresar al campo. 
Una vez que conté con el aval de los directores, docentes y mediadores, inicié el trámite formal de solicitud de autorización para desarrollar la investigación ante el Consejo de Educación Inicial y Primaria de Uruguay ( $\rightarrow$ anexo 6. «Carta de solicitud al CEIP para la realización del trabajo de campo»).

Luego de asistir a las primeras reuniones de los equipos comunitarios de lectura de ambas escuelas en las que me presenté y expliqué el motivo de mi trabajo, acordé con las maestras y mediadores de los grupos de tercer año mi presencia durante las sesiones de lectura. Me presenté también ante los niños y les expliqué qué iría a hacer en los próximos días.

Cada escuela tenía dos clases de tercer año: A y B respectivamente. En la escuela XX, cada clase contaba con un familiar lector que permanecería en el rol de mediador todo el año, mientras que en la escuela XXX las integrantes el equipo comunitario, madres, todas ellas, rotarían en forma bimensual por los grupos. En función de estas realidades, se establecieron los cuatro casos de estudio operativos para esta investigación. En la escuela XX cada caso estaría protagonizado por el mediador que ejerciera como tal en cada uno de los terceros; y en la escuela XXX, si bien se seguiría en ambas clases a todas las mediadoras que fueran a leer hasta agosto o setiembre, se investigaría el trabajo de dos de ellas, de cada una, únicamente, en una de las clases.

Finalmente, los cuatro casos de estudio resultaron configurados de esta manera:

\begin{tabular}{|l|l|l|l|c|}
\hline \multicolumn{1}{|c|}{ Casos } & \multicolumn{1}{|c|}{ Escuelas } & \multicolumn{1}{c|}{ Mediador } & \multicolumn{1}{c|}{ Clases } & $\begin{array}{c}\text { Cant. de } \\
\text { alumnos }\end{array}$ \\
\hline Primer caso & Escuela XX & Omar (abuelo) & Tercer año A & 25 \\
\hline Segundo caso & Escuela XX & Cecilia (madre) & Tercer año B & 25 \\
\hline Tercer caso & Escuela XXX & Rosario (madre) & Tercer año A & 23 \\
\hline Cuarto caso & Escuela XXX & Patricia (madre) & Tercer año B & 24 \\
\hline
\end{tabular}

El trabajo de campo en ambas escuelas se extendió entre fines de abril y principios de diciembre de 2015 ( $\rightarrow$ anexo 1. «Calendario de desarrollo del trabajo de campo»). Tenía previsto finalizarlo en setiembre, pero a mediados año se inició un conflicto entre las autoridades de la enseñanza y los sindicatos docentes, que se intensificó luego de las vacaciones de invierno y se extendió en forma intermitente hasta octubre, por lo cual algunas instancias debieron ser reagendadas.

Entre fines de abril y mediados de agosto de 2015, realicé las observaciones de las reuniones de los equipos comunitarios de lectura. Asistí a todas aquellas a las que fui invitada, relacionadas con la lectura ${ }^{31}$.

En la escuela XX participé en cinco de las seis reuniones realizadas ${ }^{32}(\rightarrow$ anexo 1.1. "Reuniones de los equipos comunitarios de lectura»). Elegí analizar en este estudio la reunión del 14 de mayo, en la que el equipo comunitario conformado en 2014 recibió a los nuevos integrantes, y la del 18 de junio, en la que se integró Cecilia, quien ofició de mediadora en tercero B. En ambas reuniones, los temas de conversación emergentes resultaron de interés para mi investigación.

\footnotetext{
${ }^{31}$ Particularmente, en la escuela XXX las integrantes del equipo comunitario de lectura se reunieron en otras oportunidades para organizar los festejos del Día del Niño y ensayar una obra de teatro.

32 En la reunión de evaluación del 30.11.2015 estuve presente solo unos minutos para despedirme del equipo comunitario de lectura ( $\rightarrow$ anexo 5. «Diario de trabajo de campo. Lunes 30 de noviembre»).
} 


\begin{tabular}{|l|l|}
\hline Fecha & Participantes del equipo comunitario \\
\hline 14.05 .2015 & Omar, Graciela, Carla, Elsa, Carolina, Leticia, Inés, Noelia \\
\hline 18.06 .2015 & Omar, Cecilia, Carla, Noelia, estudiante de Magisterio \\
\hline
\end{tabular}

En la escuela XXX participé de dos reuniones de un total de cuatro: el 22 de mayo y el 14 de julio de 2015 ( $\rightarrow$ anexo 1.1. "Reuniones de los equipos comunitarios de lectura»). La primera de estas había sido realizada luego de la Semana de Turismo para constituir el equipo comunitario, cuando aún la escuela no me había dado su aval para participar de la investigación; la última reunión fue convocada para evaluar el proyecto, a comienzo de diciembre. A diferencia de la escuela XX, las integrantes del equipo comunitario de la escuela XXX coordinaban con las maestras de cada clase los días, horarios y lecturas, por lo que, al llegar a la escuela, se dirigían directamente a los salones. Antes de retirarse, pasaban por el salón de la maestra referente (quien se desempeñaba como maestra integradora) a retirar los libros que habrían de leer en la próxima semana.

Por lo expuesto, analicé para esta investigación la reunión del 14 de julio, convocada por la maestra referente para evaluar la marcha del proyecto, ya que la reunión del 22 de mayo fue realizada expresamente para presentarme ante el equipo comunitario y conocer a sus integrantes (y por ese motivo no registré el audio).

\begin{tabular}{|l|l|}
\hline Fecha & Participantes \\
\hline 14.07.2015 & $\begin{array}{l}\text { Andrea A., Janet, Patricia, Rosario, Margareth, Laura, Mónica, } \\
\text { Mariela }\end{array}$ \\
\hline
\end{tabular}

En tercer año A (maestra Inés) de la escuela XX asistí a las sesiones de Omar, abuelo de una de las niñas de ese grupo. De las cuatro lecturas realizadas por este mediador presencié las siguientes:

\begin{tabular}{|l|c|}
\hline $\begin{array}{l}\text { Un puñado de semillas, de Mónica Hughes con ilustraciones de Luis } \\
\text { Garay (Ekaré) }\end{array}$ & 18.06 .2015 \\
\hline «La abeja haragana», de Cuentos de la selva, (Horacio Quiroga) & 30.07 .2015 \\
\hline $\begin{array}{l}\text { La manta de las historias, de Ferida Wolf y Harriet May Savitz, con } \\
\text { ilustraciones de Elena Odriozola (Norma) }\end{array}$ & 12.08 .2015 \\
\hline
\end{tabular}

En tercer año B de la escuela XX (maestra Noelia) presencié las tres primeras sesiones a cargo de Carla (mamá de Martín, alumno de tercer año A), en las que leyó algunos capítulos de Aventuras y desventuras de Casiperro del Hambre (Graciela Montes, ilustraciones de Oscar Rojas, editorial Colihue), el 26 de mayo, 1 y 18 de junio de 2015. Entremedio concurrió a leer, solo en una ocasión, el 10 de junio, Tatiana, mamá de una alumna de ese grupo, quien leyó El mayor tesoro (Arcadio Lobato, editorial SM). Esta mamá, maestra de profesión, no integraba el equipo comunitario. Cuando Carla ${ }^{33}$ dejó de ir a leer por

\footnotetext{
${ }^{33}$ Esta mamá dejó de asistir también a las reuniones del equipo comunitario de lectura.
} 
problemas de salud, fue sustituida, unos días después, por Cecilia (mamá de Sofía, también alumna de tercero A).

Cecilia desarrolló en tercero B tres sesiones de lectura; de estas puede presenciar las siguientes:

\begin{tabular}{|l|c|}
\hline $\begin{array}{l}\text { Un puñado de semillas, de Mónica Hughes con ilustraciones de Luis } \\
\text { Garay (Ekaré) }\end{array}$ & 30.07 .2015 \\
\hline Una cena elegante, de Keiko Kasza (Norma) & 12.08 .2015 \\
\hline
\end{tabular}

En tercero A (maestra Carmen) de la escuela XXX seguí a Rosario, mamá de un niño de quinto año, en cinco de las seis sesiones de lectura que realizó:

\begin{tabular}{|l|l|}
\hline $\begin{array}{l}\text { «Los juguetes» y «La chacra», Perico, de Juan José Morosoli, ilustraciones } \\
\text { de Denisse Torena (Banda Oriental) }\end{array}$ & 02.06 .2015 \\
\hline El miedo a la luz mala, de Verónica Leite (Alfaguara Infantil) & 16.06 .2015 \\
\hline $\begin{array}{l}\text { Cuando el temible tigre, de Virginia Brown, ilustraciones de Matías Acosta } \\
\text { (Banda Oriental) }\end{array}$ & 14.07 .2015 \\
\hline $\begin{array}{l}\text { León de biblioteca, de Michelle Knudsen, ilustraciones de Kevin Ilawkes } \\
\text { (Ekaré) }\end{array}$ & 21.07 .2015 \\
\hline $\begin{array}{l}\text { La manta de las historias, de Ferida Wolf y Harriet May Savitz con } \\
\text { ilustraciones de Elena Odriozola (Norma) }\end{array}$ & 11.08 .2015 \\
\hline
\end{tabular}

En el grupo de tercero B (maestra Amalia) de la escuela XXX, Patricia, madre de Bautista, alumno de segundo año, realizó cinco lecturas, de las cuales presencié las siguientes:

\begin{tabular}{|l|c|}
\hline Los secretos de Abuelo Sapo (Keiko Kasza, Norma) & 26.05 .2015 \\
\hline Una cena elegante (Keiko Kasza, Norma) & 28.07 .2015 \\
\hline
\end{tabular}

De acuerdo con lo establecido en el diseño metodológico, y luego de haber avanzado en el trabajo de campo, presenté a los mediadores con mayor experiencia en su rol de cada escuela un conjunto de cuentos de la colección Buenas Noches de la editorial Norma: Feroz... iFeroz! (Liliana Cinetto), La abuelita de arriba y la abuelita de abajo (Tomie de Paola), No te rías, Pepe, El día de campo de don Chancho, Una cena elegante (Keiko Kasza) y La manta de las historias (Ferida Wolff y Harriet May Savitz) y les solicité que seleccionaran uno, según su parecer, para leer a los niños. Tomé la decisión de presentar estos títulos pues las escuelas participantes de Biblioteca Solidaria recibieron en 2014 algunos otros de la colección mencionada para el desarrollo del proyecto, que las maestras de tercer año informaron haber leído con el agrado de sus alumnos. Se observó además en las sesiones de lectura presenciadas inicialmente que los libros ilustrados propiciaban la conversación sobre lo leído, a 
diferencia de los que no tenían imágenes ${ }^{34}$. Los mediadores tuvieron la oportunidad de llevarse esos libros para sus hogares antes de decidir cuál leer. Omar, entonces, mediador con mayor experiencia de la escuela XX, seleccionó La manta de las historias y Patricia, mediadora de la escuela XXX seleccionó Una cena elegante. Posteriormente, solicité a Rosario, mediadora de tercero A de la escuela XXX que leyera el libro elegido por Omar, y a Cecilia, mediadora de tercero B de la escuela XX que leyera el libro escogido por Patricia.

Si bien al momento del diseño metodológico había considerado comparar en dos lecturas ad hoc el hacer de los mediadores y las respuestas de los niños en función de la experiencia en el rol, descarté esta posibilidad: no había considerado en un inicio la singularidad de cada grupo y de cada momento de lectura, que siempre se encuentra atravesado por otros factores (ambiente de lectura, disponibilidad de los niños y de la maestra, entre otros). A pesar de ello mantuve el análisis de estas sesiones, descartando la posibilidad de comparación, pues además de no contar con otras sesiones de Cecilia y Patricia para analizar, en todas estas lecturas se observaron acciones de los mediadores y respuestas de los niños a considerar.

Efectué las encuestas semiestructuradas a los niños de los grupos investigados en setiembre de 2015, después de finalizar las lecturas de los mediadores. Participaron en ellas todos los niños presentes en la clase el día en que se realizaron.

Luego de haber realizado las encuestas, comencé con las entrevistas a los niños, que realicé entre mediados de setiembre y principios de octubre.

Finalmente, durante octubre y primeros días de diciembre de 2015, entrevisté a los mediadores, maestras y directoras ${ }^{35}$.

Al finalizar el trabajo de campo, en la penúltima semana del año lectivo, concurrí a las escuelas XX y XXX a agradecer a sus directoras el haberme abierto las puertas de sus escuelas y, especialmente, a los niños, mediadores y maestras el haber sido parte de mi investigación.

\subsubsection{Obtención y registro de datos}

Tanto las reuniones de los equipos comunitarios como las sesiones de lectura de los mediadores y las entrevistas se registraron por medio de audio, con expresa autorización de los presentes. Se descartó desde un inicio la filmación de estas instancias pues este procedimiento de registro no está autorizado por el Consejo de Educación Inicial y Primaria de Uruguay en sus centros de estudio.

En forma paralela, se anotaron las vivencias e impresiones de cada jornada en el diario de trabajo de campo, con el propósito de conservar el cronograma y los detalles recogidos durante la estadía en el territorio.

Las observaciones de las sesiones de lectura se auxiliaron con una pauta de observación ( $\rightarrow$ anexo 2.1. «Pauta de observación de las sesiones de lectura»). Esta pauta fue elaborada con la intención de recoger

\footnotetext{
${ }^{34}$ Esto pudo apreciarse en las sesiones de lectura de Carla en tercer año B de la escuela XX, de los capítulos de Aventuras y desventuras de Casiperro del Hambre; de Omar, del cuento «La abeja haragana», y de Rosario de los relatos «Los juguetes» y «La chacra».

${ }^{35}$ Luego de finalizado el conflicto de la enseñanza, la escuela XX no volvió a convocar a los equipos comunitarios ni reanudó las sesiones de lectura, por lo que hubo que solicitar a los mediadores que concurrieran a la escuela expresamente para entrevistarlos.
} 
in situ la mayor cantidad de información sobre el accionar del mediador antes, durante y después de la lectura, para complementar los registros de audio. En este sentido, se elaboró un borrador que se puso a prueba en las primeras instancias observadas, que posteriormente se ajustó.

La realización de la encuesta a los niños se llevó a cabo con el auxilio de un cuestionario semicerrado (anexo 2.2. "Protocolo para la encuesta a los niños»). Se intentó que este, de alguna manera, pusiera a los niños a pensar sobre aquellos aspectos sobre los que se necesitaba obtener información. El cuestionario se llevó impreso el día de la encuesta y se explicó antes de ser entregado a los niños, quienes además pudieron hacer todas las consultas que necesitaron para su completamiento.

Las entrevistas a mediadores, niños y docentes se realizaron sobre la base de un cuestionario preestablecido con algunas preguntas abiertas, orientadas a recoger las opiniones, recuerdos y experiencias ( $\rightarrow$ anexo 2.3. «Protocolos para las entrevistas»). Estas entrevistas estuvieron abiertas a las modificaciones que fueron surgiendo en el devenir de la conversación.

\subsubsection{Proceso de análisis interpretativo}

Según la perspectiva de investigación asumida, la construcción de datos es concebida como un proceso dialéctico y recursivo. El análisis interpretativo, que se considera intrínseco a este proceso, busca, por una parte, comprender los significados atribuidos por los sujetos involucrados en la investigación al problema investigado, y por otra, establecer relaciones entre los conocimientos que se construyen con los ya generados en otras investigaciones (Achilli, 2000).

En el marco de este estudio, el proceso de análisis abarcó la toma de decisiones en diferentes momentos de la investigación. En un primer momento, fue necesario considerar los criterios a utilizar para transcribir las instancias presenciadas en el trabajo de campo, siendo conscientes de que la adopción de estos criterios tendría incidencia en el análisis posterior.

Para las reuniones de los equipos comunitarios de lectura, la transcripción asumió la forma de comentario interpretativo. Esta modalidad permitió combinar las expresiones textuales de los actores con los apuntes registrados en el diario de trabajo de campo sobre la intencionalidad de los participantes, señalar momentos emotivos o tensiones percibidas in situ.

Tanto para las entrevistas como para las sesiones de lectura las transcripciones se realizaron según los criterios del análisis conversacional establecidos por Payrató (1995), reproducidos por Calsamiglia y Tusón (1999, en Tusón Valls, 2002: 148), que brinda la posibilidad de señalar con detalle diferentes aspectos. En las entrevistas se omitió el señalamiento de las entonaciones y las reiteraciones fónicas o léxicas, para facilitar la lectura de los registros. En cambio, en las sesiones de lectura de los mediadores, la transcripción se realizó con el mayor detalle de las entonaciones ascendentes y descendentes, respetando al máximo la oralidad de los actores, intentando dar cuenta, de alguna manera, de la riqueza de las conversaciones entre los participantes y especialmente de la modalidad lectora de los mediadores. Debe aclararse que el análisis del corpus transcrito no se realizó desde la perspectiva conversacional o discursiva, sino que se llevó a cabo desde su análisis temático y comentario interpretativo, en relación dialéctica con las categorías de análisis.

A los efectos de precisar la terminología empleada en el proceso de análisis interpretativo, en este punto, se entiende necesario explicitar las nociones y criterios asumidos en relación con la identificación y delimitación de las unidades de la conversación: 
Se denomina intercambio a la unidad de análisis conversacional constituida por dos intervenciones sucesivas de distintos hablantes: una de inicio o acción y otra de respuesta o reacción, e intervención, la unidad inferior o monologal de análisis conversacional. Mientras que el intercambio es la unidad de análisis menor en el diálogo o conversación, el diálogo propiamente dicho constituye la unidad mayor. (Briz Gómez 2004).

A continuación, se explicitan las convenciones de transcripción asumidas en esta investigación.

\begin{tabular}{|c|c|c|c|}
\hline \multicolumn{2}{|c|}{$\begin{array}{l}\text { Aspectos fónicos } \\
\text { /h / aspiración }\end{array}$} & \multicolumn{2}{|c|}{ Aspectos prosódicos } \\
\hline /h / aspiración & & $\begin{array}{l}\text { ¿? } \\
i ! \\
/ \\
\backslash \\
\ldots- \\
\mid \\
\| \\
<x> \\
:: \\
\text { [pp.] } \\
\text { [ff.] } \\
\text { [enf.] } \\
\text { [ac.] } \\
\text { [le.] }\end{array}$ & $\begin{array}{l}\text { Interrogación } \\
\text { Exclamación } \\
\text { Tono ascendente } \\
\text { Tono descendente } \\
\text { Corte abrupto de palabra o } \\
\text { enunciado } \\
\text { Pausa breve } \\
\text { Pausa mediana } \\
\text { Pausa de x segundos de duración } \\
\text { Alargamiento de un sonido } \\
\text { Dicho en voz baja } \\
\text { Dicho en voz alta } \\
\text { Dicho enfáticamente } \\
\text { Ritmo acelerado } \\
\text { Ritmo lento }\end{array}$ \\
\hline \multicolumn{2}{|c|}{ Aspectos relativos a los turnos de palabras } & \multicolumn{2}{|c|}{ Aspectos no léxicos } \\
\hline $\begin{array}{l}\text { Identificación: } \\
=\ldots \ldots=\end{array}$ & $\begin{array}{l}\text { Turno de palabra } \\
\text { Solapamiento de dos intervenciones }\end{array}$ & $\begin{array}{l}\{\} \\
\text { [ ] } \\
\text { (???) }\end{array}$ & $\begin{array}{l}\text { Límites en los que se producen una } \\
\text { intervención no lingüística risas, } \\
\text { estornudos, etc.) } \\
\text { Interpretación de la investigadora de } \\
\text { las acciones o de las intenciones de } \\
\text { los participantes } \\
\text { Expresión ininteligible }\end{array}$ \\
\hline
\end{tabular}

En una segunda instancia, una vez constituido el corpus sobre el cual operar, se procedió a relacionar, agrupar y cuantificar la información empírica particular obtenida en las distintas instancias del trabajo de campo, a la luz del propósito, objetivos y preguntas de investigación. Estos procedimientos permitieron establecer los ámbitos, categorías, subcategorías y parámetros de análisis, descritos en el siguiente apartado de este capítulo. Muchos de estos fueron extraídos o adaptados de la bibliografía consultada (las fuentes son explicitadas en su oportunidad); otras constituyen categorías emergentes. 
Por último, los datos así reconstruidos habilitaron los procesos de comprensión y conceptualización que hicieron posible la formulación de cierres explicativos parciales en los diferentes momentos de la redacción del informe. La búsqueda de coherencia se realizó en el doble sentido señalado más arriba: hacia dentro de la investigación, procurando desentrañar las relaciones entre las distintas parcelas de información analizada; para ello se realizaron procedimientos de triangulación de la información, intentando identificar recurrencias y contradicciones; hacia afuera, confrontando los datos elaborados con las teorías de los campos de referencia.

\section{3. Ámbitos, categorías, subcategorías y parámetros de análisis}

A continuación, se describen y explican ámbitos, categorías y parámetros de análisis. En algunos de los puntos desarrollados, y en aras de lograr una mayor claridad, se incluyeron ejemplos extraídos del trabajo de campo. En el cuadro de la página 70 podrá observarse el resumen y relación entre todos estos aspectos y los que han sido mencionados en el apartado «Líneas, propósito, objetivos y preguntas de investigación» ( $\rightarrow$ 2.1.1.).

\subsubsection{Estilo del mediador}

\section{A. Ser del mediador}

En el contexto de este trabajo, y en estrecha relación con la noción de estilos de enseñanza reseñada en el apartado "Los estilos de enseñanza o pedagógicos» ( $\rightarrow$ 1.2.6.) se concibe el ser del mediador como una configuración singular de rasgos que caracterizan en forma holística la figura de este actor.

Para delimitar este primer ámbito de análisis, los rasgos seleccionados atañen a la individualidad del mediador, su contexto de procedencia y a sus prácticas lectoras (personales, o vinculadas al ejercicio de su rol, actuales, o biográficas), que inciden en la configuración de su estilo. Los datos para la construcción de esta categoría fueron extraídos tanto del análisis de las entrevistas a los mediadores y maestras como de los tópicos de conversación en las reuniones de los equipos comunitarios de lectura. Este ámbito se desglosa a su vez en las siguientes categorías:

- El mediador en persona: incluye aspectos generales de los sujetos investigados tales como edad, ocupación, contexto de procedencia y trayectoria en el rol.

- Preferencias y prácticas lectoras: considera los hábitos de lectura y preferencias lectora de los mediadores así como las lecturas que estos recomiendan hacer a los niños (en las reuniones del equipo comunitario); en las que se identifican géneros, autores y títulos.

- Biografía lectora del mediador: abarca los aspectos de su historia lectora que pueden incidir en el desarrollo de su rol.

- Apropiación del rol de mediador: describe la experiencia y permanencia del mediador en su rol y cómo este se transforma dialécticamente. También considera sus aportes a la construcción de su función en las reuniones del equipo comunitario, cuyo análisis se efectuó sobre los siguientes parámetros emergentes:

-los comentarios de los mediadores referidos al desarrollo de su tarea: aquellos que los mediadores comparten con los otros integrantes del equipo comunitario de lectura; 
-los comentarios referidos a sus experiencias de lectura como mediador: aquellos sobre sus vivencias en las sesiones de lectura;

-los comentarios referidos a experiencias propias o de su entorno: evocaciones autobiográficas o a experiencias de lectura actuales en sus entornos familiares, con sus hijos o nietos;

- los comentarios referidos a una intención de enseñanza: en los que se enuncian un propósito específico, por ejemplo, trasmitir valores o preparar a los niños para nuevas etapas de su vida.

El siguiente cuadro ilustra estos parámetros:

\begin{tabular}{|l|l|}
\hline Parámetros de análisis & Ejemplos \\
\hline Comentarios referidos al desarrollo de su tarea & $\begin{array}{l}\text { «Con respecto a llamar la atención antes de } \\
\text { empezar a leer... te acordás que cuando } \\
\text { vinieron los de ProLEE a dar la charla decían que } \\
\text { una de las estrategias que se pueden usar es } \\
\text { decir que los libros que son modernos ya vienen } \\
\text { con un chip, que si hay mucho ruido el libro se } \\
\text { cierra y después ya no se puede abrir...» Omar } \\
{[14.05 .2015] .}\end{array}$ \\
\hline $\begin{array}{l}\text { Comentarios referidos a sus experiencias de } \\
\text { lectura como mediador }\end{array}$ & $\begin{array}{l}\text { «[...] eso depende mucho del cuento o como de } \\
\text { uno lo cuente» Cecilia [18.06.2015]. }\end{array}$ \\
\hline Comentarios referidos a experiencias propias o \\
de su entorno (actuales o autobiográficas) & $\begin{array}{l}\text { «[...] yo soy fanático... «La gallina degollada» fue } \\
\text { el primer libro que me leyeron a mí en el liceo, } \\
\text { en primero de liceo un día faltó un profesor y } \\
\text { viene el adscripto y nos lee y después conseguí } \\
\text { el libro para leerlo todo» Omar [18.06.2015]. }\end{array}$ \\
\hline $\begin{array}{l}\text { Comentarios referidos a una intención de } \\
\text { enseñanza }\end{array}$ & $\begin{array}{l}\text { «[...] yo tengo un libro que es más bien... o sea } \\
\text { yo ya los leí, pero... es más bien para adultos... } \\
\text { pero están buenos capaz que para clases } \\
\text { grandes porque es más bien de filosofía de vida. } \\
\text { Por ejemplo, quinto y sexto están en un cambio } \\
\text { de entrar al liceo. Los libros se llaman, los tienen } \\
\text { que conocer, uno se llama El secreto y el otro es } \\
\text { La magia... Son medios largos, pero habría que } \\
\text { elegir algún capítulo que ellos puedan rescatar } \\
\text { para cosas futuras... ellos van a entrar al liceo y } \\
\text { ahí hay muchas cosas nuevas que de repente } \\
\text { desde un cierto lugar llevarlos a un plano } \\
\text { positivo... les va a costar, van a tener más } \\
\text { materias... es difícil» Cecilia [18.06.2015]. }\end{array}$ \\
\hline
\end{tabular}

- Motivaciones para ejercer su rol. Incluye los propósitos que impulsan a los mediadores a desempeñar este rol en el equipo comunitario de lectura. 


\section{B. Hacer del mediador}

Este ámbito refiere a aquellas acciones que caracterizan el hacer y decir del mediador durante las sesiones de lectura. Abarca las siguientes categorías.

- Modalidad lectora: volumen de voz, entonación, velocidad, fluidez, dicción, incorporación de gestos faciales o corporales y desplazamientos.

- Acciones del mediador para organizar el espacio y administrar el tiempo de lectura:

- Dónde se ubica para leer

- Si organiza y cómo el espacio de lectura y a los niños para escuchar la lectura

-Si organiza y cómo el tiempo destinado a la sesión de lectura

-Otras acciones que realiza

- La categoría gestión de la construcción del metatexto ${ }^{36}$ fue adaptada de las propuestas por DiasChiaruttini (2015). Abarca las subcategorías finalidad de las preguntas del mediador durante la conversación sobre lo leído y finalidad de las acciones que realiza.

- La finalidad de las preguntas del mediador constituye una categoría descriptiva de las preguntas que cada mediador realiza en función de lo que busca que los niños respondan.

- Para el análisis de la finalidad de las acciones se adaptaron los siguientes parámetros: reformular, sintetizar, expandir, avalar y gestionar el error interpretativo37, empleadas por Dias-Chiaruttini (2010; 2015) en su investigación, y se incorporaron otros, emergentes del análisis realizado: delimitar momentos en la sesión de lectura, generar expectativas en los niños, evidenciar la identidad del mediador, habilitar la participación de los niños, restablecer el orden para continuar la lectura, conseguir el feedback de los niños, dirigir la atención hacia un detalle del texto o de la imagen.

El siguiente cuadro sintetiza y explica los parámetros de análisis de la subcategoría finalidad de las acciones del mediador:

\footnotetext{
${ }^{36}$ Siguiendo a Genette, se denomina metatexto al comentario que une un texto a otro texto que refiere a él sin citarlo $(1989,13)$.

${ }^{37}$ Días-Chiaruttini determina estas categorías en función de los gestos didácticos de los docentes que participaron en su investigación. En el contexto del estudio que aquí se presenta, se optó por no emplear esta nominación pues conlleva una intencionalidad que no puede atribuirse a los mediadores que protagonizan este trabajo.
} 


\begin{tabular}{|c|c|c|}
\hline Acciones del mediador & Finalidad & Ejemplos \\
\hline $\begin{array}{l}\text { Reformular las expresiones } \\
\text { de los niños }\end{array}$ & $\begin{array}{l}\text { Retoman u ofrecen una } \\
\text { paráfrasis a los dichos de los } \\
\text { niños. }\end{array}$ & $\begin{array}{l}\text { Niña: que la niña fue muy } \\
\text { amable } \backslash \\
\text { Omar: una cosa / que la niña } \\
\text { fue muy ama::ble } \\
{[18.06 .2015]}\end{array}$ \\
\hline $\begin{array}{l}\text { Sintetizar las expresiones de } \\
\text { los niños }\end{array}$ & $\begin{array}{l}\text { Brindan un resumen de lo } \\
\text { que expresan los } \\
\text { participantes de la } \\
\text { conversación. }\end{array}$ & $\begin{array}{l}\text { Niña: que el niño fue } \\
\text { humilde con ellos / | y no } \\
\text { egoísta porque:: \| siempre } \\
\text { / siempre hay que ser bueno } \\
\text { con los otros niños que no } \\
\text { tienen } \\
\text { Omar: ¿y cómo se llama } \\
\text { eso? | solidaridad } \\
\text { [18.06.2015] }\end{array}$ \\
\hline $\begin{array}{l}\text { Expandir la información del } \\
\text { texto }\end{array}$ & $\begin{array}{l}\text { Añaden información sobre lo } \\
\text { expuesto. }\end{array}$ & $\begin{array}{l}\text { Cecilia: \{y acá muestran } \backslash \mid \text { a } \\
\text { los otros animalitos } \\
\text { comiéndose la comida } \backslash \mid \text { y } \\
\text { ya estaban todos satisfechos } \\
\text { con su pancita llena } \backslash \\
\text { (muestra las ilustraciones) } \\
<10>\} \text { [30.07.2015] }\end{array}$ \\
\hline $\begin{array}{l}\text { Avalar las expresiones de los } \\
\text { niños }\end{array}$ & $\begin{array}{l}\text { Reafirman y legitiman las } \\
\text { palabras de los niños. }\end{array}$ & $\begin{array}{l}\text { Niño: hizo negocio con todo } \\
\text { Omar: exacto [18.06.2015] }\end{array}$ \\
\hline $\begin{array}{l}\text { Restablecer el orden para } \\
\text { continuar la lectura }\end{array}$ & $\begin{array}{l}\text { Ponen límites a los niños. } \\
\text { Garantizan su escucha para } \\
\text { proseguir la lectura }\end{array}$ & $\begin{array}{l}\text { Patricia: saben que (???) } \\
\text { después tengo que levantar } \\
\text { mucho la voz y después...- } \\
{[28.07 .2015]}\end{array}$ \\
\hline $\begin{array}{l}\text { Corregir un error de } \\
\text { interpretación }\end{array}$ & $\begin{array}{l}\text { Formular la interpretación } \\
\text { correcta }\end{array}$ & $\begin{array}{l}\text { Niño: [enf.] es un dinosaurio } \\
\text { es un dinosaurio } \\
\text { Patricia: es un monstruo } \backslash \mid \\
\text { es un monstruo } \backslash \mid \text { exacto } \\
\text { [26.05.2015] }\end{array}$ \\
\hline
\end{tabular}

\begin{tabular}{|c|c|c|}
\hline Acciones del mediador & Finalidad & Ejemplos \\
\hline $\begin{array}{l}\text { Delimitar momentos en la } \\
\text { sesión de lectura. }\end{array}$ & $\begin{array}{l}\text { Marcar el comienzo o el final } \\
\text { de los distintos momentos de } \\
\text { la sesión de lectura. }\end{array}$ & $\begin{array}{l}\text { Rosario: y colorín colorado } \\
\text { este cuento se ha acabado } \\
\text { Niños a coro: }\{\text { aplausos\} } \\
\text { [11.08.2015] }\end{array}$ \\
\hline $\begin{array}{l}\text { Evidenciar la identidad del } \\
\text { mediador }\end{array}$ & $\begin{array}{l}\text { Destacar el lugar del } \\
\text { mediador como integrante de } \\
\text { la comunidad o su vínculo } \\
\text { familiar y diferenciarse del } \\
\text { maestro. }\end{array}$ & \begin{tabular}{|l|} 
Patricia: $[\ldots .$.$] ya me está$ \\
empezando a fallar la vista [...] \\
ique me olvidé de los lentes! \\
Y I con esto de la bolsa me \\
olvidé la cartera [26.05.2015]
\end{tabular} \\
\hline $\begin{array}{l}\text { Generar expectativas sobre la } \\
\text { lectura }\end{array}$ & $\begin{array}{l}\text { Generar expectativa para } \\
\text { incentivar la escucha, atraer } \\
\text { su atención o generar } \\
\text { suspenso. }\end{array}$ & $\begin{array}{l}\text { Patricia: ¿viene un señor? no } \\
\text { sé si viene un señor } \backslash \text { I vamos } \\
\text { a ver si viene un señor } \\
{[28.07 .2015]}\end{array}$ \\
\hline $\begin{array}{l}\text { Habilitar la participación de } \\
\text { los niños }\end{array}$ & $\begin{array}{l}\text { Dar la palabra a los niños o } \\
\text { asegurar que los demás lo } \\
\text { escuchen. }\end{array}$ & $\begin{array}{l}\text { Omar: va...- vamos a escuchar } \\
\text { lo que dijo la compañera de } \\
\text { nuevo [18.06.2015] }\end{array}$ \\
\hline $\begin{array}{l}\text { Dirigir la atención hacia un } \\
\text { detalle del texto o de la } \\
\text { imagen }\end{array}$ & $\begin{array}{l}\text { Hacer que los niños presten } \\
\text { atención a un detalle del } \\
\text { texto o de la imagen }\end{array}$ & \begin{tabular}{l} 
Rosario: Cuando el temible \\
tigre / I visita a la abuelita \} $\\
{\text { \{ंven las garras? (muestra las }} \\
{\text { ilustraciones }\langle 10>\text { )\} }} \\
{[14.07 .2015]}$ \\
\hline $\begin{array}{l}\text { Conseguir el feedback de los } \\
\text { niños }\end{array}$ & $\begin{array}{l}\text { Conocer el impacto de la } \\
\text { lectura en los niños }\end{array}$ & $\begin{array}{l}\text { Niños a coro: \{aplausos\} } \\
\text { Rosario: ¿les gustó? } \\
\text { [11.08.2015] }\end{array}$ \\
\hline
\end{tabular}
\end{tabular}




\section{Intervenciones e intercambios entre los participantes}

A pesar de que este constituye un ámbito relacional, pues cuantifica, describe y explica de qué manera interactúan el mediador y los niños durante las sesiones de lectura, se incluyó dentro de la dimensión estilo del mediador, al centrarse en el análisis de los comentarios sobre lo leído propiciados por estos actores. Para hacer operativo este análisis se establecieron los siguientes parámetros: intervenciones de los niños, intervenciones del mediador, intercambios entre los niños.

\subsubsection{Respuestas de los niños}

\section{Respuestas de los niños en las sesiones de lectura de los mediadores}

Este ámbito considera las respuestas de los niños en las sesiones de lectura de los mediadores. Las categorías emergentes del análisis realizado se adaptaron de la propuesta de categorización del proyecto Visual Journeys (Fittipaldi 2012: 79), que al ser exhaustiva, permite dar cuenta de cómo responden los niños frente al estilo del mediador. Estas subcategorías se desplazan desde las manifestaciones más básicas: las expresiones de entusiasmo, hacia los niveles de comprensión intratextual (referencial y explícito), y extratextual (persona y vivencial); toma en cuenta además las dimensiones del texto y de la obra literaria.

En este cuadro se explica la base de categorización de las respuestas de los niños empleada en este estudio y se brinda ejemplos de ellas:

\begin{tabular}{|c|c|c|}
\hline Categorías de respuesta & Descripción & Ejemplos \\
\hline Expresiones de entusiasmo & $\begin{array}{l}\text { Manifestaciones de agrado, } \\
\text { desagrado, sorpresa, etc. frente a la } \\
\text { lectura del mediador }\end{array}$ & $\begin{array}{l}\text { Patricia: ini un poquito! \||cंun } \\
\text { bocado? | preguntó Abuelo \| ¿no } \\
\text { prefieres un banquete? | iclaro que sí! } \\
\text { respondió la tortuga } \backslash \text { | hace poco / | } \\
\text { una apetitosa [enf.] culebra / | pasó } \\
\text { por acá \| si te apresuras / | la } \\
\text { puedes atrapar \| igracias por el } \\
\text { consejo! dijo la tortuga \| y se fue } \\
\text { rápido a cazar a la culebra } \\
\text { Niño: iguau::! } \\
\text { Niños a coro: [Sorpresa.] [26.05.2015] }\end{array}$ \\
\hline $\begin{array}{l}\text { Referencias literales sobre el texto o } \\
\text { las imágenes }\end{array}$ & $\begin{array}{l}\text { Comentarios referidos a la } \\
\text { información que aporta el texto o las } \\
\text { ilustraciones en forma explícita }\end{array}$ & $\begin{array}{l}\text { Patricia: ies un tejón! } \backslash\{\text { Continúa } \\
\text { recorriendo el salón mientras } \\
\text { muestra las ilustraciones }<20>\text {.\} } \\
\text { Niño: tiene un montón de comida } \backslash \\
\text { [28.07.2015] }\end{array}$ \\
\hline $\begin{array}{l}\text { Referencias inferenciales sobre el } \\
\text { texto o las imágenes }\end{array}$ & $\begin{array}{l}\text { Comentarios sobre aspectos no } \\
\text { explícitos en el texto }\end{array}$ & $\begin{array}{l}\text { Rosario: la encuentra jugando a las } \\
\text { cartas con Caperucita \{muestra las } \\
\text { ilustraciones }<10>\} \\
{[\ldots]} \\
\text { Niño: se encuentra con la abuelita sin } \\
\text { permiso del lobo } \backslash[14.07 .2015]\end{array}$ \\
\hline
\end{tabular}




\begin{tabular}{|l|l|l|}
\hline $\begin{array}{l}\text { Referencias intertextuales o } \\
\text { interculturales }\end{array}$ & $\begin{array}{l}\text { Alusión a saberes enciclopédicos o } \\
\text { experienciales extratextuales. } \\
\text { Conexiones con otros textos u otras } \\
\text { referencias culturales }\end{array}$ & $\begin{array}{l}\text { Niño: isí! } \backslash \mid \text { es lo que iba a decir } \backslash \mid \\
\text { en un cuento todo puede pasar } \backslash \mid \text { así } \\
\text { que no es raro [Patricia, 26.05.2015] }\end{array}$ \\
\hline Referencias composicionales & $\begin{array}{l}\text { Comentarios que refieren al libro } \\
\text { como objeto (sus partes, composición } \\
\text { interna, ilustraciones, etc.) }\end{array}$ & $\begin{array}{l}\text { Niño: Igual que en la tapa (la imagen } \\
\text { de la página es la misma que la de la } \\
\text { tapa) [Omar, 18.06.2015] }\end{array}$ \\
\hline Referencias personales & $\begin{array}{l}\text { Valoraciones personales sobre el } \\
\text { texto o las imágenes }\end{array}$ & $\begin{array}{l}\text { Patricia: otra vez Tejón / | quedó un } \\
\text { poco desilusionado } \backslash \mid \text { pero no por } \\
\text { mucho tiempo pues pronto espió un } \\
\text { conejo que pasaba caminando } \\
\text { \{ecorre el salón mostrando las } \\
\text { ilustraciones. <20>\} } \\
\text { [...] } \\
\text { Niños a coro: [Expresan pena.] } \\
\text { Niño: ipobre! [28.07.2015] }\end{array}$ \\
\hline Referencias vivenciales & $\begin{array}{l}\text { Establecimiento de relaciones entre el } \\
\text { texto y las experiencias personales de } \\
\text { los lectores }\end{array}$ & $\begin{array}{l}\text { Niña: mi madre me dice } \backslash \mid \text { valorá la } \\
\text { comida que hay niños que se están } \\
\text { muriendo de hambre en la calle } \\
\text { [Omar, 18.06.2015 ] }\end{array}$ \\
\hline
\end{tabular}

\section{E. Recuerdos de los niños sobre las lecturas del mediador}

Este ámbito considera los aspectos recordados del cuento leído ad hoc para la investigación por el mediador, recuperados en la entrevista a los niños. Se parte de la base de que estos recuerdos pueden brindan indicios sobre el aporte de la lectura de los mediadores a la construcción de las referencias culturales de los niños. Del análisis de sus respuestas se concretaron los siguientes parámetros:

\begin{tabular}{|c|c|c|}
\hline Aspectos recordados & Explicación & Ejemplos \\
\hline Título & $\begin{array}{l}\text { Recuerdan el título leído ad hoc por } \\
\text { el mediador }\end{array}$ & $\begin{array}{l}\text { Sofía: me gustó más El pájaro del alma y } \\
\text { La manta de las historias [escuela XX, } \\
\text { tercero A, caso Omar, 11.09.2015] }\end{array}$ \\
\hline Argumento & $\begin{array}{l}\text { Sintetizan de qué trata el cuento } \\
\text { leído }\end{array}$ & $\begin{array}{l}\text { Axel: me acordé que:: ...- | ¿̇que era un } \\
\text { mapache el de la...-? [...] un tejón | que } \\
\text { el tejón tenía comida | y:: no le gustaba } \\
\text { siempre la misma | y quería comer algo } \\
\text { bueno | y siempre que quería comer un } \\
\text { animal pasaba algo [escuela XXX, } \\
\text { tercero B, caso Patricia, 29.09.2015] }\end{array}$ \\
\hline Marco & $\begin{array}{l}\text { Recuperan personajes, tiempo y /o } \\
\text { espacio de la narración }\end{array}$ & $\begin{array}{l}\text { Franco: [...] que había una señora que } \\
\text { hacía una una como una sábana de así } \\
\text { de todo lana [escuela XX, tercero A, caso } \\
\text { Omar, 11.09.2015] }\end{array}$ \\
\hline Acción narrativa & $\begin{array}{l}\text { Recuperan la cadena de } \\
\text { acontecimientos narrados. }\end{array}$ & $\begin{array}{l}\text { Yasmila: [...] me acuerdo que:: \\
| una:: } \\
\text { señora mayor / | era la que contaba } \\
\text { cuentos a los niños } \backslash \mid \text { tenía una ma::n } \backslash \\
\text { una gran manta / | Ilena de colores } \backslash \|\end{array}$ \\
\hline
\end{tabular}




\begin{tabular}{|c|c|c|}
\hline & & $\begin{array}{l}\text { iba a retazos... \| eh:: \| y luego / | un } \\
\text { niño se le rom...- } \backslash \mid \text { se rompió un } \\
\text { champión } \backslash \mid \text { y se le...- } \backslash \text { y después sacó } \\
\text { una parte de su manta y le:....- } \backslash \mid \text { y le } \\
\text { había hecho un parche } \backslash \mid \text { después } \\
\text { empezó a darle regalos de esa manta } \backslash \mid \\
\text { a toda la ciudad / | que...- / | donde ella } \\
\text { vivía / | y después los niños } \backslash \mid \text { y toda la } \\
\text { ciudad / | le hicieron otra manta } \backslash \| \text { me } \\
\text { había gustado la gentileza de la señora / } \\
\text { | a darle los regalos a la gente / | y } \\
\text { también } \backslash \mid \text { la humildad } \backslash \mid \text { de aquel...- } \backslash \\
\text { de aquellos niños y la ciudad que le } \\
\text { habían hecho la manta } \backslash \mid \text { [escuela XX, } \\
\text { tercero A, caso Omar } 11.09 .2015 \text { ] }\end{array}$ \\
\hline $\begin{array}{l}\text { Comentarios de los mediadores } \\
\text { durante la sesión }\end{array}$ & $\begin{array}{l}\text { Intervenciones de los mediadores } \\
\text { sobre el cuento leído }\end{array}$ & $\begin{array}{l}\text { Sandra: ¿qué te acordás de ese cuento? } \\
\text { Michael: de una cena elegante con velas } \\
\text { Y...- }<10>\text { y todas esas cosas [escuela } \\
\text { XXX, tercero B, caso Patricia, } \\
29.09 .2015 \text { ] }\end{array}$ \\
\hline
\end{tabular}

\section{F. Valoraciones de los niños sobre el mediador}

Este último ámbito se nutre del análisis de las respuestas de los niños a la encuesta; permite establecer cómo y qué valoran del mediador y si estas valoraciones se relacionan con la prácticas sociales o escolares de la lectura.

- Del análisis de los tópicos se definieron las siguientes categorías emergentes, explicitadas y ejemplificadas en el siguiente cuadro:

\begin{tabular}{|l|l|l|}
\hline Tipos de respuestas & Explicación & Ejemplos \\
\hline $\begin{array}{l}\text { Centradas en el vínculo familiar en } \\
\text { general }\end{array}$ & $\begin{array}{l}\text { En estas respuestas los niños solo } \\
\text { destacan la importancia de la } \\
\text { presencia de la familia, sin } \\
\text { mencionar su relación con la lectura. }\end{array}$ & $\begin{array}{l}\text { «Es muy lindo ver a los familiares en } \\
\text { la escuela.» [Escuela XX, Tatiana, 3. } \\
\text { B, caso Cecilia] }\end{array}$ \\
\hline $\begin{array}{l}\text { Centradas en la persona del } \\
\text { mediador }\end{array}$ & $\begin{array}{l}\text { Estas respuestas hacen énfasis en } \\
\text { algún rasgo personal del mediador. } .\end{array}$ & $\begin{array}{l}\text { «Porque es divertida. Porque buena } \\
\text { Porque es graciosa.» [Escuela XXX, } \\
\text { Elías, 3. }{ }^{\circ} \text { B, caso Patricia] }\end{array}$ \\
\hline Centradas en la lectura del mediador & $\begin{array}{l}\text { En esta subcategoría se incluyen las } \\
\text { respuestas que valoran la modalidad } \\
\text { lectora del mediador o los libros que } \\
\text { lee. }\end{array}$ & $\begin{array}{l}\text { "Me gusta que nos lea porque lee } \\
\text { bien.» [Escuela XXX, Daniel, 3. } .^{\circ} \text { A, } \\
\text { caso Rosario] }\end{array}$ \\
\hline $\begin{array}{l}\text { Centradas en la experiencia de } \\
\text { lectura con el mediador }\end{array}$ & $\begin{array}{l}\text { Son aquellas respuestas en las cuales } \\
\text { los niños destacan su experiencia de } \\
\text { lectura con el mediador. }\end{array}$ & $\begin{array}{l}\text { "Cuando nos lee un cuento estamos } \\
\text { tranquilos.» [Escuela XX, Agustina, 3. } \\
\text { B, caso Cecilia] }\end{array}$ \\
\hline Centradas en el vínculo niño-libro & $\begin{array}{l}\text { Estas respuestas refieren al vínculo } \\
\text { entre el niño y la lectura o entre el } \\
\text { niño y el libro; el mediador está } \\
\text { ausente. }\end{array}$ & $\begin{array}{l}\text { "A veces con los cuentos aprendés } \\
\text { cosas que no sabías.» } \\
\text { [Escuela XX, Sofía, 3. }{ }^{\circ} \mathrm{A}, \text { caso Omar] }\end{array}$ \\
\hline
\end{tabular}


Centradas en el libro y la lectura en general
En estas respuestas los niños se expresan sobre los libros y la lectura en general. Están ausentes los niños y los mediadores.
«Porque cuando leen se abre un mundo de imaginación.» [Escuela XX, Facundo A., 3. ${ }^{\circ}$ A, caso Omar]

- Por último, de los títulos recordados por los niños en la encuesta se sistematizó si estos fueron leídos por el mediador que participó de la investigación (en 2014 o 2015) o por otros actores.

A continuación, se presenta el cuadro que resume y relaciona propósito, objetivos, preguntas, ámbitos, categorías y parámetros de análisis ya explicitados. 


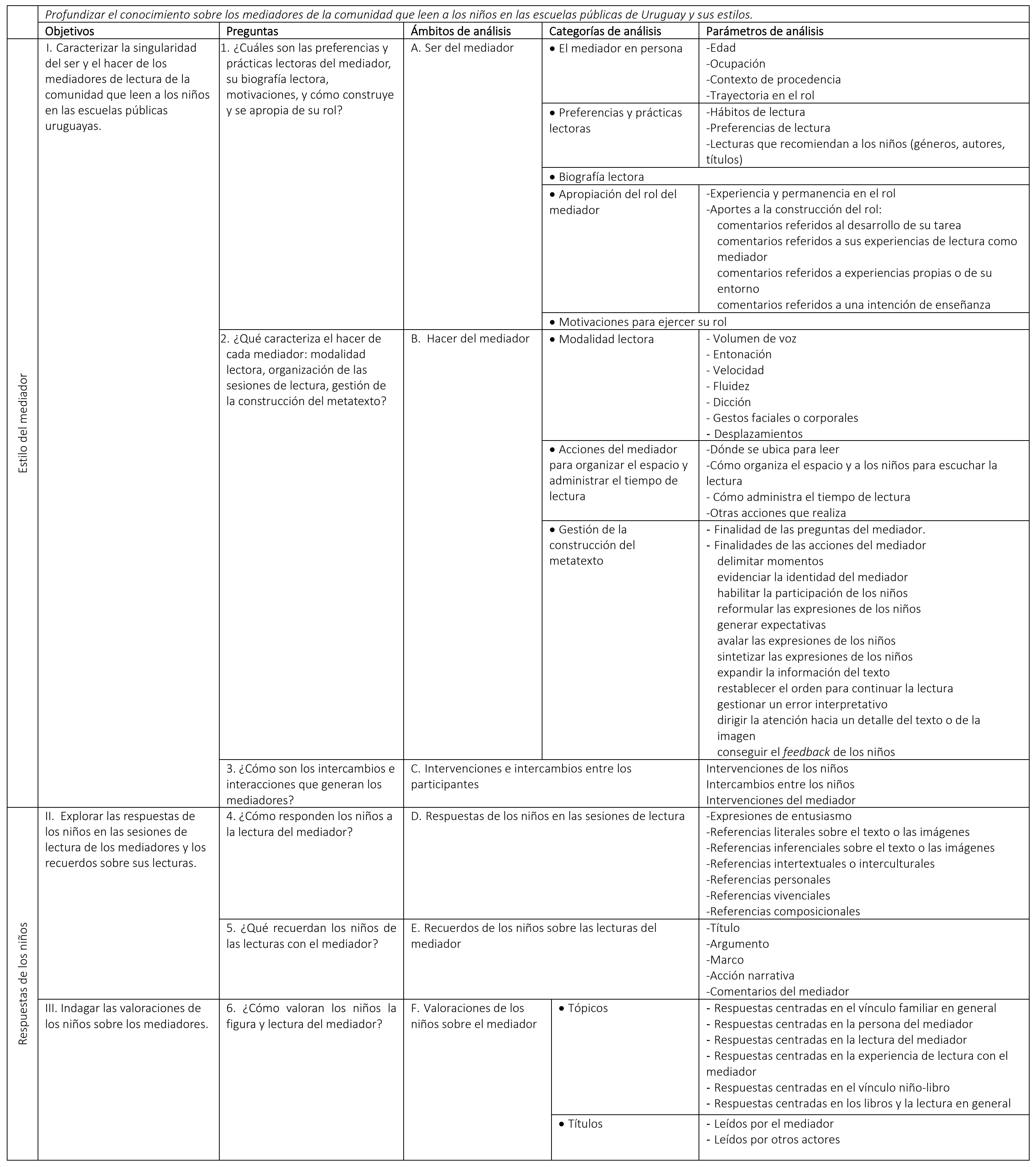




\subsection{Contexto de investigación}

Este capítulo describe de manera resumida los ámbitos en los que se desarrolló la investigación: el proyecto Biblioteca Solidaria, las escuelas XX y XX, los equipos comunitarios y clases de tercer año de cada escuela, con el propósito de ofrecer un marco contextual para el estudio.

\subsubsection{Biblioteca Solidaria}

Este proyecto se inició en 2014 por iniciativa del Programa de Lectura y Escritura en Español (ProLEE) de la Administración Nacional de Educación Pública ${ }^{38}$. Durante 2014, se desarrolló su fase piloto en 300 escuelas de todo el territorio nacional, seleccionadas por el Consejo de Educación Inicial y Primaria (sobre un total de 2300). En 2015 se llevó a cabo su consolidación con las escuelas que participaron durante 2014 y manifiesten su voluntad de continuar haciéndolo.

Para participar en Biblioteca Solidaria, los centros educativos debieron manifestar su decisión expresa de hacerlo, se comprometieron a elaborar un plan lector escolar (PLE) ${ }^{39}$ y convocar a la formación de los equipos comunitarios de lectura.

Biblioteca Solidaria se propuso brindar a los alumnos experiencias de lectura literaria (narración, poesía, teatro) y no ficcional con fines recreativos, en este sentido, aporta a las escuelas participantes una colección inicial mínima de 64 libros $^{40}$.

El proyecto apela a las familias y a la comunidad educativa convocándolas a colaborar de la formación de los escolares como lectores, habilitando su participación en los equipos comunitarios de lectura. La propuesta se fundamenta en el convencimiento de que la inclusión de los sujetos en la cultura letrada requiere de una comunidad que involucre a los estudiantes con la lectura y la escritura como prácticas sociales y culturales. Concibe una nueva dinámica de circulación de las prácticas y saberes lectores mediante la colaboración estrecha de actores sociales e instituciones educativas, con el propósito de enriquecer el vínculo con la cultura escrita (ProLEE, 2014). Sugiere además la relectura de las obras y el comentario sobre lo leído para establecer referencias culturales compartidas.

En este marco, la lectura es concebida como una herramienta indispensable para la construcción de ciudadanía e inclusión social.

\footnotetext{
${ }^{38}$ La Administración Nacional de Educación Pública (ANEP, Uruguay) es el ente autónomo que tiene por cometido elaborar, instrumentar y desarrollar las políticas educativas. Está integrado por el Consejo Directivo Central, los Consejos de Educación Inicial y Primaria, Consejo de Educación Secundaria, Consejo de Educación Técnico-Profesional (UTU) y el Consejo de Formación en Educación (Ley General de Educación nro. 18437 14.02.2014).

${ }^{39}$ El Plan Lector Escolar (PLE) es un proyecto institucional cuyo propósito es vincular a los niños y a los miembros de la comunidad con la cultura escrita, promoviendo la mejora de los niveles de lectura y las prácticas lectoras (Prolee: 2014: 3).

${ }^{40}$ Las obras fueron seleccionadas del catálogo Biblioteca mínima para educación inicial y primaria, una selección de libros de autores nacionales, hispanoamericanos y traducidos al español, realizada en 2012 por un conjunto de instituciones uruguayas vinculadas con el libro y la lectura.
} 


\subsubsection{Escuela XX}

La escuela XX ${ }^{41}$ se localiza en el barrio Belvedere (Centro Comunal Zonal 14), al oeste de la capital de Uruguay, a una distancia aproximada de 6 kilómetros del centro. Esta zona cuenta con una población de 83112 habitantes distribuidos en una superficie de 1317 hectáreas ${ }^{42}$. Atraviesa el barrio una de las principales avenidas de la ciudad sobre la que se emplaza un centro comercial de referencia para los vecinos de la zona y zonas aledañas.

El edificio escolar es relativamente moderno y fue construido en la década del setenta para el funcionamiento de este centro de estudio. Se encuentra situado en un parque, rodeado de un espacio verde, y se ubica aproximadamente a 80 metros de la avenida principal. Por este motivo, la escuela recibe, además de niños del barrio, a niños de barrios contiguos que deben viajan diariamente en vehículos particulares o en el transporte público para llegar hasta allí.

Este centro escolar está categorizado como urbano común ${ }^{43}$; funciona de lunes a viernes en el turno matutino, de 8 a 12 horas, y comparte el local con otra escuela que funciona en el turno vespertino (13 a 17 horas). La población que atiende se corresponde con el quintil 4 urbano ${ }^{44}$.

La institución cuenta con un cuerpo docente estable, en su mayoría constituido por maestros efectivos en la institución con muchos años de permanencia en ella y de antigüedad en la docencia. Trabajan en esta escuela 16 maestros, una profesora de Arte, un profesor de Educación Física, un profesor de informática y dos auxiliares de servicio. Los niños desde cuarto año en adelante cuentan con clases semanales de Inglés en la modalidad de teleconferencias. Recibe además durante todo el año a estudiantes magisteriales que realizan su último año de práctica docente (cuarto año). En 2015, este centro de estudio registró 327 niños, matriculados desde nivel inicial 4 hasta sexto año, con un promedio de 23,10 alumnos por maestro. La tasa de repetición fue de 2,9 y la de abandono de 0,40.

La escuela XX ingresó a Biblioteca Solidaria en mayo de 2014, en los inicios del proyecto. En 2015, el proyecto funcionó desde fines de abril hasta mediados de agosto; el conflicto en la enseñanza determinó de hecho la finalización de las actividades del equipo lector que no volvió a ser convocado.

\footnotetext{
${ }^{41}$ Los datos de referencia poblacional de las escuelas XX y XXX fueron extraídos del documento Informes censos 2011. Montevideo y área metropolitana:
}

http://www.montevideo.gub.uy/sites/default/files/informe_censos_2011_mdeo_y_area_metro.pdf [05.2016].

Los datos de referencia de los centros escolares fueron extraídos del Portal Monitor Educativo del Consejo de Educación Inicial y Primaria. http://www.anep.edu.uy/portalmonitor/servlet/portada [05.2016].

42 Según datos de Octavo Censo de Población realizado en 2011 en Uruguay.

${ }^{43}$ El Consejo de Educación Inicial y Primaria de la Administración Nacional de Educación Pública clasifica a sus escuelas, según su localización geográfica, en Rurales y Urbanas; subclasifica a estas últimas en Jardines de Infantes, Urbanas Comunes, Aprender, Tiempo Completo, Tiempo Extendido y de Práctica, según diferentes criterios. Las escuelas urbanas comunes son aquellas ubicadas en las zonas urbanas que quedan excluidas de las otras categorías. Pueden ser de un turno (matutino o vespertino) o de doble turno (funciona en los dos turnos y los niños concurren a uno $u$ a otro).

${ }^{44}$ En una escala del 1 al 5, el quintil 1 indica el contexto sociocultural de mayor grado de vulnerabilidad y el 5 el de menor grado. Fuente: Monitor Educativo de Enseñanza Primaria. Estado de situación 2015: http://www.anep.edu.uy/portalmonitor /PublicTempStorage/estado_de_situacion_20151181103.pdf [05.2016]. 


\subsubsection{Equipo comunitario de lectura de la escuela XX}

El equipo comunitario de lectura ${ }^{45}$ se conformó en 2014, luego de varias convocatorias y comenzó a funcionar en mayo de ese año. Se formó un grupo numeroso que después se fue decantando. En los comienzos, algunos mediadores que empezaron muy tímidamente a leer, concurrieron en duplas a las clases y luego, a medida que adquirieron seguridad empezaron a leer solos.

Según María, la directora, los mediadores que se sostuvieron en el equipo, pudieron hacerlo por iniciativa personal, y por la apertura de las maestras que los recibieron en sus clases:

[...] me parece que se sostuvieron los que por iniciativa de la persona que vino a leer logró tener continuidad | y los que no lo lograron y no tuvieron tampoco el apoyo de los maestros o...- | tanto de los maestros responsables del proyecto como de los maestros de clase que lo reciben

[...] eso me parece que puede haber ocurrido | y en cambio en las clases que hubo esta apertura y esta disposición fue donde más se sostuvo [el mediador] y donde más provechosa fue la instancia [...]

Asimismo, la directora consideró muy positiva la integración del equipo comunitario de lectura a la escuela, tanto para la institución como para los mediadores; muchos de ellos conquistaron de esta manera un lugar «no menor dentro de la comunidad educativa»:

[...] hay gente que: desde lo personal porque hay algunas personas de las que están que yo conozco I su histo::ria y su trayectoria en la institución como se acercaron en un momento como fue evolucionando ese formar parte de la escuela | creo que para ellos también [...] ha tenido un valor | y para nosotros | y en algunos casos hasta te diría hasta recuperar a esas familias desde ese lugar ha sido...- [...] desde acá sí yo lo puedo valorar así impresionante ha sido [...] 27.11.2015

En 2015 la escuela convocó a fines de abril a los integrantes que habían participado el año anterior, quienes constituyeron la base del nuevo equipo: dos abuelos: Omar y Graciela y una mamá, Carla. Desde el inicio, se sumaron a la tarea otras tres jóvenes mamás: Leticia, Carolina y Elsa; más adelante, reingresó Cecilia, quien ya había oficiado de mediadora en 2014 en algunas oportunidades, sustituyendo a Carla.

En el siguiente cuadro se visualiza la integración del equipo comunitario de la escuela XX durante 2014 y 2015:

\begin{tabular}{|l|l|}
\hline 2014 & 6 integrantes: Sandra, Carla, Cecilia, Omar, Graciela, Walter \\
\hline 2015 & 7 integrantes: Carla, Cecilia, Omar, Graciela, Leticia, Elsa, Carolina \\
\hline
\end{tabular}

\subsubsection{Reuniones del equipo comunitario de lectura de la escuela $X X$}

El equipo comunitario fue convocado a reunión por las maestras referentes entre fines de abril y julio de 2015. Luego, por la interrupción de los cursos a causa del conflicto en la enseñanza, la convocatoria cesó hasta el 30 de noviembre, cuando se realizó la reunión final de evaluación y el cierre de las actividades del equipo.

\footnotetext{
${ }^{45}$ Información proporcionada por la directora de la escuela y las maestras en sus entrevistas ( $\rightarrow$ anexo 3.1. «Entrevista a María, directora de la escuela XX»; anexo 3.3.1.2 «Entrevista a Inés, maestra de tercer año A» y anexo 3.4.1.2. «Entrevista a Noelia, maestra de tercer año B». ).
} 
Durante estas reuniones, que se realizaban a primera hora de la mañana, generalmente cuando los niños de tercer año asistían a las clases de Educación Física, las maestras referentes, Inés, de tercero A, y Noelia, de tercero B, brindaban pautas a los mediadores sobre el funcionamiento del proyecto de lectura de la escuela, sugerían libros y coordinaban las sesiones en las diferentes clases. Les aconsejaban además sobre cómo realizar su tarea y les proponían alternativas a ir a leer a aquellos que no se sintieran seguros.

Los integrantes del equipo comunitario de lectura también tuvieron en estas reuniones la oportunidad de intercambiar opiniones y experiencias. En estas instancias, compartieron consejos y comentarios referidos al desarrollo de su tarea, a sus experiencias de lectura como mediadores, a sus experiencias de lectura propias o de su entorno (actuales o autobiográficas) y a sus intenciones de enseñanza, generalmente vinculadas con un propósito moralizante o para la vida. También compartieron algunos títulos cuyas lecturas les interesaba hacer en las clases; estas sugerencias se relacionaban generalmente con sus preferencias lectoras, con las de sus hijos o nietos o con las lecturas de su infancia o adolescencia.

Los miembros más antiguos del equipo comunitario: Omar, Graciela, Carla y Cecilia registraron en las reuniones mayor cantidad de intervenciones, frente a las integrantes nuevas.

Las reuniones del equipo comunitario de lectura de la escuela XX no estuvieron exentas de tensiones surgidas entre alguna mediadora y las maestras referentes. Por ejemplo, en la reunión del 14 de mayo, ante el comentario de la maestra Inés sobre las lecturas que los mediadores proponían, que son "para que los niños se porten bien», Carla, una mamá respondió: «Me parece que está bueno... yo leía uno que la moraleja era ser buen compañero, y hay veces que están peleando, son chiquitos y está peleando y vos le decís: no, no se pega... hay veces que te van a entender, creo yo, con una historia [...]». Y en la reunión del 18 de junio, ante la sugerencia de la maestra de presentar audiocuentos en la clase a causa de que lee en voz muy baja, la misma mediadora le reprochó que el libro que le sugirió leer no era apropiado para tercer año: «[...] y lo que pasa es que ese cuento no tiene, si vos lo miraste, no tiene casi dibujos, entonces no tiene sentido que yo venga porque el libro tiene cada veinte páginas un dibujito así».

\subsubsection{Clases de la escuela XX que participaron de la investigación}

\section{Tercer año A}

Integraron la cohorte 2015 de esta clase 25 alumnos. Inés, su maestra, es efectiva en el cargo por concurso y cuenta con 27 años de experiencia profesional. Llegó a la escuela en 2015 por traslado. Fue además durante este año referente de Biblioteca Solidaria junto con su colega, Noelia, de tercer año B.

En 2015, esta clase fue visitada por Omar, abuelo de Clara (alumna de este grupo), quien leyó en cuatro oportunidades: El pájaro del alma, Un puñado de semillas, "La abeja haragana», La manta de las historias.

La docente manifestó desde el inicio una actitud positiva hacia la participación de la escuela en Biblioteca Solidaria, al aceptar ser la referente del proyecto. También demostró dar un lugar destacado en sus prácticas de enseñanza a la lectura literaria, tal como se pudo observar en la ambientación del salón de clase con bibliotecas (armadas con cajas de madera de colores). Manifestó además valorar especialmente la participación del mediador en su clase tal como se evidenció en su recibimiento a Omar: 
Inés: te extrañamos Omar \contanos \| contanos ¿qué te pasó?

Omar: algunos problemitas de salud | pero ya estoy:: || recuperado \18.06.2015

... en la organización de su clase para recibir al mediador;

... en su apoyo para mantener el clima de lectura (en los llamados de atención a los niños más inquietos);

... en su involucramiento en determinados momentos de la sesión:

Omar: $\{($ risas $)$ este es como el hijo del papanatas $\backslash \mid$ si no la gana la empata $\}$

Niños: \{risas\} [desorden]\}

Inés: \{(risas) se acomoda en el aire 12.08 .2015

... en dar continuidad a los comentarios de Omar luego de que este finalizara su sesión;

... y en sus valoraciones sobre el mediador durante la entrevista:

[sobre la presencia del mediador] a mí me resultó fantástico [...] pero además es una persona muy cálida [...] y él también es un ser muy disponible | vos le decís este o el otro | o sea tira propuestas o sea...- || me parece que ta ...- | es bárbaro para los chiquilines | como tener esa posibilidad de tener un referente varón en esa...- | en esa postura también | además bueno lee bien conversa con los chiquilines bien | me parece que tiene un plus | no escuché a otros | lectores leer en los grupos pero | me parece que tiene un plus porque él lo envuelve con esa calidez humana que tiene que es bárbaro [19.11.2015]

Tercero A contó además durante el año en que se desarrolló la investigación con una estudiante magisterial que realizó en este curso su último año de práctica docente.

\section{Tercer año B}

Esta clase contabilizó 25 niños en su cohorte 2015. Noelia, su maestra es interina en el cargo, pero es el tercer año que trabaja en la escuela y en este grado.

Durante 2015, tercer año A recibió a tres mamás lectoras: Carla, quien abandonó su rol por problemas de salud, Tatiana (de profesión maestra, quien no integró el equipo comunitario) y Cecilia, quien leyó en tres ocasiones: Así reinaba el rey Reinante, Un puñado de semillas y Una cena elegante.

Noelia es referente de Biblioteca Solidaria desde 2014. En los inicios del proyecto, realizó el curso «Estrategias de enseñanza de la lectura», dictado por el Ministerio de Educación y Cultura para los maestros referentes del proyecto. Ella, al igual que Inés manifestó una opinión positiva hacia la presencia de los mediadores en la escuela y en su clase:

[...] tiene algunas...- eh:: | tiene cosas a favor porque...- | a mí me gusta por ejemplo...- | primero viene la familia a la escuela ¿no? | es un día que viene alguien de de | de la familia a leer un cuento || eso es sumamente importante porque ellos la espe::ran | les gusta | ese cuento está en su casa muchas veces antes | entonces ellos ya...- | alguno alguno ya lo cono...- | lo conoció entonces se siente...- hay como una motivación ¿verdad? | ven a otra persona otra figura | es un momento de lectura placentera

... pero demostró cierta desconfianza en la lectura de los mediadores...

[...] a veces lo que pasa es | yo siento que eh::| la atención es la misma pero a veces || no quiero ser pedante ni nada | el maestro le pone como una impronta que a veces los papás no lo saben | entonces 
el maestro al leer...- || por ejemplo cuando vino una mamá que era maestra | la mamá de Tatiana | a leerles un cuento | eh:: había como una connotación diferente ¿verdad? | en el cambio de voces y en la atención a ciertas cosas | eh:: los papás a veces | algunos logran como modificar | y a veces hacen como algún cambio en el proceso | pero a veces es como una lectura | llana ¿ंverdad? | no hay una transformación || eh:: yo a veces...- | yo siento que los niños disfrutan | las dos formas | porque son dos formas diferentes que les lean | porque es la forma que les leen en su casa también | entonces...- es totalmente disfrutable también | yo siento que es diferente | a cómo lee el maestro en la clase a cómo lee el papá que viene

A pesar de ello, valoró especialmente la presencia de Cecilia como mamá lectora en su clase:

eh:: Cecilia bien [enf.]| había una energía | había una lectura lige::ra viste |eh:: | intervenía con algunas cosas bastante:: importa::ntes en la lectura eh:: | se nota mu::cho y se hace la diferencia | cuando eh:: | los que vienen a leer |logran tener esa lectura corrie::nte han leído antes el cuento y ...- | en los niños se nota mucho eso | en la atención ¿no? [08.10.2015]

Esta clase recibió, al igual que el de tercero A, a una estudiante de magisterio quien realizó su último año de práctica docente.

\subsubsection{Escuela XXX}

Esta escuela se emplaza en el cruce de dos avenidas, en el barrio Cerro (Centro Comunal Zonal 17), al suroeste de la capital y a 12 kilómetros de su centro. Su población es de 74238 habitantes, distribuidos en 1227 hectáreas ${ }^{46}$.

La institución funciona de lunes a viernes en el horario matutino, de 8 a 12 horas. El edificio, construido en la década del noventa para el funcionamiento de la escuela, es compartido con otro centro escolar de similares características, que funciona en el turno vespertino, de 13 a 17 horas.

Por su emplazamiento, es una escuela urbana común. Su población proviene mayoritariamente del radio escolar, y se traslada hacia el local desde distancias cercanas, caminando o en ómnibus de línea. Mayoritariamente pertenece al quintil urbano 2, por lo que es una escuela atendida por el programa Aprender del Consejo de Educación Inicial y Primaria ${ }^{47}$.

En 2015, la población de la escuela XXX ascendía a 377 alumnos, distribuidos desde Inicial 4 a sexto grado 48 .

El centro escolar cuenta con un núcleo estable de maestras efectivas, con antigüedad docente y permanencia en el grado, quienes han elegido continuar en el centro educativo; otra fracción del cuerpo

\footnotetext{
${ }^{46}$ Según datos de Octavo Censo de Población realizado en 2011 en Uruguay.

${ }^{47}$ El Programa Aprender (Atención Prioritaria en Entornos con Dificultades Estructurales Relativas) constituye una de las líneas de la política educativa desarrollada por el Consejo de Educación Inicial y Primaria. Focaliza su atención en las escuelas de población con mayor grado de vulnerabilidad (quintiles 1 y 2).
}

Fuente: http://www.ceip.edu.uy/programas/aprender [07.2019].

${ }^{48}$ Los datos de referencia poblacional de las escuelas XX y XXX fueron extraídos del documento Informes censos 2011. Montevideo y área metropolitana:

http://www.montevideo.gub.uy/sites/default/files/informe censos 2011 mdeo y area metro.pdf [05.2016]. 
docente, compuesta por maestros muy jóvenes, con escasa antigüedad en la docencia, se renueva año a año. Trabajan en la escuela 16 maestros, además de la directora y secretaria. Cuenta con profesor de Educación Física y Huerta. La escuela participa además de la modalidad de cursos de inglés a distancia, por teleconferencias dictadas por el plan Ceibal.

En 2015, la escuela XXX registró un promedio de 24,9 alumnos por maestro, una tasa de repetición de 5,9 y 1,40 de abandono. La matrícula en tercer año fue de 47 niños ${ }^{49}$.

La escuela XXX participa en Biblioteca Solidaria desde sus comienzos, en 2014. Según informó la maestra referente, el proyecto funciona desde fines de abril del citado año a la fecha. El conflicto en la enseñanza, que discontinuó las clases a mediados de 2015, no incidió en su desarrollo, y las lecturas se retomaron en la modalidad y frecuencias habituales una vez finalizado aquel, hasta el mes de noviembre, fecha prevista por la escuela para la culminación de la segunda experiencia. El cierre del proyecto se realizó con un homenaje de los niños a las mediadoras y con la entrega de un obsequio para ellas.

Cabe destacar que la escuela XXX utilizó en 2015 los fondos del proyecto Podes ${ }^{50}$, otorgado por el programa Aprender a las escuelas que funcionan dentro de su órbita, para incrementar el acervo de libros de la biblioteca escolar.

\subsubsection{Equipo comunitario de lectura de la escuela XXX}

El equipo comunitario de lectura se conformó, tanto en 2014 como en 2015, a partir de la convocatoria de los maestros de cada clase a las familias de sus alumnos, La primera convocatoria fue realizada en marzo de 2014. Rosa, la directora de la escuela, destacó el compromiso y afinidad de los docentes con el proyecto, sin cuyo impulso no se hubiera podido desarrollar:

[...] yo pienso que to::do el camino | todo lo que se ha transitado ahora | porque estamos muy conformes no solamente con los resultados | sino cómo se fue desarrollando el proyecto | es porque los docentes | están codo a codo con el trabajo mismo [...] [04.12.2015]

En 2014 el equipo estuvo integrado por ocho madres; de este grupo inicial permanecieron en 2015 Patricia, Andrea A., Mónica y Janet, quien continuó en el equipo a pesar de que su hijo más pequeño egresó de la escuela el año anterior.

\begin{tabular}{|l|l|}
\hline 2014 & $\begin{array}{l}8 \text { integrantes: Bárbara, Alejandra, Patricia, Janet, Elizabeth, Claudia, Paola y } \\
\text { Mónica }\end{array}$ \\
\hline 2015 & $\begin{array}{l}8 \text { integrantes: Patricia, Janet, Mónica, Rosario, Andrea A., Andrea B., Laura y } \\
\text { Margareth }\end{array}$ \\
\hline
\end{tabular}

\footnotetext{
${ }^{49}$ Los datos de referencia de los centros escolares fueron extraídos del Portal Monitor Educativo del Consejo de Educación Inicial y Primaria: http://www.anep.edu.uy/portalmonitor/servlet/portada [05.2016].

${ }^{50}$ El proyecto Podes (Proyecto Oportunidad de Desarrollo Educativo y Social) es un proyecto curricular, de ejecución a dos años, que otorga recursos financieros para la ejecución de una iniciativa generada y gestionada en forma autónoma por las escuelas.
} 
Mariela, la maestra referente del proyecto en 2015, indicó que este año se había logrado solucionar los problemas de funcionamiento que se suscitaron en 2014, el primero de ellos causado por la merma del equipo luego de las vacaciones de invierno:

[las madres] eran dos o tres hasta el final remando los últimos tiempos, los últimos tiempos, un montón de clases, somos un montón de clases, la escuela es muy grande. Nosotros este año venimos divino. Una por nivel, precioso. Este año venimos bárbaro. Más allá de que una se enferme y todo eso, seguimos al firme. El año pasado habíamos empezado muy bien, pero después a fin de año quedó un poquito más... se recargaron algunas [...] [14.07.2014].

El segundo, originado porque algunas integrantes del equipo comunitario de lectura querían ir a leer únicamente a las clases de sus hijos. Mariela, la maestra referente de Biblioteca Solidaria, enfatizó que este problema se logró solucionar y destacó la evolución en el compromiso y la autonomía de funcionamiento del equipo de un año a otro:

[las madres] también | se fortalecieron muchísimo ellas en la tarea de:: | de:: | leer |[las antiguas integrantes] apoyaron a las que vinieron [...] y ellas mismas se apoyaron | se fortalecieron || generaban...- | se comentaban los cuentos | se decían cuál podían...- | «bueno mirá yo leí este que está bueno ese no tanto por lo menos en el grado que yo tuve no les llamó mucho la atención»| ellas mismas iban generando | ya llegó un momento que eran totalmente autónomas | me faltó darles las llaves de la biblioteca agarren el libro y ya estaban | porque se manejaban bárbaro solas [...] [04.12.2015]

Tanto Rosa como Mariela destacaron el compromiso y la disposición de las integrantes del equipo comunitario:

Rosa: vos sabés que son muy cumplidores [las integrantes del equipo] es más el día que no pueden venir el martes porque se les complica por alguna otra situación | inmediatamente la llaman a la maestra referente a ver qué pueden coordinar a ver en qué día y en qué horario pueden venir a...- $\mid$ a participar de esa actividad en esa clase | como que no te dejan...- | el día que no pueden venir no te dejan sin concurrir al aula eso está muy bueno también [04.12.2015]

Mariela: [...] pero en realidad no puedo decir nada el grupo referente me respondió divino siempre [enf.] | ya te digo como éramos ocho que eso está bueno | siempre tenía:: u::n suplente por decirlo de alguna manera que me cubría alguna otra clases | si no se podía | me cubrían en la semana [04.12.2015]

Este sentido de compromiso era compartido con las integrantes del equipo comunitario, tal como puede valorarse en estas palabras de Patricia, mediadora de tercer año B:

[el equipo comunitario] son un grupo fantástico | son fantásticas | están mu::y comprometidas [enf.] | una de las chiquilinas || yo no estoy mucho | pero una de las chiquilinas el martes se tuvo que retirar del grupo por cuestiones personales | Laura | y ella estaba angustiada de verdad [enf.]| y eso es...- | es noble [enf.] | es es...- | porque ella está | brindando su tiempo | ella podría estar ocupando esa media hora o una hora que le lleva ir y volver de la escuela | en otra actividad I y ella siente la pérdida [enf.] | y ella se sentía mal por no poder venir || es un grupo fantástico | Janet que viene con su bebé [enf.] | vos te das cuenta que es una entrega [20.10.2015] 
Además de concurrir a leer los días asignados para esta actividad, las integrantes del equipo comunitario participaron en la organización de la biblioteca escolar, inventariando libros y promocionándolos entre los alumnos y maestros.

Y tanto la directora como la maestra referente señalaron la estrecha vinculación que se estableció entre las integrantes del equipo comunitario de lectura y la institución escolar, quienes brindaron su colaboración a la escuela más allá de la lectura en los festivales escolares y en la realización de una obra de teatro para el Día del Niño.

Debe destacarse que los orígenes del vínculo entre las madres integrantes del equipo comunitario de la escuela XXX es anterior a que este grupo se conformara. Las madres «viejas» (así se autorrefirieron en la reunión del 14.07.2015), se conocían desde hace años, desde cuando sus hijos comenzaron la escuela. Estas madres se encontraban en muchas ocasiones fuera de la escuela y, obligadamente, en la puerta del local escolar, luego de dejar a sus hijos allí cada mañana.

La maestra referente destacó este vínculo, más allá de su participación en el equipo comunitario de lectura:

[...] como grupo hum::ano como muje::res || salir y conversar | estar en otra instancia que no sea la escuela la lectura y los niño::s | y sus propios hijos ¿no? y sus casas | que lo represisan [04.12.2015]

Seguramente la trascendencia de este vínculo constituyó un factor que redundó en beneficio, tanto de estas madres, que encontraron en el equipo comunitario de lectura un espacio de realización personal, como en el funcionamiento del equipo mismo.

\subsubsection{Reuniones del equipo comunitario de lectura de la escuela XXX}

El equipo comunitario de lectura fue convocado por la escuela, en 2015, a tres reuniones: a mediados de abril, para su conformación; el 26 de mayo, a mi llegada, para presentarme al equipo, comentarles mi investigación y solicitar su autorización para hacer el trabajo de campo, y el 14 de julio, para evaluar el trabajo realizado en el periodo abril-junio, planificar la rotación de las mediadoras en el último período del año, y organizar una obra de teatro para el Día del Niño. Por fuera de estas instancias convocadas por la escuela, las madres se encontraban informalmente unos minutos antes de comenzar el turno escolar, e intercambiaban en un grupo de Messenger y Wathsapp. Las lecturas que realizaban semana a semana eran coordinadas generalmente en forma directa con las maestras de cada clase $y$, en algunas ocasiones, propuestas por ellas mismas.

En la reunión realizada el 14 de julio, las madres participaron animadamente. Las más participativas fueron Janet y Andrea A., quienes ya habían formado parte del equipo comunitario de lectura el año anterior. Durante la reunión las madres intercambiaron consejos y comentarios referidos al desarrollo de su tarea y a sus intenciones de enseñanza; experiencias de lectura propias o de su entorno (actuales o autobiográficas) y sus experiencias de lectura como mediadoras. Las lecturas que recomendaron fueron aquellas probadas en su experiencia; algunas de ellas tenían una intención moralizante.

Durante la reunión no faltaron las bromas, las anécdotas y comentarios sobre temas diversos: los hijos, la familia, el deterioro social... La maestra referente, si bien encauzó y ordenó en diferentes momentos los intercambios, participó animadamente de la reunión, sumándose a los tópicos de conversación y respetando las opiniones y comentarios de las mamás. En varias ocasiones alabó al equipo: i «Qué grupete!» y destacó su trabajo: «Ustedes estuvieron de lujo». Su rol fue principalmente el de coordinadora. En ningún momento brindó consejos sobre cómo desarrollar la tarea o qué libros leer en 
las clases. Principalmente recabó información sobre el trabajo realizado por las mediadoras hasta el momento y les informó a estas sobre las acciones (pasadas o futuras) de la escuela en torno a Biblioteca Solidaria.

\subsubsection{Clases de la escuela XXX que participaron de la investigación}

\section{Tercer año A}

Esta clase estuvo integrada por 23 alumnos. Carmen, su maestra, es una docente muy joven con solo dos años de antigüedad en la profesión que, a pesar de no ser efectiva en esta institución, pudo elegir su cargo en esta escuela por segundo año consecutivo.

Durante 2015, tercer año A recibió a tres mamás lectoras: Patricia (mediados de abril a fines de mayo), Rosario (principios de junio a fines de agosto) y Mónica (principios de setiembre en adelante). Cabe especificar que en este grupo Rosario realizó seis sesiones de lectura: "Los juguetes» y "La chacra» (relatos de Perico), El miedo a la luz mala, Cuando el temible tigre, León de biblioteca, La manta de las historias y Un puñado de semillas.

Carmen manifestó una actitud positiva a la presencia de las madres del equipo comunitario, respetando su espacio de lectura y esperando junto a sus niños la llegada de las mediadoras:

[...] cada una | cada una de las mamás es distinto | tienen una forma diferente de para::rse de plantearse en la clase || yo he intentado respetarlas a toda::s con sus formas distintas | porque claro cada una tiene su personalidad diferente [...] cada una tiene su:: | su manera de ser su estilo su...-| entonces cada uno tiene distintos aportes

[...] en los niños lo que más rescato es justamente esa la motivación | la estimulación [...] de ser una persona difere::nte | de venir...- | ser una mamá | como la mamá de cualquiera de ellos ¿no? |que lo hace especial | siempre hemos venido como recalcando mucho esol bueno de valorar el tiempo de las mamás || porque sabemos que las mamás trabajan | que las mamás...- | muchas mamás no pueden venir pero quizás les gustaría haber venido | entonces se genera como una expectativa | que eso está...- | es bien lindo [...] yo creo que el niño valora mucho eso también

... aunque manifestó ciertos reparos sobre Rosario:

[...] ella cuando empezó a venir se ponía muy nerviosa | se ponía muy nervio::sa [...] ella además es una persona como muy se::ria ${ }^{51}$ | también a veces yo pienso que quizás si yo tuviera que decirle algo como algún consejo |como alguna cosa | es justamente que se relaje más || porque ella está toda armadita siempre | con temor | y en realidad lo hacen bien || sino no tendrían la aceptación | y la recepción que tienen en los niños [...] [13.10.2105]

\footnotetext{
${ }^{51}$ Las bromas de Rosario registradas durante la reunión del equipo comunitario del 14 de julio ponen en duda el hecho de que ella sea «una persona muy seria». Seguramente su inhibición era debida a su inexperiencia, como mediadora y como lectora.
} 


\section{Tercer año B}

Esta clase contó en 2015 con 24 alumnos; estuvo a cargo de la maestra Amalia, efectiva en la institución desde hace varios años. Accedió a su cargo por concurso y contaba, al momento de realizar el trabajo de campo, con 23 años de experiencia en su labor.

Al igual que en tercero A, durante 2015 se desempeñaron las tres mamás lectoras ya mencionadas en los períodos antes detallados.

Amalia se manifestó también en forma muy positiva frente a las mediadoras. Generalmente cuando estas llegaban, suspendía la actividad que estaba realizando y se sentaba junto a algún niño a escuchar las lecturas. De las madres del equipo comunitario destacó su esfuerzo, su constancia y la actitud de disfrute que supieron generar en los niños:

[...] yo sé que es difícil pararse frente a una clase | y empezar a leer | y ellas lo hacen realmente con mucha responsabilidad || y:: | y los chiquilines realmente lo disfrutan | porque vos ves que | cada martes cuando vienen | hasta el día de hoy | ellos || disfrutan la lectura | escuchan | atienden

[...] y también lo bueno que vi fue la continuidad | desde marzo...- | desde abril que empezaron | nunca abandonaron | sie::mpre vinieron [13.10.2015] 


\section{ANÁLISIS DE CASOS}

En esta parte se presenta el resultado del análisis, organizado según los casos de estudio. El análisis de cada caso se realizó en función de lo establecido en el apartado 2.3. «Ámbitos, categorías subcategorías y parámetros de análisis». Al cierre de cada caso, se podrán leer las conclusiones particulares sobre cada uno de ellos, en las que se intentará poner en relación los distintos ámbitos investigados.

\subsection{Primer caso. Escuela XX, tercer año A, Omar}

\subsubsection{Estilo del mediador}

\section{A. Ser de Omar}

\section{El mediador en persona}

Omar tiene 65 años, es jubilado (aunque trabaja por su cuenta en forma esporádica) y abuelo de Clara, alumna de tercer año A de la maestra Inés.

En 2015, Omar, además de leer en el grupo de su nieta, leyó en los quintos y sextos años, logrando atraer la atención de los alumnos de estas clases a las que los demás mediadores generalmente no querían concurrir ${ }^{52}$.

Las lecturas de Omar en tercer año fueron esporádicas: en el mes de junio de 2015 tuvo algunos problemas de salud que lo obligaron a suspender su actividad por aproximadamente un mes. La continuidad del trabajo del equipo comunitario también se vio afectada por el conflicto de la enseñanza que se inició a mediados de año, pero se agudizó a mediados de año.

\section{Preferencias y prácticas lectoras}

Omar es un lector habitual en este momento de su vida. Entre sus preferencias, menciona un corpus amplio de lecturas, integrado por géneros de la literatura popular (cómics, novelas de cow boys, divulgación cientifica, etc.). Manifiesta leer tanto materiales de ficción como de no ficción: entre sus lecturas, se cuentan novelas, y libros y revistas sobre prehistoria:

[...] ¿ ¿mis lecturas preferidas para mí? | ah mirá | muy variado | novelas || historia me encanta || eh:: que no tienen por qué ser libros ¿no? | leo muchas...- [revistas] | y prehistoria también | prehistoria me encanta [17.11.2015]

También destacó que su autor favorito es Horacio Quiroga, un clásico de la literatura rioplatense, que conoció cuando cursaba enseñanza media y que manifestó querer leer a los niños de quinto y sexto año:

\footnotetext{
${ }^{52} \mathrm{Al}$ respecto, la directora de la escuela y Omar se refirieron en las entrevistas a la dificultad de los mediadores para ser escuchados en los grupos de quinto y sexto año, motivo por el cual ellos no quieren concurrir a estas clases. Este mismo tópico también fue mencionado por una mamá en la primera reunión del equipo comunitario el 30 de abril de 2015 y registrado en el diario de campo.
} 
[...] yo quería saber si se les puede leer algo de los cuentos de Horacio Quiroga, algo... como habíamos hablado, algo que les impacte, no sé si es demasiado fuerte «La gallina degollada» o «El almohadón de plumas» porque yo les pregunté qué les gustaría que les leyera... y enseguida me hablaron: algo de terror. Y como yo ya tenía eso en la cabeza, pero antes quiero preguntar [...] [18.06.2015]

\section{Biografía lectora}

En su biografía lectora Omar señaló dos hitos que corresponden a su infancia y a su adolescencia:

[...] la lectura en sí desde chico | porque siempre me gustó leer eh:: los cómics | y después de los cómics pasé a las novelitas de aquellas tipo Corin Tellado | pero que había...- que había de cow boys | de guerra || y después como mi primer libro | que fue de Julio Verne | De la tierra a la luna | me acuerdo clarito que leí | que llegó a mis manos | y leí y yo tendría 11 años | 11 o 12 años | no había entrado al liceo todavía [ ...] [17.11.2015]

[...] «La gallina degollada» fue el primer libro que me leyeron a mí en el liceo, en primero de liceo un día faltó un profesor y viene el adscripto y nos lee y después conseguí el libro para leerlo todo. [14.05.2015]

Y dos que corresponden a su vida adulta:

[...] tuve hepatitis | estuve cuatro meses en cama sin poderme mover | y:: y mi señora era socia de:: | de la biblioteca del club ANCAP | y me agarraba libros | por semana | yo yo creo que leía tres libros por semana || entonces iba a la biblioteca | cambiaba | los llevaba | y lo único que hacía era eso | lo único que hacía era leer | no sentir nada | estaba ahí | lo único que hacía era leer [17.11.2015] ${ }^{53}$

Yo trabajé muchos años armando exposiciones... y armé la feria del libro en el LATU cuando se hacía ahí durante años, y hacíamos durante todos los días de exposición, hacíamos una guardia para que no se caigan los stands y leíamos [enf.] de todo, de todo [14.05.2015]

En el relato vehemente de estos episodios puede observarse que Omar ha sido lector desde su niñez y que en su historia lectora la escuela supo dejar su impronta. Ha sido también desde edades tempranas un lector activo y entusiasta de diversos géneros, entre ellos los literarios.

\section{Motivaciones para ejercer el rol de mediador}

Las motivaciones de Omar por integrar el equipo comunitario de lectura fueron múltiples, en primer lugar, se destaca su deseo de cumplir con su rol de abuelo:

[...] eh:: mirá más o menos es así || con mis hijos yo me dedicaba solamente | a laburar | viste | es una edad en la que uno lo único que se piensa es hacer plata plata plata para | darle lo mejor a ellos | | y te perdés un montón de cosas | y dije bue | voy a aprovechar con mis nietos | y ta [17.11.2015]

Al respecto la maestra Inés observó:

[...] también su nieta tiene un lugar en el grupo | o sea el vínculo entre ellos | se ve precioso | yo ya lo dije es un ser muy...- | el hecho de que sea abuelo para mí suma | porque...- || pero puede ser que sea

\footnotetext{
${ }^{53} \mathrm{Al}$ respecto, puede constatarse en este episodio una ruptura y un cambio en los escenarios de lectura como los descritos por Bahloul en su investigación sobre los «poco lectores» (2002) ( $\rightarrow$ 1.2.1. «La lectura como práctica social y cultura|»).
} 
su personalidad | tiene como otra serenidad | como otra entrega me parece | él no tiene porqué:: | un padre capaz que se siente como más obligado | como que me llama la maestra de mi hijo a leer un cuento | aunque lo haga con placer | él me parece que es esencialmente el placer | de acompañar a su nieta | de volver a la escuela [...] o sea también tiene como una cierta disponibilidad [19.11.2015]

Es un hecho no menor, que debe destacarse, que Omar era el único varón del equipo comunitario de lectura y, junto con Graciela, los dos únicos abuelos.

En segundo lugar, con el propósito de inculcar en los niños el hábito de la lectura, y dejar a los niños un legado moral, aspectos que él mencionó en forma expresa en su entrevista:

[...] bueno | ya te digo | para:: inculcarles el hábito de la lectura | eso es lo principal | tener una:: vinculación más cercana con los maestros | y con con los gurises también | y con los gurises está | está genial [17.11.2015]

... al igual que la maestra Inés:

[...] a mí me parece que Omar quiere...- | tengo siempre esa sensación | que quiere enseñar algo | algo que sea bueno como como...- | como una moraleja | me da la sensación de que él siempre se va para ese lado | el maestro tiene con cada cuento | puede tener objetivos diferentes y entonces...- | me parece que las preguntas son l y me parece que los niños también acomodan el discurso a lo que Omar quiere oír | [enf.] porque es el abuelo [...] me parece que va como a la cosa familiar | ellos se ponen más | en el relato familiar o en lo...- | contestan más desde ese lugar | que desde el lugar del aprendizaje | capaz que porque las preguntas son más dirigidas a eso | capaz que es como si les hablara el propio abuelo [...] [19.11.2015]

En tercer lugar, la gratificación que le brindaba a este mediador el contacto con los niños en cada sesión de lectura constituyó otro motor para continuar con la tarea:

[...] y:: de lo que recibía | lo que más me encantaba era | después de la lectura los comentarios | había de todo | bueno vos estuviste | viste que hay de todo tipo de comentarios | algunos que te morís de risa | otros muy acertados | y otros que uno mismo | no se había puesto a pensar | que se dan cuenta que uno no $[\ldots]$

[refiriéndose a los consejos que le daría a alguien que quisiera integrar el equipo comunitario de lectura] [...] lo primero que se metan | que se metan | que van a disfrutar | aunque puedan venir pocas veces | pero que son disfrutables | [enf.] totalmente | esos momentos de lectura | que le den para adelante [17.11.2015]

Y por último, las referencias a sus vivencias lectoras a las que el mediador aludió en las reuniones del equipo comunitario, a los títulos que leyó en su adolescencia, a la intención de leer a los niños de sexto los cuentos de Horacio Quiroga (que le leyeron por primera vez en el liceo), permitiría pensar que en Omar existió el deseo de revivir, de alguna manera, esta etapa de su vida en la experiencia de mediador, de hacer que los niños de la escuela XX pudieran experimentar algo similar a lo vivido por él.

\section{Apropiación del rol de mediador}

2015 fue el segundo año de Omar en el equipo comunitario de lectura, en el que participó desde sus comienzos en 2014. Durante este año, Omar concurrió a leer a los grupos de segundo año, por lo que 
los niños de tercero ya estaban habituados a su presencia y a su hacer como mediador. Por este motivo su actividad como tal fue vivenciada, tanto por él como por los niños, como una continuidad:

Martín: me gusta | me gustó «El loro pelado» \} { } ^ { 5 4 } [ 3 0 . 1 0 . 2 0 1 5 ]

Yasmila: eh:: Un puñado de semillas | eh:: también me gustó || «La abeja haragana» || y un...- | y El jajilé azul [...] \[30.10.2015]

Hugo: El cuento que Omar leyó y que más me gustó fue «El loro pelado» porque es divertido y [me causó] un poco de tensión para mí (sic) [02.09.2015]

En este sentido, Omar manifestó:

pah:: no me acuerdo si fue este año que les leí | «El loro pelado» | que yo pensé que fue el que más les había gustado | pero capaz...- | pero a lo mejor no fue este año | fue el año pasado | a lo mejor se los leí en segundo [17.11.2015]

La maestra Inés también destacó, en su entrevista, este aspecto:

[...] los niños lo conocen desde hace tiempo | lo adoran y lo reclaman ahora que no estaba viniendo [...] [19.11.2015]

Omar oficia de mediador no solo en la escuela de su nieta Clara; en su hogar lee habitualmente para sus otros nietos y concurre también a leer al jardín de infantes del más pequeño de ellos:

[En referencia a un cuento que él escribió.] [...] yo ya los leí en casa a los gurises | a los más grandes incluso | y a todos les gustó [...]

[En referencia a La manta de las historias.] [...] incluso ya lo he contado como cuento sin tenerlo para leer | porque tengo nietos más chicos también [...]

[...] incluso tengo un nieto | que es de 5 | que va a un jardín | a un jardín público también | y a veces voy a leerles también | me ofrecí y bueno || cada tanto voy a leer un cuento | incluso acá también me prestan los libros [...] [17.11.2015]

En ocasión de la reunión del equipo comunitario del 18 de junio ( $\rightarrow$ anexo 2.1.1. «Reunión 2») Omar comentó que cuando preparó la lectura de Bolboretas para sexto grado se lo había leído antes a su nieta de 16 años para ver si le gustaba esa lectura.

Debe destacarse la activa participación de Omar en las reuniones del equipo comunitario en las que intervino para compartir con sus compañeros consejos sobre cómo desarrollar la tarea, su experiencia como mediador y sus preferencias de lectura personales o de los integrantes de su familia. Por ejemplo, en la reunión del 14 de mayo, aconsejó a las madres que se integraban al equipo en ese momento que si los niños estaban inquietos, se les podía decir: «Los libros de Biblioteca Solidaria, como son modernos, ya vienen con un chip... que si hay mucho ruido, se cierran y después ya no se pueden abrir». Les contó que la primera vez que fue a leer a la escuela estaba nervioso y le dijo esto a los niños, pero después no fue necesario volver a hacerlo porque tuvo muy buena receptividad. Comentó esto porque «puede servirle a alguien». En dicha reunión mencionó también la importancia de hablar sobre lo leído luego

\footnotetext{
${ }^{54}$ Omar leyó el cuento «El loro pelado», de Horacio Quiroga, en 2014, cuando estos niños cursaban segundo año.
} 
de finalizar la lectura. Y acotó que en estos momentos se había encontrado con "opiniones de todo tipo» que «le fascinaban». Comentó además que él incorporó este consejo con muy buenos resultados.

Por otra parte, la experiencia como mediador le permitió a Omar equilibrar en su hacer las demandas de la maestra con sus intereses de lectura personales. Fue así que en la sesión del 30 de julio llevó para leer un cuento de su autor favorito: «La abeja haragana».

En los últimos tiempos este abuelo lector además se ha animado a escribir algunas historias:

[...] y te digo algo más así chiquito | para que...- hace muchísimos años que yo veng...- | venía pensando en escribir un libro que lo tenía...- | que venía guardando cosas en el disco duro | y pensé | y me decidí ahora | y ya empecé a escribir | pero para niños | que eso no lo tenía pensado [...] ya escribí dos cuentos | tengo otros ya pensados | y un montón más en la cabeza | y la protagonista es una tal Ercilia | Ercilia se llama | y es en el | en el 1890 | en esa época [...] [17.11.2015]

Seguramente su experiencia exitosa como mediador ${ }^{55}$ y la gratificación que obtiene de ella lo ha animado a dar este paso.

La presencia de Omar en las dos jornadas de formación (en 2014 y 2015), su experiencia como mediador en los distintos ámbitos en los cuales ejerció como tal, y los espacios de intercambio que ofrecieron las reuniones del equipo comunitario hicieron posible el acopio de insumos para concebir y ejercer su rol.

[En alusión a las reuniones de los equipos comunitarios de lectura.] [...] e::s es | es bueno | es bueno porque ahí cada uno expone sus puntos de vista I sus formas y ahí fue donde aparecieron los comentarios de que:: | las clases más grandes eran más difíciles | y entonces ahí intercambiamos ideas | intercambiamos experiencias | este:: $\mathrm{y}::$ | ta y las maestras aportan | son las que más aportan ¿no? | porque ya conocen todo el grupo [17.11.2015]

[En referencia a las jornadas de formación de los mediadores.] Otra de las cosas que estaba buenísimo, que me resultaba buenísimo a mí era después de haber terminado de leer que los gurises comentaran qué les había gustado del libro, qué les había parecido bien que les había parecido mal.

Con respecto a llamar la atención antes de empezar a leer... te acordás que cuando vinieron los de ProLEE a dar la charla decían que una de las estrategias que se pueden usar es decir que los libros que son modernos ya vienen con un chip, que si hay mucho ruido el libro se cierra y después ya no se puede abrir [14.05.2015]

Por último, es interesante observar las transformaciones que Omar experimentó, tanto en su hacer con los niños, en la escuela, como en su vida personal y familiar. Sus dos años de permanencia en el rol; el contacto con los niños durante las sesiones de lectura; la oportunidad de intercambiar con los demás integrantes del equipo comunitario y con las maestras, durante las reuniones, y su presencia en las jornadas de formación le han permitido capitalizar su experiencia y crecer con ella:

... para compartir, muy generosamente, con sus compañeros de equipo sus estrategias frente a los niños y sus vivencias lectoras;

... para extender su acción hacia otros ámbitos (a su familia y al jardín de infantes de su nieto menor;

\footnotetext{
${ }^{55} \mathrm{Al}$ año siguiente de la finalización de mi trabajo de campo, la inspectora de la escuela XX, me comentó que Omar, con el ánimo y la ayuda de algunos padres del equipo comunitario, había decidido publicar estos cuentos.
} 
... para atreverse a innovar en sus sesiones de lectura, a partir de la seguridad adquirida en el contacto frecuente y en el vínculo afectivo establecido con los niños ( $\rightarrow$ «Hacer de Omar»);

... y para ensanchar sus prácticas letradas, animándose a escribir cuentos para niños;

En resumen:

Omar es lector activo y entusiasta que ha consolidado sus hábitos y preferencias de lectura en su adolescencia y juventud. Su formación como lector se remonta a estas etapas de su vida. A propósito de ello, reconoce la influencia de la literatura infantil y juvenil, de la literatura popular y, particularmente, del sistema educativo.

Su participación en el equipo comunitario de lectura de la escuela XX obedece a diversos motivos relacionados con cumplir con su rol de abuelo, con el deseo de inculcar a los niños enseñanzas morales y el hábito de la lectura, y de replicar en el ejercicio de la mediación las experiencias lectoras gratificantes de su infancia y adolescencia, haciendo que los niños experimenten también estas vivencias. El disfrute del contacto con los niños durante las lecturas e intercambios sobre estas constituyen también otra razón para que este mediador oficie como tal.

Omar ha capitalizado su experiencia: sabe cómo prepararse para leerle a los niños (practica en su hogar con sus nietos) y qué hacer frente a ellos. Logra además equilibrar en su hacer las demandas de las maestras con sus intereses de lectura personales.

Su crecimiento como mediador se refleja en su activa participación en las reuniones del equipo comunitario, en las que comparte consejos y saberes con sus compañeros, en la extensión de su rol, al comenzar a leer en el jardín de infantes de su nieto pequeño, y en la transición de lector a escritor de cuentos para niños.

\section{B. Hacer de Omar}

Cabe recordar cuáles fueron las dos sesiones de lectura de Omar que se tomaron como base para el análisis de este apartado y de los siguientes: «Intervenciones e intercambios entre los participantes» y «Respuestas de los niños en las sesiones de lectura de Omar».

\begin{tabular}{|l|c|}
\hline $\begin{array}{l}\text { Un puñado de semillas, de Mónica Hughes con ilustraciones de Luis } \\
\text { Garay (Ekaré) }\end{array}$ & 18.06 .2015 \\
\hline $\begin{array}{l}\text { La manta de las historias, de Ferida Wolf y Harriet May Savitz, con } \\
\text { ilustraciones de Elena Odriozola (Norma) }\end{array}$ & 12.08 .2015 \\
\hline
\end{tabular}

\section{Modalidad lectora}

En ambas instancias, Omar efectuó una lectura fluida, con una dicción sin omisiones, en un volumen de voz moderado que podía ser escuchado por todos, adecuando la entonación y la velocidad de su prosodia a la modalidad del enunciado y al momento del cuento. 
Acciones para organizar el espacio y el tiempo de lectura

Al llegar al salón, el mediador se ubicó frente al grupo y durante la oralización del texto y comentario sobre lo leído permaneció sentado en una silla pequeña o sobre una mesita, mientras que los niños se sentaron en el piso, en semicírculo frente a él, como lo disponía la maestra antes de su llegada.

Puede establecerse claramente en las sesiones de este mediador un esquema de desarrollo estable, con momentos claramente delimitados, con acciones que se reiteraron con escasas variaciones. Básicamente, adoptó la rutina sugerida en las jornadas de formación con los integrantes de los equipos comunitarios (presentación del libro y del autor, lectura del cuento y comentario sobre lo leído). Merece mencionarse que en las sesiones del 30 de julio (lectura de "La abeja haragana») y del 12 de agosto, Omar introdujo un «ritual», que asombró a la maestra ${ }^{56}$, al solicitar a los niños que saltaran y gritaran antes de disponerse a leer.

Las sesiones de este mediador pueden esquematizarse así:

-Antes de la lectura (en las sesiones de La manta de las historias)

Omar: vamos a hacer este ejercicio primero $\backslash$

Niños a coro: (protestan porque Omar no empieza su lectura) (???) <8>

Omar: esperamos $\backslash \mid$ parados $\backslash \mid$ para::dos $\backslash \mid$ parados todos $\backslash \mid$ (pide silencio con un chistido) amigo $\backslash \mid$ parate un cachito $\backslash=\ldots . .=$

$[\ldots]$

Omar: [ff.] fuerte $\backslash \mid$ bueno | buen día / | fuerte $\backslash$

Niños a coro \{[ff]! buen día::! [con entusiasmo]\}

Omar: y ahora a movernos / | usen toda la energía / | toda la energía / \{los niños se mueven $<5>\}$

Omar: ahora sí \(???) \{los niños vuelven a sentarse\} [12.08.2015]

-Presentación del libro (reseña del cuento, autores e ilustradores)

Omar: bueno $=\ldots . . .=$

Niño: =..... se llama Buenas Noches $\backslash$ | [el niño conoce o lee el título de la colección]

Omar: el libro de hoy se llama $=\ldots . . .=$

$[\ldots]$

Niño: La manta de las historias \(lee la tapa del libro)

Omar: La manta de las historias $\backslash[\ldots]$

Omar: es una historia en Rusia \

Niños a coro: ¿ंen Rusia? | iuh!:: \

Omar: y este libro fue escrito | por dos escritoras \[pp.] no por una \| por dos \| Ferida Wolff y Harriet May Savitz \la ilustradora | es Elena Odriozola \[18.06.15]

-Inicio de la lectura

Omar: bueno \| ahora vamos a empezar con el libro \|| Concepción vivía con su abuela / | en una casita / en la cima de un cerro [...] [18.06.15]

-Lectura y muestra de las imágenes del cuento

\footnotetext{
${ }^{56}$ Incidencia registrada en el diario de trabajo de campo el 30.07.2015 ( $\rightarrow$ anexo 5. «Diario del trabajo de campo. Jueves 30 de julio».
} 
-Finalización de la lectura

Omar: y colorín colorado \

Niños a coro: \{aplausos\}

Omar: muy bien \

Niño: iqué cuento tan corto! \[12.08.15]

-Apertura de la conversación sobre lo leído

Omar: bueno / vamos a comentar ahora un poco $\backslash=\ldots . .=$

Niño: $=\ldots . . .=$ abuelo $/$ me pareció medio triste $\backslash$

Omar: $=\ldots . . .=$ a comentar un poco el libro [18.06.15]

-Conversación sobre lo leído

-Cierre de la conversación y finalización de la sesión (en Un puñado de semillas)

Omar: no sé si la maestra quiere comentar algo /

Niño: que Concepción se ofreciera a cuidar a los niños \

Niña: que Concepción fue buena con los niños \[18.06.2015]

Durante la oralización del texto, luego de leer cada página, el mediador se detenía para mostrar las ilustraciones por unos segundos. En estos momentos, prácticamente, no realizó comentarios ni preguntas; estos se focalizaron antes y después de leer el cuento.

La finalización de la conversación en ambas sesiones quedó a criterio del mediador, cuando este presintió que se habían agotado los comentarios. Mientras que en la sesión de Un puñado de semillas dio pie a la maestra para continuar el intercambio; en la de La manta de las historias, apelando a su conocimiento del grupo, estableció abruptamente el final cuando los niños comenzaron a mostrarse inquietos ${ }^{57}$.

Omar desarrolló en sus sesiones un patrón bastante estable, con momentos claramente delimitados por acciones específicas ( $\rightarrow$ «Gestión de la construcción del metatexto»), que ordenaron su rutina y con el que los niños parecían estar familiarizados, lo que hizo posible que estos se anticipasen a las acciones del mediador:

Niño: ahora vienen las preguntas / | ¿no?

Omar: iah::! los comentarios \[12.08.2015]

\section{Gestión de la construcción del metatexto}

En el siguiente cuadro se detalla la finalidad de las acciones que Omar desplegó en las sesiones analizadas:

\footnotetext{
${ }^{57}$ Incidencia registrada en el diario de trabajo de campo el 12.08.2015. ( $\rightarrow$ anexo 5. «Diario de trabajo de campo. Miércoles 12 de agosto».
} 


\begin{tabular}{|c|c|c|c|}
\hline Finalidad de las acciones del mediador & $\begin{array}{l}\text { Un puñado de } \\
\text { semillas }\end{array}$ & $\begin{array}{l}\text { La manta de las } \\
\text { historias }\end{array}$ & Totales \\
\hline $\begin{array}{l}\text { Delimitar momentos en la sesión de } \\
\text { lectura }\end{array}$ & 5 & 4 & 9 \\
\hline Evidenciar la identidad del mediador & 4 & 2 & 6 \\
\hline Habilitar la participación de los niños & 6 & 6 & 12 \\
\hline Generar expectativas & 0 & 1 & 1 \\
\hline Avalar las expresiones de los niños & 9 & 5 & 14 \\
\hline Reformular las expresiones de los niños & 4 & 2 & 6 \\
\hline Sintetizar las expresiones de los niños & 1 & 0 & 1 \\
\hline Expandir la información del texto & 4 & 5 & 9 \\
\hline $\begin{array}{l}\text { Restablecer el orden para continuar la } \\
\text { lectura }\end{array}$ & 0 & 1 & 1 \\
\hline Totales & 33 & 26 & 59 \\
\hline
\end{tabular}

Puede observarse que este mediador desplegó múltiples y variadas acciones. Estas se concentraron al inicio y en la conversación sobre lo leído, y estuvieron casi ausentes durante la lectura.

Las acciones para delimitar los momentos de las sesiones se produjeron tanto en Un puñado de semillas como en La manta de las historias ( $\rightarrow$ «Acciones para organizar el espacio y tiempo de lectura»).

En los momentos anteriores a la lectura se observaron acciones destinadas a generar expectativas:

Omar: lo peor es que está escrito en ruso \

Niños a coro: \{risas\}

Omar: ahora les voy a | / a hablar en ruso \[12.08.2015]

.... a evidenciar la identidad del mediador:

Omar: como la última vez me tiraron de las orejas porque $\backslash$ | no pude conseguir | información sobre el autor \y el || dibujante /

Niña: ¿te tiraron de las orejas? [desconfiada] [...] [18.06.2015]

Durante la lectura, como ya se mencionó, las únicas acciones del mediador fueron su oralización del texto y la muestra de las imágenes, inmediatamente luego de leer. Se registró únicamente una acción de aval, ante la intervención de un niño.

Omar: [...] vendió el resto al vecino / | que se lo llevó al mercado de la ciudad / | allá lejos / | en el valle $\backslash\{$ muestra las ilustraciones $<12>\}$

Niño: hizo negocio con todo \}

Omar: exacto \[18.06.2015] 
En las instancias de conversación sobre lo leído, predominaron las acciones de aval como la de este ejemplo:

Omar: imuy bien! \¿usted? ¿qué hay que valorar?

Niña: mi madre me dice que hay que valorar la comida \

$[\ldots]$

Omar: no te entendí / | perdoná \

Niño: que hay que guardar siempre un poco de semillas \}

Omar: exacto \| lo que dice el compañero \[18.06.2015]

Acotadamente, en ambas sesiones también, se observaron acciones de reformulación de las expresiones de los niños:

Omar: ¿qué sacan en conclusión de esto que leímos?

Niña: que era buena \

Niña: que la niña fue muy amable $\backslash$

Omar: una cosa / que la niña fue muy ama::ble \

Niña: que hay que compartir $\backslash$

Omar: imuy bien! \| que hay que compartir /

Y excepcionalmente, de síntesis:

Omar: ¿el libro en qué se basa todo?

Niño: semillas \

Niño: solo semillas \}

Niño: en la huerta $=\ldots . . .=\backslash$

Niño: $=\ldots . . .=$ semillas $\backslash$

Omar: en que guardando un poco de semillas $=\ldots . . .=1$

Niño: $=\ldots . . .=$ tenían para comer $\backslash[18.06 .2015]$

Las acciones para expandir la información se produjeron tanto por iniciativa del mediador:

Omar: es una historia en Rusia /

Niños a coro: ¿en Rusia? | iuh!:: \

Omar: y este libro fue escrito | por dos escritoras \[pp.] no por una \| por dos \| Ferida Wolff y Harriet May Savitz \la ilustradora | es Elena Odriozola [12.08.2015]

... como a demanda de los niños:

Niño: ¿por qué se quedó sin tierra?

Omar: hay otros lugares donde los dueños de la tierra le alquilan un pedazo de tierra a la gente / para que la trabajen \| entonces ¿qué pasa? | parte de la cosecha se la tienen que dar al dueño \| como se quedó sin abuela \| que era la de cosechaba \[...] [18.06.2015]

Durante la conversación sobre lo leído se destacaron también las acciones de habilitación de la voz de los niños:

Omar: vamos ahora \|| ¿qué no les gustó del libro? | ¿qué...- que no les pareció?

Niño: no sé /

Niño: a mí no me gustó que:: la abuela muriera \| y los niños le dijeran tonta \ 
Omar: ella no habló todavía \(Da la palabra a una niña que levantó su mano, pero esta no responde.) [18.06.2015]

... y durante la lectura de La manta de La manta de las historias se registró una única acción destinada a restablecer el orden para continuar la lectura:

Omar: \{chistido\} || silencio \| porque habla despacito pero si hablamos todos / || ella no va a escuchar $\backslash$ | nadie va a escuchar \[12.08.2015]

En ninguna de sus sesiones el mediador sancionó ni corrigió los errores de interpretación de los niños:

\section{Un puñado de semillas}

Niño: lo llevaba así teniendo / (???)

Niño: ¿hay foto?

Niño: hay sí

Omar: ¿el libro en qué se basa todo?

Niño: semillas \

Niño solo semillas \}

Niño: en la huerta $=\ldots . .=\backslash$

Niño: (interrumpe) semillas $\backslash$

Omar: en que guardando un poco de semillas $=\ldots . .=$

Niño: $=\ldots . . .=$ tenían para comer $\backslash$

Omar: tenían para comer $\backslash$

Niño: $y$ en las huertas $\backslash$

Niña: que el niño fue humilde con ellos / | y no egoísta porque:: \/ siempre / siempre hay que ser bueno con los otros niños que no tienen

Omar: ¿y cómo se llama eso? | solidaridad \

\section{La manta de las historias}

Niña: que quería ser sincera con el pueblo \| haciéndole muchos regalos para:: | para:: | para la nieve \

Niño: para los niños \}

$[\ldots]$

Niña: $=\ldots . . .=$ que era sincera $\backslash$

Niña: en vez de pensar en ella / | pensó en los demás \}

Omar: imuy bien! \| en vez de pensar en ella / | pensó en los demás \\| imuy bien! \

En el primer ejemplo de Un puñado de semillas, el niño pidió por las fotos, en lugar de por las ilustraciones. Esta confusión léxica fue compartida con otro compañero, pero no fue corregida por el mediador. En el segundo, la dificultad de los tres niños estuvo en la imposibilidad de construir el sentido global de la historia. En los otros ejemplos, ambas niñas, respectivamente, confundieron el significado de las palabras humildad (con generosidad) y sinceridad (con solidaridad).

Las preguntas del mediador, que guiaron la discusión, se concentraron durante la conversación sobre lo leído.

En Un puñado de semillas, Omar realizó cinco preguntas dirigida a que los niños verbalizaran su valoración sobre el cuento:

Omar: ¿qué sacan en conclusión de esto que leímos?

Niña: que era buena \[...]

Omar: imuy bien! \¿usted? ¿qué hay que valorar?

Niña: mi madre me dice que hay que valorar la comida $\backslash[\ldots]$ 
Omar: ¿el libro en qué se basa todo?

Niño: semillas \}

Niño: solo semillas $\backslash[\ldots]$

Omar: vamos ahora \\| ¿qué no les gustó del libro? | ¿qué...- que no les pareció?

Omar: ahora al revés \| ¿qué es lo que más les gustó del libro? [18.06.2015]

En la sesión de La manta de las historias Omar realizó dos preguntas, iniciando el esquema de la sesión anterior, que luego no completó.

Omar: ¿qué es lo principal del libro? | ¿qué es lo que tiene de principal el libro?

Seguramente en el hecho de que conversación sobre lo leído quedara truncada, y la finalización de la sesión se observara apurada, en el registro de la única acción que este mediador empleó para restablecer el orden influyó la inquietud de los niños, destacada ese día en el diario de trabajo de campo, a la que ya se hizo referencia.

\section{En resumen:}

En las dos instancias observadas, Omar efectuó una lectura expresiva, en un volumen de voz que podía ser escuchado por todos. Delimitó con claridad distintos momentos en sus sesiones, que contribuyeron a crear en estas un orden previsible para los niños. Desplegó acciones variadas (7 y 9 diferentes en cada sesión, respectivamente), con escasa variación cuantitativa y cualitativa entre ambas sesiones. Las preguntas del mediador se concentraron, también, en ambas instancias, en la conversación sobre lo leído y se orientaron a hacer que los niños verbalizaran sus valoraciones sobre los cuentos.

\section{Intervenciones e intercambios entre los participantes}

El análisis de este ámbito y del siguiente: "Respuestas de los niños en las sesiones de lectura de Omar» se llevó a cabo sobre las lecturas mencionadas en el apartado «Hacer de Omar».

En ambas sesiones, se registraron productivos intercambios e intervenciones entre los niños y el mediador y entre los niños entre sí: 95 intervenciones de los niños y 52 del mediador en Un puñado de semillas y 69 de los niños y 40 del mediador en La manta de las historias. El siguiente cuadro cuantifica el análisis de este ámbito.

\begin{tabular}{|l|c|c|}
\hline & $\begin{array}{c}\text { Un puñado de } \\
\text { semillas }\end{array}$ & $\begin{array}{c}\text { La manta de las } \\
\text { historias }\end{array}$ \\
\hline Intervenciones de los niños & 86 & 55 \\
\hline Intercambios entre los niños & 9 & 14 \\
\hline Intervenciones del mediador & 52 & 40 \\
\hline
\end{tabular}

La diferencia cuantitativa de respuestas entre una sesión y otra tal vez pueda explicarse por dos factores: en primer lugar, la lectura de Un puñado de semillas constituyó una instancia de relectura de un cuento que los niños ya habían leído el año anterior. En segundo lugar, como ya se mencionó, Omar debió interrumpir abruptamente los comentarios en La manta de las historias, al observar la inquietud de los niños.

En ambas instancias, se generaron episodios muy participativos como el de este ejemplo: 
Niño: ahora vienen las preguntas / ¿ ¿no?

Omar: iah::! los comentarios \

Niño: jah::! [Desaprobación.]\

Niño: me gustó \}

Niño: me gustó \}

Niño: me gustó cuando iba a sacar un pedazo de la lana \

Niño: yo tengo algo que decir $\backslash \|$ a mí me gustó todo [12.08.2015]

Durante la lectura, mientras que el mediador leía o mostraba las imágenes, los niños aprovecharon para hacer intervenciones puntuales o para intercambiar espontáneamente entre ellos sobre el texto o las imágenes. Las intervenciones tuvieron una impronta monologal; con estas los niños exteriorizaban su comprensión sobre lo leído, buscando afianzarla. Estos comentarios no fueron interrumpidos ni censurados por el mediador, quien retomaba naturalmente la lectura luego de que se agotaban las intervenciones de los niños:

Omar: ¿por qué lloras? | preguntó Tomás enfadado \| no fue a ti a quien golpeó la policía \| mi huerto está destrozado \si el maíz \| los frijoles y el ají hubiesen madurado / | habríamos tenido comida para vender $\backslash$ | y ustedes no tendrían que robar [...]

Niño: ¿̇a ver?

Niña: ¿eran niñas también?

Niña: tienen camiseta amarilla \[...] [18.06.2015]

Se produjeron además en ambas sesiones intervenciones colectivas, como las de este ejemplo:

Omar: lo peor es que está escrito en ruso \

Niños a coro: \{risas\}

Omar: ahora les voy a | a hablar en ruso |

Niños a coro: \{[ff.] isí::! [sorprendidos]\} \{[protestas] ¿todo eso en ruso?\} [12.08.2015]

En las instancias de conversación de lo leído, el mediador formuló cinco preguntas, que reportaron una considerable cantidad de intervenciones de los niños, destacándose las de este episodio en el que se contabilizaron quince:

Omar: ¿qué es lo principal del libro? | ¿qué es lo que tiene de principal el libro?

Niña: que Babba Zarrah era una señora que siempre quería [...] que Ba...- que la señora Babba Zarrah siempre \| querí...- querí...- le hacía suéte[re]s querí...- hacerle u::na medias al al $\backslash \mid$ niño porque estaba contando las historias \|| pero después empezó a regalar de su manta a ca...- | al pueblo un regalo y lo que tenía después e...- el libro se trata $\backslash$ | de una la señora que siempre contaba historias a los niños en en en su manta en la manta de las historias $\backslash \|$ de las historias pero después empe...e:: cuando los niños tenían / || que les veía un agujero sacaba de su manta para hacerles a ellos \ Niña: y le encantaba la lana \

Niño: ¿y le encantaba la qué?

Niño: la lana \

Niña: y le encantaba compartir \

Omar: ahí está \

[...]

Omar: va...- vamos a escuchar lo que dijo la compañera de nuevo [...] compañera \(Da la palabra a una niña.) 
Niños a coro: ((???))

Omar: \{chistido\} || silencio \| porque habla despacito pero si hablamos todos / || ella no va a escuchar $\backslash$ | nadie va a escuchar \

Niño: parecían chinas las niñas \

Omar: sí \

Niño: le gustaba compartir \}

Niña: que quería ser sincera con el pueblo \| haciéndole muchos regalos para:: | para:: | para la nieve Niño: para los niños \}

Omar: a ver la \| a ver esa compañera (Da la palabra a otra niña.)

Niña: que era sincera \

Niña: en vez de pensar en ella / | pensó en los demás \

Omar: imuy bien! \| en vez de pensar en ella / | pensó en los demás \|| imuy bien! \

Niño: me gustó mucho \}

Omar: ¿eh?

Niño: me gustó mucho \

Niño: ¿por qué Babba Zarrah es un nombre raro?

Los niños también hicieron preguntas al mediador en distintos momentos de las sesiones, en busca de que este les proporcionara más información sobre el cuento:

Niño: ¿por qué se quedó sin tierra?

Omar: hay otros lugares donde los dueños de la tierra le alquilan un pedazo de tierra a la gente / I para que la trabajen \| entonces ¿qué pasa? | parte de la cosecha se la tienen que dar al dueño \| como se quedó sin abuela \| que era la de cosechaba [18.06.2015]

En ambas instancias, luego de que el mediador diese el cierre de la sesión, los niños continuaron dando sus interpretaciones y pareció que se hubieran «quedado con ganas» de continuar con lo que venían haciendo:

Omar: no sé si la maestra quiere comentar algo \

Niño: que Concepción se ofreciera a cuidar a los niños \

Niña: que Concepción fue buena con los niños \[18.06.2015]

Omar: bueno \| ¿ंestá todo? | ¿a ver Clari?

Niña: que le encantaba tejer $\backslash$

Omar: jeso también! \| que le encantaba tejer \[12.08.2015]

Los intercambios espontáneos entre los niños, ya mencionados, merecen un análisis aparte. Muchos de estos tuvieron una impronta colaborativa en la que los dichos de un niño eran complementados y expandidos por sus compañeros:

Niños: [enf.] iqué feo!\

Niño: pero están recogiendo basu::ra \

Niño: recogen lo que les sirve \

Niño: ¿̇a ver?

Niña: iah::! pero hizo un montón de cosas \

Niño: recogió basu::ra \[18.06.2015]

Otro hecho que merece destacarse es la anticipación de algunos niños a las acciones del mediador, antes del inicio de la lectura: 
Omar: bueno $\backslash=\ldots . .=$

Niño: $=\ldots . . .=$ se llama Buenas Noches $\backslash$ (El niño lee el título de la colección.\}

Omar: el libro de hoy se llama $\backslash=\ldots . .=$

Niño: $=\ldots . . .=(? ? ?))$

Niño: La manta de las historias $\backslash$ (Lee la tapa del libro.)

Omar: La manta de las historias \[12.08.2015]

... o antes de comenzar la conversación sobre lo leído:

Omar: muy bien \

Niño: ahora vienen las preguntas / I ¿no?

Omar: jah::! los comentarios \

Niño: iah::! [Desaprobación.] [12.08.2015]

En resumen:

En las sesiones de lectura de Omar se registraron productivas intervenciones e intercambios entre los niños y el mediador y entre los niños entre sí. Durante la lectura, los niños comentaron en forma espontánea, sin ser interrumpidos ni censurados por el mediador. Algunos de estos comentarios tuvieron una impronta monologal y otros adoptaron una modalidad colectiva y dialógica por la cual los dichos de un niño eran complementados y expandidos por otros.

Durante la conversación sobre lo leído, Omar formuló preguntas básicas abiertas ${ }^{58}$ que reportaron una considerable cantidad de respuestas de los niños. Dichas preguntas requirieron que los niños hicieran el esfuerzo de seleccionar, sintetizar y verbalizar un juicio de valor. Estos también se animaron a hacer preguntas al mediador en busca de ampliar información adicional para comprender el cuento.

En ciertos momentos de las sesiones analizadas, algunos niños se anticiparon a las acciones de Omar mientras que otros se resistieron a finalizar la conversación sobre lo leído, y continuaron dando sus opiniones luego de que el mediador diese el cierre.

\subsubsection{Respuestas de los niños}

\section{Respuestas de los niños en las sesiones de lectura de Omar}

El siguiente cuadro resume las respuestas de los niños en las sesiones de lectura de este mediador:

\begin{tabular}{|l|c|c|c|c|c|c|}
\hline & \multicolumn{3}{|c|}{ Un puñado de semillas } & \multicolumn{3}{c|}{ La manta de las historias } \\
\cline { 2 - 7 } & $\begin{array}{c}\text { Durante la } \\
\text { lectura }\end{array}$ & $\begin{array}{c}\text { Después de la } \\
\text { lectura }\end{array}$ & Total & $\begin{array}{c}\text { Durante la } \\
\text { lectura }\end{array}$ & $\begin{array}{c}\text { Después de la } \\
\text { lectura }\end{array}$ & Total \\
\hline $\begin{array}{l}\text { Expresiones de } \\
\text { entusiasmo }\end{array}$ & 5 & 1 & 6 & 8 & 0 & 8 \\
\hline $\begin{array}{l}\text { Referencias } \\
\text { literales al texto o } \\
\text { a las imágenes }\end{array}$ & 19 & 9 & 28 & 20 & 5 & 25 \\
\hline
\end{tabular}

58 Las preguntas básicas en el enfoque Dime buscan que los niños manifiesten sus impresiones sobre lo leído (Chambers 2007b). 


\begin{tabular}{|l|c|c|c|c|c|c|}
\hline $\begin{array}{l}\text { Referencias } \\
\text { inferenciales al } \\
\text { texto o a las } \\
\text { imágenes }\end{array}$ & 5 & 9 & 14 & 2 & 10 & 12 \\
\hline $\begin{array}{l}\text { Referencias } \\
\text { composicionales }\end{array}$ & 1 & 0 & 1 & 0 & 0 & 0 \\
\hline $\begin{array}{l}\text { Referencias } \\
\text { personales }\end{array}$ & 8 & 9 & 17 & 0 & 7 & 7 \\
\hline $\begin{array}{l}\text { Referencias } \\
\text { vivenciales }\end{array}$ & 0 & 12 & 12 & 0 & 0 & 0 \\
\hline Total & 38 & 40 & 78 & 30 & 22 & 52 \\
\hline
\end{tabular}

En ambas instancias (en La manta de las historias únicamente durante la lectura), pudieron observarse expresiones de entusiasmo de los niños, colectivas muchas de ellas:

Omar: un día triste \| la abuela murió $\backslash$

Niños a coro: [ff.] iah::! \[18.06.2015]

Omar: la confusión creció $\backslash \mid$ cuando el mugrien::to gato del sastre $\backslash \mid$ apareció de pronto ronronea::ndo $\backslash$ | muy refinado $\backslash$ | en un ajustado abrigo para gatos $\backslash$ | ya no había manta para sentarse $\backslash$ muestra las ilustraciones $<20>$ \}

Niños a coro: (???) (Murmuran.)

Niños a coro: ioh!:: iuh::! \[Asombro.]

Niño: \{aplauso\} [12.08.2015]

Durante la lectura, las respuestas de los niños que se manifestaron con mayor frecuencia fueron aquellas vinculadas con los aspectos literales de la narración verbal o en imágenes (las respuestas referenciales), como las que se observan en este fragmento:

Omar: [...] tu huerto se acabó $\backslash \mid$ Concepción se secó los ojos $\backslash \mid$ no $\backslash \mid$ no se acabó $\backslash \mid$ todavía me quedan algunas semillas $\backslash$ | está bien / | dijo Tomás $\backslash \mid$ pasándose la lengua por el labio roto $\backslash$ | esta vez / | te ayudaremos nosotros $\backslash \mid$ \{muestra las ilustraciones $<10>$ \}

Niño: ¿̇a ver?

Niña: ¿eran niñas también?

Niño: tienen camiseta amarilla \[18.06.2015]

Omar: tarde $\backslash$ | en la noche $\backslash$ | cuando todos estaban dormidos / Babba Zarrah caminó por entre la nieve / | y dejó las medias / frente la puerta de la casa de Nikolai $\backslash \mid$ \{muestra las ilustraciones $<15>$ \} poco después $\backslash$ | el cartero encontró una buf...- una bufanda enrollada en su maletín $\backslash$ | justo cuando iba a empezar sus rondas matutinas \|| ¿'saben quién hizo esta bufanda? || preguntaba a todos los que encontraba por el camino $\backslash \mid$ pero nadie sabía $\backslash \mid$ \{muestra las ilustraciones $<10>$ \}

$[\ldots]$

Niña: que a esta...- que se ataba ella con el niño y el perro \(La ilustración muestra a los personajes usando una misma bufanda.)

Niño: ahí hay un perro \[12.08.2015]

... y en menor medida, respuestas inferenciales como las siguientes: 
Omar: [...] la abuela entregó parte de la cosecha al dueño de la tierra $\backslash$ y guardó suficiente para tener con qué comer \|| vendió el resto al vecino / | que se lo llevó al mercado de la ciudad / | allá lejos / | en el valle $\backslash$ \{muestra las ilustraciones $<10>$ \}

Niña: hizo negocio con todo \[18.06.2015]

Omar: bueno \| ¿está todo? | ¿a ver Clari?

Niña: que le encantaba tejer / [12.08.2015]

En la sesión de Un puñado de semillas, también durante la lectura, estuvieron presentes las respuestas personales sobre algunos pasajes del cuento, en las que los niños manifestaban su empatía o desacuerdo con personajes o situaciones:

Omar: no se puede quedar aquí / | dijo el dueño de la tierra \| ya alquilé esta parcela a otra familia \ | pero yo puedo trabajar para usted / | dijo Concepción \| esta familia puede trabajar más que tú \ | puede cosechar más frijoles y maíz $\backslash \mid$ replicó el dueño \| entonces Concepción tuvo que dejar la casita de paredes pintadas / | y piso de tierra $\backslash\{$ muestra las ilustraciones $<10>\}$

Niños a coro: [ff.] ia::h!\

Niña: iqué lindas! \

Niña: qué malo el dueño \}

Niño: es malo $\backslash$

Niña: estás buenas las plantas \[18.06.2015]

En esta sesión se produjo, además, una única respuesta sobre aspectos composicionales de la obra, cuando un niño identificó que una ilustración reproducía la tapa del cuento que estaban leyendo:

Omar: todos los días regaba la tierra $\backslash$ | y miraba atentamente $\backslash$ | hasta que vio brotar los primeros retoños $\backslash$ | verdes y brillantes $\backslash$ | los frío::les y el ají florecieron $\backslash$ | y en el barrio / no había nada más bonito que el pequeño huerto de Concepción $\backslash$ | y ella / | estaba segura de que $\backslash$ | desde el cielo / | su $\mid$ abuela $\backslash$ cuidaba el huerto $\backslash$ \{muestra las ilustraciones $<10>$ \}

Niño: igual que en la tapa \[La imagen de esta página es la misma que la de la tapa.] [18.06.2015]

Durante la conversación sobre lo leído, las respuestas con mayor presencia, en ambas sesiones, fueron las inferenciales, como las que se observan a continuación:

Omar: ¿qué sacan en conclusión de esto que leímos?

Niña: que era buena \

Niña: que la niña fue muy amable \[18.06.2015]

Omar: a ver la \| a ver esa compañera \[Da la palabra a otra niña.]

Niña: que era sincera \

Niña: en vez de pensar en ella / | pensó en los demás \[12.08.2015]

Las respuestas literales se manifestaron en ejemplos como los siguientes:

Omar: exacto \| lo que dice el compañero \|| ¿el libro en qué se basa todo?

Niño: semillas \}

Niño: solo semillas \}

Niño: en la huerta $\backslash=\ldots . .=$

Niño: $=\ldots . . .=$ semillas $\backslash[18.06 .2015]$ 
Omar: ¿qué es lo principal del libro? | ¿qué es lo que tiene de principal el libro? Niña: que Babba Zarrah era una señora que siempre quería [...] que Ba...- que la señora Babba Zarrah siempre $\backslash$ | querí...- querí...- le hacía suéte[re]s querí...- hacerle u::na medias al al $\backslash \mid$ niño porque estaba contando las historias $\backslash||$ pero después empezó a regalar de su manta a ca...- | al pueblo un regalo y lo que tenía después e...- el libro se trata $\backslash$ | de una la señora que siempre contaba historias a los niños en en en su manta en la manta de las historias $\backslash \|$ de las historias pero después empe...e:: cuando los niños tenían / || que les veía un agujero sacaba de su manta para hacerles a ellos [12.08.2015]

... y las personales, en estos otros:

Omar: bueno / vamos a comentar ahora un poco $\backslash=\ldots . . .=$

Niño: $=\ldots . . .=$ abuelo $/$ me pareció medio triste $\backslash$

Omar: $=\ldots . . .=$ a comentar un poco el libro $\backslash$

Niño: idale! \

Niña: la abuela que murió me pareció un poco triste $\backslash$

Niña: ¿̇un poco nada más? | ¿̇un poquito? [Con ironía.] [18.06.2015]

Niño: ahora vienen las preguntas / | ¿no?

Omar: jah::! los comentarios \

Niño: iah::! \[Desaprobación.]

Niño: me gustó $\backslash$

Niño: me gustó $\backslash$

Niño: me gustó cuando iba a sacar un pedazo de la lana \

Niño: yo tengo algo que decir $\backslash \|$ a mí me gustó todo \[12.06.2015]

Únicamente en Un puñado de semillas, y durante la conversación sobre lo leído, se manifestaron las respuestas vivenciales de los niños:

Omar: ¿qué sacan en conclusión de esto que leímos?

$[\ldots]$

Niña: que hay que compartir \

$[\ldots]$

Niña: que hay que comer todo lo que nos ponen en la mesa porque si no \si no nos faltaría la comida\ [18.06.2015]

Es interesante observar la evolución de las respuestas de los niños a algunas de las preguntas que el mediador realizó durante la conversación sobre lo leído, que avanzaron desde lo referencial y explícito hacia un plano vivencial más abstracto, como puede observarse en estos pasajes de Un puñado de semillas:

Omar: ¿qué sacan en conclusión de esto que leímos?

Niña: que era buena \

$[\ldots]$

Niña: que la niña fue muy amable \

$[\ldots]$

Niña: que hay que compartir $\backslash[\ldots]$

Niña: que hay que comer todo lo que nos ponen en la mesa porque si no \si no nos faltaría la comida\ 


\section{$[\ldots]$}

Niña: mi madre me dice que hay que valorar la comida \[...]

Niño: que hay que guardar siempre un poco de semillas \

Omar: ¿el libro en qué se basa todo?

Niño: semillas \

Niño: solo semillas \}

Niño: en la huerta $\backslash=\ldots . . .=$

Niño: $=\ldots . . .=$ semillas $\backslash$

$[\ldots]$

Niño: tenían para comer $\backslash[\ldots]$

Niño: y en las huertas \

Niña: que el niño fue humilde con ellos / | y no egoísta porque:: \| siempre / siempre hay que ser bueno con los otros niños que no tienen \

$[\ldots]$

Omar: ¿y cómo se llama eso? | solidaridad \

Niña: solidaridad y no hay que ser egoísta \

$[\ldots]$

Niña: que hay que valorar lo que uno tiene $\backslash[\ldots]$

Niña: mi madre me dice $\backslash$ | valorá la comida que hay niños que se están muriendo de hambre en la calle $\backslash$

Niño: es verdad \}

Niño: mi madre me dice lo mismo $\backslash=\ldots . . .=$

$[\ldots]$

Niño: que hay que tratar bien a la gente y cuidar el mundo \}

Niño: y no hay que desperdiciar la comida \

Omar: vamos ahora \\| ¿qué no les gustó del libro? | ¿qué...- que no les pareció?

Niño: no sé $\backslash$

Niño: a mí no me gustó que:: la abuela muriera $\backslash \mid$ y los niños le dijeran tonta $\backslash[\ldots]$

Niño: que le quitaran la casa a Concepción \

Niño: que les pegaran los policías $\backslash||$ la violencia \}

Niña: que la abuela muriera $\backslash[\ldots]$

Niña: que se puede vivir de otra forma sin robar \[18.06.2015]

En estas otras respuestas se observó un mayor apego a lo literal, aunque también se observa un crecimiento desde lo explícito a lo inferencial.

Omar: ahora al revés $\backslash$ | ¿qué es lo que más les gustó del libro?

Niño: la huerta\

Niño: a mí también me gustó \}

Niño: la huerta \}

Niña: que la f...-\que la familia se ofreció a dar compañía \

Omar: imuy bien!

Niña: que viviera otra familia con ella \| allí al lado de la casa \

Niños a coro: (Discuten sobre la familia que vivía con Concepción.) [...]

Niña: que Concepción se ofreciera a cuidar a los niños \

Niña: que Concepción fue buena con los niños \} 
En la sesión de La manta de las historias, en las respuestas a la única pregunta del mediador también se observó un crecimiento desde lo explícito a lo inferencial:

Omar: ¿qué es lo principal del libro? | ¿qué es lo que tiene de principal el libro?

Niña: que Babba Zarrah era una señora que siempre quería [...] que Ba...- que la señora Babba Zarrah siempre $\backslash$ | querí...- querí...- le hacía suéter[es]s querí...- hacerle u::na medias al al $\backslash \mid$ niño porque estaba contando las historias $\backslash||$ pero después empezó a regalar de su manta a ca...- | al pueblo un regalo y lo que tenía después e...- el libro se trata $\backslash$ | de una la señora que siempre contaba historias a los niños en en en su manta en la manta de las historias $\backslash \|$ de las historias pero después empe...e:: cuando los niños tenían / || que les veía un agujero sacaba de su manta para hacerles a ellos \ Niña: y le encantaba la lana \ Niño: ¿̇y le encantaba la qué?

Niño: la lana \}

Niña: y le encantaba compartir \

Niño: parecían chinas las niñas \

Omar: sí \

Niño: le gustaba compartir $\backslash$

Niña: que quería ser sincera con el pueblo \| haciéndole muchos regalos para:: | para:: | para la nievel

Niño: para los niños \}

Omar: a ver la \| a ver esa compañera \[Da la palabra a otra niña.]

Niña: que era sincera \

Niña: en vez de pensar en ella / | pensó en los demás \

Omar: imuy bien! \| en vez de pensar en ella / | pensó en los demás \|| imuy bien! \

$[\ldots]$

Omar: bueno \| ¿está todo? | ¿a ver Clari?

Niña: que le encantaba tejer /

Omar: ieso también! \| que le encantaba tejer \[12.08.2015]

\section{En resumen}

En ambas sesiones, se produjeron expresiones de entusiasmo de los niños, tanto durante la lectura como los comentarios.

Las respuestas de los niños del tipo referencial e inferencial sobre el texto o las imágenes, las personales y las vivenciales estuvieron presentes en ambas sesiones de Omar. Se registró también una respuesta composicional en relación con una imagen del cuento Un puñado de semillas.

En la sesión de lectura de Un puñado de semillas se constató que las respuestas de los niños a algunas de las preguntas que el mediador realizó durante la conversación sobre lo leído en avanzaron desde lo referencial y explícito hacia un plano vivencial de mayor abstracción.

\section{E. Recuerdos de los niños sobre La manta de las historias}

El análisis de este ámbito se realizó sobre los aspectos que los niños recordaron de la lectura de este cuento - efectuada el 12 de agosto- en la entrevista del 11 de setiembre. 


\begin{tabular}{|l|c|}
\hline Aspectos recordados & Cant. \\
\hline Título & 1 \\
\hline Argumento & 4 \\
\hline Marco & 2 \\
\hline Acción narrativa & 2 \\
\hline No recuerdan & 1 \\
\hline
\end{tabular}

Con respecto a los aspectos recordados sobre esta sesión, una niña, Sofía, mencionó en forma espontánea su título, y frente a la pregunta de si recordaban dicho cuento, otros tres niños evocaron su argumento y a su protagonista:

Sofía: me gustó más El pájaro del alma y La manta de las historias

Facundo: que la desarmaban para hacer pa otros y eso

Sofía: por ejemplo no sé:: \| porque le hacían medias a una señora

Yasmila: me acuerdo que:: \ || una:: señora mayor / | era la que contaba cuentos a los niños [...] me había gustado la gentileza de la señora | a darle los regalos a la gente | y también | la humildad | de aquel...- de aquellos niños y la ciudad que le habían hecho la manta

También ambas niñas (como puede apreciarse en el ejemplo anterior), y además Franco, hicieron referencia a los personajes de la narración:

Franco: [...] que había una señora que hacía una una como una sábana de así de todo lana

Y él y Yasmila recuperaron aspectos de la acción narrativa:

Franco: [...] y que se contaban historias $\backslash$ | y que se ponían así [Hace el gesto de estar apretados sobre La manta de las historias como se veía en la ilustración.] \[...] creo esta parte \| [enf.] creo \| que los niños que ella tenía unos amigos que estaban así en la calle $\backslash$ | ¿no? || y también al final tiene un...- \| una nueva sábana \porque \||no sé como como \| como compartir con las con las personas que no tienen nada

Yasmila: [...] tenía una man:: | una gran manta / | llena de colores || iba a retazos...| eh:: \y luego / | un niño se le rom...- | se rompió un champión | y se le...- | y después sacó una parte de su manta y le:....| y le había hecho un parche | después empezó a darle regalos de esa manta | a toda la ciudad | que...| donde ella vivía | y después los niños | y toda la ciudad | le hicieron otra manta

Zoe e Iván, en cambio, manifestaron no recordar ningún aspecto del cuento, pese a haber estado presentes el día de su lectura, e Iván haberse mostrado muy participativo.

\section{En resumen:}

Con respecto al cuento leído ad hoc para la investigación, La manta de las historias, una niña mencionó espontáneamente su título, cuatro niños lograron recordar algunos aspectos del marco, argumento y acción narrativa mientras que otros dos manifestaron no recordar nada de dicha lectura. 


\section{F. Valoraciones de los niños sobre Omar}

En las opiniones recogidas en la encuesta, los niños manifestaron, en mayor medida, valoraciones positivas sobre este mediador: 62 opiniones positivas y 4 negativas de dos niños,

\begin{tabular}{|l|c|}
\hline Opiniones & Cant. opiniones \\
\hline Centrada en el vínculo familiar en general & 6 \\
\hline Centradas en la persona del mediador & 20 \\
\hline$\left({ }^{*}\right)$ Centradas en la lectura del mediador & 34 \\
\hline $\begin{array}{l}\text { Centradas en la experiencia de lectura con el } \\
\text { mediador }\end{array}$ & 3 \\
\hline Centradas en el vínculo niño-libro & 1 \\
\hline Centradas en el libro y la lectura en general & 66 \\
\hline Total de opiniones relevadas & 2 \\
\hline
\end{tabular}

(*) Dentro de estas respuestas se constataron 15 que valoraron la modalidad de lectura del mediador y 5 , los libros que lee.

Las opiniones positivas sobre su persona se explicitaron en juicios como el siguiente:

«Me gusta que venga porque es gracioso y divertido» [Luciana];

Solo dos niños declararon algún grado de disconformidad con la lectura de Omar:

«A mí no me gusta [... ] A mí feos» [Facundo B.]

«Me gusta pero no mucho [...] Hay veces que me aburro» [Zoe]

La mayoría de los niños valoraron su propia experiencia en las sesiones de lectura con el abuelo:

«Me gusta porque además hacemos un esfuerzo para escuchar en silencio» [Anthony]

... en segundo lugar, la lectura del mediador: su modalidad lectora y los libros que leyó:

«Tiene una gran voz para leer cuentos» [Anshie]

«Los cuentos estaban muy buenos» [Dylan]

... en tercer lugar, destacaron alguna característica de su personalidad:

"Y es muy cariñoso Omar» [Franco]

«Omar lee con el corazón» [Romina B.]

... y, marginalmente, el vínculo del niño con el libro, el libro y la lectura en general y la presencia de la familia en la escuela:

«A mí me gusta que me presten libros para leer» [Romina]

«Es muy lindo estar con tus familiares» [Carla] 
«Porque cuando leen se abre un mundo de imaginación» [Facundo A.] [02.09.2015]

Por último, cabe mencionar que 19 niños recordaron algún título leído por el mediador durante 2014 y 2015: 11 niños recordaron El pájaro del alma; 4, Un puñado de semillas; 2, «El loro pelado» (cuento que Omar leyó en 2014); 1 «La abeja haragana» y 1 La manta de las historias.

\section{En resumen:}

Los niños valoraron en mayor medida su experiencia de lectura con el mediador, y luego, la lectura y la persona del mediador. 19 niños pudieron recordar, además, algún título leído por él.

\subsubsection{Conclusiones preliminares sobre el primer caso}

Los motivos que han impulsado a Omar a ejercer el rol de mediador se relacionan con cumplir su rol de abuelo, transmitiendo a los niños un legado moral, inculcándoles el gusto y el hábito de la lectura y haciéndolos partícipes de las vivencias que a él lo formaron como lector.

Los niños se hicieron eco de estos propósitos y reconocieron en él su condición, aspecto que destacaron en sus entrevistas:

Martín: y porque es un abuelo | es el abuelo de la clase | aparte de ser el abuelo de Clara | es el abuelo de la clase

Xiomara: el abuelo de Clara | me gusta que:: | me gusta mucho que nos lea

Sandra: está perfecto | ¿y qué más te acordás de él?

Franco: que la nieta que tiene es Clara \[11.09.2015]

Vivenciaron además su entrega (de su tiempo, de su afecto, de su lectura) como un obsequio del mediador hacia ellos:

Iván: y después| me gustan que me lean \{risas\}

Sandra: te gusta que te lean | ¿quién te gusta que te lea?

Iván:: más que nada el abuelo Omar || porque | en mi casa solo || solo leo yo [...]

Sandra: ¿sí? | ¿qué recordás de cuando él [Omar] viene a leer?

Franco: que él siempre saluda a toda la clase | que cuando lo llaman al teléfono no atiende | un ejem...|| no sé | no sé qué más decirte [11.09.2015]

Omar ha podido sacar el máximo provecho al ejercicio de su rol, en tanto su ganancia de experiencia le ha permitido introducir innovaciones en su hacer con los niños y compartir vivencias y consejos con sus compañeros del equipo comunitario y maestras. Su experiencia también le ha permitido expandirse como mediador y como lector, «contaminado» a su familia y haciéndose autor de sus propios cuentos.

En relación con su hacer, la lectura de Omar, y específicamente su modalidad lectora, fue uno de los aspectos más valorados por los niños en la encuesta, destacado además por cuatro de los seis niños entrevistados:

Iván: \{risas\} ahora sí || me gusta que el abuelo Omar lea porque lee bien | para empezar [...]

Yasmila: [...] porque tiene un buen tono de voz | se escucha muy bien | y:: me encanta:: como...- | eh:: los cuentos que él escoge 
Sandra: bien | el cuento «El loro pelado» | ¿̇y por qué te gustó ese cuento?

Martín: porque lo había venido a leer el abuelo Omar | y lo leía como con...- || no sé cómo es que te puedo decir em:: || em:: | entusiasmo | con los mismos tonos del libro

Franco: porque me gustaba porque era:: | que leía hermoso | por ejemplo [11.09.2015]

Omar desarrolló en sus sesiones un patrón bastante estable, con momentos claramente delimitados por acciones específicas, que ordenaron su rutina y con el que los niños parecían estar familiarizados, lo que hizo posible que estos se anticipasen a las acciones del mediador:

Niño: ahora vienen las preguntas / | ¿no?

Omar: iah::! los comentarios \[12.08.2015]:

El hacer de Omar se caracterizó por su impronta afectiva y lúdica, constatada en el ritual de inicio de La manta de las historias y en las acciones que dejaron en evidencia su procedencia familiar. Los niños supieron hacerse cómplices de esta dinámica, respondiendo a ella con expresiones de entusiasmo, y manifestando su interés por escuchar y participar, tal como quedó evidenciado en el deseo de continuar aportando a la conversación sobre los leído al finalizar las sesiones. El afecto de los niños también pudo observarse al concluir la lectura de «La abeja haragana» cuando un pequeño grupo corrió a abrazar al mediador en el momento en que se retiraba del salón ( $\rightarrow$ anexo 5. «Diario de trabajo de campo. Jueves 30 de julio»). Estas manifestaciones de afecto se constituyeron también en un motivo de gratificación para el mediador.

Por otra parte, la continuidad del vínculo entre Omar y los niños por dos años consecutivos, su mutuo conocimiento, el desarrollo pautado de las sesiones, las vivencias gratificantes de los niños - evidenciadas en las opiniones que hacen referencia a su experiencia de lectura con el mediador, vertidas en la encuesta - , la certeza de no ser sancionados al hablar (obsérvese la ausencia de sanción a los comentarios espontáneos y la no corrección de los errores interpretativos en el apartado «Gestión de la construcción del metatexto») contribuyeron a generar y afianzar la confianza de los niños hacia este abuelo lector. Precisamente, esta confianza fue el factor que habilitó las intervenciones e intercambios dialógicos durante la lectura y la comprensión generada en forma colectiva como producto de esa conversación.

Las acciones que evidenciaban la identidad del mediador, además de señalar su procedencia familiar, le permitieron establecer un límite entre su hacer y el de la docente. Además, tanto Omar como Inés, la maestra, supieron ensamblar armoniosamente sus acciones: la primera se encargó de disponerlos en ronda para recibir al mediador, de darle a este la bienvenida, de auxiliarlo cuando los niños se inquietaban, pero se abstuvo de intervenir mientras este leía o durante los comentarios sobre lo leído. El abuelo por su parte, al finalizar su sesión le cedía la palabra a la maestra. La actitud de Inés hacia Omar y de él hacia la maestra, el vínculo entre ellos, percibido como de mutua valoración, respeto y armonía crearon un contexto especial, que hizo posible que los niños vivenciaran las sesiones de lectura como momentos especiales y diferentes al de otras escenas escolares:

Omar: [ff.] bueno \/ ¿cómo les va?

Niños a coro: [ff.] ibie::n!\

Inés: te extrañamos Omar \¿contanos \|

contanos qué te pasó?

Omar: algunos problemitas de salud I pero

ya estoy:: || recuperado \}
Inés: ¿escucharon lo que dijo:: / | Anshie?

Omar: escucharon lo que dijo la compañera \}

Inés: XXX \| decí lo que dijo Anshie tú \

Niño: [enf.] ¿Anshie? no es Anshie \| es Yasmila \

Inés: habló Anshie $\backslash$ | ni te enteraste \

Niño: [enf.] es Yasmila [...] 
Inés: nos alegramos de que vuelvas \ Omar: ella habló \

[18.06.2015]

Niño: [enf.] y Yasmila también [...]

Omar: \{(risas) este es como el hijo del papanata \

| si no la gana la empata \\}

Inés: $\{$ (risas) se acomoda en el aire $\backslash\}$

Inés: [enf.] iescuchamo::s! / | iescuchamos! \

Omar: va...- vamos a escuchar lo que dijo la

compañera de nuevo $\backslash=\ldots . .=[12.08 .2015]$

Las acciones para generar expectativas antes de comenzar a leer La manta de las historias y "La abeja haragana», la no interrupción del mediador mientras leía y mostraba las imágenes y su modalidad lectora garantizaron la escucha atenta de los niños.

El aval a las expresiones de los niños, las acciones que habilitaron su participación e incluso la única acción que puso límites al descontrol en La manta de las historias, brindaron las mejores condiciones para que la conversación posterior a la lectura se produjera y los niños se expresaran a sus anchas.

Las preguntas que Omar realizó en este momento fueron funcionales a sus motivaciones, ya señaladas más arriba, pues estuvieron orientadas a que los niños se apropiaran del mensaje de los cuentos y expresaran sus opiniones y sentires. Frente a las preguntas de este abuelo, los niños se dispusieron en el rol de nietos y se aprestaron a retribuirlo, verbalizando el mensaje que él les quiso transmitir con la lectura de cada cuento; como queda manifiesto en las respuestas personales y vivenciales observadas en la sesión de Un puñado de semillas. Al ser, además, abiertas, estas preguntas lograron que las respuestas de los niños tuvieran un efecto acumulativo y que sus interpretaciones avanzaran desde lo literal hacia lo inferencial, profundizando la comprensión sobre lo leído.

Aunque las acciones de reformulación, de síntesis y de expansión de la información del texto (estas últimas a requerimiento de los niños) no fueron las de mayor frecuencia durante las sesiones, puede decirse que el mediador realizó con ellos un aporte a la comprensión de lo leído.

En ambas sesiones, en algunos momentos de la conversación, la ausencia de acciones del mediador hizo parecer que este fuera construyendo su comprensión sobre lo leído junto con los niños. En este mismo sentido, la no intervención frente a los errores interpretativos de los niños, la predominancia de las acciones de aval ya señalada y estas palabras de Omar apuntalan esta observación:

[...] y:: de lo que recibía | lo que más me encantaba era | después de la lectura los comentarios | había de todo | bueno vos estuviste | viste que hay de todo tipo de comentarios | algunos que te morís de risa | otros muy acertados | y otros que uno mismo | no se había puesto a pensar | que se dan cuenta que uno no [17.11.2015]

Por último, cabe destacar que la no intervención frente a los errores interpretativos de los niños, si bien coadyuvó a generar espacios de intercambios de bajo riesgo para ellos, constituyó un límite al aporte del mediador, que no supo o no quiso traspasar. 


\subsection{Segundo caso. Escuela XX, tercer año B, Cecilia}

\subsubsection{Estilo de la mediadora}

\section{A. Ser de Cecilia}

\section{La mediadora en persona}

Cecilia tiene 36 años; trabaja en la tarde como empleada por lo que tiene las mañanas libres para ir a leer a la escuela de Sofía, su única hija, alumna de tercer año A de la maestra Inés.

Durante 2015 esta mediadora leyó en inicial 5 años y en tercero B (maestra Noelia) desde junio en adelante. Sus lecturas cesaron en agosto de este año al agudizarse el conflicto en la enseñanza al que ya se hizo referencia.

\section{Preferencias y prácticas lectoras}

Entre los géneros de agrado de esta mediadora se encuentran la poesía, la narrativa policial y, específicamente, los libros de autoayuda. Aunque no manifestó preferencias por un género o autor en particular, en la entrevista mencionó que "le gusta mucho» La magia y en la reunión del equipo comunitario del 18 de junio sugirió leer a los niños más grandes ese título y El secreto, ambos del género autoayuda.

me gustan much...- | o sea | me gustan varias cosas | me gusta la parte de de | poesía me gusta::n || libros que a veces leo pero personales del tipo de ...-<5> | hay un libro que me gusta mucho que se llama La magia | este:: | no tienen nada que ver con cuentos ni nada ¿no? | este:: | y bueno después | lectura de:: historia de:: de:: | tipo policiales [25.11.2015]

[En relación con los títulos que sugiere para leer a los niños.] yo tengo un libro que es más bien... o sea yo ya los leí, pero... es más bien para adultos... pero están buenos capaz que para clases grandes porque es más bien de filosofía de vida. Por ejemplo quinto y sexto están en un cambio de entrar al liceo. Los libros se llaman, los tienen que conocer, uno se llama El secreto y el otro es La magia [...] [18.06.2015]

En la actualidad, Cecilia logra reservar un momento en su rutina diaria para sus lecturas, ahora que su hija ya lee sola:

[...] pero bueno después que uno || va creciendo | ahora ya mayor como que leés un poco más que que...- | depende de los tiempos que uno también tenga | pero bueno

Sandra: cuando llegás a ser adulto es más difícil

Cecilia: claro pero de repente yo que sé a veces | en la noche por lo general | cuando uno está un poco más tranquilo [25.11.2015]

Y en su hogar, la presencia de libros y la lectura parecen tener una alta valoración:

[...] siempre le estamos comprando libros | a veces como que no tiene esa constancia porque claro ...- || a ella por ejemplo le gustan los libros del sapo Ruperto | y:: de repente no los llega a terminar de leer $\|$ pero no tiene esa constancia todavía de estar leyendo un libro que es un poquito más la::rgo y...- | pero los va leyendo le gustan [25.11.2015]

Yo tengo en casa mucha cantidad de libros, siempre le compré libros a Sofía [...] [18.06.2015] 


\section{Biografía lectora}

Los orígenes del hábito lector y del interés por la lectura de Cecilia se remontan a su infancia y a su familia. Al respecto, esta mediadora destacó la presencia de cuentos, entre ellos los clásicos, y revistas en su hogar, y evocó, reiteradamente, con mucho entusiasmo, tanto en su entrevista como en la reunión del equipo comunitario del 18 de junio, el influjo de su madre en la generación del hábito lector.

desde chica || desde chica porque a mí...- || desde chica de mi casa en realidad | porque...- | en mi casa mi madre siempre me estaba comprando | lo que antes había en realidad | las revistas aquellas de:: | del pato Donald | de Disneylandia | tenía millones de esas revistas [enf.] y ahí empecé leyendo | me compraba muchos cuentos | y no solo esos tenía otros | bueno los tradicionales | Blanca Nieves | Caperucita Roja | bueno todas esas cosas | y de ahí siempre | siempre siempre tuve | en mi casa siempre había libros | siempre leí [25.11.2015]

[...] porque yo cuando era chica mi madre me compraba libros es como una cosa que sigue yo siempre fui de leer mucho por eso casi no tengo faltas de ortografía [18.06.2015]

Cecilia quiso reproducir con su hija esa tradición familiar:

Yo tengo en casa mucha cantidad de libros, siempre le compré libros a Sofía porque yo cuando era chica mi madre me compraba libros, es como una cosa que sigue, yo siempre fui de leer mucho [18.06.2015].

La práctica de la lectura recreativa de su niñez se interrumpió en su adolescencia, cuando tuvo la necesidad de leer para estudiar, y se retomó en su vida adulta:

Cecilia: sí ahí en esa etapa como que en la adolescencia uno |\{(risas) no lees tanto sino lo que te mandan los profesores en el liceo\} y:: hasta ahí | pero bueno después que uno || va creciendo | ahora ya mayor como que leés un poco más que que...- | depende de los tiempos que uno también tenga [25.11.2015]

En su biografía lectora, Cecilia destacó únicamente un hito relacionado con la presencia de la lectura en el sistema educativo, que las palabras de Omar en la reunión del equipo comunitario trajeron a su memoria:

[Sobre los cuentos de Horacio Quiroga.] [...] son bastante fuertes... yo cuando leí esos cuentos me quedaron tan grabados... yo los leí recién en el liceo, porque en el liceo lo tenían en el programa, pero de chica en la escuela nunca, los niños de ahora no son como nosotros, porque nosotros de terror nada, mire si íbamos a leer [...] [18.06.2015]

\section{Motivaciones para ejercer el rol de mediadora}

Es posible identificar las siguientes motivaciones para ejercer el rol en esta mediadora. En primer lugar, el propósito manifiesto de estar presente en la escuela, cerca de su hija:

[...] bueno porque me pareció una buena oportunidad para:: | pasar más tiempo con ...- no solo con mi hija sino con otros niños conocerlos un poquito más y bueno ya el año pasado yo ya | había leído algún cuento en algunas clases y estuvo bueno y ta...- bueno este año ...- [25.11.2015]

Esta motivación también puede inferirse de reiterados comentarios sobre aquella durante las reuniones del equipo comunitario: 
[En alusión a los libros de la biblioteca escolar que lleva su hija a su casa.] Sofía llevó uno la otra vez que quedó recopada, le gustó, sobre los derechos de los niños. Llevó dos distintos y... le gustó mucho, porque claro, ellos no saben de eso... ahora llevó uno que era de un pato, que no me acuerdo cómo se llamaba, también andaba recopada con ese, en general le gustan todos los tipos, tiene que ser muy aburrido para que no le guste.

[En relación con los títulos que leyó en 2014 en la clase de su hija.] Sofía los eligió, porque ella tiene muchos cuentos cortos, claro, que son para más chiquitos [...]. [18.06.2015]

En segundo lugar, contribuir con su accionar al éxito escolar, de su hija y de los demás niños. De alguna manera, esta mediadora cree que su lectura los incentivará a leer por sí mismos y esto, en un futuro, redundaría en una escritura sin errores ortográficos, tal como se desprende cuando afirma que «el leer los ayuda a no tener faltas de ortografía».

En tercer lugar, acortar la distancia entre el hogar y la escuela:

[...] y bueno:: | porque es como que tenés ...- | si uno no es familiar de todos pero ellos sienten como que la familia está más cerca de ellos | o sea | no solo compartir en la casa sino también estás en la escuela compartiendo con ellos | entonces sienten como un poquito más familiar la escuela | digamos [25.11.2015]

El disfrute del rol de mediadora también se encuentra presente en sus declaraciones:

Cecilia: iah! yo les diría que vinieran | porque es una linda experiencia:: ||bueno si tienen nietos | con los nietos | aunque le puede tocar en la clase del nieto como no | y podés ver las reacciones de otros niños y cómo...- | y como comentan | y a pesar de que son de repente chiquititos | y te comentan y te dicen y se sienten identificados...- || está bueno || teniendo tiempo \{risas\} || una vez cada ta::nto | un ratito | que son quince veinte minutos ya está | y ellos lo disfrutan pila [25.11.2015]

... al igual que el deseo del reencuentro con su niñez lectora, que es otra motivación presente en esa mediadora, como puede observarse en las reiteradas referencias que hace a esta etapa de su vida en las reuniones del equipo comunitario ( $\rightarrow$ «Biografía lectora»).

Por último, puede identificarse en Cecilia un interés por contribuir a que los niños comprendan sus lecturas, como puede apreciarse en estas palabras:

[...] y de repente vos eh:: leés algo que...-| a veces hay algunas frases que ellos puede que no entienden por algunas palabras $\|$ y les explicás la...- esa palabra que de repente que vos sabés que no entienden | y ellos te escuchan | y :: ves las caritas como diciendo iah mirá lo que significaba! ¿no? [25.11.2015]

... y, también, de inculcar enseñanzas morales a través de la lectura de determinados textos, compartiendo con los niños aquellos que a ella misma le resultaron útiles en ese sentido, como puede constatarse en la alusión que hace a sus lecturas de El secreto y La magia, en la reunión del equipo comunitario del 18 de junio, a la que ya se hizo referencia.

\section{Apropiación del rol de mediadora}

Cecilia integró junto con su esposo el equipo comunitario de la escuela XX en 2014 y reingresó a este en junio de 2015, reemplazando a otra mamá, Carla, quien dejó de ir a leer por problemas de salud. 
Aunque su actuación en 2014 fue acotada ${ }^{59}$, Cecilia evocó su primera experiencia de lectura con agrado:

[...] yo leí el año pasado que me fue bárbaro en segundo, cuando ellos estaban en segundo... ¿qué fue lo que les leí...? iah!, alguno que yo tenía en casa, que Sofía los eligió, porque ella tiene muchos cuentos cortos, claro, que son para más chiquitos. [...] [18.06.2015]

Cecilia participó en una sola reunión del equipo comunitario, la del 18 de junio, en la que manifestó su interés y su disposición a concurrir a leer cualquier grupo:

[...] yo no tengo problema, también es cuestión de probar, por ejemplo, el año pasado leí solamente en segundo... después leyó mi esposo también el año pasado, que también dice que estuvo bueno [18.06.2015].

A pesar de la escasa frecuencia de sus lecturas en la escuela, Cecilia logró capitalizar su experiencia como mediadora. En la reunión del equipo comunitario a la que asistió sugirió títulos para leer y criterios para seleccionar sus lecturas:

[En relación con la selección de los cuentos a leer a los niños.] eso depende mucho del cuento o como de uno lo cuente

[...] de repente en tercero tendría que ser otro tipo de libros, lo que pasa es que yo en casa por ejemplo... son como libros de este tipo que son muy largos para leerlos acá... pero no sé en qué clase tampoco, porque depende de la clase

[...] quinto y sexto están en un cambio de entrar al liceo. Los libros se llaman, los tienen que conocer, uno se llama El secreto y el otro es La magia... Son medios largos pero habría que elegir algún capítulo que ellos puedan rescatar para cosas futuras... ellos van a entrar al liceo y ahí hay muchas cosas nuevas que de repente desde un cierto lugar llevarlos a un plano positivo... les va a costar, van a tener más materias... es difícil [18.06.2015]

También en su entrevista expresó los conocimientos sobre el desarrollo de su tarea que fue aprehendiendo durante sus sesiones de lectura:

... sobre la recepción de los niños y la incidencia de la modalidad lectora en la captación del público infantil:

[Sobre la experiencia de lectura en Inicial 5 y tercer año.] [...] y tenés pila de cosas | porque por ejemplo | en en los más chiquitos | digo son:: | es distinto a tercero porque los chiquitos están como con una expectativa a ver qué tipo de cuento le vas a leer \| va también en la manera en la que uno se los cuente | este:: | te escuchan mu::cho [...] [25.11.2015]

... sobre el aporte de la literatura a la construcción de la subjetividad:

[...] en seguida que vos decís algo que de repente ellos se sienten identificados | ellos enseguida te empiezan a decir iah yo tengo un perro igual! porque mi perro hace esto mi perro hace lo otro I y se identifican con el cuento que vos le lees que es como para la edad de ellos | y bueno después tercero:: [...] también a veces se pueden sentir en algunas cosas identificados || con ellos | con la familia con los compañero::s [...]

\footnotetext{
$59 \rightarrow$ Anexo 3.4.1.1.«Entrevista a Cecilia».
} 
[En referencia a las lecturas realizadas.] de repente puede ser por ejemplo el que leímos en tercero el de la niña que es muy pobre | digo las cosas que le pasan a esa niña | son:: | eh:: bastante fuertes y duras || o sea | de repente no no se me ocurriría contarle a mi hija ese cuento porque | me parece un poco fuerte ¿no? [...] pero también está bueno | porque son parte de la realidad | son parte de la vida [...] uno personalmente en la casa no le contaría ese cuento | pero digo cuando uno viene acá y | leés ese cuento | y vos ves las reacciones | digo ipah! | mirá las reacciones que podrían tener | que nunca te imaginás porque nunca se lo vas a leer | en realidad [25.11.2015]

... sobre el aporte de los mediadores a la comprensión de lo leído:

[...] a veces hay algunas frases que ellos puede que no entiendan por algunas palabras $\|$ y les explicás a esa palabra que de repente que vos sabés que no entienden | y ellos te escuchan | y :: ves las caritas como diciendo iah mirá lo que significaba! ¿no? [25.11.2015]

...sobre la selección de los libros:

yo creo que en realidad eh:: | en realidad me parece que | en general si uno elige | un buen libro | según la edad || yo creo que | si el libro si es lindo | si la historia es buena | a ellos les va a gustar | no creo que haya uno específicamente [25.11.2015]

... sobre cómo organizar el espacio de lectura:

[Acerca de su ubicación al leer.] | yo hice una vez || que los chiquitos | como ellos son bajitos [enf.] | a ellos les gusta que uno se siente | no más alto | sino a la misma altura de ellos | entonces yo...- el día que fui a contar el cuento me senté en una silla chiquita de ellos | y estaba a la altura de ellos | entonces como que ellos se sienten un poquito más cómodos | no leja::nos | y ahí al lado de ellos | como que es más más integrado::r | ellos...- vos te sentás al lado de ellos es como...- | te sienten más cerca [18.06.2015]

...preparar y leer los cuentos:

Cecilia: me gustó porque antes de venir a leerlo acá me dan el libro | y yo lo leo || entonces veo qué tipo de cuento es y veo | cómo lo podés contar | según las pa::rtes que tenga | entonces ahí vas viendo [25.11.205]

Cecilia ha ido descubriendo también junto con los niños el disfrute de las lecturas y de los intercambios que se producen a propósito de estas. Fue así que luego de la lectura de Una cena elegante, y de observar la respuesta entusiasta de los niños, al retirarnos del salón, realizó este comentario:

Cecilia: [Se dirige a mí.] jlindo libro este!

[Saludamos a los niños y a Noelia y nos retiramos del salón.]

Cecilia: [Me reitera.] ilindo libro! ${ }^{60}$

Como ya se ha visto, esta mediadora Cecilia ha ido obteniendo los insumos para concebir su rol y desempeñarlo en la reelaboración personal y grupal de sus vivencias, y en los intercambios suscitados en las reuniones del equipo comunitario:

Sandra: Cecilia ¿cómo valorás el:: trabajo de todo el equipo comunitario de la escuela? || ustedes son unos cuantos

${ }^{60} \rightarrow$ Anexo 3.4.2.2 «Transcripción de la sesión de sesión de lectura de Una cena elegante». 
Cecilia: es un lindo equipo porque digo:: todos colaboran | está el abuelo que creo es el que más lee | el que más está eh:: | es una buena experiencia | todos colaboran en...- | por ejemplo:: || decir | libros para leer | puede ser este || y bueno después lo que aportan las maestras

Sandra: ¿qué te parecen las reuniones?

Cecilia: porque en las reuniones todo el mundo cue::nta cómo les fue qué les pareció si tiene algún libro:: nuevo como una abuela que creo que vino y trajo...- | también y trajo libros | y algunos cuentan algunas experiencias que de repente | tienen en otros lados [25.11.2015]

\section{En resumen:}

En su vida adulta Cecilia reserva la lectura para sus momentos libres. Se reconoce lectora de diversos géneros literarios (novela policial, poesía), pero prefiere los libros de autoayuda.

Sus inicios como lectora se remontan a su infancia en la que se destaca la influencia de su hogar y particularmente de su madre. En su adolescencia menciona el abandono de la lectura recreativa, en detrimento de la que el estudio le obligaba a realizar, pero en su vida adulta ha sabido retomarla, replicando las prácticas vivenciadas en su infancia, en su hogar, con su hija.

La participación de esta mediadora en el equipo comunitario de lectura de la escuela XX obedece a múltiples y variados motivos: destacar su presencia en la escuela de su hija, contribuir con el éxito escolar de esta, pero también de los demás niños, y acercar el hogar a la escuela. También están presentes el interés de contribuir con la comprensión lectora de los niños, el deseo de inculcar, con sus lecturas, enseñanzas morales, y la intención de revivir junto con los niños las experiencias gratificantes de su niñez lectora.

Si bien la experiencia como mediadora de Cecilia es restringida, ha logrado observar cómo incide su modalidad lectora en la recepción de la lectura en los diferentes grupos en los que ha leído; sintetizar algunos conocimientos sobre cómo desarrollar su tarea, y reconocer algunos aportes de la lectura literaria a la construcción de la subjetividad y a la comprensión de lo leído. El ejercicio de su rol la ha sorprendido además disfrutando de la lectura compartida y del intercambio con los niños durante las sesiones de lectura.

Su crecimiento como mediadora se refleja tanto en la síntesis que ha logrado realizar de su rol y en su activa participación en las reuniones del equipo comunitario, en las que compartió sus consejos y saberes con sus compañeros.

\section{B. Hacer de Cecilia}

Las lecturas de Cecilia, que se tomaron como base para el análisis de este y los dos apartados que siguen: «Intervenciones e intercambios entre los participantes» y «Respuestas de los niños», fueron:

\begin{tabular}{|l|c|}
\hline $\begin{array}{l}\text { Un puñado de semillas, de Mónica Hughes con ilustraciones de Luis } \\
\text { Garay (Ekaré) }\end{array}$ & 30.07 .2015 \\
\hline Una cena elegante, de Keiko Kasza (Norma) & 12.08 .2015 \\
\hline
\end{tabular}

\section{Modalidad lectora}

En ambas sesiones, la mediadora leyó en un volumen de voz moderado, pero que podía ser escuchado por todos, con una correcta fluidez y una dicción sin omisiones, adecuando su voz a la modalidad del 
enunciado, al momento del cuento, y en algunos pasajes de Una cena elegante ${ }^{61}$, a los personajes. Cecilia incorporó estas variaciones tardíamente, al avanzar en su lectura, cuando pareció sentirse más segura, y al percibir que los niños la escuchaban atentos y participaban entusiasmados.

\section{Acciones para organizar el espacio y tiempo de lectura}

Al llegar al salón y luego de saludar, Cecilia se sentaba en una silla pequeña frente al grupo. En la sesión de Un puñado de semillas los niños permanecieron en sus lugares, mientras que en la de Una cena elegante, los niños se sentaron en el piso de espaldas al pizarrón, dispuestos por la maestra, frente a la mediadora.

En ambas sesiones pudo observarse un esquema de desarrollo que se reiteró:

-Antes de la lectura:

Cecilia: ibuen dí::a! \\{(tose) $<15>\}$ bueno hoy ando un poquito como media $\backslash \|$ engripada $\backslash \mid\{$ (risas) hoy estoy un poquito mejor pero \| ahí ahí\} [12.08.2015]

-Presentación del libro:

Cecilia: $y:: \backslash$ | este libro se llama Un puñado de semillas

Niña: $\{i a h: ! ! ~[s o r p r e s a]\}$

Cecilia: un libro muy lindo / | que les va a dejar algo / || algo:: \| para pensar / | y después se van a dar cuenta qué es [30.07.2015]

-Inicio de la lectura:

Cecilia: [...] Una cena elegante $\backslash<10$ > dice así \| la madriguera de Tejón / estaba llena de comi::da / | pero él no estaba contento [12.08.2015]

-Lectura y muestra de las imágenes del cuento. Luego de leer cada página, la mediadora se detenía a mostrar las imágenes por unos segundos, acompañando esta acción con algún comentario sobre las escenas representadas.

-Finalización de la lectura:

Cecilia: bueno $\backslash \mid$ colorín colorado $\backslash$ este cuento $/=\ldots . .=$

Niño: $=\ldots . . .=$ jeste cuento se ha acabado! \

Niños: \{aplausos\} [30.07.2015]

En ninguna de las instancias promovió la conversación sobre lo leído, coincidiendo el final de las sesiones con el de la lectura.

\footnotetext{
${ }^{61}$ En el diario de trabajo de campo queda registrado este episodio que también se percibe en los audios de la sesión.
} 


\section{Gestión de la construcción del metatexto}

En el siguiente cuadro se detalla la finalidad de las acciones que Cecilia desplegó en sus sesiones:

\begin{tabular}{|l|c|c|c|}
\hline \multicolumn{1}{|c|}{$\begin{array}{c}\text { Finalidad de las acciones de la } \\
\text { mediadora }\end{array}$} & Un puñado de semillas & Una cena elegante & Totales \\
\hline $\begin{array}{l}\text { Delimitar momentos en la sesión } \\
\text { de lectura }\end{array}$ & 3 & 3 & 6 \\
\hline $\begin{array}{l}\text { Evidenciar la identidad de la } \\
\text { mediadora }\end{array}$ & 0 & 1 & 1 \\
\hline Generar expectativas & 1 & 8 & 2 \\
\hline Avalar las expresiones de los niños & 1 & 1 & 9 \\
\hline Dirigir la atención hacia un detalle & 17 & 21 & 38 \\
\hline Expandir la información del texto & 0 & 1 & 58 \\
\hline Conseguir el feedback de los niños & 22 & 36 & 1 \\
\hline Totales & & & \\
\hline
\end{tabular}

En la construcción del metatexto, esta mediadora se caracterizó por sus acciones de expansión. Con una menor presencia, también desplegó acciones para delimitar momentos en la sesión, generar expectativas sobre la lectura, evidenciar su identidad, dirigir la atención de los niños hacia un detalle, avalar los dichos de estos o conseguir su aprobación.

Las acciones para expandir información se observaron en el momento de presentar los cuentos a leer:

[...] sus libros infantiles / han cautivado al público infantil / | en toda Latinoamérica \| y se destacan \ || especialmente por presentar a un mismo tiempo / historias divertidas / | y aleccionadoras $\backslash$ | y por tener textos sencillos / e ilustraciones mu::y expresivas $\backslash$ | aleccionadoras quiere decir que $\backslash$ | tienen lecciones $\backslash$ | ustedes leen el libro / | y tienen algo que después \| uno se pone a pensar / || que un significado tiene ese libro \| que algo rescatamos de ese libro \[12.08.2015]

... inmediatamente después de la lectura de cada página, acompañando la acción de mostrar las imágenes:

Concepción se escondió en el medio de la basura \|| [enf.] ¿para qué me vine a esta ciudad? | se preguntaba \ cuando todo pasó se asomó poquito a poco $\backslash$ | como un ratón asustado \| los niños estaban llenos de moretones $\backslash$ | y el huerto estaba todo pisotea::do \

Niño: iuh!:: \

Cecilia: \{todo lo que ya ella había hecho / || quedó en la nada \(muestra las ilustraciones $<8>$ )\} [30.07.2015]

... o en los intercambios durante la lectura:

Niño: ese no es un topo \}

Niño: andan por ahí ¿ंverdad?

Cecilia: los topos no son muy grandes \ 
Algunas de ellas se originaron a demandas de los niños:

Niña: ¿ese es el topo?

Cecilia: es el topo que se fue $\backslash[12.08 .2015]$

A pesar de que esta mediadora no promovió la conversación sobre lo leído, también ordenó su sesión con acciones específicas que delimitaron claramente cada momento ( $\rightarrow$ «Acciones para organizar el espacio y tiempo de lectura»).

Las acciones para generar expectativas, como la de este ejemplo, fueron acotadas en ambas sesiones:

Cecilia: $y:: \backslash \mid$ este libro se llama Un puñado de semillas \

Niño: iah::! \[sorpresa]

Cecilia: un libro muy lindo / | que les va a dejar algo / || algo:: \| para pensar / | y después se van a dar cuenta qué es \[30.07.2015]

Las de aval, como el que se lee a continuación, también estuvieron presentes tanto en la lectura de Un puñado de semillas como de Una cena elegante:

Cecilia: y ellos se comieron la comida \| del tejón \

Niño: ellos tienen $\backslash \mid$ comida $\backslash$

Cecilia: claro \[12.08.2015]

Mientras que las acciones que dejaron en evidencia la identidad de la mediadora:

Cecilia: ibuen dí::a! \\{(tose) $<15>\}$ bueno hoy ando un poquito como media $\backslash \|$ engripada $\backslash \mid\{$ (risas) hoy estoy un poquito mejor pero \| ahí ahí\} [12.08.2015]

... de dirigir la atención hacia un detalle:

Cecilia: \{y acá están todos los animales / | ¿dónde están? ¿a ver? | (muestra las ilustraciones <10>)\} [30.07.2015]

... y conseguir la aprobación de los niños:

Cecilia: ¿sí? || bueno y colorín colorado este cuento se ha terminado

Niños a coro: $\{$ aplausos\}

Cecilia: ¿les gustó?

Niños a coro: isí! [12.08.2015]

... aparecieron únicamente en su segunda sesión.

Entre una sesión y otra, se observó un incremento considerable en las acciones desplegadas por esta mediadora, no solo en cantidad, sino también en variedad. Al respecto, en su segunda lectura, Cecilia incorporó tres nuevas acciones, mantuvo las desplegadas en la primera e incrementó las de aval y las de expansión. En este hecho puede haber incidido tanto la seguridad que fue adquiriendo al leer, que la animó a innovar frente a los niños, el clima generado por el tono humorístico del cuento y el contexto de lectura. 
Debe hacerse mención al siguiente episodio ocurrido al inicio de la sesión de Un puñado de semillas, que pudo haber inhibido la acción de la mediadora y las respuestas de los niños ${ }^{62}$.

Cecilia: $y:: \backslash \mid$ este libro se llama Un puñado de semillas |

Niño: $\{i a h:: !$ [sorpresa]\}

Cecilia: un libro muy lindo / | que les va a dejar algo / || algo:: \| para pensar / | y después se van a dar cuenta qué es \}

Niño: (levanta la mano)

Cecilia: sí \(le da la palabra)

Niño: es $\backslash \mid$ es un capo ese libro $\backslash=\ldots . . .=$

Noelia: ¡XXX! \| iacaba::mos de hablar / | de hab...- \| respecto a esto $\backslash$ | y además te nombré! \| el momento de $\backslash \mid$ de::....- ¿no? || el momento del cuento es para escuchar $\backslash$

Niña: [pp.] hay que escuchar $\backslash$ [Hablándole al niño.]

Noelia: si ya lo leí \| si ya me lo leyeron \ || aprove::cho y lo vuelvo a retomar / | [enf.] si no lo leyeron $=\ldots . .=$

Niño: $=\ldots . . .=($ Intenta hablar.) $\{$ hace diversos gestos con su mano y rostro [está molesto]

Noelia: ¡XXX! \| si no lo leyeron $/||$ escuche $=\ldots . . .=$

Niña: $=\ldots . . .=$ que me lo cuente $\backslash$

Noelia: ¡XXX! \| [pp.] escuche \

Niño: yo (???) (intenta hablar)

Noelia: respet...- \iXXX! \escuche \gracias $\backslash \mid$ gracias $\backslash[30.07 .2015]$

\section{En resumen:}

En ambas lecturas, Cecilia realizó una lectura expresiva, en un volumen de voz que podía ser escuchado por todos. Delimitó el inicio y final de la sesión, pero no habilitó la conversación sobre lo leído. Entre una sesión y otra, se observó un incremento considerable en las acciones desplegadas por la mediadora, no solo en cantidad sino también en variedad.

\section{Intervenciones e intercambios entre los participantes}

Cabe recordar que el análisis en este apartado y el siguiente: «Respuestas de los niños en las sesiones de lectura de Cecilia» se realizó en base a las lecturas ya señaladas ( $\rightarrow$ «Hacer de Cecilia»). El siguiente cuadro cuantifica el análisis de este ámbito.

\begin{tabular}{|l|c|c|}
\hline & Un puñado de semillas & Una cena elegante \\
\hline Intervenciones de los niños & 16 & 81 \\
\hline Intercambios entre los niños & 10 & 14 \\
\hline Intervenciones de la mediadora & 20 & 61 \\
\hline
\end{tabular}

Al igual que con las acciones de esta mediadora, se presentó una clara diferencia entre la cantidad de intervenciones e intercambios registrados en la sesión de Un puñado de semillas y los de Una cena elegante pese a que la primera constituyó una instancia de relectura para los niños.

\footnotetext{
${ }^{62}$ Las palabras de la maestra pudieron haber incidido en la opinión de Abril, quien en la encuesta destacó que en las sesiones de Cecilia «Todos nos podemos quedar callados» ( $\rightarrow$ anexo 3.4.3. «Encuesta a los niños de tercer año B»).
} 
En la primera sesión se registraron, puntualmente, algunas intervenciones espontáneas, acotadas a uno o dos niños, como la siguiente:

Cecilia: $\{$ miren cómo creció todo $\backslash$ (muestra las imágenes $<10>$ )\}

Niño: jah!\

Niño: iesa planta es gigante! \[30.07.2015]

... un momento de intercambio colaborativo:

Cecilia: \{acá tienen la cas::ita / | y acá el lugar donde sembraban \\{muestra las imágenes <10>\}

Niña: iah::! / | iqué bueno! \

Niño: mejor que mi casa \}

Niño: isí! \| la casita \[30.07.2015]

...y una pregunta de un niño, que la mediadora no dejó sin respuesta:

Cecilia: $\{$ ¿ven? acá están ellos ayudando $\backslash$ (muestra las imágenes $<10>$ )\}

Niño: ¿y escaparon de la policía?

Cecilia: sí \[30.07.2015]

Tanto en una sesión como en la otra, las lecturas de Cecilia fueron seguidas con atención por los niños. La mediadora, luego de presentar los datos del cuento, autores e ilustradores se enfocó en la oralización del texto y en mostrar las imágenes, momento que acompañó con algún comentario sobre ellas $(\rightarrow$ «Gestión de la construcción del metatexto»):

En la sesión de Una cena elegante pudieron observarse episodios altamente participativos, uno de ellos con hasta diez intervenciones de los niños:

Cecilia: pero esta se zarandeaba demasiado $\backslash||$ y sacu::de $\backslash$ | que sacudió de las manos de Tejón \\| luego se escabulló lo más / rápido que pudo \\{muestra las ilustraciones $<10>$ \}

Niño: ila agarró:: ah::! \

Niña: las ratas corren mu::y rápido \}

Niña: son rápidas $\backslash$

Niño: el topo entró en la madriguera de...- \en la madriguera del...- \en la madriguera del $\backslash=\ldots . . .=$

Niño: $=\ldots . . .=$ del tejón \}

Niña: eso parece...- \parece un \((???))

Cecilia: ¿̇acá? \{señala la imagen\}

Niña: sí \

Cecilia: ¿qué hay acá? ((???))

Niña: ¿ese es el topo?

Cecilia: es el topo que se fue $\backslash$

Niña: el topo se escondió en la madriguera \

Niña: y:: y encontró la madriguera del tejón \}

Cecilia: ahí está \

También se suscitaron intervenciones espontáneas de algunos niños, a modo de exteriorización de la comprensión que iban construyendo mientras se compenetraban con el cuento:

Cecilia: \{acá está \el caballo era mucho más grande que él \(muestra las imágenes $<10>$ )\}

Niño: iqué lindo! \ 
Niño: y después el caballo va a la madriguera \

... e intercambios colaborativos que tuvieron una impronta expansiva, en la que los dichos de un niño eran complementados por los de otros:

Cecilia: se lanzó a agarrar el topo $\backslash$ | pero este $\backslash$ | era demasiado escurridizo $\backslash$ | y resbala::ba que se resbaló de las mano de Tejón \\| luego se escabulló lo más rápido que pudo \\{muestra las ilustraciones $<10>\}$

Niño: $\mathrm{m}:: \backslash$ casi lo atrapa \}

Cecilia: casi casi \

Niña: al lado de...- del \| ¿cómo se llamaba ese animal?

Niño: el tejón \

Niño: el tejón e:: \| es grande al lado del topo \

Cecilia: sí cla::ro\}

Niño: son chiquitos más o menos así \{representa con las manos el tamaño del tejón\} [12.08.2015]

En esta sesión de lectura los niños formularon cinco preguntas a Cecilia, como la que se lee a continuación, en busca de que esta les explicara algún aspecto, confuso para ellos, de la narración verbal o en imágenes; la mediadora siempre accedió a responderles:

Niño: ¿estaban afuera?

Niña: iqué pequeñita!\

Cecilia: estaba afuera de la madriguera \

Cecilia: jeso sí que sería una comida elegante!\

Niños a coro: juh::!!

Niña: iconeji::to! \

Niño: ya lo vio \[12.08.2015]

En resumen:

Al no promover esta mediadora la conversación sobre lo leído, la participación se concentró durante la lectura. Se observó una clara diferencia entre la cantidad de intervenciones e intercambios registrados en la sesión de Un puñado de semillas y los de Una cena elegante: mientras que en la primera sesión se observaron algunas pocas intervenciones, en la segunda se registraron momentos muy participativos. A pesar de ello, en ambas instancias se produjeron intervenciones espontáneas de algunos niños, que exteriorizaban de esta manera su comprensión sobre lo leído, e intercambios colaborativos en los cuales los dichos de un niño eran complementados por otros. En la segunda sesión, algunos niños además se animaron a hacer preguntas a la mediadora para que esta les explicara algún aspecto no comprendido de la historia narrada.

\subsubsection{Respuestas de los niños}

\section{Respuestas de los niños en las sesiones de lectura de Cecilia}

El cuadro que se encuentra a continuación sintetiza las respuestas de los niños en las sesiones de Cecilia, que se produjeron únicamente durante la lectura, al no promover esta mediadora la conversación posterior: 


\begin{tabular}{|l|c|c|}
\hline & Un puñado de semillas & $\begin{array}{c}\text { La manta de las } \\
\text { historias }\end{array}$ \\
\cline { 2 - 4 } & Durante la lectura & Durante la lectura \\
\hline $\begin{array}{l}\text { Expresiones de } \\
\text { entusiasmo }\end{array}$ & 8 & 16 \\
\hline $\begin{array}{l}\text { Referencias literales al } \\
\text { texto o a las imágenes }\end{array}$ & 4 & 49 \\
\hline $\begin{array}{l}\text { Referencias } \\
\text { inferenciales al texto o } \\
\text { a las imágenes }\end{array}$ & 1 & 8 \\
\hline $\begin{array}{l}\text { Referencias } \\
\text { intertextuales e } \\
\text { interculturales }\end{array}$ & 0 & 5 \\
\hline Referencias personales & 17 & 2 \\
\hline Referencias vivenciales & 3 & 0 \\
\hline \begin{tabular}{l} 
Total \\
\hline
\end{tabular} & 1 & \\
\hline
\end{tabular}

En ambas instancias se observaron manifestaciones de entusiasmo como las siguientes, y muchas de ellas fueron colectivas:

Cecilia: y:: \| este libro se llama Un puñado de semillas \

Niño: jah::! [sorpresa] [30.07.2015]

Cecilia: iahora largo \| y deja de molestarme! \| y con eso \| el caballo lo mandó a::Ito [enf.] por el aire de una sola patada $\backslash \mid\{$ muestra las ilustraciones $<10>\}$

Niños a coro: $\{$ risas\} [12.08.2015]

También en ambas sesiones estuvieron presentes las respuestas referenciales; en Una cena elegante estas fueron las de mayor frecuencia y constituyeron el $61 \%$ del total de las respuestas:

Cecilia: todos los días regaba la tierra / y miraba atentamente / hasta que vio brotar los pri...- / los primeros reto::ños verdes y brillantes | \los frijoles y el ají florecieron \| y en to::do el barrio / no había na::da más bonito que el pequeño huerto de Concepción \|| y ella estaba / | segura de que desde el cielo / su abuela cuidaba del huerto $\backslash \|$ \{miren cómo creció todo \(muestra las ilustraciones) $<10>\}$

$[\ldots]$

Niño: [enf.] esa planta es gigante $\backslash[30.07 .2015]$

Cecilia: jeso sí que sería una comida elegante! \

$[\ldots]$

Niña: iconeji::to! \

Niño: ya lo vio \[12.08.2015]

En Un puñado de semillas se registró una única respuesta inferencial cuando un niño solicitó confirmar a la mediadora su hipótesis sobre lo ocurrido en la historia: 
Cecilia: m:: \| ¿por qué llo::ras? | preguntó Tomás enfadado \| no fue a ti a quién que golpeó la policía \| mi huerto está destrozado \| si el maíz los frijoles y el ají hubieran madurado / | habríamos tenido comida para vender / | y ustedes no tendrían que robar $\backslash \|$ de nada sirve llorar $\backslash$ | tu huerto se acabó \|| Concepción se secó los ojos \| ino! \| ino se acabó! \| dijo \| todavía me quedan algunas semillas \| está bien / dijo Tomás / | pasándose la lengua por el labio roto \| esta vez te ayudaremos nosotros $\backslash \|$ \{ंven? acá están ellos ayudando $\backslash$ (muestra las ilustraciones $<10>$ )\}

Niño: ¿y escaparon de la policía? [30.07.2015]

... y en Una cena elegante se contabilizaron ocho respuestas de este tipo, como las que se leen a continuación:

Cecilia: se lanzó / a agarrar el conejo $\backslash$ | pero este / | era demasiado veloz $\backslash$ | y brinca que brincó / de las manos de tejón \|| luego se fue salta::ndo lo más / rápido que pudo \| \{iy saltó el conejo! (muestra las ilustraciones $<10>)\}$

$[\ldots]$

Niño: el conejo no escuchó \}

$[\ldots]$

Niño: y después van todos a la madriguera \| [enf.] los encierra en la madriguera y se los come a todos $\backslash[12.08 .2015]$

En ambas sesiones también se produjeron respuestas personales ( 3 y 1 en cada sesión) en las que los niños expresaron sus opiniones sobre algún pasaje del cuento o sobre la obra en sí:

Cecilia: \{todo lo que ya ella había hecho / II quedó en la nada \(muestra las ilustraciones $<10>$ )\}

Niña: iqué feo! \[30.07.2015]

Cecilia: \{acá está \el caballo era mucho más grande que él \(muestra las ilustraciones $<10>$ )\}

Niño: iqué lindo! \[12.08.2015]

En la sesión de Un puñado de semillas se observó una única respuesta vivencial, seguramente motivada por la temática del cuento:

Cecilia: bueno empieza así \| Concepción vivía con su abuela \en una casita en la cima del cerro \| juntas limpiaron el terreno para hacer un huer...- un huerto \/ sembraron maíz / frijoles / y ají \|| recuerda guardar suficientes semillas para la próxima siembra dijo la abuela \| así nu::nca te faltará de comer \|| \{acá tienen la cas::ita / | y acá el lugar donde sembraban (muestra las ilustraciones <10>)\} Niña: ah:: / | iqué bueno! \

Niño: mejor que mi casa \[30.07.2015]

En Una cena elegante se registraron tres respuestas intertextuales; las dos primeras cuando dos niñas verbalizaron la conexión que establecieron entre el texto y sus conocimientos del mundo para comprender lo leído:

Cecilia: pero esta se zarandeaba demasiado \\| y sacu::de \| que sacudió de las manos de Tejón \\| luego se escabulló lo más / rápido que pudo \\{muestra las ilustraciones $<10>$ \}

Niño: ila agarró:: ah::!!

Niña: las ratas corren mu::y rápido \}

Niña: son rápidas \[12.08.2015]

... y la tercera, cuando un niño, quien sabe un poco más que los otros sobre el tejón (animal que no pertenece a la fauna americana), aportó sus conocimientos para resolver un vacío de información, 
contribuyendo a que sus compañeros, a quienes las ilustraciones del cuento ${ }^{63}$ les generaron más dudas que certezas, construyeran comprensión sobre lo leído.

Cecilia: se lanzó a agarrar el topo $\backslash$ | pero este $\backslash$ || era demasiado escurridizo $\backslash$ | y resbala::ba que se resbaló de las manos de Tejón \|| luego se escabulló lo más rápido que pudo \

$[\ldots]$

Niña: al lado de...- del \| ¿cómo se llamaba ese animal?

Niño: el tejón \

Niño: el tejón e:: \| es \grande al lado del topo \

Cecilia: sí cla::ro\}

Niño: son chiquitos más o menos así \{representa con las manos el tamaño del tejón\} [12.08.2015]

Por último, en la sesión de Una cena elegante se observó una única respuesta intercultural cuando una niña vinculó un personaje del cuento con un conocido personaje de la cultura popular:

Cecilia: \{[enf.] Tejón voló y voló y voló un poco más (muestra las ilustraciones <15>)\}

$[\ldots]$

Niña: era Superman \[12.08.2015]

En estos cuatro últimos ejemplos es interesante observar cómo los comentarios vivenciales e interculturales se generaron en instancias participativas y colaborativas ya analizadas en el apartado «Intervenciones e intercambios entre los participantes».

Es necesario además detenerse en estos pasajes de Una cena elegante para observar el crecimiento de las respuestas de los niños desde lo referencial hacia lo inferencial o personal:

Cecilia: $\{$ el conejo encontró un lugar para esconderse $\backslash$ (continúa mostrando las ilustraciones $<10>$ )\}

Niño: ijusto a la madriguera! \

Niño: ino lo alcanzó! \

Niño: el conejo lo escuchó porque no lo agarró la \(???)

Cecilia: en su lugar \lo único que encontró \fue una nota que decía...- \| \{lo ven que está sentado en su madriguera $\backslash$ | encontró la carta $\backslash \mid$ y nada de comida $\backslash$ | (continúa mostrando las ilustraciones $<10>$ )\} y la carta decía \|| apreciado quienquie::ra que viva aquí \| lamentamos haber entrado sin invitación $\backslash||$ [enf.] pero nos perseguía un tejón espanto::so \| y no teníamos dónde escondernos $\backslash$ | las manza::nas \las lombri::ces y raíces estaban deliciosas $\backslash$ | gracias / por una cena ta:n / elegante \ \{muestra las ilustraciones $<10>$ \}

Niño: una manzana igual \

Niño: $\{$ risas\}

Niño: iah::! \| ise escondieron en la...- en la casa del...-\| del tejón! \

Niña: isí! \

Niño: ipobre Tejón! \[12.08.2015]

\footnotetext{
${ }^{63}$ En referencia a la ilustración donde se observan el topo y el tejón, el tamaño de los animales no es proporcional a su tamaño real.
} 


\section{En resumen:}

Tanto en una como en otra lectura se observaron manifestaciones de entusiasmo, respuestas referenciales, inferenciales y personales. En Un puñado de semillas, además, se produjeron tres respuestas intertextuales y una intercultural.

\section{E. Recuerdos de los niños sobre Una cena elegante}

Para este análisis se tomaron en cuenta los recuerdos de los niños sobre esta lectura, realizada el 12 de agosto, recuperados en la entrevista del 16 de setiembre.

\begin{tabular}{|l|c|}
\hline Aspectos recordados & Cant. \\
\hline Título & 0 \\
\hline Argumento & 3 \\
\hline Marco & 2 \\
\hline Acción narrativa & 1 \\
\hline No recuerdan & 3 \\
\hline
\end{tabular}

Ninguno de los niños entrevistados recordó en forma voluntaria el título de este cuento, a pesar de que Facundo lo había mencionado en la encuesta, unos días antes de la entrevista. Él, Emiliano y Marylin pudieron recordar aspectos relativos al argumento del cuento:

Marylin: el de la cena [...] porque él quería comerlos | comerlos a ellos

Facundo: | y que le quitaban la cena creo || que había un...- [...] era gracioso

Emiliano: era de una cena y de animales

Facundo y Emiliano, por su parte, recordaron algunos de los personajes:

Facundo: [...] que era de un ratón el personaje | o algo así

Emiliano: que era de un zorro y todo eso

... mientras que Marylin fue la única que pudo recordar algún detalle sobre la acción narrativa del cuento:

Marylin: cuando lo::s eh:: | cuando los animales fueron | a la madriguera y se escondieron porque se estaban escondiendo | y aparte m::: | le:: comieron la comida

Finalmente, tres niños: Agustín, Milena y Abril no pudieron recordar ningún aspecto del cuento, a pesar de haber estado presentes el día de su lectura.

En resumen:

En cuanto a los recuerdos del cuento leído ad hoc, tres niños se refirieron a aspectos relativos al argumento del cuento, dos pudieron recordar algunos de los personajes y una niña mencionó un detalle sobre la acción narrativa. Otros tres niños, por último, no pudieron recordar ningún aspecto del cuento. 


\section{F. Valoraciones de los niños sobre Cecilia}

Como puede apreciarse en este cuadro, la mayoría de los niños valoraron su experiencia de lectura con esta mediadora:

\begin{tabular}{|l|c|}
\hline Opiniones & Cant. opiniones \\
\hline Centrada en el vínculo familiar en general & 8 \\
\hline Centradas en la persona de la mediadora & 16 \\
\hline Centradas en la lectura de la mediadora & 19 \\
\hline $\begin{array}{l}\text { Centradas en la experiencia de lectura con la } \\
\text { mediadora }\end{array}$ & 2 \\
\hline Centradas en el vínculo niño-libro & 0 \\
\hline Centradas en el libro y la lectura en general & 46 \\
\hline Total de opiniones relevadas & 16 \\
\hline
\end{tabular}

$\left(^{*}\right)$ Dentro de estas respuestas se constataron 7 que valoraron la modalidad de lectura de la mediadora y 9 , los libros que lee.

Dentro de este grupo de opiniones, pudieron apreciarse algunas como esta:

"Porque me divierto mucho» [Emiliano]

«Porque aprendo animales nuevos» [Ignacio]

Solo un niño no consideró en forma positiva su experiencia de lectura con esta mamá; al respecto Agustín manifestó que le gustaba «Más o menos» que viniera a leer a la clase, justificando: "algunas veces me aburro».

En segundo lugar, los niños valoraron la modalidad de lectura y los libros que leyó Cecilia:

«Lee lindo. Lee para todos» [Alexander]

«Trae lindos cuentos» [Marylin]

«Lee sin vergüenza» [Facundo B.]

Otro conjunto de niños de tercer año B valoraron en forma genérica la presencia de las madres o las familias en la escuela, que expresaron en opiniones como las siguientes:

«Es muy lindo ver a los familiares en la escuela» [Tatiana]

Entre las opiniones que hicieron foco en la mediadora; solo una valoró su persona:

«Es buena...» [Yasmín]

Y marginalmente, se registraron respuestas que destacaron generalidades del vínculo niño-libro como esta:

«Me gustan los cuentos» [lan] [02.09.2015] 
A pesar de la escasa actuación de esta mediadora en tercero B de la escuela XX, 10 niños recordaron voluntariamente los títulos leídos por ella durante 2015: Así reinaba el rey Reinante, Un puñado de semillas y Una cena elegante.

En resumen:

Los niños de tercer año B parecieron valorar en mayor medida su experiencia de lectura con la mediadora, de la que destacaron el disfrute, la risa, la diversión (Emiliano, Luca, Sofía y Matías) el aprendizaje y la enseñanza (Tahís, Mathías e Ignacio).

\subsubsection{Conclusiones preliminares sobre el segundo caso}

Cecilia se acercó al equipo comunitario de lectura de la escuela XX principalmente para acompañar a su hija en su transcurso por la escuela. Estuvo también presente en ella el deseo de contribuir con los aprendizajes escolares de los niños, transmitir enseñanzas morales y establecer un puente entre el hogar y la escuela.

El episodio ocurrido al comienzo de la sesión de Un puñado de semillas ( $\rightarrow$ «Gestión de la construcción del metatexto») constituyó un obstáculo para los inicios de Cecilia como mediadora, que los niños pudieron percibir y al que no permanecieron indiferentes. A propósito de ello, fue muy sugestivo el episodio registrado en el diario de trabajo de campo el 30 de junio $(\rightarrow$ anexo 5. «Diario de trabajo de campo. Jueves 30 de julio») en el que un niño, al finalizar una muy tensionada sesión de lectura, se acercó a la mediadora y le dijo: "Leés muy lindo». Pese a este contratiempo, en la segunda sesión observada, la mediadora, los niños y la maestra hicieron posible otro vínculo, logrando el disfrute compartido.

Como ya se mencionó, la actuación de Cecilia en tercero B fue acotada. Por esto y porque no fue la única mamá en el equipo comunitario con quien los niños tuvieron contacto, algunos de ellos la confundieron o no pudieron retener su nombre:

Sandra: y después pusiste que el cuento que más te gustó fue Un puñado de semillas

Milena: isí!

Sandra: ¿y quién leyó ese cuento?

Milena: e:: la mamá de Sofía [16.09.2015]

Por el motivo expuesto, muchas de las valoraciones de los niños recogidas en la encuesta fueron impersonales (10 en total, contando las centradas en el vínculo familiar en general y en el vínculo del niño con el libro) y solo una respuesta valoró en forma singular la persona de la mediadora.

A pesar de la escasa experiencia en su rol, Cecilia pudo ir descubriendo junto con los niños cuán gratificante es la lectura compartida, cómo hacer para llegar a ellos y cuánto pueden aprender en esas instancias. Al respecto, ella misma también se vio sorprendida al encontrar en los cuentos que leyó interpretaciones que no había previsto inicialmente, como pudo apreciarse en su comentario al finalizar la sesión de Una cena elegante. Su experiencia le permitió también tomar algunas decisiones sobre su hacer: cómo y por qué sentarse en una silla pequeña, frente a los niños, para llegarles mejor con su lectura y representar con su voz a los personajes del cuento en algunos tramos de la lectura.

Puede afirmarse que el hacer de Cecilia, en el que predominaron las acciones de expansión, fue funcional a su propósito de contribuir con los aprendizajes de los niños y con su comprensión sobre lo leído. 
La diferencia cuantitativa y cualitativa de las acciones desplegadas y de las respuestas de los niños entre la primera y la segunda sesión observada da cabida a diversas interpretaciones. En primer lugar, la sanción de la maestra a los comentarios del niño a la que ya se hizo referencia más arriba puede explicar la inhibición de las respuestas en Un puñado de semillas. En segundo lugar, el contexto de lectura y las características del libro leído pudieron haber contribuido también a que los comentarios de los niños se produjeran en mayor medida durante la lectura de Una cena elegante ${ }^{64}$. Por último, en parte, como consecuencia de los dos factores mencionados y en parte como producto de un vínculo de confianza que se fue acrecentando, pudo constatarse una dialéctica en los intercambios entre los sujetos participantes de la mediación por la cual habilitaban y retroalimentaban mutuamente su participación; es decir: en la medida que la mediadora expandía la información sobre el texto y avalaba los comentarios de los niños, estos intercambiaban y hasta se animaban a realizar preguntas. El corolario de esta dinámica fue la construcción dialógica de la comprensión de la que dan cuenta las respuestas de los niños y de la que la mediadora también se vio beneficiada. En esta dirección abonan también las respuestas a la encuesta, ya que diez niños pudieron evocar en dicha instancia alguno de los tres títulos leídos por la mediadora en su pasaje por tercer año B. Al respecto, fue interesante encontrar en estas respuestas las de algunos niños quienes pudieron reconocer que aprendieron junto con la mediadora y así lo verbalizaron:

«Porque aprendo animales nuevos» [Ignacio]

Además, tres de los seis niños entrevistados recuperaron algún aspecto de Una cena elegante, un mes después de que Cecilia finalizara su actuación en este grupo.

Por último, las expresiones de entusiasmo que se produjeron en ambas sesiones de lectura y las respuestas que valoraron positivamente, en la encuesta, la experiencia de lectura con esta mediadora, muestran cómo disfrutaron los niños de sus lecturas.

\subsection{Tercer caso. Escuela XXX, tercer año A, Rosario}

\subsubsection{Estilo de la mediadora}

\section{A. Ser de Rosario}

\section{La mediadora en persona}

Rosario tiene 34 años, trabaja en forma rotativa en el rubro de servicios (algunos días incluso de noche), y es madre de un alumno de quinto año de la escuela XXX.

Esta mediadora participó en el equipo comunitario desde abril hasta noviembre de 2015, y concurrió a leer desde primero a cuarto año. En su entrevista ( $\rightarrow$ anexo 4.4.1.1. «Entrevista a Rosario») manifestó que en donde se sintió más cómoda fue en tercer año, pues en este nivel tuvo mayor continuidad y realizó más cantidad de lecturas.

\footnotetext{
${ }^{64} \mathrm{Al}$ respecto, Una cena elegante puede categorizarse como un libro-álbum en el cual el texto y las ilustraciones se encuentran en una relación de complementariedad. Las palabras expanden el significado de las imágenes y viceversa, produciéndose un efecto de realce entre ambos (Nikolajeva y Scott 2001 en Silva Díaz 2005: 41).
} 


\section{Preferencias y prácticas lectoras}

Rosario expresó que se ha convertido en lectora, y ha desarrollado el gusto por la lectura en su vida adulta, aunque no logró identificar autores y libros favoritos:

Sandra: te iba a preguntar cuáles son tus lecturas favoritas | ¿algún género que vos digas bueno | me gustan los cuentos de tal cosa o los cuentos de tal otra?

Rosarios: todos todos | me parece que todos los libros tienen sus...- | sus secretito su magia [05.11.2015]

Tampoco logró identificar los libros que leyó en algunos grupos por sus títulos, aunque reconoció entre estos a su preferido:

Sandra: de todos los libros que leíste | ¿hay alguno que te haya gustado más?

Rosario: sí La luz mala | no...-

Rosario: no no recuerdo ahora cuál era || pero sí fue...- | aparte hablaba de animales que no...- | no tan conocidos como perro o gato | eran otro animales pero no recuerdo ahora el nombre [05.11.2017]

[En referencia a Un puñado de semillas.] Después leí otro de una nena, que tenía un mensaje, pero no me acuerdo el nombre [piensa un momento]. De una nena que creo que había... había fallecido la abuela, y se había ido de donde ella vivía. Se había ido para otro lado, pero no me acuerdo [14.07.2015]

Las prácticas de lectura de Rosario se asimilan a las de los de los poco lectores, descritas por Bahloul (2002), tal como puede deducirse de su dificultad para referirse a sus lecturas favoritas o a los títulos que leyó a los niños. Esta constatación también surge en su mención errónea a la contratapa del libro, en la sesión de La manta de las historias el 11 de agosto:

Rosario: les comparto lo último que dice el libro \

Niño: ¡sí!

Rosario: en la tapa final \[11.08.2015]

\section{Biografía lectora}

La consolidación de los hábitos lectores y el surgimiento del gusto por la lectura en esta mediadora parecen ser muy recientes; al respecto, declaró que durante su etapa escolar no logró desarrollar estos aspectos:

Sandra: [...] ¿ंvos siempre fuiste lecto::ra?

Rosario: no [...]

Rosario: sinceramente no | cuando yo iba a la escue::la al liceo estaba medio | medio peleada con los libros | por decirlo de alguna manera [05.12.2015]

El ingreso y participación de Rosario en el equipo comunitario de la escuela XXX constituyó un mojón, tanto en su historia lectora como en la de su familia. Al respecto, identificó el influjo del tener que practicar las lecturas que realizaría posteriormente en la escuela con sus hijos, en diferentes niveles: en el personal (al mejorar su propia lectura), en el del vínculo familiar (como madre que lee a sus hijos) y en de la formación de sus propios hijos como lectores: 
Rosario: [practicar la lectura] aparte me ayudó a mí para mis hijos | el leerlo con ellos | practicarlo con ellos | me ayudó a mí a leer | ayudó a ellos [...]

Sandra: ¿vos sin ser los libros de acá vos leés otras cosas?

Rosario: sí | mi hija también tiene sus libros | de adolesce::nte | desde que empecé acá me estoy enganchando | veo un libro y ta | me engancho [05.11.2015]

\section{Motivaciones para ejercer el rol de mediadora}

Los motivos por los cuales Rosario participó del equipo comunitario son múltiples y variados. En su entrevista señaló una intención relacionada con un deseo personal de superación, de mejorar su lectura y la de sus hijos, como puede leerse en la cita anterior y en la siguiente:

[...] primero a nosotros como personas nos hace bien | segundo que a ellos les gusta que uno participe | y si es para lectura más me parece | yo participo en todo taller de lectura de lo que sea pero me parece que de lectura está muy bueno | y me parece que hoy en día nos falta leer mucho [05.11.2015]

También destacó el deseo de estar presente como madre en la escuela a la que sus hijos concurren:

[...] porque me parece un proyecto bueno | compartir con los chiquilines | compartir con mi propio hijo | que si bien no siempre va a ser para la clase de él |a él le pone contento que uno participe

En otro orden, esta mediadora adhirió a una intención militante, vinculada con su interés por los temas sociales (fue electa como concejal municipal por sus vecinos) [05.11.2015]

[...] me interesan los temas | sociales || fui postulante a concejal vecinal | salí | y siempre ando metida así en esas cosas [05.11.2015]

En relación con esta motivación, debe mencionarse que Rosario fue quien propuso, junto con otra mamá, Andrea A., en la reunión del equipo comunitario de lectura de su escuela, el 14.07.2015, la realización de una obra de teatro para los festejos del Día del Niño ( $\rightarrow$ «anexo 4.3. «Reunión del equipo comunitario de lectura»).

La gratificación personal, el bienestar que le genera a esta mediadora la entrega desinteresada de su tiempo (que los niños destinatarios de sus lecturas supieron reconocer con aplausos, cuando Rosario entraba al salón o finalizaba sus lecturas), la convicción de que con su hacer realiza un aporte valioso, se constituyeron en otras fuertes motivaciones para ejercer el rol de mediadora:

[...] o te dicen «ahí va la mamá de fulano» || o en la calle | en la almacén (sic) te saludan | la otra vez íbamos con otra mamá de lectura y nos saludaron | y dijimos «ta tiene que ser de la escuela» | \{porque no sabía ni quién era el niño (risas)\}

[...] porque para ellos también debe ser bueno porque saben que uno no trabaja pero saben que uno está brindándoles | un pedacito de nuestro tiempo de nuestra atención | de nuestras ganas de venir a compartir con ellos

[Sobre si aconsejaría a otras personas participar en el equipo comunitario de lectura.] [...] que se den el tiempo de compartir | que vean | sus hijos sus nietos cómo lo disfrutan | y lo bueno que pueden hacer por | por los demás 
[...] me parece que es un aporte | más allá de lo que hacemos de leer estos diez quince minutos | me parece que es un aporte seguir incentivando la lectura | en un mundo tan tecno... [ [...] tan tecnológico | como vivimos | como que se pierde un poco

[...] ya ahora...- | hasta la hora de hacer los deberes ya cambió uno | porque antes uno agarraba un libro | iba al índice y:: | buscaba el tema y ahora uno va y googlea |me parece que:: | está bueno incentivar la lectura | que no se pierda eso | me parece que los libros abren cabezas [05.11.2015]

El disfrute que obtiene de los intercambios con los niños es otro motor para que Rosario vaya a leer cada semana a la escuela con la mayor asiduidad:

Sandra: ¿y vos cómo vivís ese momento? [en referencia a las lecturas con los niños]

Rosario: se disfruta mucho | se disfruta [05.11.2015]

Por último, el sentido de pertenencia a un grupo de amigas (como lo es el equipo comunitario de la escuela XXX) en el vínculo que mantiene con las demás integrantes desde hace ya varios años, y que se manifestó en las continuas bromas que realizó en la reunión del 14 de julio es otro fuerte motivo para el sostenimiento de esta mediadora en su rol.

\section{Apropiación del rol de mediadora}

Rosario ingresó al equipo comunitario en 2015. A pesar de trabajar en muchas ocasiones durante la noche, nunca faltó a las sesiones de lectura previamente coordinadas con las maestras (debe recordarse que la escuela XXX funciona en el turno matutino).

La fuente de insumos de la que esta mediadora se nutrió para ejercer su rol fueron diversas. En primer lugar, ella misma identificó los aportes de sus compañeras de equipo y de las maestras:

Sandra: ¿los títulos generalmente que ustedes leen quién los elige?

Rosario: los elegimos nosotras | o una mamá dice «mirá dijeron que querían algo como de cuento como de la selva como...- | nos vamos diciendo | sino las maestras muchas veces nos aconsejan [05.11.2015]

También destacó la contribución de la jornada de formación de los equipos comunitarios de lectura ${ }^{65}$, que constituyó para Rosario un hito en su proceso de crecimiento como mediadora:

[...] yo pienso que ya cambié cuando hice el encuentro | en:: la otra escuela e::n parque Bellán | ahí yo ya cambié | la forma de leer de pararme ante a los chiquilines | ya me solté un poco más || te enseñan...- | aprendí lo práctico | porque yo iba y les iba leyendo | y les iba mostra::ndo | y no | ahí te enseñan a que tenías que leer prime::ro | después mostrar la imagen para dejar que ellos vayan...|| me ayudó empila | y ahora me siento $=\ldots . . .=[05.11 .2015]$

Este crecimiento de Rosario fue señalado también por la maestra Carmen en su entrevista:

[...] yo pienso que ella [Rosario] fue como aflojándose también entrando en confianza | con los niños | y dándose cuenta de que:: | podía hacerlo bien | pero los primeros tiempos estaba bien rígida | más

\footnotetext{
${ }^{65}$ Las mediadoras de la escuela XXX participaron por primera vez de la jornada de formación para mediadores brindada por ProLEE a fines de julio de 2015.
} 
que nada eso ¿no? || porque:: <5> | era eso por donde venía | ella quedaba paradita así con el libro [13.10.2015]

Otra evidencia de este crecimiento puede encontrarse en la reunión del equipo comunitario de lectura del 14 de julio a la que ya se hizo referencia. A pesar de que la participación de Rosario fue, en esta instancia, acotada, y sus comentarios, mayoritariamente, consistieron en bromas a sus compañeras de equipo, pudo, sin embargo, aconsejar desde su escasa experiencia, a Laura, una de sus compañeras, quien la consultó sobre la pertinencia de El miedo a la luz mala para cuarto año: «¿Para cuarto está bien este? Y Rosario le respondió: «A tercero les encantó ese. Está bueno».

En algunas ocasiones, se animó también a elegir los libros para llevar a los niños:

Rosario: una vez me pasó que fui ahora a primero hace dos martes atrás | y justo estaban hablando en el pizarrón estaba | de animales |separándolos por grupos y justo yo caí con un cuento también de animales y...- | me dice la maestra "así ideal»

Sandra: ¿pero lo habías elegido vos?

Rosario: lo había elegido yo [05.11.2015]

Y en la citada reunión del equipo comunitario, le solicitó a Mariela, la maestra referente, Cuando el temible tigre (Virginia Brown, con ilustraciones de Matías Acosta, Banda Oriental), que llevó para leer en tercer año.

Rosario ha logrado trascender su experiencia concreta como mediadora para reflexionar sobre los aportes desde su rol:

Sandra: vos pensás que:: |¿̇a ellos cómo les beneficia eso | la lectura?| ¿tienen algún aprendizaje? Rosario: sí | creo que sí | que los ayuda | cada día | el mundo que va...- | se va yendo para los costados | está bueno que ellos vayan leyendo | que les guste desde chicos | y a su vez van creciendo | los textos van cambiando | y sí | me parece que fomenta | fomenta mucho

Sandra: bien ¿y:: pensás que al maestro le sirve que venga el equipo? [05.11.2015]

Rosario: sí | sí | porque debe servir también para observar | ver | cómo son con ellos | como son...| lo de ellos debe ser más pedagógico| lo de nosotras debe ser algo más como por el lado | de:: la mamá que vienen a leer | no sé cómo explicarlo [05.11.2015]

... y reconocer constantes en su práctica:

[En referencia a la actitud de los niños.] prestan atención \|muchos se dejan llevar por la imaginación | hay alguno que se distrae pero | de repente vos venís al otro día y está súper atento | me parece que a ellos les ayuda mucho

[...] y nu::nca hubo una clase...- [enf.] | porque por ejemplo | cuando tuvimos el encuentro se hablaba de | de cómo hacer de trucos para lograr la atención | me parece que ningu::na tuvo problemas en ninguna clase | si bien a veces pueden estar más dispersos que otros días nunca tuvimos un problema de atención | o que se tuviera que cortar un li::bro | nada | me parece que eso también viene desde el año pasado | y ellos esperan el martes ansiosos [05.11.2015]

\section{En resumen:}

Del análisis realizado, puede afirmarse que Rosario presenta algunas características de los «poco lectores» descritos por Bahloul (2002): reconoce la debilidad de su trayectoria escolar, le cuesta reconocer y recordar autores y títulos de los libros leídos e identificar sus preferencias de lectura. 
El deseo de ser mejor lectora y hacer mejores lectores a los suyos constituyeron para Rosario importantes motivaciones para ejercer como mediadora, junto con su interés militante de servir a la comunidad, de destacar su presencia como madre en la escuela de sus hijos, la gratificación que le generó la entrega desinteresada de su tiempo y esfuerzo a los niños y el sentido de estar realizando un aporte valioso a la formación de estos. El sentido de pertenencia a un grupo de amigas, como lo es el equipo comunitario de la escuela XXX, el disfrute que le producen los intercambios con los niños durante las sesiones de lectura y la retribución afectiva de estos, también están presentes en las motivaciones de esta mediadora.

El ejercicio de su rol, el intercambio con sus compañeras de equipo y con las maestras, y su participación en la jornada de formación de mediadores a fines de julio de 2015 constituyen las fuentes de las cuales se nutrió Rosario para ejercer su rol.

En el atreverse a seleccionar los libros para leer a los niños, en la síntesis que realiza de sus experiencias en las sesiones de lectura y en el consejo que brinda a su compañera de equipo en la reunión del 14 de julio pueden encontrarse los indicios del crecimiento de esta mediadora como tal.

\section{B. Hacer de Rosario}

Las dos sesiones tomadas para el análisis del hacer de esta mediadora, de las intervenciones e intercambios entre ella y los niños, y las respuestas de estos, comentados en los apartados «Intervenciones e intercambios entre los participantes» y «Respuestas de los niños en las sesiones de lectura de Rosario» fueron:

\begin{tabular}{l|l}
$\begin{array}{l}\text { Cuando el temible tigre, de Virginia Brown, ilustraciones de Matías Acosta } \\
\text { (Banda Oriental) }\end{array}$ & 14.07 .2015 \\
\hline $\begin{array}{l}\text { La manta de las historias, de Ferida Wolf y Harriet May Savitz con ilustraciones } \\
\text { de Elena Odriozola (Norma) }\end{array}$ & 11.08 .2015 \\
\hline
\end{tabular}

\section{Modalidad lectora}

Rosario leyó Cuando el temible tigre y La manta de las historias en un volumen de voz moderado, con una entonación y velocidad adecuadas, correcta fluidez y dicción sin omisiones. En la primera de estas sesiones, también adecuó la velocidad de su lectura en algún pasaje:

Rosario: cuando el impo...- \| imponente hipopótamo visita a la [le.] abuelita \

\section{Acciones para organizar el espacio y tiempo de lectura}

Al llegar al salón, y luego de saludar a los niños, la mediadora se paraba de espaldas al pizarrón frente al grupo y allí permanecía hasta finalizar la lectura. Antes de comenzar a leer, saludaba los niños, particularmente en la sesión de La manta de las historias conversó con ellos sobre temas emergentes.

Las acciones desarrolladas por la mediadora en ambas sesiones se ajustaron al siguiente esquema:

-Antes de la lectura: saludo y comentarios espontáneos, 
-Presentación del libro:

Rosario: ¿estamos prontos?

Rosario: el cuento se llama Cuando el temible tigre \

Niña: [enf.] leelo ya $\backslash$

Rosario: texto de Virginia Brown \| ilustrado por Matías Acosta \\{muestra la tapa del libro $<10>$ \}

-Inicio de la lectura:

Rosario: Cuando el temible tigre / | visita a la abuelita \\{ंven las garras? \{muestra las imágenes $<10>$ \}

Niños a coro: isí! \[14.07.2015]

-Lectura y muestra de las imágenes del cuento. Durante la oralización del texto, luego de leer cada página, la mediadora se detenía a mostrar las imágenes por unos segundos sin realizar generalmente comentarios.

-Finalización de la lectura:

Rosario: y colorín colorado este cuento se ha acabado \

Niños a coro: \{aplausos\}

Rosario: ¿̇les gustó?

La mediadora no promovió la conversación sobre lo leído en ninguna de las dos sesiones observadas. En la de La manta de las historias, la maestra, inmediatamente luego de que Rosario terminó de leer, comenzó el intercambio, sin dar oportunidad de hacerlo a la mediadora. A pesar de ello, esta se sumó a este momento, retomó su participación, interrumpiendo a la maestra cuando sintió que era su oportunidad.

\section{Gestión de la construcción del metatexto}

Como puede observarse en el siguiente cuadro, las sesiones de Rosario se caracterizaron por las escasas acciones desplegadas (en comparación con las de los otros mediadores investigados):

\begin{tabular}{|l|c|c|c|}
\hline $\begin{array}{l}\text { Finalidad de las acciones de la } \\
\text { mediadora }\end{array}$ & Cuando el temible tigre & La manta de las historias & Totales \\
\hline $\begin{array}{l}\text { Delimitar momentos en la sesión } \\
\text { de lectura }\end{array}$ & 2 & 3 & 5 \\
\hline $\begin{array}{l}\text { Evidenciar la identidad de la } \\
\text { mediadora }\end{array}$ & 0 & 2 & 2 \\
\hline Dirigir la atención hacia un detalle & 2 & 0 & 2 \\
\hline Generar expectativas & 1 & 0 & 1 \\
\hline Expandir la información del texto & 2 & 6 & 8 \\
\hline
\end{tabular}




\begin{tabular}{|l|c|c|c|}
\hline Obtener el feedback de los niños & 0 & 1 & 1 \\
\hline Totales & 7 & 12 & 19 \\
\hline
\end{tabular}

En ambas ocasiones estuvieron presentes las acciones para establecer el inicio y fin de la lectura; también las de expansión, que en la segunda sesión se triplicaron con respecto a la primera, y se produjeron durante el comentario sobre lo leído iniciado por la maestra.:

Rosario: yo me imagino que ella nunca se va a quedar sin manta $\backslash$ | de las historias ¿̇no? | porque los aldeanos siempre la van $=\ldots . . .=\backslash$

Niño: $=\ldots . . .=$ [enf.] yo también | porque seguramente le van a dar de nuevo más \[11.08.2015]

Únicamente durante la lectura de Cuando el temible tigre se observó una acción destinada a hacer que los niños dirigieran su la atención a un detalle de la imagen:

Rosario: Cuando el temible tigre / | visita a la abuelita \\{己ven las garras? (muestra las imágenes ) $<10>\}$ Niños: isí! \

... y otra a generar expectativas:

Rosario: ¿qué vendrá ahora?

Niños a coro: \{risas\} [14.07.2015]

En la segunda sesión, se agregaron dos acciones que evidenciaron la identidad de la mediadora:

Rosario: ¿por qué andas mal? | ¿qué pasó?

Niño: bastante mal en todo el día \

Rosario: ¿qué pasó en la casa? | ¿no te salen las cuentas?

Niño: no \[11.08.2015]

... y una, al finalizar, para obtener el feedback de los niños:

Niños a coro: \{aplausos\}

Rosario: ¿les gustó?

En la sesión de La manta de las historias, durante los comentarios sobre lo leído que lideró la maestra Carmen, en el momento en que Rosario retomó la palabra, se registró una única pregunta de esta mediadora:

Rosario: ¿nunca ayudaron a las abuelas $\backslash$ | a desarmar...- ? | yo lo hacía cuando era chica \ Niño: [enf.] yo también \

Esta pregunta pretendió que los niños conectaran lo leído con sus vivencias, pero las respuestas de estos no se pudieron apreciar pues se produjeron desordenadas.

Vale la pena detenerse en este momento de la sesión en el que se concentraron las acciones de expansión:

Rosario: a todos nos pasa cuando damos cosas buenas \}

Niño: [enf.] claro \}

Rosario: recibimos cosas buenas $\backslash$

Niño: bueno\} 
Rosario: vuelven $\backslash||$ bueno $\backslash \mid$ [enf.] me alegro que les haya gustado $\backslash[. .$.

Rosario: ¿nunca ayudaron a las abuelas $\backslash$ | a desarmar...- ? | yo lo hacía cuando era chica $\backslash$

Niño: [enf.] yo también \

Niños a coro: (???) [conversan con entusiasmo]

Rosario: y a desarmar algún buzo $\backslash$ | vieron como que el buzo se va...- $\backslash \mid$ vos vas haciendo bien rapidito el rollito \[11.08.2015]

Se aprecia en este segmento el devenir de sus comentarios desde el plano personal más abstracto hacia lo vivencial y concreto, que dio la impresión de que la comprensión de Rosario se fue construyendo a la par de sus intervenciones.

Las escasas acciones desplegadas por esta mediadora seguramente puedan explicarse por su inexperiencia en el rol, pero también como lectora. Al respecto, la maestra Carmen destacó en su entrevista el nerviosismo y la rigidez con los que se enfrentó a los niños en las primeras sesiones de lectura. Sin embargo, de una instancia a otra y con escasos días de diferencia, se observó en el hacer de Rosario una mayor soltura, que se evidenció en el incremento numérico de las acciones, en el despliegue de otras nuevas y en su participación entusiasmada durante los comentarios sobre lo leído. Es probable que este cambio en su accionar haya estado influido por su participación en la jornada de formación, ya mencionada.

\section{En resumen:}

Rosario realizó una lectura expresiva de ambos cuentos en un volumen de voz moderado que podía ser escuchado por todos. Delimitó el comienzo y final de sus lecturas con acciones específicas. Mientras leyó, desplegó cuatro tipos de acciones diferentes en cada sesión y si bien estas fueron acotadas, las de la segunda sesión casi duplicaron a las de la primera. Por otra parte, en la segunda sesión aparecieron acciones nuevas y la mediadora se animó a participar de los comentarios sobre lo leído.

\section{Intervenciones e intercambios entre los participantes}

Debe mencionarse que el análisis de este ámbito y del siguiente: "Respuestas de los niños en las sesiones de lectura de Rosario» se realizó sobre las lecturas mencionadas en el apartado «Hacer de Rosario».

\begin{tabular}{|l|c|c|}
\hline & $\begin{array}{c}\text { Cuando el temible } \\
\text { tigre }\end{array}$ & $\begin{array}{c}\text { La manta de las } \\
\text { historias }\end{array}$ \\
\hline Intervenciones de los niños & 52 & 29 \\
\hline Intercambios entre los niños & 8 & 10 \\
\hline Intervenciones de la mediadora & 23 & 28 \\
\hline
\end{tabular}

Como puede apreciarse en el cuadro precedente, las intervenciones e intercambios de los niños y las intervenciones de Rosario en las sesiones de esta última fueron acotados en relación con los propiciados por los otros mediadores investigados.

El episodio con mayor cantidad de intervenciones sucesivas de los niños se produjo en la sesión de Cuando el temible tigre:

Rosario: la encuentra jugando a las cartas con Caperucita $\backslash\{$ muestra las ilustraciones $<10>$ \}

Niños a coro: $\{$ risas $\}$ 


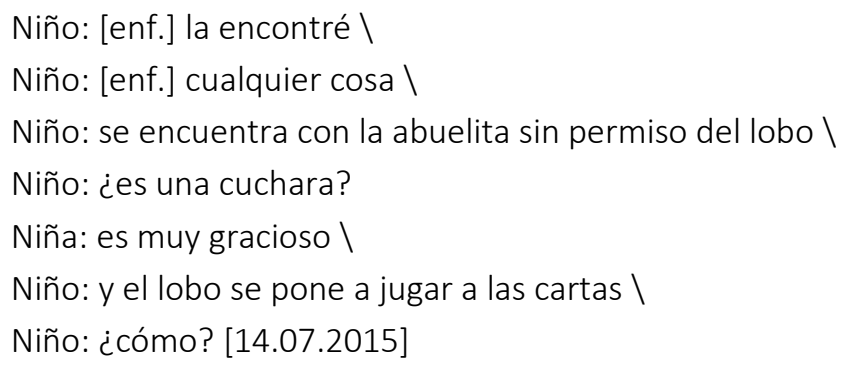

Los momentos en que la mediadora mostraba las imágenes de los cuentos fueron acompañados con los comentarios espontáneos de los niños: intervenciones monologales o los comentarios de construcción colaborativa, como los que se observan en el siguiente fragmento, ya descritos en los casos 1 y 2 :

Rosario: cuando el crue::I cocodrilo \| visita a la abuelita \\{muestra las ilustraciones <10>\}

Niño: ¿viste? | [enf.] yo sabía qué era \

Niño: abre la boca \

Niño: [enf.] se la come \[14.07.2015]

Mientras estos se producían, Rosario esperaba a que el intercambio se agotara naturalmente para retomar su lectura. La espontaneidad de los niños no fue sancionada por la mediadora en ninguna de las dos instancias.

Tampoco faltaron en estas sesiones las expresiones de entusiasmo, individuales o colectivas, que se produjeron a continuación de la lectura o acompañaron el visionado de las imágenes:

Rosario: el profesor de la escuela se sorprendió al encontrar un par de guantes en una pila de leña \ | cuando iba a recoger madera para la estufa de la escuela \| la señora Ivanov espantó a los cuervos de su lavandería con un nuevo delantal tejido / | que descubrió al lado de su bomba de agua \{[muestra las ilustraciones] $<10>\}$

Niños a coro: $\{$ risas $\}$

Niño: le hacía:: \| cosas para todos [11.08.2015]

Las respuestas a la única pregunta de la mediadora, durante la conversación sobre lo leído iniciada por la maestra Carmen, al finalizar La manta de las historias, se registraron en forma colectiva, con superposición de turnos entre los participantes, por lo que la riqueza de los intercambios no pudo ser apreciada en su cabalidad.

En la lectura de Cuando el temible tigre, los niños también verbalizaron preguntas en busca de mejorar su comprensión del cuento. Las respuestas a algunas de ellas vinieron de sus compañeros, pues frente a las dudas de los niños Rosario permaneció pasiva: no supo encontrar una estrategia para responderlas o bien, no quiso o no supo qué contestar:

Rosario: es su pequeño osito adorado \\{muestra las ilustraciones $<10>$ \}

Niña: ¡a::h!\

Niño: [enf.] mirá lo que es eso \

Niño: ¿era una abuelita o un abuelito?

Niño: [enf.] el cocodrilo el cocodrilo \

Rosario: es su pequeño cocodrilo adorado $\backslash\{$ muestra las ilustraciones. $<10>$ \}

Niño: jobvio! \es un cocodrilo \

Niño: ¡a::h! \ 
Niño: ¿y la abuela dónde está?

Niño: ahí parada con la escoba \

Niña: esa no es la abuela \

Niña: es el cocodrilo \[14.07.2015]

En esta sesión, además, una niña «levantó el guante» que la mediadora dejó caer con su pregunta, anticipándose al texto, hecho que fue posible por la estructura retahílica del mismo:

Rosario: ¿qué vendrá ahora?

Niños a coro: \{risas\}

Niña: pero cuando el feroz lobo \}

Niña: visita a la abuelita \[14.07.2015]

\section{En resumen:}

Los intercambios suscitados entre los niños y Rosario fueron acotados en cantidad en ambas sesiones. Los momentos en que la mediadora mostraba las imágenes de los cuentos fueron acompañados con comentarios espontáneos de los niños: intervenciones monologales o intercambios colaborativos y dialógicos. En la lectura de Cuando un temible tigre algunos niños también formularon preguntas que la mediadora no respondió, dejando el espacio para que lo hicieran sus compañeros.

\subsubsection{Respuestas de los niños}

\section{Respuestas de los niños en las sesiones de lectura de Rosario}

En cuadro que se despliega a continuación describe y cuantifica las respuestas de los niños en las sesiones de Rosario:

\begin{tabular}{|l|c|c|c|c|}
\hline & $\begin{array}{c}\text { Cuando el } \\
\text { temible tigre }\end{array}$ & \multicolumn{3}{|c|}{ La manta de las historias } \\
\cline { 2 - 5 } & $\begin{array}{c}\text { Durante la } \\
\text { lectura }\end{array}$ & $\begin{array}{c}\text { Durante la } \\
\text { lectura }\end{array}$ & $\begin{array}{c}\text { Después de } \\
\text { la lectura }\end{array}$ & Total \\
\hline $\begin{array}{l}\text { Expresiones de } \\
\text { entusiasmo }\end{array}$ & 17 & 8 & 5 & 13 \\
\hline $\begin{array}{l}\text { Referencias } \\
\text { literales al texto } \\
\text { o a las imágenes }\end{array}$ & 31 & 8 & 0 & 8 \\
\hline $\begin{array}{l}\text { Referencias } \\
\text { inferenciales al } \\
\text { texto o a las } \\
\text { imágenes }\end{array}$ & 5 & 2 & 2 & 4 \\
\hline $\begin{array}{l}\text { Referencias } \\
\text { personales }\end{array}$ & 3 & 1 & 2 & 3 \\
\hline
\end{tabular}




\begin{tabular}{|l|c|c|c|c|}
\hline $\begin{array}{l}\text { Referencias } \\
\text { vivenciales }\end{array}$ & 0 & 0 & 1 & 1 \\
\hline Total & 56 & 19 & 10 & 29 \\
\hline
\end{tabular}

Como puede observarse, las respuestas de los niños en la sesión de Cuando el temible tigre casi triplicaron a las de La manta de las historias, a pesar de la breve extensión del cuento ${ }^{66}$ y de la ausencia de comentarios sobre lo leído. Esto puede intentar explicarse porque el primer cuento fue elegido por la mediadora, quien probablemente ya lo conocía de antemano y era, además, de su agrado ${ }^{67}$.

En ambas instancias pudieron observarse manifestaciones de entusiasmo de los niños, tanto individuales como colectivas, como las que se leen a continuación:

Rosario: la encuentra jugando a las cartas con Caperucita \\{muestra las imágenes $<10>$ \}

Niños a coro: \{risas\} [14.07.2015]

Rosario: la confusión creció \| cuando el mugrie::nto gato del sastre apareció de pronto \ | ronroneando muy refinado en un ajustado abrig...- $\backslash$ | abrigo para gatos $\backslash$ | ya no había manta para sentarse \{muestra las ilustraciones $<10>$ \}

Niña: i[es] perá! \

Niños a coro: $\{$ risas\} [11.08.2015]

Las respuestas que se produjeron con mayor frecuencia, también en ambas lecturas, fueron las referenciales, como estas que se muestran a continuación:

Rosario: y feroces $\backslash \mid$ fauces $\backslash$ \{muestra las ilustraciones $<10>$ \}

Niño: parece un perro \}

Niño: parecen los dientes del cocodrilo $\backslash$

Niño: es verdad \| pero no es un cocodrilo \[14.07.2015]

Rosario: el profesor de la escuela se sorprendió al encontrar un par de guantes en una pila de leña \| cuando iba a recoger madera para la estufa de la escuela \| la señora Ivanov espantó a los cuervos de su lavandería con un nuevo delantal tejido / | que descubrió al lado de su bomba de agua । $\{$ muestra las ilustraciones $<10>\}[\ldots]$

Niño: le hacía:: \| cosas para todos \[11.08.2015]

A continuación, en un orden de frecuencia, se produjeron las respuestas inferenciales:

Rosario: la encuentra jugando a las cartas con Caperucita \\{muestra las ilustraciones $<10>\}[\ldots]$ Niño: se encuentra con la abuelita sin permiso del lobo \[14.07.2015]

\footnotetext{
${ }^{66}$ Este aspecto fue notado por algunos niños en distintos momentos de la lectura:

Rosario: es su pequeño \| hipopótamo / | adorado \{muestra las ilustraciones $<10>$ \} [...]

Niño: [enf.] es recorto [En referencia a la extensión del cuento.]

Rosario: y colorín colorado $\backslash$ | este cuento se ha acabado

Niño: [enf.] qué cortito \

${ }^{67}$ Rosario le pidió el libro a Mariela esa misma mañana, al finalizar la reunión del equipo comunitario de lectura del 14 de julio.
} 
Rosario: al poco tiempo la tendera tenía puesto un nuevo chal en lugar del apolillado manto que solía usar \| ahora los niños tenían que sentarse muy ju::ntos en la manta \|cuando iban a escuchar una historia \\{muestra las ilustraciones $<10>\}$ día tras día la curiosidad de los aldeanos crecía \| la bebé Olga recibió una misteriosa manta nueva $\backslash \mid$ muy suavecita y el carnicero alardeó con la elegante gorra de lana que cubría su reluciente $\backslash$ | cabeza calva $\backslash$ | ahora los niños estaban bastante apretados $\backslash$ | en la pequeñita manta de las historias $\backslash\{$ muestra las ilustraciones $<10>\}$

Niño: cada vez se volvía más pequeña \[11.08.2015]

... seguidas de las personales:

Rosario: es su pequeño tigrecito adorado $\backslash\{$ muestra las ilustraciones $<10>$ \}

Niña: ja::h! iqué lindo! \

Niña: ia:h! iqué divino! \[14.07.2015]

Rosario: a todos nos pasa cuando damos cosas buenas $\backslash$

Niño: ¡claro! \

Rosario: recibimos cosas buenas \}

Niño: bueno \[11.08.2015]

Por último, únicamente en la sesión de La manta de las historias, durante la conversación sobre lo leído, se registró la única respuesta del tipo vivencial, al identificarse un niño con la narración de la mediadora:

Rosario: ¿nunca ayudaron a las abuelas \| a desarmar...- ? | yo lo hacía cuando era chica \ Niño: [enf.] yo también \[11.08.2015]

En resumen:

En ambas sesiones de Rosario pudieron observarse manifestaciones de entusiasmo de los niños, tanto individuales como colectivas; también se registraron respuestas referenciales, inferenciales y personales. Y únicamente durante la conversación sobre lo leído en La manta de las historias se registró una única respuesta vivencial.

\section{E. Recuerdos de los niños sobre La manta de las historias}

Para este análisis se tomó en cuenta los recuerdos de esta lectura — realizada el 11 de agosto- que los niños evocaron en la entrevista del 1 de octubre.

\begin{tabular}{|l|c|}
\hline Aspectos recordados & Cant. \\
\hline Título & 0 \\
\hline Argumento & 4 \\
\hline Marco & 3 \\
\hline Acción narrativa & 0 \\
\hline Conversación & 1 \\
\hline No recuerdan & 0 \\
\hline
\end{tabular}


En esta instancia, dos de los seis niños entrevistados, Facundo y Abigail, recordaron aspectos del argumento del cuento:

Facundo: isí! | de ese me acuerdo más | que:: | que bueno | que una mujer que tenía una alfombra | quería dar | ma...- || manta o sea ¿no? | y sacaba de su alfombra las telas | y sacaba hasta que se le hacía chiquita | y luego la reponía de nuevo por si después la volvía a necesitar ¿no? | y luego cuando terminó el cuento| todos | le quisieron regalar una manta |que se fue gastando también y ella volvió a hacer otra

Abigail: La manta de las historias || era una manta que...-| iay! pero no me acuerdo mucho | era una manta que tenía libros o sea...- || la manta de libros era...- | la manta que...- | iay! no me acuerdo

... y Facundo únicamente recordó que la protagonista del cuento era «una mujer que tenía una alfombra».

\section{En resumen:}

Con respecto a los aspectos recordados sobre este cuento, dos niños mencionaron en la entrevista algún detalle del argumento y solo uno de ellos, a la protagonista de la historia.

\section{F. Valoraciones de los niños sobre Rosario}

La totalidad de opiniones que se registraron sobre esta mamá fueron positivas.

\begin{tabular}{|l|c|}
\hline Opiniones & Cant. opiniones \\
\hline Centrada en el vínculo familiar en general & 5 \\
\hline Centradas en la persona de la mediadora & 20 \\
\hline Centradas la lectura de la mediadora & 24 \\
\hline $\begin{array}{l}\left.{ }^{*}\right) \text { Centradas en la experiencia de lectura con la } \\
\text { mediadora }\end{array}$ & 51 \\
\hline Total de opiniones relevadas & 24 \\
\hline
\end{tabular}

(*) Dentro de estas respuestas se constataron 8 que valoraron la modalidad de lectura de la mediadora y 5 , los libros que lee.

Como puede observarse en el cuadro precedente, los niños valoraron, en mayor medida, su experiencia de lectura con Rosario:

«Me gusta porque no estoy molestando a los compañeros» [Matías]

«Me gusta que venga a leer porque así no me aburro» [Janina]

En segundo lugar, apreciaron la lectura de la mediadora:

«[Tiene] linda voz y no trae siempre los mismos cuentos» [Geraldine]

«Porque lee lindos cuentos y son graciosos» [Roque]

En tercer lugar, valoraron algún rasgo de su personalidad:

«Ella es muy buena con nosotros» [Nicolás] 
Y en forma acotada, centraron su opinión en el vínculo familiar en general:

«Son muy lindas todas las mamás» [Melina] [09.09.2015]

Los niños de tercer año A de la escuela XXX tendieron a recordar en la encuesta los últimos títulos que les habían leído, pero 4 destacaron León de biblioteca, que Rosario les leyó el 21 de julio.

\section{En resumen:}

La persona de la mediadora y su experiencia de lectura con ella fueron los aspectos que los niños valoraron con mayor frecuencia y solamente cuatro niños pudieron recuperar un título leído por Rosario ${ }^{68}$.

\subsubsection{Conclusiones particulares sobre el tercer caso}

El deseo de mejorar su lectura y hacer mejores lectores a los suyos fueron para Rosario importantes motivaciones para su ingreso al equipo comunitario de la escuela XXX. En este sentido, este hecho constituyó un mojón tanto en su biografía lectora como en la de su familia. Debe destacarse además entre las motivaciones de esta mediadora una dimensión política, al asignar a la lectura un efecto de transformación personal y social, que manifiesta cuando dice: «[...] los libros abren cabezas»; motivación que está muy estrechamente relacionada con su rol de concejal vecinal

La formación de Rosario como lectora parece confluir y retroalimentarse en el ejercicio de su rol. Su disfrute de la lectura fue surgiendo a la par de los cuentos que leyó a los niños:

Sandra: de todos los libros que leíste | ¿hay alguno que te haya gustado má::s?

Rosario: sí La luz mala | no...-

Sandra: ¿El miedo a la luz mala?

Rosario: El miedo a la luz mala | es el que más me gustó y el que más observé que a ellos les encantó Sandra: ¿y por qué creés que te gustó a vos y a ellos también?

Rosario: porque es como que te hace...- | justamente hablando de volar la imaginación| es como que te hace...- | como una fábula | como algo que te hace imaginar cosas [05.11.2015]

Los niños, de alguna manera, reconocieron el esfuerzo que Rosario realizaba al leerles -también con aplausos-, lo valoraron y se identificaron con ella:

«No tiene vergüenza de leer y ni de deletrear» [Geraldín]

«No tiene vergüenza y nos lee con mucho cariño» [Joaquín]

Como las integrantes del equipo comunitario de lectura eran todas mamás, y además rotaban periódicamente por las clases, algunos niños tuvieron dificultades para identificarlas, pero a pesar de ello, Facundo pudo recordar a Rosario leyéndoles La manta de las historias:

Sandra: [...] Facu y decime | ¿qué te acordás de cuando Rosario lo leyó? | ¿de su lectura?

Facundo: también me acuerdo que:: ella también se reí::a y le gustaba | y que:: | también miraba |remarcaba esas partes [01.10.2015]

\footnotetext{
${ }^{68} \mathrm{Al}$ respecto, tanto la maestra Carmen como alguno de los niños en sus entrevistas manifestaron que este fue el cuento que más les gusto; también fue destacado por Rosario a pesar de que esta lectura no se vivió con entusiasmo por ninguno de los presentes.
} 
Los niños valoraron además de esta mediadora en su pasaje por tercer año A de la escuela XXX, su experiencia de lectura con ella, a su lectura y a su persona.

Pese a que la experiencia de Rosario se remite a unos pocos meses, pudo ir creciendo con ella, adquiriendo seguridad y modificando su hacer. Descubrió además en el ejercicio de su rol cuán gratificante son las lecturas compartidas con los niños y la posibilidad de ampliar su comprensión sobre lo leído junto con ellos.

La inexperiencia de Rosario fue sentida por la maestra Carmen como un obstáculo; si bien recibió a la mediadora en su clase con beneplácito y manifestó agrado por sus lecturas; aseguró las condiciones para que desarrollara su tarea sin dificultad y no puso objeciones a su hacer, esta mediadora pareció no inspirarle confianza. Prueba de ello son sus juicios de valor sobre ella y el inicio apurado de la conversación sobre lo leído en La manta de las historias, en un intento por no perder el control de su clase.

El hacer de Rosario parece relacionarse, a la par, con su formación lectora y con su experiencia como mediadora: la ausencia de respuestas ante las interrogantes de los niños habilita esta interpretación. Por otra parte, la mediadora tampoco supo encausar la conversación sobre lo leído en ninguna de las instancias analizadas.

Los momentos del visionado de las ilustraciones de los cuentos fueron productivos en ambas sesiones: los niños aprovecharon la libertad que la mediadora les dio para intervenir e intercambiar en forma espontánea, lo que posibilitó construir la comprensión en forma colaborativa.

La modalidad lectora y el visionado de las ilustraciones constituyeron los recursos que Rosario empleó para contagiar su entusiasmo a los niños, como pudo apreciarse en las expresiones de estos, principalmente durante la lectura de Cuando el temible tigre. Al respecto, al finalizar esta sesión, fue muy interesante observar la reacción de estos niños quienes con vehemencia le solicitaron a esta mamá que continuara leyendo:

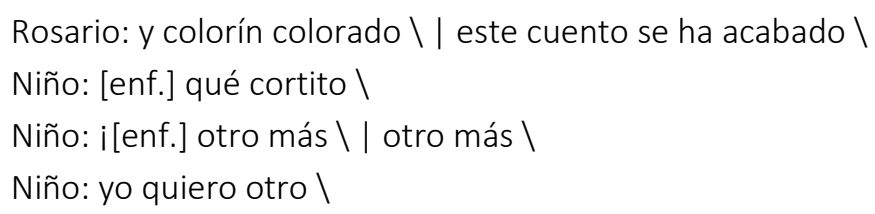

...y de este otro, quien manifestó su intención de buscar en la biblioteca de la escuela el libro que habían terminado de leer:

Niño: ahora voy a la biblioteca y lo voy a encontrar \[14.07.2015]

De igual manera, Abigail en su entrevista expresó que el libro que más le había gustado había sido uno de los que les leyó Rosario:

Sandra: y acá me pusiste que había un libro que te había gustado mucho

Abigail: sí

Sandra: ¿ंcuál era?

Abigail: El león de biblioteca [...]

Sandra: ¿por qué te gustó ese cuento en especial? 
Abigail: me gustó porque:: | porque me quiero...- | porque quiero leerlo de nuevo Sandra: ¿ah sí?

Abigail:sí | quiero tres o cuatro veces | me gusta | quiero comprármelo igual | ime encanta ese libro! [01.10.2015]

\subsection{Cuarto caso. Escuela XXX, tercer año B, Patricia}

\subsubsection{Estilo de la mediadora}

\section{F. Ser de Patricia}

\section{La mediadora en persona}

Patricia tiene 44 años, es artesana (trabaja por su cuenta), y mamá de Bautista, alumno de segundo año de la escuela XXX.

Esta mediadora cumplió su función en forma ininterrumpida durante 2015; entre abril y mediados de noviembre de este año leyó en tercero, sexto y quinto año, permaneciendo en esta clase varios meses a solicitud de los niños con quien entabló un estrecho vínculo.

\section{Preferencias y prácticas lectoras}

Patricia es una lectora habitual en su vida adulta. En su entrevista, declaró preferencias diversas: mencionó títulos, reconoció los géneros que lee y destacó aquellos que no son de su agrado. Posee además una opinión formada sobre lo que lee y sobre el acto de leer:

[Sobre su lectura actual.] ahora estoy leyendo algo que me...- | que me tiene así como:: | que lo leo | lo leo y no lo leo | estoy leyendo La chica /que soñaba con un bidón / de nafta / de gasolina y no me acuerdo | y es muy tormentoso | es muy tormentoso

Sandra: ¿es una novela?

Patricia: sí | por lo general trato de leer | de todo un poco | de todo un poco | \{menos libros de autoayuda (risas) \} || [...] ahora estoy con eso de bueno lo dejo | pero no lo quiero dejar porque |uno no puede juzgar un libro hasta no terminarlo [20.10.2015]

\section{Biografía lectora}

Patricia reconoció no provenir de un hogar en el cual la lectura fuera una práctica habitual. Tampoco la escuela dejó su huella en sus hábitos lectores:

Sandra: ¿y en la niñez | en la escue::la | en tu casa? $=\ldots . . .=$

Patricia: $=\ldots . . .=$ bueno de la escuela sí pero...- | en mi casa mis padres no eran | no no eran...- | todas mis inquietudes fueron |después |sí después | leía en la escuela lo de la escuela | tenía cuentos en casa pero no era una cosa que fuera habitual

Sus prácticas lectoras se afianzaron en la adolescencia, con su participación en un club de lectura, del que formó parte, a pesar de la sanción de sus amigas:

Sandra: vos me hablabas de que te gustaba mucho leer | ¿vos desde cuándo leés? | ¿̇en qué momento apareció la lectura en tu vida? =.... = 
Patricia: $=\ldots . . .=i a::$ h! siempre desde la adolescencia | yo me acuerdo que tenía 17 años || y:: | yo soy artesana | y entonces | yo trabajaba |iba al liceo de noche | y trabajaba para pagarme un curso de artesanías || y en la Casa de...- || la Empleada en la Ciudad Vieja | daban unos...- | daban unos cursos de artesanías y ahí me metí en un taller literario

Sandra: iah qué bueno!

Patricia: isí! yo tenía 17 años y mis amigas | me bromeaban porque yo era la...- | como la nieta | porque iban todas señoras mayores en aquella época no se leí::a mucho lly ahí fue que me enganché y me decían «ipero cómo vas a leer!» [enf.] | y yo me acuerdo que les decía «pero estamos leyendo Juana de Ibarbourou | «ipero no | vos tenés 17 años! pa pa pa» desde la adolescencia fue que me enganché

En su vida adulta pudo continuar con sus prácticas lectoras, aunque manifestó que estas tuvieron altibajos:

Patricia: isí! | isí! |! hubo...- | hubo épocas en que leía más| y épocas en las que leía menos | o porque Bautista era chi::co | viste que los tiempos...- | la lectura| no es para...-- está bueno leer en el ómnibus | pero está bueno sentarse en tu ca::sa || tranqui::la [20.10.2015]

\section{Motivaciones para ejercer el rol de mediadora}

Pueden identificarse en esta mediadora motivaciones relacionadas, como ella lo manifiesta, con su amor por los niños, el deseo de colaborar con la escuela y su gusto por la lectura:

[...] | yo | en primer lugar | tengo:: | amor por los niños || siempre que pude integrarme a algo en la escuela | siempre ...- | pudiendo dije que sí |leer me gusta | entonces | fue doble:: la alegría ¿no? | y:: vi respuesta en los chiquilines y entonces dije «bueno sí» [...] | y si se trata de lectura bueno más todavía ¿no?

Las gratas vivencias de las sesiones de lectura y la reciprocidad constatada en la respuesta de los niños constituyeron otra motivación para esta mediadora:

[En referencia a su lectura.] la respuesta fue maravillosa que llegamos a leer Los fantasmas de la escuela y Los fantasmas de la escuela pasaron de clase | me pidieron que me quedara | porque viste que rotamos todos los meses | y con quinto estuve como tres cuatro meses con ellos [...]

La retribución obtenida de la entrega desinteresada de su tiempo y afecto a los niños fue otro motor para su permanencia en el rol de mediadora:

[En referencia a su experiencia como mediadora.] me sentí:: | alegre | feliz de hacerlo | y sentía::...| lo mismo | que yo sentía | sentía que los chiquilines estaban viviendo || era un momento | ¿cómo te puedo explicar? || yo estaba dando lo mejor de mí | sentía que los chiquilines se daban cuenta de eso |ly lo retribuí::an

[...] también está que ahora los chiquilines ya me conocen | yo ya soy parte de la escuela || antes era...| cuando entraba a un salón por primera vez era preguntarme quién era:: | porque ellos curiosean ¿no? | quién sos | ahora ya no | ahora ya viene Patricia o viene la mamá de Bautista || sí ahora estoy más canchera | ya los conozco | ya los reconozco || y ya | nos vemos en la calle | «¿̇y cómo est::ás?» | «¿y cómo te fue en la escuela?»| «y me fue bien en el carné» | se crea una amistad | con los chicos 
Y si bien (como ella misma lo reconoció), Patricia no mantuvo un vínculo muy estrecho con las otras madres integrantes del equipo comunitario, el sentido de compromiso vivenciado colectivamente constituyó un estímulo para el sostén y la permanencia de todas ellas, en el grupo y en la tarea, como se puede apreciar en las palabras citadas a continuación:

[...] bien | bien || sí son un grupo fantástico | son fantásticas | están mu::y comprometidas [enf.] | una de las chiquilinas || yo no estoy mucho | pero una de las chiquilinas el martes se tuvo que retirar del grupo por cuestiones personales | Laura | y ella estaba angustiada de verdad [enf.] | y eso es...- | es noble [enf.] | es es...- | porque ella está | brindando su tiempo | ella podría estar ocupando esa media hora o una hora que le lleva ir y volver de la escuela | en otra actividad [...] Janet que viene con su bebé [enf.] | vos te das cuenta que es una entrega [enf.] || lo que recibís a cambio es la alegría de estar haciendo algo por los chiquilines [...] [20.10.2015]

\section{Apropiación del rol de mediadora}

Este fue el segundo año de Patricia en el equipo comunitario de lectura de la escuela XXX al que se integró en sus comienzos, en 2014 y en el que permaneció en forma ininterrumpida:

Al respecto, evocó con agrado su experiencia como tal:

Sandra: debe haber sido muy buena la experiencia para que vos decidieras continuar

Patricia: isí! isí! isí! | fue buena la experiencia | yo me sentí:: | alegre | feliz de hacerlo |

Patricia reconoció el influjo de su experiencia como mediadora en su hacer:

[...] una se pone más canchera | y pasa en todo ¿no? | y también está que ahora los chiquilines ya me conocen $[\ldots]$

Ha logrado además capitalizar en el ejercicio de su rol los criterios de selección de las lecturas que llevó al aula:

yo creo que hay que buscar || más que nada | me parece a mí [...] buscar el interés ¿̇entendés? | no es lo que a mí me gustaría | que ellos leyeran | sino tratar de ver | por dónde van los (???) |qué es lo que está pasando por la cabecita de ellos | y esa es la manera de atraparlos | me parece

yo a los de quinto | a los de quinto le voy con libros con novelas | no les voy con cuentitos cortos | porque es una manera de dejarlos enganchados me parece a mí [enf.] | y los chiquitos se enganchan con cue::ntos | con mucha ilustració::n | pocas palabras y mucha ilustración

Por último, su hacer también le ha permitido tomar conciencia de su aporte concreto a los niños, en función de sus propósitos:

[En referencia a sus sesiones de lectura.] los chiquilines bajan un cambio || bajan un cambio | tenés que atrapa::rlos | tenés que saluda::rlos |darles un tie::mpo porque no es todo mágico |no están | acostumbrados de repentes a la serenidad de la lectura | entonces darles sus tiempos saluda::rlos | ahí empiezan a prestar atención | empiezan a:: | a meterse a estar...- | y yo pienso que eso les debe servir para todas las áreas ¿̇no? | porque es necesaria la concentració::n [...] [20.10.2015]

En resumen:

Patricia es una lectora habitual en su vida adulta que manifestó tener preferencias lectoras diversas. Posee también una opinión formada sobre lo que lee y el acto de lectura en sí. 
Aunque no proviene de un hogar lector, consolidó sus prácticas lectoras en su adolescencia, concurriendo a un club de lectura.

Entre sus motivaciones para ejercer el rol de mediadora se encuentran su manifiesto amor por los niños y el deseo de colaborar con la escuela a la que concurren su hijo. Sus gratas vivencias con los niños durante las sesiones de lectura constituyeron otra motivación para esta mediadora. La gratificación que le brindó la entrega desinteresada de su tiempo y afecto y el reconocimiento de los niños también fue un motivo de fuerza para Patricia. Si bien no participó plenamente del grupo de amigas, base del equipo comunitario de lectura, valoró muy especialmente la contribución de las demás madres lectoras y encontró en este grupo el sostén necesario para continuar ejerciendo su rol.

Esta mediadora reconoció en su hacer la fuente de insumos para ejercer su tarea. Su crecimiento como mediadora se evidenció en la síntesis que realizó sobre cómo desarrollar su tarea, en la formación de criterios de selección de los libros para leer en cada clase y en el reconocimiento del aporte que realizó a los niños.

\section{B. Hacer de Patricia}

Las sesiones de lectura que constituyeron la base del análisis de este apartado como de los que siguen: «Intervenciones e intercambios entre los participantes»y «Respuestas de los niños» fueron:

\begin{tabular}{|l|c|}
\hline Los secretos de Abuelo Sapo, de Keiko Kasza (Norma) & 26.05 .2015 \\
\hline Una cena elegante, de Keiko Kasza (Norma) & 28.07 .2015 \\
\hline
\end{tabular}

\section{Modalidad lectora}

Patricia leyó Los secretos de Abuelo Sapo y Una cena elegante en un volumen de voz moderado a alto pues en ambas instancias los niños se entusiasmaron mucho con las lecturas y tendieron a comentar en forma desordenada. Su fluidez fue correcta y su dicción sin omisiones. En ambas sesiones adecuó la velocidad de su prosodia (en algunos pasajes del cuento) y su entonación a la modalidad del enunciado; e incorporó gestos faciales o corporales, teatralizando algunos momentos del cuento:

Patricia: [enf.] no era una tortuga / | [enf.] era una tortuga voraz \\{recorre el salón mientras muestra las ilustraciones e imita cómo se infló el sapo <20>\} [26.05.2015]

Patricia: <10> ¿quién tiene hambre? \{toca su abdomen, representando tener hambre\} [28.07.2015]

\section{Acciones para organizar el espacio y el tiempo de lectura}

Tanto en Los secretos de Abuelo Sapo como en Una cena elegante Patricia recorrió el salón mientras leía, deteniéndose para mostrar las imágenes. Los niños permanecieron en sus asientos.

En ambas lecturas, el esquema de desarrollo se reiteró. La mediadora delimitó con claridad los diferentes momentos. Antes de comenzar a leer, saludó a los niños y conversó con ellos. En Una cena elegante, introdujo la lectura de una manera lúdica.

Las acciones desarrolladas por esta mediadora pueden sintetizarse así:

-Antes de la lectura (en la sesión de Una cena elegante) 
Patricia: <10> ¿quién tiene hambre? Patricia: <10> ¿quién tiene hambre? \{toca su abdomen, representando tener hambre\}

Niños a coro: iyo! \

Patricia: bueno vamos a hablar de Una cena elegante (???) \

Niño: iah no! \[enf.] me va a venir más hambre \

Patricia: ¿cómo se imaginan Una cena elegante ustedes? [28.07.2015]

Presentación del libro:

Patricia: esta cena elegante es un poco $\backslash \mid$ especial $\backslash \mid$ ¿ंverdad?

Niño: porque si no me va a venir más hambre \}

(La mediadora espera que los niños hagan silencio.)

Patricia: es una historia que nos cuenta \

Niño: isilencio!

Patricia: isilencio! \\{recorre el salón mostrando la tapa del libro $\langle 20>\}$ es una historia que nos cuenta Keiko Kasza / \{continúa recorriendo el salón mostrando la tapa del libro <25> | de Una cena elegante [28.07.2015]

-Inicio de la lectura:

Patricia: yo me lo como \| ia mí qué me importa! \| un día Abuelo Sapo y Sapito / | salieron a caminar por el bosque \|| y ahí van ellos pa::nchos de la ma::no \\{recorre el salón de clase mostrando las ilustraciones $<15>\}[26.05 .2015]$

-Lectura y muestra de las imágenes del cuento. Luego de leer cada página, la mediadora recorría el salón mostrándoles las imágenes a los niños. Algunas veces acompañó esta acción con comentarios, pero siempre dejó un espacio para que estos verbalizaran su interpretación o anticiparan el resto de la historia.

-Finalización de la lectura

Patricia: y colorín colorado \}

Niños a coro: este cuento se ha acabado \{aplausos\} [28.07.2015]

-Apertura de la conversación sobre lo leído

Patricia: ¿ustedes son astutos y valientes? [26.05.2015]

-Conversación sobre lo leído

-Cierre de la conversación y finalización de la sesión

Patricia: claro la cena elegante la tenemos \¿̇les gustó chiquilines? [28.07.2015]

En ambas sesiones, el intercambio sobre lo leído fue acotado en el tiempo. Cabe señalar que la mediadora logró establecer una continuidad entre la lectura y la conversación sobre lo leído: en la de Los secretos de Abuelo Sapo el cierre de la lectura coincidió con la apertura de la conversación, y en la de Una cena elegante estableció una continuidad entre la introducción a la lectura y la presentación del libro. 


\section{Gestión de la construcción del metatexto}

En el siguiente cuadro puede observarse la finalidad de las acciones que Patricia desplegó en sus sesiones:

\begin{tabular}{|c|c|c|c|}
\hline Finalidad de las acciones de la mediadora & $\begin{array}{l}\text { Los secretos de } \\
\text { Abuelo Sapo }\end{array}$ & Una cena elegante & Totales \\
\hline $\begin{array}{l}\text { Delimitar momentos en la sesión de } \\
\text { lectura }\end{array}$ & 3 & 4 & 7 \\
\hline Evidenciar la identidad del mediador & 6 & 1 & 7 \\
\hline Dirigir la atención hacia un detalle & 2 & 2 & 4 \\
\hline Generar expectativas & 19 & 6 & 25 \\
\hline Expandir la información del texto & 13 & 4 & 17 \\
\hline Avalar las expresiones de los niños & 14 & 5 & 19 \\
\hline Habilitar la participación de los niños & 5 & 2 & 7 \\
\hline $\begin{array}{l}\text { Restablecer el orden para continuar la } \\
\text { lectura }\end{array}$ & 0 & 7 & 7 \\
\hline Corregir un error de interpretación & 1 & 4 & 5 \\
\hline Conseguir el feedback de los niños & 0 & 1 & 1 \\
\hline & 63 & 36 & 99 \\
\hline
\end{tabular}

Las acciones desplegadas por Patricia en sus dos lecturas persiguieron diversos propósitos. En ambas estuvieron presentes las acciones para delimitar los distintos momentos de las sesiones, ya descritos en el apartado anterior.

Como se aprecia en el cuadro, las acciones para genera expectativa, como la que se expone a continuación, fueron a las que más recurrió esta mamá en Los secretos de Abuelo Sapo, y las segundas en Una cena elegante.

Niño: [enf.] este encuentra todo! \{señala a su compañero\} $\backslash \mid$ totalmente de acuerdo que es una tortuga \

Patricia: ¿'es una serpiente? ¿es una tortuga? | vamo[s] a ver \| a ver \[26.05.2015]

Las acciones de aval, que fueron las de mayor frecuencia en la segunda sesión y las segundas en la primera se manifestaron en ejemplos como el siguiente:

Niño: [enf.] los pumas son diferentes $\backslash$

Patricia: son diferentes los pumas sí \[26.05.2015] 
La mediadora tampoco escatimó las acciones de expansión de información, con mayor presencia en la primera sesión que en la segunda:

Patricia: [enf]. no era una tortuga / | era una tortuga voraz \\{recorre el salón mientras muestra las ilustraciones e imita cómo se infló el sapo $<20>\}$

Niño: [enf.] se hinchó:: \| se infló \[26.05.2016]

Las acciones de evidencia de la identidad de la mediadora también se observaron en ambas instancias:

Patricia: [...]| Sapito está preocupado $\backslash \mid$ pero su abuelo promete $\backslash \mid$ compartir con él sus secretos más especiales $\backslash$ | cuando de enfrentar $\backslash \|$ a los predadores $\backslash \mid$ ya me está empezando a fallar la vista $\backslash \mid$ del bosque central \ique me olvidé de los lentes! \| con esto de la bolsa me olvidé la cartera [Alude a la bolsa que identifica a los mediadores de los equipos comunitarios de lectura y en la cual llevan los libros.] [26.05.2016]

Acciones como las del próximo ejemplo fueron utilizadas con la finalidad de dirigir la atención de los niños hacia detalles de las ilustraciones:

Patricia: \{risas\} [enf.] la cara de amor que tienen estos sapos \/ ipor favor! \imirá! \[26.05.2015]

Las destinadas a habilitar la participación de los niños tuvieron en ambas sesiones una presencia más acotada, y se expresaron en ejemplos como el siguiente, antes de comenzar la lectura de Una cena elegante y durante la misma en Los secretos de Abuelo Sapo:

Patricia: $=\ldots . . .=$ ¿cómo te imaginás vos Una cena elegante? ¿vos?

Niña: con velas \

Patricia: [enf.] con velas \¿̇vos? [28.07.2015]

Patricia se preocupó además en ambas sesiones por corregir los errores de interpretación de algunos niños, si estos se continuaban luego de que el texto aclarara las confusiones. Esta acción se observó en ambas sesiones, pero tuvo mayor presencia en Una cena elegante:

Niño: salió el tejón a buscar la comida \

Niña: no eso es un topo $\backslash$

Patricia: [enf.] es un tejón \{continúa recorriendo el salón mientras muestra las ilustraciones $<20>$ \}

En esta misma sesión, se observó la siguiente acción para obtener el feedback de los niños luego de una lectura trabajosa para la mediadora, en la que los niños se desordenaron constantemente, pero que fue vivida con mucho entusiasmo por todos los presentes ( $\rightarrow$ anexo 4.5.4.2. «Transcripción de la sesión de lectura de Una cena elegante» y Anexo 5. «Diario del trabajo de campo. Martes 28 de julio»).

Precisamente por ese entusiasmo, que por momentos pareció salirse de control, la mediadora debió recurrir a acciones como esta:

Patricia: saben que (???) después tengo que levantar mucho la voz y después...- $\mid$

... que fueron necesarias para restablecer el orden y continuar la lectura. Estas acciones fueron las de mayor frecuencia en esta sesión y superaron a las de expansión de la información, que le siguieron en cantidad.

Al iniciar la sesión de Una cena elegante, Patricia realizó algunas preguntas buscando generar expectativas (el contraste de las respuestas esperadas y la posterior lectura del cuento seguramente 
iban a tener este efecto), y promover la discusión, estableciendo un puente entre los conocimientos previos de los niños y el texto:

Patricia: <10> ¿quién tiene hambre? \{toca su abdomen, representando tener hambre\}

Niños a coro: iyo! \

Patricia: bueno vamos a hablar de Una cena elegante $\backslash((? ? ?))$

Niño: iah no! \[enf.] me va a venir más hambre \

Patricia: ¿cómo se imaginan Una cena elegante ustedes? [...]

Niño: Una cena elegante yo $=\ldots . . .=$

Patricia: $=\ldots . . .=$ ¿cómo te imaginás vos Una cena elegante? ¿vos?

Niña: con velas $\backslash$

Patricia: [enf. con velas \¿ंvos? [28.07.2015]

Al terminar la lectura, en ambas sesiones, formuló algunas preguntas (una en la primera y cuatro en la segunda), buscando iniciar los comentarios sobre lo leído y la conexión con el plano vivencial, pero las respuestas que obtuvo fueron acotadas, a pesar de que algunas de ellas buscaron enriquecer y profundizar el intercambio:

\section{Los secretos de Abuelo Sapo}

Patricia: ¿ustedes son astutos y valientes?

Niños a coro: ¡sí! \

Niña: yo no $\backslash$

Patricia: ¿cuando la ocasión lo amerita? | ¿eh?

Niño: de vez en cuando \

Patricia: ¿de vez en cuando? | ¿por ejemplo?

\section{Una cena elegante}

Patricia: ¿a alguno le pasó una vez así? | que tenemos algo en casa / | y queremos algo más \y no nos damos cuenta que en casa tenemos lo que necesitamos?

El hecho de que la mediadora debió llamar la atención o esperar el silencio de los niños para continuar leyendo en varias oportunidades puede explicar la diferencia cuantitativa entre las acciones que desplegó en una y otra sesión: las de Los secretos de Abuelo Sapo casi duplican a las de Una cena elegante. Probablemente, Patricia, al notar la inquietud de los niños apuró su lectura y economizó sus acciones, con el propósito de que la sesión llegara exitosamente a su fin.

\section{En resumen:}

En las dos instancias analizadas, Patricia realizó una lectura expresiva, en un volumen moderado, aunque en algunos tramos debió levantar la voz para garantizar que los niños la escucharan. Delimitó con claridad distintos momentos y realizó preguntas: antes de la lectura, en Una cena elegante, y después de la lectura en ambas sesiones, para promover los comentarios sobre lo leído, aunque estos fueron acotados. Las acciones que la mediadora desplegó fueron variadas, y las de la primera sesión casi duplicaron a las de la primera.

\section{Intervenciones e intercambios entre los participantes}

Para el análisis de las Intervenciones e intercambios entre los participantes y de las respuestas de los niños se tomaron en cuenta las sesiones mencionadas al inicio del apartado B. «Hacer de Patricia». 


\begin{tabular}{|l|c|c|}
\hline & $\begin{array}{c}\text { Los secretos de Abuelo } \\
\text { Sapo }\end{array}$ & Una cena elegante \\
\hline Intervenciones de los niños & 146 & 134 \\
\hline Intercambios entre los niños & 16 & 32 \\
\hline Intervenciones de la mediadora & 73 & 66 \\
\hline
\end{tabular}

Como puede observarse, las intervenciones de los niños y las de la mediadora fueron bastante equitativas en ambas lecturas.

En el episodio más entusiasta de Una cena elegante se contabilizaron dieciséis intervenciones consecutivas de los niños:

Patricia: isilencio! \| \{recorre el salón mostrando la tapa del libro $<20>\}$ es una historia que nos cuenta Keiko Kasza / \{continúa recorriendo el salón mostrando la tapa del libro $<25>$ \} | de Una cena elegante $\backslash$

Niño: ¿qué es eso?

Niño: un cuis \

Niño: [enf.] eso es cualquiera \[Despectivo.]

Niña: Una cena elegante \(Lee la tapa del libro.)

Niño: un mapache $\backslash$

Niños a coro: (???) (Continúa la discusión desordenada.)

Niño: iXXX! \XXXX! \vamos a (???) y le digo \poneme pollo todo \

Niño: [enf.] un perro $\backslash$

Niño: [enf.] un oso \}

Niño: [enf] un koala \

Niño: [enf.] se está yendo \}

Niño: [enf.] un mapache $\backslash$

Niño: [enf.] es un mapache $\backslash$

Niño: [enf.] eso es un mapache $\backslash$

Niña: parece un mapache $\backslash$

Niño: [enf.] un mapache $\backslash$ [28.07.2015]

Los niños aprovechaban el momento del visionado de las imágenes para verbalizar sus interpretaciones. Los comentarios de los niños, que Patricia no sancionó, se produjeron en forma espontánea, asumiendo muchas veces la modalidad monologal (como puede apreciarse en la cita anterior) o colaborativa, como la del ejemplo a continuación:

Patricia: ihola sapos! siseó la culebra \| me los voy a comer de almuerzo \|| Sapito dio un alarido y corrió a esconderse $\backslash$ | pero:: \| Abuelo $\backslash \mid$ ¿estaba asustado? \{recorre el salón mostrando las ilustraciones $<20>$ \}

Niño: no \| se ve que no \

Niño: iesperá! \

Niño: no estaba asustado \

Niño: isí::! \| estaba \

Niño: estaba medio ahí \

Niño: estaba asombrado \[26.05.2015] 
Además de no sancionar estos comentarios, la mediadora los promovió, festejando las divertidas ocurrencias de algún niño, como puede apreciarse en este ejemplo de Los secretos de Abuelo Sapo:

Niño: ¿a ver? ¿a ver? ¿a ver? ¿a ver?

Patricia: ¿a ver? ¿̇a ver? ¿a ver? \{risas\} $\|$ ¿a ver? ¿a ver? ¿̇a ver? [Imita al niño.]

Niño: correr $\backslash$

Niño: salió corriendo \}

Niño: correr como un desacatado \

Patricia: \{risas\} [enf.] la cara de amor que tienen estos sapos \/ ipor favor! \imirá! [26.05.2015]

Los niños respondieron en forma acotada las escasas preguntas que Patricia realizó. Al respecto, el episodio más participativo se registró luego de finalizar la lectura de Los secretos de Abuelo Sapo:

Patricia: ¿ustedes son astutos y valientes?

Niños a coro: isí! \

Niña: yo no $\backslash$

Patricia: ¿cuando la ocasión lo amerita? | ¿eh?

Niño: de vez en cuando \}

Patricia: ¿de vez en cuando? | ¿por ejemplo?

Niño: iyo qué sé!

Amalia: \{risas\}

Niños a coro: (???) [Discuten.]

Niño: cuando lo precise maestra $\backslash$ (Refiriéndose a la mediadora.) \| cuando lo precise maestra $\backslash$

Niños a coro: (???) [Continúan intercambiando entusiasmados.]

Niño: cuando lo precise maestra \[26.05.2015]

Por otra parte, las respuestas de los niños antes y después de la lectura se produjeron también espontáneamente, de manera desordenada, superponiéndose unas a otras lo que dificultó su apreciación para la investigación.

Algunos niños también se atrevieron a hacer algunas preguntas a la mamá lectora buscando aclarar aspectos puntuales del cuento, como las de estos ejemplos. En todos los casos, la mediadora accedió a responderles:

Patricia: [le.] un eno::rme $\backslash \mid$ eno::rme eno::rme eno::rme ${ }^{69}$ [enf.] $\backslash \mid$ monstruo apareció $\backslash$

Niña: [enf.] ¿monstruo? | ¿monstruo? [Asombrada.]

Patricia: imonstruo::! \{recorre el salón mostrando las ilustraciones <15>\} [26.05.2015]

Niño: ¿es el ratón o el topo?

Patricia: es el conejo \[28.07.2015]

En Los secretos de Abuelo Sapo llamó la atención el siguiente suceso en el que los niños se acoplaron a la dinámica lúdica planteada por el libro (que posee una estructura retahílica) y acompañaron a la mediadora en su lectura:

Patricia: iah! vamos a seguir con el cuento \| capaz que sí que alguien dijo que había una tortuga \| nosotros no sabemos \¿ta? || \{recorre el salón mostrando las ilustraciones $<15>$ \} ipobre sapo! \\| se

\footnotetext{
${ }^{69}$ La palabra enorme no está reiterada en el texto.
} 
va corriendo pero despavorido \|| Sapito \|estaba escondido entre los arbustos / temblando de miedo $\backslash \|$ pero recordó los secretos de su abuelo $\backslash \|$ ser valiente $y$ astuto $\backslash \mid=\ldots . . .=$

Niños a coro: $=\ldots . . .=$ iser valiente $y$ astuto! $\backslash[$ Al unísono con la mediadora.] [26.05.2015]

\section{En resumen:}

Las intervenciones de los niños y las de la mediadora fueron cuantitativamente equitativas en ambas sesiones. Tanto en Los secretos de Abuelo Sapo como en Una cena elegante se registraron momentos muy participativos entre todos los actores. Los niños, por su parte, protagonizaron intervenciones e intercambios espontáneos de modalidad monologal o dialógica que la mediadora no solo no sancionó, sino que también, en algunas ocasiones, festejó.

Patricia realizó unas pocas preguntas después de ambas lecturas y, también, antes de comenzar a leer Una cena elegante; las respuestas de los niños a estas preguntas fueron acotadas en cantidad y se produjeron en forma desordenada, no pudiendo ser valoradas cabalmente para la investigación. Algunos niños realizaron también preguntas a la mediadora que esta accedió a responder.

En algún pasaje de Los secretos de Abuelo Sapo, los niños se acoplaron a la lectura de la mediadora, anticipándose a la retahíla de este cuento.

El entusiasmo de los niños ante los textos que Patricia les leyó se expresó a lo largo de las dos sesiones, tanto en forma individual como colectiva.

\subsubsection{Respuestas de los niños}

\section{Respuestas de los niños en las sesiones de lectura de Patricia}

En el cuadro que se exhibe a continuación podrá observarse la clasificación y cuantificación de las respuestas de los niños en las sesiones de esta mediadora:

\begin{tabular}{|l|c|c|c|c|c|c|}
\hline & \multicolumn{2}{|c|}{ Los secretos de Abuelo Sapo } & \multicolumn{3}{c|}{ Una cena elegante } \\
\hline & $\begin{array}{c}\text { Durante la } \\
\text { lectura }\end{array}$ & $\begin{array}{c}\text { Después } \\
\text { de la } \\
\text { lectura }\end{array}$ & Total & $\begin{array}{c}\text { Durante la } \\
\text { lectura }\end{array}$ & $\begin{array}{c}\text { Después } \\
\text { de la } \\
\text { lectura }\end{array}$ & Total \\
\hline $\begin{array}{l}\text { Expresiones de } \\
\text { entusiasmo }\end{array}$ & 11 & 4 & 15 & 16 & 1 & 17 \\
\hline $\begin{array}{l}\text { Referencias literales } \\
\text { al texto o a las } \\
\text { imágenes }\end{array}$ & 37 & 0 & 37 & 38 & 0 & 38 \\
\hline $\begin{array}{l}\text { Referencias } \\
\text { inferenciales al texto } \\
\text { o a las imágenes }\end{array}$ & 63 & 0 & 63 & 36 & 0 & 36 \\
\hline $\begin{array}{l}\text { Referencias } \\
\text { composicionales }\end{array}$ & 0 & 0 & 0 & 1 & 0 & 1 \\
\hline $\begin{array}{l}\text { Respuestas } \\
\text { intertextuales o } \\
\text { interculturales }\end{array}$ & 3 & 0 & 3 & 1 & 0 & 1 \\
\hline
\end{tabular}




\begin{tabular}{|l|c|c|c|c|c|c|}
\cline { 6 - 7 } $\begin{array}{l}\text { Referencias } \\
\text { personales }\end{array}$ & 4 & 2 & 6 & 14 & 0 & 14 \\
\hline $\begin{array}{l}\text { Referencias } \\
\text { vivenciales }\end{array}$ & 0 & 4 & 4 & 0 & 1 & 1 \\
\hline Total & 118 & 10 & 128 & 106 & 2 & 108 \\
\hline
\end{tabular}

El entusiasmo de los niños ante los textos que Patricia leyó se expresó a lo largo de las dos sesiones, tanto en forma individual como colectiva, tal como puede observarse a continuación:

Patricia: ini un poquito! \||¿ंun bocado? | preguntó Abuelo \| ¿no prefieres un banquete? iclaro que sí! respondió la tortuga \| hace poco / | [enf.] una apetitosa culebra / | pasó por acá \| si te apresuras / | la puedes atrapar \/ igracias por el consejo! dijo la tortuga \| y se fue rápido a cazar a la culebra Niño: iguau::! \

Niños a coro: (???) [Sorpresa.] [26.05.2015]

Patricia: apreciado quienquiera que viva acá \| aquí \| lamentamos haber entrado sin invitación / | pero nos perseguía un tejón espantoso y no teníamos / | dónde más escondernos \| las manza::nas \| lombri:: ces \|y raí::ces \

Niño: iag! [Desagrado.]

Patricia: estaban deliciosas $\backslash$ | igracias $\backslash \mid$ por una cena $\backslash \mid$ tan elegante! \

Niño: iguau! \[28.07.2015]

Las de referencia inferencial fueron el tipo de respuestas más frecuentes en Los secretos de Abuelo Sapo y las segundas en Una cena elegante:

Patricia: ¿es una serpiente? ¿ंes una tortuga? | vamo[s] a ver \| a ver \[Da tiempo para que los niños discutan las hipótesis sobre el próximo personaje.] <15>

Niño: ¿a ver? ¿a ver?

Niño: es una tortuga $\backslash \|$ es una tortuga totalmente $\backslash \|$ totalmente de acuerdo que es una tortuga $\backslash \mid$ por la forma de la boca $\backslash$

Niños a coro: (???) (Piden ver las ilustraciones.)

Niño: [enf.] es una tortuga es una tortuga \

Niño: ino! \| [enf.] no es una tortuga \

Niño: por la forma de la boca \

Niño: [enf.] es una tortuga \

Niño: no hay duda \

Niño: [enf.] no es una tortuga $\backslash$

Niña: [enf.] una víbora [26.05.2015]

Patricia: aterrizó exactamente / donde había comenzado \|en su propia madriguera \| imenos mal! / | illegué a casa! \| exclamó Tejón \| para qué quiero una cena elegante de todas formas $\backslash$ | tengo bastante / buena comida aquí mismo \\{recorre el salón mostrando las ilustraciones $<20>\}[\ldots]$

Niño: [enf.] se comieron todo \}

Niño: [enf.] y se fueron desapareciendo \}

Niña: [enf.] y se fueron escapando \

Niño: [enf.] y se fueron escapando y se comieron todo $\backslash$ 
Niño: [enf.] se le escaparon los sabandijas \}

Niño: [enf.] se comieron todo $\backslash$

Niña: [enf.] qué porquerías \[28.07.2015]

Estas respuestas se produjeron generalmente frente a las ilustraciones que se anticipaban al texto o frente a la falta de conocimientos previos de los niños para interpretarlas (a propósito de esto, el dibujo del tejón en Una cena elegante les causó gran desconcierto pues no conocían este animal).

También en ambas sesiones se registraron respuestas referenciales como las de estos ejemplos:

Patricia: en ese preciso momento / | apareció una culebra \

Niño: iqué te dije! \

Niño: es una especie de serbiente (sic) \

Niño: [enf.] es una serpiente \[26.05.2015]

Patricia: entonces \| Tejón salió de su madriguera a rastras / | y se puso ávido / | a buscar su cena elegante $\backslash\{$ recorre el salón mientras muestra las ilustraciones $<15>\}$

Niño: salió el tejón a buscar la comida \

Niña: no eso es un topo \[28.07.2015]

... respuestas personales, como estas que se aprecian a continuación:

Patricia: isí! \| estaba asustado \| nunca en su vida había visto una criatura más espantosa \| intentó escapar $\backslash \mid$ pero el monstruo lo atrapó $\backslash\{$ recorre el salón mostrando las ilustraciones $<20>$ \} [...]

Niña: ahora sí \| que se pone bueno el cuento [26.05.2015]

Patricia: otra vez Tejón / | quedó un poco desilusionado \| pero no por mucho tiempo pues pronto espió un conejo que pasaba caminando \\{recorre el salón mostrando las ilustraciones $<20>\}[\ldots]$

Niños a coro: (???) [Expresan pena.]

Niño: ipobre! \[28.07.2015]

... y, marginalmente, respuestas interculturales, como estas:

Patricia: Sapito $\backslash \mid$ saltó de los arbustos $\backslash \mid$ \{recorre el salón mostrando las ilustraciones $<20>\} \backslash \mid$ io::h Abuelo! gritó [enf.] \| fuiste ta::n astuto! \| iestuviste maravilloso! \ ||Abuelo Sapo sonrió lleno de alegría \| igracias! le dijo \| ahora / | el tercer / | y último secreto \|| [le. pero antes de que pudie::ra decir otra palabra:: \\{recorre el salón mostrando las ilustraciones $<20>\}[\ldots]$

Niño: $=\ldots . . .=[$ enf.] un puma $\backslash$

Niño: [enf.] un camaleón \

Niño: [enf.] los pumas son diferentes $\backslash[26.05 .2015]$

Patricia: ¡¿tú?! \i¿comerme que a mí?! \se burló el caballo \ino creo! \\{recorre el salón mostrando las ilustraciones $\}<20>\}[\ldots]$

Niño: ipa! [enf.] mirá lo que es el caballo son terribles \[28.07.2015]

Entre estas llamó la atención esta intervención de un niño, que en Los secretos de Abuelo Sapo, aludió al pacto ficcional narrativo:

Patricia: en un cuento todo puede pasar $\backslash$

Niño: sí \es lo que iba a decir \| así que no es raro \[26.05.2015] 
Por último, tanto en Los secretos de Abuelo Sapo como en Una cena elegante las respuestas vivenciales se concentraron durante la conversación sobre lo leído, a propósito de las preguntas de Patricia:

Patricia: ¿ ¿ustedes son astutos y valientes? [...]

Niña: yo no \}

Patricia: ¿cuando la ocasión lo amerita? | ¿eh?

Niño: de vez en cuando \[26.05.2015]

Patricia: ¿a alguno le pasó una vez así? | que tenemos algo en casa / | y queremos algo más \y no nos damos cuenta que en casa tenemos lo que necesitamos? | ¿sí? | nos pasa a veces ¿no?

Niño: mi padre se pensó que faltaba algo pero...- \[28.07.2015]

En algunos pasajes, en ambas sesiones, los participantes expusieron sus puntos de vista en forma entusiasta, sin darse la posibilidad de escucharse entre ellos, tal como puede observarse en las citas de las respuestas inferenciales que se encuentran más arriba, en este mismo apartado. En cambio, en otros momentos, sí puso observarse una retroalimentación y un crecimiento en las respuestas de los niños:

Patricia: $=\ldots . . .=$ iser valiente $\mathrm{y}$ astuto! $\backslash \|$ vio unas bayas silvestres $/ \mid$ y decidió rápidamente lo que tenía que hacer $\backslash\{$ recorre el salón mostrando las ilustraciones $<10>\}$

Niño: bichitos de luz $\backslash[\ldots]$

Niño: unas mariquitas imirá! \\{señala la ilustración a su compañero\} [...]

Niño: imirá! [enf.] aquí hay unas mariquitas $\backslash$

Niño: las mariquitas se comen al gigante ese \[26.05.2015]

Patricia: aterrizó exactamente / donde había comenzado \| en su propia madriguera \| imenos mal! / | illegué a casa! \| exclamó Tejón \|para qué quiero una cena elegante de todas formas $\backslash$ | tengo bastante / buena comida aquí mismo \\{recorre el salón mostrando las ilustraciones $<20>$ \}

Niños a coro: (???)[Expresiones de sorpresa.]

Niño: [enf.] qué sabandija \

Niño: [enf.] se comieron todo \}

Niño: y se fueron desapareciendo \

Niña: [enf.] y se fueron escapando \

Niño: [enf.] y se fueron escapando y se comieron todo $\backslash$

Niño: [enf.] se le escaparon los sabandijas \}

Niño: [enf.] se comieron todo $\backslash$

Niña: [enf.] qué porquerías \[28.07.2015]

\section{En resumen:}

En ambas sesiones de Patricia, las respuestas literales e inferenciales fueron las de mayor frecuencia, seguidas por las personales, mientras que las vivenciales e interculturales fueron acotadas.

\section{E. Recuerdos de los niños sobre Una cena elegante}

Para el análisis de este ámbito se consideraron los recuerdos de los niños sobre la lectura de Una cena elegante, del 28 de julio, en la entrevista del 29 de setiembre. 


\begin{tabular}{|l|c|}
\hline Aspectos recordados & Cant. \\
\hline Título & 0 \\
\hline Argumento & 4 \\
\hline Marco & 3 \\
\hline Acción narrativa & 0 \\
\hline Conversación & 1 \\
\hline No recuerdan & 0 \\
\hline
\end{tabular}

De esta lectura, cuatro niños recordaron algún aspecto del argumento del cuento:

Abel: era divertido

Iliana: : era que:: | un mapache había hecho todo comida...- | en todo comida elegante || pero creo que era...- | y después todos los animales y se le comieron toda la comida [...] todos esos animales que:: hacía comida |pero...- | pero él no les daba por eso fueron y:: | para vengarse | se comieron la comida de él

Estiven: porque::...- e::I...- | el animal no me acuerdo qué era | y siempre iba a todos lados | a ver si conseguía una...- | algo para comer [...] y:: cuando:: lo...- | cuando encontraba algo para comer lo...| los ani...- | los veía a los animales | y los animales se les escapaban | y todos iban a la madriguera de él

Axel: me acordé que:: ...- |¿ंque era un mapache el de la...-? [...] un tejón | que el tejón tenía comida | y:: no le gustaba siempre la misma | y quería comer algo bueno | y siempre que quería comer un animal pasaba algo [29.09.2015]

Como puede observarse en estas citas, Estiven, lliana y Axel mencionaron personajes del cuento; específicamente estos dos últimos recordaron a su protagonista como un mapache.

Por último, un niño, Michael, recordó un comentario que Patricia realizó al inicio de la sesión:

Sandra: ¿qué te acordás de ese cuento?

Michael: de una cena elegante con velas y...-<10> y todas esas cosas

... y únicamente Priscilla, entre los entrevistados, no recuperó recuerdos sobre Una cena elegante, confundiendo este cuento con otro de la misma autora: El estofado del lobo.

\section{En resumen:}

En relación con la lectura analizada, cuatro niños recordaron algún detalle del argumento del cuento, tres recordaron personajes y, específicamente, mencionaron a su protagonista. 


\section{F. Valoraciones de los niños sobre Patricia}

Patricia recogió valoraciones positivas de todos los niños encuestados.

\begin{tabular}{|l|c|c|}
\hline & Cant. opiniones & \\
\hline Centrada en el vínculo familiar en general & 4 & 10 \\
\hline Centradas en la persona de la mediadora & 19 & 21 \\
\hline$\left({ }^{*}\right)$ Centradas la lectura de la mediadora & 1 & \\
\hline $\begin{array}{l}\text { Centradas en la experiencia de lectura con la } \\
\text { mediadora }\end{array}$ & 55 & \\
\hline Centradas en el vínculo niño-libro & 55 & \\
\hline Total de opiniones relevadas & & \\
\hline
\end{tabular}

$\left(^{*}\right)$ Dentro de estas respuestas se constataron 8 que valoraron la modalidad de lectura de la mediadora y 4, los libros que leyó.

Los niños destacaron, en primer lugar, sus experiencias de lectura con esta mediadora, con opiniones como esta:

«A mí me gusta porque es divertido» [Nahuel]

En segundo lugar, apreciaron la lectura de la mediadora: su modalidad lectora, los libros que lee, sus enseñanzas:

«A mí me gusta porque narra bien» [Milagros]

«Cuenta cuentos graciosos» [Ariel]

En tercer lugar, los niños valoraron a la persona de la mediadora con opiniones como estas:

«Es divertida. Es buena. Es graciosa» [Elías]

Por último, solo un niño mencionó en la encuesta, en forma voluntaria, la lectura de Una cena elegante. La mayoría recordó los títulos leídos por otra mamá, Mónica, pues estos eran los de más reciente lectura para ellos, al momento de la encuesta.

\section{En resumen:}

Los niños de tercer año B de la escuela XXX valoraron en mayor medida su propia experiencia de lectura con la mediadora, en segundo lugar, su lectura, y por último, algunos aspectos de su persona.

\subsubsection{Conclusiones particulares sobre el cuarto caso}

Para Patricia, el estar en contacto con los niños, transmitirles el gusto por la lectura y el deseo de colaborar con la escuela a la que concurre su hijo constituyeron las principales motivaciones que la llevaron a actuar como mediadora. También estuvieron presentes en ella las vivencias cargadas de 
afecto, el reconocimiento obtenido y la gratificación resultante de la entrega desinteresada de su tiempo, disponibilidad y lecturas a los niños.

La alternancia de las mediadoras en las diferentes clases de la escuela XXX y el hecho de que todas ellas fueran madres, dificultó que algunos niños pudieran recordar su nombre con precisión o identificarla - muchos se refirieron a ella, vagamente, como «la madre de... »-. Es por eso que su aporte, al igual que el de Rosario, no fue individualizado por los niños en forma espontánea.

Patricia fue construyendo su rol a partir de la reflexión sobre la experiencia adquirida durante sus dos años de permanencia en él: reconoció la importancia del mutuo conocimiento entre ella y los niños para el ejercicio de la mediación; formó sus propios criterios de selección de los libros según las características del grupo al que fue a leer, y consideró la incidencia de su aporte y el de sus compañeras del equipo comunitario de lectura a la formación de los niños como lectores.

En cuanto a su hacer, Patricia delimitó con claridad los distintos momentos en sus sesiones, haciendo que la transición entre estos no fuera percibida como un quiebre. Esta mamá también se caracterizó por conversar con los niños sobre el tema del cuento antes de comenzar a leer para introducirlos en su lectura, en busca de generar expectativas sobre lo leído.

Lo lúdico estuvo muy presente en las sesiones de Patricia; este componente pareció ser muy necesario para ella, un fin en sí mismo:

Sandra: entonces lo que venía ahora | es cómo vivís esas actividades de lectura

Patricia: con alegría | con alegría sí || es media que es una fiesta | es una fiesta

Sandra: ¿y qué consejo le darías por ejemplo a un nuevo integrante [del equipo comunitario]?

Patricia: a::h que se deje llevar | que es fantástico que lo disfrute esto es un goce sí sí | no hay...- | no

hay fórmulas | es entregarse nada más [...] [20.10.2015]

... además de como un medio para captar la atención de los niños y mantenerlos atentos en sus lecturas.

Muchas de las acciones que desplegó Patricia en sus sesiones estuvieron orientadas a generar ese efecto lúdico. En este sentido, fueron funcionales a sus propósitos las acciones para generar expectativas sobre lo leído, que tuvieron una importante presencia cuantitativa en ambas sesiones y las que dejaron en evidencia su identidad. También en esta dirección operó la complicidad con la que festejó las divertidas ocurrencias de los niños.

Esta mediadora también estuvo también muy atenta a que los niños comprendieran sus lecturas. A este propósito fueron funcionales sus acciones de expansión, de dirigir la atención hacia detalles de las ilustraciones, de corrección de los errores de interpretación y hasta las dirigidas a reestablecer el orden para poder continuar con la lectura.

Los niños reconocieron ambas intencionalidades de Patricia y así lo manifestaron. Con respecto a la primera, diez niños destacaron en la encuesta, con matices, lo divertida que es ella, con opiniones como esta:

«Es graciosa y cuenta muy lindo» [Ariel]

En esta misma dirección, en la entrevista, Iliana logró recuperar esta característica:

Sandra: ¿y qué te acordás de Patricia leyendo?

Iliana: que era muy divertida 
Con respecto a la segunda, los niños recordaron, por ejemplo, que:

«Nos enseña moralejas» [Tomás]

En las sesiones de Patricia el momento de la lectura fue el más provechoso para la construcción de comprensión. El clima lúdico logrado por la mediadora, a través de sus acciones, constituyó un estímulo para que los niños comentaran en forma espontánea y construyeran en forma colaborativa y acumulativa su comprensión. Los niños respondieron a esta impronta con efusividad, pero también con acertadas interpretaciones sobre lo leído, y aunque en varias oportunidades la mediadora debió poner límites al desborde logró retomar el control y su atención para continuar con la lectura.

La escucha atenta de Patricia a los comentarios de los niños, sus acciones de aval y la no sanción a su espontaneidad también obraron en el mismo sentido, haciendo que se sintieran seguros de emitir sus opiniones y de intercambiar entre ellos, favoreciendo de esta manera la comprensión.

Las preguntas que la mediadora realizó tuvieron también un sesgo lúdico y pudieron haber sido un buen puntapié para iniciar la conversación sobre lo leído, aunque al no lograr que los niños se escucharan entre sí esta instancia se desaprovechó.

Esta mamá lectora, en su paso por tercer año B de la escuela XXX contó además con el apoyo de la maestra Amalia, quien siempre la recibió en su clase - tanto a ella como a Rosario-, con amabilidad. Sin llegar a establecer con ella complicidad, mostró una actitud positiva hacia su presencia, destacó y apoyó su labor:

Amalia: [...] Patricia realmente le pone este toque:: | más de narradora || entonces | despierta la intriga en los guri::ses | hace las pausas para que ellos intervengan [...] en Patricia se nota otra madurez | cuando lee [...] [13.10.2015] 


\section{CONCLUSIONES}

\subsection{Comparativa de los cuatro casos investigados}

En cuanto al ser de los mediadores...

Los cuatro sujetos investigados poseen un vínculo familiar con un niño de la escuela a la que concurren: Omar tiene a su nieta, Cecilia y Patricia a sus únicos hijos y Rosario, a uno de sus hijos.

Todos ellos se encuentran en distintas situaciones ocupacionales: Omar es jubilado, pero trabaja en forma esporádica; Patricia es trabajadora independiente, y Rosario y Cecilia trabajadoras dependientes. El concurrir a leer a la escuela ha constituido una opción para ellos que obedece a una motivación particular, al entender de esta tesista, más poderosa que el querer ocupar el tiempo libre.

Tres de los mediadores (Omar, Cecilia y Patricia) presentaron al momento del trabajo de campo dos años de permanencia en el rol, mientras que Rosario había ingresado en 2015 al equipo comunitario y por lo tanto no había cumplido un año lectivo en el mismo. Mientras que Rosario, Patricia y Omar venían realizando la tarea en forma asidua, en 2015, Cecilia se integró en forma tardía al equipo comunitario (aunque ya había participado con algunas lecturas en 2014). La relación entre la experiencia y la permanencia de los mediadores puede sintetizarse de la siguiente manera:

\begin{tabular}{|c|c|c|}
\hline & Permanencia & Experiencia \\
\hline Omar & + & + \\
\hline Cecilia & + & - \\
\hline Rosario & - & + \\
\hline Patricia & + & + \\
\hline
\end{tabular}

Al finalizar el trabajo de campo, todos los mediadores investigados habían concurrido a leer, además de a la clase de sus niños, a otros grupos de la escuela, de acuerdo con la organización interna de cada institución.

Con respecto a sus biografías lectoras, puede determinarse que Omar y Patricia presentan una trayectoria lectora continua, mientras que Cecilia y Rosario manifestaron tener una trayectoria discontinua; particularmente, el haber retomado la lectura en su vida adulta, en el caso de Rosario, se relaciona con su rol de mediadora. Los cuatro actores indagados se mostraron en la entrevista como lectores en actividad; a diferencia de Omar, Cecilia y Patricia, en Rosario no se pudo determinar sus preferencias lectoras, al no poder esta última mencionar qué textos leía específicamente. En este sentido, se encontraron en ella algunos rasgos que la caracterizan como «poco lectora» (Bahloul 2002). Entre las lecturas del agrado de Rosario parecieron tener gran peso los cuentos y relatos que leyó a los niños.

Omar y Patricia, los dos mediadores con mayor permanencia y experiencia en el rol -también los mayores en edad-identificaron hitos concretos en sus biografías que los marcaron en su formación como lectores: el primero, en el sistema educativo y la segunda en un círculo de lectura. Cecilia, en cambio, señaló que su formación lectora había iniciado en su hogar, bajo la influencia de su madre. 
Cada mediador se acercó a la mediación con propósitos personales diversos, además del de querer contribuir de una manera u otra con la formación de los niños. En Omar, Cecilia y Rosario estuvieron presentes, en la vivencia de su rol, algunos aspectos de sus biografías lectoras: así, los dos primeros intentaron revivir, de alguna manera, en el ejercicio de la mediación, las vivencias gratificantes en torno a la lectura de su infancia y adolescencia y Rosario intentó revertir su fracaso escolar, reconociendo las carencias que le dejó la escuela en su formación como lectora. A diferencia de los otros dos mediadores, esta última no tiene un pasado lector que evocar, en términos de nostalgia, en su práctica de la mediación. En este sentido, su ingreso al equipo comunitario de lectura estableció una ruptura con su historia escolar en la que reconoce haber estado «peleada» con los libros.

La valoración positiva sobre la lectura, personal y /o de su entorno, fue otro elemento común a todos los mediadores. En este orden, Omar destacó la importancia de la creación de hábitos de lectura en los niños; Cecilia, la presencia de libros en su hogar; Patricia manifestó su gusto por la lectura y Rosario, expresó que «los libros abren cabezas».

En cuanto a la apropiación del rol, los cuatro mediadores evidenciaron haber capitalizado y reelaborado su experiencia para aprender de ella y compartir sus saberes con otros mediadores. También en el ejercicio de su rol descubrieron el disfrute de los libros y lecturas e incrementaron su comprensión de lo leído junto a los niños.

En cuanto al hacer de los mediadores...

Los cuatro mediadores investigados realizaron una lectura fluida, que puede tipificarse como expresiva $(\rightarrow$ 1.2.5.1. «El mediador de lectura y la lectura en voz alta»). Las tres mediadoras introdujeron además otras variaciones: Cecilia, para representar las voces de los personajes, Rosario, en la velocidad de algunos fragmentos del cuento y Patricia incorporó gestos y desplazamientos para teatralizar algunos pasajes de sus lecturas.

Ninguno de los mediadores limitó su hacer únicamente a leer: todos ellos organizaron sus sesiones con momentos y rutinas prestablecidas e incorporaron acciones diversas que orientaron los intercambios e intervenciones de los niños.

Las acciones y rutinas preestablecidas les permitieron a los mediadores organizar su trabajo y ganar seguridad en su labor, y a los niños, conocer de antemano cómo se iban a desarrollar las sesiones y saber qué se esperaba de ellos, qué podían hacer y qué no.

Omar, Rosario y Patricia, en diferente medida, conversaron sobre lo leído antes de comenzar (es el caso de Patricia) o al finalizar sus lecturas. En Patricia y Omar, puede pensarse que las preguntas o temas de conversación posteriores a la lectura pueden haber sido producto de una planificación previa, pero únicamente en Omar pudo observarse un aprovechamiento de dichas instancias por parte de los niños.

En relación con las acciones desplegadas para la construcción del metatexto pudo constatarse también que los mediadores con mayor formación lectora de base, experiencia y permanencia: Omar, Patricia, desplegaron mayor cantidad de acciones y demostraron algún grado de planificación de sus sesiones.

Por otra parte, en Omar, Cecilia y Patricia pudo encontrarse una relación entre algunas de sus motivaciones para ejercer como mediadores y su hacer. Pero, si bien en este sentido Omar concretó en una «metodología» de conversación con los niños su interés por dejarles un legado moral en cada una de sus lecturas, Patricia generó expectativas entre ellos para cumplir con sus objetivos lúdicos, y Cecilia desplegó una modalidad dialógica, funcional a su intención de ayudar a los niños a comprender lo leído, no puede establecerse que esta confluencia haya sido prevista por los mediadores. 
Cabe mencionar que la escasez de acciones observadas en las sesiones de Rosario parece tener que ver además de con su menor experiencia en el rol, con su escasa formación como lectora; al respecto, ya se señaló la ausencia de sus respuestas ante las interrogantes que los niños le plantearon.

En cuanto a las respuestas de los niños...

En todas las sesiones analizadas se registraron intervenciones e intercambios entre los niños, muchos de estos en forma espontánea. Estos comentarios no fueron censurados por los mediadores -en el caso de Patricia, además, fueron estimulados - , lo que ayudó a que los niños generaran confianza hacia ellos, condición de base para que la conversación sobre lo leído resultara fructífera. La no censura a los niños, al igual que el conjunto de acciones que desplegaron los cuatro actores indagados, brindaron las condiciones para que, a partir de la conversación, todos los participantes construyeran sentido sobre lo leído en forma dialógica ( $\rightarrow$ 1.2.5.2. «El mediador de lectura y la conversación sobre lo leído»).

Los niños reconocieron la entrega del tiempo y afecto del abuelo y las tres mamás en estas lecturas compartidas y los retribuyeron con su participación comprometida; sus preguntas, intervenciones e intercambios reflejaron ese compromiso.

En cuanto a los cuentos leídos ad hoc para la investigación, aquellos niños que pudieron recordar algún aspecto sobre aquellos al momento de la entrevista retuvieron principalmente su argumento. Como un dato al margen, podría creerse que, en el caso de Omar, la relectura incidió en el recuerdo de los niños -es el caso de la mención al título Un puñado de semillas-, al igual que las preferencias del mediador, en los cuentos de Quiroga, hecho que también se constató con Rosario y León de biblioteca. Pero dejando de lado estos datos, por demás insuficientes, en el marco de este trabajo solo pudo constatarse que los niños tienden a recordar los últimos títulos que les han leído.

La mayoría de los niños expresaron valoraciones positivas sobre los mediadores. En estas valoraciones, se destacaron las menciones a su modalidad de lectura, hecho que puede relacionarse con la influencia de este factor en la comprensión sobre lo leído, en las situaciones de lectura en voz alta. Los cuatro mediadores fueron valorados principalmente por las experiencias gratificantes de lectura de los niños junto a ellos. Esto permite sostener que la disposición a leerles puede tener una incidencia importante en las escenas de lectura protagonizada por los mediadores. En este sentido, la influencia de los aspectos vinculares entre el mediador y sus destinatarios emerge por sobre otros factores con fuerza en este estudio. Más allá del libro leído y de la experticia del mediador, en el marco de esta indagación, y para que acepten la mediación, a los niños parece interesarles, principalmente, quién acerca las historias, el modo en que lo hace y la circulación afectiva que se produce entre los actores involucrados.

\subsection{Conclusiones generales}

Esta investigación trató de los mediadores de lectura de la comunidad que concurren a leer a las escuelas públicas. De un abuelo jubilado y de tres madres trabajadoras. En los estilos que estos desarrollan puede reconocerse su impronta familiar y comunitaria y, en este sentido, puede decirse que el estilo de Omar es el de un «abuelo» que lee a sus «nietos», el de Cecilia, por su modalidad dialógica, el de una «mamá» que lee a sus hijos, y el de Patricia, el de una «animadora» comunitaria.

En los mediadores investigados pueden establecerse algunas dimensiones configurativas de sus estilos, a saber: 


\section{- Una dimensión experiencial}

La experiencia y permanencia en el rol constituyen variables de peso en la configuración de los estilos de los mediadores. En este sentido, la confianza ganada con la experiencia permitió a Omar, por ejemplo, introducir innovaciones en el esquema de sus sesiones y conducir en forma eficiente la conversación sobre lo leído (en la medida en que pudo hacer que los niños se escucharan entre sí y aprovecharan esta escucha atenta para construir comprensión en forma colaborativa). Este intento se observó también en Patricia, quien, sin embargo, en las sesiones presenciadas, no logró ordenar los intercambios entre los niños para que fueran aprovechados. También en los mediadores con mayor permanencia pudo observarse una relación entre las acciones desplegadas y las motivaciones por las cuales se acercaron a la función, aunque no pueda establecerse - como ya se indicó- una previsión al respecto. El factor experiencia puede también explicar, en parte, el incremento de las acciones de Cecilia y Rosario, entre sus primeras y segundas sesiones de lectura. Esta constatación reafirma las observaciones de Martín-Barbero y Lluch (2010) sobre la importancia del factor mencionado en la dimensión formativa de los mediadores.

\section{- Una dimensión personal}

En lo que podría nominarse como una dimensión personal de la mediación, los cuatro mediadores investigados manifestaron tener, además de propósitos de enseñanza, propósitos personales para ejercer la función, no vinculados en forma directa con la lectura, que los impulsaron a integrarse a los equipos comunitarios. Dentro de estos se ubica el interés de Omar por cumplir su rol de abuelo; el de Cecilia por acompañar, desde su rol de madre a su hija, en su trayectoria escolar; el «amor por los niños» de Patricia y el deseo de superación personal de Rosario. Cabe señalar que en la bibliografía relevada no se encontraron antecedentes sobre esta dimensión.

El deseo de servir a la comunidad en forma generosa se manifestó también en todos los mediadores de distintas maneras. En este orden, el ejemplo más emblemático es el de Rosario cuya labor como mediadora se ensambló con su labor como concejal municipal y en ese sentido, el estilo de esta mediadora asume una dimensión explícitamente política, aspecto señalado por Martín-Barbero y Lluch (2010) y por Álvarez Zapata y Castrillón (2009). A los ojos de esta tesista, no deja de ser elocuente cómo quien parece ser la lectora menos formada como tal manifieste este grado de consciencia frente a su rol.

\section{- Una dimensión formativa}

El ejercicio del rol permitió a los mediadores crecer en dos direcciones, en lo que podría configurar una dimensión formativa de la mediación: por un lado, en la capitalización de saberes sobre su hacer y por otro, en su formación como lectores.

En relación con el primer aspecto señalado, los cuatro actores indagados lograron capitalizar de alguna manera sus experiencias, que trasladaron a su hacer y compartieron con sus compañeros de tareas. Así, por ejemplo, Omar expresó sus saberes y vivencias en las reuniones del equipo comunitario de lectura; Cecilia descubrió la manera de lograr que la lectura fuera vivida como una experiencia de cercanía, al ubicarse en una silla pequeña para leerles a los niños de Inicial; Rosario pudo seleccionar y recomendar libros a sus compañeras y Patricia aprendió a captar la atención y el interés del auditorio más difícil: los niños de quinto y sexto.

Al ser convocados para leer en las escuelas, los abuelos y madres llevaron en sus mochilas, como únicos insumos, las vivencias lectoras idealizadas de su infancia y adolescencia, su bagaje lector y sus prácticas 
de lectura, personales o familiares. Estos saberes constituyeron la base sobre la que fueron construyendo su rol. En el andar, el intercambio con sus compañeros de equipo y con las maestras referentes, y la participación en la jornada anual de formación de mediadores emergieron como instancias formativas valiosas. Al respecto debe destacarse el aporte de esta última, dimensionado por Rosario, en su entrevista, y por Omar, en sus comentarios en las reuniones del equipo comunitario.

La incidencia de las reuniones de los equipos comunitarios en la formación de los mediadores merece su consideración aparte. Estas instancias no solo habilitaron la participación y los intercambios entre todos ellos, sino que se constituyeron en verdaderos espacios de construcción de aprendizajes y en el motor de transformación de sus prácticas. Esta observación concuerda con lo constatado por MartínBarbero y Lluch (2010) sobre la importancia del intercambio entre los mediadores como oportunidad constitutiva en su formación como tales.

Debe además mencionarse el sentido de pertenencia al equipo comunitario que, en el caso de la escuela XXX contribuyó al sostenimiento de sus integrantes en el rol. Este hecho no pudo constatarse en la escuela XX y tal vez pueda relacionarse con la mayor autonomía - brindada o conquistada - del equipo de la escuela XXX frente al de la escuela XX, indagación que quedó al margen de este estudio.

Las conversaciones sobre lo leído constituyeron, además, instancias formativas no solo para los niños sino también para los mediadores quienes se beneficiaron de los comentarios de los niños para ampliar su comprensión, tal como lo manifestaron Omar y Cecilia en sus entrevistas. Esta constatación se encuentra en sintonía con lo señalado por Martín-Barbero y Lluch (2010) quienes señalan la doble impronta del mediador como agente y como actor de los procesos formativos que promueve.

\section{- Una dimensión transformativa}

El ejercicio de la función de mediación impulsó a tres de los mediadores investigados a trascender su rol, expandiendo su cultura escrita. En este sentido, Omar comenzó a escribir cuentos para niños; Cecilia descubrió en la literatura infantil un nuevo corpus para disfrutar y Rosario identificó haber mejorado sus habilidades lectoras. Todos ellos además crearon en sus hogares nuevos escenarios de lectura, involucrando a sus familias en sus prácticas lectoras - tal es el caso de Omar, quien solicitó la opinión de sus nietos sobre los libros que leería en la escuela-, y de Rosario, con sus hijos, a quienes les ayudó a mejorar sus capacidades lectoras.

La mediación lectora también contribuyó a que los mediadores reflexionaran sobre sus aportes a la formación de los niños; de esta manera, Omar identificó su influjo en la formación de los hábitos lectores de los niños; Cecilia valoró el acercamiento de la familia a la escuela; Rosario, la incidencia de la lectura en la formación de ciudadanía y Patricia, el aporte de la serenidad de la lectura.

\section{- Una dimensión dialógica y afectiva}

En el ejercicio de la mediación lectora, los mediadores fueron descubriendo, además, el disfrute recíproco en las lecturas compartidas. Omar y Cecilia manifestaron su asombro frente a aquellas respuestas de los niños que no habían previsto, y Rosario y Patricia sintieron el reconocimiento y la gratitud de los niños por su labor.

Puede identificarse principalmente en los estilos de Cecilia y Patricia una impronta de lectura dialógica como la descrita en el apartado $\rightarrow$ 1.2.5.2. «El mediador de lectura y la conversación sobre lo leído».

La generación de confianza también fue dialógica. Al respecto, la creación de un clima lúdico a partir de las acciones para generar expectativas, la habilitación y la no censura de la participación de los niños y 
el aval a sus interpretaciones que caracterizaron los estilos de los mediadores investigados, contribuyeron al establecimiento de la confianza entre los participantes de la mediación.

\section{- Una dimensión disruptiva}

Los mediadores fueron configurando sus estilos no solo a partir de su bagaje previo y de la construcción de su rol, sino también en la negociación más o menos planificada, más o menos explícita, con las condiciones establecidas por las maestras que los recibían en sus clases. Estas, en mayor o menor medida, habilitaron o restringieron su hacer, asignándoles lecturas, momentos, espacios para leer, preceptuando qué debían hacer los niños frente a los mediadores... Frente a las condiciones iniciales, todos los mediadores buscaron la manera de cumplir con sus propósitos. Fue así como Omar logró leerles a los niños los cuentos de Horacio Quiroga; Rosario aprovechó la interrupción de Carmen para tomar la palabra en la sesión de La manta de las historias y Patricia introdujo gestos lúdicos en sus sesiones de lectura. Como ya se dijo más arriba, ningún mediador se limitó únicamente a leer; cada uno, a su manera, aportó un plus a su función.

Por último, este estudio prefigura a los mediadores de lectura investigados, por su origen familiar y comunitario, por la singularidad de los estilos pedagógicos que despliegan, como actores claves en la construcción del vínculo de los niños con la lectura. Estos sujetos, al compartir la diversidad de sus prácticas, brindan a los niños la posibilidad de vivenciarlas en su dimensión social y cultural y, a la lectura, como "acontecimiento de pluralidad», al colocar, al decir de Larrosa, "una experiencia junto a otra experiencia» (2011: 38-40). De esta manera concretan el propósito de otorgar a la lectura su perspectiva humana, democrática y democratizante y el de la literatura que, en tanto proceso de recepción y de actualización interpretativa del discurso (Mendoza Fillola, 2008), contribuye a que comprendamos la cultura, construyamos nuestra individualidad y el sentido de pertenencia a una comunidad, propósitos de la educación literaria.

Este trabajo, además, pretendió dar cuenta de la pertinencia y potencialidad de la noción de estilo de enseñanza introducida por Cols por la que se optó, para profundizar y singularizar a los mediadores de lectura de la comunidad que concurren a leer a las escuelas públicas de Uruguay. Siguiendo a la autora, en esta indagación pudo también constatarse las relaciones que se establecen entre la acción y la identidad de los actores investigados (Cols 2007: 350).

Para dar cierre a estas conclusiones, y como sucede en todos los procesos de construcción de conocimientos, en el camino que se recorre en busca de certezas, aparecen nuevas preguntas:

¿Cómo inciden los estilos de los mediadores de lectura de la comunidad en la formación de los escolares como lectores? En las respuestas y valoraciones de los niños pudo observarse, por ejemplo, un crecimiento de la comprensión e interpretación sobre lo leído, pero para poder determinar la incidencia de los mediadores en la formación lectora de los niños habría que ahondar en su contribución a la creación de hábitos lectores, en la consolidación de su comportamiento lector, entre otros aspectos. En estas configuraciones singulares que constituyen los estilos de los mediadores tal vez pueda situarse el punto de partida que permita indagar con mayor profundidad sobre este aspecto.

¿En qué se diferencian los estilos de estos mediadores de los de los docentes? ¿Cómo incide cada uno de ellos en la formación de los escolares como lectores? La bibliografía consultada opone el modelo lector docente, hegemónico y único validador de los sentidos que circulan en el aula en torno a la lectura con los diversos modos de leer de la comunidad. Queda comprobar si esta afirmación es cierta para la escuela uruguaya, para sus docentes y mediadores de la comunidad. 
¿Cómo incide el vínculo maestro-mediador en el hacer de este último? En el trabajo de campo pudo observarse la apertura de las maestras mayores hacia la labor de los mediadores y la desconfianza de las más jóvenes, en algunas anécdotas puntuales que habilitan a pensar sobre la incidencia de este vínculo en las acciones de los mediadores.

Por último, surge como tópico interesante indagar sobre el legado del sistema educativo en la formación lectora inicial de estos mediadores y ahondar sobre cuáles de esos saberes pueden haber incidido y cómo sobre sus estilos de mediación. 


\section{REFERENCIAS BIBLIOGRÁFICAS}

ACHILLI, E. (2005). Investigar en antropología social: los desafíos de transmitir un oficio. Rosario: Centro de Estudios Antropológicos en Contextos Urbanos, Facultad de Humanidades y Artes, Universidad Nacional de Rosario-Laborde.

Altet, M. (1993). « «Styles d'enseignement, styles pédagogiques»». En Houssaye, J. (dir.). La pédagogie: une encyclopédie pour aujourd'hui. Paris: ESF Éditeur, 89-102.

Álvarez ZaPATA, D. y S. Castrillón, S. (2009). «De la mediación de la lectura o cómo ir "más allá"». En Miret Bernal I. y C. Armendano (coords.). Lectura y bibliotecas escolares. Madrid: Organización de Estados Americanos para la Educación, la Ciencia y la Cultura, 83-92.

AMAT, V. (2010). «Compartir per construir. Aprendre a valorar àlbums a cicle inicial». En Articles de Didàctica de la Llengua i de la Literatura, (52), 32-41.

BAHLOUL, J. (2002). Lecturas precarias. Estudio sociológico sobre los «poco lectores». México: Fondo de Cultura Económica.

BAJOUR, C. (2009). «¿Qué tiene que ver la promoción de la lectura con la escuela?». En Imaginaria [en línea], (259). Recuperado de https: / /imaginaria.com.ar /2009 /11/¿que-tiene-que-ver-lapromocion-de-la-lectura-con-la-escuela / [07.2019].

BAJOUR, C. (2010). «La conversación literaria como situación de enseñanza». En Imaginaria [en línea], (282). Recuperado de https: / /imaginaria.com.ar /2010/11/la-conversacion-literaria-comosituacion-de-ensenanza / [07.2019].

BERMÚDEZ ANDERSON, K., et. ál. (s. d.). Mediación intercultural. Una propuesta para la formación. Barcelona-Sevilla: Junta de Andalucía-Generalitat de Catalunya. Recuperado de https: / lacoge.org / [07.2019].

BERNSTEIN, B. B. (1988). Clases, códigos y control. Madrid: Akal.

BEUCHAT, C. (2013). «Están los libros, están los niños... Consideraciones sobre la lectura en voz alta». En Unidad de Currículum y Evaluación. Bibliotecas Escolares CRA. A viva voz. Lectura en voz alta. Chile: Ministerio de Educación de Chile, 16-27.

Bressoux, P., M. Bru, M. Altet y C. Leconte-Lambert (1999). «Diversité des practiques d'enseignement à l'école élémentaire». Revue Française de Pédagogie, (126), 97-110.

BRITO A., P. Pineau y M. Southwell (coord.) (2012). «La lectura y la escritura en la escuela». Explora Pedagogía. República Argentina: Ministerio de Educación, Ciencia y Tecnología.

Briz GómEZ, A. (2004). ¿Cómo se comenta un texto coloquial? Barcelona: Ariel.

BoMBINI, G. (2002). «Sabemos poco acerca de la lectura». En Lenguas Vivas, año 2, (2), 28-32.

BOMBINI, G. (2008). «La lectura como política educativa». En Revista Iberoamericana de Educación [en línea], (46), 19-35. Recuperado de https: / /rieoei.org/RIE /article /view /714, DOI: https: / /doi.org/https: / /doi.org/10.35362/rie460714 [07.2019].

BONACCORSI, J. (2003). «Scénographie de la médiation de la lecture: une approche par croisement des niveaux d'observation». X. ${ }^{\circ}$ Colloque biláteral franco-roumain, CIFSIC, 1-8. Université de Bucarest. Recuperado de https: / /archivesic.ccsd.cnrs.fr/sic 00000711/document [07.2019]. 
BoURDIEU, P. y J. C. Passeron (1998). La reproducción. Elementos para una teoría del sistema de enseñanza. México, D.F.: Fontamara.

BouRdieU, P. y L. J. D. Wacquant (1995). Respuestas. Por una antropología reflexiva. México D.F.: Grijalbo.

BouRdieU, P. y R. Chartier (2010). «La lectura: una práctica cultural». En Bourdieu, P. El sentido social del gusto. Elementos para una sociología de la cultura. Buenos Aires: Siglo XXI, 253-273.

BRUNER, J. S. (1997). La educación, puerta de la cultura. Madrid: Visor.

Burgos, C., M. Corredor, I. Molina y C. Suárez (2002). «De los estilos pedagógicos y su impacto en el aprendizaje de los alumnos». En Civilizar (3), 22-30.

CALLEJAS, M. y M. Corredor (2002), «La renovación de los estilos pedagógicos: colectivos para la investigación y la acción en la universidad». En Revista Docencia Universitaria [en línea], vol. 3

(1), Recuperado de https: / /revistas.uis.edu.co /index.php/revistadocencia /article /view /1374 /1786 [07.2019].

CALLEJAS, M. et ál (2008). «La reflexión sobre los estilos pedagógicos y la innovación curricular en la universidad». En Praxis \& Saber, año 4, (8), 41-61.

CASCón SORIANO, P. (2000). «La mediación». Cuadernos de Pedagogía, (287), 72-76.

CASTEDO, M. (2011). «La formación de mediadores de la cultura escrita en el contexto latinoamericano». En Martínez Olivé, A. et ál. La formación de mediadores en el contexto educativo. Cuadernos Redplanes. CERLALC-Unesco, 30-36.

Cavallo, G. y R. Chartier (1998). «Introducción». En G. Cavallo y R. Chartier (dir.), Historia de la lectura en el mundo occidental. Madrid: Taurus.

CerLALC-Unesco (2011). Metodología común para explorar y medir el comportamiento lector. Bogotá: Cerlalc-Unesco.

CERRILLO, P. y S. Yubero (coords.) (2003). La formación de mediadores para la promoción de la lectura: Contenidos de referencia del Máster de Promoción de la Lectura y Literatura Infantil (1.a edición). Cuenca: Centro de Estudios y Promoción de la Lectura y la Literatura Infantil (CEPLI), Universidad de Castilla-La Mancha.

CERRILLO, P., E. Larrañaga y S. Yubero (2007). Libros, lectores y mediadores: la formación de los hábitos lectores como proceso de aprendizaje. Cuenca: Ediciones de la Universidad de Castilla-La Mancha.

CERRILLO, P., C. Cañamares (2008). «Recursos y metodología para el fomento de la lectura. El CEPLI». En Participación Educativa,(8), 76-92.

Cerrillo, P. (2009). «Sociedad y lectura. La importancia de los mediadores en lectura». Conferencia en la Fundación Gubelkian. Lisboa. Recuperado de https: / /www.oei.es/historico/fomentolectura llectura sociedad conocimiento cerrillo.pdf [07.2019].

CerRILLO, P. y S. Yubero (coord.). (2017). La formación de mediadores para la promoción de la lectura (2. ${ }^{\text {a }}$ edición). Cuenca: Centro de Estudios y Promoción de la Lectura y la Literatura Infantil, Universidad de Castilla-La Mancha. 
Chambers, A. (2007a). Dime. Los niños, la lectura y la conversación. México: Fondo de Cultura Económica.

Chambers, A. (2007b). El ambiente de la lectura. México: México: Fondo de Cultura Económica.

CHARTIER, A. M. y J. Hébrard (1994). Discursos sobre la lectura (1880-1980). Barcelona: Gedisa.

CHARTIER, A. M. (2004). Enseñar a leer y escribir. Una aproximación histórica. México: Fondo de Cultura Económica.

Chartier, A. M. (2009). «Lo que leen los jóvenes y las instituciones educativas: de la transmisión a la mediación». En Miret Bernal, I. y C. Armendano (coords.). Lectura y bibliotecas escolares. Madrid: Organización de Estados Iberoamericanos para la Educación, la Ciencia y la Cultura, 2748.

CHARTIER, R. (1995). Sociedad y escritura en la Edad Moderna. La cultura como apropiación. México: Instituto Mora.

CHARTIER, R. (1996). El mundo como representación. Estudios sobre historia cultural. Barcelona: Gedisa.

CHARTIER, R. (2000). Las revoluciones de la cultura escrita. Dialogo e intervenciones. Barcelona: Gedisa.

Colomer, T. (1996). «La didáctica de la literatura: temas y líneas de investigacción e innovación.» En Lomas, C. (ed.). La educación lingüística y literaria en la enseñanza secundaria, Barcelona: Horsori, 123-142.

Colomer, T. (2004). «El papel de la mediación en la formación de lectores». En Colomer, T., E. Ferreiro y F. Garrido. Lecturas sobre lecturas 1. México coedición Colombia: Conaculta-Asolectura, 9-29.

COLOMER, T. (2005). Andar entre libros. La lectura literaria en la escuela. México, D.F: Fondo de Cultura Económica.

Colomer, T. (2012). «Las discusiones infantiles sobre álbumes ilustrados». En Colomer, T. y M. Fittipaldi (coords.) La literatura que acoge: inmigración y lectura de álbumes. Barcelona: Banco del Libro-GRETEL-SM, 87-118.

Colomer, T y A. M. Margallo (2013). «Las respuestas literarias a álbumes ilustrados en contextos multiculturales». En En Linguarum Arena. Revista do Programa Doutoral em Didática de Línguas da Universidade do Porto, vol. 4, 21-37.

Cols, E. (2007). Estilos de enseñanza. Sentidos personales y configuraciones de acción tras la semejanza de la palabra (tesis de doctorado). Buenos Aires: Universidad de Buenos Aires.

CoLS, E. (2011). Estilos de enseñanza: sentidos personales y configuraciones de acción tras la semejanza de la palabra. Rosario: Homo Sapiens.

COOK-GUMPERZ, Y. (1998). La construcción social de la alfabetización. Barcelona: Ediciones Paidós.

CRUz Calvo, M. (2013). Lectura literaria en secundaria: la mediación de los docentes en la concreción de los repertorios lectores (tesis de doctorado). Barcelona: Universidad de Barcelona.

CucuzzA, H. y P. Pineau (2001). «El proyecto HISTELEA (Historia Social de la Enseñanza de la Lectura y la Escritura en la Argentina)». Recuperado de http: / /hum.unne.edu.ar /investigacion /educa Lalfa /UniversidaddeLuj\%E1n.pdf [07.2019]. 
CucuzzA, H. (dir.) y R. Spregelburd. (codir.) (2012). Historia de la lectura en la Argentina. Del catecismo colonial a las netbooks estatales. Buenos Aires: Ediciones del Calderón.

DE LEÓN, I. (2005). «Los estilos de enseñanza pedagógicos. Una propuesta de criterios para su determinación». En Revista de Investigación (57), 69-97.

DIAS-CHIARUTTINI, A. (2010). Le debat interprétatif dans l'enseignement de la lecture et de la littérature à l'ecole (tesis de doctorado). Lille: Université Lille 3-Charles de Gaulle.

DiAS-CHIARUTTINI, A. (2011). «Former les enseignants au débat interprétatif : places et enjeux des styles enseignants». En Repères [en línea] 44. Recuperado de https: / /journals.openedition.org /reperes /182, DOI: $10.4000 /$ reperes.182 [07.2019].

DiAs-CHIARUTTINI, A. (2012). «L'enseignement du français aux frontières de l'extrascolaire». En Recherches, 57. Recuperado de www.recherches. lautre.net /wp-content /uploads /2014/06 1023-039-Dias.pdf [07.2019].

DIAS-CHIARUTTINI, A. (2014). "Le débat interprétatif : un genre disciplinaire. Apports et limites d'un "outil" d'analyse de l'évolution d'une discipline scolaire. En Linguarum Arena. Revista do Programa Doutoral em Didática de Línguas da Universidade do Porto, vol, 5, 9-20.

DIAS-CHIARUTTINI, A. (2015). Le debat interpretatif dans l'enseignement du français. Berna: Peter Lang.

Díaz SunIco, M. (2005). «El concepto de placer en la lectura». Educación, Lenguaje y Sociedad, III, (3), 21-32.

FIORI, E. M. (1978). «Aprender a decir su palabra. El método de alfabetización del profesor Paulo Freire». En Freire, P. Pedagogía del oprimido. México, D.F.: Siglo XXI.

FERREIRO, E. (2004). «Acerca de las no previstas pero lamentables consecuencias de pensar solo en la lectura y olvidar la escritura cuando se pretende formar al lector». En Colomer, T., E. Ferreiro y F. Garrido. Lecturas sobre lecturas 1. México coedición Colombia: Conaculta-Asolectura, 9-29.

FERREIRO, E. (2006). «Acerca de rupturas o continuidades en la lectura». En Lecturas sobre lecturas 20. México: Conaculta, 45-65.

FEUERSTEIN, R., R.S. Feuerstein y L.H. Falik (2010). Beyond smarter: Mediated learning and the brain's capacity for change. New York: Teachers College Press.

FISH, S. (1998). «¿Hay algún texto en esta clase?». En Palti. E. J. (ed.). «Giro lingüístico» e historia intelectual». Buenos Aires: Universidad Nacional de Quilmes, 217-236.

FITTIPALDI, M. (2009). «El rol de los saberes previos, la mediación y el intercambio en la lectura de un álbum». Bellaterra Journal of Teaching \& Learning Language \& Literature, vol. 1,(1), 49-66.

FITTIPALDI, M. (2012). «La categorización de las respuestas infantiles ante los textos literarios. Análisis de algunos modelos y propuestas de clasificación». En Colomer, T. y M. Fittipaldi. La literatura que acoge: inmigración y lectura de álbumes. Barcelona: Banco del Libro-GRETEL-SM, 69-85.

FREIRE, P. (1978). Pedagogía del oprimido. México, D.F.: Siglo XXI.

FREIRE, P. (1986). La importancia de leer y el proceso de liberación. Madrid: Siglo XXI.

Fundación Mempo Giardinelli - Programa de Abuelas Cuentacuentos (s.d.). Abuelas Cuentacuentos [en línea]. Recuperado de http: / /www.fundamgiardinelli.org /abuelascuentacuentos/index.html [07.2019]. 
GarCía CANCLINI, N. (2015). «Leer en papel y en pantallas. El giro antropológico». En García Canclini et. ál. Hacia una antropología de los lectores. Madrid-México D.F.: Paidós-Fundación TelefónicaUniversidad Autónoma Metropolitana, 4-37. Recuperado de https: //publiadmin.fundaciontelefonica.com/index.php/publicaciones ladd descargas?tipo fichero=pdf\&idioma fichero=es es\&title=Towards+a+Reader\%C2\%B4s+A nthropology\&code=475\&lang=en\&file=Haciaunaantropologia. pdf [07.2019].

GenetTe, G. (1989). Palimpsestos. La literatura en segundo grado. Madrid: Taurus.

GUIDALI, M. (2014). Incidencia de un programa de alfabetización familiar: evaluación de actitudes y conocimientos sobre el mundo letrado en niños de sectores populares (tesis de maestría). La Plata: Universidad Nacional de La Plata.

HÉBRARD, J. (1989). «La escolarización de los saberes elementales en la época moderna». Revista de Educación, (288), 63-104.

HÉBRARD, J. (2000). «El aprendizaje de la lectura en la escuela: discusiones y nuevas perspectivas. Buenos Aires: Conferencia en la Biblioteca Nacional de Buenos Aires. Recuperado de http: / Lwww.r020.com.ar/extradocs/lectura.pdf [07.2019].

HÉBRARD, J. (2006). «La puesta en escena del argumento de la lectura: El papel de la escuela». En Encuentro con lecturas y experiencias escolares. Conferencia Flacso, Argentina, 12 de agosto de 2006. Recuperado de http: / /blogs.flacso.org.ar/claudiapeirano/files/2009/09 Lconferencia hebrard 12082006.pdf [06.2015].

InSTITUTO INTERDISCIPLINARIO DE LEITURA PUC-RIO CÁTEDRA UnESCO DE LEITURA PUC-RIO (2013). Projeto agentes de leitura: dando conta do caminho. Río de Janeiro.

KALMAN, J. (2003). «El acceso a la cultura escrita: la participación social y la apropiación de conocimientos en eventos cotidianos». Revista Mexicana de Investigación Educativa, 8, (17), 37 66.

KALMAN, J. (2008). «Discusiones conceptuales en el campo de la cultura escrita». Revista Iberoamericana de Educación [en línea], (46), 107-134. Recuperado de https: / /rieoei.org /historico/documentos/rie46a00b.pdf [07.2019].

Kaufman, A. M. (coord.) (2007). Leer y escribir: el día a día en las aulas. Buenos Aires: Aique.

KAUFMAN, A.M., D. LERNER y M. CASTEDO (2015). Alfabetización en la unidad pedagógica. Especialización docente de nivel superior. Documento transversal $n .^{\circ}$ 2. Leer y aprender a leer. Buenos Aires: Ministerio de Educación de la Nación.

LABORATORIO CONTEMPORÁneo de Fomento de LA LeCTURA (LCFL) (s.d.). Nuevas destrezas para los mediadores de lectura. Ministerio de Educación, Cultura y Deporte de España-Fundación Germán Sánchez Ruipérez. Recuperado de https: / /fundaciongsr.org/recursos-2 / [07.2019].

LAHIRE, B. (2004). «Introducción». En Lahire, B. (comp.) Sociología de la lectura. Del consumo cultural a las formas de la experiencia literaria. Barcelona: Gedisa.

LARROSA, J. (2011). La experiencia de la lectura. Estudios sobre literatura y formación. México: Fondo de Cultura Económica.

LeRneR, D. (2001). Leer y escribir en la escuela: lo real, lo posible y lo necesario. México: Fondo de Cultura Económica. 
MARGAllo, A. M. (2012). «Claves para formar lectores adolescentes con talento». En Leer.es. [en línea] Recuperado de https: / /leer.es/recursos /investigar /detalle /- /asset publisher /3fAFCQK7mwkO /content /claves-para-formar-lectores-adolescentes-con-talento-ana-mariamargallo [07.2019].

MARTínez BONAFÉ, J. (1988). «El estudio de casos en la investigación educativa». En Investigación en la Escuela (6), 44-50.

Martín-Barbero, J. (1987). De los medios a las mediaciones. Comunicación, cultura y hegemonía. México: Ediciones G. Gili.

MARTín-BARBero, J. y Lluch, G. (2010). Proyecto: lectura, escritura y desarrollo en la sociedad de la información. Bogotá (Colombia)-Valencia (España): CERLALC-Unesco.

MENdOZA FILLOLA, A. (2008). «La educación literaria: bases para la formación de la competencia lectoliteraria». Alicante: Biblioteca Virtual Miguel de Cervantes. Recuperado de http: / Lwww.cervantesvirtual.com/nd/ark: /59851/bmcf19d9 [07.2019].

MeEk, M. (2004). En torno a la cultura escrita. México D.F.: Fondo de Cultura Económica.

MEKIS, C. (s.d.). «Prólogo». En El mediador de lectura. La formación del lector integral. Santiago de Chile: IBBY Chile.

MEKIS, C. (2013). «El maravilloso papel del mediador del CRA». En Unidad de Educación Parvularia. Plan Nacional de Fomento de la Lectura, División de Educación General- Ministerio de Educación, Actas del Seminario Internacional ¿Qué leer? ¿Cómo leer? Perspectivas sobre lectura en la infancia, Santiago de Chile, 375-387.

Molina ITURRONDO, A. (2001). «Leer y conversar sobre los cuentos favoritos: la lectura dialógica en la alfabetización temprana». En Lectura y Vida. Revista Latinoamericana de Lectura, año 22 (1), 40-46.

Montero, M. L. (1990). «Los estilos de enseñanza y las dimensiones de la acción didáctica». En Palacios González J., Á. Marchesi y C. Coll (comps.) Desarrollo psicológico y educación III. Madrid: Alianza Editorial, 273-296.

MORENO, C. et ál (2014). «Impacto del estilo pedagógico integrador en los estudiantes de licenciatura en educación básica de la Facultad de Estudios a Distancia». En Formación Universitaria, vol. 7 (6), 37-44.

MUNITA, F. y E. Riquelme (2009). «La arquitectura de la ficción y el lector infantil: conjeturas sobre el proceso de articulación en la comprensión literaria». Estudios Pedagógicos, vol. 35(2), 261-268.

MUNITA, F. y M. Manresa (2012). «La mediación en la discusión literaria». En Colomer, T. y M. Fittipaldi (coords.) La literatura que acoge: inmigración y lectura de álbumes. Barcelona: Banco del LibroGRETEL-SM, 119-142.

MUNITA, F. (2014). El mediador escolar de lectura literaria. Un estudio del espacio de encuentro entre prácticas didácticas, sistemas de creencias y trayectorias personales de lectura (tesis de doctorado). Barcelona: Universidad Autónoma de Barcelona.

PASTOR DE JONES., I. (2017). «Relación entre estilos de enseñanza y tipos de personalidad en docentes de nivel superior». En Perspectiva Educacional. Formación de Profesores, vol. 56, (1), 62-83. 
PATTE, G., (2011). Déjenlos leer los niños y las bibliotecas. México, D.F: Fondo de Cultura Económica.

Pérez Camacho, C. y A. López Ojeda (2015). «Los usos sociales de la lectura: del modo tradicional a otras formas colectivas de leer». En García Canclini et. ál. Hacia una antropología de los lectores. Madrid-México: Ediciones Culturales Paidós, Fundación Telefónica, Universidad Autónoma Metropolitana-Unidad Iztapalapa, 41-104.

PetIT, M. (1999). Nuevos acercamientos a los jóvenes y la lectura. México. Fondo de Cultura Económica.

Petit, M. (2001). Lecturas: del espacio íntimo al espacio público. México. Fondo de Cultura Económica.

PETIT, M. (2005). «Lectura y familia». En Petit, M. Lecturas sobre lecturas 16, México D.F.: ConacultaDirección General de Publicaciones, 9-22.

PETIT, M. (2016). Leer el mundo. Experiencias actuales de transmisión cultural. México, D.F.: Fondo de Cultura Económica.

PINEAU, P. (2001). "¿Por qué triunfó la escuela? o la modernidad dijo: "Esto es educación" y la escuela respondió: "Yo me ocupo". En Dussel, I., M. Caruso y P. Pineau. La escuela como máquina de educar. Tres escritos sobre un proyecto de la modernidad. Buenos Aires: Paidós, 28-52.

Poulain, M. (2011). «Una mirada a la sociología de la lectura». En Perfiles Educativos, vol. 33, (132), 193-202.

Pozo, J. I. (2010). Teorías cognitivas del aprendizaje. Madrid: Ediciones Morata.

PRIVAT. (2001). «Socio-lógicas de las didácticas de la lectura». En Lulú Coquette, año 1, (1), 47-63.

Programa la Escuela lee Más (2007). Los docentes como mediadores de lectura. La Plata: Dirección General de Cultura y Educación de la Provincia de Buenos Aires.

ProLEE (2018). Biblioteca Solidaria. Montevideo: ANEP-Codicen.

REINHARD, W. (1998). «¿Hubo una revolución en la lectura a finales del siglo XVIII?». En Cavallo, G. y R. Chartier. Historia de la lectura en el mundo occidental. Madrid: Taurus, 435-472.

ReNDón URIBE, A. (2013). «Hacia una conceptualización de los estilos de enseñanza». Revista Colombiana de Educación, (64), 175-195.

RIQUELME, E. y F. Munita (2011). «La lectura mediada de literatura infantil como herramienta para la alfabetización emocional». En Estudios Pedagógicos, XXXVII (1), 269-277).

RIQUELME, E. (2013). La lectura mediada de literatura infantil como herramienta para el desarrollo de competencias emocionales (tesis de doctorado). Universidad Autónoma de Madrid: Madrid.

ROBLEDO, B. H. (s.d.). El mediador de lectura. La formación del lector integral. Santiago de Chile: IBBY Chile.

RocKWELL, E. (1991). «Palabra escrita, interpretación oral: los libros de texto en clase». En Infancia y Aprendizaje (55), 29-43.

RocKWELL, E. (2001a). «La lectura como práctica cultural. Conceptos para el estudio de los libros escolares.» Educação e Pesquisa, vol. 27 (1), 11-26.

ROCKWELL, E. (2001b). «En torno al texto: tradiciones docentes y prácticas cotidianas». En Rockwell, E. (coord.). La escuela cotidiana. México: Fondo de Cultura Económica, 198-222. 
SeHRINGER, C. y B. Griotti (2002). «En qué pensamos cuando se trata de formar mediadores que "sepan seleccionar" literatura para chicos?». En Lectura y Vida. Revista Latinoamericana de Lectura, año 23 (1), 46-51.

SILVA-DíAZ, M. C. (2005). Libros que enseñan a Leer: álbumes metaficcionales y conocimiento literario. (tesis de doctorado). Barcelona: Universidad Autónoma de Barcelona.

SIMONS, H. (2011). El estudio de caso: teoría y práctica. Madrid: Morata.

SIRO, A. (2005). «El desafío de una continuidad: Una mirada sobre la intervención del mediador en la formación de lectores de álbumes». En Silva-Díaz. M y A. Siro. Lecturas sobre lecturas 17, México D. F.: Conaculta-Dirección General de Publicaciones, 47-91.

SIX, J. F. (1997). Dinámica de la mediación. Barcelona: Paidós.

SOLER, M. (2003). «Lectura dialógica. La comunidad como entorno alfabetizador». En Teberosky, A. y Soler, M. (eds.). Contextos de alfabetización inicial. Barcelona: Horsori, 47-63.

STAKE, R. E. (2013). Investigación con estudio de caso. Madrid: Morata.

SuÁrez MANTILLA, C. (comp.) (2008). Los estilos pedagógicos y su impacto en el aprendizaje de los alumnos (2001-2008). Bogotá: Fondo de Publicaciones de la Universidad Sergio Arboleda.

TÉBAR BeLMONTE, L. (2011). El profesor mediador del aprendizaje. Bogota: Magisterio.

TÉBAR BELMONTE, L. (2016). «La función mediadora de la educación». En Revista de la Universidad de La Salle, (70). Recuperado de https: / /revistas.lasalle.edu.co /index.php /Is /article /view /4019 [07.2019].

Tough, J. (1979). Lenguaje, conversación y educación. El uso curricular del habla en la escuela desde los siete años. Madrid: Visor.

TUSÓN VALLS, A. (2002). «El análisis de la conversación: entre la estructura y el sentido». En Estudios de Sociolingüística, vol. 3 (1), 133-153.

VALLS, R., M. Soler y R. Flecha (2008). «Lectura dialógica: interacciones que mejoran y aceleran la lectura». En Revista Interamericana de Educación (46), 71-87.

VYGOTSKY, L. (1979). El desarrollo de los procesos psicológicos superiores. Barcelona: Crítica.

WeLLS, G. (dir.) (2003). «La cuestión de la investigación dialógica». En Acción, conversación y texto. Aprendizaje y enseñanza a través de la investigación. Sevilla: MCEP Sevilla.

WitTrock, M. (comp.) (1997). La investigación de la enseñanza III. Barcelona: Paidós- Ministerio de Educación y Ciencia. 
Anexos 



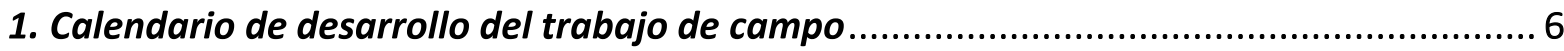

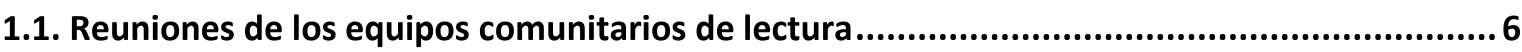

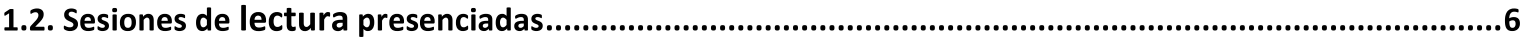

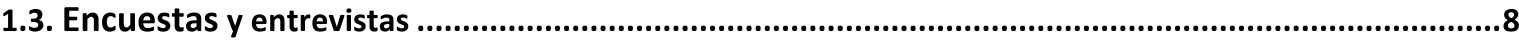

2. Instrumentos para la obtención y el registro de datos ............................................... 9

2.1. Pauta de observación de las sesiones de lectura......................................................................................9

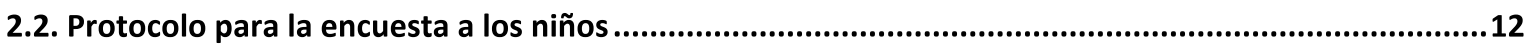

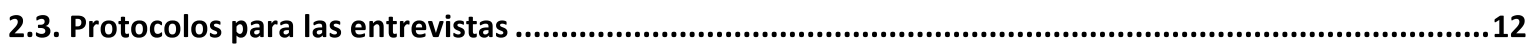

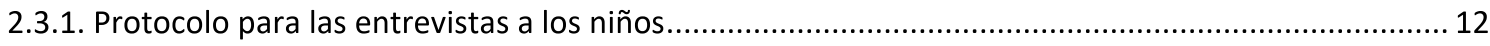

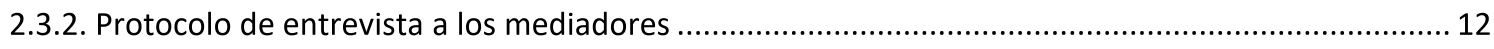

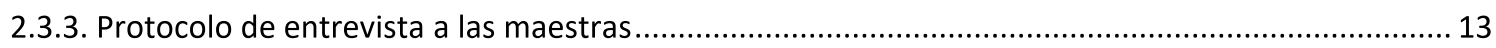

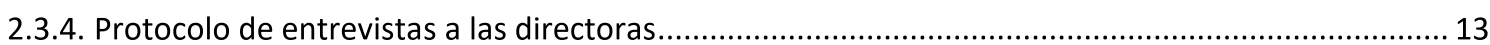

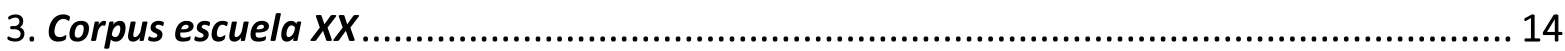

3.1. Entrevista a María, directora de la escuela XX.................................................................... 14

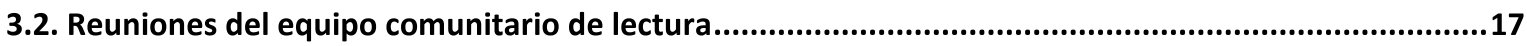

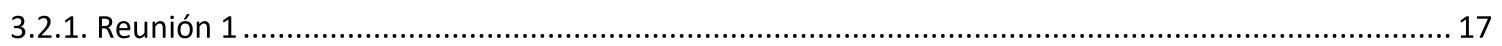

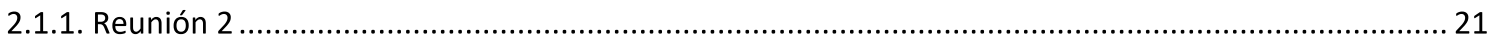

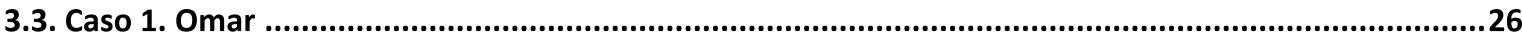

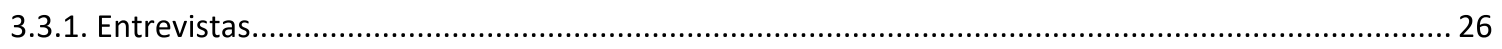

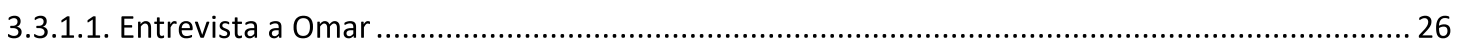

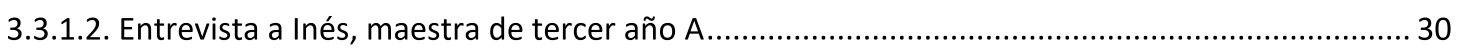

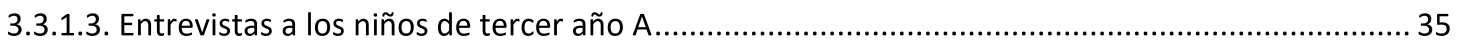

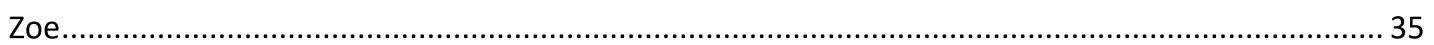

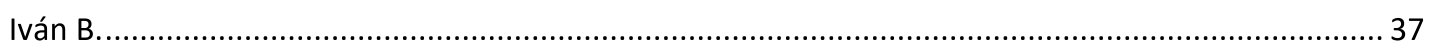

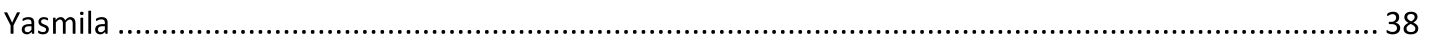

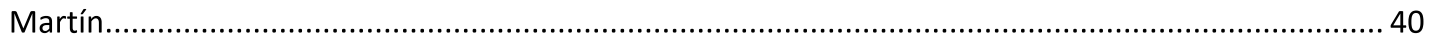

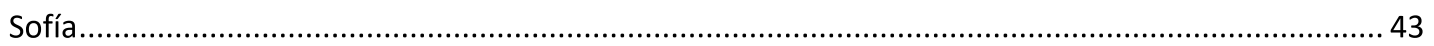

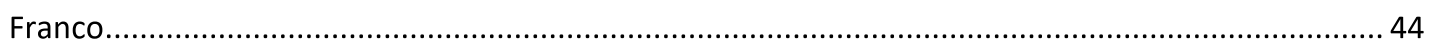

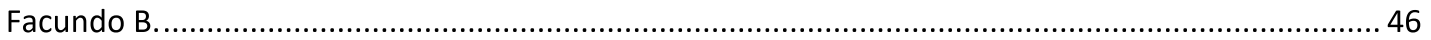

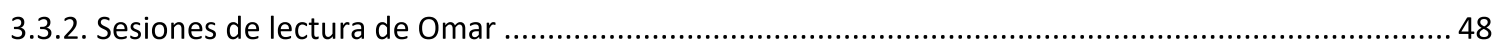

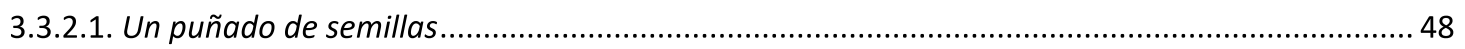

Pauta de sistematización de las observaciones de la sesión de lectura de Un puñado de semillas .... 48

Transcripción de la sesión de lectura de Un puñado de semillas ........................................................ 52

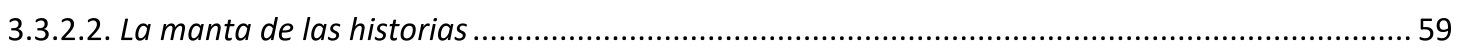

Pauta de sistematización de las observaciones de la sesión de lectura de La manta de las historias. 59

Transcripción de la sesión de lectura de La manta de las historias ..................................................... 62

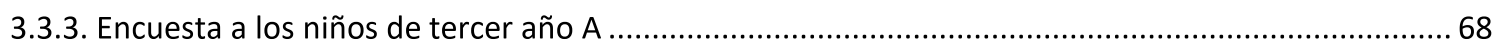

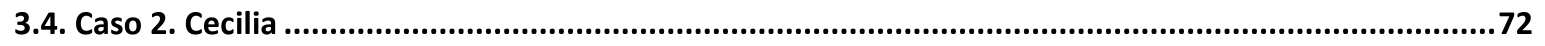

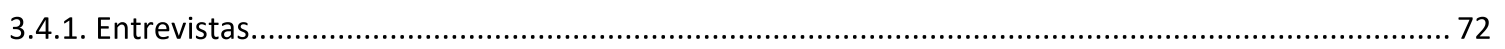

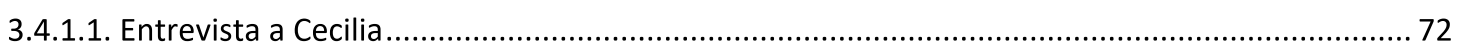


3.4.1.2. Entrevista a Noelia, maestra de tercer año B ................................................................... 76

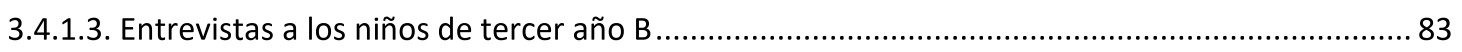

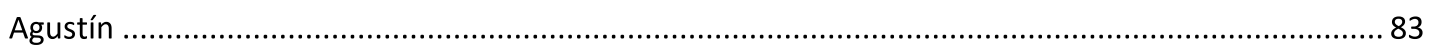

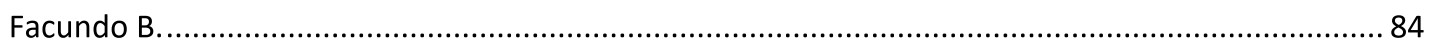

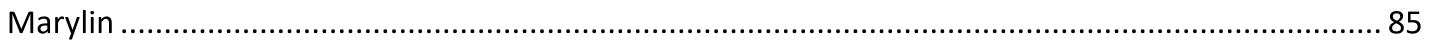

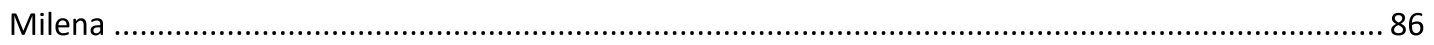

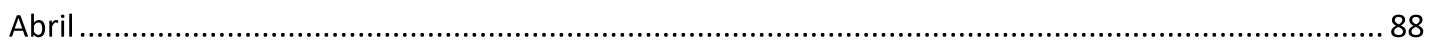

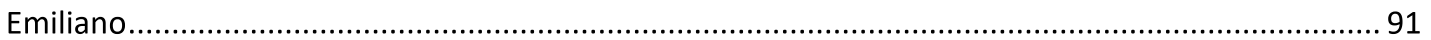

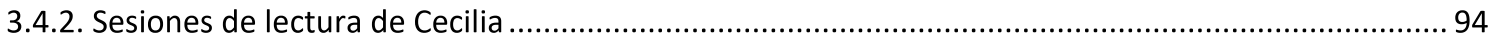

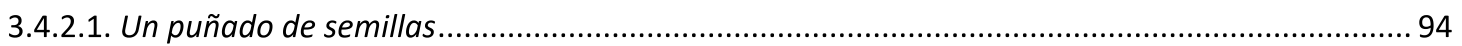

Pauta de sistematización de las observaciones de la sesión de lectura de Un puñado de semillas .... 94

Transcripción de la sesión de lectura de Un puñado de semillas ........................................................97

3.4.2.2. Sesión de lectura de Una cena elegante ............................................................................... 101

Pauta de sistematización de las observaciones de Una cena elegante ............................................ 101

Transcripción de la sesión de lectura de Una cena elegante ............................................................ 105

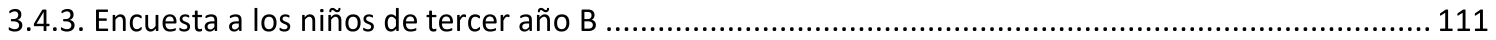

4. Corpus escuela XXX................................................................................ 114

4.1. Entrevista a Rosa, directora de la escuela XXX .......................................................................114

4.2. Entrevista a Mariela, maestra referente de Biblioteca Solidaria ...................................................117

4.3. Reunión del equipo comunitario de lectura .......................................................................124

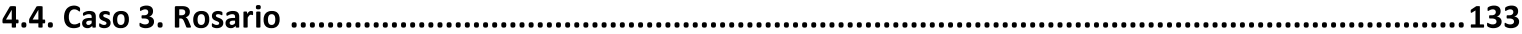

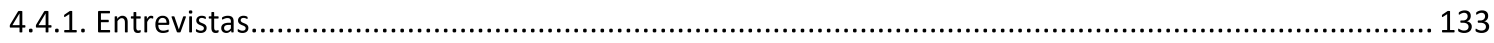

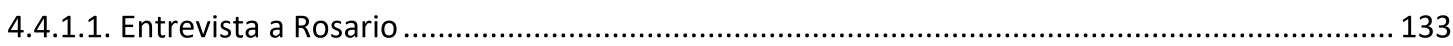

4.4.1.2. Entrevista a Carmen, maestra de tercer año A..................................................................... 137

4.4.1.3. Entrevistas a los niños de tercer año A ................................................................................. 146

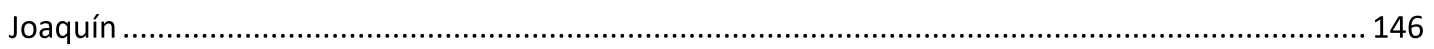

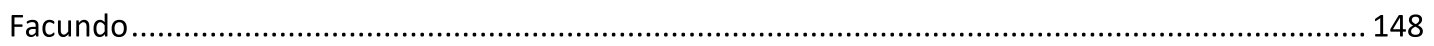

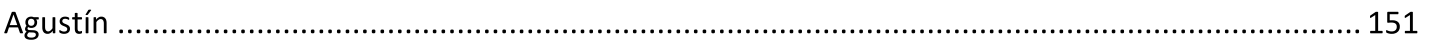

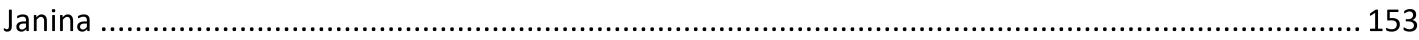

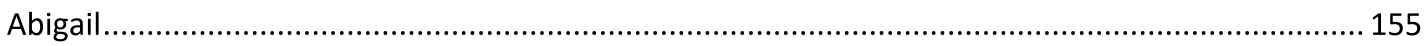

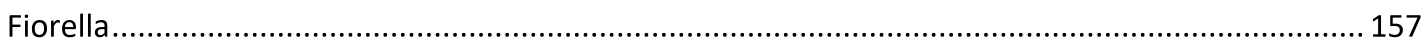

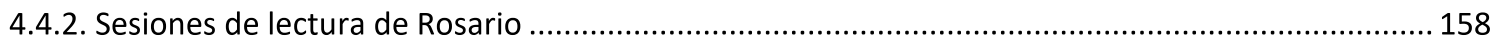

4.4.2.1. Cuando el temible tigre................................................................................................. 158

Pauta de sistematización de las observaciones de la sesión de lectura de Cuando el temible tigre . 158

Transcripción de la sesión de lectura de Cuando el temible tigre ..................................................... 161

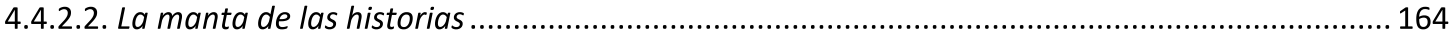

Pauta de sistematización de las observaciones de la sesión de lectura de La manta de las historias

Transcripción de la sesión de lectura de La manta de las historias ............................................... 167

4.4.3. Encuesta a los niños de tercer año A ......................................................................................... 172

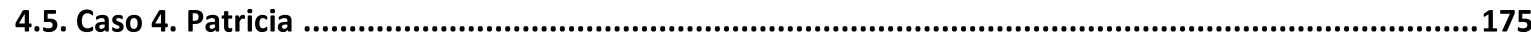

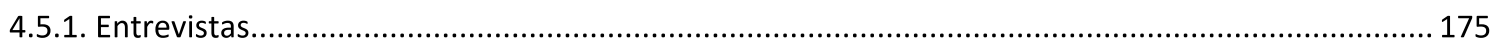

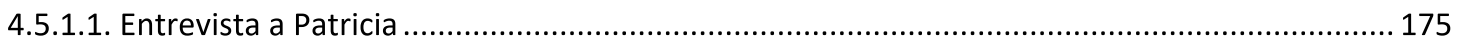

4.5.1.2. Entrevista a Amalia, maestra de tercer año B .................................................................... 180 
4.5.1.3. Entrevista a los niños de tercer año B .............................................................................. 183

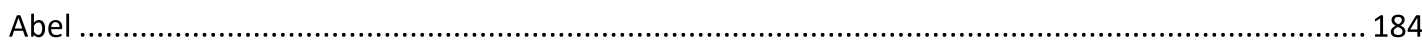

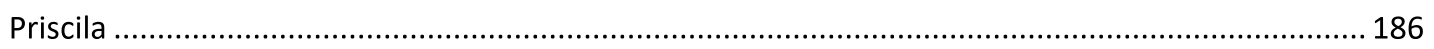

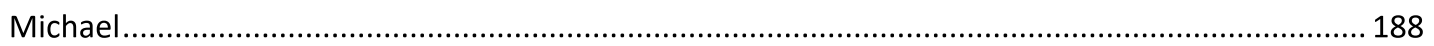

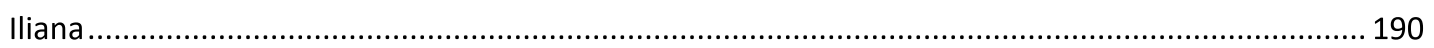

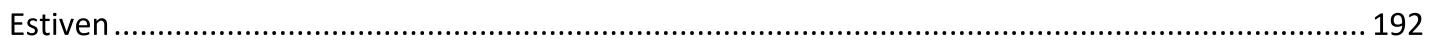

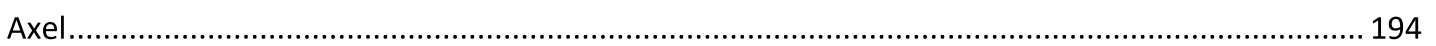

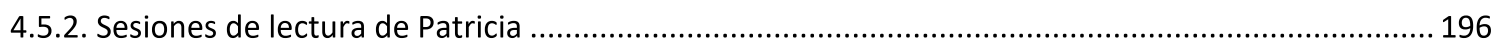

4.5.2.1. Los secretos de Abuelo Sapo ......................................................................................... 196

Pauta de sistematización de las observaciones de la sesión de lectura de Los secretos de Abuelo Sapo

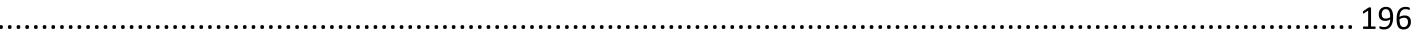

Transcripción de la sesión de lectura de Los secretos de Abuelo Sapo ............................................ 199

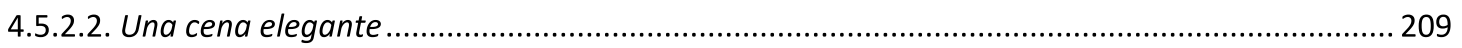

Pauta de sistematización de las observaciones de la sesión de lectura de Una cena elegante......... 209

Transcripción de la sesión de lectura de Una cena elegante ............................................................ 212

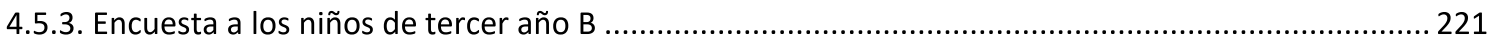

5. Diario de trabajo de campo...................................................................................... 224

6. Carta de solicitud al CEIP para la realización del trabajo de campo .............................. 243

7. Resolución del CEIP ................................................................................................... 245

8. Carta de aval de la Dra. Ana María Margallo ......................................................... 246

9. Carta de aval de la Mag. María Noel Guidali ......................................................... 247 


\section{Calendario de desarRollo del trabajo de CAMPO}

\subsection{Reuniones de los equipos comunitarios de lectura}

\begin{tabular}{|l|l|}
\hline Escuela Xx & Escuela $\mathrm{XXX}$ \\
\hline 30.04 .2015 & 22.05 .2015 \\
\hline 14.05 .2015 & 14.07 .2015 \\
\hline 03.06 .2015 & \\
\hline 18.06 .2015 & \\
\hline 20.07 .2015 & \\
\hline
\end{tabular}

\subsection{Sesiones de lectura presenciadas}

\begin{tabular}{|c|c|c|}
\hline 26.05 .2015 & Carla, $3 .^{\circ} \mathrm{B}$, escuela XX & $\begin{array}{l}\text { Aventuras y desventuras de } \\
\text { Casiperro del Hambre, primer } \\
\text { capítulo (Graciela Montes, } \\
\text { Colihue) }\end{array}$ \\
\hline 26.05 .2015 & Patricia, 3. ${ }^{\circ} \mathrm{A}$ y $\mathrm{B}$, escuela XXX & $\begin{array}{l}\text { Los secretos de Abuelo Sapo } \\
\text { (Keiko Kasza, Norma) }\end{array}$ \\
\hline 01.06 .2015 & Carla, $3 .^{\circ} \mathrm{B}$, escuela XX & $\begin{array}{l}\text { Aventuras y desventuras de } \\
\text { Casiperro del Hambre, } \\
\text { segundo capítulo (Graciela } \\
\text { Montes, Colihue) }\end{array}$ \\
\hline 02.06 .2015 & Rosario, $3{ }^{\circ} \mathrm{A}$ y $\mathrm{B}$, escuela $\mathrm{XXX}$ & $\begin{array}{l}\text { «Los juguetes» y «La chacra» } \\
\text { (Perico. Juan José Morosoli, } \\
\text { Banda Oriental, ilustraciones } \\
\text { de Denisse Torena) }\end{array}$ \\
\hline 10.06.2015 & Tatiana, $3 .{ }^{\circ} \mathrm{A}$, escuela $\mathrm{XX}$ & $\begin{array}{l}\text { El mayor tesoro (Arcadio } \\
\text { Lobato, SM) }\end{array}$ \\
\hline 16.06 .2015 & Rosario, 3. ${ }^{\circ} \mathrm{A}$ y $\mathrm{B}$, escuela $\mathrm{XXX}$ & $\begin{array}{l}\text { El miedo a la luz mala } \\
\text { (Verónica Leite, Alfaguara } \\
\text { Infantil) }\end{array}$ \\
\hline 18.06.2015 & Omar, 3. ${ }^{\circ} \mathrm{A}$, escuela XX & $\begin{array}{l}\text { Un puñado de semillas } \\
\text { (Mónica Hughes, } \\
\text { ilustraciones de Luis Garay, } \\
\text { Ekaré) }\end{array}$ \\
\hline
\end{tabular}




\begin{tabular}{|c|c|c|}
\hline 18.06 .2015 & Carla, $3 .^{\circ} \mathrm{B}$, escuela XX & $\begin{array}{l}\text { Aventuras y desventuras de } \\
\text { Casiperro del Hambre, tercer } \\
\text { capítulo (Graciela Montes, } \\
\text { Colihue) }\end{array}$ \\
\hline 14.07 .2015 & Rosario, $3 .^{\circ} \mathrm{A}$, escuela XXX & $\begin{array}{l}\text { Cuando el temible tigre } \\
\text { (Virginia Brown, ilustraciones } \\
\text { de Matías Acosta, Banda } \\
\text { Oriental) }\end{array}$ \\
\hline 21.07.2015 & Rosario, $3 .{ }^{\circ} \mathrm{A}$ y B escuela XXX & $\begin{array}{l}\text { León de biblioteca (Michelle } \\
\text { Knudsen, ilustraciones de } \\
\text { Kevin llawkes, Ekaré) }\end{array}$ \\
\hline 28.07 .2015 & Patricia, 3..$^{\circ}$ A y B escuela XXX & $\begin{array}{l}\text { Una cena elegante (Keiko } \\
\text { Kasza, Norma) }\end{array}$ \\
\hline 30.07 .2015 & Cecilia, 3. ${ }^{\circ}$ B, escuela XX & $\begin{array}{l}\text { Un puñado de semillas } \\
\text { (Mónica Hughes, } \\
\text { ilustraciones de Luis Garay, } \\
\text { Ekaré) }\end{array}$ \\
\hline 30.07 .2015 & Omar, $3 .^{\circ} \mathrm{A}$, escuela XX & $\begin{array}{l}\text { "La abeja haragana» } \\
\text { (Cuentos de la selva, Horacio } \\
\text { Quiroga, edición aportada } \\
\text { por el mediador) }\end{array}$ \\
\hline 04.08 .2015 & Mónica, $3 .^{\circ}$ A y B escuela XXX & $\begin{array}{l}\text { «El loro pelado» y «La guerra } \\
\text { de los yacarés» (Cuentos de } \\
\text { la selva, Horacio Quiroga, } \\
\text { editorial Lea) }\end{array}$ \\
\hline 11.08 .2015 & $\begin{array}{l}\text { Rosario, } 3 .^{\circ} \text { A y } 3 . .^{\circ} \text { B escuela } \\
\text { XXX }\end{array}$ & $\begin{array}{l}\text { La manta de las historias } \\
\text { (Ferida Wolf y Harriet May } \\
\text { Savitz, ilustraciones de Elena } \\
\text { Odriozola, Norma) }\end{array}$ \\
\hline 12.08 .2015 & Cecilia, $3 .^{\circ} \mathrm{B}$, escuela XX & $\begin{array}{l}\text { Una cena elegante (Keiko } \\
\text { Kasza, Norma) }\end{array}$ \\
\hline 12.08 .2015 & Omar, 3. ${ }^{\circ} \mathrm{A}$, escuela XX & $\begin{array}{l}\text { La manta de las historias } \\
\text { (Ferida Wolf y Harriet May } \\
\text { Savitz, ilustraciones de Elena } \\
\text { Odriozola, Norma) }\end{array}$ \\
\hline
\end{tabular}




\subsection{Encuestas y entrevistas}

\begin{tabular}{|l|l|}
\hline 27.04 .2015 & Entrevista inicial con la directora de la escuela XX \\
\hline 22.05 .2015 & Entrevista inicial con la directora de la escuela XXX \\
\hline 02.09 .2015 & Encuesta a los niños de tercer año A, escuela XX \\
\hline 02.09 .2015 & Encuesta a los niños de tercer año B, escuela XX \\
\hline 09.09 .2015 & Encuesta a los niños de tercer año B, escuela XXX \\
\hline 09.09 .2015 & Encuesta a los niños de tercer año A, escuela XXX \\
\hline 11.09 .2015 & Entrevista a los niños de tercer año A, escuela XX \\
\hline 16.09 .2015 & Entrevista a los niños de tercer año B, escuela XX \\
\hline 29.09 .2015 & Entrevista a los niños de tercer año B, escuela XXX \\
\hline 01.10 .2015 & Entrevista a los niños de tercer año A, escuela XXX \\
\hline 08.10 .2015 & Entrevista a Noelia, maestra de tercer año B, escuela XX \\
\hline 14.10 .2015 & Entrevista a Carmen, maestra de tercer año A, escuela XXX \\
\hline 14.10 .2015 & Entrevista a Amalia, maestra de tercer año B, escuela XXX \\
\hline 20.10 .2015 & Entrevista a Patricia, mediadora de tercer año B, escuela XXX \\
\hline 05.11 .2015 & Entrevista a Rosario, mediadora de tercer año A, escuela XXX \\
\hline 17.11 .2015 & Entrevista a Omar, mediador de tercer año A, escuela XX \\
\hline 19.11 .2015 & Entrevista a Inés (maestra de tercer año A, escuela XX) \\
\hline 25.11 .2015 & Entrevista a Cecilia (mediadora de tercer año B, escuela XX) \\
\hline 27.11 .2015 & Segunda entrevista a María, directora de la escuela XX \\
\hline 04.12 .2015 & Segundrevista a Mariela, maestra referente de la escuela XXX \\
\hline 04.12 .2015 & Entrevista a Rosa, directora de la escuela XXX \\
\hline
\end{tabular}




\section{INSTRUMENTOS PARA LA OBTENCIÓN Y EL REGISTRO DE DATOS}

\subsection{Pauta de observación de las sesiones de lectura}

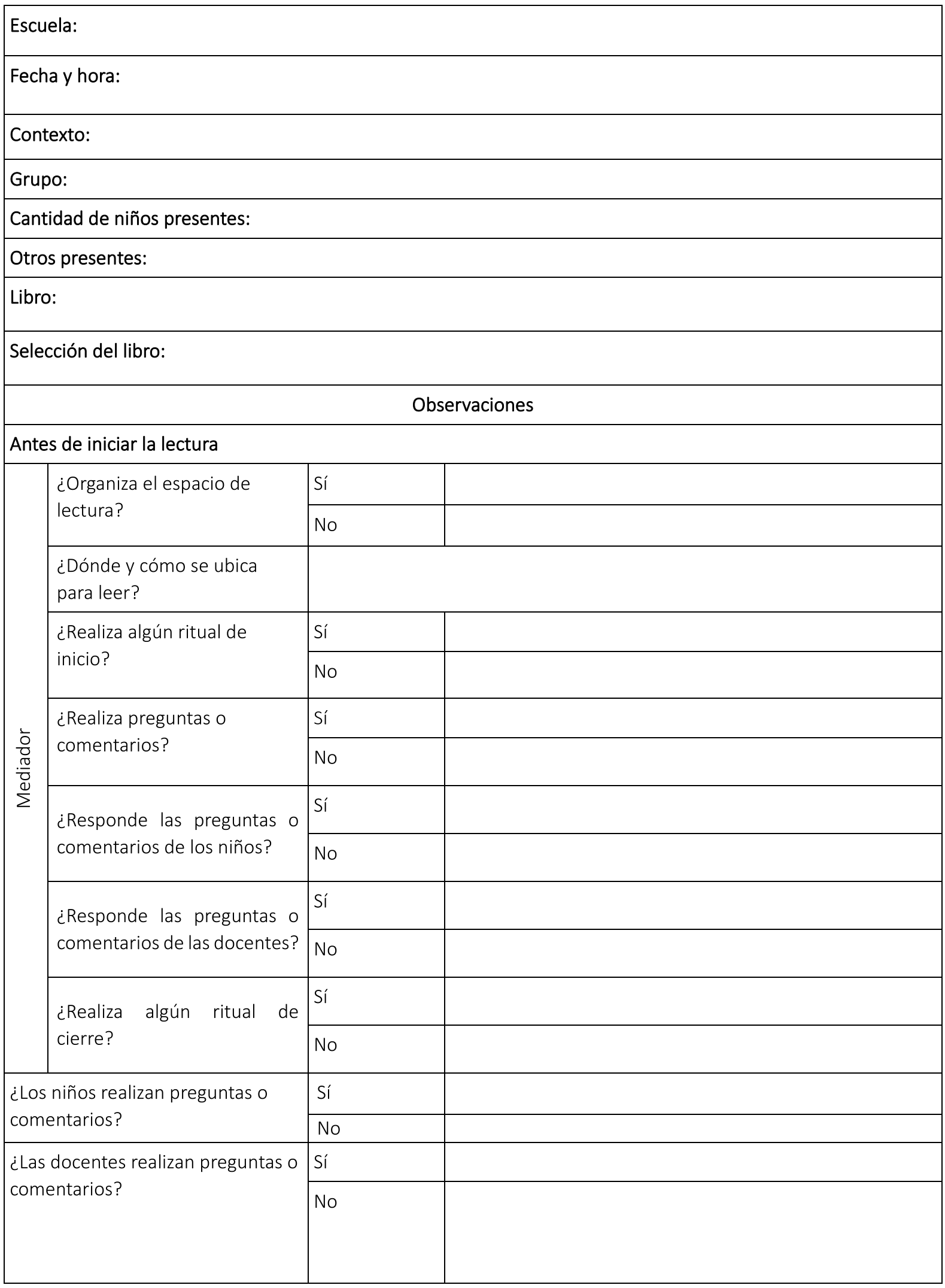




\begin{tabular}{|c|c|c|c|}
\hline & rante la lectura & & \\
\hline & & Sí & \\
\hline & & No & \\
\hline & & Sí & \\
\hline & ¿Mvinestra las imagenes? & No & \\
\hline & & Sí & \\
\hline & . & No & \\
\hline & & Muy bajo (--) & \\
\hline & & Bajo (-) & \\
\hline & Volumen de voz & Moderado $(-+)$ & \\
\hline & & Alto $(+)$ & \\
\hline & & Muy alto (++) & \\
\hline & Velocidad & \begin{tabular}{|l} 
Lenta \\
Moderada \\
Rápida
\end{tabular} & \\
\hline$\frac{\overline{0}}{0}$ & Fluidez & $\begin{array}{l}\text { +Fluidez } \\
\text {-Fluidez }\end{array}$ & \\
\hline$\sum^{\frac{\omega}{2}}$ & Dicción & $\begin{array}{l}\text { Sin omisión de } \\
\text { fonemas } \\
\text { Con omisión } \\
\text { de fonemas }\end{array}$ & \\
\hline & ¿Adecua la entonación o & Sí & \\
\hline & $\begin{array}{l}\text { momento, situación del } \\
\text { cuento, personajes o } \\
\text { modalidad del enunciado? }\end{array}$ & No & \\
\hline & ¿Incorpora gestos faciales o & Sí & \\
\hline & corporales? & No & \\
\hline & & Sí & \\
\hline & 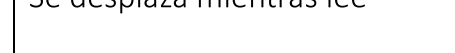 & No & \\
\hline & ¿Realiza preguntas & Sí & \\
\hline & comentarios? & No & \\
\hline & ¿Responde preguntas & Sí & \\
\hline & comentarios de los niños? & No & \\
\hline
\end{tabular}




\begin{tabular}{|c|c|c|c|}
\hline \multirow{2}{*}{\multicolumn{2}{|c|}{$\begin{array}{l}\text { ¿Realiza algún ritual de } \\
\text { cierre? }\end{array}$}} & Sí & \\
\hline & & No & \\
\hline \multirow{2}{*}{\multicolumn{2}{|c|}{$\begin{array}{l}\text { ¿Los niños realizan preguntas o } \\
\text { comentarios? }\end{array}$}} & Sí & \\
\hline & & No & \\
\hline \multirow{2}{*}{\multicolumn{2}{|c|}{$\begin{array}{l}\text { ¿Las docentes realiza preguntas o } \\
\text { comentarios? }\end{array}$}} & Sí & \\
\hline & & No & \\
\hline \multicolumn{4}{|c|}{ Después de la lectura } \\
\hline \multirow{2}{*}{\multicolumn{2}{|c|}{ ¿Realiza preguntas? }} & Sí & \\
\hline & & No & \\
\hline \multirow{6}{*}{$\begin{array}{l}\frac{1}{0} \\
\frac{\pi}{\overline{0}} \\
\frac{\overline{0}}{2} \\
\sum^{\frac{d}{2}}\end{array}$} & \multirow{2}{*}{$\begin{array}{l}\text { ¿Responde preguntas o } \\
\text { comentarios de los niños? }\end{array}$} & Sí & \\
\hline & & No & \\
\hline & \multirow{2}{*}{\begin{tabular}{|l|} 
¿Responde preguntas o \\
comentarios de las docentes?
\end{tabular}} & Sí & \\
\hline & & No & \\
\hline & \multirow{2}{*}{$\begin{array}{l}\text { ¿Realiza algún ritual de } \\
\text { finalización? }\end{array}$} & Sí & \\
\hline & & No & \\
\hline \multirow{2}{*}{\multicolumn{2}{|c|}{$\begin{array}{l}\text { ¿Los niños realizan preguntas o } \\
\text { comentarios? }\end{array}$}} & Sí & \\
\hline & & No & \\
\hline \multirow{2}{*}{\multicolumn{2}{|c|}{$\begin{array}{l}\text { ¿Las docentes realizan preguntas } \\
\text { o comentarios? }\end{array}$}} & Sí & \\
\hline & & No & \\
\hline \multicolumn{4}{|c|}{ Interacciones entre los actores } \\
\hline \multicolumn{2}{|c|}{$\begin{array}{l}\text { Actitud del mediador hacia los } \\
\text { niños }\end{array}$} & & \\
\hline \multicolumn{2}{|c|}{$\begin{array}{l}\text { Actitud de la docente hacia el } \\
\text { mediador }\end{array}$} & & \\
\hline \multicolumn{2}{|c|}{$\begin{array}{l}\text { Actitud de los niños hacia el } \\
\text { mediador }\end{array}$} & & \\
\hline \multicolumn{2}{|c|}{$\begin{array}{l}\text { Actitud del mediador hacia la } \\
\text { docente }\end{array}$} & & \\
\hline
\end{tabular}




\subsection{Protocolo para la encuesta a los niños}

Nombre

Escuela

Clase........

Me gusta/ No me gusta que venga a leer a mi clase porque (escribe tes motivos):

1)

2)

3)

El cuento que leyó y que más me gustó fue. porque

\subsection{Protocolos para las entrevistas}

\subsubsection{Protocolo para las entrevistas a los niños}

- ¿Qué opinas de que las mamás o abuelos vengan a leer a tu clase?

- ¿Qué cuento de los que leyó recordás?

- ¿Qué recordás de ese cuento?

- ¿Te gustó ese cuento? ¿Por qué?

- ¿Te acordás cuando leyó ?

- ¿Qué recordás de esa historia?

¿Te gustó? ¿Por qué?

- El próximo año que vas a estar en cuarto, ¿te gustaría que vinieran los padres o abuelos a leer? - ¿Qué les pedirías que leyeran?

\subsubsection{Protocolo de entrevista a los mediadores}

- Por qué decidió integrarse al equipo de lectura?

- ¿Cómo vive las actividades de lectura con los niños?

- ¿Cree que a los niños les sirve que venga alguien de la familia a leer a la escuela? ¿Por qué? 
- ¿Cree que al maestro, para sus propósitos de enseñanza, le sirve?

- ¿Cuando usted lee, qué observa en los niños?

- Usted hace dos años que está en el equipo comunitario ¿verdad? ¿Cómo capitalizó su experiencia? (Para los mediadores que permanecen desde 2014.)

- ¿Cómo elige sus lecturas?

- ¿Cuáles piensa usted que fueron las lecturas que más les gustaron a ellos?

- ¿Por qué cree que gustaron estas lecturas?

- ¿'Recuerda cuando leyó ? ¿Qué le pareció ese libro?

- ¿¿n qué momento de su vida incorporó la lectura?

- ¿Cómo vive la lectura hoy?

- ¿Qué opinión tiene de la labor del equipo comunitario de la escuela?

- ¿Cómo valora los momentos de reunión con el equipo?

- ¿Qué consejo le daría usted a un padre, a un abuelo o a un exalumno que el año que viene quiere entrar al equipo?

\subsubsection{Protocolo de entrevista a las maestras}

- ¿Qué opinás de que los padres o los abuelos vengan a leer a la escuela? ¿Pará qué sirve que la familia venga a leer a la escuela?

- Vos que podés ver leer a. ...y también ves a tus niños cuando leen contigo, ¿Qué observás en ellos?

- ¿Cuál pensás que sería el escenario ideal cuando viene a leer ? ¿Qué querrías que hicieran los mediadores? ¿Qué querrías que hicieran los niños?

- ¿Qué recordás específicamente de cuando.. vino a leer (nombre del cuento leído)?

- ¿Pensás que los niños aprendieron algo con ese cuento?

- Si tuvieras que darle un consejo a. sobre su lectura, ¿qué le dirías?

\subsubsection{Protocolo de entrevistas a las directoras}

¿Cómo se conformó el equipo comunitario de lectura? ¿Cuál es su historia?

¿En qué de diferencia el grupo lector de este año del del año pasado?

¿Cuál crees que es el aporte que realiza el equipo comunitario de lectura a la escuela y a sus niños? 


\section{CORPUS ESCUELA XX}

\subsection{Entrevista a María, directora de la escuela XX}

Fecha y hora: 02.12.2015, 08.00 horas

Lugar: oficina de la directora

Participantes: María, investigadora

Sandra: María me interesa recuperar la historia del equipo lector | cómo se conformó cómo lo recibió la escuela cómo lo ves vos desde la dirección

María: ¿como una valoración del grupo lector?

Sandra: me interesa rescatar además su historia | el proceso del grupo

María: [el grupo lector] empezó el año pasado | se hicieron varias convocatorias | la verdad es que yo estuve más involucrada el año pasado que este en lo que fue la dinámica de convocatoria y de trabajo del grupo | como pasa siempre se formó un grupo grande después como que se va decantando y hay un grupo que ha quedado más estable | muchos de ellos perduran son los que siguen trabajando este año | y con respecto a la historia creo que el año pasado estuvo más sistemático ¿no? | este año por alguna causa que ya conocemos pero además porque lo más difícil siempre es sostener | me parece que se sostuvieron los que por iniciativa de la persona que vino a leer logró tener continuidad I y lo que no lo lograron y no tuvieron tampoco el apoyo de los maestros o...- | tanto de los maestros responsables del proyecto como de los maestros de clase que lo reciben I eso es un trabajo que hay que hacer mucho que es que el maestro que recibe $\|$ al papá o al abuelo que viene a leer bueno tiene que estar dispuesto a recibirlo | eso no es poca cosa | eso es el cincuenta por ciento o más de la continuidad del proyecto | yo entiendo también a los maestros | por el apremio de...- | hubo mucha actividad en la escuela, hubo mucha cosa | sobre todo en las clases grandes, la urgencia que le entra al maestro de poder dar lo curricular a veces no se llega a valorar el impacto que puede tener la persona que viene a leer | y bueno se deja de lado en función de otras cuestiones | eso me parece que puede haber ocurrido | y en cambio en las clases que hubo esta apertura y esta disposición fue donde más se sostuvo y donde más provechosa fue la instancia ¿no? | eso en relación a la parte que le corresponde a la escuela | el aporte es fundamental | a mí me parece que || que está buenísimo la instancia de que alguien venga y lea | más allá de que el maestro después retome eso o no porque eso tiene también | tiene como como dos miradas | hay maestros que siguen con la impronta de que todo lo que se hace sacar...- llevar agua para mi molino \{risa\} y ver cómo lo vinculo con lo que estoy dando | y después está el otro que realmente entiende que ese es un momento de lectura y punto | que las cuestiones van a surgir este...- | solas o por lo menos motivadas por esto pero no por | el esfuerzo del maestro de llevarlas a determinado lugar | no sé si soy clara | en esas circunstancias también hubo como diferentes experiencias | que igual son todas valiosas | el hecho de poder tener la instancia ya es valioso | y este con respecto también a las personas yo me doy cuenta de que para muchas de ellas fue un lugar no menor dentro de la comunidad educativa | hay gente que:: desde lo personal porque hay algunas personas de las que están que yo conozco | su histo::ria y su trayectoria en la institución como se acercaron en un momento como fue evolucionando ese ese formar parte de la escuela | creo que para ellos también...- este tú has tenido oportunidad de conversarlo | pero ha tenido un valor | y para nosotros | y en algunos casos hasta te diría hasta recuperar a esas familias desde ese lugar ha sido...- $\|$ eso capaz que los maestros porque el 
maestro que está este año no lo estuvo el año anterior no lo valoran pero desde acá sí yo lo puedo valor así impresionante ha sido...- || y sí muchísimo para hacer | yo hablaba con las compañeras | la convocatoria tiene que ser constante porque no alcanza con convocar una vez y...- | hay que estar permanente | hay que mostrar en qué consiste explicar | este el año pasado algunas mamás que empezaron muy tímidamente lo habían hecho en duplas | me parece que eso había ayudado | recuperar como esa instancia | eh:: con la gente que va a participar del grupo y el otro gran debe es a nivel de la escuela | bueno como escuela | y como clase para recibir este este trabajo | me parece que ahí también hay una pata que quedó | un poco renga || pero la valoración final termina siendo positiva || uno siempre va aprendiendo de cosas que...- que se van mejorando | el año pasado tuvo un impulso | o por lo menos el acompañamiento del trabajo con biblioteca virtual || entonces ahí se hizo muy fuerte | y este año como el trabajo de la maestra Ceibal estuvo más ligado al trabajo de arte || y no tanto a este proyecto | bueno quedó como más solo en ese sentido | este...- || y mucha cosa los terceros que son las maestras que están a cargo del proyecto estuvieron con mucha cosa en la vuelta y a veces no deben haber podido dedicarle todo | yo creo que | igual cualquiera de las dos Noe e Inés | tienen como mucha experiencia muchas ganas y muchas potencialidades para aportarle al proyecto | Noe no sabemos si va a estar el año que viene ojalá que sí pero Inés continúa y me parece que...- | Inés va a poder darle continuidad y afirmarlo un poco más

Sandra: vos me hablabas de que algunos maestros recibieron mejor que otros la Biblioteca Solidaria ¿vos podés decir que estos son los maestros de los últimos ciclos o de las clases iniciales?

María: en realidad tengo como algunas cuestiones más puntuales eh:: || no depende del ciclo | no va asociado a nada | va asociado al maestro específicamente | seguramente con la mejor intención del maestro también no lo pongo en duda | a veces porque no se comprende en profundidad a nivel del colectivo en qué consiste la Biblioteca Solidaria $\|$ yo creo que hay que hacer todo un trabajo de:: dar a conocer esto ¿no? | porque es la manera de que la gente se comprometa y se involucre || ahí falta por eso digo que es una:: cuestión que nos quedó pendiente | tanto del grupo de los referentes como de la dirección || pero no creo que esté ligada al nivel estuvo ligado a cada maestro

Sandra: vos ya me dijiste algunas cosas pero...- || ¿cuál crees que fue el aporte del equipo comunitario? ¿en qué incidió el grupo lector?

María: $<5>$ y yo creo que sobre todo en acercar la lectura desde otro lugar \| que muchas veces por distintos motivos no lo hace el propio maestro también lo podría hacer y a veces lo hace sumado al grupo lector pero mu::chas veces no $\|$ yo creo que cuantos más somos y más personas traemos más diversidad hay y más nos enriquecemos todos || | hubo gente que bueno de la que continuó | no puede dejar de pensar en los abuelos [enf.] tanto Omar como Graciela que fueron una cosa los dos...- | y cuánto se les generó a ellos también | entonces me parece que ellos están convencidos de esto | y también en la medida en que lo vienen a hacer desde ese lugar | lo que aportan es mucho mayor || habría que ver cómo se amplía lo de ellos y cómo se suma más gente | yo creo que a la clase le aportó eso sobre todo | el acercarse a la lectura desde otro lugar | el conocer otros autores otro tipo de narrativa | de poesía de lo que estuvieron compartiendo $\|$ ya te digo de que haya otras personas que también entren a la clase y que también sean otras personas que enseñan | de la lectura y todo lo que tiene que ver con...| con cómo me dispongo | con el silencio | con la postura | con esas cosas que son bien importantes y que bueno a veces no se trabaja lo suficiente | pero la continuidad de estas situaciones hace que eso 
tenga que surgir | porque si alguien pudo ir todo el año a leer es porque en esa clase...- | ya sea porque lo convocaron I se hizo explícito o porque fue surgiendo hay una disposición a escuchar que no es poca cosa | no escuchamos nada últimamente | a mí me parece que el aporte es bien interesante sí | yo lo valoro

Sandra: vos me hablabas de que hay que ajustar muchas co::sas || ¿'eso es porque ustedes piensan seguir con Biblioteca Solidaria?

María: y sí si nos permiten yo creo que sí por eso que te decía | porque:: esto se va a ver a largo plazo || son dos años y se han visto:: este cosas que han mejorado mucho | y es cierto otras que han quedado estancadas y alguna que se ha perdido y alguna...- no sé | bueno pero hay que insistir | yo creo que este año nos pasó no solo con esto sino con varias cosas que nos vimos como desbordados | en la cantidad de actividades | este capaz que eso fue un error de | querer abarcar muchas cosas este y bueno el que mucho abarca poco aprieta dicen | yo creo que el secreto está en eso que habíamos logrado en algún momento que era vincular una cosa con otra para que no se haga como una suma de cosas | que no es una cosa | y otra otra y otra sino como todo eso se conjuga para llegar a un mismo...- || entonces eso faltó y hay ahí como una | una parte desde el lugar de la dirección que tendría que haber estado y bueno | que después se verá por qué fue que no estuvo | pero yo creo que sí que seguir tiene que seguir | y que bueno ahora tenemos la experiencia | de cuáles son los puntitos que están fallando | yo por lo menos te dije la convocatoria | el poder sostener | el dar a conocer el proyecto tanto a la comunidad de padres como a los propios maestros | el trabajar con el maestro en la apertura a ese proyecto | este me parece que son como varias puntas que van a habilitar a que esto vuelva a tener un repunte un empujoncito sí sí

Sandra: y con respecto al grupo lector ¿ivos notás algún cambio entre el equipo del año pasado y el de este?

María: vos sabés que no tengo demasiados insumos para decirte \|l creo que lo que permitió fue consolidar algunas cosas compartir esa experiencia con algunas personas que se sumaron pero $\|$ no sabría precisamente cuánto de experiencia acumulada hay | yo lo pienso en función de algunas personas sé que hubo más personas en el grupo las chiquilinas siempre me hablaron de siete ocho nueve que anduvieron con distinta permanencia algunos más estables otros que fueron y vinieron I pero no tengo más insumos para decirte cómo lo vivieron ellos

Sandra: mi idea era esa recuperar lo institucional para tener más insumos para mi trabajo

María: yo creo que:: este año a nivel institucional | faltó darle más lugar a esta experiencia ¿no? | por lo menos a nivel institucional | sé que hubo situaciones puntuales mu::y potentes | pero faltó como esa cuestión más de...- | porque hubo mucha co::sa y sobre todo el proyecto de arte acaparó muchísimo este:: | y bueno era una posibilidad que tampoco la podíamos perder [...] valoro pila la experiencia | me parece que todo aporta | que:: los logros son de todos y:: que las cosas que están:: para mejorar también son responsabilidad de todos | y que bueno que la manera de sacarlo es así poder juntarnos | volvemos siempre a lo mismo a mí...- | yo trato de no decirlo | en todas las instancias siempre decimos lo mismo con el tema del tiempo | es una realidad || ahora nosotros creo que logramos...- | ojalá lo podamos sostener | logramos muchísimo con poder generar este tiempo:: para los maestros | habría que pensar para el año que viene cómo generar más espacios institucionales porque si bien te dan...- teníamos las salas | o te las dan con determinadas temáticas | o tenés tanto para hablar que no te alcanza el tiempo 
|| hay algunas ideas vamos a ver quién se suma | de generar otras instancias bueno para el que quiera | porque hay mucha gente que está con ganas de:: seguir formándose | de leer | de pensar cosas | y bueno vamos a ver si eso sale || las instancias de formación son muy pocas nosotros tenemos por ejemplo hay pila de gente que yo quiero que escriba las cosas | hay mucha cosa para escribir | primero para recuperar la memoria del maestro | la memoria de la escuela | y para poder compartir | entre nosotros | y si a alguien le sirve con alguien | pero se hace mucho | como se hace en todas las escuelas | yo estoy convencida de que en todos lados se hacen cosas maravillosas | no tenemos cultura de escribir no tenemos los tiempos | más allá de que sepamos cómo o no | sea académico no sea académico | pero dar cuenta de lo que hacemos | porque en realidad ni nosotros mismos nos valoramos entonces cuando vos lo sacás para afuera decís ipa::h! mirá

Sandra: claro porque la escritura tiene esa función la de poder generar conocimiento

María: exacto y de reflexionar sobre lo que hacemos | pero bueno es un debe | vamos a ver si podemos hacer algo por lo menos

Sandra: bueno María imuchísimas gracias!

María: un placer

Sandra: me pongo a las órdenes para lo que pueda ayudar

\subsection{Reuniones del equipo comunitario de lectura}

\subsubsection{Reunión 1}

Fecha y hora: $14.05 .2015,08.00$ horas

Lugar: salón de tercer año $A$

Participantes: Omar, Graciela, Carla, Elsa, Carolina, Leticia, Inés y Noelia (maestras referentes), investigadora (9 participantes)

Inés lidera la reunión. Da la bienvenida a los nuevos integrantes y les explica cómo se desarrolla el proyecto Biblioteca Solidaria en la escuela (biblioteca de aula, biblioteca ambulante, lectura por parte del equipo comunitario) y cuál es la tarea de los mediadores. Propone alternativas a ir a leer: si los mediadores no se sienten seguros de hacerlo en un comienzo, pueden presentar libros: ir a la clase con una caja de libros, tomar uno, recomendarlo y «leer un pedacito» y dejar a los niños elegir.

Explica que va a haber una caja de libros en cada clase para que cada niño elija uno, lo lleve a su casa y lo devuelva a la semana. Luego habrá una biblioteca circulante con «libros más lindos» que rotará periódicamente por las distintas clases de la escuela y estará en el salón por media hora, cuarenta minutos, aproximadamente.

Inés dice que la modalidad de ir a leer a las clases puede ser «la más difícil» y explica que otra posibilidad es ir a narrar, porque implica una vivencia personal, algo que ya se sabe, y es «mucho más fácil». Ir a leer puede dar vergüenza, hay que tener «un nivel de expresividad mayor». Hace énfasis en que hay varias opciones para «ir acercándose». 
Luego invita a los mediadores a mostrar los libros que trajeron para leer en las distintas clases de la escuela.

Graciela (abuela de un alumno de cuarto año) muestra una colección de librillos de fábulas ilustradas con moralejas (que una empresa de productos lácteos promocionó y canjeó a cambio de envases de leche un tiempo atrás). Ella adquirió estos libros para sus nietos y los seleccionó para leer en quinto año: «Yo traje esta colección que tiene moralejas. Cada cuento tiene moralejas... No sé si para chicos..., la moraleja es para más grandecitos. Hace años que los tengo en casa. Los compré para mis nietos cuando eran más chiquitos. Cuando los vio dijo “iAh, yo me acuerdo! (risas)”. A él le encantan... se acordó y... a él seguro que le gustarían».

Omar (abuelo de una niña de tercero) comenta su experiencia de lectura en 2014 y su estrategia para hacer que los niños le presten atención. Alude a la jornada con equipos comunitarios en la cual participó el año pasado: «Con respecto a llamar la atención antes de empezar a leer... te acordás que cuando vinieron los de ProLEE a dar la charla decían que una de las estrategias que se pueden usar es decir que los libros que son modernos ya vienen con un chip, que si hay mucho ruido el libro se cierra y después ya no se puede abrir. La primer vez que fui a leer dije eso porque no sabía. Porque la primera vez viste que vas medio nervioso, después no hubo problema porque los gurises estaban recopados de escuchar leer a alguien que no era el maestro, y después nunca más lo dije, y después que vos hablaste de eso me acordé... No sé si puede servirle a alguien».

Inés comenta que algunos maestros se ponen nerviosos si los niños no atienden por lo que hay que buscar estrategias para conseguir la atención. A sus alumnos (de tercer año), en cambio les pareció «fascinante» cuando Omar fue a leerles.

Interviene la maestra Noelia explicando que hasta tercer año la atención es «como mágica». A partir de cuarto, hay que usar diferentes estrategias de acuerdo con la edad e interés de los alumnos. Insiste en que a estas clases los mediadores pueden ir a recomendar libros y autores, deben «buscar diferentes estrategias».

Inés indica que las historias de terror, espanto, amor, tragedia pueden ser más atractivas para los niños más grandes (sugiere a autores como Horacio Quiroga).

Elsa, la mamá con la niña pequeña comenta: «Yo no pude traerlos que es más bien para chiquitos porque no pude ir a la biblioteca. Porque mi mamá trabaja en el Banco Hipotecario, ahora está en la Agencia Nacional de Vivienda, y ella allí tiene biblioteca. Y siempre me trajo a mí y a mi hermana más grande los de Teo. A mí son libros que me encantan. Son antiguos, pero para los niños chicos están buenos».

Otra mamá, Carla, aporta Cuentos que no son cuento: «Se trata de una abuela que cuenta cinco historias, entonces ayuda al niño a cómo cuidar su cuerpo, que las partes son íntimas, en una de las historias que... la autoestima al niño, que él es valioso... son cinco historias de una abuela a sus nietos, pero está bastante fácil para que lo entiendan. Es más bien para chiquitos hasta segundo, tercero, no sé si para más grandes».

Inés destaca que todos los libros que llevaron las dos mamás son «para que los niños se porten bien» y Graciela le responde: «Ellos lo dicen... no sé si lo hacen después» entre las risas de todos. 
Inés continúa comentando sobre las opciones para seleccionar los libros de acuerdo con las edades de los niños. Sugiere para los más chiquitos cuentos de la vida cotidiana, las distintas versiones de los cuentos clásicos, cuentos de animales...

Carla agrega: «Me parece que está bueno... yo leía uno que la moraleja era ser buen compañero, y hay veces que están peleando, son chiquitos y está peleando y vos le decís: no, no se pega... hay veces que te van a entender, creo yo, con una historia...».

Ante el cuestionamiento de esta mamá, Inés aclara que «están buenos y que hay que usarlos». Solicita además establecer un vínculo con el maestro para poder ir orientando y mejorando la selección de libros y la lectura.

Leticia pregunta cuál es el tiempo estimado para leer en las clases. Inés le responde que un cuento puede llevar «cinco minutos, diez minutos como máximo». La mamá consulta si puede comentar la lectura con los niños e Inés le responde que «depende un poco de para qué dé» tiene que ver si el libro o el maestro del grupo habilitan los comentarios. La idea es «ir, leer el cuento por el cuento en sí mismo, es decir yo vengo y te regalo esto que es un cuentito y me voy».

Leticia, comenta: «Te pregunto esto porque yo tengo el libro que capaz que todos conocen de la película La historia $\sin$ fin... que es muy vieja esa película y yo tengo el libro... y para mí es... yo lo tengo guardado no dejo que lo toquen porque son las películas que a mí me gustaron mucho, y yo el libro lo tengo guardado, se los leo, pero es más bien para grandes... quinto y sexto. En realidad, es un libro grande, es un libro gordo, por eso te pregunto qué tiempo porque es para leerlo en tres cuatro veces». Inés le menciona que la lectura de los mediadores está pensada en forma quincenal, pero que ella puede ver.

Noelia acota que contar las anécdotas, las vivencias en torno a ese libro también es muy valioso de transmitir, que puede empezarse el libro y dejarlo para que los niños y la maestra continúen leyéndolo, que esta acción constituye una apertura muy importante.

Omar vuelve a aludir a la jornada con los equipos comunitarios desarrollada por ProLEE en la cual él participó e indica que en esta se les sugirió a los mediadores que luego de la lectura, comentaran sobre lo leído: «Otra de las cosas que estaba buenísimo, que me resultaba buenísimo a mí era después de haber terminado de leer que los gurises comentaran qué les había gustado del libro, qué les había parecido bien que les había parecido mal. Y ahí había opiniones de todo tipo que a mí me fascinaban». Inés le responde: «Depende, de para qué dé... la situación... de cómo se integra el maestro... del espacio. Hay una parte que es libre... es como es con los hijos...».

Inés comenta que la escuela había previsto la presencia de los mediadores con una frecuencia quincenal. Noelia acota que la lectura de un libro en partes en forma quincenal, no es conveniente.

Sugiere llevar el libro, mostrárselo a los niños, contarles el argumento, decirles que también está en película. Inés dice que explicar por qué el libro es valioso para uno, puede ser motivador: el mediador puede comenzar la lectura y dejarla para que el niño o el maestro continúen. Sugieren que el mediador lo empiecen y lo siga la maestra o los niños «que ellos investiguen cómo sigue la historia».

Omar interviene: "Otra de las cosas que... estaba buenísimo, que me resultaba buenísimo a mí era después de haber terminado de leer... era que los gurises comentaran qué era que les había gustado del 
libro y qué no, qué les había parecido bien, que les había parecido mal... Y ahí había opiniones de todo tipo que eso... a mí me fascinaban».

Inés solicita que se organice el calendario de las reuniones del equipo comunitario y sugiere ir apoyando e ir construyendo el trabajo de los mediadores en sucesivas reuniones. Noelia acota que en 2014 el equipo se reunía en forma mensual. Inés menciona que las reuniones podrían ser cada 15 días, los jueves. Comenta además que puede ser interesante en cada reunión leer algo para ellos.

Fijan el 11 de junio para la próxima reunión del equipo. Los maestros referentes comunican el cronograma de horarios indicados por los maestros.

Los mediadores solicitan leer en las clases en donde están sus hijos o nietos, pero distribuyen su presencia en todas las clases de la escuela desde nivel inicial hasta sexto año.

Inés comenta la importancia de la presencia de varones en la educación para convencer a Omar de ir a leer a quinto y sexto año. Él se muestra de acuerdo. Omar y Graciela (los mediadores más experimentados) irán a leer a los grupos de los niños más grandes de la escuela.

Hay apertura de los maestros a que los mediadores aporten sus lecturas para ir a leer.

Omar consulta cuándo es el lanzamiento del proyecto en la escuela. Las docentes le aclaran que va a ser el 26 de mayo (Día del Libro en Uruguay) y allí se invitará a la comunidad a participar del equipo comunitario. El abuelo sugiere: «Nosotros mismos tenemos que ir en grupo de dos o tres y apretar a la gente que...».

Inés sugiere «ir de a poquito», consolidar el grupo primero y luego invitando a la gente que puede ser». Luego Inés lee para todos Bolboretas (Xavier Docampo y Xosé Cobas, Everet, Galicia). Recomienda la lectura de ese libro para las clases grandes "que son las más difíciles», y explica que les encanta principalmente por sus ilustraciones.

A continuación, mediadores y docentes seleccionan los libros para leer las próximas dos semanas. Omar elige el que acaban de leer para sexto año e Inés le comenta que con ese libro «te van a adorar», y agrega que quienes no tengan libros para leer, pueden buscar entre los de la escuela. Indica que lo mejor es que «uno lea lo que lo conmueva a uno». Graciela se ofrece a elegir los libros para cuarto y quinto; posteriormente leerá las fábulas que ella seleccionó.

Carolina solicita leer El Principito (Antoine de Saint Exupéry), el libro que a ella le regalaron cuando egresó de la escuela y que ella no puede olvidar: «¿El Principito no lo tienen? ... Yo lo tenía... A mí me gustaría leerlo algún día para las clases más... o sea tercero, cuarto o sexto. iMe encanta! Me lo regalaron cuando salí de sexto año de escuela y iah!. Y lo tuve años...».

Descartan La historia sin fin (Michael Ende) para las clases de niños más pequeños.

Inés recomienda Yaci y su muñeca (cuento popular brasileño), sintetiza su argumento y se ofrece a prestárselo a Carolina.

Los mediadores manejan Pateando lunas (del uruguayo Roy Berocay, Santillana), Inés dice que este libro es para presentar.

Carla acota que con las clases grandes «tuvieron problemas» en 2014. 
Inés solicita a Omar que lea El pájaro del alma en su clase la próxima semana, ya que ella necesita de esa lectura.

Graciela consulta si hay algún libro que pueda servir para cuarto o quinto e Inés le dice que esos libros «que a ella le funcionan con sus nietos son una buena idea».

Carolina solicita los Cuentos de la selva (Horacio Quiroga) que «están buenos para quinto o sexto».

Inés recomienda libros, comenta los criterios de selección y aconseja: «A los niños les gusta que le repitan las historias».

Omar se lleva Bolboretas, Seamos amigos otra vez y El pájaro del alma para leer la próxima semana.

Graciela se lleva Cuentos de la selva y Leticia Yaci y su muñeca.

Carolina y Elsa leerán los libros seleccionados por ellas.

Inés le sugiere a Carla que lea en la clase de Noelia (tercer año) Aventuras y desventuras de Casiperro del Hambre, de Graciela Montes en varias partes, que lea todo primero y luego fijen la fecha para ir a leer.

Finaliza la reunión y se retiran los participantes.

\subsubsection{Reunión 2}

Fecha y hora: $18.06 .2015,08.00$ horas

Lugar: salón de tercer año $B$

Participantes: Omar, Cecilia, Carla, maestra Noelia, estudiante de Magisterio, investigadora

Presencio la cuarta reunión del año del equipo comunitario de lectura que se realiza en el salón de Noelia, mientras sus niños se encuentran en la clase de Educación Física. Los integrantes del equipo lector fueron convocados con tiempo a través de mensajes de texto, pero como el día está muy frío, asisten solo tres: Omar, Carla y Cecilia quien se reincorpora al equipo en el día de hoy, pues había participado también en 2014.

Al iniciar, la maestra destaca la presencia de Cecilia, le da la bienvenida e invita a los demás a compartir su experiencia de lectura, hasta el momento. Comienza hablando Omar quien relata su experiencia en sexto año: «El cuento era muy corto... este y quedaron... yo por las dudas lo preparé antes porque no sabía. Tenía la experiencia de la otra señora que había dicho que se dispersaban... y entonces...el nombre del cuento era Mariposas 1 . Antes de empezar les digo: "Yo tengo una nieta", que es verdad, "de dieciséis años", y le mostré el cuento que les iba a leer y me dice: "abuelo: a sexto año un cuento que se llama Mariposas". Y se lo leí y cuando terminé de leerlo ella estaba con una sonrisa y ahí quedaron todos totalmente... e incluso me preguntaron todos: “¿cuántos años dijiste que tenía? ..." así un silencio total y después cuando terminé pregunté: "¿qué sacan de todo esto?", que estuvo muy bueno porque hubo de todo y al otro sexto no se lo pude leer porque tenían otra actividad no sé qué, cuál era... voy a tratar de leerles ese mismo».

\footnotetext{
${ }^{1}$ El título del cuento es Bolboretas.
} 
Cecilia acota sobre el comentario de Omar de que los niños de sexto se dispersan: «eso depende mucho del cuento o como de uno lo cuente».

Luego sigue el turno de Carla, quien comenta sobre la lectura en tercer año de Aventuras y desventuras de Casiperro del Hambre de Graciela Montes: "A mí me gustó además la atención que prestaron algunos... bárbaro, les gusta, no sé me parece a mí que les gusta...».

Cecilia comenta: «Va a haber que probar con los nuestros también».

Se produce un breve intercambio entre Noelia y Carla quienes conversan sobre las características de los niños de tercer año en general, que son «inquietos y movedizos». Comenta sobre las características del grupo y de esta franja etaria que tienen que ver «con una transformación de ellos». Omar las interrumpe diciendo: «A mí me fue bastante bien en la clase de Inés».

Noelia invita a Omar a repetir su experiencia en quinto ya que le fue tan bien en sexto: «Si te fue tan bien... uno cuando tiene un éxito lo puede seguir repitiendo». Omar se muestra muy dispuesto a intentar en quinto. Agrega además que está yendo a leer al jardín de infantes al que concurre su nieto menor: «[...] te cuento más: estoy leyendo además a leer también en el jardín al que va mi otro nieto, fui me ofrecí y enseguida aceptaron. El único problema es que no tenía un cuento tan como para esa edad... leí «El loro pelado» que ya más bien es como para primero, segundo... estuvieron quietos y todo, pero no sé, se rieron mucho cuando hablaba el loro, pero no sé si entendieron [...] el error fue mío, porque yo leí ese libro pensando que les iba a gustar, a lo mejor les gustó porque se reían, pero no sé si lo entendieron».

Noelia se ofrece a prestarle libros para que lea en el jardín y Omar acota: "Justamente te dije esto porque les iba a manguear algo para ellos».

Cecilia interviene ofreciendo los libros que tiene en su casa: "Yo tengo en casa mucha cantidad de libros, siempre le compré libros a Sofía porque yo cuando era chica mi madre me compraba libros, es como una cosa que sigue, yo siempre fui de leer mucho por eso casi no tengo faltas de ortografía».

Carla y Cecilia conversan entre ellas sobre los libros que les gustan a sus hijos: los de la serie del sapo Ruperto, los de detectives y los de la serie Voces anónimas. Carla le presta a Cecilia Nubes, de Olaondo para que lea en segundo. Luego se reintegran a la conversación del grupo.

Noelia le pregunta a Omar qué horarios dispone para leer en los quintos. Él responde que a primera hora de la mañana es mejor para él, por motivos de trabajo y aclara que aunque es jubilado aún continúa trabajando en ocasiones. Convienen en que Omar irá a leer, además de en tercer año, que es la clase de su nieta, en los quintos y sextos.

La maestra les comenta a los demás presentes que Carla tiene la voz muy suave que a veces no se escucha y que tiende a bajar la voz cuando lee. Le propone que lleve a la clase una selección de audiocuentos de autores uruguayos: Espínola, Morosoli, que pertenecen a una maestra de la escuela y que estos pueden ser «una ayuda» para Carla. Le recomienda hacer un día la presentación de un cuento y al otro, escuchar el audiocuento porque es «muy interesante escuchar a los escritores leer sus cuentos». Acota: «Galeano grababa mucho igual que Benedetti». 
Cecilia pregunta sobre este procedimiento y Noelia aclara: «Ella viene y presenta el libro, les cuenta del autor, porque hay veces cuando uno va leyendo, va disminuyendo, la voz se va gastando» y al otro día viene a presentar el audio. También sugiere contar cuentos más cortos.

Carla, un poco molesta, contesta que Aventuras y desventuras de Casiperro del Hambre no es un libro apropiado para el grado: "Y lo que pasa es que ese cuento no tiene, si vos lo miraste, no tiene casi dibujos, entonces no tiene sentido que yo venga porque el libro tiene cada veinte páginas un dibujito así». Noelia le responde: «Son diferentes estrategias que podés ir buscando». Sugiere también que puede probar con un cuento más corto y Carla manifiesta estar de acuerdo. La mediadora acota que trajo un cuento que su hijo quiere que lea en su clase: «Traje este cuento que quiero que lo vea Inés, este es de Martín que quiere que se lo lea a la clase (muestra un ejemplar de Violeta autografiado por su autora, Susana Olaondo), no sé si está para tercero o para más chicos». Noelia está de acuerdo en que el cuento de Olaondo se lea en los dos terceros y comenta que en su clase y en la de Inés están armando la biblioteca de aula.

Carla agrega: «Y tengo otro que me olvidé ahora que es de... se llama... es de por ejemplo la honestidad, la generosidad, todo así, que se lo habíamos prestado a la maestra de segundo Myriam, que le encantó, porque son cuentos cortitos, entonces quería ver si podía traerlo para leerlo en tercero... ella quería comprar el libro».

Carla y Cecilia conversan sobre los libros que sus hijos llevaron para leer en sus hogares. Carla dice con agrado que su hijo llevó un libro sobre ortografía: «El otro día me gustó porque se llevó de ortografía y le digo: "para vos y tu papá", porque claro, tiene faltas de ortografía Martín, entonces leía y dice: "ah, mirá, yo no sabía", "¿viste?, ese te hace bien", entonces leyó y aprende de ahí. A Martín le gusta mucho de la Tierra, de los planetas, todas esas cosas».

Cecilia comenta «Sofía llevó uno la otra vez que quedó recopada, le gustó, sobre los derechos de los niños. Llevó dos distintos y... le gustó mucho, porque claro, ellos no saben de eso... ahora llevó uno que era de un pato, que no me acuerdo cómo se llamaba, también andaba recopada con ese, en general le gustan todos los tipos, tiene que ser muy aburrido para que no le guste...». Insiste en que leer los ayuda a no tener faltas de ortografía: "Yo siempre dije que el leer los ayuda a no tener faltas de ortografía. A mí me ayudó muchísimo. Yo, faltas de ortografía casi no tengo..., a veces alguna palabra muy rebuscada.... Yo siempre estoy atrás de ella corrigiéndole... a veces soy media pesada, pero bueno... lo que pasa que hoy en día ves mucha gente con muchas faltas de ortografía».

El intercambio se desvía hacia la relación entre la ortografía y la escritura en los celulares. Omar contribuye a la discusión: «Y ni mires los celulares... eso está destruyendo el idioma».

Noelia en seguida interrumpe y redirige nuevamente la conversación. Pregunta entonces a Cecilia qué le gustaría leer. Ella comenta: "Yo leí el año pasado que me fue bárbaro en segundo, cuando ellos estaban en segundo... qué fue lo que les leí... iah!, alguno que yo tenía en casa, que Sofía lo eligió, porque ella tiene muchos cuentos cortos, claro, que son para más chiquitos, de repente en tercero tendría que ser otro tipo de libros, lo que pasa es que yo en casa por ejemplo... son como libros de este tipo que son muy largos para leerlos acá... pero no sé en qué clase tampoco, porque depende de la clase». Noelia le dice que lo importante es que ella se sienta cómoda al leer y que después puede cambiar de clase si ella quiere. 
Cecilia: «Yo no tengo problema, también es cuestión de probar, por ejemplo, el año pasado leí solamente en segundo... después leyó mi esposo también el año pasado, que también dice que estuvo bueno».

Comentan también que hay otra mamá interesada en integrar el equipo comunitario de lectura, pero como no recuerdan su nombre, no pueden identificarla.

Noelia continúa conversando con Cecilia sobre la lectura en segundo grado. Acuerdan que la semana próxima leerá en estos grupos Un puñado de semillas. Como ese libro va a ser leído por Omar en tercero, convienen en que él le dejará el libro a Inés para que Cecilia lo retire al final del turno.

Cecilia comenta: «Yo tengo un libro que es más bien... o sea yo ya los leí, pero... es más bien para adultos... pero están buenos capaz que para clases grandes porque es más bien de filosofía de vida. Por ejemplo, quinto y sexto están en un cambio de entrar al liceo. Los libros se llaman, los tienen que conocer, uno se llama El secreto y el otro es La magia... son medios largos, pero habría que elegir algún capítulo que ellos puedan rescatar para cosas futuras... ellos van a entrar al liceo y ahí hay muchas cosas nuevas que de repente desde un cierto lugar llevarlos a un plano positivo... les va a costar, van a tener más materias... es difícil». Noelia sugiere que los traiga: «Hay que verlos» porque los tiempos de lectura son cortos y hay que buscar los momentos apropiados, ver el proceso de los niños y evaluar si las lecturas son pertinentes: «traelos y los leemos con Inés».

La reunión prosigue con la organización de la lectura y el cronograma. Noelia dice que en la escuela están trabajando sobre el tema huertas y que las maestras de segundo pueden estar interesadas en leer algún libro sobre esta temática, además de Un puñado de semillas. Le sugiere a Cecilia que maneje más de una posibilidad para leer, en función de lo que sienta más cómoda y le recomienda que lea Yací y Una pindó.

Cecilia comenta que ella puede leer todos los días de mañana a las 8.00. Noelia coordinará con las maestras de segundo los días y horarios de lectura.

Omar pregunta: «Después al otro sexto, al que ya les leí... yo quería saber si se les puede leer algo de los cuentos de Horacio Quiroga, algo... como habíamos hablado, algo que les impacte, no sé si es demasiado fuerte "La gallina degollada" o "El almohadón de plumas" porque yo les pregunté qué les gustaría que les leyera... y enseguida me hablaron: algo de terror. Y como yo ya tenía eso en la cabeza, pero antes quiero preguntar... yo soy fanático... "La gallina degollada" fue el primer libro que me leyeron a mí en el liceo, en primero de liceo un día faltó un profesor y viene el adscripto y nos lee y después conseguí el libro para leerlo todo».

Cecilia agrega: «Son bastante fuertes... yo cuando leí esos cuentos me quedaron tan grabados... yo los leí recién en el liceo, porque en el liceo lo tenían en el programa, pero de chica en la escuela nunca, los niños de ahora no son como nosotros, porque nosotros de terror nada, mire si íbamos a leer...».

Omar opina: «Pero viste que va cambiando, cada vez los niños son más vivos. Nosotros éramos unos nabos [...] estaría bueno hablar todo sobre la vida de él [Horacio Quiroga] en una clase».

Cecilia agrega: «O que ellos mismos también, de repente avisarles, y ver qué pueden averiguar de Horacio Quiroga».

Noelia recomienda que para más adelante pueden preparar un juego de preguntas y respuestas para que los niños de sexto le regalen a los de quinto. 
Omar manifiesta que tiene que ver dónde consigue el libro porque su ejemplar lo prestó y no se lo devolvieron. Noelia se ofrece a traerlo el libro de su biblioteca personal.

Antes de finalizar la reunión ajustan el cronograma de lectura para los terceros, quintos y sextos y convienen reunirse después de las vacaciones de invierno. Noelia les comenta que se contactó con un grupo de narradoras que vendrán a narrar al equipo comunitario, un día en que estén todos presentes.

Les consulto a Carla y a Omar si ellos van a continuar leyendo en los terceros a lo que Omar me contesta: «Sí, sí cuando me convoquen como al maestro Tabárez».

Les cuento también que en la próxima reunión les voy a traer los libros que les pediré que lean para mi investigación para que ellos los conozcan y me den su opinión.

Omar cuenta: «Yo trabajé muchos años armando exposiciones... y armé la feria del libro en el LATU cuando se hacía ahí durante años, y hacíamos durante todos los días de exposición, hacíamos una guardia para que no se caigan los stands y leíamos de todo, [enf.] de todo.»

Carla entusiasmada dice: «A mí me encantaría trabajar en una biblioteca, iah!, ime encanta leer!, tengo libros de Agatha Christie y de pila de autores...».

Mientras salimos del salón continuamos conversando informalmente sobre anécdotas de libros y de lectura.

\footnotetext{
${ }^{2}$ Director técnico de la selección uruguaya de fútbol.
} 


\subsection{Caso 1. Omar}

\subsubsection{Entrevistas}

\subsubsection{Entrevista a Omar}

Fecha y hora: 17.11.2015, 08.00 horas

Lugar: secretaría de la escuela

Participantes: Omar, investigadora

Sandra: Omar ¿por qué decidió integrarse al equipo de lectura?

Omar: eh:: mirá más o menos es así || con mis hijos yo me dedicaba solamente | a laburar | viste | es una edad en la que uno lo único que se piensa es hacer [enf.] plata plata plata para | darle lo mejor a ellos | | y te perdés un montón de cosas | y dije bue | voy a aprovechar con mis nietos | y ta

Sandra: en las actividades de lectura ¿cómo vive esas instancias con los niños? | ¿qué recibe de ellos?

Omar: sentir placer || y:: de lo que recibía | lo que más me encantaba era | después de la lectura los comentarios | había de todo | bueno vos estuviste | viste que hay de todo tipo de comentarios | algunos que te morís de risa | otros muy acertados | y otros que uno mismo | no se había puesto a pensar | que se dan cuenta que uno no

Sandra: ¿por qué cree que a los niños les sirve que venga un abuelo | o una mamá a leer a la escuela?

Omar: y creo que es para crear mismo el hábito de lectura ¿no? || eso:: con la televisión la computadora se está perdiendo

Sandra: y al maestro ¿para sus propósitos de enseñanza le sirve?

Omar: ah:: yo creo que le sirve | sí sí yo creo que sí

Sandra: ¿en algún momento sintió como que el maestro no notaba el aporte?

Omar: no | en ninguno | en todas las clases fui bien recibido | en todas | por los niños

Sandra: ¿y cuando usted lee qué observa en los niños?

Omar: y eso según las edades | los más chico::s | este:: || están más atentos | y:: a los más grandes si el te...- si el tema...- | si es un tema fuerte | los atrapás

Sandra: ¿cómo cuál por ejemplo?

Omar: y por ejemplo para sexto | yo ya había tenido comentarios de otras madres del año pasado de que e:: no | no lograban que los gurises | estuvieran atentos incluso hasta una madre se levantó y se fue e:: | entonces yo | hablando con las maestras | eh:: dijimos mirá yo quiero leerles algo que les impacte | que les pegue | y entonces | eh: fueron dos libros que leí a los quintos y sextos | uno era Bolboretas que se trata del primer beso | ahí ya eh:: quedaron como atentos | y después el segundo libro | fue «La gallina degollada» de Quiroga | que eso fue:: sensacional | porque fue un [enf.] silencio absoluto | hasta que terminé de leer

Sandra: iqué impresionante! [enf.] | hay que saber buscar el tema 
Omar: creo que sí | creo que sí | las maestras en eso creo que | en eso son las que están eh:: más duchas ¿no?

Sandra: el otro día cuando entrevisté a los chiquilines de Inés decían que los libros que más les habían gustado escuchar eran Un puñado de semillas y «El loro pelado»

Omar: [enf.] mirá vos | el Puñado de semillas para esa edad es muy fuerte porque se muere la abuela | es interesante para otros años

Sandra: el otro que les gustó fue «El loro pelado» | Quiroga siempre gusta ¿no?

Omar: sí sí está bueno

Sandra: ¿usted hace dos años que está en el equipo comunitario ¿verdad? I ¿cómo capitalizó su experiencia? | porque es una experiencia

Omar: y justamente el primer año:: | yo estaba ahí que no sabía bien qué leer | mucho más nervioso | porque aunque son niños me importan | este año mucho más tranquilo | y ya sabiendo un poco más qué tipo de lectura leer para | para cada edad ¿no?

Sandra: ¿y cómo elige esas lecturas?

Omar: principalmente las que orienta la maestra

Sandra: ¿cuáles son sus lecturas preferidas?

Omar: ¿mis lecturas preferidas para mí? | ah mirá | muy variado | novelas || historia me encanta || eh:: que no tienen por qué ser libros ¿no? | leo muchas...- [revistas] | y prehistoria también | prehistoria me encanta | y te digo algo más así chiquito | para que ...- hace muchísimos años que yo veng...- $\backslash$ venía pensando en escribir un libro que lo tenía...- | que venía guardando cosas en el disco duro | y pensé | y me decidí ahora | y ya empecé a escribir | pero para niños | que eso no lo tenía pensado

Sandra: [enf.] iqué divino! | el año que viene puede contarles sus libros | iqué maravilla! [enf.]

Omar: ya escribí dos cuentos | tengo otros ya pensados | y un montón más en la cabeza | y la protagonista es una tal Ercilia | Ercilia se llama | y es en el | en el 1890 | en esa época

Sandra: [enf.] iqué lindo Omar! | les va a gustar mucho a los chiquilines

Omar: yo ya los leí en casa a los gurises | a los más grandes incluso | y a todos les gustó

Sandra: después tendría que presentarlo en algún concurso

Omar: mirá ya tengo una profesora de Literatura que es amiga de mi hija | que los leyó y me dijo | a mí me parece que ya es demasiado | "esto hay que llevarlo a una editorial»

Sandra: ¿vio el concurso del MEC que hay todos los años? | ahí sí podría llevarlo | este año me parece que ya fue | pero cuando hay llamados así de cosas inéditas | está muy bueno

Omar: iah! sí | capaz que sí | que después elijo alguno

Sandra: <6> la pregunta era | ¿cómo elige las lecturas que usted lleva a la clase?

Omar: entre los dos con el maestro | porque a veces se usa...- | me piden cosas que es justo lo que están estudiando | aprovechamos las dos cosas 
Sandra: usted ya me comentó lo que había leído en sexto | y del grupo de Inés | ¿usted cuáles piensa que fueron las lecturas que más les gustaron a ellos?

Omar: ipah::! no me acuerdo si fue este año que les leí | «El loro pelado» | que yo pensé que fue el que más les había gustado | pero capaz...- | pero a lo mejor no fue este año | fue el año pasado | a lo mejor se los leí en segundo

Sandra: puede ser si es el mismo grupo | ¿y por qué cree que les gustó?

Omar: \{risas\} capaz que fue...- que es el que más me gusta a mí

Sandra: de Quiroga

Omar: sí es el que más me gusta a mí de lo que he leído de Horacio Quiroga ¿no?

Sandra: ¿a usted le gusta mucho Quiroga?

Omar: y sí a mí me encanta || y «La abeja haragana» también | ese está bueno | pero yo creía que era «El loro pelado»| la verdad que...-

Sandra: ¿usted recuerda cuando yo le pedí que leyera La manta de las historias? I ¿qué le pareció ese libro?

Omar: [enf.] iah::! buenísimo

Sandra: ¿le gustó ese libro? | ¿qué recuerda de ese día? | hace ta::nto

Omar: [enf.] no | todo | todo | ese...- que incluso ya lo he contado como cuento sin tenerlo para leer | porque tengo nietos más chicos también $\mid<4>$ y creo que todo | me acuerdo bien

Sandra: ¿y qué recuerda de los niños ese día?

Omar: creo ese día estaban medios inquie::tos

Sandra: ya le digo cuando fue \{consulto mi diario $<8>$ \} fue el 12 de agosto sí $\|$ qué recuerda de las respuestas de ellos? | ¿alguna que usted recuerde especialmente?

Omar: $<6>$ no | vos sabés que no

Sandra: ¿y qué cree que de ese cuento | le interesó más a los niños?

Omar: y creo que fue cuando todos juntaron lana para llevarle de nuevo | para que volviera a hacer la manta | creo que esa la parte más...- | que era la parte más importante del libro también | creo

Sandra: sí ellos se acordaron de esa parte también

Omar: que hablaba de ser solidario | es un lindo libro para seguirlo leyendo

Sandra: yo lo dejé en la escuela | le digo por si el año que viene les interesa | lo dejé acá

Omar: incluso tengo que un nieto | que es de 5 | que va a un jardín | a un jardín público también | y a veces voy a leerles también | me ofrecí y bueno || cada tanto voy a leer un cuento | incluso acá también me prestan los libros | así que para mí esto también fue súper positivo

Sandra: usted me contaba recién que le gusta mucho leer | haciendo un poco de memoria | ¿en qué momento de su vida identifica la lectura como actividad | que incorporó así | para disfrutar? 
Omar: la lectura en sí desde chico | porque siempre me gustó leer eh:: los cómics | y después de los cómics pasé a las novelitas de aquellas tipo Corin Tellado | pero que había de cow boys | de guerra || y después como mi primer libro | que fue de Julio Verne | De la tierra a la luna | me acuerdo clarito que leí | que llegó a mis manos | y leí y yo tendría 11 años | 11 o 12 años | no había entrado al liceo todavía || no teníamos ta::nta televisión | no teníamos computadora | era otra cosa

Sandra: y en la adolescencia y la juventud | ¿cómo vivió la lectura?

Omar: y capaz que fue menos || sí | ahí fue menos porque ya | de los...- los 16 a los...- | hasta que me casé | ya más era bailes | y ahí ya no leía tanto | leía bastante menos | y después que me casé | arranqué de vuelta

Sandra: siempre es al revés ¿no? | la gente cuando se casa tiene hijos deja | de leer porque bueno | porque los tiempos son menos | y trabaja

Omar: y el televisor en el cuarto | anula la lectura | eso anula...- tuve...- | tuve hepatitis | estuve cuatro meses en cama sin poderme mover | y:: y mi señora era socia de:: | de la biblioteca del club ANCAP | y me agarraba libros | por semana | yo creo que leía tres libros por semana || entonces iba a la biblioteca | cambiaba | los llevaba | y lo único que hacía era eso | lo único que hacía era leer | no sentir nada | estaba ahí | lo único que hacía era leer

Sandra: y actualmente me dijo que leía mucho también

Omar: sí sí | sí

Sandra: ¿cómo vive la lectura hoy?

Omar: a los nietos les leo $\mid\langle 6\rangle$ y:: yo de vez en cuando también | porque los libros están caros y los intercambio | ¿viste? | uno compra uno y:: lo pasamos | otro compra otro

Sandra: y acá en el barrio no hay bibliotecas ¿no? | porque yo la que ubico más cerca es la del Prado pero no sé si tiene socios

Omar: y creo que hay otra allá | cerca del puente | en unos edificios que hay | no sé si todavía está | había una | no sé si está porque yo iba a sacar libros ahí

Sandra: ¿usted qué opinión tiene de la labor del equipo comunitario de la escuela? | ustedes son muchos integrantes | son unos cuantos

Omar: < 5> bueno | ya te digo | para:: inculcarles el hábito de la lectura | eso es lo principal | tener una:: vinculación más cercana con los maestros | y con los gurises también | y con los gurises está | está genial

Sandra: ¿cómo valora los momentos de reunión con el equipo?

Omar: <5> e::s es | es bueno | es bueno porque ahí cada uno expone sus puntos de vista | sus formas y ahí fue donde aparecieron los comentarios de que:: | las clases más grandes eran más difíciles | y entonces ahí intercambiamos ideas | intercambiamos experiencias | este:: y:: | ta y las maestras aportan | son las que más aportan ¿no? | porque ya conocen todo el grupo...-

Sandra: y ustedes los que tienen más experiencia | yo veía que aportan mucho a los otros integrantes | Graciela por ejemplo 
Omar: ah:: sí ni que hablar | eso pasa en todos los ámbitos ¿no? | el que tienen más experiencia | es el que tiene más información <8> ojalá que siga este proyecto ¿no?

Sandra: esperemos que sí | y esperamos que la escuela también siga || Omar una última pregunta | ¿qué consejo le daría usted a un papá que el año que viene quiere entrar al equipo? | ¿̇o a otro abuelo? | ¿o a un exalumno?

Omar: eh:: || lo primero que se metan | que se metan | que van a disfrutar | aunque puedan venir pocas veces | pero que son disfrutables | [enf.] totalmente | esos momentos de lectura | que le den para adelante

Sandra: que vengan a leer

Omar: que vengan a leer | cuanto más grande es el equipo mejor | sí sí | y si se pudiera este:: | no sé | cortar el recreo | en vez de 30 minutos hacerlo de 20 | y tener 20 minutos más para leer | a la hora del recreo | eso estaría...- | estaría bueno también

Sandra: ojalá que puedan seguir el año que viene | la verdad que han hecho un muy lindo trabajo || he visto cosas | preciosas | de parte de to::dos | de los maestros | de los niños y de las familias

Omar: aparte ya las estadísticas dieron | de que subió | de que subió e::I | nivel de lectura | en la escuela | que antes | habían dicho | en las diez cosas que le gustaban más | la lectura no estaba entre esas diez | y ahora ya está | del año anterior a este | ahora ya está la lectura | así que:: | algo | dio resultado

Sandra: Omar algo que usted quiera agregar

Omar: no ya | creo que no | está todo

Sandra: yo tengo en casa otra Manta de las historias | se la voy a traer | y se la dejo para los nietos suyos | porque la escuela ya tiene | ¿a ver si grabó? | sí quedó todo grabado | [enf.] igracias Omar!

\subsubsection{Entrevista a Inés, maestra de tercer año $A$}

Fecha y hora: 19.11.2015, 08.00 horas

Lugar: salón de tercer año A durante la clase de Educación Física de los alumnos

Participantes: Inés, investigadora

Sandra: Inés || ¿qué tal te resultó | que Omar quien fue que vino a leer acá | haya venido || con sus cuentos a leer a la clase?

Inés: <6> a mí me resultó fantástico tenemos...- || yo creo que además tuve suerte porque es un varón | hay pocos referentes varones en la escuela | o sea el profesor de Educación Física solamente | bueno e::I tallerista de música | pero además es una persona muy cálida | o sea | los niños lo conocen desde hace tiempo | lo adoran y lo reclaman ahora que no estaba viniendo | entonces me resultó fantástico | le...- || estos niños son muy alborotados y con él...- | o sea tienen como una expectativa de la llega::da del cuento | yo que sé | y él también es un ser muy disponible | vos le decís este o el otro | o sea tira propuestas o sea...- || me parece que ta ...- | es bárbaro para los chiquilines | como tener esa posibilidad de tener un referente varón en esa...- | en esa postura también | además bueno lee bien conversa con los chiquilines bien |me parece que tiene un plus | no escuché a otros | lectores leer en los grupos pero | me parece que tiene un plus porque él lo envuelve con esa calidez humana que tiene que es bárbaro 
Sandra: ¿y vos que rescatás de esos momentos | de lectura con Omar | de tus niños con Omar? Inés: me parece que hay una circulación de afecto || ahí:: tremenda ¿no? | eh:: ta | que yo creo que es como tienen que ser dados los cuentos | a los niños les gusta más que venga él | a ellos les encanta que les lean siempre | cualquiera que venga | pero el hecho de que sea sistemático que él vino tantas veces | ellos ya saben que va a pasar algo lindo y ya como disponen el alma así ¿¿no?

Sandra: $<5>$ ¿vos pará qué pensás que sirve que venga otro de afuera a leer?

Inés: $<5>$ [piensa]

Sandra: ¿para los aprendizajes de los chiquilines?

Inés: <8> o sea...- | a mí me parece que a veces...- que a veces está separado | me parece que a esta edad de los niños ocho o nueve años | es una edad en la que ya poca gente les lee | porque cuando son chiquitos están como más acompañ::ados | los padre cuentan leen todo...- | pero como ahora los niños saben leer solos a la gente le parece que no tiene que leerles | va no sé si le parece | la práctica se reduce | porque la palabra se redujo mu::cho | porque el encuentro se redujo | pero además | aun en los padres muy ocupados y preocupados de sus hijos | que alguien les lea a los niños | a esta edad no...no es muy común | entonces eso queda como:: encerrado en la escuela y en el maestro esencialmente | y entonces que vengan otras personas que no sean maestros a leer || a mí me parece que está bueno ver a los niños | o sea | a los niños | a mí me encantan los cuenteros y que me lean cuentos todavía me gusta y ya estoy | \{[enf.] grande grande (risas)\} | y es todo lo que voy a decir\} $\|$ y nada $\|$ me parece que esencialmente tiene que ver con eso | con poner otras...- | otras personas que hagan estas...- | estas entregas ¿no?

Sandra: ¿y el hecho de que sea un abuelo | en vez de una mamá | como en el caso de Omar? | en otras escuelas son todas mamás | pero acá hay abuelos | ¿hay diferencias?

Inés: <3> si fuera un padre...- || y capaz que si fuera un padre | a mí me parece sobre todo es que es que es varón | pero || también su nieta tiene un lugar en el grupo | o sea el vínculo entre ellos | se ve precioso | yo ya lo dije es un ser muy...- | el hecho de que sea abuelo para mí suma | porque...- || pero puede ser que sea su personalidad | tiene como otra serenidad como otra entrega me parece | él no tiene porqué:: | un padre capaz que se siente como más obligado | como que me llama la maestra de mi hijo a leer un cuento | aunque lo haga con placer | él me parece que es esencialmente el placer | de acompañar a su nieta | de volver a la escuela | el tipo trabaja pero está jubilado | o sea también tiene como una cierta disponibilidad | a veces a los padres...- | aunque lo hagas con | con energía y con cariño y con ganas me parece que el abuelo | para mí suma más

Sandra: vos que podés ver leer Omar | y:: bueno también ves a tus niños cuando leen contigo | ¿vos qué observás con uno y con otro || si tuvieras que comparar decir «con Omar pasa esto conmigo pasa esto»?

Inés: <6>

Sandra: ¿vos ves que hay difere::ncias? I ¿o que es lo mismo para ellos que lea uno o que lea otro?

Inés: no lo mismo no es || lo mismo no es porque:: porque:: | yo te digo | a ellos les encanta que les lean | yo leo cotidian...- | o sea yo no leo cuentos todos los días pero leo muchos | para ellos es como un 
evento | es como una fiesta | ellos se ponen más contentos | aunque los cuentos que yo les lea les encanten | y te piden | y yo qué sé | ahora que yo no estuve | ellos tienen biblioteca de aula y no cambiaron libros en un mes estaban como desesperados que querían | este grupo tiene eso | me parece que es una fiesta | para ellos que venga Omar tiene ese plus | es como educación física | es una actividad especial para mí es como...- | ellos lo viven como una especie de fiesta | se ponen más contentos

Sandra: vos que observás cuando los niños leen con Omar y contigo ¿qué observás que responden? | ¿hay algo diferente?

Inés: ¿̇en los niños o en la postura de Omar y la mía?

Sandra: en los niños

Inés: me parece que preguntamos distinto || que ponemos e...- | a mí me parece que Omar quiere...- | tengo siempre esa sensación | que quiere enseñar algo | algo que sea bueno como...- | como una moraleja | me da la sensación de que él siempre se va para ese lado | el maestro tiene con cada cuento | puede tener objetivos diferentes y entonces...- | me parece que las preguntas son | y me parece que los niños también acomodan el discurso a lo que Omar quiere oír | [enf.] porque es el abuelo | entonces ellos...- | también lo acomodan a lo que yo quiero oír cuando yo les pregunto | o sea | ellos saben cómo es portarse bien y saben | y después no hacen nada o muchos no hacen pero saben | me parece que va como a la cosa familiar | ellos se ponen más | en el relato familiar o en lo...- | contestan más desde ese lugar | que desde el lugar del aprendizaje | capaz que porque las preguntas son más dirigidas a eso | capaz que es como si les hablara el propio abuelo | ellos se colocan en un lugar que es más como del vínculo familiar que del pedagógico | me da la sensación

Sandra: vos me dijiste recién que tenés otros propósitos que Omar no tiene | y eso se refleja en las preguntas

Inés: claro porque:: | porque uno tiene...- | vos tenés en la cabeza el microchips | enriquecer el vocabulario de esto ¿viste? | capaz que no me centro tanto en el mensaje que el cuento quiere transmitir porque por lo general es bastante obvio || me parece | y vas más como a la metáfora | al enriquecer el vocabulario | a la estructura || a las inferencias || es otro...- | es otro...- | es otra cosa | o a nada | cuando lo hacés solo para regalar lo regalás | terminó el cuento viste 15 minutos antes de la salida terminó el cuento | y nos vamos o a veces lo hacés con el objetivo de que algunos niños procesen determinadas cosas que vos sabés que están pasando | no sé unos padres se separan y leés el El Polilla porque tiene la teoría de los lados | o cosas que vos sabés que están pasando y lo hacés para eso y lo hacés y lo dejás ahí | y después...- | no sé tiene otro...- | o sea él viene a regalar y ellos van a recibir | yo creo que él siempre quiere enseñar igual | no sé si porque es la escuela o es el abuelo y quiere transmitir cosas lindas | él siempre quiere enseñar | él siempre tiene esa postura no es que termina el cuento y se va o que parte es la que más te gustó | él siempre va a qué aprendimos de esto | cómo hacemos para ser más bueno | me parece que él siempre está como parado en ese lugar

Sandra: si vos pudieras elegir | viene un papá o una mamá a | ¿cuál sería ese escenario ideal? | ¿qué querrías que hicieran? | ¿qué querrías que hicieran los niños?

Inés: en el escenario ideal yo quisiera que la persona || leyera o narrara algo que fuera muy significativo || para:: la persona | porque me parece que la autenticidad es como | básica | todo lo demás es secundario | si vos contás un cuento o lees un cuento que para vos | para tu niñez | en tu emoción está 
soldado || eso || este:: | después me parece que eh:: lo otro || no sé | por eso me parece que los cuentos tienen que ser elegidos | que no...- o sea por lo menos conversados con el maestro | y:: pero más que para ver a veces | a veces incluso hasta la calidad literaria puede ser llegar a ser secundaria si uno...- | si el cuento es significativo para la persona que lo lee | y si es un cuento nuevo que no tiene relación con su historia | que realmente le encuentre | la cuestión | Omar una de las cosas que hacía | bueno para los grandes | cosas de sangre | de muerte porque sabemos que esa edad es para eso | él también tiene como esa visión | "yo los engancho con esto» || eh:: pero me parece que nada | o tiene que ser significativo así o tiene que gustarte | [enf.] mucho | entonces a partir de ahí | lo demás | no:: sé |me parece secundario

Sandra: ¿te acordás específicamente cuando él vino a leer La manta de las historias?

Inés: [enf.] ipa::!

Sandra: yo sé que...- que está muy lejos en el tiempo

Inés: recordame el cuento

Sandra: el cuento de Babba Zarrah que:: | vos les dijiste a los nenes | cuando terminó «vamos a tejer cuadraditos para armar entre todos una manta»

Inés: me acuerdo del cuento | pero del momento en particular || y las historias tenías que ver con $=\ldots . . .=$ Sandra: $=\ldots . . .=$ ¿te acordás que ella iba tejiendo y destejiendo | para darles a las personas del pueblo una prenda?

Inés: $<5>$

Sandra ¿no te acordás?

Inés: cuando me decís La manta de las historias me hago un cuento | me lo imagino | pero...- | no me acuerdo del cuento | y me acuerdo del momento que lo leyó ¿cuál era la pregunta específica es...-?

Sandra: ¿qué recordabas de esa lectura? | ¿qué habías observado en los niños? | claro pasó que después vino la huelga | el viaje

Inés: claro fue hace mucho tiempo | sé que fue un cuento novedoso para los niños porque otros cuentos que él leyó ya los conocían | o tenían alguna referencia || o porque leyó cosas de autores que conocían o cuentos que algunos conocían y otros no | ese cuento era nuevo | y:: || no tengo mucho para decir | che

Sandra: ¿más o menos cuántos años de trabajo tenés Inés?

Inés: $\langle 5>\{$ risas $\}=\ldots . .=\}$

Sandra: $=\ldots . .=\{($ risas $)$ no doy apellidos $\}$

Sandra: yo me recibí...- | yo tengo 27 años | 27 años de trabajo | en Primaria | 26 porque un año tomé licencia | estuve eh:: | diez años sin grupo | en Primaria | y después tengo trabajo en educación no formal

Sandra: porque vos tenés otra formación 
Inés: sí claro | tengo trabajo en educación no formal | y el hecho de haber estado diez años sin grupo |yo era secretaria | y mi proyecto era Literatura | entonces hice el curso de bibliotecas escolares | en la [biblioteca] Pedagógica | que estaba una mujer genial | que se jubiló ese año | que a mí me:: me ayudó pegué un salto en ese sentido ¿no? | porque te hace mirar la literatura infantil de otra manera | a mí me:: siempre me gustó leer | pero igual además de esos 27 años | tengo todos lo::s | años de Magisterio $\mathrm{y} \mid$ desde gurisa siempre trabajando con niños

Sandra: y eso mismo te iba a preguntar la lectura en tu vida...-

(Entran los niños que regresan de la clase de Educación Física haciendo mucho barullo. Interrumpimos la entrevista unos minutos. Algunos piden para ir al baño. Inés da instrucciones a los niños para que se organicen y tranquilicen. Se escucha la voz del profesor de Educación Física. Salimos al pasillo a terminar la entrevista.)

Inés: es así | en mi casa no había libros || yo...- mi vieja terminó:: terminó la escuela | y no había no había libros | los dos | mi mamá y mi papá leían perfectamente | escribían perfectamente | sin faltas de ortografía | yo tengo más base de narrado | mi madre nos contaba cuentos | no era una casa que tuviera libros | pero tenía una amiga | ponele que cuando me mudé para el Paso de la Arena cuarto o quinto | que en su casa había muchos || leí \{Mujercitas y Sisi emperatriz (risas)\}| bueno leí todo eso\} | después la escuela tuvo una influencia muy importante | pero a los diez años ponele | leí me acuerdo el primer libro que lo empecé a leer y no pude | Frederick Forsythy no sé cómo se pronuncia un libro denso ¿viste? | de un alemán | 10 años y leía los libros que leían lo padres de mi amiga en realidad | y después entre los...- | con mis profesores de Literatura tuve mucha suerte | y después mis amigos || yo este:: estaba en el Bauzá en el 83 | que era un momento de explosión cultural | y entre los 16 y los 20 años | entre los 16 y los 19 años \{(interrumpimos la entrevista por el ruido que hacen los niños) <15>\} leí Cortázar y II bueno todos los latinoamericanos todo eso | leíamos | nosotros leíamos ¿viste? de bajarte del ómnibus no poder parar | y después en Magisterio hubo cosas | por ejemplo García Márquez no me gustaba | empezaba a leer y me daba calor y me daba no le podía entrar | todo el mundo decía que era fantástico | y en Magisterio en sí tuve una profesora que era || así soberbia | que en un...- \{continúa el ruido $<10>$ \} que en un cuento de una hoja media | y es mi escritor preferido | no hay libro que no haya leído | bueno los ensayos capaz | me parece que en mí influyen especialmente los amigos | la educación el momento político | yo que sé | porque en mi casa no

Inés: ichiquilines! (tranquiliza a los niños que siguen muy inquietos)

Sandra: dejalos | ya terminamos

Sandra: ahora nos vamos al deber ser | vos que tenés una impronta muy especial | de que te gusta leer a tus niños | de que lees con frecuencia en tu clase | no mirando lo que vos hacés sino mirando a la escuela |¿vos pensás que la lectura en la escuela tiene el lugar que tiene que tener? I ¿tendría que tener más? ¿tendría que tener menos? || la lectura de literatura

Inés: yo creo que no tiene | que tiene que tiene que tener más | yo creo que hay mucho dedicado a las ta::blas | pero es como un encare en general | igual el programa tiene ahora un apartado de Literatura que no sé cuánto puede incidir pero que antes no lo tenía || a mí me parece que tiene que tener más | creo que es básico en la formación | creo que no tienen el lugar que tiene que tener | creo que los 
maestros se centran más en otras cosas | yo también | pero me parece que no tiene el lugar que tiene que tener

Sandra: para terminar | ¿vos cuando entraste a esta escuela sabías que tenía la Biblioteca Solidaria?

Inés: no

Sandra: ¿y por qué te enganchaste como referente?

Inés: porque Noelia era la referente el año pasado y es mi paralela | y nos pusieron el espacio de coordinación los lunes | y nos quedaba bien | incluso María no sabía que yo había hecho el curso de bibliotecas escolares | no sé si me dijo te gusta querés o te parece | no me acuerdo y como a mí me gusta enganché | pero en realidad no sabía | no sabía que la escuela tenía el proyecto | eso no || pero Noelia era la referente y me tocó

Sandra: vos me dijiste que tenés otra formación

Inés: yo tengo un posgrado de gestión de centros educativos | de la Católica | que en realidad lo hice porque trabajo en gestión en otro trabajo | en la escuela pública no

Sandra: esto te lo pregunto porque vos me lo habías mencionado en otro momento

Inés: me parece que incide más el curso de bibliotecas escolares | y que yo soy una lectora compulsiva | me parece que eso tiene más que ver | me compro libros de niños | voy a la feria y me compro | tengo mi propia colección de libros infantiles porque...- || y como siempre estoy trabajando con niños | son esas cosas que vos usás | ahora cuando me fui me los llevé | porque tengo los que no se mezclan | y a veces | es esa | si vas a otro país o a las ferias de libros | a veces es esa oportunidad | y después no los ves | porque a Olaondo la encontrás en todas las escuelas | hay libros que aparecen muchos pero otros no

Sandra: ¿algo que quieras agregar Inés?

Inés: no no sé | yo contenta de estar en el proyecto

\subsubsection{Entrevistas a los niños de tercer año $A$}

Fecha y hora: 11.09.2015, 09.00 horas

Lugar: pasillo frente a los baños al final del corredor

Participantes: Zoe, Iván, Yasmila, Martín, Sofía, Franco, Facundo, investigadora

\section{Zoe}

Sandra: hola Zoe | ¿cómo estás? | las preguntas que te voy a hacer hoy| son para un trabajo que yo estoy haciendo | ¿te acordás de que hace unos días les hice unas preguntas en una hojita?

Zoe: $\{$ mueve la cabeza [asiente]\}

Sandra: ¿qué opinás de que Omar venga a leer?

Zoe: a veces no me gusta mucho

Sandra: ¿cómo? (no puedo escuchar por el ruido externo de los niños que se desplazan) 
Zoe: a veces no me gusta mucho

Sandra: ¿̇y por qué?

Zoe: no sé por qué | me aburre || un poco

Sandra: ¿qué es lo que te aburre?

Zoe: $<9>$ que me lean

Sandra: ¿qué lea quién?

Zoe: cualquiera

Sandra: el otro día escribiste | "a veces sí me gusta porque es lindo»| (leo lo que escribió en la encuesta)| ¿cuándo te gustó por ejemplo?

Zoe: cuando leyó El pájaro del alma

Sandra: cuando leyó El pájaro del alma | ¿y por qué te gustó ese libro?

Zoe: $<8>$ porque era lindo y $\ldots$-.

Sandra: porque era lindo | ¿qué recordás de ese libro?

Zoe: que:: el pájaro del alma abría el cajón de la alegría y era cuando estaba feliz | y cuando abría el cajón de:: de cuando estaba tristel y era cuando estaba llorando o algo de eso

Sandra: ¿te acordás de cuando Omar leyó un cuento | La manta de las historias?

Zoe: $<8>$

Sandra: ¿no te acordás?

Zoe: no \{mueve la cabeza [niega]\}

Sandra: decime Zoe| el año que viene que van a estar en cuarto | ¿te gustaría que vengan los papás o los abuelos a leerles?

Zoe: sí [Dudosa, sin comprometerse.]

Sandra: ¿qué libro les pedirías que leyeran?

Zoe: $<15>$

Sandra: ¿alguno en especial?

Zoe: \{mueve con la cabeza [niega]\}

Sandra: ¿no? | ¿quién te gusta más que lea? | ¿alguna mamá? | ¿la maestra?

Zoe: la maestra

Sandra: lee lindo Inés | ¿no? | es divertida

Zoe: sí

Sandra: muy bien Zoe | igracias por venir! ¿podés pedirle a Iván que venga para aquí? 
Iván B.

Sandra: ¿cómo estás Iván? | lo que te voy a preguntar es para un trabajo que estoy haciendo yo | ¿te acordás de qué hace unos días les hice unas preguntas por escrito?

Iván: \{mueve la cabeza [asiente]\}

Iván: ¿qué opinás de que Omar o las mamás vengan a leer?

Iván: ime encanta!

Sandra: ¿por qué te gusta?

Iván: \{iahora sí! (risas)! || me gusta que el abuelo Omar lea porque lee bien | para empezar | después $<10>$ eh-... $<9>$

Sandra: el otro día pusiste | «están buenos los libros que lee»

Iván: y después | \{me gustan que me lean |(risas)\}

Sandra: te gusta que te lean | ¿quién te gusta que te lea?

Iván:: más que nada el abuelo Omar || porque | en mi casa solo || solo leo yo | a veces | agarro los libros I y me pongo a leer

Sandra: ¿y te gusta que venga alguien de la familia a leer a la escuela?

Iván: sí

Sandra: yo me acuerdo de un día que leyeron un cuento con Omar que vos te levantaste y lo abrazaste ¿te acordás?

Iván: \{sí (sonríe)\}

Sandra: ¿vos ya lo conocés de antes a Omar?

Iván: sí porque es el abuelo de una amiga mía

Sandra: ah:: | y de los cuentos que leyó Omar | ¿de cuáles te acordás?

Iván: de Un puñado de semillas y $<6>$ ah:: y ahora no me acuerdo del nombre de uno | pero era sobre un pajarito que estaba dentro de una jaula

Sandra: ¿El pájaro del alma?

Iván: ese | El pájaro del alma

Sandra: del día que leyó Omar La manta de las historias | ¿te acordás?

Iván: no

Sandra: aquella historia que la abuela iba uniendo cuadraditos | e iba armando una manta | ¿no te acordás?

Iván: no

Sandra: ustedes el año que viene van a estar en cuarto ¿ंverdad? | ¿les gustaría que siguiera viniendo el abuelo Omar o una mamá a leerles? 
Iván: \{mueve la cabeza [asiente]\}

Sandra: ¿sí? | ¿por qué?

Iván: la verdad porque me gusta que me lean cuentos | y los que lee Omar son rebuenos porque trae libros que son reinteresantes

Sandra: muy bien | imuchas gracias Iván! pará que te digo...-

Iván: ¿ZZoe?

Sandra: Zoe ya estuvo | ¿no vino Belén?

Iván: Yasmila

Sandra: Yamila | ¿podés decirle que venga?

Iván: okey

\section{Yasmila}

Sandra: Yamila | ¿cómo estás? | ¿bien?

Yasmila: bien

Sandra: aguardame un segundito que tengo que ordenar...- | \{ordeno mis papeles\} bien ibuen día!

Yasmila: buen día

Sandra: eh:: | las preguntas que te voy a hacer ahora | eh:: tienen que ver con un trabajo que estoy haciendo | que he venido a...-- | a mirar cómo lee Omar |¿̇te acordás?

Yasmila: \{mueve la cabeza [asiente]\}

Sandra: ¿qué opinás de que las mamás o abuelos vengan a leerles?

Yasmila: me gusta que venga el abuelo Omar

Sandra: ¿por qué te gusta que él venga a leer?

Yasmila: m:: me gusta porque lee Omar | porque tiene un buen tono de voz | se escucha muy bien | y:: me encanta:: como...- | eh:: los cuentos que él escoge

Sandra: ¿te gusta?...- | y de esos cuentos ¿cuál te gustó? | por ejemplo

Yasmila: eh:: Un puñado de semillas | eh:: también me gustó || «La abeja haragana» || y un...- | y El jajilé azul | que había ...-

Sandra iah:: El jajilé azul! (me sorprendo porque este cuento fue leído por Omar en 2014.) | eh:: Yamila ..- $^{-}$

Yasmila: sí

Sandra: Yas::mila ¿ंverdad? (me corrijo porque noto que estoy pronunciando mal el nombre de la niña.)

Yasmila: sí

Sandra: bien || eh:: || ¿ंvos te acordás cuando Omar leyó un libro que se llama La manta de las historias? 
Yasmila: sí

Sandra: ¿te acordás de ese cuento?

Yasmila: sí

Sandra: ¿qué te acordás?

Yasmila: me acuerdo que:: || una:: señora mayor | era la que contaba cuentos a los niños | tenía una man:: | una gran manta | llena de colores || iba a retazos... | eh:: | y luego | un niño se le rom...- | se rompió un champión ${ }^{3} \mid$ y se le...- | y después sacó una parte de su manta y le::...- | y le había hecho un parche | después empezó a darle regalos de esa manta | a toda la ciudad | que...- | donde ella vivía | y después los niños | y toda la ciudad | le hicieron otra manta

Sandra: iexcelente! | ¿te había gustado ese cuento?

Yasmila: [enf.] me encantó

Sandra: ¿por qué?

Yasmila: me había gustado la gentileza de la señora | a darle los regalos a la gente | y también | la humildad | de aquel...- de aquellos niños y la ciudad que le habían hecho la manta

Sandra ite acordás muy bien del cuento!

Yasmila sí

Sandra: este...- y:: |¿qué otra cosa del abuelo Omar | recordás cuando él viene a leer?

Yasmila: me acuerdo que la última vez que vino | nos hizo...- | nos leyó | El pájaro del alma

Sandra: ¿y qué te acordás de ese cuento?

Yasmila: me acuerdo que el pájaro del alma tenía | tenía muchos cajones || de emociones | impulsos || y también se...- | sentimientos | tenía...- | caminaba con una pata porque la otra la tenía escondida abajo de la ala (sic) con las llaves con todas las llaves de aquellos cajones

Sandra: hermoso cuento ese I te acordás muy bien de ese cuento

Yasmila: sí

Sandra una última pregunta | el año que viene van a pasar a cuarto | ¿verdad? || e::m también |¿̇es gustaría que viniera una mamá | o siguiera Omar leyéndoles?

Yasmila: sí me encantan los cuentos | mi mamá a veces...- || yo le pido a mamá o a papá... | o cuando me...- | o también yo me leo | un libro antes de dormir

Sandra: te gusta mucho leer a ti también

Yasmila: me encanta leer

Sandra: ¿y qué libro le pedirías a Omar | o a esa mamá que venga a leer que te lea? | por ejemplo Yasmila: me gustaría pedir que me leyera...- $<6>$

\footnotetext{
${ }^{3}$ Así se denomina en Uruguay al calzado deportivo.
} 
Sandra: si vos pudieras decir «ah:: yo quiero que me leas | tal cosa»

Yasmila: El país de las cercanías

Sandra: ¿te gusta ese libro? | ¿sí? | es un libro largo

Yasmila: sí | a veces lo leo por Internet

Sandra: ah:: claro | ¿por la xo?

Yasmila: por la xo

Sandra: iqué lindo Yasmila! | muchas gracias

Yasmila: de nada

(Interrumpe Inés para avisar que se trasladaron al salón de tercero B.)

Sandra: perdón | ¿Anthony?

Yasmila: faltó

Sandra: ¿Martín?

Yasmila: Martín | igracias!

Sandra: igracias a vos!

\section{Martín}

Sandra: buenas Martín | ¿cómo andás? | ¿bien?

Martín: bien

Sandra: esperá que voy a cerrar un poco | porque si no no vamos a escuchar nada (cierro la puerta que comunica con el pasillo que da a los salones)

Martín: vamos a mirar una película

Sandra: [enf.] ah:: van a mirar una película ¿̇cuál?

Martín: Anina

Sandra: iah::! iqué lindo! | y después van a leerlo capaz | sentate un poquito

Martín: \{hace un gesto [no comprende lo que le pregunto]\}

Sandra: ¿me dejás hacerte unas preguntas para un trabajo que yo estoy haciendo? | ¿te acordás de las preguntas que les hice el otro día?

Martín: \{mueve la cabeza [asiente]\}

Sandra: ¿sí?

Martín: sí

Sandra: ¿qué opinás de que las mamás o los abuelos vengan a leer a la escuela?

Martín: me gusta | me gustó «El loro pelado» [se anticipa a las preguntas que le voy a hacer, tal vez porque sus compañeros le comentaron qué voy a preguntar] 
Sandra: bien | el cuento «El loro pelado» | ¿̇y por qué te gustó ese cuento?

Martín: porque lo había venido a leer el abuelo Omar | y lo leía como con...- || no sé cómo es que te puedo decir em:: || em:: | entusiasmo | con los mismos tonos del libro

Sandra: ah:: claro | hacía los mismos tonos de voz de los personajes | ¿decís vos?

Martín: sí

Sandra: muy bien | ¿y por qué te gusta que venga a leer Omar?

Martín: y porque es un abuelo | es el abuelo de la clase | aparte de ser el abuelo de Clara | es el abuelo de la clase

Sandra: el abuelo de la clase | porque él ya venía el año pasado a leerles | ¿verdad?

Martín: no

Sandra: ¿no?

Martín: no el año pasado no | el año pasado venían | creo que otros padres | y él:: | no me acuerdo | una vez fue que vino él creo

Sandra: vos pusiste acá «porque lee con entusiasmo y humor y porque nos hace preguntas» | ¿te acordás de alguna pregunta que haya hecho?

Martín: em:: qué hacía...- || em:....- en Un puñado de semillas qué hacía | la niña cuando salía al...- | al barrio al otro lugar

Sandra: Martín yo me acuerdo que cuando | yo vine a verlos | que leían con él eh:: vos siempre levantabas mucho la ma::no | opinabas mucho || ¿por qué?

Martín: [enf.] porque me gusta es como...- | un tic nervioso que tengo que quiero ser yo

Sandra: pero | estabas muy atento al cuento que se leía | ¿verdad?

Martín: sí | en una parte no me acuerdo si vos fuiste esa vez | que él nos preguntó una vez...- | nosotros le preguntamos qué segnificaba (sic) una palabra...- | no me acuerdo qué palabra era | una palabra...-

Sandra: y él siempre les respondía

Martín: sí

Sandra: ¿vos te acordás cuando Omar leyó un cuento que se llama La manta de las historias?

Martín: <3> no

Sandra: un cuento donde había una señora que hacía una manta | tejía

Martín: no ese no lo leímos

Sandra: ¿no estabas ese día?

Martín: n:: no estuve entonces

Sandra: una señora anciana | mayor que vivía en un pueblo

Martín: ¿que vivía en una montaña? 
Sandra: en una montaña | con nieve

Martín: no

Sandra: capaz que vos no estabas ese día | ¿̇y algún otro libro que hayas leído con Omar que te acuerdes?

Martín: e:: <6> E::l pájaro del alma

Sandra: ¿̇y por qué te acordás de ese cuento?

Martín: y porque...- |no sé como...- | ahí ya no sé cómo decirte

Sandra: ¿qué te acordás del cuento?

Martín: que el pájaro con la pata abría lo::s cajones de los sentimientos

Sandra: ¿y qué te provocó ese cuento cuando lo escuchabas?

Martín: era divertido

Sandra: ¿sí? | ¿te hacía pensar? ¿te ponía triste?

Martín: triste no pensar sí

Sandra: bueno | decime | el año que viene que van a estar en cuarto | si ustedes | pudieran | invitar a los abuelos o a los papás a leer | ¿los invitarían de nuevo?

Martín: sí

Sandra: ¿qué les pedirías que leyeran?

Martín: [enf.] todos los libros que haya en la escuela

Sandra: $\{$ (risas) itodos los libros que haya en la escuela!\} | ¿alguno en especial?

Martín: «El loro pelado»

Sandra: «El loro pelado» | él ya lo leyó «El loro pelado»

Martín: fue el que más me gustó

Sandra: ¿y qué te acordás de ese cuento?

Martín: que tipo el pájaro | se volaba...- | iba iba volando hasta un árbol cerca de la casa | y:: apareció un un jaguar ab...- abajo y el loro iba bajando bajando | y el...- el leopardo lo agarró y le sacó no me acuerdo unas plumas y él estaba en una cueva | y después volvió y le crecieron y después fueron a matar al leopardo Sandra: muy bien | bueno muchas gracias Martín | esperá que te digo quién viene ahora

Martín: ¿quién viene?

Sandra: ¿Sofía vino?

Martín: sí gracias

Martín: [enf.] gracias a vos Martín 


\section{Sofía}

Sandra: Sofi | ibuen día! | ¿cómo estás? | ¿bien?

Sofía: bien

Sandra: bueno mirá | las preguntas que yo te voy a hacer | eh:: son para un trabajo que yo estoy haciendo | que he venido a la clase cuando leyó Omar | ¿te acordás?

Sofía: sí

Sandra: ¿y que pensás de:: | que vengan los familiares a leer a la escuela? | una mamá:: | un abuelo Sofía: porque a mí me gusta::...- | a mí encantan los libros | y yo cada martes voy a ver si mis abuelos me llevan | y yo siempre leo un libro | y:: yo tengo tres...- | un libro que tiene 365 cuentos | y otro que se lla| eh:: || eh:: | cuentos para soñar o algo así | y bueno me gusta leer y escuchar a las personas que me leen y cosas así

Sandra: vos escribiste que te gusta que lea el abuelo Omar | ¿por qué te gusta?

Sofía: porque a veces con los libros tenés imaginaciones | y viste cuando ves películas de terror y eso no...- $\mid$ te quedan en la cabeza y...- pero los libros a veces te...- | te traen imaginaciones y algunos...-

Sandra: muy bien y de cuando vino a leer Omar | ¿de qué te acordás | de las veces que él vino a leer

Sofía: ¿cómo de qué me acuerdo?

Sandra: ¿de qué te acordás | de esos días que él vino a leer? <5> || ¿cómo lee él? || ¿te gustaba? ¿pasabas bien? | ¿te divertías?

Sofía: me gustó más El pájaro del alma y La manta de las historias

Sandra: justo te iba a preguntar por La manta de las historias | ¿por qué te gustó ese libro?

Sofía: porque:: || por ejemplo no sé:: | porque le hacían medias a una señora y por ejemplo | no sé | ayudar a una persona y regalarle algo es muy lindo porque si en tu cumpleaños no te regalan ningún regalo es medio...-

Sandra: ¿cómo era ese cuento?

Sofía: iah::! | feliz más o menos feliz

Sandra ¿te gustó como terminó?

Sofía: sí

Sandra: Sofía:: || y vos me dijiste que te había gustado otro cuento que era...

Sofía: El pájaro del alma

Sandra: ¿ por qué te gustó?

Sofía: porque yo en el cuaderno de Matemática y Lengua dibujé al pájaro con unas cajas | y por ejemplo me gusta que:: | que haya...- | me gustó ese libro porque hay cajas de amor | de tristeza y cosas así | y a veces | en tu vida pensás mucho en el amor y cosas así 
Sandra: ¿el año que viene que van a estar en cuarto | te gustaría que siguieran viniendo a leerles Omar u otras mamás?

Sofía: \{mueve la cabeza [asiente]\}

Sandra: ¿sí | ¿por qué?

Sofía: y porque no sé:: | como te dije | me encanta

Sandra: ¿si vos pudieras elegir ese libro para que ellos lean? dirías | me gusta este

Sofía: m:: elegiría:: Violeta || de Susana Olaondo

Sandra: bueno | muy bien muchas gracias Sofía | ¿Santiago vino?

Sofía: ah:: Santiago González | no vino

Sandra: no vino Santiago || ¿a ver? || ¿Franco vino?

Sofía: Luciana sí | ¿le digo que venga?

Sandra sí || gracias

\section{Franco}

Sandra: hola Agustín ¿cómo andás? ¿bien?

Franco: Franco

Sandra: ah:: Franco perdón || yo no me acuerdo de todos los nombres | por eso me confundo

Sandra: voy a hacer algunas preguntas para un trabajo mío parecidas a las que respondieron el otro día ¿qué opinan de que las mamás | papás | abuelos | vengan a leerles?

Franco: qué sí que me gusta

Sandra: vos escribiste que te gusta que Omar lea porque::...- $\|$ ¿ te acordás?

Franco: sí te había escrito:: | varias cosas

Sandra: ¿por ejemplo?

Franco: porque me gustaba porque era:: | que leía hermoso | por ejemplo

Sandra: vos escribiste otra cosa | «es muy cariñoso Omar»

Franco: es cierto

Sandra: ¿sí? | ¿qué recordás de cuando él viene a leer?

Franco: que él siempre saluda a toda la clase | que cuando lo llaman al teléfono no atiende | un ejem...- || no sé | no sé qué más decirte

Sandra: está perfecto | ¿y qué más te acordás de él?

Franco: que la nieta que tiene es Clara

Sandra: que es el abuelo de Clara | ¿̇y por qué decís que es cariñoso?

Franco: [enf.] porque tiene media pinta 
Sandra ¿media pinta?

Franco: [enf.] no sé cómo explicarte

Sandra: a ver pensá

Franco: no sé cómo explicarte | n::o se me ocurre nada [molesto con la pregunta.]

Sandra: ¿algún libro que él haya leído y te haya gusta::do?

Franco: por ejemplo El pájaro...-

Sandra: ¿el pájaro...-?

Franco: de | la | vida | creo [dudoso]

Sandra: ¿y qué te acordás de ese cuento en especial?

Franco: que era de un pájaro que abría | cofres con una llave que tenía acá en la pata | y:: que | que era de las emociones

Sandra: ¿`y por qué te llamó la atención ese cuento? $=\ldots . . .=$

Franco: $=\ldots . . .=$ porque porqué mirá $\|$ yo recién cuando...- $\|$ un impulso...- | por ejemplo te hago un impulso de ponerte a hablar en toda la clase | tenés que controlarlo | y eso es un un ejemplo que te dije recién

Sandra: iah:: claro! | el cuento hablaba de los impulsos

Franco: sí porque tenía los cofres del amor de | de del del enojo | de de todo

Sandra: ¿y ese día que leyó ustedes cómo estaban? || yo no estaba ese día

Franco: estábamos contentos

Sandra: ¿estaban tranquilos? | ¿escuchaban en orden?

Franco: sí tranquilos

Sandra: Franco | ¿vos te acordás cuando leyó un cuento que se llama La manta de las historias?

Franco: ¿la qué?

Sandra: La manta de las historias

Franco: [enf.] ah:: sí me acuerdo yo

Sandra: ¿qué te acordás?

Franco: que que de una niña que de una niña \| que que había una señora que hacía una una como una sábana de así (hace el gesto de cubrir su cuerpo con la manta) de todo lana (sic) | y que se contaban historias | y que se ponían así (Hace el gesto de estar apretados sobre La manta de las historias como se veía en la ilustración del cuento.)

Sandra: cierto | ¿y qué más te acordás?

Franco: creo esta parte | [enf.] creo | que los niños que ella tenía unos amigos que estaban así en la calle | ¿no? || y también al final tiene un...- | una nueva sábana

Sandra: cierto | ¿te había gustado ese cuento? 
Franco: sí| también

Sandra: ¿por qué te había gustado?

Franco: porque || no sé como como | como compartir con las con las personas que no tienen nada

Sandra: ¿algún otro cuento que recuerdes que leyó Omar?

Franco: $<6>$ ay no sé

Sandra: ¿no? el año que viene cuando estén en cuarto | ¿te gustaría que siguieran viniendo Omar o una mamá a leer?

Franco: [enf.] sí | me encantaría

Sandra: ¿qué cuento les pedirías que | que te lean?

Franco: hay un cuento que se llama La máquina del tiempo || ese me gustaría que leyeran

Sandra: ¿̇y te acordás quién | escribió ese cuento?

Franco: no me acuerdo

Sandra: ¿por qué lo recomendarías a ese cuento?

Franco: es medio de aventuras | de artefactos | medio de acción y de comedia

Sandra: muy bien Franco | muchas gracias

Franco: ¿a quién llamo?

Sandra: a ver II ¿a Facundo B.?

Franco: sí vino

Facundo B.

Sandra: ihola Facundo! ¿cómo andás? ¿bien?

Facundo: bien \{sonríe\}

Sandra: ¿te querés sentar un segundito | así estás más cómodo?

Facundo: $\{$ se sienta\}

Sandra: las preguntas que te voy a hacer | tienen que ver con las que respondieron el otro día por escrito I ¿te acordás que les pregunté yo?

Facundo: no me acuerdo

Sandra: ¿qué opinaban de que las mamás o los abuelos vinieran a leerles a la clase?

Facundo: no me gusta que me lean

Sandra: ¿no te gusta que | te lea nadie o no te gusta que te lean las mamás | u Omar?

Facundo: [p.] no me gusta $\|$ no no me gusta

Sandra: ¿que lea Inés tampoco? 
Facundo: $<4>$ no sé si es cuento que a mí me gusta sí me gusta

Sandra: ah:: si es algún cuento que te guste:: | sí

Facundo: claro

Sandra: ¿ ¿pero los que leyó Omar te gustaron?

Facundo: me gustaron sí pero algunos no me gustan

Sandra: ¿cuáles te acordás que te gustaron y cuáles no? | decís «este no me gustó | pero este sí»

Facundo: $<6>$ eh [dudoso] || ¿cuál es el que escribí ahí? \{señala mis papeles\}

Sandra: a ver <6> acá escribiste uno | ¿te acordás cuál es?

Facundo: \{mueve la cabeza [niega]\}

Sandra: acá pusiste El pájaro del alma || ¿por qué te acordás de ese cuento?

Facundo: no sé

Sandra: <5> Facu y:: || ¿̇alguno que no te haya gustado?

Facundo: el de:: la lombriz y la hormiga | ¿cómo era que se llamaba?

Sandra: la lombriz y la hormiga ¿ese cuento...-? | no lo conozco

Facundo: la hormiga se escondía...- || una víbora...- | no me acuerdo

Sandra: ¿̇ese cuento lo leyó Omar?

Facundo: sí | la hormiga se había escondido debajo de una hoja

Sandra: <4> ¿la hormiga o la abeja?

Facundo: ahí va | la abeja

Sandra: ¿y ese cuento por qué no te gustó?

Facundo: no

Sandra: ¿por qué?

Facundo: porque era muy cortito y eso

Sandra: ¿vos te acordás de un día que vino Omar a leer un cuento que se llama La manta de las historias?

Facundo: [enf.] isí!

Sandra: ¿qué te acordás de ese cuento?

Facundo: que la desarmaban para hacer pa otros y eso

Sandra: la desarmaban para hacer otras cosas | ¿y qué más te acordás?

Facundo: $<10>$

Sandra: ¿te había gustado ese cuento?

Facundo: ese sí 
Sandra: ¿por qué te había gustado?

Facundo: $<5>$ no sé nada más

Sandra: muy bien | ¿y si el año que viene vinieran los abuelos y las mamás a leer de vuelta | a vos te gustaría o les dirías: «no yo no quiero que vengan»

Facundo: eh:: | me gustaría | pero el cuento que me gustaría

Sandra: ¿qué cuento les pedirías que lean?

Facundo: no me acuerdo de ninguno

Sandra: ¿de qué podría tratar ese cuento?

Facundo: $<10>$

Sandra: ¿qué cuentos te gustan a vos?

Facundo: me gustan...- | puse ahí \{señala mis papeles\}

Sandra: algún tema que te guste` | por ejemplo hubo amigos que dijeron que les gustaban los cuentos de aventuras | otros | que le gustaban los cuentos de Susana Olaondo | ¿hay algún cuento preferido para vos?

Facundo: $<5>$ no sé el de La manta de las historias

Sandra: bueno muchas gracias Facu

Facundo: ¿a quién le toca ahora?

Sandra: ya terminamos

\subsubsection{Sesiones de lectura de Omar}

\subsubsection{Un puñado de semillas}

Pauta de sistematización de las observaciones de la sesión de lectura de Un puñado de semillas

Escuela: XX

Fecha y hora: $18.06 .2015,09.00$ horas

Contexto: la sesión de lectura se realizó en el salón de clase

Grupo: $3 .{ }^{\circ} \mathrm{A}$

Cantidad de niños presentes: 23

Otros presentes: maestra Inés, estudiante de Magisterio, investigadora 


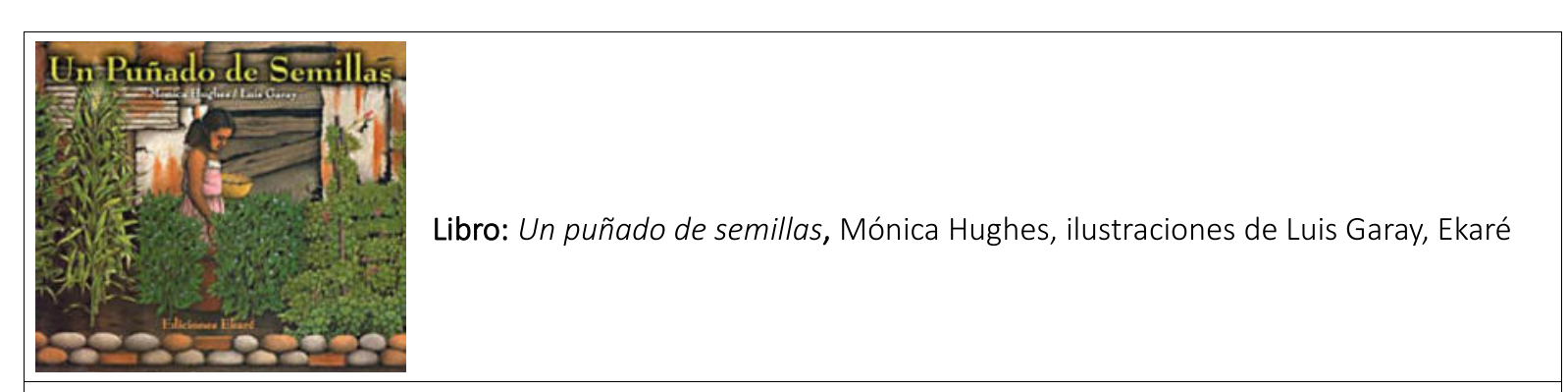

Selección del libro: El libro fue seleccionado por la maestra quien solicitó a Omar su lectura. Es una instancia de relectura pues el libro fue leído el año anterior.

\begin{tabular}{|c|c|c|c|}
\hline \multicolumn{4}{|c|}{ Observaciones } \\
\hline \multicolumn{4}{|c|}{ Antes de iniciar la lectura } \\
\hline \multirow{13}{*}{$\begin{array}{l}\frac{1}{0} \\
\frac{0}{0} \\
\frac{.0}{0} \\
\stackrel{0}{\Sigma}\end{array}$} & \multirow{2}{*}{$\begin{array}{l}\text { ¿Organiza el espacio de } \\
\text { lectura? }\end{array}$} & Sí & \\
\hline & & Nox & $\begin{array}{l}\text { Cuando Omar llega al salón, los niños se disponen } \\
\text { rápidamente en sus lugares, de acuerdo con lo establecido } \\
\text { por la maestra: sentados en el piso, enfrentados al } \\
\text { mediador, en semicírculo. Están rodeados por las mesas en } \\
\text { las cuales se sientan habitualmente. }\end{array}$ \\
\hline & $\begin{array}{l}\text { ¿Dónde y cómo se ubica } \\
\text { para leer? }\end{array}$ & \multicolumn{2}{|c|}{ Frente a los niños, se sienta en una silla pequeña. } \\
\hline & \multirow{2}{*}{$\begin{array}{l}\text { ¿Realiza algún ritual de } \\
\text { inicio? }\end{array}$} & Sí & \\
\hline & & No $x$ & \\
\hline & \multirow[t]{2}{*}{$\begin{array}{l}\text { ¿Realiza preguntas o } \\
\text { comentarios? }\end{array}$} & Síx & $\begin{array}{l}\text { Dice que anteriormente «le tiraron de las orejas» por no } \\
\text { haber conseguido información sobre el libro a leer y su } \\
\text { autor y que ahora esos datos los tiene en la contratapa del } \\
\text { libro. }\end{array}$ \\
\hline & & No & \\
\hline & \multirow{2}{*}{$\begin{array}{l}\text { ¿Responde las preguntas o } \\
\text { comentarios de los niños? }\end{array}$} & Sí & \\
\hline & & Nox & \\
\hline & \multirow[t]{2}{*}{$\begin{array}{l}\text { ¿Responde las preguntas o } \\
\text { comentarios de las } \\
\text { docentes? }\end{array}$} & Sí x & $\begin{array}{l}\text { Frente a un comentario de la maestra sobre su ausencia, } \\
\text { comenta por qué no pudo concurrir en las semanas } \\
\text { anteriores a leer por motivos de salud. }\end{array}$ \\
\hline & & No & \\
\hline & \multirow{2}{*}{$\begin{array}{l}\text { ¿Realiza algún ritual de } \\
\text { cierre? }\end{array}$} & Sí & \\
\hline & & No $x$ & \\
\hline \multirow{2}{*}{\multicolumn{2}{|c|}{$\begin{array}{l}\text { ¿Los niños realizan preguntas o } \\
\text { comentarios? }\end{array}$}} & Sí $x$ & $\begin{array}{l}\text { Se registra un único comentario: una niña pregunta sobre } \\
\text { la frase de Omar: ¿Te tiraron de las orejas?»(con asombro). }\end{array}$ \\
\hline & & No & \\
\hline \multicolumn{2}{|c|}{ ¿Las docentes realizan preguntas o } & Sí x & La maestra pregunta al mediador sobre su ausencia en días \\
\hline
\end{tabular}




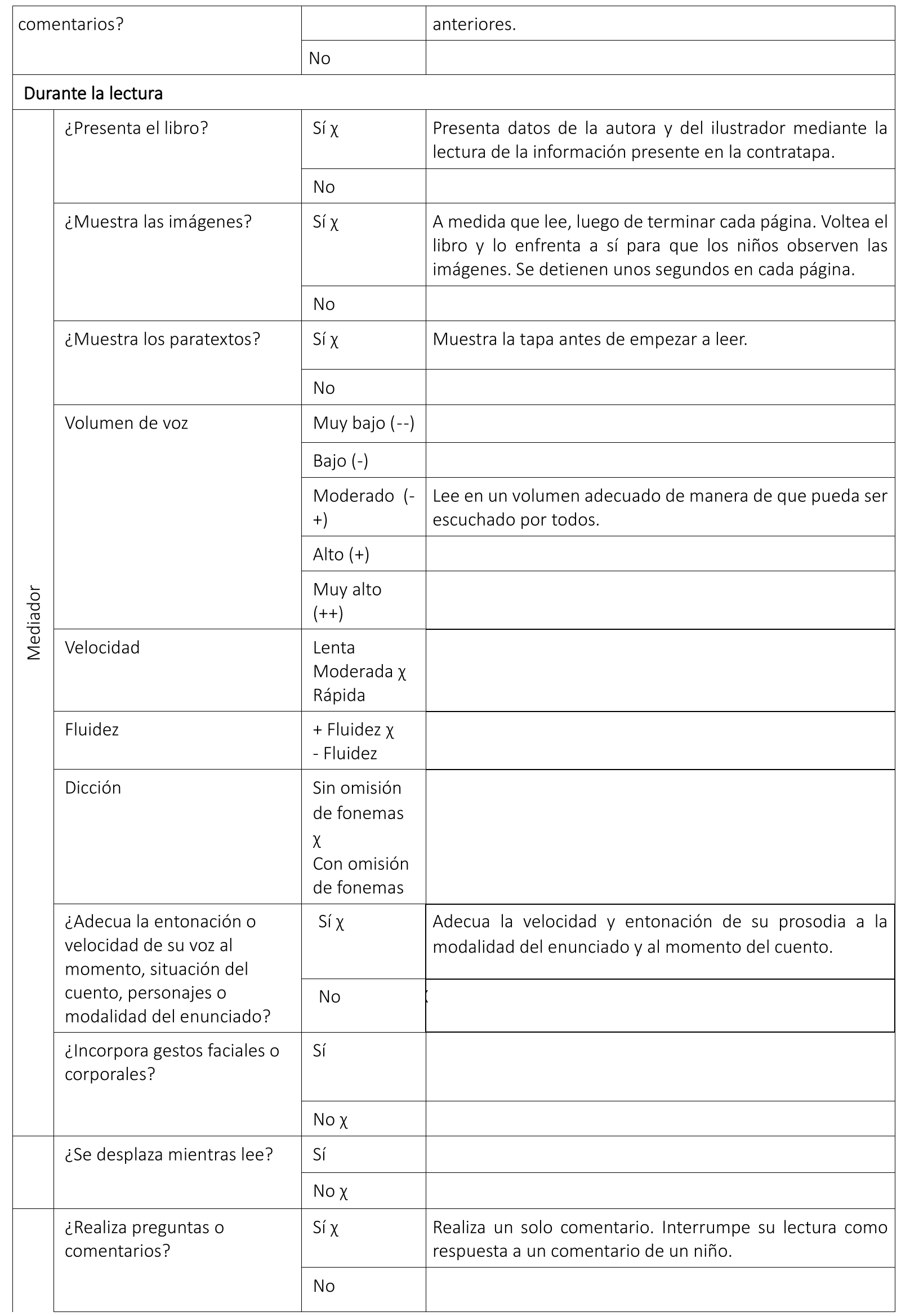




\begin{tabular}{|c|c|c|c|}
\hline & \multirow{2}{*}{$\begin{array}{l}\text { ¿Responde preguntas o } \\
\text { comentarios de los niños? }\end{array}$} & Sí x & \multirow[t]{2}{*}{ En una sola ocasión. } \\
\hline & & No & \\
\hline & \multirow{2}{*}{$\begin{array}{l}\text { ¿Responde a preguntas o } \\
\text { comentarios de las } \\
\text { docentes? }\end{array}$} & Sí & \\
\hline & & No $x$ & \\
\hline & \multirow[t]{2}{*}{$\begin{array}{l}\text { ¿Realiza algún ritual de } \\
\text { cierre? }\end{array}$} & Sí x & $\begin{array}{l}\text { El mediador agradece su escucha a los niños y estos } \\
\text { aplauden. Al finalizar el cuento abre el espacio de } \\
\text { comentarios. }\end{array}$ \\
\hline & & No & \\
\hline \multirow{2}{*}{\multicolumn{2}{|c|}{$\begin{array}{l}\text { ¿Los niños realizan preguntas o } \\
\text { comentarios? }\end{array}$}} & Sí x & En forma espontánea. \\
\hline & & No & \\
\hline \multirow{2}{*}{\multicolumn{2}{|c|}{$\begin{array}{l}\text { ¿Las docentes realizan preguntas o } \\
\text { comentarios? }\end{array}$}} & Sí x & $\begin{array}{l}\text { Los comentarios de la maestra durante la lectura se dirigen } \\
\text { a mantener el orden de la clase y a controlar el } \\
\text { comportamiento de algunos niños. } \\
\text { En una ocasión, la maestra se dirige al mediador, } \\
\text { interrumpiendo su lectura para llamar la atención de los } \\
\text { niños. }\end{array}$ \\
\hline & & No & \\
\hline \multicolumn{4}{|c|}{ Después de la lectura } \\
\hline \multirow{8}{*}{$\begin{array}{l}\frac{1}{0} \\
\frac{\pi}{0} \\
\frac{.0}{0} \\
\sum\end{array}$} & \multirow[t]{2}{*}{ ¿Realiza preguntas? } & Síx & \\
\hline & & No & \\
\hline & \multirow{2}{*}{$\begin{array}{l}\text { ¿Responde preguntas o } \\
\text { comentarios de los niños? }\end{array}$} & Sí x & \\
\hline & & No & \\
\hline & \multirow{2}{*}{$\begin{array}{l}\text { ¿Responde preguntas o } \\
\text { comentarios de las } \\
\text { docentes? }\end{array}$} & Sí x & $\begin{array}{l}\text { En una sola ocasión refuerza el llamado de atención de la } \\
\text { maestra hacia un niño. }\end{array}$ \\
\hline & & No & \\
\hline & \multirow{2}{*}{$\begin{array}{l}\text { ¿Realiza algún ritual de } \\
\text { finalización? }\end{array}$} & Sí x & Se despide de los niños antes de retirarse. \\
\hline & & No & \\
\hline \multirow{2}{*}{\multicolumn{2}{|c|}{$\begin{array}{l}\text { ¿Los niños realizan preguntas o } \\
\text { comentarios? }\end{array}$}} & Síx & En forma espontánea. \\
\hline & & No & \\
\hline \multirow{2}{*}{\multicolumn{2}{|c|}{$\begin{array}{l}\text { ¿Las docentes realizan preguntas o } \\
\text { comentarios? }\end{array}$}} & Sí x & $\begin{array}{l}\text { Al terminar la lectura, continúa comentando el cuento con } \\
\text { sus alumnos. El mediador se retira. }\end{array}$ \\
\hline & & No & \\
\hline \multicolumn{4}{|c|}{ Interacciones entre los actores } \\
\hline \multicolumn{2}{|c|}{$\begin{array}{l}\text { Actitud del mediador hacia los } \\
\text { niños }\end{array}$} & \multicolumn{2}{|c|}{ Escucha con respeto sus preguntas y comentarios. } \\
\hline \multicolumn{2}{|c|}{$\begin{array}{l}\text { Actitud de las docentes hacia el } \\
\text { mediador }\end{array}$} & \multicolumn{2}{|c|}{$\begin{array}{l}\text { La maestra habilita la participación del mediador al iniciar la sesión de } \\
\text { lectura. Escucha con respeto el cuento. Colabora en el control de la clase. }\end{array}$} \\
\hline
\end{tabular}




\begin{tabular}{|l|l|}
\hline $\begin{array}{l}\text { Actitud de los niños hacia el } \\
\text { mediador }\end{array}$ & $\begin{array}{l}\text { Escuchan con atención. Se compenetran con la historia leída. Participan } \\
\text { en forma espontánea y ordenada. Se muestran entusiasmados en la } \\
\text { discusión. }\end{array}$ \\
\hline $\begin{array}{l}\text { Actitud del mediador hacia las } \\
\text { docentes }\end{array}$ & $\begin{array}{l}\text { Acepta las interrupciones de la docente en los llamados de atención a los } \\
\text { niños. }\end{array}$ \\
\hline
\end{tabular}

Transcripción de la sesión de lectura de Un puñado de semillas

Omar: [ff.] bueno \/ ¿cómo les va?

Niños a coro: ibie::n \

Inés: te extrañamos Omar \¿contanos $\backslash \mid$ contanos qué te pasó?

Omar: algunos problemitas de salud | pero ya estoy:: || recuperado \

Inés: nos alegramos de que vuelvas \}

(Conversan sobre el Día del Abuelo que se festeja el 19 de junio.)

Omar: bueno $\backslash \mid$ hoy vamos a leer $\backslash \mid$ Un puñado de semillas | se llama el libro \

Niño: ah:: sí | ilo conozco! \

Niños (a coro) iyo lo conozco! \

Niño: a mí me encanta \

Inés: lo escuchan de nuevo | lo escuchan de nuevo \

Omar: como la última vez me tiraron de las orejas porque $\backslash$ | no pude conseguir | información sobre el autor \y el || dibujante /

Niña: ¿te tiraron de las orejas? [desconfiada]

\{La maestra le quita unos papeles a dos niños que juegan sin prestar atención a la actividad. Paulatinamente, todos comienzan a concentrarse a estar más atentos.\}

Omar: gracias a la maestra $\backslash$ | vino todo en el libro $\backslash$ | no tuve que precisar buscar $\backslash$ | así que hoy les voy a dar la información \| la autora se llama Mónica Hughes $\backslash$ || \{Omar comienza a leer la tapa y contratapa\} nació en Inglaterra / | y pasó los primeros años de su vida en Egipto \|| durante la Segunda Guerra Mundial / | se enlistó en el Servicio Naval de Mujeres \| y luego \| en 1952 \| se trasladó a Canadá donde pasó el resto de su vida | su escritura incluye obras de ciencia ficción \|| novelas de aventura y de misterio / | así como cuentos $\backslash$ | de corte realista / e histórico \| fue reconocida por su trabajo/ | con el premio a la Asociación Americana de Bibliotecas $\backslash$ | el Premio Canadiense del Libro/ | menciones $\backslash$ | en la lista de honor /de ibebei (IBBY) | / |y una nominación a la medalla de Hans Christian /h/Andersen en $1984 \backslash$

Niño: ¿quién? $=\ldots . . .=$

Omar: $=\ldots . . .=/ \mathrm{h} /$ Andersen $\backslash$

Niños: $\{$ comentan (???)\}

Omar: y el ilustrador se llama Luis Garay \| es un artista nicaragüense \| que también vive en Canadá / $=\ldots . .=$

Inés: $($ llama la atención a un niño) $=\ldots . . .=$ iperdón! \| ¿iDylan!? \perdoná Omar $\backslash=\ldots . . .=$ 
Omar: $=\ldots . . .=$ y sus pinturas han sido e:: expuestas $\backslash$ | e:n Centroamérica y en Canadá $\backslash \mid$ con Un puñado de semillas / | se inició en la ilustración de libros para niños $\backslash$ | ha ilustrado también una excelente antología de cuentos / | de la tradición oral / americana latina \|| bueno \| ahora vamos a empezar con el libro \| Concepción vivía con su abuela / | en una casita / en la cima de un cerro | juntas / | limpiaron el terreno / para hacer un huerto \| sembraron maíz / | frijoles y ají / || recuerda guardar suficientes semillas para la próxima siembra / | dijo la abuela \| así nunca te faltará de comer $\backslash\{<11>$ Omar muestra las imágenes del libro\}

Niños a coro: jah::!

Niño: lo llevaba así teniendo / (???)

Niño: ¿hay foto?

Niño: hay sí \}

Omar: todos los días / | Concepción bajaba a la quebrada a buscar agua \| y regresaba con pesados baldes / | colgados de sus hombros \| vaciaba con cuidado el agua / | alrededor / | de las matas de maíz \

Niño: ¿matas?

Omar: pasaron semanas \| el sol brillaba \| luego | llegaron las lluvias / | y el maíz creció muy alto \|| los tallos de los frijoles se enroscaron en busca del sol / | y las matas de ají / | florecieron \ || cuando el maíz los frijoles y el ají maduraron / | la abuela entregó parte de la cosecha al dueño de la tierra $\backslash$ y guardó suficiente para tener con qué comer $\backslash \|$ vendió el resto al vecino / | que se lo llevó al mercado de la ciudad / | allá lejos / | en el valle $\backslash\{<12>$ Omar muestra las imágenes del libro\}

Niña: hizo negocio con todo $\backslash$

Omar: exacto $\backslash$

Omar: un día triste \| la abuela murió \

Niños a coro: [ff.] iah::! \

Omar: no se puede quedar aquí / | dijo el dueño de la tierra \| ya alquilé esta parcela a otra familia \| pero yo puedo trabajar para usted / | dijo Concepción \| esta familia puede trabajar más que tú $\backslash$ | puede cosechar más frijoles y maíz \| replicó el dueño \| entonces Concepción tuvo que dejar la casita de paredes pintadas / | y piso de tierra $\backslash\{<10>$ Omar muestra las imágenes del libro\}

Niños a coro: [ff.] ah...।

Niña: iqué lindas \

Niña: qué malo el dueño \}

Niño: es malo \

Niña: estás buenas las plantas \}

Niño: ya vas a ver $\backslash$

Omar: ven a vivir con nosotros / | dijo la mujer del vecino \| pero Concepción \| sabía que ellos tenían siete hijos $\backslash$ | que alimentar $\backslash$

Niños a coro: ipah::! \[sorpresa] 
Omar: me iré para allá \/ dijo Concepción señalando el valle nublado \| donde estaba la ciudad \| es una caminata muy larga para piernas tan cortas / | dijo con tristeza la mujer del vecino $\backslash$ | mis piernas se han hecho fuertes de tanto cargar agua \| Concepción se despidió y abrazó a la mujer del vecino y a sus hijos \que dios $\backslash$ | te acompañe $\backslash$ le dijeron $\backslash\{<14>$ Omar muestra las imágenes del libro\}

Niña: ipará! \| ¿cuántos hijos tiene? \

$\{$ Una niña le hace un gesto a su compañero de al lado para que preste atención y la deje escuchar la lectura.\}

Niño: tiene siete $\backslash$

Niño: idiecisiete! \

Niña: [enf.] iay dios mío!\

Omar: Concepción $=\ldots . .=$

Inés: $=\ldots . . .=$ (Ilama la atención) iBelén!

Omar: hizo un atado con el maíz \| los frijoles y el ají \que la abuela había guardado \| y partió con su pequeña carretilla / | con...- por el sendero pedregoso $\backslash$ | que bajaba al valle $\backslash$ una caminata muy muy larga \

Niño: muy muy larga \

Omar: Concepción tenía los pies cansados $\backslash$ | rotos $\backslash$ | cuando por fin llegó $\backslash$ | al barrio que rodeaba la ciudad $\backslash$ | vio cientos de ranchos de hojalata $\backslash$ | plástico y cartón $\backslash||$ estaban amontonados unos encima de otros $\backslash$ | ¿esto es la ciudad? | pensó desalentada $\backslash$ | y yo que creí que sería hermosa $\backslash\{<8>$ muestra las imágenes\}

Niña: ¿a ver? | iah::! iqué feo! \

Niño: jah::!

Niños: iqué feo! \

Niños a coro: (comentan (???))

Omar: caminó por los estrechos callejones / | llenos de barro $\backslash=\ldots . . .=$

Inés: $=\ldots . . .=$ Franquito $\backslash$ (llama la atención a un niño)

Omar: =..... y ya agotada por el cansancio / | se topó con una pandilla de niños $\backslash \mid$ ¿no ves por dónde vas / tonta \| perdón \| contestó Concepción amablemente \| los niños tenían la ropa rota \| la cara sucia $\backslash$ | y el pelo...- $\backslash$ | y el pelo enmarañado \|| pero cuando Concepción les sonrió / | ellos también le sonrieron $\backslash\{<11>$ muestra las imágenes $\}$

Niña: ¿̇a ver?

Omar: me llamo Tomás $\backslash$ | y tú $\backslash$ | ¿de dónde vienes? | Concepción señaló $\backslash$ | los cerros a la distancia y dijo \| mi abuela murió $\backslash$ | si quieres puedes quedarte con nosotros / | te enseñaremos a recoger basura / para venderla $\backslash$ | y a sacar comida de los puestos de venta $\backslash$ | $\sin$ que te vean $\backslash=\ldots . . .=$

Inés: $=\ldots . . .=$ iSanti! \(llama la atención a un niño)

Omar: $=\ldots . . .=$ eso es robar $/ \mid$ dijo Concepción sorprendida $\backslash \mid$ Tomás se encogió de hombros $\backslash||$ es mejor que morirse de hambre \|| tengo maíz $\backslash$ | frijoles y ají \| dijo Concepción \| mostrando su carretilla \|| eso no no es suficiente para una comida buena \|| contestó Tomás con desprecio $\backslash$ | cuando crezcan las 
plantas \| habrá suficiente \ya verás \| aquí no crecerán jamás \¿estás loca? \| Tomás la miró un rato y luego agregó | pero de todos modos / puedes quedarte con nosotros $\backslash\{<7>$ muestra las imágenes\}

Niño: pero están recogiendo basura \

Niño: recogen lo que les sirve \}

Omar: y así Concepción se quedó a vivir con los niños $\backslash$ | a la orilla del basural $\backslash$ | construyó un pequeño muro de piedras $\backslash$ | con el mango roto de una olla \| cavó la tierra / | y plantó Un puñado de semillas / | de maíz \|de frijoles $\backslash \mid$ y de ají $\backslash\{<10>$ muestra las imágenes $\}$

Niña: ¿̇a ver?

Niña: ah:: pero hizo un montón de cosas \

Niño: recogió basu::ra\

Omar: todos los días regaba la tierra $\backslash$ | y miraba atentamente $\backslash \mid$ hasta que vio brotar los primeros retoños $\backslash$ | verdes y brillantes $\backslash$ | los frijo::les y el ají florecieron $\backslash$ | y en el barrio / no había nada más bonito que el pequeño huerto de Concepción $\backslash$ | y ella / | estaba segura de que $\backslash$ | desde el cielo / | su | abuela \cuidaba el huerto $\{\langle<6>$ muestra las imágenes $\}$

Niño: Igual que en la tapa (la imagen de la página es la misma que la de la tapa)

Omar: pero un día \| Tomás y los otros niños / | legaron corriendo \|| hasta el basural \| perseguidos por la policía \| los niños corrían y lloraban \| los policías gritaban y los golpeaban\ | Concepción se escondió en medio de la basura \| ¿para qué me vine a la ciudad? \| se preguntaba \| cuando todo pasó / | se asomó poquito a poco \| como un ratón asustado \| los niños estaban llenos de moretones / | y el huerto estaba todo pisoteado $\backslash\{<10>$ muestra las imágenes $\}$

Niña: ¿̇a ver?

Niña: ¿qué hizo la policía? \}

Niña: yo vi a la policía /

Niño: toda la policía \| sí \

Omar: ¿por qué lloras? | preguntó Tomás enfadado \| no fue a ti a quien golpeó la policía \| mi huerto está destrozado \si el maíz \| los frijoles y el ají hubiesen madurado / | habríamos tenido comida para vender $\backslash$ | y ustedes no tendrían que robar $\backslash$ | de nada te sirve llorar $\backslash \mid$ tu huerto se acabó $\backslash$ | Concepción se secó los ojos $\backslash$ | no $\backslash$ | no se acabó $\backslash$ | todavía me quedan algunas semillas $\backslash$ | está bien / | dijo Tomás $\backslash$ | pasándose la lengua por el labio roto $\backslash$ | esta vez / | te ayudaremos nosotros $\backslash$ | $<<>$ muestra las imágenes\}

Niño: ¿̇a ver?

Niña: ¿eran niñas también?

Niña: tienen camiseta amarilla \}

(Una niña vuelve a solicitar a su compañero que deje de molestar pues no le deja escuchar la lectura.)

Omar: con la ayuda de todos / | araron un trozo grande de terreno / | y sembraron el resto de las semillas de la abuela $\backslash$ | hicieron turno para regar las matas y cuidarlo $\backslash$ | prontos el maíz creció muy alto $\backslash$ | las matas de maíz estaban go::rdas $\backslash$ y firmes $\backslash$ | y brillaban los peque...- $\backslash \mid$ los pequeños ajíes verdes y amarillos $\backslash$ || haremos una gran fiesta dijo Tomás $\backslash$ | y el resto / | lo llevaremos a vender al mercado \| 
[pp.] pero siempre debemos guardar semillas para la próxima siembra \| recomendó Concepción \ $\{<11>$ muestra las imágenes\}

Niño: ¿a ver?

Omar: cocinaron el maíz y los frijoles con el ají \/ el delicioso aroma de la comida se esparció por el barrio \| cuando comenzaron a comer / | otra pandilla de niños hambrientos apareció \| Concepción y Tomás los invitaron a compartir la comida \| nuestro huerto no alcanzará para alimentar a todos los niños del barrio $\backslash$ | se lamentó Concepción $\backslash$ | pero entonces tuvo una idea $\backslash$ | tomó Un puñado de semillas que había guardado / | y se las dio al jefe de la otra pandilla \|| le explicó cómo preparar la tierra $\backslash$ | cómo sembrar y regar las plantas $\backslash$ | y siempre deberás guardar suficientes semillas para la próxima siembra \| y para compartir con otros n::iños del barrio $\backslash$ | le dijo Concepción $\backslash$ | tal como la abuela \| le había dicho a ella \|| el muchacho $\backslash$ | prometió hacerlo $\backslash\{<6>$ muestra las imágenes $\}$

Niño: ¿̇a ver?

Omar: Concepción \| estaba segura de que la abuela le sonreía desde el cielo $\backslash$ | y que sus ojos ya no estaban nublados por la edad $\backslash \mid$ sino brillantes como las estrellas sobre el barro $\backslash$

Niño: ¿a ver? | ¿qué pasó?

Niña: limpiaron todo \}

Omar: y se terminó $\backslash \|$ y unas palabras más $\backslash \|$ en el mundo existen mu::chos millones de niños abandonados $\backslash$ | al igual que Concepción $\backslash$ | la niña de esta historia \| lograron sobrevivir gracias a su coraje \ | ingenio y perseverancia / | para encontrar día tras día la comida \| abrigo / | y un lugar dónde dormir $\backslash$ | pero en medio de este duro tra::bajo diario $\backslash$ | la comunicación y el entendimiento / | pueden convertirse en valiosas armas para la supervivencia $\backslash||$ surgen entonces $\backslash$ | la solidaridad y la esperanza $\backslash$ | que al ser compartidas $\backslash$ | se propagan $\backslash$ | como las semillas que sabiamente la abuela dejó a Concepción $\backslash \mid$ a todos ellos $\backslash \mid$ a todos los niños y niñas abandonados $\backslash$ | está dedicado este libro $\backslash$ | también a los que tienen familia $\backslash \mid$ comida $\backslash$ | y un lugar dónde vivir $\backslash$ | porque los libros nos ayudan a comprender las vidas $\backslash$ | y los sentimientos de los demás $\backslash \mid$ nos enseñan a ser solidarios con las personas que nos rodean $\backslash \mid$ con los que tienen mucho $\backslash \mid$ con los que tienen poco $\backslash \mid$ y también con los que tienen solo esperanzas $\backslash$ | los libros / | son como Un puñado de semillas $\backslash$ | retoñan $\backslash$ | en men...- $\backslash$ | mentes despiertas $\backslash$ | y cultivan en nosotros / | el deseo de construir / | un mundo mejor $\backslash$ | muchas gracias $\backslash$

Niños a coro: $\{$ aplausos\}

Omar: bueno / vamos a comentar ahora un poco $\backslash=\ldots . .=$

Niño: $=\ldots . . .=$ abuelo $/$ me pareció medio triste $\backslash$

Omar: $=\ldots . . .=$ a comentar un poco el libro $\backslash$

Niño: idale! \

Niña: la abuela que murió me pareció un poco triste \}

Niña: ¿un poco nada más? | ¿un poquito? [con ironía]

Omar: ¿qué sacan en conclusión de esto que leímos?

Niña: que era buena \

Niña: que la niña fue muy amable \ 
Omar: una cosa / que la niña fue muy ama::ble \

Niña: que hay que compartir \

Omar: imuy bien! \|que hay que compartir /

Niña: (???)

Niña: que hay que comer todo lo que nos ponen en la mesa porque si no \si no nos faltaría la comida \ Omar: imuy bien! \¿usted? ¿qué hay que valorar?

Niña: mi madre me dice que hay que valorar la comida \}

Niño: (???)

Omar: no te entendí / | perdoná \

Niña: que hay que guardar siempre un poco de semillas \

Omar: exacto \| lo que dice el compañero \

Omar: ¿el libro en qué se basa todo?

Niña: semillas\

Niño: solo semillas \

Niño: en la huerta $\backslash=\ldots . . .=$

Niño: $=\ldots . . .=$ semillas $\backslash$

Omar: en que guardando un poco de semillas $=\ldots . .=\backslash$

Niña: =.....= tenían para comer $\backslash$

Omar: tenían para comer \}

Niña: y en las huertas \}

Niño: que el niño fue humilde con ellos / | y no egoísta porque:: \| siempre / siempre hay que ser bueno con los otros niños que no tienen \

Omar: ¿y cómo se llama eso? \| solidaridad \

Niña: solidaridad y no hay que ser egoísta \

Omar: imuy bien!

Niña: que hay que valorar lo que uno tienel

Omar: imuy bien!\

Niña: mi madre me dice $\backslash$ | valorá la comida que hay niños que se están muriendo de hambre en la calle $\backslash$

Niño: es verdad \}

Niño: mi madre me dice lo mismo \}

Niño: (???) $=\ldots . .=$

Inés: $=\ldots . .=$ perdoname un segundo $\backslash=\ldots . .=$

Omar: =....= amigo $\backslash \mid$ compañero $\backslash \mid$ vamos a escuchar $\backslash$ 
Inés: =....= [ff.] iDylan! \| habló Agustín / | y tú no lo escuchaste / | y yo tampoco $\backslash \mid$ porque como vos hablaste no lo pude escuchar $\backslash$ | Agustín $\backslash \mid$ ¿podés repetir?

Omar: hay que escuchar a los compañeros \

Niño: que hay que tratar bien a la gente y cuidar el mundo \

Niño: y no hay que desperdiciar la comida \

Omar: vamos ahora \|| ¿qué no les gustó del libro? | ¿qué...- que no les pareció?

Niño: no sé /

Niño: a mí no me gustó que:: la abuela muriera \| y los niños le dijeran tonta \

Omar: ella no habló todavía \(da la palabra a una niña que levantó la mano, pero esta no responde)

Niña: $<5>$

Omar: ¿te olvidaste?

Niño: que le quitaran la casa a Concepción \

Niña: que les pegaran los policías \|| la violencia \

Niña: que el abuelo muriera \

Niño: ella no habló todavía \

Niña: (???)

Omar: no te oí perdón \

Niña: que se puede vivir de otra forma sin robar \

Omar: muy bien $\backslash \mid$ que se puede vivir de otra forma sin robar $\backslash$

Niño: (???)

Omar: perdoná que el abuelo...- $\backslash \mid$ el abuelo Omar está sordo \}

Niño: que se puede vivir sin violencia \}

Omar: muy bien $\backslash$

Niño: ¿por qué se quedó sin tierra?

Omar: hay otros lugares donde los dueños de la tierra le alquilan un pedazo de tierra a la gente / I para que la trabajen $\backslash$ | entonces ¿qué pasa? | parte de la cosecha se la tienen que dar al dueño $\backslash$ | como se quedó sin abuela \| que era la de cosechaba \

(Se pierden algunos comentarios pues pasa por el pasillo un grupo de niños gritando.)

Inés: no escuché $\backslash$ | silencio Franco \| Agustín \| hacé un esfuerzo \| no escuchamos nada \¿podés hablar más fuerte? | silencio \

Niño: queremos escuchar otro cuento \}

Omar: ahora al revés \| ¿qué es lo que más les gustó del libro?

Niño: la huerta।

Niño: a mí también me gustó \

Omar: la huerta \ 
Niña: que la f...-\que la familia se ofreció a dar compañía \

Omar: imuy bien!\

Niña: que viviera otra familia con ella \| allí al lado de la casa \

Niños a coro: (Discuten sobre la familia que vivía con Concepción.)

Omar: no sé si la maestra quiere comentar algo /

Niños: que Concepción se ofreciera a cuidar a los niños \

Clara: que Concepción fue buena con los niños \}

Inés: (Comienza a hablar sobre el vocabulario del cuento. Omar permanece en el salón de clase, pero el comentario se da por finalizado.)

\subsubsection{La manta de las historias}

Pauta de sistematización de las observaciones de la sesión de lectura de La manta de las historias

\begin{tabular}{|c|c|c|c|}
\hline \multicolumn{4}{|c|}{ Escuela: XX } \\
\hline \multicolumn{4}{|c|}{ Fecha y hora: $12.08 .2015,08.30$ horas } \\
\hline \multicolumn{4}{|c|}{ Contexto: la sesión de lectura se realiza en el salón de clase. } \\
\hline \multicolumn{4}{|c|}{ Grupo: $3 .^{\circ} \mathrm{A}$} \\
\hline \multicolumn{4}{|c|}{ Cantidad de niños presentes: 22} \\
\hline \multicolumn{4}{|c|}{ Otros presentes: maestra Inés, investigadora } \\
\hline \multicolumn{4}{|c|}{$\begin{array}{l}\text { Lamantá dé } \\
\text { las historias } \\
\text { Elena Odriozola, }\end{array}$} \\
\hline \multicolumn{4}{|c|}{ Selección del libro: el libro fue seleccionado por el mediador entre los propuestos por la investigadora } \\
\hline \multicolumn{4}{|c|}{ Observaciones } \\
\hline \multicolumn{4}{|c|}{ Antes de iniciar la lectura } \\
\hline \multirow{4}{*}{$\begin{array}{l}\frac{1}{0} \\
\frac{0}{0} \\
\frac{.0}{0} \\
\frac{0}{2}\end{array}$} & \multirow{2}{*}{$\begin{array}{l}\text { ¿Organiza el espacio de } \\
\text { lectura? }\end{array}$} & Sí & \\
\hline & & No $\chi$ & $\begin{array}{l}\text { Los niños se disponen de acuerdo con lo establecido por la } \\
\text { maestra, sentados en el piso, en semicírculo, delante del } \\
\text { pizarrón, enfrentados al mediador. La maestra y yo nos } \\
\text { ubicamos en una mesa pequeña a la izquierda de la ronda. }\end{array}$ \\
\hline & $\begin{array}{l}\text { ¿Dónde y cómo se ubica para } \\
\text { leer? }\end{array}$ & \multicolumn{2}{|c|}{ Se sienta sobre una mesa, enfrentado a los niños. } \\
\hline & ¿Realiza algún ritual de & Sí x & Antes de comenzar la lectura da los buenos días. Pide a los \\
\hline
\end{tabular}




\begin{tabular}{|c|c|c|}
\hline \multirow[t]{2}{*}{ inicio? } & & $\begin{array}{l}\text { niños que se paren y que salten «con toda la energía». Luego } \\
\text { que los niños terminan y se calman espontáneamente, les } \\
\text { pide que se sienten de nuevo y presten atención. }\end{array}$ \\
\hline & No & \\
\hline \multirow{2}{*}{$\begin{array}{l}\text { ¿Realiza preguntas o } \\
\text { comentarios? }\end{array}$} & Síx & \\
\hline & No & \\
\hline \multirow{2}{*}{$\begin{array}{l}\text { ¿Responde las preguntas o } \\
\text { comentarios de los niños? }\end{array}$} & Síx & \\
\hline & No & \\
\hline \multirow{2}{*}{$\begin{array}{l}\text { ¿Responde las preguntas o } \\
\text { comentarios de las docentes? }\end{array}$} & Síx & \\
\hline & No & \\
\hline \multirow{2}{*}{$\begin{array}{l}\text { ¿Realiza algún ritual de } \\
\text { cierre? }\end{array}$} & Sí & \\
\hline & No $\chi$ & \\
\hline \multirow{2}{*}{$\begin{array}{l}\text { ¿Los niños realizan preguntas o } \\
\text { comentarios? }\end{array}$} & Sí $\chi$ & En una sola ocasión. \\
\hline & No & \\
\hline \multirow{2}{*}{$\begin{array}{l}\text { ¿Las docentes realizan preguntas } \\
\text { o comentarios? }\end{array}$} & Sí & \\
\hline & No $x$ & \\
\hline
\end{tabular}

\section{Durante la lectura}

\begin{tabular}{|c|c|c|}
\hline \multirow[t]{2}{*}{ ¿Presenta el libro? } & Sí x & \\
\hline & No & \\
\hline \multirow[t]{2}{*}{ ¿Muestra las imágenes? } & Sí x & $\begin{array}{l}\text { A medida que lee, luego de terminar cada página. Voltea el } \\
\text { libro y lo enfrenta a sí para que los niños observen las } \\
\text { imágenes. Se detienen unos segundos en cada página. }\end{array}$ \\
\hline & No & \\
\hline \multirow[t]{2}{*}{ ¿Muestra los paratextos? } & Sí $x$ & Muestra la tapa antes de empezar a leer. \\
\hline & No & \\
\hline \multirow[t]{5}{*}{ Volumen de voz } & Muy bajo (--) & \\
\hline & Bajo (-) & \\
\hline & $\begin{array}{l}\text { Moderado (- } \\
+)\end{array}$ & Lee en un volumen adecuado. Es escuchado por todos. \\
\hline & Alto $(+)$ & \\
\hline & Muy alto $(++)$ & \\
\hline Velocidad & $\begin{array}{l}\text { Lenta } \\
\text { Moderada } \chi \\
\text { Rápida }\end{array}$ & \\
\hline Fluidez & +Fluidez $\chi$ & \\
\hline
\end{tabular}




\begin{tabular}{|c|c|c|}
\hline & - Fluidez & \\
\hline Dicción & $\begin{array}{l}\text { Sin omisión de } \\
\text { fonemas } \chi \\
\text { Con omisión } \\
\text { de fonemas }\end{array}$ & \\
\hline \multirow{2}{*}{$\begin{array}{l}\text { ¿Adecua la entonación o } \\
\text { velocidad de su voz al } \\
\text { momento, situación del } \\
\text { cuento, personajes o } \\
\text { modalidad del enunciado? }\end{array}$} & Sí X & $\begin{array}{l}\text { Adecua la velocidad y entonación de su prosodia a la } \\
\text { modalidad del enunciado y al momento del cuento. }\end{array}$ \\
\hline & No & \\
\hline \multirow{2}{*}{$\begin{array}{l}\text { ¿Incorpora gestos faciales o } \\
\text { corporales? }\end{array}$} & Sí & \\
\hline & No $x$ & \\
\hline \multirow{2}{*}{ ¿Se desplaza mientras lee? } & Sí & \\
\hline & No $x$ & \\
\hline \multirow{2}{*}{$\begin{array}{l}\text { ¿Realiza preguntas o } \\
\text { comentarios? }\end{array}$} & Sí & \\
\hline & No $\chi$ & \\
\hline \multirow[t]{2}{*}{$\begin{array}{l}\text { ¿Responde preguntas o } \\
\text { comentarios de los niños? }\end{array}$} & Sí x & $\begin{array}{l}\text { Omar escucha a los niños, pero no les responde. Retoma la } \\
\text { lectura sin dificultad luego de las interrupciones. } \\
\text { Accede a la solicitud de un niño de mostrarle nuevamente } \\
\text { una imagen del cuento. }\end{array}$ \\
\hline & No & \\
\hline \multirow{2}{*}{$\begin{array}{l}\text { ¿Responde preguntas o } \\
\text { comentarios de las } \\
\text { docentes? }\end{array}$} & Sí $x$ & \\
\hline & No & \\
\hline \multirow[t]{2}{*}{$\begin{array}{l}\text { ¿Realiza algún ritual de } \\
\text { cierre? }\end{array}$} & Sí x & $\begin{array}{l}\text { Cierra la lectura con: «Colorín, colorado» } \\
\text { Abre el espacio de comentarios al que los niños ya están } \\
\text { acostumbrados. }\end{array}$ \\
\hline & No & \\
\hline \multirow[t]{2}{*}{$\begin{array}{l}\text { ¿Los niños realizan preguntas y } \\
\text { comentarios? }\end{array}$} & Sí $x$ & $\begin{array}{l}\text { A lo largo del cuento interrumpen con frecuencia la lectura } \\
\text { con preguntas o comentarios en forma espontánea. }\end{array}$ \\
\hline & No & \\
\hline \multirow[t]{2}{*}{$\begin{array}{l}\text { docentes realiza preguntas o } \\
\text { entarios? }\end{array}$} & Sí x & $\begin{array}{l}\text { Los comentarios de la maestra durante la lectura se dirigen } \\
\text { a mantener el orden de la clase y a controlar el } \\
\text { comportamiento de algunos niños. Se ríe ante las bromas } \\
\text { de Omar. }\end{array}$ \\
\hline & No & \\
\hline \multicolumn{3}{|c|}{ Después de la lectura } \\
\hline \multirow[t]{2}{*}{ ¿Realiza preguntas? } & Síx & \\
\hline & No & \\
\hline \multirow{2}{*}{$\begin{array}{l}\text { ¿Responde preguntas o } \\
\text { comentarios de los niños? }\end{array}$} & Síx & \\
\hline & No & \\
\hline
\end{tabular}




\begin{tabular}{|c|c|c|}
\hline \multirow{2}{*}{$\begin{array}{l}\text { ¿Responde preguntas o } \\
\text { comentarios de las docentes? }\end{array}$} & Síx & \multirow{2}{*}{$\begin{array}{l}\text { En una sola ocasión refuerza el llamado de atención de la } \\
\text { maestra hacia un niño. }\end{array}$} \\
\hline & No & \\
\hline \multirow{2}{*}{$\begin{array}{l}\text { ¿Realiza algún ritual de } \\
\text { finalización? }\end{array}$} & Sí & \\
\hline & No $x$ & \\
\hline \multirow[t]{2}{*}{$\begin{array}{l}\text { ¿Los niños realizan preguntas o } \\
\text { comentarios? }\end{array}$} & Sí x & $\begin{array}{l}\text { Responden las preguntas que realiza el mediador y } \\
\text { formulan otras preguntas. }\end{array}$ \\
\hline & No & \\
\hline \multirow[t]{2}{*}{$\begin{array}{l}\text { ¿Las docentes realizan preguntas } \\
\text { o comentarios? }\end{array}$} & Sí $\chi$ & $\begin{array}{l}\text { Al terminar la lectura, la maestra continúa comentando el } \\
\text { cuento con sus alumnos. El mediador se retira. }\end{array}$ \\
\hline & No & \\
\hline \multicolumn{3}{|l|}{ Interacciones entre los actores } \\
\hline $\begin{array}{l}\text { Actitud del mediador hacia los } \\
\text { niños }\end{array}$ & \multicolumn{2}{|c|}{ Escucha con respeto las preguntas y comentarios. } \\
\hline $\begin{array}{l}\text { Actitud de las docentes hacia el } \\
\text { mediador }\end{array}$ & \multicolumn{2}{|c|}{$\begin{array}{l}\text { La maestra habilita la participación del mediador al iniciar la sesión de } \\
\text { lectura. Escucha con respeto el cuento. Se encarga del control de la clase. } \\
\text { La estudiante magisterial no interviene. }\end{array}$} \\
\hline $\begin{array}{l}\text { Actitud de los niños hacia el } \\
\text { mediador }\end{array}$ & \multicolumn{2}{|c|}{$\begin{array}{l}\text { Escuchan con atención. Se compenetran con la historia leída. Participan } \\
\text { en forma espontánea, en orden. En ocasiones hablan sin esperar su turno, } \\
\text { a coro. Se muestran entusiasmados en la discusión. }\end{array}$} \\
\hline $\begin{array}{l}\text { Actitud del mediador hacia las } \\
\text { docentes }\end{array}$ & \multicolumn{2}{|c|}{$\begin{array}{l}\text { Acepta las interrupciones del docente en los llamados de atención a los } \\
\text { niños. }\end{array}$} \\
\hline
\end{tabular}

Transcripción de la sesión de lectura de La manta de las historias

Niña: ¡hola!\

Omar: ihola amor!\

Inés: [ff.] ilván! \| Iván se sienta en el piso\ | los varones se sientan en el piso\ | las nenas se sientan en el piso\\{niños se mueven y comentan (???) <22>\} iBelén! \| [ff.] ¿podés escuchar el cuento? | ¿sí? | bien $\backslash \mid$ todos los niños que trajeron el permiso del paseo que yo todavía no lo pedí lo guardan en el bolsillo ahora\| ahora ninguna palabra ningún movimiento / | vamos a escuchar a Omar \

\{El abuelo espera que todos los niños se acomoden y se ordenen para comenzar\}

Omar: vamos a hacer este ejercicio primero \}

Niños a coro: (protestan porque Omar no empieza su lectura (???) <8>)

Omar: esperamos $\backslash \mid$ parados $\backslash \mid$ para::dos $\backslash \mid$ parados todos $\backslash \mid$ \{chistido [pide silencio]\} amigo $\backslash \mid$ parate un cachito $\backslash=\ldots . .=$

Inés: $=\ldots . . .=i e h:: !$ iFacundo!

Omar: [ff.] fuerte \| bueno | ibuen día! / | fuerte \

Niños a coro: [ff.] ibuen día::! [con entusiasmo]

Omar: y ahora a movernos / | usen toda la energía / | toda la energía/ \{los niños se mueven $<5>\}$ 
Omar: ahora sí

Niños: \{(???) los niños vuelven a sentarse $\}$

Omar: bueno $=\ldots . . .=$

Niño: =.....= se llama Buenas Noches $\backslash$ | [el niño conoce o lee el título de la colección]

Omar: el libro de hoy se llama $\backslash=\ldots . .=$

Niño: $=\ldots . . .=(? ? ?)$

Niño: La manta de las historias $\backslash$ (lee la tapa del libro)

Omar: La manta de las historias \}

Niña: \{suspira iah::! /\}

Niño: [pp.] ¿La manta de las qué?

Omar: es una historia en Rusia /

Niños a coro: ¿en Rusia? | iuh!::।

Omar: y este libro fue escrito | por dos escritoras $\backslash$ [pp.] no por una $\backslash \mid$ por dos $\backslash \mid$ Ferida Wolff y Harriet May Savitz\la ilustradora | es Elena Odriazola

Niño: ¿'es señor o señora?

Omar: sí \| la señora \| (mira la tapa del libro) fue a Rusia \

Niños a coro: \{(???) comentan en forma desordenada\}

Omar: lo peor es que está escrito en ruso /

Niños a coro: $\{$ risas\}

Omar: ahora les voy a | / a hablar en ruso \

Niños a coro: [ff.] isí::! [sorprendidos] [protestan] ¿todo eso en ruso?

Omar: bueno\ | en lo más profundo de las montañas cubiertas de nieve\ | quedaba la pequeña aldea / | donde vivía | / Babba Zarrah \

Niños a coro: ¿eh::? [sorprendidos]

Niñas: ¿Babba Zarrah?

Niña: te estás comiendo una hoja \}

Omar: un día \| Babba Zarrah / notó que había un agujero/ | en el zapato de Nikolai / || cuando el niño se fue | decidió tejerle unas medias bonitas y abrigadoras | \pero había caído tanta nieve ese invierno | \que nadie pudo llegar a la aldea / para llevar lana \¿cómo iba a tejer las medias sin lana? | toda pregunta tiene una respuesta $\backslash$ | dijo Babba Zarrah $\backslash$ | simplemente | tengo que concentrarme | se sirvió un vaso de té dulce / | para poder pensar mejor | \y antes de haberse tomado tres sorbos / Babba Zarrah / ya sabía lo que tenía que hacer $\backslash \|$ voy a desarmar ${ }^{4}$ un trozo de mi manta de las historias $\backslash$ | y así podré usar la lana | para las medias de Nikolai $\backslash \mid$ \{muestra las ilustraciones del cuento $<10>$ \}

Niño: eso:: parece una china \(mirando la ilustración)

\footnotetext{
${ }^{4}$ En el cuento se lee «desbaratar».
} 
Niño: ¡sí!

Omar: tarde \ | en la noche \| cuando todos estaban dormidos / Babba Zarrah caminó por entre la nieve / | y dejó las medias / frente la puerta de la casa de Nikolai $\backslash$ | \{muestra las ilustraciones $\langle 8>$ \} =...= Inés: =...= ¡Sofía! \(Ilama la atención a una niña que se distrae)

Omar: \{continúa mostrando las ilustraciones $<8>$ \} poco después $\backslash$ | el cartero encontró una buf...- una bufanda enrollada en su maletín \| justo cuando iba a empezar sus rondas matutinas || ¿saben quién hizo esta bufanda? || preguntaba a todos los que encontraba por el camino \| pero nadie sabía \| \{muestra ilustraciones $<8>$ \}

Niño: ¿̇a ver?

Niña: ¿qué? [sorpresa]

Niña: que a esta...- que se ataba ella con el niño y el perro \(la ilustración muestra a los personajes usando una misma bufanda)

Niño: ahí hay un perro \

Omar: el profesor de la escuela se sorprendió de encontrar un par de guantes $\backslash$ | en la pila de leña \| cuando iba a recoger madera / | para la estufa de la escuela \|| la señora Ivanov / | espantó el cuervo de su lavandería \| con un nuevo delantal tejido/ | que descubrió / | al lado de su bomba de agua \|| $\{$ muestra las ilustraciones $<4>$ \}

Niño: volvé \

Omar: \{vuelve a mostrar la página solicitada por el niño $<10>\}$

Niño: iah::! mirá el perro\

Niña: ¿el perro colgado? [asombro] <6>

Omar: al poco tiempo\ | la tendera \| tenía puesto un nuevo chal / | en lugar del apolillado manto que solía usar \| ahora \| los niños \| tenían que sentarse imuy juntos! / | en la manta\ | cuando iban a escuchar las historias $\backslash \mid$ \{muestra las ilustraciones $<13>$ \}

Niños a coro: (murmullo (???))

Omar: día tras día \| la curiosidad de los aldeanos crecía \|| la bebé Olga / | recibió una misteriosa manta nueva $\backslash=\ldots . . .=$

Niño: ¿̇la qué? $=\ldots . . .=$

Omar: =..... = muy suavecita $\backslash \mid$ y el carnicero $\backslash \mid$ alardeó $\backslash \mid$ con su elegante gorra de lana $\backslash \mid$ que cubría su reluciente cabeza calva $\backslash \|$ ahora los niños $\backslash$ | estaban bastante apretados en la pequeñ::ita manta de las historias $\backslash \mid$ \{muestra las ilustraciones $<15>$ \}

Niña: yo no veo nada \

Niña: la bebita sola \

Niña: pensé que...- $\backslash$

Niño: no es una bebita | es una señora \

Niño: iah:: bueno! \| lo mismo \ 
Omar: la confusión creció $\backslash$ | cuando el mugrien::to gato del sastre $\backslash$ | apareció de pronto ronronea::ndo $\backslash$ | muy refinado $\backslash$ | en un ajustado abrigo para gatos $\backslash$ | ya no había manta para sentarse $\backslash$ | \{muestra las imágenes $<25>$ \}

Niños a coro: (???) \{murmuran\}

Niños a coro: ioh!:: iuh::! [asombro]

Niño: \{único aplauso\}

Inés: (Ilama la atención) Franquito...-\

Omar: los aldeanos $\backslash$ | le pidieron al alcalde $\backslash$ | que los ayudara a resolver el misterio $\backslash \mid$ ya saben lo que siempre dice Babba Zarrah $\backslash$ | replicó el alcalde $\backslash$ | toda pregunta $\backslash$ | tiene una respuesta $\backslash$ | cuando los niños vieron las me::dias la bufa::nda los guantes $\backslash$ | [ac.] el delantal el chal la gorra \| la mantita y el abrigo del gato $\backslash$ | todo en un mismo sitio $\backslash \mid$ gritaron $\backslash$ | [enf.] todas estas prendas se parecen a la vieja manta/ | de las historias de Babba Zarrah \|| pero ella\ | ya no la tiene \| dijo Nikolai \| iajá! \|| dijo el alcalde \| [le.] Babba Zarrah usó la lana de su manta \| para hacer estos regalos\} \|| ahora | nos corresponde a nosotros / | darle una sorpresa a Babba Zarrah $\backslash \|$ \{muestra las ilustraciones $<12>\}$

Niño: hay una con vestido ahí \

Niño: ¿̇uál?

Omar: entonces | mientras Babba Zarrah dormía | en cada casa | tomaron un poco de lana de cada manta | para dej ...- poder dejar algunos ovillos de lana / | frente a la puerta del hogar/ | de Babba Zarrah \|| Babba Zarrah \| se sorprendió cuando abrió la puerta de su casa en la mañana \| [enf.] nunca antes había visto tanta lana / | en tan diversos colores $\backslash$ | y encima de los ovillos $\backslash$ | un un letrero que decía $^{5} \backslash$ | para tu nueva manta / | [le.] de las historias $\backslash\{$ muestra las imágenes $<13>$ \}

Nino: ahí está el cartel y la lana \

Niña: ¿̇a ver?

Niño: iy cuánta lana!\

Niño: no veo nada | te pusiste ahí =....= \}

Omar: $=\ldots . . .=$ cuando los niños fueron otra vez a casa de Babba Zarrah / | a escuchar una historia \| encontraron \| una colori::da manta nueva \| y el relato sobre una aldea / | en la que todos compartían con su prójimo\ || mientras abrazaba a los chicos al despedirse / | Babba Zarrah \| notó un agujero en el suéter de Alexandra \|| quería tejerle a la niña una sorpresa \| pero la nieve \| todavía cubría las montañas $\backslash$ | y no había forma de conseguir \| lana en la aldea \|| Babba Zarrah sabía que toda pregunta tiene una respuesta \| miró su nueva manta de las historias / | y sonrió \

Niño: y si | ¿cómo hacés para tejer si no tenés lana?/

Omar: y colorín colorado \}

Niños a coro: \{aplausos\}

Omar: muy bien\

Niño: iqué cuento tan corto! \

\footnotetext{
${ }^{5}$ En el cuento se lee: «Y encima de los ovillos de lana, había un letrero:».
} 
Niño: ahora vienen las preguntas / | ¿no?

Omar: iah::! los comentarios \

Niño: iah::! \[desaprobación.]

Niño: me gustó \

Niño: me gustó \

Niño: me gustó cuando iba a sacar un pedazo de la lana \}

Niño: yo tengo algo que decir \\| a mí me gustó todo \

Omar: ¿qué es lo principal del libro? | ¿qué es lo que tiene de principal el libro?

Niña: que Babba Zarrah era una señora que siempre quería $=\ldots . . .=/$

Inés: =....= perdoná un poquito \| está hablando la compañera\(Ilama la atención a Iván)

Niña: =..... que Ba...- que la señora Babba Zarrah siempre $\backslash \mid$ querí...- querí...- le hacía suéters querí...hacerle u::na medias al al $\backslash \mid$ niño porque estaba contando las historias $\backslash||$ pero después empezó a regalar de su manta a ca...- | al pueblo un regalo y lo que tenía después e...-el libro se trata $\backslash \mid$ de una la señora que siempre contaba historias a los niños en en en su manta en La manta de las historias $\backslash \|$ de las historias pero después empe...- e:: cuando los niños tenían / || que les veía un agujero sacaba de su manta para hacerles a ellos \}

Niña: y le encantaba la lana \

Niño: ¿y le encantaba la qué?

Niño: la lana \

Niña: y le encantaba compartir \}

Omar: ahí está \

Inés: ¿̇escucharon lo que dijo:: / | Anshie?

Omar: ¿escucharon lo que dijo la compañera?

Inés: Iván \| decí lo que dijo Anshie tú \

Niño: [enf.] ¿Anshie? no es Anshie \| es Yasmila \

Inés: habló Anshie $\backslash$ | ni te enteraste $\backslash$

Niño: [enf.] es Yasmila \

Niños a coro: [enf.] habló Anshie \

Niña: hablé yo \}

Omar: ella habló \

Iván: [enf.] y Yasmila también /

Niña: imaestra!\

Omar: \{risas\} este es como el hijo del papanatas $\backslash$ | si no la gana la empata \

Niños: \{risas\} [desorden]

Inés: $\{$ (risas) se acomoda en el aire $\}$ 
Inés: [enf.] iescuchamo::s!/ | iescuchamos! \

Omar: va...- vamos a escuchar lo que dijo la compañera de nuevo $\backslash=\ldots . .=$

Inés: $=\ldots . . .=$ iAnthony! $\backslash$ (Ilama la atención al niño)

Inés: que se llama Anshie\ | y que también habló \

Niño: Yasmila dijistel

Inés: ahí está \

Niño: que hable un poquitito más alto \

Inés: y ustedes se callan \

Omar: compañera (da la palabra a la niña)

Niños a coro: (???)

Omar: \{chistido\}

Omar: silencio \ | porque habla despacito pero si hablamos todos / || \ella no va a escuchar $\backslash$ | nadie va a escuchar \

Niño: parecían chinas las niñas \

Omar: sí \

Niño: le gustaba compartir \

Niña: que quería ser sincera con el pueblo\| haciéndole muchos regalos para:: | para:: | para la nieve \ Niño: para los niños \

Omar: a ver la...- \| a ver esa compañera \(da la palabra a otra niña)

Niña: que era sincera \

Niña: en vez de pensar en ella / | pensó en los demás \

Omar: imuy bien! \| en vez de pensar en ella / | pensó en los demás \|| imuy bien! \

Niño: me gustó mucho\

Omar: ¿eh?

Niño: me gustó mucho\}

Niño: ¿por qué Babba Zarrah es un nombre raro?

Omar: y porque era de un país muy:: lejos \

Niña: ¿de qué país era? | ¿de Rusia? /

Omar: y por los nombres / Nikolai \| Ivanov \

Niños a coro: (comentan desordenados sobre los nombres de los personajes (???))

Omar: bueno \/ ¿está todo? | ¿a ver Clari?

Niña: que le encantaba tejer/

Omar: jeso también! \| que le encantaba tejer \

(Continúa hablando Inés.) 

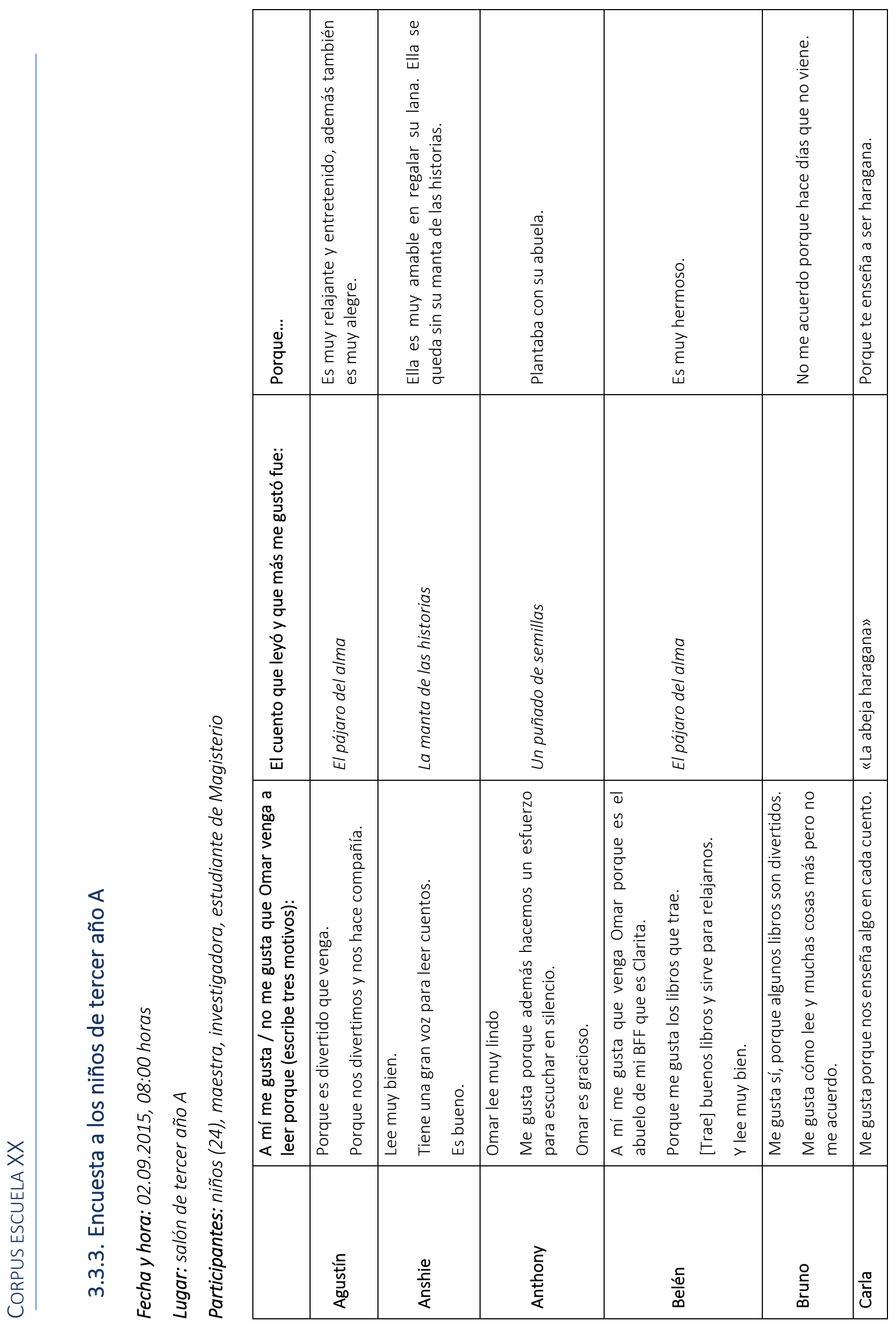


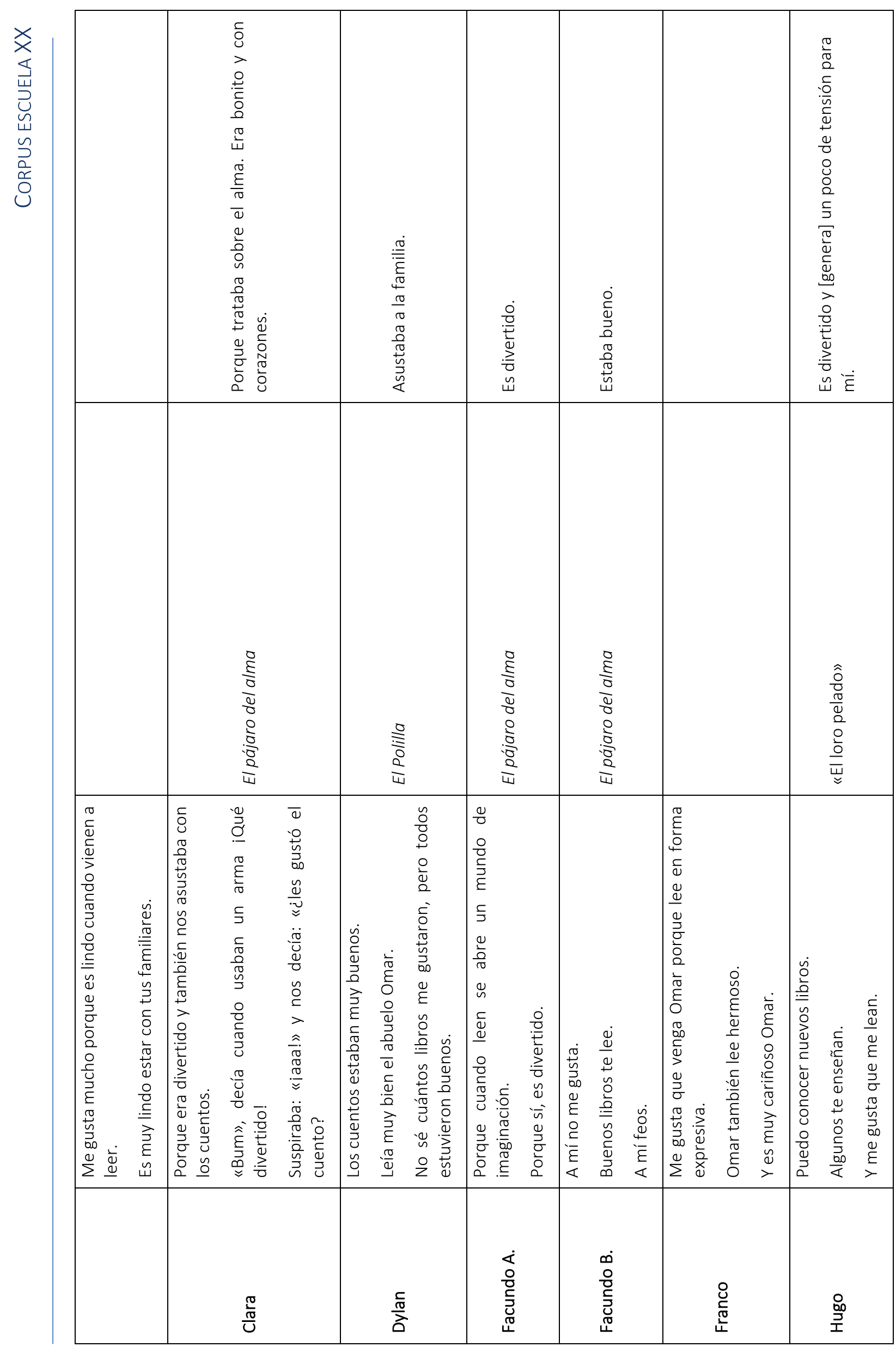




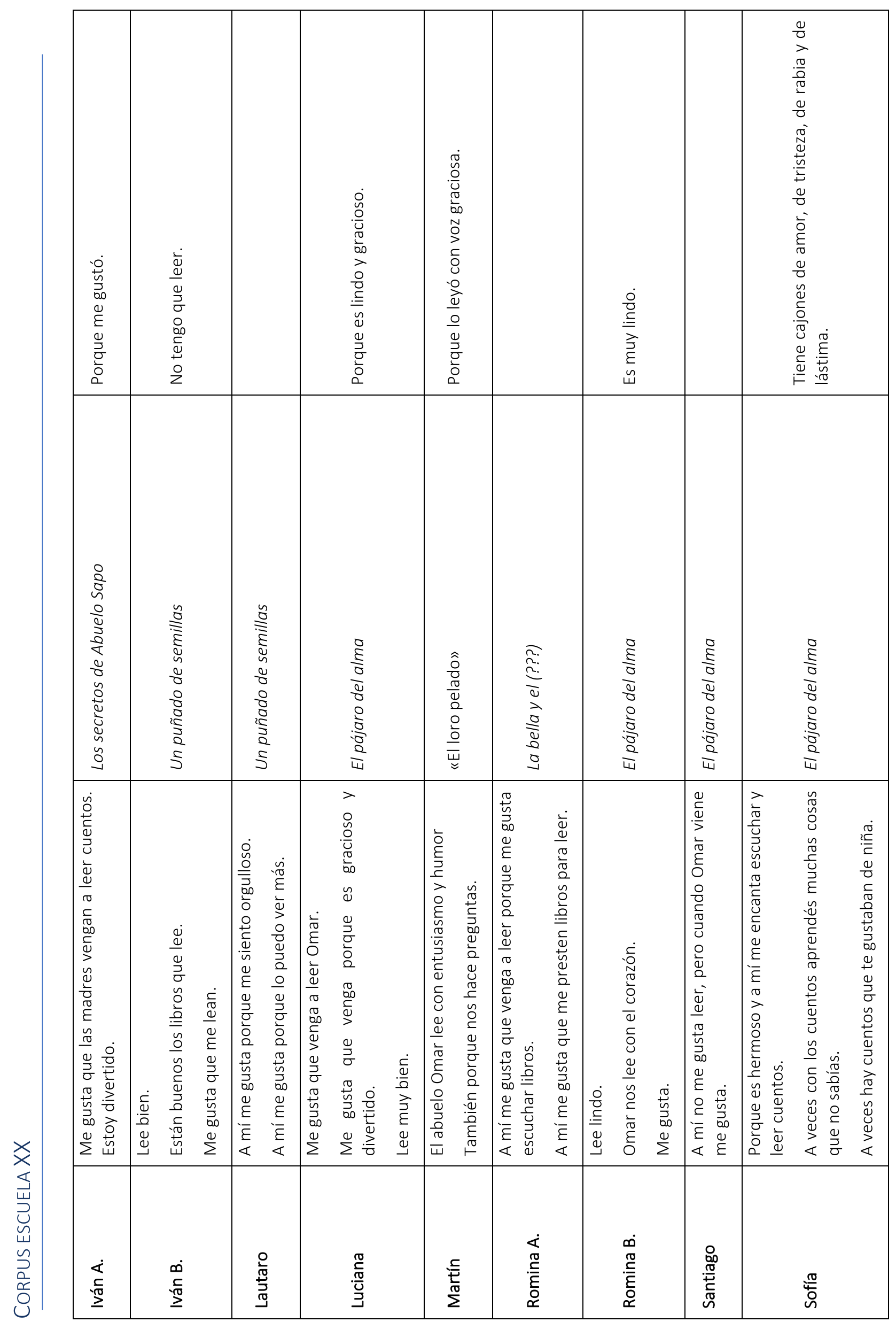




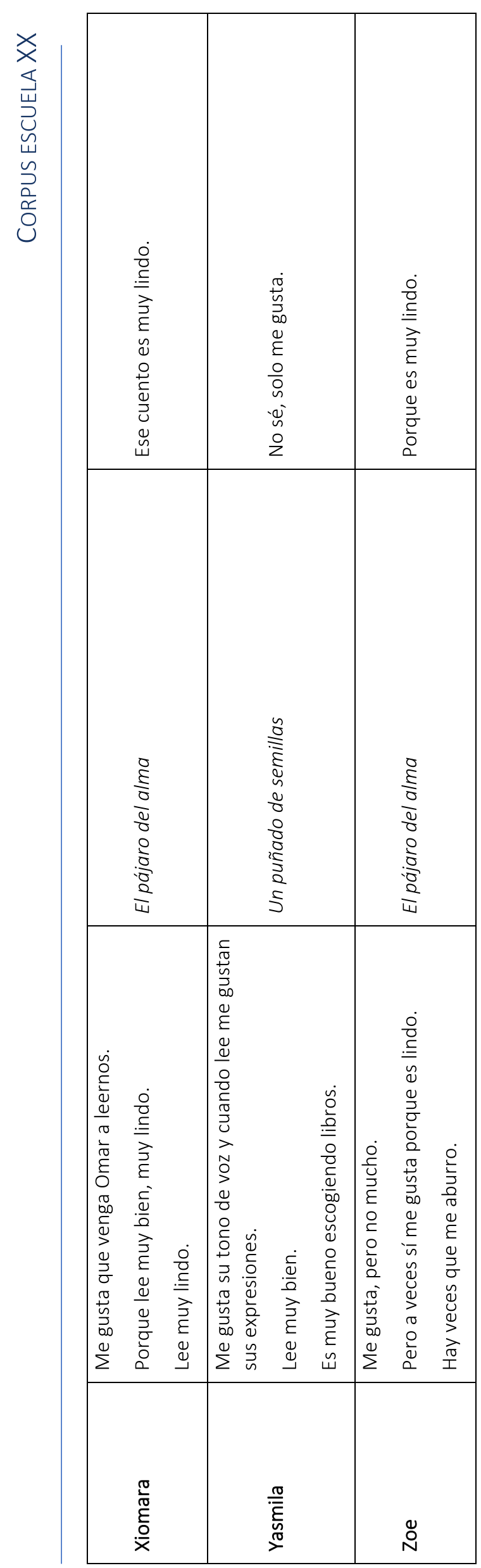




\subsection{Caso 2. Cecilia}

\subsubsection{Entrevistas}

\subsubsection{Entrevista a Cecilia}

Fecha y hora: 25.11.2015, 08:45 horas

Lugar: salón de tercer año (se encuentra vacío porque la clase salió de paseo)

Participantes: mediadora, esposo de la mediadora, investigadora

Sandra: Cecilia la:: primera pregunta | ¿por qué decidiste vos integrarte al equipo comunitario de lectura?

Cecilia: bueno porque me pareció una buena oportunidad para:: | pasar más tiempo con ...- no solo con mi hija sino con otros niños conocerlos un poquito más y bueno ya el año pasado yo ya | había leído algún cuento en algunas clases y estuvo bueno y ta...- bueno este año ...-

Sandra: ellos se acuerdan de cuando ustedes vienen a leer

Cecilia: iah! sí sí sí | y los chiquitos también | los chiquitos...- | está muy bueno también | yo les leí a los de jardinera | y era uno de un perro y se identificaban todos con el perro | todos tenía un perro como ese \{risas\}

Sandra: ¿en qué clases leíste este año?

Cecilia: en tercero y en jardinera ${ }^{6}$

Sandra: cuando vos venís a leer a inicial o a tercero | ¿qué rescatás de esos momentos de lectura?

Cecilia: y tenés pila de cosas | porque por ejemplo | en los más chiquitos | digo son:: | es distinto a tercero porque los chiquitos están como con una expectativa a ver qué tipo de cuento le vas a leer \|| va también en la manera en la que uno se los cuente | este:: | te escuchan mu::cho | eh::y además tod...en seguida que vos decís algo que de repente ellos se sienten identificados | ellos enseguida te empiezan a decir [enf.] ah yo tengo un perro igual porque mi perro hace esto mi perro hace lo otro | y se identifican con el cuento que vos le lees que es como para la edad de ellos | y bueno después tercero:: | son más grandes y también te prestan mucha atención | o sea están muy atentos porque también después saben que ellos de repente después tienen que:: hablar sobre ese cuento| y prestan atenció::n | de también a veces se pueden sentir en algunas cosas identificados || con ellos | con la familia con los compañero::s || es otra cosa también | son más grandes | y es otro tipo de atención pero está está muy bueno también Sandra: ¿ por qué pensás que a los niños les sirve que vengan las mamás o un abuelo a leer?

Cecilia: y bueno:: | porque es como que tenés ...- | si uno no es familiar de todos pero ellos sienten como que la familia está más cerca de ellos | o sea | no solo compartir en la casa sino también estás en la escuela compartiendo con ellos | entonces sienten como un poquito más familiar la escuela | digamos Sandra ¿vos pensás que al maestro le sirve que venga la familia a leer?

\footnotetext{
${ }^{6}$ Inicial nivel 5
} 
Cecilia: sí porque también ve::n | observan en los alumnos | las reacciones que ellos tienen cuando viene:: | alguie::n | alguien de afuera ¿no? | alguien que no está con ellos todos los días | o sea | es la mamá de un compañero de otra clase o el abuelo:: o la tía o quien fuera y dicen [enf.] iah! mirá también vienen como decir también puede venir la familia no es que venimos solo nosotros

Sandra: ¿qué observás en los niños cuando vos leés?

Cecilia: se identifican | ellos...- ya cuando vos empezás a leer el cuento | depende de la manera en que lo cuentes ya ellos prestan otro tipo de atenció::n | vos ves que no se aburren | que no se distraen || que están siempre atentos a lo que vos estás diciendo | y de repente vos eh:: leés algo que...- | a veces hay algunas frases que ellos puede que no entienden por algunas palabras $\|$ y les explicás la...- esa palabra que de repente que vos sabés que no entienden | y ellos te escuchan | y :: ves las caritas como diciendo [enf.] iah! mirá lo que significaba ¿no?

Sandra: ¿cuándo te integraste al equipo?

Cecilia: el año pasado | el año pasado también leí

Sandra: ¿qué te aportó la experiencia de lectura?

Cecilia: en realidad no mucho porque yo el año pasado muchas veces no leí | y este año me tocaron dos veces nada más pero digo | eh:: <3> no sé de repente alguien de afuera me tendría que decir a mí a ver si tengo que cambiar algo en la manera de leer o de contar el cuento digamos | pero digo | en general es una experiencia muy buena || y ...- | no sé | capaz que ...- yo por mi lado creo que es una buena experiencia | creo que leo:: bien \{risas\}

Sandra: yo te preguntaba por tu seguridad | si venciste la timidez

Sandra: seguridad sí no tengo ningún inconveniente | me encanta | en ese sentido timidez no tengo \{risas\}

Sandra: Cecilia las lecturas que vos Ilevás a la clase...- $\mid$ yo me acuerdo que estuve en $=\ldots . . .=$

Cecilia: $=\ldots . . .=$ la de:: | la de jardinera fue una de un perro pero no me acuerdo cómo se llama el libro | sé que | contaba todas las cosas que hacía un perro | y la de tercero | era un cuento | que era de una niña que era muy pobre | eh::

Sandra: ¿Un puñado de semillas?

Cecilia: jesa! [enf.]

Sandra: ¿la elegiste vo::s?

Cecilia: no | esa me lo dio la maestra | para leérselos a ellos

Sandra: la otra lectura fue Una cena elegante

Cecilia: ¿la del perro?

Sandra: la que yo te solicité | ¿vos te acordás?

Cecilia: $<6>$ entonces fueron tres veces que leí 
Sandra: $<15>$ (Busco en mi diario la fecha en que leyó Una cena elegante.) fue el 12 de agosto ¿te acordás que el cuento era sobre un tejón | que el cuento terminaba con una ca::rta | fue hace un tiempo ya

Cecilia: sí sí ahora sí

Sandra: ¿qué recordás de ese día? | ¿algo en especial?

Cecilia: me acuerdo sí que a los chiquilines les gustó mucho este cuento || y que to...- después...- | o sea:: \| eh: ellos viste que siempre son un poco hiperactivos en tercero entonces quieren | a la misma vez que vos estás contando el cuento ya ellos | siempre eh:: || te dicen algo o algún comentario | y bueno y después...- | se genera ese comentario en ese momento pero ya | lo que se genera es como que todos empiezas a participar | y todos te hacen un comentario y:: de algo que les gustó | y todos...- está muy bueno

Sandra: de tus lecturas favoritas | de las tuyas no la de los niños | ¿qué te gusta leer?

Cecilia: $<6>$

Cecilia: me gustan much...- | o sea | me gustan varias cosas | me gusta la parte de | poesía me gusta::n || libros que a veces leo pero personales del tipo de ...- $<5>$ | hay un libro que me gusta mucho que se llama La magia | este:: | no tienen nada que ver con cuentos ni nada ¿no? | este:: | y bueno después | lectura de:: historia de:: de:: | tipo policiales

Sandra: y Cecilia ¿cuál pensás que de todas las lecturas...- el tema o el auto::r o el género de los que has leído en tercero les gustó más a los niños? | algún título que identifiques además de los que hablamos

Cecilia: yo creo que en realidad eh:: | en realidad me parece que | en general si uno elige | un buen libro | según la edad || yo creo que | si el libro es lindo | si la historia es buena | a ellos les va a gustar | no creo que haya uno específicamente | de repente puede ser por ejemplo el que leímos en tercero de la niña que es muy pobre | digo las cosas que le pasan a esa niña | son:: | eh:: bastante fuertes y duras || o sea | de repente no se me ocurriría contarle a mi hija ese cuento porque:: | me parece un poco fuerte ¿no? | las cosas que le pasan son muy duras | se muere la familia | queda sola en la calle | entonces como que son cosas duras | pero también está bueno | porque son parte de la realidad | son parte de la vida | y ese cuento estuvo muy bueno | porque:: claro | uno personalmente en la casa no le contaría ese cuento | pero digo cuando uno viene acá y | leés ese cuento | y vos ves las reacciones | digo ipah! | mirás las reacciones que podrían tener | que nunca te imaginás porque nunca se lo vas a leer | en realidad | pero depende | yo creo hay libros muy buenos que uno de repente | no los lee pero que en la escuela hay | ese tipo de cuentos y ellos lo disfrutan igual || y aparte se da eso de que ellos te...- te:: || te dicen algo y te comentan y se genera como la otra vez | toda una conversación un diálogo donde ellos ...- vos los ves | y parecen como más grandes ¿no? [enf.] | por la expresión y todo eso

Sandra: bueno ya hablamos de cuando leíste Una cena elegante | me contaste que | que les había gustado

Cecilia: sí

Sandra: ¿algo más que te acuerdes de ese día? ¿de los niños? || ¿de algo en especial? | te pregunto porque fue hace mucho 
Cecilia: yo sé que sí | que ese día estuvo bueno se generó un diálogo | un ida y vuelta | y a ellos les gustó mucho ese cuento

Sandra: ¿y qué aspecto del cuento te pareció que les pudo haber gustado? || ¿ंo que aprendieron de esa lectura?

Cecilia: $<6>$ yo no me acuerdo mucho del cuento en general pero:: | el cuento sé que algo tenía | el tema de que les dejaba algo como...- $\|$ no te quiero mentir pero no me acuerdo bien | pero creo era algo que de repente ellos | el no ser egoísta con los demás | y aprender a comparti::r |y a hacer...- | siempre estar bien con los demás ¿no? | Ilevarse bien

Sandra: ¿qué opinión tuviste de este libro?

Cecilia: me gustó porque antes de venir a leerlo acá me dan el libro | y yo lo leo || entonces veo qué tipo de cuento es y veo | cómo lo podés contar | según las pa::rtes que tenga | entonces ahí vas viendo

Sandra: vos me decís que sos lectora | que te gusta leer mucha cosa | ¿̇en qué momento de tu vida apareció la lectura?

Cecilia: desde chica || desde chica porque a mí...- | desde chica de mi casa en realidad | porque...- | en mi casa mi madre siempre me estaba comprando | lo que antes había en realidad | las revistas aquellas de:: | del pato Donald | de Disneylandia | [enf.] tenía millones de esas revistas y ahí empecé leyendo | me compraba muchos cuentos | y no solo esos tenía otros | bueno los tradicionales | Blanca Nieves | Caperucita Roja | bueno todas esas cosas | y de ahí siempre | siempre siempre tuve [enf.] | en mi casa siempre había libros | siempre leí

Sandra: ¿y después en tu adolescencia y juventud?

Cecilia: sí ahí en esa etapa como que en la adolescencia uno | \{(risas) no lees tanto sino lo que te mandan los profesores en el liceo\} y:: hasta ahí | pero bueno después que uno || va creciendo | ahora ya mayor como que leés un poco más que que...- | depende de los tiempos que uno también tenga | pero bueno Sandra: cuando llegás a ser adulto es más difícil

Cecilia: claro pero de repente iyo qué sé! a veces | en la noche por lo general | cuando uno está un poco más tranquilo

Sandra: vos contabas que le leés a tu hija

Cecilia: sí ahora ya lee solo ella así que...- | lee sola y ella agarra los libros sola y siempre le estamos comprando libros | a veces como que no tiene esa constancia porque claro ...- || a ella por ejemplo le gustan los libros del sapo Ruperto | y:: de repente no los llega a terminar de leer || pero no tiene esa constancia todavía de estar leyendo un libro que es un poquito más la::rgo y...- | pero los va leyendo le gustan | y aparte bueno tienen la XO de la escuela | que están mucho con eso | pero después lee sí | ella sola siempre está | leyendo y eso

Sandra: Cecilia ¿cómo valorás el:: trabajo de todo el equipo comunitario de la escuela? || ustedes son unos cuantos 
Cecilia: es un lindo equipo porque digo:: todos colaboran | está el abuelo que creo es el que más lee | el que más está eh:: | es una buena experiencia | todos colaboran en...-- por ejemplo:: || decir | libros para leer | puede ser este || y bueno después lo que aportan las maestras

Sandra: ¿qué te parecen las reuniones?

Cecilia: porque en las reuniones todo el mundo cue::nta cómo les fue qué les pareció si tiene algún libro:: nuevo como una abuela que creo que vino y trajo...- | también y trajo libros | y algunos cuentan algunas experiencias que de repente | tienen en otros lados

Sandra: ¿qué consejo le darías a una:: mamá o a un abuelo a alguien que el año que viene que se quiera integrar el año que viene al equipo de la XX? ¿qué les dirías?

Cecilia: ah yo les diría que vinieran | porque es una linda experiencia:: || bueno si tienen nietos | con los nietos | aunque le puede tocar en la clase del nieto como no | y podés ver las reacciones de otros niños y cómo...- | y como comentan | y a pesar de que son de repente chiquititos | y te comentan y te dicen y se sienten identificados...- || está bueno || teniendo tiempo \{risas\} || una vez cada ta::nto | un ratito | que son quince veinte minutos ya está | y ellos lo disfrutan pila || es como un recreo también | porque a veces uno llega y ellos están trabajando y bueno cortamos | el maestro los hace cortar los hace sentarse | en el pi::so | o muchas veces como | yo hice una vez || que los chiquitos | como ellos son bajitos [enf.] | a ellos les gusta que uno se siente | no más alto | sino a la misma altura de ellos | entonces yo...- el día que fui a contar el cuento me senté en una silla chiquita de ellos | y estaba a la altura de ellos | entonces como que ellos se sienten un poquito más cómodos | no leja::nos | y ahí al lado de ellos | como que es más más integrado::r | ellos...- vos te sentás al lado de ellos es como...- | te sienten más cerca | estás como...- | como la maestra | como si fueras la maestra de ellos | o una tía || cla::ro porque si vos te sentás le::jos | todavía que sos una persona extraña y te sentás lejos | es distinto es como más frí::o | en cambio su vos te acercás | te ponés más cerca de ellos le contás me llamo así | me llamo así mi nombre es ta::I | les voy a leer tal cuento a ver si les gusta | y después ya te comentan | ya te empiezan a hablar y entran en confianza enseguida \{risas\}

Sandra: algo más que quieras decir de esta experiencia

Cecilia: en general como que...- | digo ...- | es una experiencia buena || tuvimos poquitas reuniones y eso | porque fue un año especial | en general estuvo | bárbaro

Sandra: ojalá el año que viene puedan seguir | te agradezco mucho Cecilia

\subsubsection{Entrevista a Noelia, maestra de tercer año B}

Fecha y hora: $08.10 .2015,08.00$ horas

Lugar: salón de segundo año (Noelia se encuentra a cargo de los niños por ausencia de su maestra)

Participantes: Noelia, investigadora

Sandra: Noelia estas son preguntas | para complementar un poco lo que yo observé en las clases ¿no? acordate que yo observo la lectura de los...- de los papás de los abuelos \| eh:: y bueno sobre eso es la entrevista || decime ¿qué tal te resultó:: por ejemplo que Cecilia fuera a leer a tu clase?

Noelia: ¿Cecilia fue la primera? 
Sandra: no la segunda

Noelia: ah eso <20> (interrumpe para solicitar a los niños que hagan silencio.) eh:: Cecilia bien [enf.]| había una energía | había una lectura lige::ra viste |eh:: | intervenía con algunas cosas bastante:: importa::ntes en la lectura eh:: | se nota mu::cho y se hace la diferencia | cuando eh:: | los que vienen a leer | logran tener esa lectura corrie::nte han leído antes el cuento y...- | en los niños se nota mucho eso | en la atención ¿no?

Sandra vos decís que todo eso se refleja y los niños prestan más atención

Noelia: prestan más atención sí

Sandra: bien I ¿qué opinión tenés de que los padres o los abuelos vengan a leer a la escuela?

Noelia: tiene algunas...- eh:: | tiene cosas a favor porque...- | a mí me gusta por ejemplo...- | primero viene la familia a la escuela ¿no? | es un día que viene alguien de | de la familia a leer un cuento || eso es sumamente importante porque ellos la espe::ran les gusta | ese cuento está en su casa muchas veces antes | entonces ellos ya...- | alguno ya lo cono...- | lo conoció entonces se siente...- hay como una motivación ¿verdad? | ven a otra persona otra figura | es un momento de lectura placentera | a veces nosotros los maestros tendemos a | a hacer una lectura | frente a algún trabajo | y este es el momento de la lectura por placer | que no tiene otro signif...- || el maestro le pone otro significado ¿verdad | pero que venga alguien a leerles por placer es sumamente importante $\|$ en algunas familias se ha dado como otra cuestión de | de buscar co::sas | o de...- (un niño interrumpe para preguntar si puede cambiarse de lugar) de buscar co::sas eh:: | de traer libros de su niñe::z | ahí distintas motivaciones | en los adultos mueve ciertas situaciones | que me parece que están lindas ¿no? | los nietos traen libros que leyeron ellos cuando eran ni::ños | o los vuelven a buscar | o los tratan...- || algunas cosas que tiene en contra | es que a veces no lográs | que sea como...- eh:: | que los padres pueden venir sistemáticamente ¿no? | o porque eh:: | trabajan | o porque les pasó algo | o porque empezaron a trabajar entonces ya dejan de venir | y entonces cuando lográs un cierto grupo | empiezan como...- | empiezan a desaparecer ¿no? | las cosas cotidianas de su casa o el médico es como...- | se nos ha hecho difícil hacer un trabajo puntual | en los dos años que sistemáticamente vengan los mismos padres | son muy poco los padres | que han permanecido | por diferentes ocupaciones

Sandra: bien | si vos tuvieras que comparar | cuando viene la familia a leer o cuando lee la maestra ¿cuál es la diferencia?

Noelia: ¿siempre en el caso de Cecilia?

Sandra: por ejemplo cuando Cecilia vino y había preparado el cuento

Noelia: al grupo...- a tercer año...- | a mi grupo le gusta que le lean | al grupo le gusta que le lean | entonces...- eh || a veces || a veces lo que pasa es | yo siento que eh::| la atención es la misma pero a veces || no quiero ser pedante ni nada | el maestro le ponen como una impronta que a veces los papás no lo saben | entonces el maestro al leer...- || por ejemplo cuando vino una mamá que era maestra | la mamá de Tatiana | a leerles un cuento | eh:: había como una connotación diferente ¿iverdad? | en el cambio de voces y en la atención a ciertas cosas | eh:: los papás a veces | algunos logran como modificar | y a veces hacen como algún cambio en el proceso | pero a veces es como una lectura | llana ¿iverdad? | no hay una transformación || eh:: yo a veces...- | yo siento que los niños disfrutan | las dos formas | 
porque son dos formas diferentes que les lean | porque es la forma que le leen en su casa también | entonces...- es totalmente disfrutable también | yo siento que es diferente | a cómo lee el maestro en la clase a cómo lee el papá que viene

Sandra: si vos tuvieras que:: que pensar el escenario ideal de lectura del mediador|| ¿qué esperás que él o ella haga? ¿qué esperás que hagan los niños?

Noelia: el ideal es primero yo como desde rol docente | el maestro debe preparar la clase | para el mediador | porque el mediador es alguien que viene diez minutos | me parece que primero el maestro tiene que preparar la clase ¿no? | dar ciertas rutinas o reglas de que...- || a la hora de llegar el mediador | sería interesante que la clase fuera como un espacio más grande donde los niños se pudieran sentar en el sue::lo | tuvieran como otra prep...- | en el suelo alrededor | dura unos minutos | a veces uno corre entre que viene a las ocho eh:: (<30> interrumpe para hacer callar a los niños) eh:: me parece que a veces | no tanto...- sino lo que nosotros....- que a veces ahora como pensándolo | lo que el maestro genera cuando llega el mediador | a veces es como la rutina diaria | llega...- | tiene que haber un clima para el cuento || eh:: tiene que haber...- tiene que haberlo hecho esperarlo | porque los niños lo esperan además | si llega si no llega si viene hoy si no viene hoy | eh:: y sería como importante que a veces la clase fuera como un lugar | donde este pudieran sentarse en el sue::lo alrededo::r que no entrara nadie | que a veces eso no nos pasa | crear un lugar especial para eso lo veo como una utopía porque en realidad I en la clase y en las escuelas muy pocas veces hay un lugar específico y sería como sacarlos y entrarlos en lo cotidiano I pero más allá de eso me parece es como el docente se para frente al grupo y frente al mediador | que va a leer | pero es el rol del maestro el que tiene que lograr el clima

Sandra: y qué esperás que hagan los niños cuando lee el mediador

Noelia: primero que lo escuchen atentamente || yo quiero que se entusiasmen que...- | primero que lo escuchen | después que les dejen esa cuestión del gustito ¿no? | como iqué lindo! ¿no? | que puedan disfrutar de la historia

Sandra: \{ruido (espero que los niños bajen la voz) $<8>\}$ si tuvieras que darle un consejo por ejemplo a Cecilia | sobre su actividad cuando viene a leer ¿qué le dirías?

Noelia: a mí me gustó mucho cómo trabajaba Cecilia | o sea venía con el cuento había un intercambio con ellos | capaz que en la forma de leer con algunas cosas puntuales que tienen que ver con las [...] con pero me parece que la intervención que hacía...- a mí me gustaba cómo trabajaba| capaz que le diría alguna cosa puntual sobre la forma como...- $\mid$ los silencios $::$ sobre su lectura $=\ldots . . .=$

Sandra: $=\ldots . .=$ ¿sobre su modo lector?

Noelia: sobre su modo lector

Sandra: ¿te acordás cuando ella leyó eh:: Una cena elegante?

Noelia: sí

Sandra: ¿qué recordás en especial de ese momento?

Noelia: eh:: yo cuando lo leí | no me parecía que fuera un cuento:: no:: | que pudiera sacar como alguna cosa ¿no verdad? eh:: | yo lo que observé es que a los niños les gustó mu::cho || les llamó la atención ¿verdad? | por el disfrute | y después ellos...- | y después conversando con ellos hubieron cosas que 
salieron del cuento que yo no había reflejado | el poder sacarle el jugo ¿no? | nosotros conversamos después | y:: | y después cuando volvimos | nosotros trabajamos cosas del Abuelo Sapo | ellos retomaron cosas de esta historia

Sandra: ¿cómo los viste con respecto a otra instancia de lectura? ¿hubo algo distinto ese día?

Noelia: no

Sandra: ¿te parece que ese cuento estuvo bien elegido Noelia?

Noelia: sí (Vuelve a interrumpir la lectura para solicitar silencio a los niños. El ruido se hace cada vez mayor) para mí todos los cuentos están bien elegidos \{risas\} | por ejemplo si yo comparo cuando | vino la primera mamá | por la forma de leer | y el cuento que era mu::y largo | ese cuento no::...- | o sea me parece que los cuentos que son concretos ¿no? | en ese momento así que eh:: cuando...- | me parece que para los mediadores | para el grupo lector | las historias tienen que...- en algunos casos | es importante que puedan seguir | pero en los casos como los grupos más chicos | me parece que es interesante eso de que | eh:: puedan venir | leer la historia | y:: al otro [día] otra historia ¿no? | o poder repetir la historia | nosotros hacemos repetidos los cuentos que ellos han leído | los hemos vuelto a leer porque ellos lo piden || eh:: repetir la historia || eh:: no::...-- | a veces no elegimos bien pero a veces...| me doy cuenta por ejemplo una novela | yo me doy cuenta ahora que yo les estoy leyendo novelas que la diferencia es (???) a la otra o día a día ¿no? (Noelia trata de tranquilizar a los niños nuevamente.)

Sandra: de ese cuento en particular ¿qué te parece que les interesó más a los ni::ños?

Noelia: $<10>$ eh:: una cosa que a ellos les gusta mucho es como esa cosa reiterativa en la historia ¿no? | las palabras que son reiterativas en la historia || eh:: y el final | como el concepto eso que era además...| nada | de buscar...- eso les llamó la atención | pero les llama siempre como lo reiterativo de la historia ¿no? | las palabras que se repiten | o:: ese cambio de...- | (???) y el final de la historia que fue como...I [enf.] fue chocante

Sandra: ¿qué aprendizajes te parece que le dejó ese cuento?

Noelia: las historias como que les van dejando un mensaje en el tiempo yo no...- | o sea me parece que no logran como...- decir qué bueno esto | a mí me parece que cuando vos te das cuenta | en el momento que estás contando la historia ellos recuerdan | lo que le pasó a fulani::to | es como algo que les va quedando en el disco duro | pero yo no sé si en verdad ellos...- | yo no sé si ellos logran...- | les queda en el disco duro y lo vas retomando eh:: || en algunos puntos pero...- | para mí es como que va...- | es por ejemplo cuando leí La manta ¿no?

Noelia: a ellos les llamó la atención que no tuviera malvados || fue una historia muy sencilla muy simple || lo que más les llamó la atención es eso que no había malvados en la historia ¿no? || es como algo | que o sea | que a ellos les va quedando frente a algunas situaciones o algo hacen un comentario ¿no? | de «lo que mucho abarcan» | pero este:: || no creo que sea como algo...- bueno...- | estos los niños (???) y a todos | yo creo que algu::nos | logran analizar y les van quedando como unas ciertas cosas y a otros como algunos vestigios ¿no? | y hay que volver a leerlo | (???) de esto de cuando uno aprende | aprende porque está jugando porque está disfrutando| porque...- | es como eso

Sandra: a mí me llamó la atención | todo lo que vos leés en tu clase || tenés presente la lectura la incorporás muchísimo a tu clase | entonces ¿cómo vinculás eso con tu biografía lectora? 
Noelia: ah:: || o sea | en mi infancia | y en mi casa | siempre hubieron libros || mi pa...- mi papá y mi abuelo eran muy lectores | eh:: y a mí bueno | me daban muchos libros | hoy en día no soy una lectora en mi casa | eso también | me cuesta mucho hoy en día leer | porque leo mucha::...- | me cuesta leer por placer || porque lo que leo es | lectura específica con lo que trabajo ¿no? | la didáctica || porque lo otro...- | lo que sí ahora me pasa | es que disfruto mucho cuando les leo a mis hijas | les leo mucho a mis hijas | o sea mi lectura placentera del día son los libros infantiles \{risas\} | ime fascinan los libros infantiles! | pero hace mucho que no leo una novela | años ¿no? pero en mi casa siempre hubo libros | siempre me regalaban libros | este:: me traían libros | libros de poemas había...- | mi papá es un lector | mi mamá no tanto pero mi papá es un lector que lee de a tres libros || siempre se compró...- | lo del diario ¿no? | en mi casa siempre hubo diarios | semana::rios | en mi casa también se lee el diario | yo no leo mucho queda apilado ahí queda apilado \{risas\} pero en mi casa siempre hubo diarios

Sandra: ¿y en la adolescencia vos seguiste manteniendo ese gusto por la lectura?

Noelia: sí me gustaba | me gustaban mucho las novelas | mi problema con los libros y con las novelas es que yo lo empiezo a leer y hasta que no lo terminé no hago otra cosa || entonces en mi adolescencia lo hacía | por ejemplo Cien años de soledad es un libro que ama::ba | eh:: La [Crónica de una ] muerte...| leía me gustaba mucho García Márquez eh:: | pero lo hacía en una semana era así... | impulsivo | hasta yo que sé [enf.] había apagón y seguía leyendo | después ya lo dejé de hacer | a veces lo hago pero después como...- || si el libro me engancha | porque hay libros que:: ta || pero en casa siempre hubieron libros | o sea somos de comprar libros | nunca los leo | tengo una biblioteca llena de libros que nunca leí y nunca los voy a leer | a veces me pasa ¿viste? de comprar \{risas\} y esos libros que compré son un regalo y están al servicio | pero ta | sé que esos libros nunca voy a leer | pero tiene que ver con la historia lectora

Sandra: ¿cuánto hace que te recibiste?

Noelia: me recibí en el 2003

Sandra: o sea que hace más de diez años ya | ¿de la formación del Instituto | qué recordás? | ¿qué te aportó el instituto para que enseñes a leer?

Noelia: yo hice un pro...- | yo hice un programa | que duraba tres años | hoy en día tampoco | no hay didáctica | eh:: | tuve algún profesor...- | tuve un profesor del taller de Lengua el último año | no había materias relacionadas | no tengo recuerdos ¿no? | tuve una materia Idioma Español que tenía que ver con la gramática || recién el último año tuve un profesor eh:: | del taller de lengua | que profundizó en algunos temas | pero en el recorrido | lo que he ido aprendiendo | como cuestiones puntuales | y he ido buscado las formas de buscar estrategias | y de (???) | y de tratar de ver las cosas cotidianas

Sandra: ¿como una autoformación?

Noelia: sí | de buscar eso | y hay cosas que...- | que hago...- | al principio hacía muchas cosas que yo había recibido como niña | en la escuela | porque no hubo una didá::ctica relacionada con la Lengua || el último año tuve un taller de Lengua que era Dotti || brillante || la verdad | que me tocó y era brillante y era súper exigente | pero fue el último año y un taller || no:: no había una profundización | pero tampoco en ninguna área | capaz que más en Matemá::tica | pero al principio yo enseña::ba... | primero enseñaba con ideas previas | era todo con ideas previas | y he ido cambiando | y también enseñé como me enseñaban a mí | y después | me he ido dando cuenta que:: | tiene que haber otro proceso | 
entonces he tratado de cambiar | en un momento quería como...- | y también de acuerdo al año | cuando yo estaba...- tenía primer año trabajaba mucho con el libro de cuento | entonces un tema lo relacionaba con un libro de cuento | ya en tercer año es más difícil | pero trato de buscar en la literatura | y ahora estoy un poquito volviendo a la gramática | a enseñar la gramática | porque:: hay | sobre todo para los terceros || eh:: el año pasado trabajé mucho desde la literatura || y me parece que hay que volver un poquito...- | ir probando | es ir probando || pero lo que trato de hacer es eso | primero | desde lo...- | desde la literatura | primero entre todos | y cualquier otra introducción | y ver...- | y ver los cambios también de los de los autores | me cuesta que ellos puedan reflejar | sacar la estructura | como modificarles la estructura | porque ellos ya lo tienen incorporado | llegan a primero con (???) | yo estuve una experiencia en primero | y me encantó cuando pude ver eso | la escolarización | y el haber pasado por la:: | por la escuela ¿verdad? | en algunos casos tienen que ver con las familias | o sea tiene que ver con las familias $=\ldots . . .=$

Sandra: $=\ldots . . .=$ ¿tiene que ver con Inicial?

Noelia: cla::ro | pero:: Inicial es otro mundo | no hay escolarización | no hay escolarizació::n de:: | de los contenidos | (???) | y lo que traté es como eso | que ellos jugaran | que ellos pudieran conocer | primero conocer || eso es fundamental | que ellos puedan saber ¿no? | los autores | que conozcan los temas primero | que conozcan los autores | por lo menos algunos cuentos de los autores | y después que puedan comparar ¿no? | porque los autores se basan en una línea entonces...-| trato de hacer eso | pero nadie...- | pero no hubo algo o alguien || primero yo no tuve didáctica | no hay didáctica | al no haber didáctica y...- | y te puede tocar directoras que sepan mucho de la práctica...- $\mid$ y yo tuve una materia que era Orientación al Aprendizaje | entonces eh:: | era un desastre | muy chaucha ¿viste? | era de tres años | había que sacar maestros...- | fue desastroso | pero tratamos

Sandra: quedan dos preguntitas más || ¿a vos te parece que la lectura de literatu::ra en la escuela | tiene el lugar justo? | ¿ le sobra o le falta? | ¿vos dedicarías más tiempo | menos tiempo o está bien el que le dedicás?

Noelia: no | en la escuela me parece que habría que dedicarle más tiempo || ah:: | me parece que a los maestros nos cuesta mucho poder entender | eh:: el enseñar por el placer | yo encuentro que...- | que si vos hacés una lectura por placer | le estás enseñando mucho más que enseñarles cómo...- | eh:: || me parece que los maestros lo perdemos eso en lo cotidiano || por los tiempos ¿no? | y más en la escuela de cuatro horas | querés dar esto y dar lo otro | enseñar a leer (???) | me parece que habr::ía que tomar || eh:: || puntualmente | en forma diaria no sé si diaria | pero ese momento | ese rato en que alguien te cuento y poder escuchar | el poder compartir | a veces no lo hacemos por lo cotidiano | pero también lo hacemos por otras cosas ¿no? | por esa cuestión de:: del disfrutar | los maestros tenemos como que el juego:: | es como...- ¿ंviste? || o la lectura:: | ese momento de lectura lo hacemos una vez a la semana || o cada tanto ¿no? | eh::| y es interesante que se pueda | porque ellos disfrutan | trabajás vocabulario trabajás un montón de cosas

Sandra: y la última pregunta que es especial para vos $\|$ este es el segundo año que sos referente del proyecto || ¿por qué aceptaste este desafío? | porque es un desafío | es una carga | que además es un trabajo extra 
Noelia: bueno | \{primero tengo una directora que me ayuda muchísimo (risas)\}| tampoco es una carga o sea tengo ahí un apoyo de dirección | muy fuerte || eso es lo primero | eh:: segundo...- | primero | a nivel personal a mí me fascina meterme a hacer cosas porque también tienen que ver con una preparación | o sea | porque si no lo hago | no encuentro el tiempo cotidiano para poder prepararlo | tiene que ver con un tema de formación que es individual | luego el apoyo de dirección | y como algo individual porque a mí me ayuda a prepararlo | o sea a buscar información a leer a estar en contacto con cosas | que a nivel de las posibilidades no lo están ¿iverdad? | la posibilidad de tener un taller con las escuelas y poder escuchar otras cosas otras propuestas | de poder ir a una charla | a una conferencia | y que me den el dí::a para ir a una conferencia | y yo poder escuchar eso | eso tiene que ver con la formación | y es más...- || y segundo | porque a mí me gustan mucho los cuentos [enf.] || entonces eso | y la posibilidad de tener los libros | esa cuestión de poder tenerlos y:: poder utilizarlos | y que lleguen a la escuela ¿no? I y de conversar con las familias | conversar con las familias es muy lindo | a mí me gusta también || son todas cosas que me gustan |entonces no es una carga || eh:: | sí creo que tengo mu::chos debes | porque hay muchas co::sas que se podrían hacer o deber hacer | pero:: | pero ta en lo cotidiano se me va | a mí me aporta muchísimo || me aporta | primero porque no siento una presión porque desde la dirección hay un apoyo | segundo porque tengo for...- | me están formando | o sea...| y busco estrategias para pode::r | como tengo la obligación de | busco cosas para poder leer ¿no? | porque si no tuviera la obligación a veces capaz que en lo cotidiano no lo hacés | y es eso poder compartir la experiencia | me gustó mucho más este año que hubo otra referente | porque fue como::...Sandra: Inés también enganchó enseguida

Noelia: eso me gustó ta...- | porque además de que nos llevamos bárbaro | y:: somos recompañeras | o sea...- | por cómo dejarla también más a ella | en algunas cosas | es otra experien...-- | y hay otra persona con otra cabeza y otras cosas $\mathrm{y}::$ | y otra experiencia y cosas muy buenas

Sandra: Noelia ¿̇algo más que me quieras decir

Noelia: \{que manden más libros (risas)\}

Sandra: $\{a$ lo mejor vienen algunos más (risas)\}

Noelia: no eso | en la escuela hay un montón | pero nos cuesta a veces lo cotidiano:: || y hemos ido transformando | o sea || en relación con el año pasado a este año...- | el año pasado hubo más bloqueo | a nivel del maestro ¿no? | o sea fue más difícil | que entraran ¿viste?| había como...- | no era una contra | pero también en lo cotidiano es mu::cho más difícil || y este año yo noté que:: | ha sido diferente | que había otra apertura || eso también está bueno decirlo porque es eso | es un cambio de dinámica | hubo un proceso | el año pasado empezamos a mitad de año | este año ya empezamos desde el inicio | o sea:: hay un cambio ¿no? | y eso | y a veces no contamos lo cotidiano | (???)

Sandra: bueno | muchas gracias Noelia

Noelia: gracias a vos 


\subsubsection{Entrevistas a los niños de tercer año $B$}

Fecha y hora: 16.09.2015, 09.00 horas

Lugar: pasillo frente a los baños al final del corredor

Participantes: Agustín, Facundo, Marylin, Milena, Abril, Emiliano, investigadora

\section{Agustín}

Agustín: hola Agustín | ¿vos te acordás que | yo estuve viniendo a ver a las mamás leer?

Agustín: sí

Sandra: eh:: primero a Carla y después a Cecilia || entonces estas preguntas que yo te hago son para un trabajo que yo estoy haciendo || ¿sí? | yo no soy inspectora | ni vengo a evaluar nada ni a poner pruebas | es un trabajo para mí ¿sí?

Agustín: \{mueve la cabeza [asiente]\}

Sandra: ¿vos te acordás cuando hice las preguntas por escrito hace unos días? I ¿vos te acordás que dijiste que no te gustaba mucho que vinieran a leer las mamás? | que te gustaba más o menos \¿por qué?

Agustín: po::rque:: | me aburría | porque mientras que ellas estaban || me quedaba sentado | y entonces me aburría

Sandra: ¿sí? no hay algún cuento que hayan leído y que te haya gustado?

Agustín: el Abuelo Sapo | esa vez no me aburrió nomás

Sandra: ¿̇el Abuelo Sapo quién lo leyó?

Agustín: la maestra

Sandra: ¿te aburrís cuando leés con la maestra y con las mamá:: $\mathrm{o}=\ldots . . .=$ ?

Agustín: $=\ldots . . .=$ con la maestra y con las mamás | pero con el Abuelo Sapo no me aburro | que me lean cualquier cosa pero...- $\mid$ me aburro

Sandra: es el único libro con el que no te aburrís | ¿y vos te acordás cuando venía Carla a leer? ¿te acordás lo que leyó?

Agustín: más o menos

Sandra: más o menos | ¿por qué?

Agustín: no me gustaba porque siempre leía una parte | y después leía la otra parte | y todo así | y entonces no tenía gracia

Sandra: ¿te costaba entenderlo?

Agustín: sí

Sandra: claro | y te acordás cuando vino a leer Cecilia | vino dos o tres veces | Cecilia es la mamá de una niña del otro tercero 
Agustín: la madre de Sofía

Sandra: sí | que vino a leer...- | ya te digo || eh:: Un puñado de semillas y Una cena elegante ¿qué te parecieron estos cuentos?

Agustín: \{mueve la cabeza [niega]\}

Sandra: ¿no te acordás?

Agustín: \{mueve la cabeza [niega]\}

Sandra: ¿podés decir por qué no te gustó?

Agustín: <15>

Sandra: bueno muchas gracias | Agustín (Se retira sin hablar.)

\section{Facundo B.}

Sandra: ¿Facundo? | ¿cómo andás Facundo? | ¿bien?

Facundo: sí

Sandra: bueno ¿vos te acordás que el otro día yo vine a hacerles unas preguntas sobre | eh:: las mamás que leen? | ¿vos te acordás de las mamás que han venido a leer?

Facundo: sí la mamá de Tatiana y ...-

Sandra: ¿la mamá de Tatiana?

Facundo: $<7>$

Sandra: ¿de Cecilia te acordás? || ¿de algún libro que haya leído ella? |

Facundo: ¿El mayor tesoro? $<10>$

Sandra: ¿te acordás cuando venía Carla \| la mamá de una nena del tercero de Inés \| que les leía / $=\ldots . .=$ ?

Facundo: $=\ldots . . .=$ ¿la mamá de Martín?

Sandra: iah cierto! | la mamá de Martín || ¿te acordás del cuento que leyó?

Facundo: $\langle 6\rangle$

Sandra: ¿qué te acordás de esos cuentos que leyeron las mamás?

Facundo: $<8>$

Sandra: ¿recordás algo?

Facundo: no

Sandra: vos me pusiste acá...- | me pusiste | «porque trae cuentos graciosos» | ¿vos te acordás de alguno de esos cuentos graciosos?

Facundo: $<8>$

Sandra: ¿no? || y decime | ¿te gusta que te lean? | ¿que lea Noelia o que lean las mamás? 
Facundo: $<7>$

Facundo: vos escribiste que te gustó el cuento Una cena elegante el cuento que leyó Cecilia $\backslash \mid$ ¿te acordás de ese cuento?

Facundo: sí

Sandra: ¿qué te acordás de ese cuento?

Facundo: que era de un ratón el personaje | o algo así | y que le quitaban la cena creo || que había un...| no me acuerdo nada más

Sandra: ¿y por qué dijiste que te gustó mucho ese cuento?

Facundo: porque era gracioso

Sandra: porque era gracioso

Facundo: sí

Sandra: ¿y qué te pareció cómo lo leyó Cecilia?

Facundo: $<3>$

Sandra: bueno eh:: muchas gracias Facundo

\section{Marylin}

Sandra: ¿Marylin? | ¿cómo estás Marylin? sentate un momentito | ¿me dejás grabar lo que vos me decís?

Marylin: \{mueve la cabeza [asiente]\}

Sandra: si podés hablá fuerte así queda grabado

Marylin: \{mueve la cabeza [asiente]\}

Sandra: Marylin ¿vos te acordás los días que yo estuve acompañando a las mamás que vienen a leer?

Marylin: sí

Sandra: que opinás de que las mamás los familiares vengan a leerles

Marylin: me gusta que me lean cuentos

Sandra: sí ¿quién te gusta que te lea cuentos? ¿las mamás? ¿la maestra?

Marylin: las mamás

Sandra: ¿las mamás? | ¿por qué?

Marylin: $<6>$

Sandra: acá pusiste que Cecilia «trae lindos cuentos y eh:: | «se esfuerza en leernos a nosotros» | ¿por qué decís esto?

Marylin: porque algunas mamás no quieren leernos y algunas sí

Sandra: ¿te acordás de las mamás que vinieron a leerles? 
Marylin: $<6>$

Sandra: ¿te acordás de la mamá que vino a leerles un libro a principio de año? | una novela en capítulos? Marylin: ¿la mamá de Martín?

Sandra: la mamá de Martín | ¿te acordás de ellas?

Marylin: porque trajo un cuento lindo y se esforzó al leerlo

Sandra: ¿y qué te acordás de esos cuentos que | leyó | primero la mamá de Martín y después la mamá de Sofía?

Marylin: de:: | de los perritos | y:: el de la mamá de Sofía | de que tenía que plantar

Sandra: ¿qué te pareció ese cuento? | que se llama Un puñado de semillas escribiste acá

Marylin: porque era lindo | y plantaban

Sandra ¿y qué más te acordás de ese cuento?

Marylin: eh:: | la niña tenía semillas y tres amigos

Sandra: bien | ¿y algún otro cuento que recuerdes que hayan leído las mamá::s | que te haya gustado?

Marylin: el de la cena

Sandra: el de la cena | ¿qué te gustó del cuento de la cena?

Marylin: cuando lo::s eh:: | cuando los animales fueron | a la madriguera y se escondieron

Sandra ¿y por qué te gustó este cuento?

Marylin: \{sonríe\} porque se estaban escondiendo | y aparte m::: | le:: comieron la comida porque él quería comerlos comerlos a ellos

Sandra: y ese cuento | ¿te acordás del nombre de quien lo leyó o del nombre [título] del cuento?

Marylin: no me acuerdo de quién lo leyó ni de nada

Sandra: bien | bueno muy bien muchas gracias | Marylin

Marylin: bueno (se retira)

\section{Milena}

Sandra: por acá | ¿Milena? | sentate si querés

Milena: $\{$ se sienta\}

Sandra: Milena buen día | las preguntas que yo te voy a hacer son para un trabajo mío | ¿te acordás que el otro día les hice unas preguntas por escrito?

Milena: sí

Sandra: ¿`vos te acordás de cuándo vinieron las mamás a leer?

Milena: sí

Sandra: ¿quiénes? | ¿y te acordás cómo se llaman? 
Milena: no sé si...- | un día vino una maestra e:: <4 > | y no me acuerdo cómo se llamaba

Sandra: ¿y de las mamás que vienen a leer?

Milena: no \{mueve la cabeza [niega]\}

Sandra: ¿no? || ¿vos te acordás que a principio de año vino una mamá que se llama Carla que es la mamá de Martín?

Milena: sí

Sandra: y después vino otra mamá que se llama Cecilia | que es la mamá de Sofía

Milena: sí

Sandra: ¿te acordás de ellas?

Milena: sí \{mueve la cabeza [asiente]\}

Sandra: ¿te acordás de alguno de los libros que leyeron?

Milena: sí eh:: |El mayor tesoro

Sandra: El mayor tesoro que lo leyó la mamá de Tatiana | ¿no? | y:: || de los que leyó Ceci::lia y la otra mamá e:: | Carla | ¿te acordás de esos libros?

Milena: no

Sandra: ¿de qué se trataban tampoco?

Milena: ¿no?

Sandra: acá pusiste | «me gusta que vengan a leer porque a veces traen cuentos | nuevos»

Milena: sí

Sandra: ¿te acordás de algunos de esos cuentos?

Milena: sí |l pero no me acuerdo el nombre

Sandra: pusiste también | «porque tal vez a esas mamás las conocemos»

Sandra: ¿las conocés de otros lados a las mamás que han venido a leer?

Milena: sí e:: || yo siempre| eh:: cuando vengo a la fila | veo a la mamá de Martín <4> y la saludo

Sandra: ¿y qué te acordás de ella cuando venía a leer?

Milena: $\mathrm{m}::$ nada

Sandra: también pusiste «me enca::nta que ellas | que ellas nos conozcan»

Milena: sí

Sandra: ¿porque escribiste esto?

Milena: porque:: | a veces eh:: $<6>$

Sandra: y después | pusiste que el cuento que::| más te gustó fue Un puñado de semillas

Milena: isí! 
Sandra: ¿̇y quién leyó ese cuento?

Milena: eh:: la mamá de Sofía

Sandra: la mamá de Sofía que es Cecilia ¿ंverdad? | ¿y qué te acordás de ese cuento?

Milena: e:: de que eran unos unos niños | que había una señora que siempre les daba semillas como mágicas | y se las comían | y siempre (???) encontraban un manjar en::al lado del árbol

Sandra: ajá

Milena: y:: | cada día en un minuto se acabaron las semillas || y vinieron unos | y:: la niña | les dijo:: | que que se las comiera | y dijo no que eran para los dos | entonces se las dio a (???) compartieron las semillas

Sandra: imuy bien! | decime e:: Milena | ¿y:: por qué te gustó ese cuento en especial?

Milena: e:: porque:: a mí me gusta mucho | como:: la huerta y cosas así | y como este hablaba de semillas | lo empecé | lo empecé a leer porque lo compré

Sandra: ¿vos compraste el libro? | ¿lo tenés en casa?

Milena: sí

Sandra: eh:: Milena ¿vos te acordás cuando Cecilia les leyó Una cena elegante?

Milena: no \{mueve la cabeza [niega]\}

Sandra: ¿no te acordás?

Milena: no

Sandra: iah! | decime: ¿vos querés que siguieran viniendo estas mamás a leer el año que viene | cuando estén en cuarto? | ¿que siguieran leyendo?

Milena: sí

Sandra: ¿qué te gustaría que leyeran?

Milena: no sé | un cuento del futuro o algo así

Sandra: ¿te gusta leer a vos? | ¿lees en casa?

Milena: sí

Sandra: muchas gracias Milena

Abril

Sandra: ¿cómo andás || Abril?

Abril: bien

Sandra: muchas gracias por venir

Abril: \{sonríe\}

Sandra: tenés cara de asustada

Abril: \{ríe\} 
Sandra: si a vos te encanta escuchar cuentos || cuando yo te he visto en la clase | vos estás muy atenta siempre | participás | hacés preguntas | levantás la mano || ¿te gusta leer?

Abril: $\{$ (risas) sí\}

Sandra: ¿y que te lean?

Abril: más o menos

Sandra: ¿más o menos? I ¿te gusta más leer vos?

Abril: sí

Sandra: ¿te acordás que hace unos días les hice unas preguntas por escrito?

Abril: isí!

Sandra: vos pusiste eh:: que te gustaba que vinieran las mamás a leer| porque «todos nos podemos quedar callados | y podemos escuchar cómo leen»

Abril: sí

Sandra: ¿sí? || ¿hay algún otro motivo por el que te gusta que vengan las mamás?

Abril: y porque es un momento que:: todos estamos tranquilos y:: | y compartimos algo | entre todos | con las familias

Sandra: ¿te acordás de las mamás que han venido a leer a la clase?

Abril: más o menos

Sandra: ¿más o menos?

Abril: más o menos | de algunas

Sandra: ¿de quién te acordás?

Abril: la madre:: la madre de Martín | del abuelo de Clarita / $y\langle 5\rangle=\ldots . .=$

Sandra: $=\ldots . .=$ ¿y de Cecilia la mamá de Sofía?

Abril: sí | y de la madre de Facundo Santos

Sandra: ¿sí? | no la conozco yo| decime de los cuentos que ellos leyeron cuál te gustó más?

Abril: el rey Reinante

Sandra Así reinaba el rey reinante | ¿qué recordás de ese cuento?

Abril: que el rey tenía...- | que había un rey que era muy rico |que:: tenía todo de oro | y había un hada que él le pedía un deseo al hada || y:: era como...- y el hada lo convirtió en:: | en caramelo

Sandra: ¿te gustó ese cuento? ¿por qué?

Abril: no sé porque | porque me gustó

Sandra: ¿y te acordás quién les leyó ese cuento?

Abril: creo que Sandra

Sandra: ¿Sandra \eh::?

Abril: la madre de Facundo 
Sandra: la mamá de Facundo | bien || decime Abril | y de los que leyeron Cecilia y:: Carla

Abril: más o menos

Sandra: más o menos | ¿vos te acordás el libro que Carla les leyó a principios de año?

Abril: \{mueve la cabeza [niega]\}

Sandra: un libro con muchas pá::ginas | con varios capítulos || que trataba de perritos /

Abril: jah sí!

Sandra: ¿te acordás de ese libro?

Abril: no me acuerdo

Sandra: ¿te acordás si te gustó?

Abril: no

Sandra: y después pusiste que el cuento que leyeron las mamás | y que te gustó más fue Un puñado de semillas

Abril: sí

Sandra: ¿y por qué te gustó ese cuento?

Abril: y porque mostra...- || es como que mostraba | que una niña que...- || en realidad mostraba de que tenés que cuidar el medio...- el medio ambiente | y plantar muchas plantas para que sigan creciendo Sandra: y después pusiste que te gustaba porque:: | "era lindo pero un poquito triste»

Abril: sí porque | la abuela había muerto || y:: y a la niña le habían pisado todo | todos los huertos que tenía ella

Sandra: cierto | ¿y te acordás quién lo leyó?

Abril: ese:: | ese sí lo leyó Sandra la mamá de Facundo

Sandra: ¿Sandra o Cecilia?

Abril: no | Sandra

Sandra: eh:: | bueno muy bien | ¿y algo más que te acuerdes de las mamás que leen?

Abril: no

Sandra: y decime | el año que viene cuando estén en cuarto

Abril: sí

Sandra: ¿te gustaría que las mamás vinieran a leer de vuelta?

Abril: sí

Sandra: ¿sí? ¿qué les pedirías que vinieran a leer?

Abril: a mí me gustaría que vinieran a leer Julieta qué plantaste || y:: me gustaría que vinieran porque es como un momento que estamos todos tranquilos || que estamos todos...-

Sandra: imuy bien! | bueno muchas gracias | Abril

Abril: (regresa a la clase) 


\section{Emiliano}

Sandra: Emiliano ¿ंverdad?

Emiliano: sí

Sandra: ihola! | buen día Emiliano | ¿cómo estás? ¿bien?

Emiliano: bien

Sandra: mirá | ¿vos te acordás que el otro día les hice unas preguntas por escrito?

Emiliano: sí

Sandra: vos te acordás qué les pregunté |qué opinaban de que las mamás y los abuelos vinieran a leer

a la escuela

Emiliano: sí

Sandra: ¿te acordás qué me dijiste?

Emiliano: que me pongo orgulloso

Sandra: que te ponés orgulloso | ¿y por qué?

Emiliano: no sé | porque me gusta | porque me gusta que me lean cuentos

Sandra: ¿y quién te gusta que te lea cuentos?

Emiliano: todos

Sandra: acá pusiste | «porque me divierto mucho» | «porque me pongo orgulloso | y porque me gusta que me lean cuentos»

Emiliano: el padre de Clarita | la madre de Martín | como cuatro veces y después $=\ldots . . .=$

Sandra: $=\ldots . .=$ ¿ंel padre o el abuelo?

Emiliano: el abuelo | y la madre de Martín

Sandra: ¿y te acordás de la mamá de Sofía?

Emiliano: sí | de la madre de Sofía sí

Sandra: ¿te acordás de sus nombres?

Emiliano: eh:: Claudia es la madre de Martín | y el abuelo | y después no me acuerdo

Sandra: ¿de qué libros que ellos leyeron te acordás?

Emiliano: $\{$ mueve la cabeza[niega]\}

Sandra: ¿ninguno ninguno? || acá pusiste El rey reinante |

Emiliano: Así reinaba el rey reinante

Sandra: ¿te acordás quién lo leyó?

Emiliano: la maestra

Sandra: la maestra leyó El rey reinante y:: | por ejemplo yo me acuerdo que:: || la mamá de Martín les leyó las aventuras de Casiperro del Hambre | ¿te acordás?

Emiliano: es una historia 
(No se escucha el audio pues se superpone al sonido de una sirena que pasa por la calle.)

Sandra: vos recién dijiste que vino a leer unas cuantas veces | sí | a principios de año

Emiliano: cuatro veces

Sandra: sí | cuatro veces | imuy bien!

Sandra: ¿te gustó esa historia?

Emiliano: sí

Sandra: ¿por qué te gustó?

Emiliano: $\{$ silencio\}

Sandra: ¿̇:: || te acordás cuando Cecilia | vino a leerles un libro que se llama Una cena elegante |que yo estaba en la clase?

Emiliano: sí

Sandra: ¿qué te acordás de ese libro?

Emiliano: que era de un zorro y todo eso

Sandra: ¿y de los personajes te acordás?

Emiliano: no

Sandra: ¿te gustó ese libro?

Emiliano: ime encantó!

Sandra ¿por qué te gustó?

Emiliano: porque era de una cena y de animales / pero no me acuerdo de los personajes

Sandra: y después pusiste acá que te gustó El rey Reinante \|l ¿por qué te gustó ese libro?

Emiliano: el rey Reinante que era de caramelos y todo eso

Sandra: bien | era de golosinas

Emiliano: sí

Sandra: muy bien I| ¿algo más que te acuerdes de ese cuento en especial?

Emiliano: no

Sandra: Emiliano || contame | el año que viene cuando estén en cuarto ¿verdad? | te gustaría que vinieran las mamás a leer de vuelta | o el abuelo Omar?

Emiliano: sí

Sandra: ¿sí? | ¿por qué?

Emiliano: porque me gusta

Sandra: ¿qué les pedirías que te leyeran?

Emiliano: Julieta qué plantaste

Sandra: ¿quién leyó ese cuento antes? ¿te acordás?

Emiliano: Ana Laura 
Sandra: ¿quién es Ana Laura?

Emiliano: la maestra de segundo

Sandra: ah:: | la maestra de segundo | que les leyó a ustedes || ¿y por qué te gustó ese cuento?

Emiliano: porque:: | el lobo era malo | y tenía todo | y tenía todo | y:: la mulita hacía trampas | plantaba cosas todo para ella | y hacía trampa || y la mulita decía | yo voy a plantar papas yo me quedo con lo de abajo y vos con lo de arriba después y cómo es | y después eh:: | llamó e:: el lobo | y después eh:: | se agarró las papas | las papas | y la mulita se quedó con...- | cómo es | y se hizo hacer papas fritas | papas | cómo es papas al horno | papas asadas papas al almíbar | y no me acuerdo más

Sandra: ¿por qué te gustó ese cuento?

Emiliano: me gustó mucho

Sandra: sí | ¿pero por qué te gustó tanto?

Emiliano: porque el lobo era siempre malo || y la mulita siempre hacía trampas|| y terminaba que el lobo...- | que el lobo se plantaba...- | plantaban trigo | y ahí terminaba | y hacía...- | y hacía harina y todo eso | y la mulita se quedó | y ahí el lobo quedó enfurecido y se puso... | quedó todo azul Sandra: bueno muchas gracias Emiliano

Emiliano: (se retira) 


\subsubsection{Sesiones de lectura de Cecilia}

\subsubsection{Un puñado de semillas}

Pauta de sistematización de las observaciones de la sesión de lectura de Un puñado de semillas

\begin{tabular}{|c|c|c|c|}
\hline \multicolumn{4}{|c|}{ Escuela: XX } \\
\hline \multicolumn{4}{|c|}{ Fecha y hora: $30.07 .2015,08.30$ horas } \\
\hline \multicolumn{4}{|c|}{ Contexto: la sesión de lectura se realizó en el salón de clase, al comienzo del turno. } \\
\hline \multicolumn{4}{|c|}{ Grupo: $3 .{ }^{\circ} \mathrm{B}$} \\
\hline \multicolumn{4}{|c|}{ Cantidad de niños presentes: 22} \\
\hline \multicolumn{4}{|c|}{ Otros presentes: maestra Noelia, estudiante de Magisterio, investigadora } \\
\hline \multicolumn{4}{|c|}{ 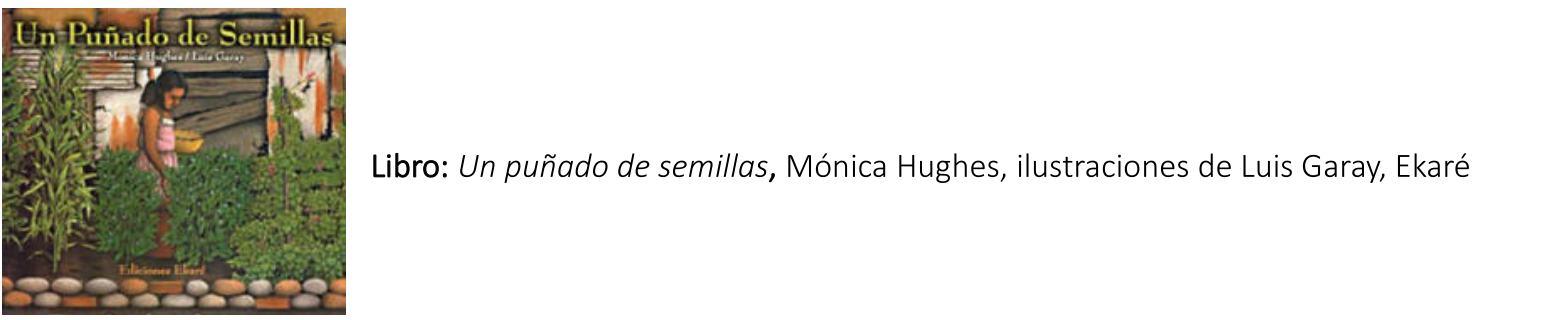 } \\
\hline \multicolumn{4}{|c|}{ Selección del libro: El libro fue seleccionado por la maestra, quien le solicitó a la mediadora que lo leyera. } \\
\hline \multicolumn{4}{|c|}{ Observaciones } \\
\hline \multicolumn{4}{|c|}{ Antes de iniciar la lectura } \\
\hline \multirow{10}{*}{$\begin{array}{l}\frac{\pi}{0} \\
\frac{0}{0} \\
\frac{\pi}{0} \\
\frac{0}{2} \\
\sum\end{array}$} & \multirow{2}{*}{$\begin{array}{l}\text { ¿Organiza el espacio de } \\
\text { lectura? }\end{array}$} & Sí & \\
\hline & & No $x$ & $\begin{array}{l}\text { Los niños se disponen en sus mesas, como lo hacen } \\
\text { habitualmente frente al pizarrón. Se encuentran esperando } \\
\text { a la mediadora. La maestra se ubica en su escritorio frente al } \\
\text { salón, en una esquina. La estudiante magisterial y la } \\
\text { investigadora se ubican detrás de los niños en el extremo } \\
\text { opuesto del salón. }\end{array}$ \\
\hline & $\begin{array}{l}\text { ¿Dónde y cómo se ubica para } \\
\text { leer? }\end{array}$ & \multicolumn{2}{|c|}{ Se sienta frente a los niños en una silla alta, de espaldas al pizarrón. } \\
\hline & \multirow{2}{*}{$\begin{array}{l}\text { ¿Realiza algún ritual de } \\
\text { inicio? }\end{array}$} & Sí & \\
\hline & & No $\chi$ & \\
\hline & \multirow{2}{*}{$\begin{array}{l}\text { ¿Realiza preguntas o } \\
\text { comentarios? }\end{array}$} & Sí x & \\
\hline & & No & \\
\hline & \multirow{3}{*}{$\begin{array}{l}\text { ¿Responde las preguntas o } \\
\text { comentarios de los niños? }\end{array}$} & Síx & \\
\hline & & No & \\
\hline & & Sí & \\
\hline
\end{tabular}




\begin{tabular}{|l|l|l|}
\hline \multirow{2}{*}{$\begin{array}{l}\text { ¿Responde las preguntas o } \\
\text { ¿Realiza algún ritual de } \\
\text { cierre? }\end{array}$} & No $\chi$ & \\
\cline { 2 - 3 } & Sí $\chi$ & \\
\hline \multirow{2}{*}{$\begin{array}{l}\text { cLos niños realizan preguntas o } \\
\text { comentarios? }\end{array}$} & Sí $\chi$ & $\begin{array}{l}\text { Los niños ven el libro y muchos parecen reconocerlo. } \\
\text { Un niño intenta explicar que el libro le gusta, pero la } \\
\text { maestra no lo deja hablar. }\end{array}$ \\
\hline \multirow{2}{*}{$\begin{array}{l}\text { ¿Las docentes realizan preguntas } \\
\text { o comentarios? }\end{array}$} & Sí $\chi$ & \\
\cline { 2 - 3 } & No & \\
\cline { 2 - 3 } & & \\
\end{tabular}

\section{Durante la lectura}

\begin{tabular}{|c|c|c|}
\hline \multirow[t]{2}{*}{ ¿Presenta el libro? } & Sí x & $\begin{array}{l}\text { Presenta el título. Muestra la tapa. Da su opinión sobre el } \\
\text { libro. }\end{array}$ \\
\hline & No & \\
\hline \multirow[t]{2}{*}{ ¿Muestra las imágenes? } & Sí x & $\begin{array}{l}\text { A medida que lee, luego de terminar cada página. Voltea el } \\
\text { libro y lo enfrenta a sí para que los niños observen las } \\
\text { imágenes. Se detienen unos segundos en cada página }\end{array}$ \\
\hline & No & \\
\hline \multirow[t]{2}{*}{ ¿Muestra los paratextos? } & Sí & \\
\hline & No $x$ & \\
\hline \multirow[t]{5}{*}{ Volumen de voz } & Muy bajo (--) & \\
\hline & Bajo (-) & \\
\hline & $\begin{array}{l}\text { Moderado }(- \\
+)\end{array}$ & Lee en un volumen adecuado. Es escuchada por todos. \\
\hline & Alto $(+)$ & \\
\hline & Muy alto $(++)$ & \\
\hline Velocidad & $\begin{array}{l}\text { Lenta } \\
\text { Moderada } \chi \\
\text { Rápida }\end{array}$ & \\
\hline Fluidez & $\begin{array}{l}\text { +Fluidez } \chi \\
\text { - Fluidez }\end{array}$ & \\
\hline Dicción & $\begin{array}{l}\text { Sin omisión de } \\
\text { fonemas } \chi \\
\text { Con omisión } \\
\text { de fonemas }\end{array}$ & \\
\hline \multirow{2}{*}{$\begin{array}{l}\text { ¿Adecua la entonación o } \\
\text { velocidad de su voz al } \\
\text { momento, situación del } \\
\text { cuento, personajes o }\end{array}$} & Sí $\chi$ & \\
\hline & No & \\
\hline
\end{tabular}




\begin{tabular}{|c|c|c|}
\hline \multicolumn{3}{|l|}{ modalidad del enunciado? } \\
\hline \multirow{2}{*}{$\begin{array}{l}\text { ¿Incorpora gestos faciales o } \\
\text { corporales? }\end{array}$} & Sí & \\
\hline & No $x$ & \\
\hline \multirow{2}{*}{ ¿Se desplaza mientras lee? } & Sí & \\
\hline & No $x$ & \\
\hline \multirow{2}{*}{$\begin{array}{l}\text { ¿Realiza preguntas o } \\
\text { comentarios? }\end{array}$} & Síx & Comenta las imágenes mientras las muestra \\
\hline & No & \\
\hline \multirow[t]{2}{*}{$\begin{array}{l}\text { ¿Responde preguntas o } \\
\text { comentarios de los niños? }\end{array}$} & Síx & $\begin{array}{l}\text { Le da la palabra a un niño que levanta la mano antes de } \\
\text { comenzar a leer. } \\
\text { Responde a una pregunta que le realiza una niña. }\end{array}$ \\
\hline & No & \\
\hline \multirow{2}{*}{$\begin{array}{l}\text { ¿Responde preguntas o } \\
\text { comentarios de las } \\
\text { docentes? }\end{array}$} & Sí & \\
\hline & No $\chi$ & $\begin{array}{l}\text { Al finalizar la lectura, le solicita a la maestra unos minutos } \\
\text { para leer el epílogo del cuento. }\end{array}$ \\
\hline \multirow{2}{*}{$\begin{array}{l}\text { ¿Realiza algún ritual de } \\
\text { cierre? }\end{array}$} & Sí x & Cierra con «Colorín, colorado...». \\
\hline & No & \\
\hline \multirow[t]{2}{*}{$\begin{array}{l}\text { ¿Los niños realizan preguntas y } \\
\text { comentarios? }\end{array}$} & Sí x & $\begin{array}{l}\text { En forma espontánea hacen algunos comentarios y } \\
\text { expresiones de sorpresa, agrado o desagrado de acuerdo } \\
\text { con lo que les provoque la lectura }\end{array}$ \\
\hline & No & \\
\hline \multirow[t]{2}{*}{$\begin{array}{l}\text { docentes realiza preguntas o } \\
\text { entarios? }\end{array}$} & Síx & $\begin{array}{l}\text { Al iniciar la sesión, explica a los niños que deben escuchar } \\
\text { en silencio y atentos. Solicita a un niño (lan) } \\
\text { reiteradamente que no interrumpa la lectura d la } \\
\text { mediadora con sus comentarios. }\end{array}$ \\
\hline & No & \\
\hline \multicolumn{3}{|c|}{ Después de la lectura: no realiza intercambios después de la lectura. } \\
\hline \multirow[t]{2}{*}{ ¿Realiza preguntas? } & Sí & \\
\hline & No & \\
\hline \multirow{2}{*}{$\begin{array}{l}\text { ¿Responde preguntas o } \\
\text { comentarios de los niños? }\end{array}$} & Sí & \\
\hline & No & \\
\hline \multirow{2}{*}{$\begin{array}{l}\text { ¿Responde preguntas o } \\
\text { comentarios de las docentes? }\end{array}$} & Sí & \\
\hline & No & \\
\hline \multirow{2}{*}{$\begin{array}{l}\text { ¿Realiza algún ritual de } \\
\text { finalización? }\end{array}$} & Sí & \\
\hline & No & \\
\hline \multirow[t]{2}{*}{$\begin{array}{l}\text { ¿Los niños realizan preguntas o } \\
\text { comentarios? }\end{array}$} & Sí & \\
\hline & No & \\
\hline
\end{tabular}




\begin{tabular}{|l|l|l|}
\hline \multirow{2}{*}{$\begin{array}{l}\text { ¿Las docentes realizan preguntas } \\
\text { o comentarios? }\end{array}$} & Sí & \\
\cline { 2 - 3 } & No & \\
\hline Interacciones entre los actores & \\
\hline $\begin{array}{l}\text { Actitud de la mediadora hacia los } \\
\text { niños }\end{array}$ & Escucha con respeto sus preguntas y comentarios. \\
\hline $\begin{array}{l}\text { Actitud de las docentes hacia la } \\
\text { mediadora }\end{array}$ & $\begin{array}{l}\text { La maestra, luego de que la mediadora comienza a leer no interrumpe su } \\
\text { lectura, queda al margen, aunque está atenta a ella y a lo que sucede en } \\
\text { la clase. La estudiante magisterial no interviene. }\end{array}$ \\
\hline $\begin{array}{l}\text { Actitud de los niños hacia la } \\
\text { mediadora }\end{array}$ & $\begin{array}{l}\text { Escuchan con atención. Se compenetran con la historia leída. Participan } \\
\text { en forma espontánea y ordenada en pocas ocasiones. }\end{array}$ \\
\hline $\begin{array}{l}\text { Actitud de la mediadora hacia las } \\
\text { docentes }\end{array}$ & $\begin{array}{l}\text { Acepta las interrupciones de la maestra en los llamados de atención a los } \\
\text { niños. }\end{array}$ \\
\hline
\end{tabular}

Transcripción de la sesión de lectura de Un puñado de semillas

Cecilia: ibuen día!

Noelia: buen día \| dejan las cosas \| nos vamos a sentar (se dirige a los niños que están conversando y parados) / | y vamos a escuchar | [enf.] Tatiana y Matías \| ¿se animan a darse vuelta y prestar atención al cuento? || ¿sí Tatiana? | gracias \

Cecilia: bue::no \| ibuen día para to::dos! /

Niños a coro: ibuen día!\

Cecilia: y:: \| este libro se llama Un puñado de semillas |

Niño: $\{i a h::$ i [sorpresa] $\}$

Cecilia: un libro muy lindo / | que les va a dejar algo / || algo:: \| para pensar / | y después se van a dar cuenta qué es $\backslash$

Niño: \{levanta la mano\}

Cecilia: sí (le da la palabra al niño)

Niño: es $\backslash$ | es un capo ese libro / =.....=

Noelia: $=\ldots . . .=i l a n ! ~ \ \mid$ [enf.] acaba::mos de hablar $/ \mid$ de hab...- $\backslash \mid$ respecto a esto $\backslash \mid$ y además te nombré $\backslash$ | el momento de $\backslash$ | de:....- ¿no?/ || el momento del cuento es para escuchar $\backslash$

Niña: [p.] hay que escuchar (hablándole al compañero que interrumpió)

Noelia: si ya lo leí \| si ya me lo leyeron \|| aprove::cho y lo vuelvo a retomar / | [ff.] si no lo leyeron $/=\ldots . .=$

lan: $=\ldots . . .=\{$ hace gestos de fastidio [intenta hablar $]\}$

Noelia: ilan! \| [ff.] si no lo leyeron / || escuche $=$......-

Niña: $=\ldots . . .=$ que me lo cuente $\backslash$ 
Noelia: [enf.] Alexandra \/ [p.] escuche \

Niño: yo (???) [el niño intenta decir que el libro ya lo escuchó o lo leyó]

Noelia: respet...- \ilan! \escuche \gracias \| gracias \

Cecilia: bueno empieza así \/ Concepción vivía con su abuela \en una casita en la cima del cerro $\backslash$ | juntas limpiaron el terreno para hacer un huer...- un huerto \| sembraron maíz / frijoles / y ají $\backslash$ || recuerda guardar suficientes semillas para la próxima siembra dijo la abuela \| así nu::nca te faltará de comer $\backslash$

Cecilia: $\{<9>$ acá tienen la cas::ita / | y acá el lugar donde sembraban / (muestra las imágenes)\}

Niña: ah:: / | iqué bueno! \

Niño: mejor que mi casa \

Niño: sí \| la casita \

Niña: el nombre de ella es medio raro \}

Cecilia: todos los días Concepción bajaba a la quebrada \| a buscar agua / y regresaba con los pesados baldes colgados de sus hombros $\backslash$ | va::ciaba con cuidado el agua alrededor de las matas de maíz \|| pasaban las sema::nas / | el sol brilla::ba \|| luego / | llegaron las lluvias y el maíz creció mu::y alto $\backslash$ | los tallos de los frijo::les se enroscaron en busca del sol / y las matas de ají florecieron \| cuando el maíz \| los frijoles y el ají maduraron \| la abuela entregó parte de la cose::cha al dueño de la tierra $\$ | y guardó suficiente / para tener con qué comer $\||$ vendió el resto al vecino \| que lo llevó al mercado de la ciudad / allá lejos / en el valle \

Cecilia: $\{<10>$ estas son las matas $\backslash \|$ de las que habla $\backslash$ (muestra las imágenes)\}

Niño: ipah \qué raras! \

Niña: ¿̇a ver?

Cecilia: $\{<11>$ y crecieron muy rápido $\backslash$ (muestra las imágenes)\}

Cecilia: un día triste \la abuela murió $\backslash$ | no te puedes quedar aquí / dijo el dueño de la tierra a Concepción $\backslash$ | ya alquilé esta parcela a otra familia \| pero yo puedo trabajar para usted dijo Concepción \esta familia puede trabajar más que tú / | puede cosechar más frijoles y maíz / | replicó el dueño $\backslash$ | entonces Concepción tuvo que dejar la casita de paredes pinta::das y piso de tierra\

Cecilia: $\{<7>$ acá el dueño que le está pidiendo que se vaya \(muestra las imágenes)\}

Cecilia: ven a vivir con nosotros dijo la mujer del vecino \| pero Concepción / sabía que ellos tenían siete hijos que alimentar $\backslash||$ me iré para allá / | dijo señala::ndo el valle nublado donde estaba la ciudad $\backslash$ | es una caminata demasiado larga para piernas tan cortas dijo con tristeza la mujer del vecino $\backslash$ | mis piernas se han hecho fuertes de ta::nto cargar agua $\backslash$ | Concepción se despidió / y abrazó a la mujer del vecino / y a sus hijos \| que dios te acompañe le dijeron \

Cecilia $\{<6>$ y ahí estaba la señora / | con sus siete hijos $\backslash$ (muestra las imágenes)\}

Niños a coro: \{ipuh::! ipah::! [sorpresa]\} 
Cecilia: Concepción hizo un atado con el maíz \los frijoles / y el ají que la abuela había guardado $\backslash$ | y partió con su pequeña carretilla por el sendero pedregoso \que bajaba al valle $\backslash||$ fue una caminata mu::y mu::y larga \/ Concepción tenía los pies cansa::dos y rotos / cuando por fin llegó al barrio que rodeaba la ciudad $\backslash$ | vio cie::ntos de ranchos de hojala::ta / | plástico y cartón / que estaban amontonados / unos encima de otros $\backslash \|$ i ¿ esto es la ciudad?! / pensó desalentada $\backslash$ | y yo que creí que era hermosa \}

Cecilia: $\{<8>$ esta es la ciudad donde llegó ¿no? | no era lo que ella pensaba (muestra las imágenes)\}

Niños a coro: iuh::!\

Cecilia: caminó por los estrechos callejones llenos de barro $\backslash$ | y ya agotada por el cansa::ncio / se topó con una pandilla de niños $\backslash$ | ¿no ves por dónde vas tonta? \| perdón contestó Concepción amablemente $\backslash$ | los niños tenían la ropa rota $\backslash$ | las caras sucias y el per...- \y el pelo enmarañado $\backslash$ | pero cuando Concepción les sonrió / | ellos también sonrieron \

Cecilia: $\{<6\rangle$ acá está cuando se encuentra con esos niños $\backslash \mid$ para ella son $\backslash \|$ nuevos ¿no? (muestra las imágenes)\}

Cecilia: me llamo Tomás / | ¿y tú? | de dónde vienes? || Concepción señaló los cerros a la distancia y dijo $\backslash \mid$ mi abuela murió $\backslash \mid$ si quieres $\backslash \mid$ puedes quedarte con nosotros $\backslash \mid$ te enseñaremos a recoger basura / para venderla / | y a sacar comida de los puestos de venta sin que te vean \ |[enf.] eso es robar dijo Concepción sorprendida \| Tomás se encogieron...- $\backslash$ | se encogió de hombros $\backslash \|$ es mejor que morirse de hambre $\backslash$ | tengo maíz frijoles y ají / | dijo Concepción mostrando su carretilla $\backslash$ | eso no es suficiente para una buena comida \ contestó Tomás con desprecio \| cuando cre::zcan las plantas habrá suficiente / | [enf.] ya verás $\||$ aquí no crecen jamás / iestás loca! \|| Tomás la miró un rato y luego agregó \| pero de todos modos puedes quedarte con nosotros $\backslash$

Cecilia: \{<8> y acá:: ven que los niños viven en un basural ¿no? | recogen de ahí / | lo que comen (muestra las imágenes)\}

Niño: ¿̇a ver?

Cecilia: y así \| Concepción se quedó a vivir con los niños a la orilla del basural \| construyó un pequeño muro de piedras $\backslash$ | con el mango roto de una olla / | cavó la tierra y plantó un puñado de semillas de maíz / | de frijoles y de ají /

Cecilia: $\{<10>$ ¿ven? sin tener mu::cho / | ella trató de \arar la tierra (muestra las imágenes)\}

Cecilia: todos los días regaba la tierra / y miraba atentamente / hasta que vio brotar los pri...- / los primeros reto::ños verdes y brillantes | \los frijoles y el ají florecieron \| y en to::do el barrio / no había na::da más bonito que el pequeño huerto de Concepción \ || y ella estaba / | segura de que desde el cielo/ su abuela cuidaba del huerto \}

Cecilia: $\{<11>$ miren cómo creció todo (muestra las imágenes)\}

Niño: iah!\

Niño: iesa planta es gigante! \ 
Cecilia: pero un día \| Tomás y los otros niños llegaron corriendo hasta el basural \| perseguidos por la policía \| los niños \| los niños corrían y lloraban \| los policías grita::ban y los golpeaban $\backslash$ | Concepción se escondió en el medio de la basura \|| [enf.] ¿para qué me vine a esta ciudad? / | se preguntaba \cuando todo pasó se asomó poquito a poco \| como un ratón asustado \| los niños estaban llenos de moretones $\backslash$ | y el huerto estaba todo pisotea::do \

Niño: iuh::!

Cecilia: $\{<10>$ todo lo que ya ella había hecho / I quedó en la nada\(muestra las imágenes)\}

Niña: iqué feo!\

Cecilia: $\mathrm{m}:: \backslash$ | ¿por qué llo::ras? | preguntó Tomás enfadado \| no fue a ti a quién golpeó la policía \| mi huerto está destrozado \| si el maíz los frijoles y el ají hubieran madurado / | habríamos tenido comida para vender / | y ustedes no tendrían que robar \|| de nada sirve llorar $\backslash$ | tu huerto se acabó $\backslash||$ Concepción se secó los ojos $\backslash$ | ino! \| [enf.] no se acabó $\backslash$ | dijo \| todavía me quedan algunas semillas \| está bien / dijo Tomás / | pasándose la lengua por el labio roto \| esta vez te ayudaremos nosotros \

Cecilia: $\{<8>$ ¿ven? acá están ellos ayudando (muestra las imágenes)\}

Niño: ¿y escaparon de la policía?

Cecilia: sí \

Cecilia: con la ayuda de todos / araron un trozo grande de terreno/ y sembraron el resto de las semillas de la abuela $\backslash$ | hicieron turnos para regar las ma::tas y cuidarlas $\backslash$ | pronto $\backslash$ | el maíz creció muy alto $\backslash$ | las matas de los frijoles estaban gordas y firmes / y brillaban los pequeños ajíes verdes y amarillos $\backslash$ | haremos una gran fiesta / dijo Tomás $\backslash$ | y el resto lo llevaremos a vender al mercado $\backslash$ | pero siempre deberemos guardar semillas para la próxima siembra \| recordó Concepción \

Cecilia: $\{<11>$ siempre ella recordó lo que le dijo la abuela ¿no? que siempre que guada::ra / | las semillas / | iba a poder sembrar \(muestra las imágenes)\}

Cecilia: cocinaron el maíz y los frijoles con el ají \| el delicioso aroma de la comida se esparció por todo el barrio \| cuando comenzaban a comer otra pandilla de niños hambrientos apareció $\backslash$ | Concepción y Tomás / los invitaron a comerla...- / | a compartir la comida \|| nuestro huerto no alcanzará para alimentar a todos los niños del barrio \se lamentó Concepción \| pero ento::nces $\backslash$ | tuvo una idea $\backslash$ | tomó un puñado de las semillas que había guardado $\backslash$ y se las dio al jefe de la otra pandilla \| le explicó cómo preparar la tierra \| cómo sembrar \| y cómo preparar...- / | regar las plantas $\backslash \|$ y siempre debes guardar semillas para la próxima siembra / y compartir con los otros niños del barrio $\backslash$ | le dijo Concepción $\backslash$ | ta::I como la abuela le había dicho a ella $\backslash$ | el muchacho prometió hacerlo \}

Cecilia: $\{<5>$ y acá le está entregando las semillas / (muestra las imágenes) $\}=\ldots . . .=$

Niño: $=\ldots . . .=$ ¿a ver?

Cecilia: $\{<13>$ para ellos poder / cultivarlas $\backslash$ (muestra las imágenes)\} 
Cecilia: Concepción estaba segura de que la abuela sonreía desde el cielo / | y que sus ojos ya no estaban nublados por la eda::d $\backslash$ | sino brilla::ntes como las estrellas sobre el barrio

Cecilia: $\{<4>$ acá está pensando en su abuela / en medio del basural ¿no? \(muestra las imágenes)\} Niño: jah!

Cecilia: bueno $\backslash \mid$ colorín colorado $\backslash$ este cuento $/=\ldots . .-$

Niño: $=\ldots . . .=[$ enf.] este cuento se ha acabado $\backslash$

Niños: $\{a p l a u s o s\}$

Noelia: bueno \{se para\}

Cecilia: leo esta parte / y (???) /

Noelia: idale! \| idale! \

Cecilia: esta es una parte que tiene el libro que dice que son unas palabras finales / | como para que ustedes puedan entender un poquito más el cuento \a pesar de que es bastante claro ¿no? | dice \unas palabras finales $\backslash$ | en el mundo / existen mu::chos / millones de niños abandona::dos $\backslash$ || al igual que Concepción \| la niña de esta historia \|| logran sobrevivir gracias a su coraje \ ingenio y perseverancia / para encontrar día tras día comida \abrigo / y un lugar donde dormir \ || pero en medio de este duro trabajo diario \| la comunicación y el entendimiento / | pueden convertirse en valiosas armas para la supervivencia \| surgen entonces / | la solidaridad y la esperanza $\backslash$ | que al hacer comp...- al ser compartidas $\backslash$ | se propagan como las semillas que sabiamente la abuela dejó a Concepción $\backslash$ | a todos ellos $\backslash$ | a todos los ni::ños y niñas abandonados $\backslash$ | está dedicado este libro $\backslash||$ también a los que tienen fam::ilia / comi::da / y un lugar donde vivir $\backslash||$ porque los libros nos ayudan a comprender las vi::das $\backslash$ y los sentimientos de los demás $\backslash \|$ nos enseñan a ser solidarios con las personas $\backslash$ | que nos rodean $\backslash$ |con los que tienen mucho $\backslash$ con los que tienen poco / y también con los que tienen solo esperanzas \|| los libros son como un puñado de semillas $\backslash$ | retoñan en mentes despiertas / | y cultivan en nosotros el deseo de construir un mundo mejor \}

Niños a coro: \{aplausos\}

Noelia: imuchísimas gracias! (Se acerca a Cecilia mientras los niños conversan.)

\subsubsection{Sesión de lectura de Una cena elegante}

Pauta de sistematización de las observaciones de Una cena elegante

Escuela: XX

Fecha y hora: $12.08 .2015,09: 30$ horas

Contexto: salón de tercer año B

${ }^{7}$ En el cuento se lee barro. 
Grupo: $3 .^{\circ} \mathrm{B}$

Cantidad de niños presentes: 21

Otros presentes: maestra Noelia, investigadora, estudiante de Magisterio

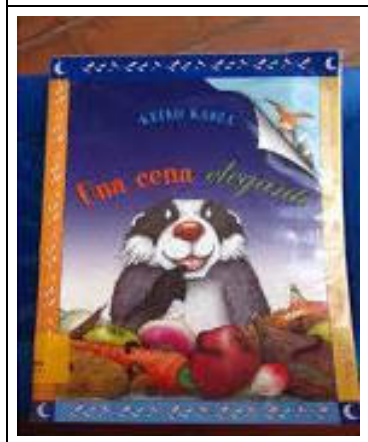

Libro: Una cena elegante, texto e ilustraciones de Keiko Kasza, editorial Norma

Selección del libro: Fue solicitado por la investigadora, a los efectos de la investigación. Contó con la aprobación de la mediadora.

\begin{tabular}{|c|c|c|c|}
\hline \multicolumn{4}{|c|}{ Observaciones } \\
\hline \multicolumn{4}{|c|}{ Antes de iniciar la lectura } \\
\hline \multirow{13}{*}{$\begin{array}{l}\frac{\pi}{0} \\
\frac{0}{0} \\
\frac{.0}{0} \\
\frac{d}{2}\end{array}$} & \multirow{2}{*}{$\begin{array}{l}\text { ¿Organiza el espacio de } \\
\text { lectura? }\end{array}$} & Sí & \\
\hline & & No $x$ & $\begin{array}{l}\text { La maestra y los niños están esperando la llegada de la } \\
\text { mediadora. Los niños se sientan en el piso, enfrentados al } \\
\text { pizarrón. } \\
\text { La estudiante de Magisterio y la investigadora se ubican en } \\
\text { un extremo del salón, atrás de los niños. } \\
\text { La maestra se ubica también detrás. }\end{array}$ \\
\hline & $\begin{array}{l}\text { ¿Dónde y cómo se ubica } \\
\text { para leer? }\end{array}$ & \multicolumn{2}{|c|}{$\begin{array}{l}\text { Cecilia se ubica de espaldas al pizarrón, frente a los niños, se sienta en una } \\
\text { silla pequeña. }\end{array}$} \\
\hline & \multirow{2}{*}{$\begin{array}{l}\text { ¿Realiza algún ritual de } \\
\text { inicio? }\end{array}$} & Sí & \\
\hline & & No $x$ & \\
\hline & \multirow{2}{*}{$\begin{array}{l}\text { ¿Realiza preguntas o } \\
\text { comentarios? }\end{array}$} & Síx & Comenta sobre su estado de salud (está con gripe). \\
\hline & & No & \\
\hline & \multirow{2}{*}{$\begin{array}{l}\text { ¿Responde las preguntas o } \\
\text { comentarios de los niños? }\end{array}$} & Sí & \\
\hline & & No $x$ & \\
\hline & \multirow{2}{*}{$\begin{array}{l}\text { ¿Responde las preguntas o } \\
\text { comentarios de las } \\
\text { docentes? }\end{array}$} & Sí & \\
\hline & & No $x$ & \\
\hline & \multirow{2}{*}{$\begin{array}{l}\text { ¿Realiza algún ritual de } \\
\text { cierre? }\end{array}$} & Sí & \\
\hline & & No $x$ & \\
\hline \multirow{2}{*}{\multicolumn{2}{|c|}{$\begin{array}{l}\text { ¿Los niños realizan preguntas o } \\
\text { comentarios? }\end{array}$}} & Sí x & \\
\hline & & No & \\
\hline \multirow{2}{*}{\multicolumn{2}{|c|}{$\begin{array}{l}\text { ¿Las docentes realizan preguntas o } \\
\text { comentarios? }\end{array}$}} & Sí & \\
\hline & & No $x$ & \\
\hline
\end{tabular}




\section{Durante la lectura}

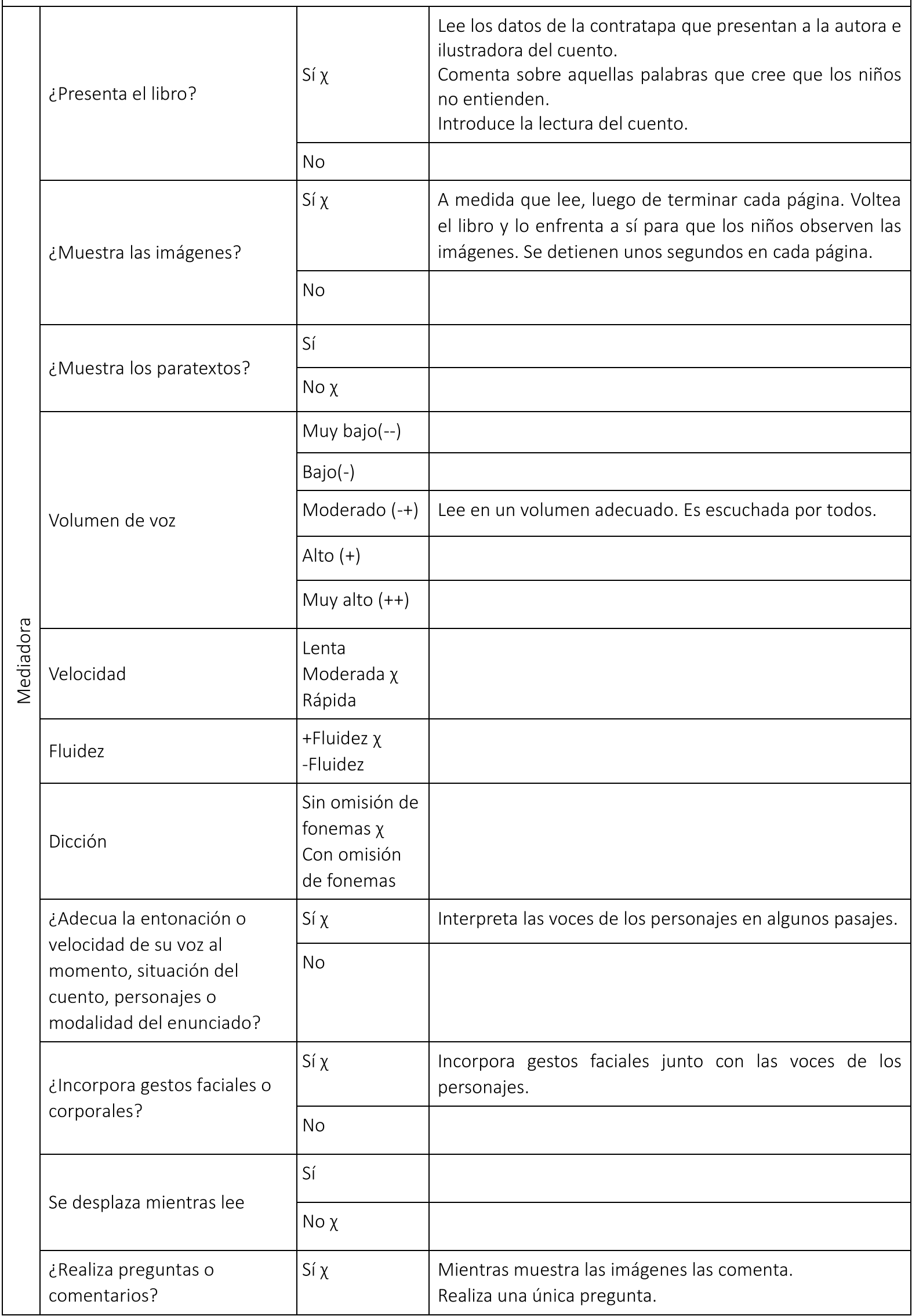




\begin{tabular}{|c|c|c|c|}
\hline & & No & \\
\hline & ¿ Resnonde preountaso & Sí $\chi$ & \\
\hline & comentarios de los niños? & No & \\
\hline & ¿Realiza algún ritual de & Síx & Cierra la lectura con «Colorín, colorado». \\
\hline & cierre? & No & \\
\hline ¿Lo & s niños realizan preguntas o & Sí $\chi$ & Realizan comentarios espontáneos mientras la mediadora \\
\hline com & hentarios? & No & muestra las imágenes. \\
\hline ¿Las & s docentes realiza preguntas o & Sí & \\
\hline com & hentarios? & No $x$ & \\
\hline Des & pués de la lectura: no realiza int & ercam & és de la lectura. \\
\hline & ¿Realiza preguntas? & Sí & \\
\hline & & No & \\
\hline & ¿Responde preguntas o & Sí & \\
\hline$\frac{0}{0}$ & comentarios de los niños? & No & \\
\hline$\frac{.}{0}$ & ¿Responde preguntas o & Sí & \\
\hline$\sum$ & comentarios de las docentes? & No & \\
\hline & ¿Realiza algún ritual de & Sí & \\
\hline & & No & \\
\hline ¿̇o & s niños realizan preguntas o & Sí x & Un niño le dice antes de que se retire: «Leés muy lindo» \\
\hline & & No & \\
\hline ¿Las & s docentes realizan preguntas & Sí & \\
\hline & mentarios? & No $x$ & \\
\hline Inte & racciones entre los actores & & \\
\hline $\begin{array}{l}\text { Acti } \\
\text { niñc }\end{array}$ & $\begin{array}{l}\text { tud de la mediadora hacia los } \\
\text { os }\end{array}$ & Escuc & peto sus preguntas y comentarios. \\
\hline $\begin{array}{l}\text { Acti } \\
\text { mec }\end{array}$ & $\begin{array}{l}\text { tud de la docente hacia la } \\
\text { diadora }\end{array}$ & $\begin{array}{l}\text { La } \mathrm{m} \\
\text { Dura } \\
\text { magi }\end{array}$ & $\begin{array}{l}\text { ubica en una mesa de los niños a corregir los cuadernos. } \\
\text { ión no presta atención a la mediadora. La estudiante } \\
\text { nterviene. }\end{array}$ \\
\hline $\begin{array}{l}\text { Acti } \\
\text { mec }\end{array}$ & $\begin{array}{l}\text { tud de los niños hacia la } \\
\text { diadora }\end{array}$ & $\begin{array}{l}\text { Escuc } \\
\text { form } \\
\text { inter }\end{array}$ & $\begin{array}{l}\text { tención. Se compenetran con la historia leída. Participan en } \\
\text { nea, en orden. En ocasiones hablan a coro en forma } \\
\text { e muestran entusiasmados con la historia. }\end{array}$ \\
\hline $\begin{array}{l}\text { Acti } \\
\text { doc }\end{array}$ & $\begin{array}{l}\text { tud de la mediadora hacia las } \\
\text { entes }\end{array}$ & $\begin{array}{l}\text { No h } \\
\text { lectu }\end{array}$ & ión entre la mediadora y la maestra durante la sesión de \\
\hline
\end{tabular}


Transcripción de la sesión de lectura de Una cena elegante

Noelia: guardamos el cuaderno\| porque vienen a leernos el cuento \

Niño: [enf.] Omar \

Noelia:[enf.] no $\backslash$ (???)

Niño: (???)

Niño: [enf. ] viene el cuento \

Noelia: bueno \es el momento...-

Sandra: ¡buen dí::a!\

Noelia: que tenemos $\backslash$ | es el momento de es $\backslash$ cu $\backslash \mid$ char $\backslash$

Noelia y niños a coro: ¡buen día::!!

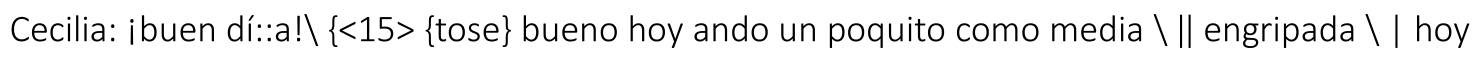
estoy un poquito mejor\} \{(risas) pero \| ahí ahí\} \}

Cecilia: bueno $\backslash \mid$ \{hoy es un libro que se llama:....- \{muestra la tapa del libro\} \| [Cecilia me mira a mí esperando aprobación para empezar a leer pues ve que yo demoro en encender el segundo grabador.]

Sandra: dale \।

Cecilia: eh:: \| se llama / Una cena elegante \\{continúa mostrando la tapa del libro\}

Niño: iah::! \

Niño: iyo lo tengo! \

Cecilia: de Keiko K::...- \ de Keiko Kazsa \\| es una escritora e ilustradora de cuentos para niños que nació en Japón / || pero hace muchos años que vive en Estados Unidos / | con su esposo y sus dos hijos \|| eh:: sus libros infantiles / han cautivado al público infantil / | en toda Latinoamérica $\backslash$ y se destacan \|| especialmente por presentar a un mismo tiempo / historias divertidas / | y aleccionadoras $\backslash$ | y por tener textos sencillos / e ilustraciones mu::y expresivas $\backslash$ | aleccionadoras quiere decir que $\backslash$ | tienen lecciones $\backslash$ | ustedes leen el libro / | y tienen algo que después $\backslash$ | uno se pone a pensar / || que un significado tiene ese libro \| que algo rescatamos de ese libro \| bueno $\backslash$ | vamos a empezar con el libro \| Una cena elegante $\backslash<6>$ dice así $\backslash \mid$ la madriguera de Tejón / estaba llena de comi::da / | pero él no estaba contento \| manza::nas \lombri::ces y raíces $\backslash$ [enf.] lo mi::smo de siempre! suspiró \| quisiera comerme / una cena elega::nte para variar \ $\{<8>$ (muestra las ilustraciones) $\}$

Niño: $\mid a h ! \backslash$

Niño: (???)

Cecilia: entonces Tejón salió de su madriguera $\backslash \mid$ arrastr...- a rastras $\backslash \|$ y se puso...- $\backslash \mid$ y puso ávido...- / | y se puso ávido a buscar una ce...- \a buscar su cena elegante \ 
Cecilia: $\{<5>$ ahí está él sale de la cueva $\backslash$ | para ir a buscar su cena elegante $\backslash \mid$ (muestra las imágenes)\}

Cecilia: muy pronto / | Tejón espió un topo que esta...- $\backslash$ | que pasaba caminando $\backslash \mid$ im::! pensó $\backslash \|$ ¿qué tal un taco de topo con salsa picante?

Niños a coro: $\{$ risas $\}$

Cecilia: ieso sí! \|| que sería una cena mu::y elegante \

Niño: pero eso es un zorro $\backslash$

Niño: se parece \

Niña: qué chiquito el topo \

Niño: ese no es un topo $\backslash$

Niño: andan por ahí ¿ंverdad?

Cecilia: los topos no son muy grandes $\backslash$

Niña: parece un zo::rro \

Niña: sí se parecel

Niño: pero saltó $\backslash$

Cecilia: se lanzó a agarrar el topo $\backslash$ | pero este $\backslash$ | | era demasiado escurridizo $\backslash$ | y resbala::ba que se resbaló de las manos de Tejón \|| luego se escabulló lo más rápido que pudo \

Niño: $\mathrm{m}:: \backslash$ casi lo atrapa \

Cecilia: casi cas i

Niña: al lado de...- del \| ¿cómo se llamaba ese animal?

Niño: el tejón \

Niño: el tejón e:: \| es \grande al lado del topo \

Cecilia: sí cla::ro \

Niño: son chiquitos más o menos así (representa con las manos el tamaño del topo)

Cecilia: Tejón quedó un poco desilusionado $\backslash$ | pero no por mucho tiempo $\backslash \mid$ pues muy pronto espió a una rata que pasaba caminando \}

Niños a coro: iah::! \(expresiones de desagrado)

Cecilia:im::! pensó $\backslash=\ldots . . .=$

Niño: $=\ldots . . .-$ para ellos son ricos $\backslash$

Cecilia: ¿qué tal una hamburguesa de ra::ta cubierta de salsa de queso?

Niños a coro: [expresiones de desagrado]

Cecilia: ieso sí \| sería una cena / elega::nte! \ 
Niños a coro: ino!:: \

Niños a coro: iuh::! \[expresiones de desagrado]

Niños: isería fea! /

Cecilia: $\{$ muestra las imágenes $<8>\}$

Niños: [enf.] esperá esperá \¿̇::I | el topo ahí se está metiendo...- /

Cecilia: se está escondiendo \

Niño: ipero el ratón ya lo vio!\

Niño: el topo está allá \

Cecilia: ipero el ratón ya lo vio! \| ¿a ver qué pasa? \

Cecilia: se lanzó a agarrar / la rata \।

Niño: $; a h !:: \backslash$

Cecilia: pero esta se zarandeaba demasiado $\backslash||$ y sacu::de $\backslash$ | que sacudió de las manos de Tejón $\backslash$ || luego se escabulló lo más / rápido que pudo\

Niño: ¡la agarró:: ah::! \

Niña: las ratas corren mu::y rápido \

Niña: son rápidas \

Niño: el topo entró en la madriguera de... \en la madriguera del...- $\backslash$ en la madriguera del $\backslash=\ldots . .=$

Niño: =..... = del tejón \

Niña: eso parece...- \parece un triángulo \

Cecilia: ¿̇acá? \{muestra la imagen al niño que se lo solicitó\}

Niño: sí \

Cecilia: ¿qué hay acá? (???) \{continúa mostrando la imagen\}

Niña: ¿ंese es el topo?

Cecilia: es el topo que se fue $\backslash$

Niña: el topo se escondió en la madriguera \

Niña: y:: y encontró la madriguera del tejón \

Cecilia: ahí está \}

Cecilia: otra vez Tejón / quedó un poco desilusionado \| pero no por mu:: cho / tiempo \| pues muy pronto $\backslash \mid$ espió un conejo $\backslash \|$ que pasaba caminando $\backslash \mid\{<5>$ (muestra las imágenes) $\}$

Cecilia: im::! pensó $\backslash \|$ ¿qué tal una banana split de conejo cubierta con salsa de chocolate caliente?

Niño: ¡no::! 
Cecilia: jeso sí que sería una comida elegante! \

Niños a coro: ¡uh::!!

Niña: iconeji::to!\

Niño: ya lo vio \

Cecilia: $\{<8>$ el conejo encontró un lugar para esconderse $\backslash$ (muestra las imágenes)\}

Niño: ijusto a la madriguera!\

Niño: ino lo alcanzó!!

Niño: el conejo lo escuchó porque lo agarró la (???)

Cecilia: el conejo estaba atento \

Niña: isí! \

Cecilia: se lanzó / a agarrar el conejo $\backslash$ | pero este / | era demasiado veloz $\backslash$ | y brinca que brincó / de las manos de tejón \|| luego se fue salta::ndo lo más / rápido que pudo \| iy saltó el conejo! $\backslash\{<5>$ (muestra las imágenes) $\}$

Niño: ipuá::! /

Niños a coro: (???)

Niña: se ve que...-

Cecilia: [enf.] y sí $\backslash$ | quería escapar \

Niño: pero $\backslash$ | pero todos los animales son chiquitos al lado de él \

Cecilia: iah sí! \

Niño: y después van todos a la madriguera \| [enf.] los encierra en la madriguera y se los come a todos

Cecilia: y el conejo encontró un lugar para esconderse $\backslash \mid$ ipo::bre Tejón! \| había perdido tres cenas $\backslash$ | seguidas $\backslash||$ iy ahora tenía mucha mucha hambre! \| [enf.] y gritó! \| [enf.] tengo hambre \|| [enf.] tengo ta::nta hambre que me podría comer un caba::Ilo \

Cecilia: $\{<5>$ y acá está gritando como loco \(muestra las imágenes)\}

Niñas: ahí sí que es chiquitito $\backslash \mid$ al lado del caballo $\backslash$

Cecilia: jah sí! \

Cecilia: dijo una voz malgeniada \|| Tejón no podía creer su mala suerte \| justo allí mirándolo con sorna desde su altura / | había un enorme caballo con cara de bravucón \

Niño: ¡oh::! \

Cecilia: itú! / | ¿come::rme a mí? | se burló el caballo \|| ino creo! \

Niño: iah:!:

Cecilia: $\{<7>$ acá está \el caballo era mucho más grande que él \(muestra las imágenes)\} 
Niño: iqué lindo! \

Niño: y después el caballo va a la madriguera \

Niños a coro: (???)

Cecilia: \{<8>y acá están todos los animales / | ¿dónde están a ver? \| (muestra las imágenes)\}

Niña: [enf.] en $\backslash$ | en la madriguera de...- \| del tejón \

Cecilia: [enf.] ahí está::\

Cecilia: iahora largo \| [enf.] y deja de molestarme $\backslash$ | y con eso $\backslash$ | el caballo lo mandó a::Ito [enf.] por el aire de una sola patada \

Niños: $\{$ risas $\}$

Cecilia: con el caballo sí que no pudo \

Niña: [enf.] ahí sí es chiquitito \}

Cecilia: ahí sí \| cambiaron los roles \

Niño: iqué pequeño!

Niño: ivoló alto como el conejo!\

Cecilia: \{<16> [enf.] Tejón voló y voló y voló un poco más \| (muestra las imágenes)\}

Niña: $\{[$ enf.] terminó en la madriguera $\backslash($ risas $)\}$

Niño: ahí están todos \}

Niños a coro: ahí estaban todos los animales en la madriguera \}

Niño: era Superman \

Cecilia: hasta que itum! \|| cayó \| aterrizó exactamente en donde había comenzado \| en su propia madriguera \|| [enf.] menos mal \| Ilegué a ca::sa \exclamó Tejón \| ¿para qué quiero una cena elega::nte de todas formas? | tengo bastante buena comida aquí mismo \|| \{<10> y acá muestra cómo cayó \| en su propia madriguera \| (muestra las imágenes)\}

Niño: [enf.] cayó de cabeza\

Niño: iqué pequeña! \

Niño: (???)

Niño: [enf.] es muy chica \

Niño: ¿estaban afuera?

Niña: iqué pequeñita!\

Cecilia: estaba afuera de la madriguera \

Cecilia: pero Tejón se equivocaba \| to::da su comida habí::a desaparecido \

Niños: ioh! \ 
Cecilia: en su lugar $\backslash$ lo único que encontró $\backslash$ fue una nota que decía...- $\backslash \mid\{\langle 6\rangle$ lo ven que está sentado en su madriguera $\backslash$ | encontró la carta $\backslash \mid$ y nada de comida $\backslash \mid$ (muestra las imágenes)\} y la carta decía \|| apreciado quienquie::ra que viva aquí \| lamentamos haber entrado sin invitación $\backslash \|$ [enf.] pero nos perseguía un tejón espanto::so \| y no teníamos dónde escondernos $\backslash$ | las manza::nas \las lombri::ces y raíces estaban deliciosas \| gracias / por una cena ta:n / elegante \

Niño: iah::! \| ise escondieron en la...- en la casa del...-\| del tejón! \

Niña: isí! \

Niño: !pobre Tejón!\

Cecilia: y ellos se comieron la comida \| del tejón \

Niño: ellos tienen $\backslash \mid$ comida $\backslash$

Cecilia: claro $\backslash$

Cecilia: $\{<10>$ y acá muestran $\backslash \mid$ a los otros animalitos comiéndose la comida $\backslash$ | y ya estaban todos satisfechos con su pancita llena \| (muestra las imágenes)\}

Niña: y quedan (???)\

Cecilia: ¿̇en dónde?

Niña: en el medio \

Niña: y se comieron una cena elegante \

Cecilia: ¿sí? || bueno y colorín colorado este cuento se ha terminado \}

Niños: \{aplausos\}

Cecilia: ¿les gustó?

Niños a coro: [enf.] sí \

Cecilia: muy bien \

Noelia: imuchas gracias!

Cecilia: ino por favor!

Cecilia: (Se dirige a mí.) [enf.] lindo libro este

[Saludamos a los niños y a Noelia y nos retiramos del salón.]

Cecilia: (Me reitera.) [enf.] lindo libro \ 


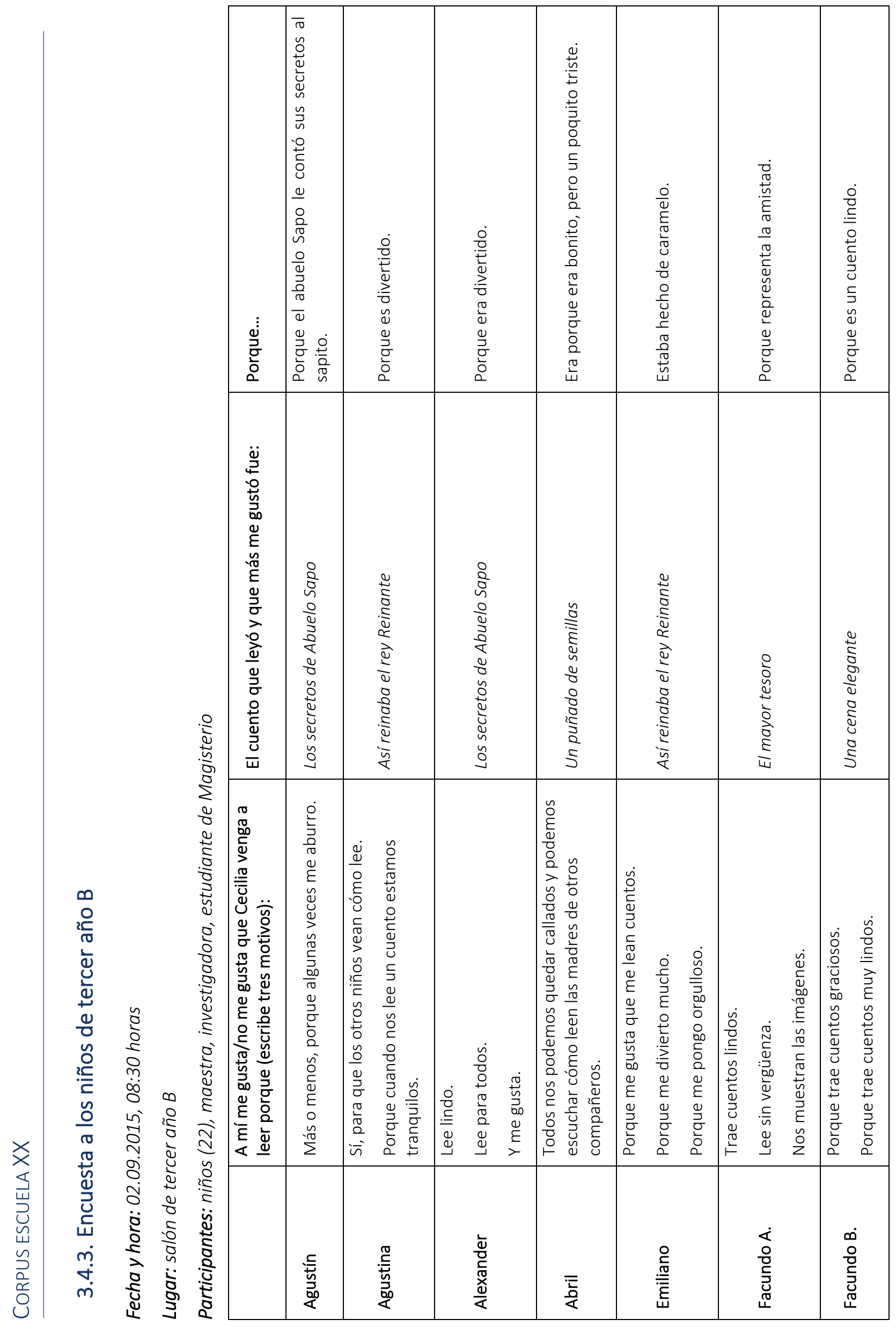




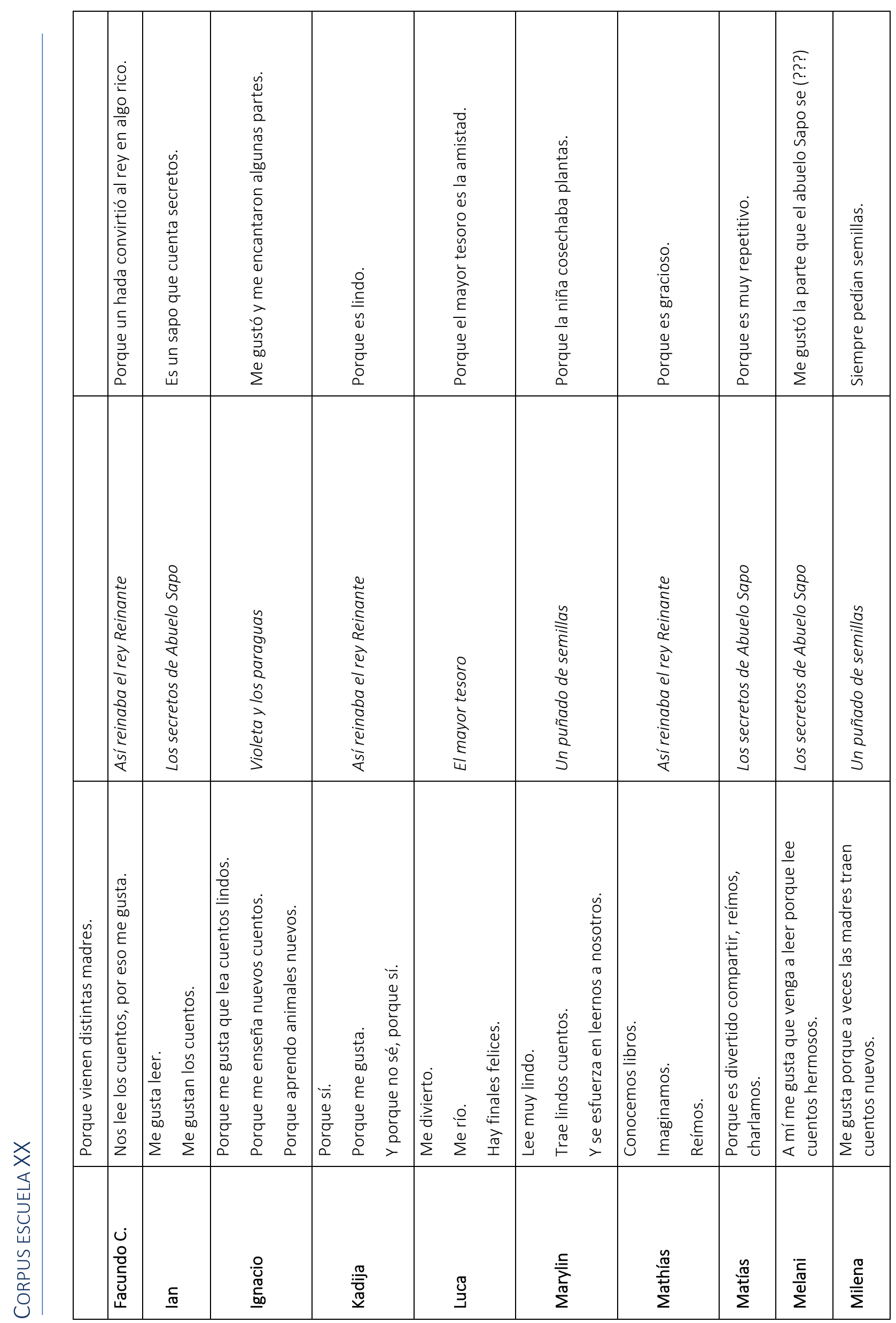




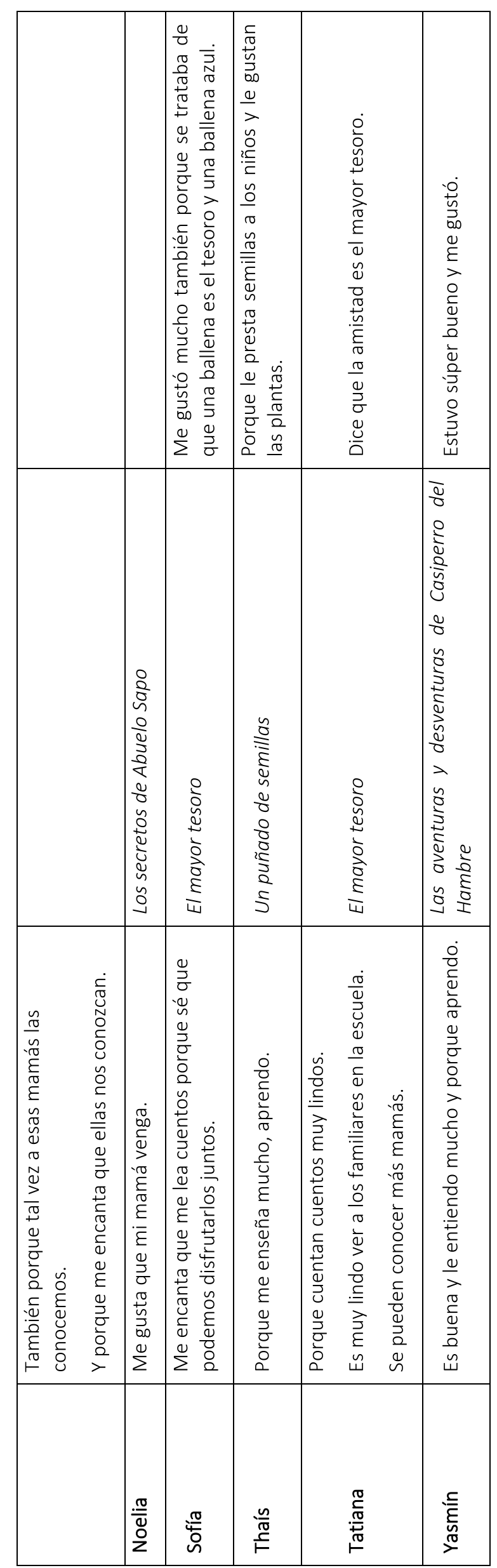




\section{CORPUS ESCUELA XXX}

\subsection{Entrevista a Rosa, directora de la escuela XXX}

Fecha y hora: 04.12.2015, 8:00 horas

Lugar: oficina de la directora

Participantes: Rosa, investigadora

Sandra: Rosa buen día son I cinco preguntas que te voy a hacer

Rosa: buen día | a ver decime

Sandra: primero que nada || quiero que me cuentes la historia del grupo lector | lo que recuerdes desde los inicios del año pasado hasta ahora

Rosa: justamente todo arranca el año...- pasado | en los días administrativos | donde uno de los maestros que ahora no está que es Álvaro | propone crear un espacio | para crear una sala de lectura || y bueno ahí como que ya todos los maestros | se engancharon en la propuesta | aportando ide::as | que después esto se va a ir ajustando con las salas docentes | todo lo que es...- | el continuar con el proyecto de Biblioteca Solidaria || yo algo te tengo que decir | de verdad lo tengo que destacar

Sandra: sí

Rosa: es el compromiso que tienen | a nivel docente el compromiso que hay [enf.] de trabajo | y la responsabilidad que tienen || yo pienso que to::do el camino | todo lo que se ha transitado ahora | porque estamos muy conformes no solamente con los resultados | sino cómo se fue desarrollando el proyecto | es porque los docentes | están codo a codo con el trabajo mismo || bueno la prueba está en que vos estuviste haciendo el trabajo de investigación::n | y cómo verdaderamente se organizó || tenemos...- | generalmente tenemos | por año | vamos delegando parte del trabajo || los maestros apuestan a ir rotando este tipo de responsabilidades de cómo organizar | cómo ir ajustando | las actividades | los cronogramas || si bien ellos consu::Itan | nos vamos ajustando| pero un gran recurso que tenemos || que la verdad que nos ha dado mucho resultado | que se discu::te | y se buscan nuevas soluciones es la sala docente | si hay algo para ajustar en el proyecto mismo en el trabajo | se ajustan en las salas

Sandra: ese espacio es fundamental

Rosa: sí

Sandra: Rosa ¿̇y el grupo de madres lectoras?

Rosa: bueno mira | se convoca...- | estoy hablando prácticamente de los inicios | se convoca a sala...se convoca a una asamblea (Rosa se para para cerrar la puerta) || se convoca a una asamblea donde se les presenta a los papás el proyecto | de Biblioteca Solidaria | se les explica | cómo realmente se pensaba organizar | y bueno y ahí fue que se fue enganchando la gente || acá otra característica que tiene la escuela que si...- | que los padres | en cierta manera responden || los comprometés | los llamás | les explicás || tenés que tener esa paciencia | pero los papás responden en general | viste que acá venían...| el cronograma era de todos los martes | esto se viene ajustan...- | y desde que empezó el proyecto | vos sabés que esto se viene cumpliendo | si bien muchos padres han quedado de un año para otro | 
otros van rota::ndo | pero vos sabés que son muy cumplidores | es más el día que no pueden venir el martes porque se les complica por alguna otra situación | inmediatamente la llaman a la maestra referente a ver qué pueden coordinar a ver en qué día y en qué horario pueden venir a...- | a participar de esa actividad en esa clase | como que no te dejan...- | el día que no pueden venir no te dejan sin concurrir al aula eso está muy bueno también || eso sí | después tenemos el espacio de discusión que generalmente es los viernes | el espacio de discusión que fue lo que vieron

Sandra: ¿ंcon los padres?

Rosa: con la maestra referente | está la presencia del director y los padres | y ahí hay un espacio de discusión que es muy interesante | de cómo ellos se manifiestan y cómo se sintieron en el aula || y bueno después ellos mismos van haciendo otro tipo de aportes | «bueno mirá yo tengo afinidad en esta clase en esta no»| ellos van manejando determinadas instancias para que ellos se sientan cómodos || al momento de...- | con respecto a las charlas que nos daba el proyecto | también la asistencia fue muy...| muy buena | la asistencia fue muy buena || hay compromiso yo lo que te tengo que destacar es el compromiso | el compromiso tanto del equipo de los maestros | el vínculo que tienen con los padres | y por otro lado el compromiso de los padres

Sandra: o sea que desde un inicio la escuela los recibió | hubo apertura

Rosa: se enganchan enseguida con las propuestas nuevas con determinados atractivos | por decirlo de alguna manera | ellos se enganchan

Sandra: ¿ ¿hubo diferencias en...- en cuanto la recepción del equipo lector por clases | en el sentido de que por ejemplo las maestras de las clases lo hayan recibido de una manera y los de las clases grandes de otro?

Rosa: no no no | podrá haber alguna...- | alguna complicación con algún niño un poco más problemático con problemas de conducta que haya que llamarle la atención | pero no | y vos sabés que lo que nos llamó también la atención | que se les explicó de antemano [enf.] | que no porque tuviese a su hijo o a su nieto en determinada clase tenía que ir a esa clase \| era compartir el tiempo de lectura | en otros grupos | y el rotar en todos los grupos | y eso dio muchísimo resultado || los vuelve mucho más conocedores de la escuela | de cómo trabaja la escuela || las responsabilidades y la...- | y la apertura que tiene cada maestro | que ellos te lo manifiestan | en las mismas...- | estas jornadas de los viernes que es la instancias de reflexión que tenemos de cómo ha sido el trabajo | que las tenemos generalmente casa quince días | ahí ellos vuelcan...- | salen cosas muy interesantes

Sandra: ¿cuál creés que fue el aporte del equipo | a la escuela?

Rosa: y bueno | mirá | mirá tenemos || varias puntas por decirlo de alguna manera | lo primero el vínculo con la comunidad en general | el acercamie::nto que...- | no porque sea una escuela un poco más abierta y todo...- | mejorar los vínculos | les das confianza | al papá | o a los abuelos || ellos te van aportando determinadas ideas | de funcionamiento hasta de organización | le bu::scan la vuelta en la manera de buscar soluciones no te vienen con problemas $\|$ y después me parece que lo más importante son los resultados que se han tenido | a nivel pedagógico | porque no es el hecho de leer por leer | por el placer simplemente || sino que ahí se crearon | no solamente el hábito de la lectura | bueno también el gusto || pero cómo el maestro después a partir de ese tex...- | de esa lectura | cómo trabaja la lectura y planifica la lectura | lo venimos viendo | en lectoescritura | la prueba está que este año | más allá que 
nos involucramos en el proyecto del maestro integrador | pero bajó impresionante el índice de repetición | ahora tenemos | a nivel...- || a nivel...- [enf.] || institucional| solamente 19 niños nos quedaron repetidores $\|$ impresionante $\|$ y después aquella instancia de que el chiquilín | el hábito y el gusto por ir a la sala de lectura con un cronogra::ma | con una persona diferente que venga a trabajar con ellos || es un placer || la verdad que...- | nosotros hace años que venimos...- | y el año que viene | vamos a continuar con el proyecto || pero dándole otra mirada porque con la co::mpra que se hizo...- | ya juntamos los libros | el año que viene a nivel pedagógico || ya apuntando a ciencias de la naturaleza y a ciencias sociales || y los libros son preciosos

Sandra: hermosos | hicieron una elección preciosa

Rosa: sí sí | dio trabajo | viste que nos llevó me::ses también | bueno primero se consultó al maestro | y después la elección de los libros que realmente apuntaran para hacer un abordaje realmente educativo ¿no?

Sandra: los títulos que me mostró el otro día Rocío idivinos!

Rosa: sí sí

Sandra: $<3>$ vos si tuvieras que comentarme algún cambio que haya tenido el grupo de madres lectoras del año pasado a este | ¿hubo algún crecimiento que se notó?

Rosa: con respecto a la escuela que era lo que yo te decía | viste que nos llevó meses | la confianza y el vínculo | no solamente por parte de la dirección |vos las ves con otro compromiso | «¿qué precisás?» | «¿necesitás algo más?»| «vengo mañana»| ese tipo...- | «¿la maestra necesita algo»? | mirá se me propuso en determinado grupo | que viniera otro día | esas instancias de flexibilidad en cuanto al trabajo mismo | y después lo que me llamó muchísimo la atención este año | fue que este equipo de lectura preparara para los chiquilines el Día del Niño| una obra de teatro | eran ellos | hicieron la representación | y estuvo espectacular | el placer con el que trabajó esa gente |los gurises |cómo disfrutaron de esa obra de teatro preparada por el equipo | fue impresionante || vos ves ca::mbios | cambios de actitud | de compromiso en el trabajo | cómo ellas dedicaron no solamente porque venían a ensayar acá para la obra de teatro | sino el tiempo que dedicaron extra en la casa para reunirse | formar un guion | impresionante | vinieron todas | todas disfrazadas | y nos representaron a nosotros $=\ldots . .=$

Sandra: $=\ldots . .=$ hay algunas mamás que son impresionantes

Rosa: impresionante | sí sí

Sandra: son muy divertidas

Rosa: y después lo otro la parte de...- | llegado el momento cuando le dimos el cierre al proyecto | los muchachos de quinto y sexto | prepararon las obras | y la jornada de danzas para ellas | hay una devolución del trabajo nuestro hacia ellas y viceversa ¿no? | ellos disfrutaron impresionante de ese día | de esa instancia || y bueno | se les hizo un obsequio también de un libro para ellas | de un libro de cocina | para ellas | felices | esa gente está feliz | de antemano esto continúa

Sandra: estas son las preguntas básicas | por eso yo te dije que era cortito | ¿algo que quieras agregar? | a mí me interesa recuperar eso | el rol del equi::po | de las mamás $=\ldots . . .=$

Rosa: $=\ldots . .=$ mirá si hay algo que tengo que resaltar $=\ldots . .=$ 
Sandra: $=\ldots . .=$ su crecimiento $=\ldots=$

Rosa: $=\ldots . . .=$ resaltar en todo esto $\mid$ si no parte de un compromiso colectivo en la parte del proyecto en sí | de la lectura | del equipo de lectura | pero tiene que haber un compromiso | el compromiso docente | porque mirá que aquí las muchachas son las que impulsan | las que hacen | tiene que estar organizadito | el tema del cronograma | ir viendo || tenés resultados impresionantes || la verdad que nosotros por ejemplo |este proyecto Biblioteca Solidaria | lo ajustamos como proyecto curricular de centro || a nivel institucional | porque los resultados se dan || y es lo que el maestro...- | si no hay acue::rdos | entre maestros | y la comunidad | yo pienso que los resultados no se dan || tienen que haber acuerdo y compromiso | porque...- | parte de ahí la cosa

Sandra: bueno era más que nada eso | recuperar un poco la historia del equi::po || para ver su aporte | cuál había sido desde tu lugar su aporte

Rosa: claro | el tema ya te vuelvo a repetir | acá se hizo prácticamente parte del lanzamiento a nivel nacional también | con jornadas cultura::les | por eso te digo | hay cosas donde las respuestas se ven | desde el trabajo en sí mismo | ahora si las cosas no funcionan | me parece | si el colectivo no acompaña | es difícil || se te hace muy difícil | es más | los resultados yo dudo que se vean

Sandra: [enf.] muchísimas gracias Rosa

\subsection{Entrevista a Mariela, maestra referente de Biblioteca Solidaria}

Fecha y hora: 04.12.2015, 9:00 horas

Lugar: salón de Mariela

Participantes: Mariela (maestra referente)

Sandra: son más o menos quince veinte minutos | Mariela || vos | ¿qué te acordás de la historia del grupo lector ¿cómo se conformó::? || ¿cómo podrías reseñar esa historia?

Mariela: e::I proyecto comenzó a funcionar en el año 2014 | lo primero que hicimos cuando había que conformar el equipo lector | fue pedirle a:: cada una de las maestras | que:: les solicitara a las madres | si podían concurrir a la escue::la | una vez por sema::na | a leer un li::bro | contarles el proyecto y demás | estuvieron interesadas | varias madres | en el 2014 creo que fueron seis siete || e::mpezaron a hacer las reuniones con el maestro referente | que en el 2014 era Rocío || y ahí se fue con::solidando el equipo de trabajo | igual hubo:: | algunos inconvenientes en la formación | algunos liderazgos en el grupo | que de a poco se fueron moldando | adaptándose a la tarea | con algunos miedos | con algunas inseguridades | pero bien | se siguió adelante | el equipo llegó a fin de año co::n || cuatro o cinco | referentes firmes en la tarea =.....=

Sandra: $=\ldots . . .=$ en el 2014

Mariela: en el 2014 | este año en el 2015 | se volvió a hacer la misma tarea por si se querían integrar nuevos padres | las cuatro o cinco personas que estaban de::I 2014 siguieron | continuaron con la tarea || y se integraron | cuatro más || en total fuimos ocho || en la escuela tenemos | para trabajar siete grupos | siete niveles | siete niveles || así que trabajó una por nivel | y tenía una como:: || remota | suplente | que:: | que me iba cubriendo las clases si alguna no 
podía y demás | así que este año el grupo | en 2015 el grupo estuvo consolidado por ocho madres | firmes todo el año

Sandra: ¿cómo recibió la escuela ese grupo | en 2014 cuando vino? ¿vos | qué notaste? | en la escuela en los niños | los maestros

Mariela: bien || e::stábamos todos que no sabíamos para dónde arrancar ¿no?| obviamente en 2014 el proyecto era muy nuevo| los maestros no sabíamos | a qué nos enfrentábamos | el maestro referente también | porque los lineamientos estaban claros pero había que instrumentarlo y llevarlo a cabo y:: | si bien no es una tarea difícil | es complicada por donde estamo::s | inmersos | que la escuela implica tie::mpo | estamos con niño::s || las madre:: s | llevan su tiempo | porque hay que explica::rles | hay que apoyarlas | hay que llevarlas | hay que ayuda::rlas || porque:: | a mitad de año es como los niños de primero | se manejan solos | pero a principio de año necesitan | el apoyo y la orientación del maestro para todo || entonces eso es lo que lleva un poquito más de:: I de tiempo trabajo y dedicación después el proyecto | se encamina y marcha y este año fue igual pero la escuela abierta a la propuesta | los gurises tambié::n | y todos los maestros | bien || los maestros no hay ninguno que se hayan negado | a recibir al | padre lector | ninguno

Sandra: la pregunta que te iba a hacer ahora tenía que ver con eso \| ¿todos los maestros recibieron por igual por igual al proyecto | en el sentido de que:: | hubo por ejemplo en las clases grandes un poquito más $\mid$ o las clases chicas $=\ldots . . .=$

Mariela: ¿cómo la receptividad decís tú? |

Sandra: sí | la receptividad

Mariela: no | ninguno tuvo eso inconveniente | el proyecto seguía funcionando | y además hicimos juntos con el proyecto [Biblioteca Solidaria] el proyecto Podes | lo amparamos para tener nuevos libros | o sea nos involucramos mucho más todos [enf.]| el año pasado estábamos un poquito que no sabíamos | bien | si:: había dado resulta::dos || si:: estábamos todos afín con el proyecto de continuar | y como los resultados fueron buenos lo continuamos en 2015 con este proyecto Podes para tener más libros || pero:: toda la...- | la cantidad de maestros | todos | se involucraron perfectamente y con | la receptividad con los padres | pulimos algunas cosas del año 2014 ¿no? || con respecto a la relación maestro:: | maestro-padre | maestro-padre lector | porque de repente claro | como tampoco sabíamos cómo era la propuesta bien los dejamos medios solos para que padre actuara y en realidad pulimos algunas cosas de que...- | estuviera el maestro más | involucrado participando de la lectura junto con el padre que no lo dejara tan solo | para que:: | bueno para que las cosas fueran mejor | ese tipo de cosas se pulió

Sandra: y los demás padres | ¿los que no participaron?

Mariela: los demás padres vieron bien la propuesta | todos sabían | aparte veían a las madres que se reunían en la puerta con el bolsito y el pin II entonces todos sabían de la propuesta el proyecto los chiquilines | tambié::n les contaban | entonces ya sabían que los martes de repente a la primera hora ya era el horario de lectura || en realidad toda la comunidad participó | en forma directa o indirecta de::I | proyecto || y como las veían en la puerta ya:: siempre fuimos ...- | «el 
año que viene te espero» | «el año que viene te espero» | "el año que viene te espero»| a ver si se involucra más cantidad de gente

Sandra: ¿cuál fue el aporte que vos creés | que hizo el equipo lector? <4> no sé || el aporte | en general

Mariela: ¿a la escuela?

Sandra: a la escuela | lo que vos identifiques

Mariela: este año el equipo lector tuvo:: | dos o tres referentes mu::y fuertes || que hicieron por ejemplo...- || prepararon para toda la escuela en forma espontánea una obra de teatro | que eso marcó así un antes y un después también de::...- | de:: || de la lectura | que no eran solamente las madres lectoras | sino que vinieron a hacernos un rega::Io | nos trajeron un prese::nte | se mataron de la risa | porque...- | porque representaron dramatizaron una situación de aula | que primero íbamos haciendo un hilo conductor y después al final dijeron "lo hacemos en forma espontánea» | nos sacaron las túnicas a todas las maestras | subieron al escenario | y estuvo Imaravilloso | y eso hizo que los gurises las vieran desde otro punto de vista | que no solamente eran las mamás que venían | o era mi mamá [enf.] | eso también lo tratamos de rotar que no era solamente la mamá del niño que estaba en segundo | que siempre iba a leer a segundo sino que hoy era la mamá de ese niño | mañana era otra | pasado era la otra pasado era la tía del otro compañero | y así rotando | siempre ellas también...- | también trataban de que...- || pasar por la clase de su hijo | porque para ellas era muy importante pasar | y que el niño | su propio hijo las viera | pero tratar de rotarlas | por ejemplo lo que nos generó bastante problemas al principio era:: | «yo con los grandes no» "yo con los chicos no» | o sea ver las fortalezas | y después | desde mitad del año en adelante ya | podrían cubrir cualquier clase que no tenían ningún tipo de inconveniente si era chico si era grande si era de mediana edad | y después de la relación de ellas con la escuela ¿no? || para todo [enf.] | para todo para todo me colaboraron en todo lo que se inventó después más | siempre conté con el equipo lector | no solamente en la tarea propia de la lectura de ProLEE | sino habíamos creado un grupo | bastante fuerte | y por ejemplo ahora fue el festival | y les solicité a todas la colaboración para la venta de comida | y estuvieron todas ahí | al firme | presentes || todas | todas | lo que les pidas ¿iviste? están siempre

Sandra: Mariela | ¿vos entonces | notás una evolución en lo que fue el grupo lector en 2014 |de lo que fue en 2015 ?

Mariela: sí sí sí sí | en ese sentido sí | en el compromiso |

Sandra: ¿en la tarea misma de leer?

Mariela: también | se fortalecieron muchísimo ellas en la tarea de:: | de:: | leer | apoyaron a las que vinieron | a las que vinieron nuevas en el 2015 | porque todo el equipo no era nuevo o sea algunos estaban en 2014 | y ellas mismas se apoyaron | se fortalecieron || generaban...- | se comentaban los cuentos | se decían cuál podían...- | «bueno mirá yo leí este que está bueno dio buenos resultados I ese no tanto por lo menos en el grado que yo tuve no les llamó mucho la atención»| ellas mismas iban generando | ya llegó un momento que eran totalmente autónomas | me faltaba darles las llaves de la biblioteca agarren el libro y ya estaba| porque se manejaban | bárbaro| solas | así que eso está | buenísimo || y año a año como todo ¿no? | cuando uno se 
engancha en un proyecto y empieza| a trabajar en base al proyecto y todo $\|$ se van viendo los ca::mbios | los avances las fortalezas y el involucramiento | estaban con pena de finalizar ¿no? | bueno cuando les dije termina en octubre porque en noviembre empiezan meses complica::dos y demás | ya estaban con pena | porque no querían | porque querían seguir viniendo y ...- | [enf.] basta de lectura || aparte nosotros queríamos prepararle la fiesta a ellas que le hicimos la fiesta de despedida | y también | tuvimos que cambiar varias veces por funcionamiento general de la escuela la:: | la fecha | y bueno | se les hi::zo | estaban muy emocionadas | súper contentas (entra un niño a hacer una pregunta e interrumpe a la maestra) súper contentas $\| \mathrm{y}::<5>$ \{y me perdí (risas)\}

Sandra: eso | que estaban emocionadas con la fiesta

Mariela: con la fiesta| y bueno de ahí en más quedaron súper involucradas | que después las llamé para el tema del festival y quedaron...- | y bueno venimos...- | en el 2016 seguimos | vamos a ver cómo es la propuesta | y cuáles son los participantes

Sandra: por ejemplo | cuándo empiecen el año que viene ¿vos| qué les sugerirías? || bueno | tenemos que || mejorar esto | tenemos que hacer esto de la misma manera

Mariela: <5> yo les sugeriría:: un poquito más de...- | no tan lectu::ra de repente dentro de los cuentos sino más como narraciones | para que ir cambiando modalidades que no sea todo leer leer leer I cuento | yo ya les sugerí al final por ejemplo que ellas hicieran el raconto | de la historia | no dejen tanto que las maestras hagan a...- | el raconto de preguntar sino ellas mismas | y los personajes y cuáles son y qué les sugirió el título y les gustó y por les gustó y por qué no les gustó | o sea un poquito más de charla de interacción | no solamente vengo leo el libro y «nos vemos chiquilines» | y nos vamos | que eso era un poco lo que pasaba el primer año | de repente | entonces este año se mejoraron algunas cosas | de la interacción |con el maestro | con los niños en el momento de la lectura entonces | yo focalizaría ahí para ir...- | para ir dejándolas un poquito más...- || más libres | ahora tienen que venir con los...- | con los libros de Podes | que yo no he podido abrir | las cajas para ver | ellas vienen...- | quedaron que el martes vienen a sellar | todos los libros | a hacer el inventa::rio | y van a pasar con alguna cantidad de libros $x$ | por las clases para que los chiquilines sepan que hay libros nuevos ¿no? | y ellos sepan también que:: | la plata fue invertida en eso proyecto y que el proyecto se ganó | que los libros están y que tenemos un montón de libros para el año que viene || eso está bueno || sí sí | la verdad que | bien de bien | el grupo de referentes | diez puntos | la verdad que nada |

Sandra: la verdad que más suerte yo no podía haber tenido al venir a esta escuela | es increíble Mariela: y no ellas en participar porque en realidad del año 2014 eran...- | son cuatro || y bueno hay una que viene que no tiene::...- | Janet que no tiene los nenes porque ya se fueron de la escuela | pero está tan...- bueno después van a venir sus nietos y el bebé chiquito de ella | pero en este momento no tiene a nadie | viene porque escuela para ella es todo | y nosotros tratamos de | fomentar eso || también el equipo de la escuela hace ¿viste? | es un equipo refere::nte | tratamos | en mayor o menor medida | con mejor o peor onda | porque a veces no estamos pun pa arriba | tratamos de involucrarnos siempre todas | en este proyecto nos involucramos todos porque era a beneficio de noso::tros [enf.] | de los ni::ños de la escuela y de ellas mismas | y ellas mismas se empoderan | logran otra...- | otra cuestión con los gurises || ven a la escuela de otro 
pu::nto | ven lo que nosotros hacemos | a veces | que no hacen nada las maestras | siempre las críticas ¿no? | a veces no son tan constructivas | entonces no ven desde otro punto de vista cuando están afuera están comentando también cosas buenas || porque ven la interna | ven el movimiento que a veces parece que...- | iah! anda una maestra dando vuelta | no | estábamos dando vueltas por determinados motivos ¿no? | que la gente que nos ve de afuera | o el que está esperando una entrevista con la directora o algo ven | no entiende nada| solo nosotros los que estamos en el sistema:: | lo conocemos y lo manejamos || entonces ellas también lo...- | lo pudieron ver | eso está buenísimo | en la despedida estaban copadas | felices | felices | les encantó | [enf.] estuvo relinda

Sandra: iqué lindo! sí Rosario me comentó eso | me dijo que...- | que estuvo relindo | se habían emocionado mucho

Mariela: sí sí lloraban | estaban... | estaban felices | se sacaban fotos todas juntas | las mandan al grupo de Wathsapp | a un grupito de Wathsapp (comentamos sobre intercambiar las fotos del día de la despedida del equipo lector) | ellas me suben todo en el Wathsapp y tenemos fotos de | todas |lora::ndo | todas juntas | divinas | estaban súper emocionadas sí | y los gurises | participaron divino porque era | para ellas || sino no hubiesen...- | por más que nosotros generemos o intentemos hacer cosas con los gurises...- cuando los gurises no están involucrados en una tarea | no la hacen | es cuando les aburre algo | no se involucran | cuando ven que nosotras | los maestros estamos reafín con la tarea estamos reinvolucrados y ellos también salen las cosas | salió realmente divino || y se acue::rdan quién les leyó | que ese ya lo habían leído | ellas mucho miedo tenían de eso también les generaba || «¿`y si ya lo leyeron el cuento»? | y en general también las respuestas de ellas | «¿cómo les fue?»| «¿cómo estuvo el grupo»? | pudieron hacer la...- | realizar la lectura | siempre bien | nunca hubo...- | algo que les molest...- | bueno algún niño inquieto por supuesto [enf.] estamos co::n | veinte gurises adentro de una clase | es obvio que alguno se puede || tener más inquietud que otro | pero en realidad siempre les respondieron bien | ellas con eso nunca tuvieron...- | con la conducta que era un tema que ellas pensaban | lo ven de afuera tipo es un caos la escuela es un caos | adentro de la clase se trabaja | todo el tiempo trabajando || y los gurises...- (entra un niño a y hace una pregunta y Mariela contesta) || y los gurises responden a eso | porque a ellas las escuchaban y las espera::ban | las esperaban todo el tiempo (entra nuevamente el niño a convidar con torta de su cumpleaños y le agradecemos)

Sandra: dos preguntitas me quedan por acá || Mariela || ¿vos | por qué aceptaste el desafío de ser referente? |fue una tarea más de las que tenés

Mariela: porque:: | el año pasado estuve involucrada junto con Rocío y en realidad quedó:: Rocío como muy | adelante del proyecto y:: || uno estaba ayudando y participando pero en realidad || quedó sola mi compañera | entonces dije este año bueno | vamos a hacer un cambio para que no:: | no se sobrecargue | la tarea | en una persona | pero en realidad no hubo una definición de...- | por algo específico tipo la escuela me eligió a mí | no | en realidad era porque el año pasado entre las dos lo llevamos y yo sentí que en realidad Rocío lo llevó mucho más adelante I el proyecto que yo porque yo pude participar poco por los...- | por los tiempos pedagógicos ¿̇no? | por el grupo | y este año como estoy en este rol | de maestro integrador que no tengo el grupo 
a cargo | específicamente le dije a Rocío «bueno yo | te libero un poquito» | lo llevo yo un poquito más encaminado || me facilitó todo el aprendizaje del año pasado | Rocío me pasó los lineamientos y todo | ya con el año anterior este año:: fue:: | maravilloso y mucho más fácil | y en realidad a principio de año fue que hicimos con Rocío y con Nadia

Sandra: claro

Mariela: los cursos de...- | allá en la biblioteca | cuando se hizo la presentación fuimos las tres | y bueno los llevamos ahí entre las tres tratábamos de colaborar entre las dos Nadia y yo a Rocío en:: | todo lo que se pudo | pero como siempre tenía que haber uno [enf.] | que figurara era Rocí::o | y:: los cursos on line los foros y eso Rocío era la que los podía hacer porque nosotros no teníamos tiempo estábamos en otros cursos || entonces como que | los siguió Rocío el año pasado | y bueno este año dijimos «vamos a rotar» | el año que viene vamos a ver si rotamos de vuelta ¿no? \{risas\} porque está bueno también involucrar y que todos vean esta tarea porque parece sencilla | «ah bueno es organizar a las madres» y no es sencillo | no es sencillo | lleva su trabajo | es complejo | es divino | es súper disfrutable | cuando formas el grupo...- | el grupo referente es maravilloso | pero es...- | lleva su tiempo su trabajo su dedicación | hay que estar ¿no? | hay que estar con las ma::dres | hay que estar con el li::bro || todas llegaban | perfecto | los martes | pero no todas en el mismo momento a la misma hora | entonces vos andás corriendo permanentemente

Sandra: claro

Mariela: pero | está bueno | está bueno | la tarea está buena | sí les muy bueno la verdad que sí || y el proyecto es...- | está muy bueno | la verdad que sí || porque a veces hay proyectos en general que no::...- |que se plantean en las escuelas y no dan resultados | no se ven | los resultados | no se dan | en este caso...- | como todo tiene que seguir un tiempo más | pero está...- | está bueno | estaría buenísimo que se involucraran todos los años otr...- | otros pa::dres para bueno | para de a poquito abrir más a...- | a la...- | a la comunidad | o en algún futuro lograr que salgan los libros también a las casas ¿no? | que eso es...- | es bastante...- | bastante difícil...| bastante difícil de lograr | pero bueno | de a poco vamos | ya tenemos una biblioteca tenemos más libros yo qué sé | lo que nos habíamos en un pasado pensado | se logró | así que bueno

Sandra: ¿algo más que quieras agregar? | ¿que vos quieras comenta::r?

Mariela: <4> como negativo no tengo

Sandra: yo quiero todo | lo negativo lo positivo todo

Mariela: negativo en realidad no por esas cuestiones que había que pulir ponele negativas con respecto al año pasa::do | pero en realidad no puedo decir nada el grupo referente me respondió divino siempre [enf.] | ya te digo como éramos ocho que eso está bueno | siempre tenía:: u::n suplente por decirlo de alguna manera que me cubría alguna otra clases | si no se podía | me cubrían en la semana || entonces ya está | las maestras este año más receptivas y abiertas que el año anterior | porque el año pasado estábamos como reacia::s bueno a lo desconocido | como todo un poquito a ver cómo...- | y este año al contrario mejor | mejor los gurises esperábamos a las madres | me reclamaban si no venían entonces tratábamos de | de coordinar otra...- | otro mome::nto porque de repente con los grandes más que nada se hicieron novelas | entonces iban 
capítulo a capítulo | y para tratar de terminar la historia || pero de hecho por ejemplo | para el festejo del Día de las Madres | sexto año con las madres lectoras | que fueron dos o tres siguieron la historia de Los fantasmas de la escuela ly le hicieron una representación de Los fantasmas de la escuela o sea que estaban...- | las madres que leyeron...- | o sea las dos que leyeron en sexto estaban fascinadas de la vida | porque en realidad fue una de las historias que ellas leyeron |y a los gurises les encantó | y bueno las representaron y ellas estaban recopadas | fascinadas || sí sí | así que bueno veremos cómo sigue el año que viene | el 2016 | a ver quién sigue de referente también porque está bueno rotar y que todas || pasen por la tarea | y bueno nada | se va afianzando el proyecto | como negativo este año no |en 2014 podíamos decir que había más cosas como negativas

Sandra: a mí me interesaba recuperar esa historia | ese:: transcurrir | ese crecimiento

Mariela: cuando fueron al taller les encantó:: tambié::n | que el año pasado...- | que eso estuvo muy bueno y eso hay que resaltarlo| que en el 2014 cuando empezó | tenía que ir un referente del grupo [enf.] || y bueno eso generó quién va || entre ellas mismas | que de última está bueno abrirlo a todas | y bueno las que puedan van por supuesto | y las que no...- | siempre va a pasar que no no van a poder ir todas | en este caso fueron varias del grupo mío | fueron varias fueron casi todas | y vinieron copadas con las actividades que habían hecho | estaban fascinadas | esto es por fuera ¿no? I se hacían chistes arriba del ómnibus me mandaban los Wathsapp y las conversaciones me mandaban fotos después se fueron a...- | a almorzar todas juntas | a tomar un café | [enf.] bárbaro | la salida ya les sirvió a ellas más allá de lo que iban a hacer | como grupo hum::ano como muje::res || salir y conversar | estar en otra instancia que no sea la escuela la lectura y los niño::s | y sus propios hijos ¿no? y sus casas | que lo reprecisan | \{ino no lo que lloré de la risa ese día! | no te puedo explicar las conversaciones | decían cualquier cosa decían «parecíamos niños chicos en el ómnibus» | me mandaban...- | se mandaban audios desde donde estaban senta::das | unas en el fondo y otras adelante | yo me hacía el plato porque me las imaginaba | y las fotos en el ómnibus no no no (risas)\} | pasaron rebien y estaban reafín con el curso cuando fueron | entonces eso estaba bueno porque el año pasado era una [enf.] || sola que tenía que ir | y eso generó en el grupo | quién iba | «voy yo» va la otra «no no puedo» |o entre comillas ¿no? va la más capacitada la menos capacitada la que lee mejor | la que no lee tan bien | entonces generó | cómo era la selección | de la persona | y al habilitar ahora que fueran to::das || bueno la que puede...- yo les dije «la que pueda ir | bárbaro» [enf.] | trate de ir una | y las que no | bueno no...- | no se puede...- | se organizaron y fueron |creo que fue una sola que no fue | pero $=\ldots . . .=$

Sandra: $=\ldots . . .=$ claro pero las otras van y les cuentan

Mariela: claro exacto | pero habilita a que:: | a están todas a no generar esa:: | selección de alguna manera que a veces genera ¿viste? quien tiene que ir quién puede ir | ¿a quién elegís? a la que participa más en hora::I a la que sabe leer mejor la la que se va a desenvolver mejor con ustedes que algo pueden...- tienen que explicar de la escuela o del funcionamiento del grupo ¿no? | entonces a veces eso genera un poquito de...- || de situaciones...- | complicadas | difíciles | pero también entiendo por el lado de ustedes del espa::cio del luga:::r de la coordinació::n || eso está...- | eso fue buenísimo este año 
Sandra: bueno || bueno muchísimas gracias Mariela

Mariela: no por favor | [enf.] a vos también!

\subsection{Reunión del equipo comunitario de lectura}

Fecha y hora: 14.07 .2015 , 08.00 horas

Lugar: salón de la maestra referente

Participantes: Mariela (maestra referente), Andrea A., Rosario, Margareth, Laura, Mónica, Patricia, Janet, investigadora (9 participantes)

La reunión se realiza para evaluar el primer tramo de trabajo del equipo comunitario de lectura (mayo y junio) y para redistribuir a las mediadoras en el próximo bimestre: agosto y setiembre.

Comienzan comentando sobre las mamás que no pudieron asistir los últimos días a leer porque estaban enfermas. Laura comenta que Andrea B., quien estuvo enferma, le avisó por Wathsapp que esta semana retomará sus lecturas. Mariela informa que "el último mes fue bravo», que muchos niños y maestros estuvieron enfermos y que la asistencia a la escuela se vio mermada.

Janet, quien se ausentó unos días por enfermedad de su bebé, dice que a su regreso los niños la esperaban con mucho entusiasmo y agrega: «El caso mío ni hablar. El caso mío ni hablar. jimagínate! era llegar yo de vuelta y era como... pero ellos ya me conocen y el crecimiento de los niños es extraordinario, la verdad».

Mariela indaga sobre cómo se sintieron las madres en el acto de lanzamiento del proyecto, que se realizó en mayo. Comentan entre todas lo bien que se portaron los niños; las mediadoras vivieron esta instancia con mucho agrado: «Ustedes estuvieron de lujo», afirma.

Andrea A. refiere a la integración de los chicos nuevos que ingresaron a la escuela este año: «Un tema aparte es la integración de los chicos nuevos que vinieron a la escuela. Porque hay muchos que... en cuarto, que estuve yo, y en quinto, principalmente, ingresos nuevos que no sabían lo que era [Biblioteca Solidaria] le fueron comentando los compañeros y ise prendieron enseguida! El tema de que intervenían, hablaban, se reían mucho. Hay lecturas que a ellos los enganchan porque el libro ese que yo les estaba leyendo en capítulos trataba mucho sobre lo que era la adolescencia de los chiquilines, el primer despertar, de un niño enamorándose de una niña, las aventuras de ser chico y pasar a adolescente. $Y$ era como que estaban en una nube los chiquilines. Se transportaban. La verdad que divino».

Mariela les pregunta sobre el clima de trabajo en las clases y la actitud de los niños, su participación. Todas las mamás opinan que trabajan cómodas.

Janet cuenta que los niños de segundo le reclamaron que leyó un cuento que ya habían leído el año anterior: «Ellos te decían "Ese libro ya lo leí". Entonces yo les digo: "Bueno, pero si este libro ya lo leímos vamos a refrescar, a ver qué te acordás vos del libro". Entonces ellos empiezan a atender y empiezan a refrescar y se acuerdan (???) y dicen: "A ver, déjame pensar". Esto es como refrescando la memoria, a ver lo que ustedes se acuerdan, porque esto estamos hablando que lo leyeron el año pasado».

Margareth interrumpe: «A mí me pasó mucho que los tenían en la casa los libros: "El libro ese lo tengo en mi casa. Yo ya lo leí. " Bueno, si lo leíste me tenés que ayudar a leerlo». 
Laura acota: «A mí lo que me pasó más en jardinera es que sacan los libros por las películas. Los cuentos clásicos. "Yo vi la película y ahora pasa esto y ahora lo otro...". No te dejan leerlo porque te lo cuentan ellos y aparte... "No, vamos a escuchar, vamos a escuchar porque hay compañeros que no las vieron. ¿Cuántos no los vieron?" Y son dos y los otros quedan así. Y ahora pasa esto y ahora lo otro, no te dejan leerlo porque te lo cuentan ellos. Viste que la película es más extensa que el cuento. "Y te falta esta parte. Y te falta esta otra parte. Pero vos no nos leíste esta parte. Pero no está en el libro esto. El libro es distinto que la película"», la mediadora trata de hacerles entender que la trama de los cuentos y la de las películas pueden ser distintas. A pesar de ello dice: «A mí me gustó trabajar más en jardinera y cuatro años que con los niños más grandes».

Mariela opina al respecto: «Con la tecnología están avanzadísimos» y agrega que está bueno que conozcan las diferentes versiones del cuento.

La reunión continúa; Andrea A. comenta que el grupo de cuatro es un grupo muy especial, muy participativo. Compara su experiencia de lectura en inicial este año con la del año anterior: «Cuatro es un grupo muy especial. iIntervienen de una manera! Hay uno o dos casos, una o dos nenas y se enganchan todas las demás y se enganchan todos los varones. Interactúan y te preguntan y te dicen. Y van y le preguntan a la maestra. La maestra interactúa con ellos. El algo que... el año pasado con cuatro y con cinco yo no lo noté, sí lo noté con cuatro años este año. Intervienen muchísimo, muchísimo».

Janet asiente: «Este año no fui a primero ipero en segundo, en sexto, en las demás clases... sexto!»

Andrea A. está impactada de la respuesta de los grupos de cuatro: "Cuatro años es una delicia, sinceramente una delicia. Es una cosa... son divinos». Janet agrega: «Se hacen. iSon divinos, divinos, divinos!».

Andrea A. se asombra de que los niños tengan opinión crítica sobre lo que leen: «Yo te digo: ese día salí con la boca acá. Porque me llamó la atención poderosísimamente y muy alto el tema valores. ¡Cómo intervienen y tienen opinión crítica! Eso es lo que más me llamó la atención».

Laura reclama: «Que para ser tan chiquitos vos no tenés los libros. En realidad a mí me pasó».

Janet relata que en otros jardines del barrio también se están implementando las bibliotecas escolares en los grupos de dos y tres: «Aunque ahora también se está implementando mucho la biblioteca en tres también. Se está implementando mucho también la biblioteca en dos y tres. Porque en el jardín de dos y tres que está acá abajo que tiene cuatro, cinco y seis... Otro que está ahí, el de la Intendencia, mi nieta va ahí y con tres años ya tienen sus cositas pa poner los libros, y como una biblioteca chiquita pa ellos. Está muy bueno». Laura también realiza un comentario al respecto: «A nivel de cuatro se está haciendo la biblioteca. Están juntando libros para ellos mismos. Tienen una caja grandota. Me la mostró la maestra. Y todos traen libros. Y se ponían a revolver, viste: "Y este lo traje yo. Y este otro lo traje yo. Y este me lo dio mi mamá". Cuando hacía cinco años después me iba para cuatro. Y salían cuando el profesor [de Educación Física] los venía a buscar. "Los están esperando ahí" ». Las madres se ríen frente al hecho de que los niños prefieran quedarse con la mediadora que ir a la clase de Educación Física.

Al respecto, Mariela les comenta que los niños van a preguntarle sobre las mediadoras cuando estas nos llegan, que las están esperando con ansias: «¿Qué pasa con las que leen?». 
Janet continúa: «A mí me pasó el caso de que los niños de sexto me hicieron una pregunta: "Y vos a qué venís". Porque yo soy de afuera. No tengo a nadie acá. "Pero bueno ustedes son hijos postizos. No me puedo desprender de ustedes. No puedo cortar". Porque a Ángel le faltan como cuatro años para venir». Las mamás bromean que a su bebé le faltan unos cuantos años para empezar la escuela, pero que lo va acostumbrando. La mediadora informa que va a ir a leer al jardín de su nieta en el que también se desarrolla Biblioteca Solidaria, a solicitud de su hija a quien no le gusta leer: «De igual manera ahora me invitaron para el programa ProLEE que tienen también en el jardín. Mañana tengo que ir, pasado mañana, porque es mi nieta que va ahí. iY a la madre no le gusta nada! Y entonces me mandaron un libro para que lo prepare todo. $Y$ mañana tengo que ir a cuatro y cinco. Y mi nieta me dice: "Abuela, mirá que el miércoles tenés que ir a leerme." "Sí, yo voy", le digo. Y a mí como que me da... Es para adelantarla a ella. Pero está bueno integrar... Mismo en el habla, en el razonamiento... Hay partes del libro que de repente, vos le leés uno de Peter Pan que ellos... o Blancanieves "¿Y de qué estás hablando?". Porque ahora, como vos decís, es todo dibujitos, computación, agresivos, pero no hay una Cenicienta...».

Estas últimas palabras de Janet dan pie para desviar la conversación y distenderse hablando de los dibujos animados que miran sus hijos y nietos. La maestra referente las escucha con respeto y comenta lo difícil que es que la lectura compita con la televisión.

Janet comenta con nostalgia las diferencias entre los libros de cuento que leen sus hijos y los libros «de antes» que leía ella cuando era niña: «Yo lo que he visto ahora en los libros por ejemplo hay diferencias ¿viste? Vos mirás los libros de los de antes y mirás los de ahora, algunos tienen relieve otros tienen formatos diferentes, atrás los colores, que eso también como que los atrapa. Yo por supuesto tengo libros viejos y se ve la diferencia de uno y otro. Entonces vos los ponés frente a dos libros y siempre te va a agarrar el de relieve o el que tiene más fotos».

Mariela evoca los libros clásicos de su infancia, sin colores ni imágenes. Las mediadoras asienten. Janet continúa: «Sí, sí, sí. El formato nuevo de los libros como que les interesa más. También debe ser para que los chiquilines también le den un poco más de interés a los libros ¿no? Porque puede ir a la biblioteca y agarrás los libros y de repente como sos un niño en la biblioteca no te vas a agarrar un libro clásico; agarrás aquel que tiene dibujitos, que tiene un relieve, que tiene algo como para armar como un rompecabezas. Es como interactivo. Que tenga algo como un juego, un juego como para leer. Ahí va: la lectura es un juego».

Mariela interrumpe comentando que a la escuela han llegado libros nuevos. Los trae y los muestra. Las mamás los hojean con atención. Les comenta que se han presentado a los fondos del proyecto Podes ${ }^{8}$ para poder comprar más libros.

Se hace silencio mientras hojean los libros nuevos y Andrea A. aprovecha para contar sobre su última lectura en inicial con el libro que le recomendó Mariela: «No sabés el laburo que me tocó hacer con el último libro que me diste para inicial. Era sobre el tema... No te metas conmigo. Pero para cuatro años me costó... las palabras. Porque trata el tema de... sobre los abusadores, entonces costó, pero que después se engancharon de una manera que la verdad me quedé... ianonadada!», dice con mucho énfasis.

\footnotetext{
${ }^{9}$ Los fondos de Podes financian a aquellas escuelas Aprender que, mediante la presentación de un proyecto, justifiquen la inversión.
} 
Janet recuerda: «Yo el año pasado que había una colección arriba de una biblioteca de los más chiquititos. Unos libros chiquitos: Esperando un bebé...».

Margareth la interrumpe para contar su experiencia de lectura en segundo: «Yo, en segundo, yo les leí un libro que traje de casa, que tiene muchos cuentos, que se llama Cuentos para dormir. Y se engancharon muchísimo, segundo año las dos clases. Mirá que inclusive las maestras me lo pidieron para sacar fotocopias y cosas para hacer, porque los atrapó. Yo después si querés te lo traigo porque tenemos que rotar. Yo estaba media indecisa porque aparte es un libro grande y pesado (se ríen todas), pero lo eligió Bayron. Son cuentos cortos. Son muchos cuentos cortos, y hay fábulas ¿viste?, tiene diferentes cosas, y entonces los atrapó a los gurises. Aparte inclusive yo se lo plantee a las maestras porque me lo pidió Bayron. Entonces le digo: "pero vos ya te lo sabés de memoria". Y él dice: "pero yo quiero que mis compañeros lo escuchen porque a mí me gusta". Porque él cuando está que se aburre de mirar tele y eso te dice: “¿me leés tal cuento?”, aunque se los sepa de memoria».

Continúan mirando los libros atentamente. Janet dice: «Hay muchos cuentos cortitos que son más para los chiquititos y hay otros que son más elevados como para los grandes. Los derechos y los deberes, por ejemplo, yo lo leí en cuarto y en quinto y estuvo muy bueno, por el tema de la discriminación y todas esas cosas. Entonces ellos se veían y aparte yo, en mi caso, hago una autoevaluación con ellos. Que participen qué es lo que hacen mal dentro de lo que el cuento les enseñó. Y ellos se autoevalúan».

Mariela interrumpe y consulta a las demás mediadoras: «¿Hacen ustedes una autoevaluación con ellos? Preguntan de qué se trataba, los personajes... ¿¿sí?». Las mediadoras asienten; Janet le responde: «A veces ni es necesario preguntar» y Margareth acota: «Ellos te hablan o te interrumpen en el cuento: “¿Viste que tal cosa?”. Actúan, aparte que participan mucho. Mirá que yo tuve quinto y segundo, pero muy bien. Bien diferentes. Aparte que en quinto yo tenía temor, pero no, vos sabés que no, muy bien la verdad». Laura agrega: «A mí a veces como que me da chucho». Mariela la tranquiliza: «Los gurises se enganchan», y comenta como anécdota una actividad en la que participaron todos los niños de la escuela sobre Peter Pan en la que se mostraron muy entusiasmados.

Comienzan a conversar sobre la obra de teatro que tienen intención de preparar para el Día del Niño (segundo fin de semana de agosto) como un obsequio del equipo lector para todos los niños de la escuela. Esta actividad fue propuesta por Andrea A. y Rosario. Mariela aclara: «La podemos hacer por grupos; no tenemos por qué hacerlo con toda la escuela al mismo momento».

El bebé de Janet comienza a llorar e interrumpe la conversación: «Esto tiene potencia», dice su mamá. Las participantes de la reunión dirigen su atención hacia él. La mamá comenta que le están saliendo los dientes y agrega: «Empezar de vuelta después de trece años». Los siguientes minutos conversan sobre el bebé. Janet comenta que «tiene pegote» con su madrina que es Andrea A.

Al finalizar este episodio, Mariela propone organizar el cronograma de rotación para el próximo período. Le solicito a Rosario si puede quedarse algunos días más en tercero: «Unos días más puede ser, Rosario». La mediadora asiente. Sus compañeras y Mariela le increpan que ha permanecido callada toda la reunión y ella se justifica por su cansancio: «Yo que trabajé ayer». Janet bromea: «Ahora yo te paso al gordo y te despertás enseguidita. No te hagas problema». Todas se ríen.

La maestra referente indaga: «¿Cómo quieren hacer? ¿Quién baja y quién sube?». Andrea A. informa: «Tengo el cuento que yo no terminé. Yo estaba en quinto. Vos te acordás que en una yo no había venido 
y después no vino la maestra. Y con uno llevo más adelantado y con otros menos. Y tiene como dos capítulos de uno y en otra como seis». Mariela propone que le pase el libro a Patricia quien tomará su lugar en quinto.

Laura comunica: «Yo me perdí. Ya me habían cambiado. Yo no vine. Hicimos el cambio y yo no vine. Creo que era en tercero que me habían dicho».

«Bueno, chicas, tengo para elegir: inicial, primero, segundo, cuarto y sexto», reclama la maestra referente. Andrea A. dice: "A mí poneme en cualquiera» y Janet le contesta: "A mí dame primero. Porque el año pasado me quedé con las ganas: primero (se ríe)». A inicial irá Mónica, Margareth a segundo, Rosario quedará en tercero, Laura irá a cuarto, Patricia a quinto y Andrea A. en sexto. Janet compartirá el nivel con Andrea B.

Mariela comenta que se va a integrar al equipo comunitario de lectura una abuela, quien hará las suplencias. Las mamás consultan quién es, pues no la conocen.

Janet aporta para leer en primer año el libro que le entregó en el hospital el programa Uruguay crece contigo de Presidencia de la República", cuando nació su bebé: «A mí me dieron este libro que está bueno. Esto me dieron cuando nació él. Pero mirá vos, viene con todo. Trajo un CD. Tiene, por ejemplo: (lee el índice del libro), "Está bueno conversar", "Bienvenido el bebé", "Los primeros colores", "La cocina de mi casa". Y aparte que trae folletos».

Laura la interrumpe para contar que su hermana tiene un bebé de dos meses: «Es obsesionada. Lo que le dice la pediatra al pie de la letra. Y se puso a leer el librito ese y ahí entró en discusión. Porque el libro dice una cosa y la pediatra le dice otra. ¿Y a quién le hago caso?». Las mamás se ríen con esta anécdota. Janet continúa comentando: «Es todo una cosa que sacó el Ministerio. La edición que sacó el Ministerio entonces acá te pone los años que van de cero y cinco años. Y viene con todo, con el CD que lo escucha todo el día, que viene con música para ellos. Es muy bueno. Tiene todo. Es de la Presidencia de la República, de Uruguay Crece Contigo. A todos les dan. Cuando él nació me dice la doctora: "Es un regalo pa' usted", aparte de lo que da la Sociedad ${ }^{10}$ ¿no? Supuestamente esto lo tienen que dar Salud Pública, pero no lo dan, me parece».

Las mamás se distienden con el bebé y entretanto llega Patricia de leer en sexto (aproximadamente a las 9.00 horas). Saluda con un beso a todas muy animada y toma en brazos al bebé de Janet.

Mariela interrumpe la conversación informal y consulta sobre los libros leídos en inicial: La cartera de mi abuela (Magdalena Helguera, con ilustraciones de Verónica Leite, editorial Alfaguara) Winnie y los dinosaurios (Valerie Thomas y Paul Korky, editorial Océano), Olegario y Una Pindó (Susana Olaondo, editorial Alfaguara Infantil). Laura acota: "Yo les llevé, un día que Margareth no pudo ir, yo les leí el que le estaba leyendo a primero: Niña Bonita. Y luego les leí Olegario». Andrea A. agrega: «Yo cuando hice la suplencia en inicial me diste No te metas conmigo».

En primero, Sapo enamorado, Sapo tiene miedo (Max Velthuijs, editorial Ekaré), Niña bonita (Ana María Machado, con ilustraciones de Rocío Faría, editorial Ekaré).

\footnotetext{
9 Esta publicación se entrega a todos los padres de los recién nacidos en Uruguay, junto con set de bienvenida para promover el desarrollo integral de los niños y niñas.

http://crececontigo.opp.gub.uy/inicio/multimedia cc/presentacion se bienvenida ucc opp\#.WIJJ6qjibIW [12.2016].

${ }^{10}$ Servicio médico privado.
} 
Margareth informa sus lecturas en primero: «El último que leí fue En dónde está la pelota, los otros dos... creo que leí una vez Blancanieves y otro... no me acuerdo cuál fue que leí la primera vez».

En segundo las lecturas fueron Niña Bonita, Una pindó y Beso a beso (Margaret Wild, con ilustraciones de Bridget Strevens-Marzo, editorial Ekaré). Janet agrega que leyó en esta clase El baile de los bichos.

La maestra referente consulta a Rosario sobre las lecturas que realizó en tercero: Por un color, Julieta, ¿qué plantaste? La mediadora agrega: «Este el Perico, tenemos el de "Los hijos" y... el de "Los juguetes" y después el de la luz mala». Leyó también El baile de los bichos (Francisco Espínola, con ilustraciones de Silvana Franzani, Cal y Canto), en una ocasión en que Andrea A. no pudo concurrir a cuarto año ${ }^{11}$.

En cuarto año Andrea A. informa que leyó Cuentos por teléfono (Gianni Rodari, editorial Juventud): «Fueron varios cuentos del mismo libro y en quinto, este mismo libro y Buscabichos (Julio César Da Rosa, con ilustraciones de Banda Oriental).

En sexto Patricia leyó la novela Los fantasmas de la escuela (Ignacio Martínez, Ediciones del Viejo Vasa). Mariela le menciona que continuará leyendo este libro en quinto y que Andrea le pasará los capítulos que le falta leer. Patricia y Andrea A. revisan las partes de la novela Los fantasmas de la escuela que faltan leer y le dice que ese libro lo sacó de la «biblioteca de arriba».

Margareth informa otro de los títulos que leyó en primero: «Me acordé Mariela cuál era el otro que leí, era Mirasuelo12》. Laura recuerda: "A mí me faltan. Te acordás que una vez que yo llevé dos que eran bien cortitos, pero no me acuerdo». Al rato agrega: «¿Por qué no?, era uno» y rectifica «¿Por qué yo?».

Rosario recuerda otro título que leyó en tercero: «Después leí otro de una nena, que tenía un mensaje, pero no me acuerdo el nombre [piensa un momento]. De una nena que creo que había había fallecido la abuela, y se había ido de donde ella vivía. Se había ido para otro lado, pero no me acuerdo». Mariela le recuerda el título: Un puñado de semillas (Mónica Hughes, con ilustraciones de Luis Garay, editorial Ekaré) y Rosario asiente entusiasmada: «iAh, sí! Un puñado de semillas». Andrea A. acota que «ese libro es precioso».

Andrea A. recuerda un libro «de unos compañeros que acosan a otros compañeros y los tratan mal. Muy, muy bueno. iCómo sabían [los niños] lo que tenían qué hacer!».

Mariela les comenta a las mamás que va a armar un grupo de Wathsapp con los celulares de todas. Les propone subir a buscar los libros que leerán en el próximo bimestre y les pregunta: «¿Qué hacemos para el Día del Niño?».

Janet interrumpe: «El Sapo Ruperto lo tenés arriba ¿no?».

Andrea A. propone representar una escena del Chavo del 8 para celebrar el Día del Niño en la escuela. Rosario bromea: «¿Y quién es la actriz protagonista?», todas se ríen. Andrea agrega: «Disfrazarnos y chivear un rato». Mariela agrega: «Lo que ustedes quieran», que lo importante es ir ensayando.

Rosario hojea los libros que Mariela tiene en su biblioteca, le pregunta: «¿De estos se podían leer ahora hoy? ¿O estos los tenías vos en reserva por algo?». Hojea Cuando el temible tigre (de Virginia Brown,

\footnotetext{
${ }^{11}$ Menciona títulos leídos en todas las clases a las que fue a leer.

12 En referencia a Azul es el color del cielo, de Magdalena Helguera, con ilustraciones de Sebastián Santana (editorial Alfaguara Infantil).
} 
ilustraciones de Matías Acosta, Alfaguara Infantil). La maestra referente le responde que sí que puede llevarlos.

Las madres siguen hablando y bromeando sobre la obra de teatro, mientras Rosario continúa hojeando Cuando el temible tigre. En un momento interrumpe a la referente y le dice: «Mariela: para tercero lo agarro, ¿̇ta?», pero esta no le presta atención.

Mariela informa que se va a realizar una actividad para homenajear a los niños en la escuela y que tienen algo más de un mes para ensayar. Les propone ensayar los martes luego de las lecturas en las clases, porque los jueves y viernes los niños tienen clases de inglés. Les consulta si en lugar de la obra de teatro quieren hacer una obra de títeres.

Las mamás evocan el día de la presentación del equipo comunitario de lectura. Andrea A. comenta sobre el día de la presentación del equipo comunitario: "Se acuerdan que cuando representamos esas partecitas de cuentos, los niños «estaban todos expectantes. La verdad es que quedaron... la verdad bastante grato aquello que se les brindara algo. iLos niños tenían una novelería!». Las mamás se ríen cuando cuenta que los niños quedaron convencidos de que Patricia quedaría en el lugar de la maestra. Mariela las alaba: «iQué grupete!» y destaca lo importante que es la presencia de las mamás en la escuela. Rosario agrega: «Nos faltó la canción».

Janet propone: «Tanto sea una obra de teatro como una obra de títeres está bueno como se la hagas pero también como un mensaje, no tanto en el mundo de los niños, pero... estaba pensando en adultos ¿no?... ahí está. Como un mensaje del entorno en que están viviendo ellos, pero todo de parte del adulto, Como una perspectiva para ellos en el futuro. Cómo sobrellevar los tiempos que estamos ahora ¿no? Con la violencia, con todo eso, ¿no?».

Las madres y la maestra referente continúan intercambiando animadamente sobre la forma y el contenido de la obra de teatro. Patricia bromea: «A mí no me hagan bullyng... ¿ ¿no?», y todas se ríen.

Janet prosigue: «Porque viste que todas las obras de teatro son... medio educativas, pero no son de... lo mismo el tema de los niños hiperactivos que vos lo ponés por allá...y cómo recibirlos el niño (???) se va después de las cuatro horas y lo que vive y ¿no?. Y lo que te trae acá y lo que afecta en el entorno... Como que te ponés dentro de lo que va pasando, y sacando que ellos son niños que tienen que jugar, que tienen que aprender, que no tienen que tomar tan a pecho todo lo que está pasando afuera. Yo pienso de esa manera porque escuchando y mirando todo uno aprende ¿no?». Comenta sobre su hija y las vivencias en enseñanza media, desde que salió de la escuela: «Ahora me sale con cada una que...». Mariela les propone entonces armar un guion para la ocasión.

Las participantes de la reunión continúan hablando sobre la violencia en la sociedad, las actitudes de sus hijos... cuentan anécdotas diversas, sobre los viajes en ómnibus. Entremedio, Rosario comenta: «Es una orden municipal que los niños tienen que ir sentados» y Laura reafirma: «Es una orden municipal».

Mariela retoma las riendas de la reunión: convienen en que van a recrear una jornada escolar con distintas situaciones vividas en el día a día y Janet agrega: «Pero terminar con un mensaje». Dice: «Podríamos hablar de las llegadas tarde». Todas las presentes estallan en risas. Mariela comenta que también podrían trabajar los saludos de buen día, pedir permiso.

En los últimos minutos de la reunión la conversación vuelve a virar hacia las anécdotas: los padres que quieren que sus hijos sean abanderados en la escuela. Rosario comenta al respecto: «Y de repente los 
padres se piensan que porque su hijo pasó con sote va a ser el de la uruguaya y no porque después es por votación y después los padres no están conformes».

La maestra referente y las mamás coordinan que se juntarán para preparar la obra de teatro los próximos martes. Rosario dice: "Andá diciéndole a las maestras que vamos a precisar túnicas. Andá pidiéndole a Sonia, a Miriam... no vayas a pedirle a Nadia para mí porque...»; y todas se ríen.

Mariela les comenta que el viernes 24 de julio se realizará el encuentro de los equipos comunitarios de lectura en el parque Bellán a las 13.30 horas y que podrán ir todas. Rosario bromea: «Vas a tener que actualizarte, Andrea». Mariela dice que les va a pasar la información por el grupo de Wathsapp que va a crear, y Andrea informa que tienen un grupo de Messenger con las mamás que estaban en el equipo comunitario el año pasado. Comentan que estas mamás «viejas» se conocen desde hacen años, cuando sus hijos comenzaron la escuela. Rosario le pregunta a Mariela si conoce a una maestra de la tarde, quien le pedía que cuando su hijo comenzara primero lo pasara para la tarde. Este comentario da pie a que Janet pregunte: «¿`Y de tarde cómo anda lo de ProLEE?». Mariela le responde que no sabe; no tienen comunicación porque son dos escuelas separadas, que el año pasado no habían armado el equipo comunitario. Janet agrega: «Las maestras no leían, el año pasado leían las maestras, solo que una madre nada más». Laura agrega que le comentó a una madre de la tarde: «Pero vos sabés que yo tengo una conocida que trae al niño acá en la tarde. Y yo lo que le hablado es lo que hacen. "Pero ahí no hacen esto. Pero con mi nene no hacen eso. Pero con mi nene no hacen lo otro." Y así viste que vos decís...». Janet la interrumpe: «El programa en la tarde está muy apagado, muy apagado». Mariela las entusiasma: "lo que pasa es que si los padres no responden... porque nosotros incentivamos, motivamos, los llamamos. Pero si ustedes no están, yo no puedo seguir adelante, ni nosotros ni la escuela ni nadie. Porque los podemos citar un montón de veces nosotros, pero de repente queda uno para toda la escuela, se agota, dos días lo hace. No podés. Porque nosotras venimos del año pasado también, pero algunos que estuvieron, eran dos o tres hasta el final remando los últimos tiempos, los últimos tiempos, un montón de clases, somos un montón de clases, la escuela es muy grande. Nosotros este año venimos divino. Una por nivel, precioso. Este año venimos bárbaro. Más allá de que una se enferme y todo eso, seguimos al firme. El año pasado habíamos empezado muy bien, pero después a fin de año quedó un poquito más... se recargaron algunas ¿no? Pero se terminó divino igual ¿no? No podemos decir nada porque los resultados bárbaros a pesar de que... claro».

Janet asiente y agrega: «Es ese el tema. Es una iniciativa de ellos. Pero el año pasado venían los padres y leían en el grupo del hijo y nada más». El resto de las mamás asienten con la cabeza y Mariela acota: «Este grupo bárbaro, pero el resto es lo que pasa...»; es una integración» agrega Janet.

Rosario interrumpe y le pregunta a Mariela: «¿Me llevo este? ¿O te lo dejo o vos me lo das?». Y se lleva Cuando el temible tigre, con la autorización de la maestra referente.

Patricia le dice a Mariela: «Me llevo este ¿ta?», en referencia a Los fantasmas de la escuela.

Mariela pregunta si alguien precisa libros de la sala de lectura y le comunica a Mónica que tiene ir primero con el grupo de cinco y luego con el de cuatro porque los niños tienen clase de Educación Física. Laura le aconseja: «Yo había dicho, hablá bien, porque a la maestra de cinco le queda mejor que yo fuera nueve menos cuarto, y coordinaba bien, salía cuatro de gimnasia y yo entraba. Para que no te quedes esperando, hablá bien con ella, que ella me había dicho que empezara nueve menos cuarto». 
Elige luego el libro El miedo a la luz mala (de Verónica Leite, Alfaguara Infantil) y pregunta: «Para cuarto está bien este?», y Rosario le responde "A tercero les encantó ese. Está bueno».

Le comento a Mariela que los cuadernos para los equipos comunitarios están en la inspección, pero ella no vio a la secretaria de la escuela para solicitárselos.

Le pregunta a Rosario: «¿ ¿ Vos seguís en tercero?» Y esta le responde: «Yo sigo en tercero y tengo que buscar libros para leer». Yo le comento que traje algunos libros para que ella y Patricia lean para mi investigación. Les pido si se pueden quedar un momentito después de la reunión para conversar sobre esto.

Andrea A. rechaza el libro que Mariela le da: «Me corren de segundo con ese, me parece». Entonces Janet le recomienda: «Yo tengo un libro de fábulas. Está buenísimo, está buenísimo. Tengo que meterlo en la bolsa».

Las mamás se dirigen a la biblioteca de la escuela con la maestra referente, se retiran riéndose y conversando. 


\subsection{Caso 3. Rosario}

\subsubsection{Entrevistas}

\subsubsection{Entrevista a Rosario}

Fecha y hora: $05.11 .2015,10.30$ horas

Lugar: comedor de la escuela

Participantes: Rosario, investigadora

Sandra: Rosario las preguntas que te voy a hacer ahora es para complementar | las observaciones que:: || que yo hice en el trabajo de campo | ¿sí?

Rosario: \{mueve la cabeza [asiente] mientras busco el cuestionario\}

Sandra: ¿vos estás en el equipo comunitario desde el año pasado | o ingresaste este año?

Rosario: no | ingresé este año

Sandra: ¿y por qué decidiste integrarte al equipo?

Rosario: porque me parece un proyecto bueno | compartir con los chiquilines | compartir con mi propio hijo | que si bien no siempre va a ser para la clase de él | a él le pone contento que uno participe || sí y me interesan los temas | sociales || fui postulante a concejal vecinal | salí | y siempre ando metida así en esas cosas

Sandra: ¡buenísimo! | ¿vos cómo vivenciás cuando vas a la clase la lectura con los chiquilines?

Rosario: precioso | la atención $=\ldots . . .=$

Sandra: $=\ldots . . .=$ ¿vos cómo te sentís?

Rosario: bien de bien la atención que ellos te prestan | después que te ven | recorriendo la clase | o te dicen «ahí va la mamá de fulano» || o en la calle | en la almacén te saludan | la otra vez íbamos con otra mamá de lectura y nos saludaron | y dijimos «ta tiene que ser de la escuela | \{porque no sabía ni quién era el niño (risas)\}

Sandra: yo escuchaba ahora que te aplaudían

Rosario: isí!

Sandra: en tercero también te aplaudían cuando terminabas de leer | y cuando entrabas a la clase también te aplaudían

Rosario: porque para ellos también debe ser bueno porque saben que uno no trabaja pero saben que uno está brindándoles | un pedacito de nuestro tiempo de nuestra atención | de nuestras ganas de venir a compartir con ellos

Sandra: vos pensás que:: | ¿a ellos cómo les beneficia eso | la lectura? | ¿tienen algún aprendizaje?

Rosario: sí | creo que sí | que los ayuda | cada día | el mundo que va...- | se va yendo para los costados | está bueno que ellos vayan leyendo | que les guste desde chicos |y a su vez van creciendo | los textos van cambiando | y sí |me parece que fomenta | fomenta mucho 
Sandra: bien ¿y:: pensás que al maestro le sirve que venga el equipo?

Rosario: sí | sí | porque debe servir también para observar | ver | cómo son con ellos | como son...- | lo de ellos debe ser más pedagógico | lo de nosotras debe ser algo más como por el lado | de:: la mamá que vienen a leer | no sé cómo explicarlo

Sandra: ¿recreativo?

Rosario: recreativo| lo de ellos debe de ser algo más pedagógico ¿qué debe ser? ¿qué hacemos? ¿cómo era el cuento?

Sandra: ¿y vos cómo vivís ese momento?

Rosario: se disfruta mucho | se disfruta

Sandra: ¿`vos qué observás en los chiquilines cuando les estás leyendo?

Rosario: prestan atención || muchos se dejan llevar por la imaginación | hay alguno que se distrae pero | de repente vos venís al otro día y está súper atento | me parece que a ellos les ayuda mucho

Sandra: ¿hay alguna anécdota que te acuerdes? | de todas las clases que fuiste a leer

Rosario: no | eso de que a medida que vos vas leyendo ellos te van diciendo | iah::! | y ves la foto | y vos ves que ellos se enganchan y está buenísimo

Sandra: de todos los libros que leíste | ¿hay alguno que te haya gustado má::s?

Rosario: sí La luz mala | no...-

Sandra: ¿El miedo a la luz mala?

Rosario: El miedo a la luz mala | es el que más me gustó y el que más observé que a ellos les encantó

Sandra: ¿y por qué creés que te gustó a vos y a ellos también?

Rosario: porque es como que te hace...- | justamente hablando de volar la imaginación| es como que te hace...- | como una fábula | como algo que te hace imaginar cosas

Sandra: ¿los títulos generalmente que ustedes leen quién los elige?

Rosario: los elegimos nosotras | o una mamá dice «mirá dijeron que querían algo como de cuento como de la selva» como...- | nos vamos diciendo | sino las maestras muchas veces nos aconsejan

Sandra: yo veo que ustedes como grupo trabajan muy unidas | muy coordinadas muy compactas

Rosario: una vez me pasó que fui ahora a primero | a primero hace dos martes atrás | y justo estaban hablando en el pizarrón estaba | de animales | separándolos por grupos y justo yo caí con un cuento también de animales y...- | me dice la maestra «así ideal»

Sandra: ¿pero lo habías elegido vos?

Rosario: lo había elegido yo |

Sandra: ¿cuál era ese cuento te acordás? | ¿o quién era el autor?

Rosario: no no recuerdo ahora cuál era || pero sí fue...- | aparte hablaba de animales que no...- | no tan conocidos como perro o gato | eran otro animal pero no recuerdo ahora el nombre 
Sandra: bueno no importa | ¿vos empezaste...- | ustedes empezaron en mayo o en abril por allí?

Rosario: en abril más o menos

Sandra: ¿y siempre has venido?

Rosario: sí

Sandra: ¿vos sentís que cambiaste a::Igo con la experiencia de lectura por ejemplo?

Rosario: yo pienso que ya cambié cuando hice el encuentro | en:: la otra escuela e::n parque Bellán | ahí yo ya cambié | la forma de leer de pararme ante a los chiquilines | ya me solté un poco más || te enseñan...- | aprendí lo práctico | porque yo iba y les iba leyendo | y les iba mostra::ndo | y no | ahí te enseñan a que tenías que leer prime::ro | después mostrar la imagen para dejar que ellos vayan...- || me ayudó empila $\mid \mathrm{y}$ ahora me siento $=\ldots . . .=$

Sandra: $=\ldots . . .=y$ con la experiencia también

Rosario: $=\ldots . . .=$ con la experiencia también

Sandra: te iba a preguntar cuáles son tus lecturas favoritas | ¿algún género que vos digas bueno |me gustan los cuentos de tal cosa o los cuentos de tal otra?

Rosarios: todos todos | me parece que todos los libros tienen sus...- | sus secretitos su magia

Sandra: ¿y de los libros que les gustaron más a los niños de los que les has leído?

Rosario: de los que:: | tienen así como misterios | como cosas así | como lo de la luz mala | cosas que no saben lo que va a pasar al final |

Sandra: ¿vos leíste en inicial? | ¿¿n qué clases leíste?

Rosario: yo leí en primero segundo tercero cuarto

Sandra: o sea que en casi...- | menos en las clases grandes en casi todas

Rosario: sí

Sandra: ¿y hay alguna clase en especial que vos digas iah! esta clase me gustó más?

Rosario: creo que en tercero | a lo que participé más en tercero | como que nos conocíamos y era...fue más fluido

Sandra: ¿te acordás cuando leíste?...- | esto fue hace mucho tiempo | vos leíste La manta de las historias | ¿qué te acordás de ese día?

Rosario: sí | me acuerdo de que los chiquilines se engancharon mu::cho | con el tema de que:: | de todos iban aportando cosas en el cuento | y:: | estuvo bueno | el otro que me encantó fue el | el León de biblioteca | ese también

Sandra: ese les encantó

Rosario: ese también | a mí me encantó ese libro

Sandra: yo pensé que iba a ser difícil | pero no || les gustó mucho 
Sandra: y de ese día en particular | del día de La manta de las historias | de ellos | ¿hay algo más que te acuerdes?

Rosario: sí | que estaban muy...- | muy enganchados ese día con el cuento | les encantó | aplaudieron mucho | participaron

Sandra: ¿te parece que estuvo bien elegi::do?

Rosario: sí | sí <5> y dejó como:: un final | abierto ¿no?

Sandra: cierto sí || era un final abierto | bueno y ahora un poquito | contame sobre tu historia lectora | ¿vos siempre fuiste lecto::ra?

Rosario: no

Sandra: ¿ 0 te fue gustando a medida que $?=\ldots . .=$

Rosario: $=\ldots . . .=$ sinceramente no $\mid$ cuando yo iba a la escue::la al liceo estaba medio $\mid$ medio peleada con los libros | por decirlo de alguna manera | [enf.] y sí |aparte me ayudó a mí para mis hijos | el leerlo con ellos | practicarlo con ellos | me ayudó a mí a leer | ayudó a ellos

Sandra: ¿y ahora vos decís que te gusta leer?

Rosario: sí

Sandra: ¿vos sin ser los libros de acá vos leés otras cosas?

Rosario: sí | mi hija también tiene sus libros | de adolesce::nte | desde que empecé acá me estoy enganchando | veo un libro y ta | me engancho

Sandra: ¿pensás que es importante? ...- | hoy ya me dijiste algo hoy cuando empezamos a hablar | ¿qué opinión tenés de que los papás las mamás los abuelos vengan a la escuela a leer?

Rosario: $y::$ es importante

Sandra: ¿y por qué es importante?

Rosario: primero a nosotros como personas nos hace bien | segundo que a ellos les gusta que uno participe | y si es para lectura más me parece | yo participo en todo taller de lectura de lo que sea pero me parece que de lectura está muy bueno | y me parece que hoy en día nos falta leer mucho

Sandra: ¿qué consejo les darías...- | por ejemplo el año que viene si se arma el equipo comunitario y vienen | otros papás | ¿qué consejo le darías a esos padres que se integran a esos abuelos?

Rosario: que se den el tiempo de compartir | que vean | sus hijos sus nietos cómo lo disfrutan | y lo bueno que pueden hacer por | por los demás || y que:: se van enganchando uno y otro y se van enganchando más | de repente nosotras de mi grupito de las mamás que no se animaron que eran muy tímidas | capaz que el año que viene las podemos terminar de convencer

Sandra: sí sí | ustedes tienen un grupo muy lindo | muy sólido

Rosario: sí sí | me parece que es un aporte | más allá de lo que hacemos de leer estos diez quince minutos | me parece que es un aporte seguir incentivando la lectura | en un mundo tan tecno...-

Sandra: tan tecnologizado 
Rosario: tan tecnológico | como vivimos | como que se pierde un poco

Sandra: $\mathrm{y}$ si ahora les das a los chiquilines un celular o un libro $=\ldots . . .=$

Rosario: $=\ldots . . .=$ ya ahora...- $\mid$ hasta la hora de hacer los deberes ya cambió uno | porque antes uno agarraba un libro | iba al índice y:: | buscaba el tema y ahora uno va y googlea | me parece que:: | está bueno incentivar la lectura | que no se pierda eso | me parece que los libros abren cabezas

Sandra: es verdad eso || ¿cómo son las maestras con las mamás lectoras? | ¿todas las maestras son igua::les? ¿dan cabida?

Rosario: sí sí

Sandra: ¿y cómo se sientes ustedes?

Rosario: muy cómodas la verdad | y nu::nca hubo una clase...- | porque por ejemplo | cuando tuvimos el encuentro se hablaba de | de cómo hacer de trucos para lograr la atención | me parece que ningu::na tuvo problemas en ninguna clase | si bien a veces pueden estar más dispersos que otros días nunca tuvimos un problema de atención | o que se tuviera que cortar un li::bro |nada | me parece que eso también viene desde el año pasado | y ellos esperan el martes ansiosos

Sandra: bueno era esto Rosario | son poquitas preguntas | ¿algo que me quieras agrega::r?

Rosario: no | que estaría bueno que esto se pudiera extender a más escuelas | sobre todas escuelas de contexto crítico | y se agradece que estén acá porque como madre uno agradece también | que haya un interés

Sandra: ojalá la escuela pueda seguir || la idea es esa de que...-| pueda cada uno | si les sirvió | incorporarlo y continuarlo | por lo menos si está el equipo en la escuela || bueno muchas gracias Rosario Rosario: no por favor | a las órdenes Sandra

(Continuamos hablando del acto de finalización del proyecto que se realizará próximamente.)

\subsubsection{Entrevista a Carmen, maestra de tercer año $A$}

Fecha y hora: $14.10 .2015,08.00$ horas

Lugar: salón de tercer año $A$

Participantes: Carmen, investigadora

Sandra: buen día Carmen ¿estás bien? las preguntas que te voy a hacer van a tener que ver con lo que vos observás | de los intercambios que los mediadores hacen con los niños | con el aporte que hacen

Carmen: bien [piensa] || bien

Sandra: la entrevista es eso | para complementar el trabajo de campo | si está grabando no tengo que anotar

Carmen: bien genial

Sandra: qué opinión por ejemplo tenés | de los mediadores cuando vienen a leer ¿cómo te resultó su trabajo en la clase? 
Carmen: yo creo que es muy positivo | porque o sea | porque las mamás cuando vienen a leer | son un un referente distinto del docente | el docente muchas veces tiene que leer | pero no solamente por el goce estético por el mero placer de leer de escuchar | una historia de escuchar un cuento |sino que a veces tiene que leer textos | textos de geografía textos que son de estudio que muchas veces son más densos | y la lectura siempre es una herramienta digamos | que está | continuamente presente en distintos campos | entonces se hace mucho más...- | a veces se hace mucho más tedioso que sea uno | por eso me parece positivo porque es una persona diferente | una voz diferente| hace que el que sea una persona diferente estimula | a los chiquilines de otra manera | viste que ellos están expectantes de que venga esa persona a leer | «ah ya te vas a ir | no vas a venir más| ah qué lástima» | viste que fue toda una aprehensión | me da como esa sensación que renueva motiva o estimula de otra forma | el que venga u::na persona que no sea el...- |siempre el mismo| es una voz distinta | es otra posición porque la mamá viene de otra manera con otras características con otra disposición | que a veces el docente está pendiente de | la conducta o de lo que sea entonces...- | y tiene otro manejo también de clase | se genera una relación con los niños diferente | entonces me parece que es muy positivo porque es totalmente renovador innova | ingresan digamos || otras cosas del afuera | tiene otra carga subjeti::va también | que está bueno | no sé | por lo menos me parece a mí | para los chiquilines acá es sumamente positivo

Sandra: ¿vos lo viste con las tres mamás que vinieron a leer?

Carmen: cada una | cada una de las mamás es distinto | tienen una forma diferente de para:rse de plantearse en la clase || yo he intentado respetarlas a toda::s con sus formas distintas | porque claro cada una tiene su personalidad diferente | esta mamá por ejemplo última || ella es como más...- | como más tranqu::ila |como...- | no le gusta...- | me da la sensación que le gustaba menos la parte de interacción entonces como que...- | ella leía el cue::nto | pero es más | más callada más escueta en su forma de ser entonces | como que no se daba capaz que tanto al diálogo | en cambio por ejemplo con otras mamás que han venido | que le gusta como esa dinámica de charlar con los ni::ños | se extienden en esa parte más de socialización con ellos || pero | yo creo que todas tienen su:: | su manera || porque es una...- | es como un estilo propio | cada uno tiene un estilo propio | cada una tiene su:: | su manera de ser su estilo su...- | entonces cada uno tiene distintos aportes | aparte cada uno se centra en lo que le parece importante a cada uno | algunas se centran más en la lectura propiamente el texto | otros en cuál es la interpretación que quieren | en conectar con la realidad | en experiencias | traen experiencias propias | hay como...- | cada uno desde su bagaje | tiene eso de...-|| de aportar de una manera distinta || yo creo que cada una de las mamás...- | nosotros trabajamos como...- | creo que con cuatro | sí cuatro capaz que con cinco | Patricia vino algunas veces | y las que estuvieron estables...- | Rosario fue la que estuvo más estable | la que vino durante más tiempo | y después vino bueno...- | Mónica me salía Sonia [enf.] nada que ver

Sandra: y vos de esos momentos de lectura | ¿qué rescatar del aporte que ellas hacen | por ejemplo de lo que vos observás en los niños?

Carmen: en los niños lo que más rescato es justamente eso la motivación | la estimulación | como se genera un ámbito de...- | capaz que si yo me pongo a leer el cuento | cualquier día | a cualquier hora || dentro de lo que fuera la planificación de la clase | yo creo que no se genera la misma respuesta | la respuesta que...- | justamente por esto que veníamos nombra::ndo | de ser una persona difere::nte | de venir...- | ser una mamá | como la mamá de cualquiera de ellos ¿no? |que lo hace especial | siempre 
hemos venido como recalcando mucho eso| bueno de valorar el tiempo de las mamás || porque sabemos que las mamás trabajan | que las mamás...- | muchas mamás no pueden venir pero quizás les gustaría haber venido | entonces se genera como una expectativa | que eso está...- | es bien lindo | y además mucho de estos cuentos han sido disparadores para otras lecturas | para otras lecturas en casa para otras lecturas en la clase || han sido motivadores || me acuerdo cuando leímos La leyenda de la luz mala | fue...- | fue como el disparador para trabajar y para indagar | para que trajeran materiales | respecto de esa leyenda y de otras | con las que seguimos trabajando | pero más que nada rescato eso | ser una persona | que dedi::ca su tiempo | yo creo que el niño valora mucho eso también || ser una persona que quizás deja su casa o su familia o se hace su tiempo| y ellos eso lo rescatan y lo escuchan con mucho respeto | porque | ha pasado que hay cuentos que no les han gustado || y más allá de que no les han gustado ellos han estado | siempre:: | en una actitud de respe::to de atención | y uno se da cuenta yo los miro de acá les veo las cara::s $\mid$ o algunas actitudes $=\ldots . . .=$

Sandra: $=\ldots . . .=$ ¿cuáles fueron esos cuentos que vos decís que no?

Carmen: que ha habido algunos cuentos que no tienen tanta llega:: da o quizás este $=\ldots . . .=$

Sandra: $=\ldots . . .=$ ¿pero vos te acordás cuáles fueron

Carmen: no sé ahora no me acuerdo | pero sé que ha habido algunos...- |algún que otro cuento que no han sido los que más les han gustado || otros al contrario || son los que más recuerdan ¿verdad? | que ellos siempre están comentando | siempre hacen referencia | ahora justo no me puedo acordar el título | pero tampoco fuero::n | no te digo que desagrado | pero fueron más tediosos aburrieron un poco más | la temática del cuento no eran el que más les atraía | yo creo que el que...- | era un lindo cuento | para mi gusto era un lindo cuento | era uno de unas semillas

Sandra: ¿Un puñado de semillas?

Carmen: creo que ese era el que::...- | yo no sé si era por el clima de cla::se | qué motivo | pero | fue uno de los cuentos que menos les...- | y me acuerdo que hablamos con Amalia | de que ese justamente tenía un lindo mensaje | y que ellos yo los había notado como medios...- | pero han sido como excepciones | con decirte que no me puedo acordar del título | creo que era ese

Sandra: sobre las semillas creo que es ese que me acuerde

Carmen: algo de las plantas | pero después en general siempre | se genera como esa cosa de mucha expectativa | con decirte que hoy me crucé una mamá en la puerta de la escuela y me dijo «Elías no va a venir | porque está enfermo me dice | pero no quería faltar | porque vienen las mamás a leer» | entonces se generan esas cosas que para mí son sumamente rescatables porque | impulsa a leer en casa a buscar | materiales sobre la temática de la que se leyó el cue::nto o...- || en general ha sido muy motivador

Sandra: ¿'vos ves que eso lo hacen? | ¿que van a leer después en la casa?

Carmen: mirá | ¿si ellos leen en su casa? | mirá son...- | la lectura viste que es un tema bien complicado | hay quienes la aman y quienes no quieren nada | y:: | en esta clase hay | varios niños digamos que | demuestran | gran interés por la lectura y traen libros| traen li::bros | participan de bibliotecas | hay de todo en la clase | hay niños | no son la mayoría| porque no voy a mentir no son la mayoría | que sí que traen estos materiales y que se intere: :san o que investigan en la XO o buscan audiocuentos | y 
traen a la clase y los pudimos escuchar | hemos leído novelas en la clase | los viernes y siempre un éxito total | siempre tratando de hacer el tiempo para poder leer el capítulo de la novela || yo | no sé si ellos son...- | si la idea es | consultarme si ellos son difusores | digamos de esta actitud lectora ¿no?

Sandra: continuadores

Carmen: | no sé | no me animaría a decirte que sí| no no me:: | no me parece | pienso que::| queda dentro del círculo más escolar | porque si | yo me pongo a mirar otros aspectos de la escolaridad | y no:: | no se nota esa | esa cultura lectora en | en otros aspectos | en el aspecto de la escritu::ra o:: |a la hora de crear un cuento por ejemplo de crear una historia no...- | a veces | yo que soy una muy lectora porque me encanta | siempre recurro a aquello que leí para poder escribir | acá no aparece | a veces el lenguaje es muy po::bre |entonces...- || igual ellos son niños | pero | no:: | yo...- | para mí no no sucede eso | puede ser en alguno dos o tres casos | Facundo por ejemplo | Facundo es un niño que:: I va a la casa y (pasa el profesor de Educación Física con los niños gritando) Facundo es un niño por ejemplo va a la ca::sa $y::$ | investiga pero tiene una avidez por su propia forma de ser | que bueno que los padres tratan de satisfacer y acompañar | tiene un hogar que impulsa | además es un niño | que tiene trastorno por déficit atencional | y es un niño muy ávido en todo lo que tiene que ver con las artes | entonces la familia acompaña eso | Facu::ndo Elia::na que va a una biblioteca | que siempre trae libros | Melina | son niños que...- | que está::n | de alguna manera los acompaña la fami::lia | o los llevan a la biblioteca |o los papás...- | en el caso creo que es Melina que el que su papá trabaja en el SUNCA | entonces le trae libros de una biblioteca | pero son muy pocos los casos donde | pasa eso que la familia también se involucra| en este proyecto por lo menos | después tenemos...- | bueno Abigail la mamá es una de las mamás lectoras | que es Rosario pero no Rosario la que venía acá la otra Rosario | así que::..| yo pienso que no | que no no se refleja en la casa eso

Sandra: bien | y si vos tuvieras que comparar por ejemplo cuando leen algunas mamás y cuando leés vos | ¿qué es diferente para vos en la respuesta de los niños? | en la respuesta de los niños ¿cuál es la diferencia?

Carmen: en la respuesta de los niños [piensa] yo lo primero que vi | la primera vez que vino a leer una mamá | la primera vez | cuando se inició | yo lo que...- | lo que veía | lo primero que vi | desde:: | la mamá y desde mí ¿no? | la postura de la mamá y la maestra es diferente | y el objetivo también | entonces me parece que el niño...- | que uno cuando...- | como docente interviene en la casa y hace una lectura | por más que uno quiera trabajar el goce estético siempre estás con esa intención de ir hacia determinadas cosas | de trabajar inferencias de trabajar determinadas estrategias de lectura | por más que estés | simplemente disfrutando | el texto | pero la intervención siempre de diferente | yo creo que el niño también | no sé | yo no lo estudié | pero me parece que responde diferente | también porque quien se para adelante de la clase | una cosa es la maestra y otra es la...- | es una mamá que viene | como en esa:: cuestión más como de disfrute | ellos lo ven como más de disfrute me parece | me parece a mí | capaz estoy totalmente equivocada | me da esa impresión de que el niño que ve a esa mamá:: | que viene a leer a la clase | ya cuando entra...- | abre la puerta | la reacción de los niños siempre es como de mucha alegría es de estar contentos | porque bueno ta vamos a cortar con la clase | vamos a cerrar los cuadernos y vamos a escuchar a la mamá que en cambio $=\ldots . . .=$

Sandra: =.... ¿ ¿vos decís que no manifiestan esa alegría cuando vos leés? 
Carmen: \{no::: no te voy a mentir (risas)\} porque forma parte de las rutinas de la clase | el docente está muy ligado al salón a la rutina de clase por eso digo que es aire fresco las mamás | lo que no quiere decir que no disfruten | de:: de la histo::ria | del cuento | de los materiales que uno haya traído para | para leer con ellos || porque sí lo disfrutan | pero es distinto | es bien distinto | pienso yo | no sé desde afuera cómo se verá | pienso yo | pero me da como la sensación como de que hay otra actitud | más relajada | más como | de mayor alegría| porque es como que se quiebra la rutina | de la clase | para hacer un momento para lee::r | simplemente por e::I goce de leer | no hay una actividad posterior | donde uno tenga que | que escribir ni que inventar ni que crear ni que dibujar ni...- | simplemente es bueno leemos | y nos quedamos con aquello que nos gustó | pero yo pienso que por ese lado la reacción es distinta | de ellos

Sandra: bueno y:: si vos tuvieras que imaginar el papá ideal que viene a leer | el ideal ¿no? |y los niños ideales que escuchan ¿cómo | cómo sería esa escena? || ¿cómo te la imaginás?

Carmen: sí [piensa] es difícil | es difícil sí | mirá eh:: | yo que sé a mí eso de ideal no me gusta mucho | pero | a ver | pienso que...- |como el gru::po | e::I niño | el grupo de niños como ideal para lectura ¿verdad? | tiene que ver con un niño ávido | con ga::nas | con entusiasmo || un niño que se involu::cra | no me parece que:: un...-| eh:: que el grupo ideal sea el niño ese pasivo que está:: meramente escuchando meramente | sentadito callado | me parece que...- | que el grupo ideal para trabajar para lectura |no es justamente | ese niño que está calladi::to tranquili::to| pero que uno no sabe si te está escuchando o no | sino me parece que está bueno ese niño que interactúa contigo | que vos estás leyendo sí | y te interrumpe | pero interacciona contigo | tú quizás estás con un libro con ilustraciones | y es capaz de hacer relaciones | relaciona con cosas que le pasaron | ese niño que asiente | que está como todo el tiempo en esa sintonía | en ese diálogo | a veces gestual | a veces oral | pero que en todo el tiempo a vos te va dando como una devolución | porque uno va haciendo esa lectura es como que:: a | que a medida que ellos van interaccionando contigo y con la lectura | uno va viendo como esa devolución | bueno me voy dando cuenta de que van comprendiendo | que les va llegando este mensaje o que el cuento fue atrapante o que:: | uno va como midiendo | y el papá:: lector ideal es tan difícil | porque yo que sé | me parece que:: | uno no puede:: | pedirles mu::cho | yo creo que estas mamaś tienen mucho de positivo | en el sentido de que son voluntarias || o sea que | expresan su deseo de veni::r | de colaborar | uno las ve que se sienten sumamente orgullosas de pertenecer al...- | a este equ::ipo | y se sienten fortaleci::das | y además lo toman con mucho compromiso | pero | a ver | pensando en eso de cómo sería el papá ideal | yo pienso que tiene tener cierta apertura | cierta paciencia porque en ese grupo ideal que yo decía / un grupo que no es un grupo calladito silencioso también hay que tener cierta flexibilidad para comprender los niño::s | para entender que bueno los grupos son así | que:: | a veces me pueden interrumpir | me puedo perder como les pasa a las mamá::s | me puedo perder en la lectura porque claro me hablan me distraigo | pero creo que | en este equipo de estas mamás sucede justamente eso | porque ellas están muy motivadas | lo toman con mucha responsabilidad | respetan a los niños | yo pienso que una persona que no tiene interés en hacer esto | sin duda no está acá | por lo ta::nto || pienso que ellas tienen esas | características que las hacen...- || valiosas para los niños pero además creo que | hacen aportes de significatividad interrumpe el electricista que está reparando la instalación eléctrica de la escuela y Carmen sale del salón a atenderlo $<5>\}$ 
Sandra: ¿algo más que vos digas | que tendrían que hacer la::s mamás cuando vienen a leer?| que si vos tuvieras que decir «mirá yo te aconsejaría que hicieras ta::I cosa»

Carmen: bien | no sé | eso depende de...- | de cada mamá | cada mamá tiene su...- | su personalidad su forma $=\ldots . . .=$

Sandra: $=\ldots . . .=$ Rosario por ejemplo $=\ldots . . .=$

Carmen: $=\ldots . . .=$ Rosario que fue la que más leyó $\mid$ Rosario por ejemplo $\mid$ ella cuando empezó a venir se ponía muy nerviosa | se ponía muy nervio::sa | muy...- | yo me acuerdo que las primeras veces que vinieron yo hable con ellas les dije «bueno mirá» | que se quedaran tranquilas | que se relaja::ran | que bueno que...- | que a veces claro la lectura hace que:: | uno se sienta como muy observado quizás | ellas se sentían como muy observadas | con ese miedo de equivocarme de trancarme | no es fácil el poder oralizar la lectu::ra | adelante de tantos niño::s | con las características de los grupos que:: | \{no son grupos de angelitos sino de niños (risas)\} | entonces ella se ponía muy nerviosa || yo pienso que | ella además es una persona como muy se::ria | también a veces yo pienso que quizás si yo tuviera que decirle algo como algún consejo |como alguna cosa | es justamente que se relaje más || porque ella está toda armadita siempre | con temor | y en realidad lo hacen bien || sino no tendrían la aceptación | y la recepción que tienen en los niños | más que nada eso | ese temor en tener confianza en sí misma | en sí misma en que puede hacerlo bien | en que puede leer para los niños | perfectamente bien sin...| ella el mayor temor que por lo menos me decía a mí | bueno justamente tenía miedo como a equivocarse como | a trancarse | a que no le saliera bien ¿no? | justamente por esa cosa de:: | que tenemos todos | de las...- | hasta de las épocas escolares podríamos decir ¿verdad? | es el leer bien | el poder |decodificar de manera corre::cta | y bueno que eso en realidad es una cuestión de práctica también

Sandra: ¿vos ves que ella fue cambiando luego?

Carmen: yo pienso que ella fue como aflojándose también entrando en confianza | con los niños | y dándose cuenta de que:: | podía hacerlo bien | pero los primeros tiempos estaba bien rígida | más que nada eso ¿no? || porque:: <5> | era eso por donde venía | ella quedaba paradita así con el libro | quizás otra cosa bueno de que...- | no tener miedo de invadir las clase | porque a veces también las mamás entran con esa cosa de «no quiero invadir» | pero por lo menos desde mi lugar yo en ese rato | abro la puerta para | para que ellos puedan | acercarse a los chiquilines | poder conversar | poder | dialogar con e::llos | o trabajar o manejarse como a ellas les parezca | por eso siempre uno está como acompañando también | pero más que nada aflojarse | digo confiar en que pueden | pueden hacerlo

Sandra: te voy a pedir que te acuerdes cuando ella leyó La manta de las historias

Carmen: [enf.] sí me acuerdo

Sandra: ¿'vos te acordás cómo se vivió ese momento? || ya hace tiempo pero...-

Carmen: a mí me cuesta mucho | poder analizarlo \{me levanto a cerrar la puerta para evitar los ruidos del taladro del electricista $<30>\}$ a mí me cuesta un poco el poder...- $<4>\mid$ el poder de alguna manera analizarlo porque yo lo analizo con mirada de maestra

Sandra: bueno sí eso es lo que quiero 
Carmen: yo me acuerdo | fue un libro muy potente | la historia de las mantas | me acuerdo clarito de la historia porque era | justamente una manta que la iban destejiendo | y se convertían en nuevas cosas continuamente | y a su vez era una manta que servía para contar historias | y era como que se vivía esa historia | se reescribía de manera continua | para mí era un libro bien poderoso | con muchas posibilidades de | de interpretació::n | de lectura || yo me acuerdo que a mí lo que me pasaba con Rosario | que fue la que lo leyó | yo no puedo mucho con mi genio y:: | al final trato generalmente de | apoyar lo que la mamá lee| bueno tratando de intervenir para que siempre quede un mensaje o una reflexión | respecto del libro para pensarlo un poquito al final | y yo me acuerdo que yo participé:: | me acuerdo más o menos lo que dije | porque me había gustado mucho la historia | muy muy linda muy sensible || yo lo que yo creo es que quizás es pedir mucho | quizás las mamás | o en este caso | hubiera estado bueno que | que quizás explotado un poco más | digamos | el mensaje de::I cuento del mensaje | de que hubiera podido aproximarse más a los niños | desde mensaje que nos daba | porque además era un relator de historias | era una manta que | justamente tenía que ver con la función que ellas estaban también desempeñando en ese momento | que era el de transmitir y llevar historias | quizás hubiera estado bueno que hubiera...- | ella desde sí misma | pero pienso que por...- | por su manera de ser también se esté...- | no se ani::ma | a ir un poquito más| pero || la lectura en general está bie::n | lo que me parece que estaría bueno es poder explorar un poco más eso | pero me parece que también hay que tener un domini::o del texto || de la comprensión del texto | de la interpretación de ese texto | mayor | que capaz que no era la que:: | la que estaba manejando Rosa::rio | no sé cuánt...- | si ya había tenido aproximación a ese libro | quizás no | no es lo mismo escucharlo como lo estaba escuchando yo que estar leyéndolo | yo por ejemplo yo por ejemplo soy una persona | que te leo el cuento pero antes lo tengo que haber leído porque si no...- | yo te lo leo | pero | me pasa mucho me pasaba cuando era estudiante ¿no? | yo no puedo | que me lean | lo tengo que leer yo | y después | la oralidad no me queda mucho | entonces me pasa con las mamás | que a veces | leen acá y yo estoy haciendo una cosa o estoy...- | yo lo tengo que ver para comprenderlo $\mid$ y:: | y a veces quizás ella si era la primera vez que estaba con ese texto |capaz que no tenía ese...- | ese domi::nio del cue::nto | [enf.] yo que sé no sé | hay muchos (???) también | es lo que yo digo | son mamás que vienen a darnos una mano | y me parece que hay que...- | no sé no me gusta mucho | hacer comparaciones porque me parece que no | pero por ese aspecto quizás | estaría bue::no | ir como un pasito más | pero ya es exigir otra cosa también

Sandra: ¿y vos que observaste en los niños ese día?

Carmen: el cuento les gustó | quizás no fue | de las historias que más los atrapó | no fue de los que más les gustó | por ejemplo el León | el León de biblioteca | les gustó mu::cho más | hubo como una respuesta | pero no fue de los que más les gustó | quizás | pero | yo me acuerdo que participa::ron | no me acuerdo mucho de Facundo como había estado || pero | que siempre es como muy participativo | pero pienso que | por lo poco que me puedo acorda::r | de los niños | en situación | \{pasa que me acuerdo más del León (risas)\} || y:: pienso que la reacción | fue buena | hubo apertura | sin duda hubo | diálogo || se generó como esa cosa de...- | en este caso | justamente po::r la forma de ser de la mamá no se generó como...- | me parece que | se podía haber generado más...- | yo que sé | uno a la hora...| a ver cómo puedo decirlo para que me entiendas | uno cuando hace la lectura de un cuento | hay todo como una postu::ra a la hora de leer el cuento | en la entonació::n | en la emoción que uno le da:: | uno como que | juega también un poco con eso a apropiarse del cuento a ser el cuentero ¿no? | y 
ellos también | al no tener tanta:: | a ver | no sé cómo decirlo | pericia | no sé experiencia| la lectura para así para grupos | hace que también capaz que | no se genere como ese clima de...- | más atrapante | a veces esta mamá | a veces era como un poco más calma::da y | a veces como que el cuento a veces pasaba de largo | porque también uno tiene que | a veces poner un poco de expectativa | desde la entonación desde la:: narrativa oral ¿no? | quizás por ese lado también | puede ser que los niños hayan estado un poco más calma::dos más quietos | pero yo me acuerdo que es una historia mu::y linda | por eso decía que era poderosa | porque me parecía que era un cuento bastante bueno para trabajar como varias cosas $\mid$ no sé qué me ibas a decir $=\ldots . . .=$

Sandra: $=\ldots . . .=$ si vos te acordás de algún momento especial del cuento que les hubiera gustado a ellos les hubiera llamado la atención

Carmen: ahora en este momento no me acuerdo

Sandra: pasó mucho tiempo

Carmen: pasó mucho tiempo sí | pasó mucho tiempo | sé que al final | él bueno |desteje totalmente la alfombra | y hace me::dias y buzos y gorros | y no sé qué cosas hacía ya a esta altura | sé que tejía objetos para que todo el mundo estuviera abrigado | y al final vuelven a tejerle | le tejen otra manta | yo creo que ahí estaba el punto...- | el punto álgido de:: | de la historia | en eso de bueno | él compartía esas historias | pero además en esas historias ponía mucho más | que | meramente una historia | sino que las hacía vida y compartía| su historia de vida || me parece...- | y los demás quisieron devolverle esas historias que él | transmitía | se las quisieron devolver | me parece que ahí había mucho para explotar rico desde la parte literaria | del aspecto literario | pero me parece que ahí quizás | se podía haber apelado a la emoción a lo afectivo | eso desde una mirada de afuera $<4>$ haciendo...- | hilando muy fino ¿no?

Sandra: ¿ ¿después que pasó la lectura del cuento ellos te comentaron algo más del cue::nto? | ¿en algún momento vos sentiste que se acordaran?

Carmen: vos sabés que ese no es de los que más ellos...- | no no hubo comentario sobre ese cuento | ese cuento no es de los más...- | de los que más ellos | recuerdan || mismo al otro día cuando:: | ellos escribían y todo me parece que no no salió ese cuento para nada | quizás te puedan hablar de otros | de Julieta, ¿qué planta::ste? | de otros | que también son cuentos que hemos leído varias veces | además Julieta | muchas veces |e::I del león de la biblioteca que a ellos les sorprendió mucho eso de un león en la biblioteca

Sandra: ¿te comentaron sobre ese cuento en algún momento?

Carmen: ellos en realidad queda en el espacio | en el espacio en el tiempo de la lectura con las mamás | ellos como que quedan en ese tiempo | no son niños que suelen comentarte | algo sobre esa historia | es como que cierran |y no hay una devolución posterior | por lo menos hacia mí no hay | o un comenta::rio | estoy pensando si alguna refere::ncia...- | alguna referencia cuando estamos trabajando otro tema sí | por ejemplo estamos trabajando otra cosa o una fábula o un cuento | y hablando de la estructura de un texto | o hablando de un determinado tema | y ahí sí traen cosas | de...- | "sí como pasaba en tal cuento» | pero no con este cuento || es que yo en realidad | me acuerdo de:: | partes del cuento | no me lo acuerdo mucho yo tampoco 
Sandra: ¿vos identificás aprendizajes?

Carmen: respecto con ese cuento no || con ese cuento no | pero no |

(Regresan los niños de la clase de gimnasia y damos por finalizada la entrevista.) 


\subsubsection{Entrevistas a los niños de tercer año $A$}

Fecha y hora: 01.10.2015, 09.00 horas

Lugar: patio interior central de la escuela

Participantes: Joaquín, Facundo, Agustín, Janina, Abigail, Fiorella, investigadora Joaquín

Sandra: hola Joaquín ¿cómo andás?

Joaquín: bien | ayer tuve práctica en el club porque tenemos campeonato

Sandra: iqué bueno! | ¿cómo van en el campeonato? ¿van bien?

Joaquín: vamos bien sí | vamos con mucha energía | practicamos bien | no nos dejan | jugar la pelota en todo el día | porque vamos...- | o sea...- | hagamos | el físico bien

Sandra: imirá! | hacen la parte de preparación física

Joaquín: claro

Sandra: ¡mirá qué lindo! | bueno Joaquín | las preguntitas que yo te voy a hacer...- | ¿'vos te acordás que les hice por escrito unas preguntitas la otra vez?

Joaquín: sí | por qué nos había gustado | el cuento || qué parte fue la que más nos gustó | y qué | pensamos de que las mamás vengan a leer

Sandra: ¿y vos qué me habías contestado cuando yo te pregunté eso?

Joaquín: me gusta que vengan porque no tienen vergüenza

Sandra: porque no tienen vergüenza | ¿y qué más me pusiste?

Joaquín: $<10>$ iay! | no me acuerdo

Sandra: ¿te acordás de algo más?

Joaquín: \{mueve la cabeza [niega]\}

Sandra: vos me pusiste | que...- | que Rosario no tiene vergüenza y:: | que les lee con mucho cariño Joaquín: jahí va!

Sandra: ¿y cómo te das cuenta?

Joaquín: porque:: lee alegre || deja salir la voz

Sandra: imuy bien!

Joaquín: [enf.] mucho mucho

Sandra: imuy bien! |¿te acordás cuando | vino a leer Mónica vino a leer Patricia ¿te acordás? | y vino a leer | ¿quién más vino a leer?

Joaquín: jay! | una alta $<5>$ no me sale el nombre

Sandra: $<5>$ ¿Patricia? 
Joaquín: sí

Sandra: ¿y quién más? ¿te acordás?

Joaquín: <5>

Joaquín: ¿te acordaste qué les leyó Patricia?

Joaquín: sí

Sandra: ¿qué les leyó?

Joaquín: nos leyó |iah! | el de la gallina | y el lobo

Sandra: el de la gallina y el lobo ¿te acordás cómo se llama ese cuento?

Joaquín: no

Sandra: y después les leyó otro cuento que se llama Los secretos de Abuelo Sapo I| ¿te acordás de ese cuento?

Joaquín: mucho no

Sandra: ¿no te acord...- nada?

Joaquín: <5>

Sandra: y después vino a leer | Rosario

Joaquín: ¡Rosario! [Asiente con énfasis.]

Sandra: ¿sí? te acordás de Rosario? | ¿te acordás qué leyó ella?

Joaquín: fue ese que te dije $<4>$ el del zorro y la gallina

Sandra: el del zorro y la gallina | y después les leyó otro libro que se llama La manta de las historias || iperdón! | sí La manta de las historias

Joaquín: no de ese no me acuerdo

Sandra: ¿no te acordás nada de ese cuento?

Joaquín: \{mueve la cabeza [niega]\}

Sandra: bueno y acá me pusiste que el cuento que:: | más te gustó fue «La guerra de los yacarés» Joaquín: sí

Sandra: ¿qué te acordás de ese cuento?

Joaquín: me acordé que:: | que fueron a pedir ayuda y entre todos empezaron a reconstruir | un tanque Sandra: un tanque imuy bien!

Joaquín: me gustó esa parte porque se ayudaron entre todos | todos dan una mano

Sandra: muy bien sí | es verdad | ¿y te acordás quién escribió ese cuento?

Joaquín: iay! | lo tengo en la punta de la lengua <8> ahora no me sale 
Sandra: ¿algún otro cuento que hayas leído de ese mismo autor? $\langle 6\rangle$ ¿aunque no te acuerdes el nombre?

Joaquín: El libro de la selva ${ }^{13}$ que son muchos pero | eran todos lindos

Sandra: iah! son del mismo autor |es verdad itenés razón! || Joaquín una pregunta | cuando el año que viene cuando pasen a cuarto | ¿a vos te gustaría seguir leyendo con las mamás?

Joaquín: sí me encantaría

Sandra: ¿sí? | ¿y qué cuento les pedirías que te leyeran?

Joaquín: «La guerra de los yacarés» | e::l | el que era | el que era de una fiesta y todo eso | e::I | el del zorro y:: | y ¿a ver cuál más? | y el del zorro y la gallina y:: || y el del sapo y el sapito no sé

Sandra: el del sapo y el sapito es Los secretos de Abuelo Sapo

Joaquín: jahí va! Los secretos de Abuelo Sapo

Sandra: ¿ahora te acordaste de ese libro?

Joaquín: me acordé de un cachito sí que:: | que él peleaba...- | que siempre:: cuando terminaba con algo empezaba con lo otro | porque protegía al nieto

Sandra: al nieto ies cierto! ¿te acordás si era triste o divertido?

Joaquín: era divertido

Sandra: ¿divertido?

Joaquín: divertido sí

Sandra: ¿̇y te acordás la lectura que hizo Patricia de ese cuento?

Joaquín: \{mueve la cabeza [niega]\}

Sandra: ¿no? no importa | bueno muchas gracias Joaquín | ¿te animás a decirle a Facundo que venga? Joaquín: \{mueve la cabeza [asiente]\}

\section{Facundo}

Sandra: ¿cómo andás Facu bien?

Facundo: bien

Sandra: ¿estabas ansioso por venir? ¿para contarme | para hablar conmigo?

Facundo: isí!

Sandra: ¿te acordás qué hace unos días les hice unas preguntas por escrito?

Facundo: sí

Sandra: ¿te acordás que te pregunté qué pensabas de las mamás lectoras?

Facundo: sí

\footnotetext{
${ }^{13}$ Cuentos de la selva
} 
Sandra: ¿y vos qué pusiste? | ¿te acordás?

Facundo: que sí que me gustaba porque leen cuentos divertidos | que me gustaba porque bueno...- | iay no sé!

Sandra: | idale! porque nos leen cuentos divertidos y:: || nos reímos

Facundo: ia::h | verdad! sí | nos reímos y:: || y nos divertimos

Sandra: y pusiste algo más | no sé si te acordás

Facundo: el cuento que me gustaba

Sandra: sí:: | también | ¿qué escribiste?

Facundo: el de la tortuga

Sandra: «La tortuga gigante»

Facundo: «La tortuga gigante»

Sandra: ese quién lo leyó

Facundo: lo leyó la mamá de:: || la mamá de Abigail

Sandra: ¿la mamá de Abigail cómo se llama? | ¿te acordás?

Facundo: no

Sandra: y han venido otras mamás a leer | ¿te acordás quiénes son?

Facundo: sí | pero no me acuerdo tampoco el nombre

Sandra: ¿y:: las mamás de quién son?

Facundo: de otro compañero de primero

Sandra: una de primero | y te acordás que vino una mamá de un compañero de quinto o de sexto

Facundo: sí || que...- | tampoco me acuerdo

Sandra: una es la mamá de Martín creo ¿puede ser? | de quinto

Facundo: $\{$ mueve la cabeza [niega]\}

Sandra: también pusiste otra cosa acá Facu | que te gustaba que Rosario viniera | porque conocías muchos libros y aprendías

Facundo: sí verdad | podías conocer muchos libros y aprendías

Sandra: muy bien | ¿vos te acordás cuando Patricia vino a leer | un cuento | a la clase que yo estaba? | que vos levantaste mu::cho la mano | hiciste muchos comentarios $\mid$ ¿te acordás $=\ldots . . .=$

Facundo: sí pero no me acuerdo qué cuento fue

Sandra: ese cuento te había encantado a vos

Facundo: ¿el de los flamencos? |

Sandra: no | un cuento que había dos sapitos 
Facundo: $<4>$ dos sapitos [piensa]

Sandra: que uno era un abuelo y el otro el nieto

Facundo: ja::h sí! | [enf.] que el abuelo lo llevaba a pasear

Sandra: ¿qué te acordás de ese cuento?

Facundo: me acuerdo que:: | que al abuelo...- | me acuerdo que ellos salían a caminar || y que había un animal | no me acuerdo cuál era || que los quería atacar ¿no? || y:: || y:: no sé qué más pasó no me acuerdo mucho

Sandra: ¿te acordás si era divertido | era triste? | ¿qué sensación te había causado?

Facundo: [enf.] era divertido | muy divertido

Sandra: ¿te acordás de Patricia leyendo ese cuento?

Facundo: sí

Sandra: ¿qué te acordás?

Facundo: de cuando:: | miraba a::I | libro y leía | y de cuando |asustaban esas partes | y bueno | y ta nada más

Sandra: ¿y después te acordás cuando Rosario vino a leerles un cuento que se llama La manta de las historias?

Facundo: isí! | de ese me acuerdo más | que:: | que bueno | que una mujer que tenía una alfombra | quería dar | ma...- || manta o sea ¿no? | y sacaba de su alfombra las telas | y sacaba hasta que se le hacía chiquita | y luego la reponía de nuevo por si después la volvía a necesitar ¿no? | y luego cuando terminó el cuento| todos | le quisieron regalar una manta |que se fue gastando también y ella volvió a hacer otra

Sandra: muy bien | es cierto ite acordás bastante de ese cuento! | Facu y decime | ¿qué te acordás de cuando Rosario lo leyó? | ¿de su lectura?

Facundo: también me acuerdo que:: ella también se reí::a y le gustaba | y que:: | también miraba |remarcaba esas partes

Sandra: es cierto | y vos me dijiste que el cuento que más te gustó fue «La tortuga gigante»

Facundo: sí

Sandra: ¿̇y te acordás quién lo leyó?

Facundo: la mamá del niño de primero | que no me acuerdo cómo se llama=.....=

Sandra: $=\ldots . . .=$ ¿Mónica?

Facundo: Mónica | Mónica

Sandra: ¿y por qué te gustó ese cuento?

Facundo: y porque una tortuga que:: | que el hombre la ayudó y:: | resistió mucho como para llegar a...| a la ciudad como para que lo atendieran | [enf.] y fue muy lindo

Sandra: ¿y por qué fue lindo? 
Facundo: y fue lindo porque bueno | fue como para ayudarse entre ellos | porque él la ayudó...- | él la ayudó primero a ella | y ella después a él | porque le quiso devolver el favor

Sandra: imuy bien! | Facu una última pregunta | e::I | año que viene que vas a estar en cuarto ¿ंverdad? | ¿te gustaría que siguieran las mamás leyendo con ustedes?

Facundo: sí obvio

Sandra: ¿y qué les pedirías que leyeran?

Facundo: y que siguieran leyendo:: | otros cuentos que no conociera yo

Sandra: otros cuentos que vos no conozcas |muy bien || bueno muchas gracias Facu | [enf.] me encantaron tus respuestas

Facundo: bueno

Sandra: ¿le decís a:: || Nicolás hay uno solo ¿ंverdad?

Facundo: Nicolás no hay

Sandra: ¿XXX tercero A? || ¿no hay ningún Nicolás?

Facundo: no | capaz que hay pero no es su primer nombre que le dicen

Sandra: ia::h! | bueno dejá que le pregunto a Carmen | ¿Agustín vino? | ¿le decís que venga? | y después averiguo quién es Nicolás

\section{Agustín}

Sandra: hola Agustín ¿cómo andás? ¿bien?

Agustín: \{mueve la cabeza [asiente]\}

Sandra: bueno gracias por venir || Agustín ¿vos te acordás | de las preguntas que yo te hice el otro día | por escrito?

Agustín: \{mueve la cabeza [asiente]\}

Agustín: iah::! \{suspira\} | que el libro aquel que me gustaba era el Abuelo Sapo

Sandra: ¿ese te había gustado?

Agustín: sí

Sandra: ¿qué más te había preguntado yo?

Agustín: la última vez que | que vos viniste fue cuando la maestra contó el cuento del tejón aquel | que vos dijiste «iqué bien!»

Sandra: imuy bien! | Agus ¿̇y vos te acordás que yo les pregunté también qué pensabas de las mamás que vienen a leer?

Agustín: iahá! \{mueve la cabeza [asiente]\}

Sandra: ¿te gusta | que vengan las mamás?

Agustín: sí 
Sandra: ¿sí? | ¿te acordás quiénes vinieron a leer a la clase?

Agustín: vino:: || una llamada Margareth | las otras las conozco | me olvidé los nombres

Sandra: ¿te olvidaste los nombres? | ¿te acordás mamás de quiénes eran?

Agustín: no \{mueve la cabeza [niega]\}

Sandra: $<6>$ ¿no?

Agustín: una yo la conoz...- | una mamá yo la conozco | es...- | es como se dice | la madre de un amigo:: mío | que es...- | como se dice | no es la madre de mi amigo | porque él...- | ella...- | mi amigo | él jugaba con el hijo | de ella

Sandra: jah! | ¿y te acordás del amigo cómo se llama?

Agustín: Bautista

Sandra: ia::h! bien| ¿la mamá de Bautista?

Agustín: jahá! \{mueve la cabeza [asiente]\}

Sandra: ¿la mamá de Bautista? | bien | ¿te acordás que vinieron a leer...- | primero vino Patricia || ¿te acordás?

Agustín: jahá! \{mueve la cabeza [asiente]\}

Sandra: ¿qué les leyó Patricia?

Agustín: \{mueve la cabeza [niega]\}

Sandra: y después vino:: | a leerles | Rosario

Agustín: iahá! \{mueve la cabeza [asiente]\}

Sandra: ¿te acordás qué leyó ella?

Agustín: no me acuerdo mucho

Sandra: ¿nada? | y después vino Mónica | la última mamá que vino a leer || ¿y vos te acordás que con Rosario leyeron un libro que se llama La manta de las historias?

Agustín: ese nunca lo había escuchado

Sandra: capaz que vos no estabas justo ese día | sí puede ser que no estuvieras

Agustín: \{mueve la cabeza [niega]\}

Sandra: ¿y del día que vino Patricia a leerles el Abuelo Sapo qué te acordás?

Agustín: me acuerdo que:: el abuelo Sapo le enseñó a Sapito cómo a defenderse | aparecía | una serbiente (sic) | luego una tortuga | y luego un monstruo

Sandra: y luego un monstruo | [enf.] te acordás muy bien del cuento| ¿por qué te acordás tanto?

Agustín: porque era buenazo

Sandra: ¿sí?

Agustín: jahá! \{mueve la cabeza [asiente]\} 
Sandra: ¿y:: de Patricia leyendo ese día de qué te acordás?

Agustín: \{suspira\}

Sandra: $<6>$ ¿nada?

Agustín: \{mueve la cabeza [niega]\}

Sandra: ¿te gustó cómo lo leyó?

Agustín: \{mueve la cabeza [asiente]\}

Sandra: Agus una última pregunta | el año que viene cuando estén en cuarto | ¿te gustaría que venga a leer a la clase otra mamá?

Agustín: sí

Sandra: ¿`y qué libro les pedirías?

Agus: jah! $<6>$ ino sé::!

Sandra: ¿no? | ¿no tenés alguno en especial? | ¿o algún tema?

Agustín: Agustín: iahá! \{mueve la cabeza [niega]\}

Sandra: ¿no? | ¿ninguno?

Agustín: iahá! \{mueve la cabeza [niega]\}

Sandra: bueno imuy bien! | Agus ¿vos sabés quién es Nicolás?

Agustín: ¿Nicolás?

Sandra: porque acá hay un niño que me puso Nicolás tercero A pero que no sabemos quién es

Agustín: iahá! \{mueve la cabeza [niega]\}

Sandra: bueno le pregunto a Carmen | ¿Janina está?

Agustín: voy a ver si está

Sandra: ¿no está? | y si no está Janina ¿Nahuel?

Agustín: voy a ver

Sandra: dale

\section{Janina}

Sandra: Janina | ¿cómo estás?

Janina: bien

Sandra: Janina mirá las preguntas que te voy a hacer | son | parecidas a las del otro día | ¿vos te acordás lo que yo les pregunté || por escrito | para que ustedes escribieran? | ivos escribiste un montón! | mirá todo lo que escribiste [enf.]

Janina: \{mira la hoja escrita\} 
Sandra: ¿te acordás que yo les había preguntado qué pensaban de las mamás que vienen a leer? | ¿y vos qué me respondiste?

Janina: sí | me gusta que vengan las madres a leer a nosotros

Sandra: ¿y qué es lo que te gusta?

Janina: me gusta:: || me gustan los cuentos que leen | y:: me gustan los cuentos que tienen aventuras y eso | me gusta escuchar también

Sandra: te gusta que ellas lean | vengan a leer y escucharlas cuando leen imuy bien!

Janina: $\{$ mueve la cabeza [asiente]\}

Sandra: y acá pusiste «Me gusta que Rosario venga a leer porque así no me aburro» | y me pusiste «Me gusta que venga a leer todos los martes» y escribiste el título de un libro que te gustó mucho | de un cuento | perdón

Janina: era la gama...- | ese me gustó porque | es traviesa | ella es traviesa y | hace aventuras ella

Sandra: ¿hace aventuras? I ¿y por qué te gustó tanto? ¿por eso?

Janina: sí

Sandra: ¿sí? ¿y qué te acordás de ese cuento?

Janina: me acuerdo que no hacía caso a su madre cuando | la madre le decía las cosas que eran peligrosas en el bosque | y:: la niña no escuchaba | no la escuchaba a ella

Sandra: la niña no escuchaba a la madre | muy bien | o sea la desobedecía

Janina: sí

Sandra: ¿vos te acordás el día que vino a leer Rosario un cuento que se llama La manta de las historias? Janina: no

Sandra: ¿no? ¿no te acordás nada de ese cuento?

Janina: no porque creo que no vine yo

Sandra: vos capaz que no viniste ese día

Sandra: ¿y cuando vino Patricia a leerles?

Janina: $<8>$

Sandra: ¿la madre de Bautista de segundo?

Janina: ese día sí que no vine

Sandra: bueno | y una última pregunta | Janina | el año que viene cuando estén en cuarto | ¿te gustaría que las mamás | vinieran a leerles | de vuelta?

Janina: sí | me gustaría mucho

Sandra: ¿y qué les pedirías que lean?

Janina: que me lean un cuento | cuentos 
Sandra: ¿qué cuentos?

Janina: uno || \{uno aventurero (risas)\}

Sandra: uno de aventuras | ¿hay alguno que te guste? | ¿algún autor? | algún tema?

Janina: más o menos ahí

Sandra: ¿sí? ¿cuál es? ¿te acordás?

Janina: $<5>$

Sandra: ¿no? | bueno igual tenés de aquí al año que viene para pensar y elegir

Sandra: bueno muchas gracias Janina | ¿le decís a Abigail? ¿vino?

Janina: sí

Abigail

Sandra: hola Geraldín ¿cómo estás? ¿bien?

Abigail: Abigail

Sandra: Abigail iperdón! | bueno ahora sí | aún no me acuerdo del nombre de todos || bueno muchas gracias por venir | Abigail te voy a hacer preguntas | muy parecidas a las que les hice el otro día por escrito | ¿te acordás que yo les había preguntado qué pensaban de las mamás que venían a leer

Abigail: <5> me gustó el cuento | me gustó que vengan | me gustó que vengan | y me divertí mucho con ustedes

Sandra: con las mamás sí

Abigail: con las mamás es verdad

Sandra: ¿algún otro motivo?

Abigail: me gusta que vengan porque cuando termina el cuento nos | dicen si nos gustó |la parte que nos gusta más | y eso

Sandra: y a vos te gusta hablar sobre eso | imuy bien!

Abigail: sí

Sandra: y acá me pusiste que había un libro que te había gustado mucho

Abigail: sí

Sandra: ¿cuál era?

Abigail: El león de biblioteca

Sandra: ¿por qué te gustó ese libro?

Abigail: porque el león || se quedaba sentado a escuchar el cuento | y ayudaba a los niños a alcanzar los libros arriba de la biblioteca arriba del todo | a la parte que no llegaban | el león agarraba a un niño y lo levantaba | y alcanzaba el libro para que:: lo escuche 
Sandra: ite acordás muy bien del cuento!

Abigail: sí

Sandra: ¿ por qué te gustó ese cuento en especial?

Abigail: me gustó porque:: | porque me quiero...-- porque quiero leerlo de nuevo

Sandra: ¿ah sí?

Abigail: sí | quiero tres o cuatro veces | me gusta | quiero comprármelo igual | [enf.] me encanta ese libro

Sandra: es difícil de conseguir pero si yo lo veo lo voy a traer a la clase y lo voy a dejar \|l Abigail ¿vos te acordás de otros libros que hayas leído con las mamás?

Abigail: sí | me acuerdo de uno del cuento de la selva que tiene muchos cuentos

Sandra: ¿quién lo leyó

Abigail: Mónica | Mónica | Rosario y || Margareth

Sandra: ¿vos te acordás cuando un día vino Rosario a leerles un libro que se llama La manta de las historias

Abigail: $m:: \mid$ sí

Sandra: ¿sí? ¿qué te acordás de ese cuento?

Abigail: sí | me acuerdo una parte nomás

Sandra: bueno lo que te acuerdes

Abigail: ¿ंqué era?

Sandra: La manta de las historias

Abigail: La manta de las historias || era una manta que...-| iay! pero no me acuerdo mucho | era una manta que tenía libros o sea...- || la manta de libros era...- | la manta que...- | iay! no me acuerdo

Sandra: a ver | cuando hacés así con las manos es porque | tenía cuadritos ¿iverdad?

Abigail: exacto sí

Sandra: bien | ¿y qué pasaba con esos cuadritos?

Abigail: pasaba que | esos cuadritos me gustaban | también me gustó | me gusta más este libro que el otro | bueno me gustaron todos los libros que ellas me leyeron | nos leyeron

Sandra: ese te acordás que iban agregando cuadritos que después los tejían los destejían

Abigail: exacto

Sandra: Abigail el año que viene cuando estén en cuarto y empiecen devuelta el año | ¿a vos te gustaría que volvieran las mamás a leerles?

Abigail: sí || ime encanta que me lean!

Sandra: ¿sí? | ¿te gusta mucho que vengan las mamás a leer? |

Abigail: sí 
Sandra: ¿sí? iqué lindo! || Abigail ¿̇y qué les pedirías que te leyeran | algo que a vos te guste mucho | si pudieras elegir y decirles «mirá yo quiero que lean este cuento» | o me lean de este tema| o de este autor

Abigail: $<8>$ el del libro de la:: | selva

Sandra: el libro de la selva Los cuentos de la selva

Abigail: sí porque Rosario nos contó un día | que un camaleón ¿viste? | que era el cumpleaños del camaleón | y ahí iban cambiando las palabras | bueno | ahí llevaron una torta de lombriz y eso || y bueno || y bueno a mí me gustó porque iban cambiando las palabras | y bueno ime encantó! | me gustó porque | tiene mucha:: | mucha:: || mucha:: gracia

Sandra: ¿sí? porque era divertido | bueno muchas gracias Abigail ahora sí esperamos que venga Fiorella

\section{Fiorella}

Sandra: Fiorella | buen día ¿̇cómo estás?

Fiorella: \{mueve la cabeza [asiente]\}

Sandra: bueno gracias por venir Fiorella

Fiorella: \{mueve la cabeza [asiente]\}

Sandra: te voy a hacer unas preguntitas | iguales a las que hice el otro día por escrito ¿te acordás?

Fiorella: sí

Sandra: ¿vos te acordás que les pregunté qué pensaban de las mamás que vienen a leer?

Fiorella: sí

Sandra: ¿y vos qué escribiste te acordás? ¿te gusta?

Fiorella: sí

Sandra: ¿qué libro te acordás que hayan leído?

Fiorella: $<10>$

Sandra: ¿algún libro en especial?

Fiorella: sí

Sandra: ¿cuál?

Fiorella: <8> Julieta, ¿qué plantaste?

Sandra: Julieta, ¿qué plantaste? | ¿y por qué te gusta ese libro?

Fiorella: porque hay muchas cosas de plantas

Sandra: Fiorella | vos pusiste que te gustaba que vinieran a leer | porque te gustaban los cuentos ¿sí? | porque las mamás son relindas ¿sí? | ¿por qué te gusta que vengan las mamás a leer?

Fiorella: porque son buenas con nosotros 
Sandra: ¿sí? | Fiorella | ¿y te acordás un día que vino a leerles Rosario un cuento que se llama La manta de las historias

Fiorella: no

Sandra: ¿no?

Fiorella: $<10>$

Sandra: bueno no importa || Fiorella || pusiste que te gustaba «El loro pelado»

Fiorella: sí

Sandra: ¿por qué te gustó ese cuento? ¿quién lo leyó?

Fiorella: $<8>$

Sandra: ¿te acordás la mamá que lo leyó?

Fiorella: no

Sandra: bueno no importa | ¿el año que viene cuando estés en cuarto te gustaría que vinieran las mamás a leer?

Fiorella: sí

Sandra: ¿sí? | ¿te gustaría que volvieran a leer? || ¿qué les pedirías que te leyeran?

Fiorella: $<8>$

Sandra: ¿hay algún cuento en especial?

Fiorella: $<6>$

Sandra: bueno muchas gracias Fiorella | voy a ir a buscar ahora a Nicolás

(Acompaño a Fiorella al salón.)

\subsubsection{Sesiones de lectura de Rosario}

\subsubsection{Cuando el temible tigre}

Pauta de sistematización de las observaciones de la sesión de lectura de Cuando el temible tigre

\begin{tabular}{|l|}
\hline Escuela: XXX \\
\hline Fecha y hora: $14.07 .2014,10.30$ horas \\
\hline Contexto: salón de clase, luego del recreo \\
\hline Grupo: $3 .{ }^{\circ} \mathrm{A}$ \\
\hline Cantidad de niños presentes: 23 \\
\hline Otros presentes: maestra Carmen, investigadora \\
\hline
\end{tabular}




\begin{tabular}{|c|c|c|c|c|}
\hline & $\begin{array}{c}\text { Cuando } \\
\text { el } \\
\text { temible } \\
\text { tigre }\end{array}$ & \multicolumn{3}{|c|}{$\begin{array}{l}\text { Libro: Cuando el temible tigre, Virginia Brown, Ilustraciones de Matías Acosta, Banda } \\
\text { Oriental }\end{array}$} \\
\hline \multicolumn{5}{|c|}{$\begin{array}{l}\text { Selección del libro: La mediadora seleccionó el libro y se lo solicitó a la maestra referente en la reunión del } \\
\text { equipo comunitario, realizada ese mismo día más temprano. }\end{array}$} \\
\hline \multicolumn{5}{|c|}{ Observaciones } \\
\hline \multicolumn{5}{|c|}{ Antes de iniciar la lectura } \\
\hline \multirow{13}{*}{$\begin{array}{l}\frac{\pi}{\frac{0}{0}} \\
\frac{0}{0} \\
\frac{0}{0} \\
\sum\end{array}$} & \multirow{2}{*}{\multicolumn{2}{|c|}{$\begin{array}{l}\text { ¿Organiza el espacio de } \\
\text { lectura? }\end{array}$}} & Sí & \\
\hline & & & No $x$ & $\begin{array}{l}\text { Los niños se disponen en sus asientos tal como lo hacen } \\
\text { habitualmente. La maestra y yo nos ubicamos en unos } \\
\text { bancos vacíos al fondo del salón. }\end{array}$ \\
\hline & \multicolumn{2}{|c|}{$\begin{array}{l}\text { ¿Dónde y cómo se ubica } \\
\text { para leer? }\end{array}$} & \multicolumn{2}{|c|}{ Parada frente al grupo, de espaldas al pizarrón y frente a la clase. } \\
\hline & \multirow{2}{*}{\multicolumn{2}{|c|}{$\begin{array}{l}\text { ¿Realiza algún ritual de } \\
\text { inicio? }\end{array}$}} & Sí & \\
\hline & & & No $x$ & \\
\hline & \multirow{2}{*}{\multicolumn{2}{|c|}{$\begin{array}{l}\text { ¿Realiza preguntas o } \\
\text { comentarios? }\end{array}$}} & Sí & \\
\hline & & & No $x$ & \\
\hline & \multirow{2}{*}{\multicolumn{2}{|c|}{$\begin{array}{l}\text { ¿Responde las preguntas o } \\
\text { comentarios de los niños? }\end{array}$}} & Sí & \\
\hline & & & No $x$ & \\
\hline & \multirow{2}{*}{\multicolumn{2}{|c|}{$\begin{array}{l}\text { ¿Responde las preguntas o } \\
\text { comentarios de la docente? }\end{array}$}} & Sí & \\
\hline & & & No $x$ & \\
\hline & \multirow{2}{*}{\multicolumn{2}{|c|}{$\begin{array}{l}\text { ¿Realiza algún ritual de } \\
\text { cierre? }\end{array}$}} & Sí & \\
\hline & & & No $x$ & \\
\hline \multirow{2}{*}{\multicolumn{3}{|c|}{$\begin{array}{l}\text { ¿Los niños realizan preguntas o } \\
\text { comentarios? }\end{array}$}} & Sí x & \\
\hline & & & No & \\
\hline \multirow{2}{*}{\multicolumn{3}{|c|}{$\begin{array}{l}\text { ¿La docente realiza preguntas o } \\
\text { comentarios? }\end{array}$}} & Sí & \\
\hline & & & No $x$ & \\
\hline \multicolumn{5}{|c|}{ Durante la lectura } \\
\hline$\sum^{0}$ & ¿Presenta el libro? & & Sí $x$ & Muestra la tapa del libro y menciona a su autora \\
\hline
\end{tabular}




\begin{tabular}{|c|c|c|}
\hline & No & \\
\hline \multirow[t]{2}{*}{ ¿Muestra las imágenes? } & Síx & $\begin{array}{l}\text { A medida que lee, luego de terminar cada página. Voltea } \\
\text { el libro y lo enfrenta para que los niños observen las } \\
\text { imágenes. Se detienen unos segundos en cada página. }\end{array}$ \\
\hline & No & \\
\hline \multirow{2}{*}{ ¿Muestra los paratextos? } & Sí & \\
\hline & No $\chi$ & \\
\hline \multirow{5}{*}{ Volumen de voz } & Muy bajo (--) & \\
\hline & Bajo (-) & \\
\hline & Moderado $(-+)$ & Es escuchada por todos. \\
\hline & Alto $(+)$ & \\
\hline & Muy alto $(++)$ & \\
\hline Velocidad & $\begin{array}{l}\text { Lenta } \\
\text { Moderada } \chi \\
\text { Rápida }\end{array}$ & \\
\hline Fluidez & $\begin{array}{l}\text { +Fluidez } \chi \\
\text {-Fluidez }\end{array}$ & \\
\hline Dicción & $\begin{array}{l}\text { Sin omisión de } \\
\text { fonemas } \chi \\
\text { Con omisión } \\
\text { de fonemas }\end{array}$ & \\
\hline \multirow{2}{*}{$\begin{array}{l}\text { ¿Adecua la entonación o } \\
\text { velocidad de su voz al } \\
\text { momento, situación del } \\
\text { cuento, personajes o } \\
\text { modalidad del enunciado? }\end{array}$} & Síx & En una ocasión \\
\hline & No & \\
\hline \multirow{2}{*}{$\begin{array}{l}\text { ¿Incorpora gestos faciales o } \\
\text { corporales? }\end{array}$} & Sí & \\
\hline & No $\chi$ & \\
\hline \multirow{2}{*}{ Se desplaza mientras lee } & Sí & \\
\hline & No $\chi$ & \\
\hline \multirow{2}{*}{$\begin{array}{l}\text { ¿Realiza preguntas o } \\
\text { comentarios? }\end{array}$} & Sí $x$ & \\
\hline & No & \\
\hline \multirow{2}{*}{$\begin{array}{l}\text { ¿Responde preguntas o } \\
\text { comentarios de los niños? }\end{array}$} & Sí & \\
\hline & No $x$ & \\
\hline \multirow{2}{*}{$\begin{array}{l}\text { ¿Realiza algún ritual de } \\
\text { cierre? }\end{array}$} & Sí $x$ & Cierra la lectura con: «Colorín, colorado» \\
\hline & No & \\
\hline
\end{tabular}




\begin{tabular}{|c|c|c|c|}
\hline \multirow{2}{*}{\multicolumn{2}{|c|}{$\begin{array}{l}\text { ¿Los niños realizan preguntas o } \\
\text { comentarios? }\end{array}$}} & Sí x & \multirow[t]{2}{*}{ En forma espontánea. } \\
\hline & & No & \\
\hline \multirow{2}{*}{\multicolumn{2}{|c|}{$\begin{array}{l}\text { ¿La docente realiza preguntas o } \\
\text { comentarios? }\end{array}$}} & Sí & \\
\hline & & No $x$ & \\
\hline \multicolumn{4}{|c|}{ Después de la lectura: no realiza intercambios después de la lectura } \\
\hline \multirow{8}{*}{$\begin{array}{l}\frac{0}{0} \\
\frac{0}{0} \\
\frac{.0}{0} \\
\frac{0}{2}\end{array}$} & \multirow[t]{2}{*}{ ¿Realiza preguntas? } & Sí & \\
\hline & & No & \\
\hline & \multirow{2}{*}{$\begin{array}{l}\text { ¿Responde preguntas o } \\
\text { comentarios de los niños? }\end{array}$} & Sí & \\
\hline & & No & \\
\hline & \multirow{2}{*}{$\begin{array}{l}\text { ¿Responde preguntas o } \\
\text { comentarios de la docente? }\end{array}$} & Sí & \\
\hline & & No & \\
\hline & \multirow{2}{*}{$\begin{array}{l}\text { ¿Realiza algún ritual de } \\
\text { finalización? }\end{array}$} & Sí & \\
\hline & & No & \\
\hline \multirow{2}{*}{\multicolumn{2}{|c|}{$\begin{array}{l}\text { ¿Los niños realizan preguntas o } \\
\text { comentarios? }\end{array}$}} & Sí x & \\
\hline & & No & \\
\hline \multirow{2}{*}{\multicolumn{2}{|c|}{$\begin{array}{l}\text { ¿La docente realiza preguntas o } \\
\text { comentarios? }\end{array}$}} & Sí X & \\
\hline & & No & \\
\hline \multicolumn{4}{|c|}{ Interacciones entre los actores } \\
\hline \multicolumn{2}{|c|}{$\begin{array}{l}\text { Actitud de la mediadora hacia los } \\
\text { niños }\end{array}$} & \multicolumn{2}{|c|}{ Escucha con respeto sus preguntas y comentarios. } \\
\hline \multicolumn{2}{|c|}{$\begin{array}{l}\text { Actitud de la docente hacia la } \\
\text { mediadora }\end{array}$} & \multicolumn{2}{|c|}{$\begin{array}{l}\text { Habilita la participación dla mediadora al iniciar la sesión de lectura. } \\
\text { Escucha con respeto el cuento. Colabora en el control de la clase. Realiza } \\
\text { comentarios con complicidad. }\end{array}$} \\
\hline \multicolumn{2}{|c|}{$\begin{array}{l}\text { Actitud de los niños hacia la } \\
\text { mediadora }\end{array}$} & \multicolumn{2}{|c|}{$\begin{array}{l}\text { Escuchan con atención. Se compenetran con la historia leída. Participan en } \\
\text { forma espontánea y ordenada. Se muestran entusiasmados en la discusión. }\end{array}$} \\
\hline \multicolumn{2}{|c|}{$\begin{array}{l}\text { Actitud de la mediadora hacia la } \\
\text { docente }\end{array}$} & \multicolumn{2}{|c|}{$\begin{array}{l}\text { Escucha con respecto sus comentarios. No hay interacción entre la } \\
\text { mediadora y la docente durante la sesión de lectura. }\end{array}$} \\
\hline
\end{tabular}

Transcripción de la sesión de lectura de Cuando el temible tigre

Rosario: ¿estamos prontos? /

(Los niños continúan conversando unos minutos. Algunos piden silencio a sus compañeros. La mediadora espera que hagan silencio para continuar.)

Rosario: el cuento se llama Cuando el temible tigre $\backslash$

Niña: ileelo ya! \

Rosario: texto de Virginia Brown\ | ilustrado por Matías Acosta \\{muestra la tapa del libro $<10>$ \}

Niño: ¿Matías Acosta? | yo me llamo Matías \

Rosario: cuando el temible tigre / | visita a la abuelita \\{己ven las garras? (muestra las imágenes) $<5>\}$

Niños: isí! \

Niños a coro: $\{$ risas $\}$ 
Niño: ¿qué cosa?

Rosario: es su pequeño tigrecito adorado $\backslash$ \{muestra las imágenes $<5>$ \}

Niña: iah::! iqué lindo! \

Niña: iah::! iqué divino!\

Niño: el tigre es lo más lindo pero a la carita le falta un poco de maquillaje \

Rosario: cuando el impo \| imponente hipopótamo visita a [le.] la abuelita \{muestra las imágenes $<5>\}$

Niños: iu::h! \[sorprendidos]

Niño: imiren lo que es eso! \

Niño: ya se fue $\backslash$

Rosario: es su pequeño $\backslash \mid$ hipopótamo / | adorado \\{muestra las imágenes $<10>$ \}

Niño: ipero tiene algo atrás también! \

Niño: jes recorto!\

Niño: iah::! \

Niños a coro: $\{$ risas $\}$

Rosario: cuando el horrible oso visita a la abuelita $\backslash\{$ (muestra las imágenes) $<5>\}$

Niña: iel horrible oso! \

Niño: no es horrible \

Niño: eso no es horrible \}

Niña: Nahuel es ese \

Rosario: es su pequeño osito adorado $\backslash$ \{muestra las imágenes $<5>$ \}

Niña: ia::h!...।

Niño: imirá lo que es eso! \

Niño: ¿'era una abuelita o un abuelito? /

Niño: jel cocodrilo el cocodrilo!\

Rosario: cuando el crue::| cocodrilo $\backslash \mid$ visita a la abuelita \{muestra las imágenes $<5>$ \}

Niño: ¿viste? \/ iyo sabía qué era!\

Niño: abre la boca \

Niño: ise la come! \

Rosario: es su pequeño cocodrilo adorado $\backslash\{$ muestra las imágenes $<5>$ \}

Niño: jobvio! \es un cocodrilo \

Niño: ia::h! \

Niño: ¿̇y la abuela dónde está?

Niño: ahí parada con la escoba \}

Niña: esa no es la abuela \

Niña: es el cocodrilo \

Rosario: pero \{muestra las imágenes $<6>$ \}

Niño: oh \oh \

Niño: ¿y eso? 
Rosario: ¿qué vendrá ahora?

Niños a coro: $\{$ risas $\}$

Rosario: pero cuando el feroz lobo $\backslash$

Niña: visita a la abuelita \

Niña: [enf.] no:: \

Rosario: de feroces ojos \{muestra las imágenes $<5>$ \}

Niños a coro: $\{$ risas\}

Niño: parecen botones los ojos \}

Niños a coro: \{risas\}

Niño: los botones $\backslash$

Rosario: y feroces $\backslash \mid$ fauces \{muestra las imágenes $<5>$ \}

Niño: parece un perro \

Niño: parecen los dientes del cocodrilo \}

Niños: es verdad \pero no es un cocodrilo \

Rosario: visita a la abuelita \\{muestra las imágenes $<5>$ \}

Niños a coro: \{risas\}

Niño: ¿̇en serio?

Niña: ipero ese no es la abuela es el cocodrilo!\

Rosario: la encuentra jugando a las cartas con Caperucita \\{muestra las imágenes $<10>$ \}

Niños a coro: $\{$ risas $\}$

Niño: ¡la encontré!\

Niño: icualquier cosa!\

Niño: se encuentra con la abuelita sin permiso del lobo \}

Niño: ¿'es una cuchara?

Niña: es muy gracioso $\backslash$

Niño: y el lobo se pone a jugar a las cartas \

Niño: ¿cómo?

Rosario: volvemos a atrás porque si no queda medio \| cuando el feroz lobo visita a la abuelita \| [enf.] la encuentra jugando con Caperucita $\backslash$ \{muestra las imágenes $\langle 10\rangle$ \}

Niños: $<5>$

Niños: (Protestan en forma desordenada porque el cuento es corto.)

Rosario: y colorín colorado \| este cuento se ha acabado \

Niños: iqué cortito! \

Niño: iotro más! \| iotro más! \

Niño: yo quiero otro \}

Niño: ahora voy a la biblioteca y lo voy a encontrar \

Maestra: ¿se imaginaron al Lobo Feroz?

\{Aumentan las risas.\} 
(Nos despedimos y nos retiramos del salón.)

\subsubsection{La manta de las historias}

Pauta de sistematización de las observaciones de la sesión de lectura de La manta de las historias

\begin{tabular}{|c|c|c|c|}
\hline \multicolumn{4}{|c|}{ Escuela: XXX } \\
\hline \multicolumn{4}{|c|}{ Fecha y hora: $11.08 .2015,08: 00$ horas } \\
\hline \multicolumn{4}{|c|}{ Contexto: salón de clases } \\
\hline \multicolumn{4}{|c|}{ Grupo: $3 .^{\circ} \mathrm{A}$} \\
\hline \multicolumn{4}{|c|}{ Cantidad de niños presentes: 21} \\
\hline \multicolumn{4}{|c|}{ Otros presentes: maestra Carmen, investigadora } \\
\hline \multicolumn{4}{|c|}{$\begin{array}{lll}\text { Camantá de } \\
\text { las historias }\end{array}$} \\
\hline \multicolumn{4}{|c|}{$\begin{array}{l}\text { Selección del libro: Fue solicitado por la investigadora, a los efectos de la investigación. Contó con la aprobación } \\
\text { de la mediadora. }\end{array}$} \\
\hline \multicolumn{4}{|c|}{ Observaciones } \\
\hline \multicolumn{4}{|c|}{ Antes de iniciar la lectura } \\
\hline \multirow{8}{*}{$\begin{array}{l}\frac{\pi}{0} \\
\frac{0}{0} \\
\frac{\pi}{0} \\
\frac{\alpha}{2}\end{array}$} & & Sí & \\
\hline & $\begin{array}{l}\text { ¿Organiza el espacio de } \\
\text { lectura? }\end{array}$ & No $x$ & $\begin{array}{l}\text { Los niños se disponen en sus asientos tal como se } \\
\text { disponen habitualmente. La maestra y yo nos ubicamos en } \\
\text { unos bancos vacíos al fondo del salón. } \\
\text { Los niños están esperando con interés a la mediadora. La } \\
\text { reciben con aplausos y gritos de entusiasmo. Suspenden la } \\
\text { tarea que están haciendo y se disponen a escuchar la } \\
\text { lectura. }\end{array}$ \\
\hline & $\begin{array}{l}\text { ¿Dónde y cómo se ubica } \\
\text { para leer? }\end{array}$ & \multicolumn{2}{|c|}{ Parada frente al grupo, de espaldas al pizarrón. } \\
\hline & \multirow{2}{*}{$\begin{array}{l}\text { ¿Realiza algún ritual de } \\
\text { inicio? }\end{array}$} & Sí & \\
\hline & & No $\chi$ & Saluda al ingresar al salón. \\
\hline & \multirow{2}{*}{$\begin{array}{l}\text { ¿Realiza preguntas o } \\
\text { comentarios? }\end{array}$} & Sí $x$ & \\
\hline & & No & \\
\hline & & Sí x & \\
\hline
\end{tabular}




\begin{tabular}{|c|c|c|c|}
\hline \multirow{3}{*}{\multicolumn{2}{|c|}{\begin{tabular}{|l|l|}
$\begin{array}{l}\text { ¿Responde las preguntas o } \\
\text { comentarios de los niños? }\end{array}$ \\
$\begin{array}{l}\text { ¿Responde las preguntas o } \\
\text { comentarios de las } \\
\text { docentes? }\end{array}$
\end{tabular}}} & No & \\
\hline & & Sí & \\
\hline & & No $\chi$ & \\
\hline \multirow{2}{*}{\multicolumn{2}{|c|}{$\begin{array}{l}\text { ¿Realiza algún ritual de } \\
\text { cierre? }\end{array}$}} & Sí x & $\begin{array}{l}\text { Les pregunta a los niños: «¿[es]tán prontos para } \\
\text { empezar?» }\end{array}$ \\
\hline & & No & \\
\hline \multirow{2}{*}{\multicolumn{2}{|c|}{$\begin{array}{l}\text { ¿Los niños realizan preguntas o } \\
\text { comentarios? }\end{array}$}} & Síx & \\
\hline & & No & \\
\hline \multirow{2}{*}{\multicolumn{2}{|c|}{$\begin{array}{l}\text { ¿La docente realiza preguntas o } \\
\text { comentarios? }\end{array}$}} & Sí & \\
\hline & & No $\chi$ & \\
\hline \multicolumn{4}{|c|}{ Durante la lectura } \\
\hline \multirow{2}{*}{\multicolumn{2}{|c|}{ ¿Presenta el libro? }} & Sí X & \\
\hline & & No & \\
\hline \multirow{13}{*}{$\begin{array}{l}\frac{\pi}{0} \\
\frac{0}{0} \\
\frac{\pi}{0} \\
\frac{0}{2}\end{array}$} & \multirow[t]{2}{*}{ ¿Muestra las imágenes? } & Sí x & $\begin{array}{l}\text { A medida que lee, luego de terminar cada página. Voltea } \\
\text { el libro y lo enfrenta a sí para que los niños observen las } \\
\text { imágenes. Se detienen unos segundos en cada página. }\end{array}$ \\
\hline & & No & \\
\hline & \multirow{2}{*}{ ¿Muestra los paratextos? } & Sí x & Muestra la contratapa cuando la lee. \\
\hline & & No & \\
\hline & \multirow{5}{*}{ Volumen de voz } & Muy bajo(--) & \\
\hline & & Bajo (-) & \\
\hline & & Moderado $(-+)$ & Es escuchada por todos. \\
\hline & & Alto $(+)$ & \\
\hline & & Muy alto $(++)$ & \\
\hline & Velocidad & $\begin{array}{l}\text { Lenta } \\
\text { Moderada } \chi \\
\text { Rápida }\end{array}$ & \\
\hline & Fluidez & $\begin{array}{l}\text { +Fluidez } \chi \\
\text {-Fluidez }\end{array}$ & \\
\hline & Dicción & $\begin{array}{l}\text { Sin omisión de } \\
\text { fonemas } \chi \\
\text { Con omisión } \\
\text { de fonemas }\end{array}$ & $\begin{array}{l}\text { En la lectura no omite fonemas, pero cuando pregunta a } \\
\text { los niños se registra una omisión propia del habla } \\
\text { coloquial: «¿̇es]tán prontos para empezar?» }\end{array}$ \\
\hline & & Sí $x$ & \\
\hline
\end{tabular}




\begin{tabular}{|c|c|c|c|}
\hline \multirow{3}{*}{\multicolumn{2}{|c|}{$\begin{array}{l}\text { ¿Adecua la entonación o } \\
\text { velocidad de su voz al } \\
\text { momento, situación del } \\
\text { cuento, personajes o } \\
\text { modalidad del enunciado? }\end{array}$}} & No & \multirow{2}{*}{\begin{tabular}{|l|} 
\\
\end{tabular}} \\
\hline & & Sí x & \\
\hline & & No & \\
\hline \multirow{2}{*}{\multicolumn{2}{|c|}{ Se desplaza mientras lee }} & Sí & \\
\hline & & No $x$ & \\
\hline \multirow{2}{*}{\multicolumn{2}{|c|}{$\begin{array}{l}\text { ¿Realiza preguntas o } \\
\text { comentarios? }\end{array}$}} & Sí & \\
\hline & & No $x$ & \\
\hline \multirow{2}{*}{\multicolumn{2}{|c|}{$\begin{array}{l}\text { ¿Responde preguntas o } \\
\text { comentarios de los niños? }\end{array}$}} & Sí & \\
\hline & & No $x$ & \\
\hline \multirow{2}{*}{\multicolumn{2}{|c|}{$\begin{array}{l}\text { ¿Realiza algún ritual de } \\
\text { cierre? }\end{array}$}} & Sí & \\
\hline & & No $x$ & \\
\hline \multirow{2}{*}{\multicolumn{2}{|c|}{$\begin{array}{l}\text { ¿Los niños realizan preguntas o } \\
\text { comentarios? }\end{array}$}} & Sí & \multirow{2}{*}{ En forma espontánea. } \\
\hline & & No & \\
\hline \multirow{2}{*}{\multicolumn{2}{|c|}{$\begin{array}{l}\text { ¿La docente realiza preguntas o } \\
\text { comentarios? }\end{array}$}} & Sí & \\
\hline & & No $\chi$ & \\
\hline \multicolumn{4}{|c|}{ Después de la lectura } \\
\hline \multirow{8}{*}{$\begin{array}{l}\frac{0}{0} \\
\frac{0}{0} \\
\frac{0}{0} \\
\frac{0}{2}\end{array}$} & \multirow{2}{*}{ ¿Realiza preguntas? } & Sí $x$ & \\
\hline & & No & \\
\hline & \multirow{2}{*}{$\begin{array}{l}\text { ¿Responde preguntas o } \\
\text { comentarios de los niños? }\end{array}$} & Sí & \\
\hline & & No $\chi$ & \\
\hline & \multirow{2}{*}{$\begin{array}{l}\text { ¿Responde preguntas o } \\
\text { comentarios de la docente? }\end{array}$} & Sí & \\
\hline & & No $\chi$ & \\
\hline & \multirow{2}{*}{$\begin{array}{l}\text { ¿Realiza algún ritual de } \\
\text { finalización? }\end{array}$} & Sí $x$ & Pregunta a los niños si les gustó el cuento. \\
\hline & & No & \\
\hline \multirow{2}{*}{\multicolumn{2}{|c|}{$\begin{array}{l}\text { ¿Los niños realizan preguntas o } \\
\text { comentarios? }\end{array}$}} & Sí x & \\
\hline & & No & \\
\hline \multirow{2}{*}{\multicolumn{2}{|c|}{$\begin{array}{l}\text { ¿La docente realiza preguntas o } \\
\text { comentarios? }\end{array}$}} & Sí $x$ & $\begin{array}{l}\text { Al terminar la lectura continúa comentando el cuento con } \\
\text { sus alumnos. La mediadora permanece presente. }\end{array}$ \\
\hline & & No & \\
\hline \multicolumn{4}{|c|}{ Interacciones entre los actores } \\
\hline
\end{tabular}




\begin{tabular}{|l|l|}
\hline $\begin{array}{l}\text { Actitud de la mediadora hacia los } \\
\text { niños }\end{array}$ & Actitud de respeto y complicidad con los niños. \\
\hline $\begin{array}{l}\text { Actitud de la docente hacia la } \\
\text { mediadora }\end{array}$ & $\begin{array}{l}\text { Habilita la participación de la mediadora durante la lectura, pero toma la } \\
\text { iniciativa durante la conversación sobre lo leído. }\end{array}$ \\
\hline $\begin{array}{l}\text { Actitud de los niños hacia la } \\
\text { mediadora }\end{array}$ & $\begin{array}{l}\text { Escuchan con atención. Se compenetran con la historia leída. Participan en } \\
\text { forma espontánea y ordenada. Se muestran entusiasmados en la discusión. }\end{array}$ \\
\hline $\begin{array}{l}\text { Actitud de la mediadora hacia la } \\
\text { docente }\end{array}$ & $\begin{array}{l}\text { Acepta la interrupción de la docente luego de la lectura, pero cuando surge } \\
\text { la oportunidad retoma la palabra. }\end{array}$ \\
\hline
\end{tabular}

Transcripción de la sesión de lectura de La manta de las historias

Rosario: ¿cómo andan?

Niño: [aaa] Las mantas y la historia \[lee la tapa del libro]

Niño: [aaa] La manta de las historias I

Niño: nunca lo escuche \

Niño: muy bueno \

[Los niños intentan leer la tapa del libro.]

(La mediadora espera que los niños, la maestra y yo terminemos de acomodarnos en nuestros asientos.)

Rosario: bueno \/ ya les dije buen d::ía /

Niños a coro: ¡buen día::!\

Rosario: ¿andan bien? /

Niños a coro: ¡bie::n!\

Niño: $<5>$ mal $\backslash$

Rosario: ¿por qué andas mal? / | ¿qué pasó?

Niño: bastante mal en todo el día \}

Rosario: ¿qué pasó en la casa? | ¿no te salen las cuentas? /

Niño: no \

Niño: es que yo me dormí \

Rosario: $<5>$ bueno $\backslash \mid$ hoy vamos a leer el cuento La manta de las historias $\backslash \mid$ calguno lo conoce? /

Niños: no \

Niño: yo creo que lo escuché igual \

Rosario: las autoras son \| Ferida Wolf y Harriet May Savitz \

Niño: creo que conozco esa tapa \

Rosario: ¿sí? <5> ¿[es]tán prontos para empezar?

Niños a coro: ¡sí::!! 
Rosario: en lo más profundo de las mentañas (sic) \| cubiertas de nieve $\backslash$ | quedaba la pequeña aldea donde vivía Babba Zarrah ${ }^{14} \backslash$ | a los niños les encantaba sentarse en la grande y vieja manta de las historias de Babba Zarrah $\backslash \mid$ para escuchar sus relatos $\backslash\{$ muestra las imágenes $<10>$ \}

Niño: ipa::h! qué grande!\

Niño: (???)

Rosario: un día \| Babba Zarrah \| notó que había un agujero en el zapato de Nikolai \| cuando el niño se fue $\backslash$ | decidió tejerle unas medias muy bonitas y abrigadoras $\backslash$ | pero había caído ta::nta nieve ese invierno que nadie pudo llegar a la aldea para llevar lana \ || ¿cómo iba a tejer las medias sin lana? / | toda pregunta tiene una respuesta dijo Babba Zarrah $\backslash \mid$ simplemente $\backslash$ | tengo que concentrarme $\backslash \mid$ se sirvió un vaso de té dulce para poder pensar mejor $\backslash \mid$ y antes de beberse...- $\backslash \mid$ y antes de haberse tomado tres sorbos $\backslash$ | Babba Zarrah ya sabía lo que tenía que hacer $\backslash||$ voy a desbaratar un trozo de mi manta de las historias $\backslash$ | y así podré usar la lana:: para las medias de Nikolai \| dijo $\backslash$

Niño: ¿̇a ver?

Niño: le tiraron con un tronco grande \

Rosario: tarde en la noche $\backslash$ | cuando todos estaban dormidos $\backslash$ | Babba Zarrah caminó por entre la nieve y dejó las medias frente a la puerta de la casa de Nikolai \{muestra las imágenes $<10>$ \}

Rosario: poco después \| el cartero encontró una bufanda arrollada en su maletín \| justo cuando iba a empezar sus rondas matutinas $\backslash$ | ¿saben quién hizo esa bufanda? | preguntaba a todos los que encontraba en el camino? | pero nadie sabía \{muestra las imágenes $<10>$ \}

Niño: ip::ah!\

Niño: (???)\

Rosario: el profesor de la escuela se sorprendió al encontrar un par de guantes en una pila de leña \| cuando iba a recoger madera para la estufa de la escuela \/ la señora Ivanov espantó a los cuervos de su lavandería con un nuevo delantal tejido / | que descubrió al lado de su bomba de agua \{muestra las imágenes $<10>\}$

Niño: $\{$ risas\}

Niño: le hacía:: \| cosas para todos \

Rosario: al poco tiempo la tendera tenía puesto un nuevo chal en lugar del apolillado manto que solía usar $\backslash$ | ahora los niños tenían que sentarse muy ju::ntos en la manta \|cuando iban a escuchar una historia \\{muestra las imágenes $<10>\}$

Rosario: día tras día la curiosidad de los aldeanos crecía \/ la bebé Olga recibió una misteriosa manta nueva $\backslash$ | muy suavecita y el carnicero alardeó con la elegante gorra de lana que cubría su reluciente $\backslash$ | cabeza calva \| ahora los niños estaban bastante apretados ggestualiza con el cuerpo cómo se encontraban los niños sentados junto a la manta\} \| en la pequeñita manta de las historias $\backslash$ \{muestra las imágenes $<10>\}$

14 Lee /babá sarrá/ 
Niño: cada vez se volvía más pequeña \

Rosario: la confusión creció $\backslash$ | cuando el mugrie::nto gato del sastre apareció de pronto $\backslash$ | ronroneando muy refinado en un ajustado abrig...- \| abrigo para gatos $\backslash$ | ya no había manta para sentarse \{muestra las imágenes $<10>\}$

Niña: i[es] perá! \

Niños a coro: $\{$ risas $\}$

Rosario: los aldeanos le pidieron al alcalde $\backslash$ | que los ayudara a resolver el misterio $\backslash$ | ya saben lo que siempre dice Babba Zarrah $\backslash \mid$ replicó el alcalde $\backslash$ | toda pregunta tiene una respuesta $\backslash||$ cuando los niños vieron las medias $\backslash$ | la bufanda $\backslash$ | los guantes $\backslash$ | el delanta::I \| el chal $\backslash \mid$ la gorra $\backslash$ | la mantita $\backslash$ | y el abrigo del gato $\backslash$ | todo en el mismo sitio $\backslash$ | gritaron [enf.] todas estas pren...- $\backslash \mid$ prendas se parecen a la vieja manta de la historia de Babba Zarrah \| pero ella ya no la tiene dijo Nikolai \| iajá! [enf.] dijo el alcalde Babba Zarrah usó la lana de su manta para hacer estos obsequios ahora nos corresponde a nosotros $\backslash$ | darle una sorpresa a Babba Zarrah \{muestra las imágenes $<10>$ \}

Rosario: entonces $\backslash$ | mientras Babba Zarrah dormía \| en cada casa tomaron un poco de lana de cada manta para poder dejar algunos ovillos de lana frente a la puerta del hogar de Babba Zarrah \| Babba Zarrah se sorprendió cuando abrió la puerta de su casa en la mañana \| nunca antes había visto tanta lana \| en tan diversos colores / | y encima de los ovillos \| de la lana había un letrero \| para tu nueva manta de las historias \{muestra las imágenes $<10>$ \}

Niños: \{risas\}

Rosario : cuando los niños fueron otra vez a la casa de Babba Zarrah \|a escuchar una historia \| encontraron una colorida nueva manta $\backslash$ | y el relato $\backslash$ | sobre una aldea en la que todos compartían con su prójimo $\backslash \mid$ mientras abrazaba a los chicos al despedirse \| Babba Zarrah notó un agujero en el suéter de Alexandra \|| quería tejerle a la niña una sorpresa \| pero la nieve aún cubría las montañas \ | y no había forma de conseguir lana en la aldea \|| Babba Zarrah sabía que toda pregunta tiene una respuesta \|miró su nueva manta de las historias y se sonrió \

Niño: iah::! pero de nuevo la va a gastar \

Rosario: y colorín colorado este cuento se ha acabado \

Niños a coro: \{aplausos\}

Rosario: ¿̇es gustó?

(La maestra interrumpe sin dar tiempo a la mediadora y comienza a hacer preguntas sobre el cuento leído. Rosario permanece frente a la clase esperando $\langle 06: 10\rangle$. Cuando nota una pausa más prolongada en el discurso de la maestra, aprovecha para intervenir.)

Rosario: yo me imagino que ella nunca se va a quedar sin manta \| de las historias ¿no? / | porque los aldeanos siempre la van $\backslash=\ldots . .=$

Niño: =.....= iyo también $\mathrm{i} \backslash \mid$ porque seguramente le van a dar de nuevo más $\backslash$

Rosario: les comparto lo último que dice el libro \}

Niño: isí! \ 
Rosario: en la tapa final \

Niño: is::h! \

Rosario: Babba Zarrah tiene una hermosa manta de lana en la que en los niños aman sentarse \/ para escuchar sus historias $\backslash$ | cuando cuando Babba Zarrah se da cuenta de que sus vecinos necesitan ropa nueva \| desbarata en secreto su manta de las historias \| para tejerles las prendas que necesitan $\backslash$ p pronto ya no queda ni un hilo de la manta pero los aldeanos tienen una solución para eso $\backslash$

Niño: iqué bueno! de nuevo lo van a hacer \

Carmen: así que bueno $\backslash$ | vieron como ese dicho ¿verdad? / | el bien compartido es doblemente bien $\backslash$ | no cuando uno comparte ¿verdad? / él nunca se va a quedar sin la manta porque $\backslash$ | porque como pone todo su cariño \| todo su afecto para los demás \| no solamente cuando cuenta sus historias \ | sino también cuando deshace esa manta \|| los demás se dan cuenta ¿y qué hacen justamente? / | les devuelven mediante los ovillos de lana \| para que esa alfombra siempre esté presente \

Rosario: a todos nos pasa cuando damos cosas buenas $\backslash=\ldots . .=$

Niño: $=\ldots . . .=$ iclaro! \}

Rosario: recibimos cosas buenas $\backslash=\ldots . .=$

Niño: $=\ldots . . .=$ bueno /

Rosario: vuelven $\backslash \|$ bueno $\backslash \mid$ me alegro que les haya gustado $\backslash$

Niños a coro: $\{$ aplausos\} $\backslash$

Rosario: bueno Carmen $\backslash \mid$ muchas gracias $\backslash$

Carmen: anduvimos bien \

Niña: la Camila me enseñó a coser \

Carmen: ¿quién? /

Niño: la Camila \

Rosario: ¿nunca ayudaron a las abuelas \| a desarmar...- ? / | yo lo hacía cuando era chica \

Niño: iyo también!\

Niños: (???) (intercambian con entusiasmo)

Rosario: y a desarmar algún buzo $\backslash$ | vieron como que el buzo se va...- $\backslash \mid$ vos vas haciendo bien rapidito el rollito\

Niños: $<6>$

Carmen: [enf.] bueno quedó silencio \}

Niño: mi abuela tiene de madera y de...- $\backslash$

Carmen: iah::! las agujas \

Niño: y tiene unas pelotas \

Carmen: sí ovillos \| ovillos igenial! \ 
Rosario: imuchas gracias por su atención chiquilines!

Niños a coro: $\{$ aplausos\}

(Nos retiramos del salón.) 


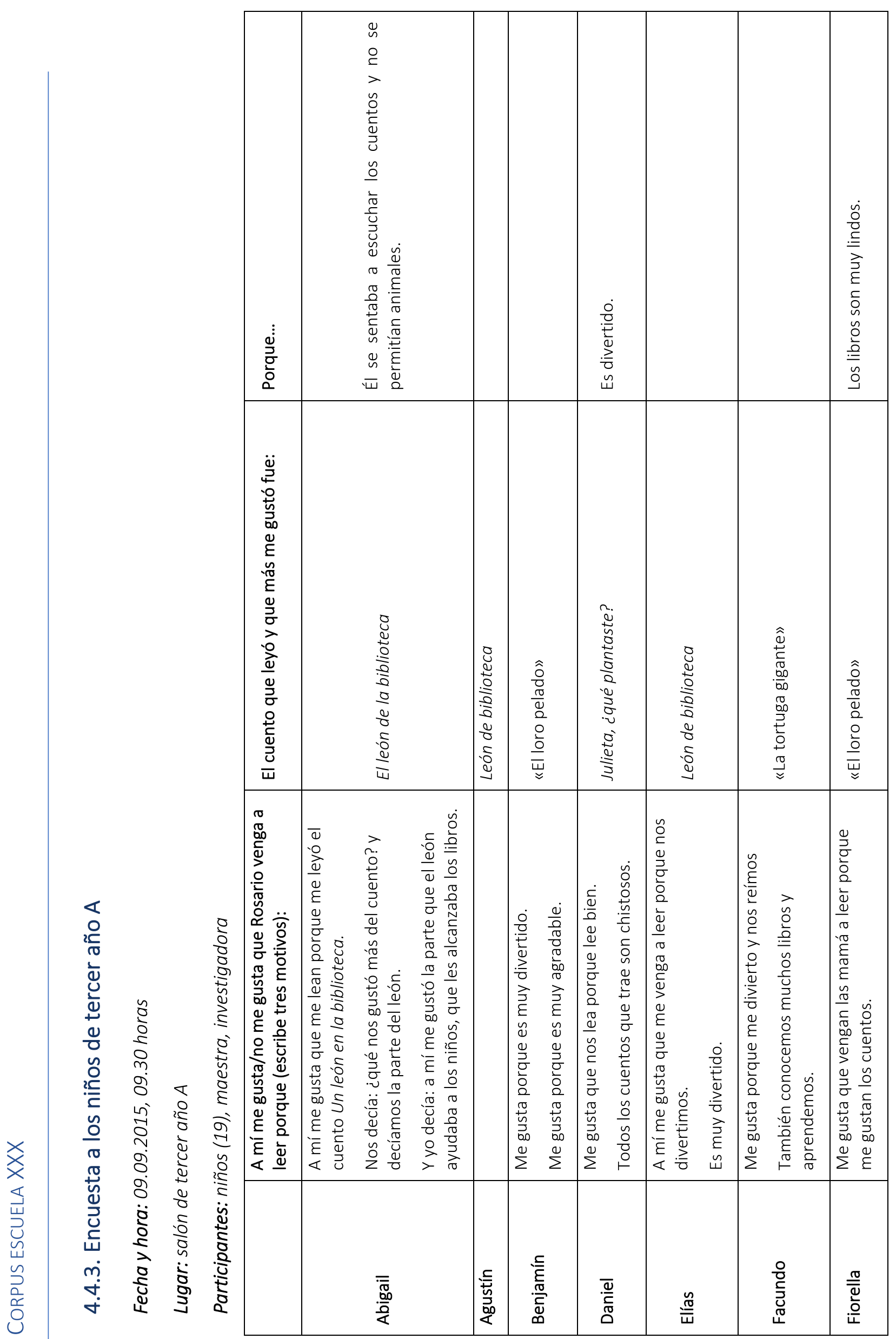




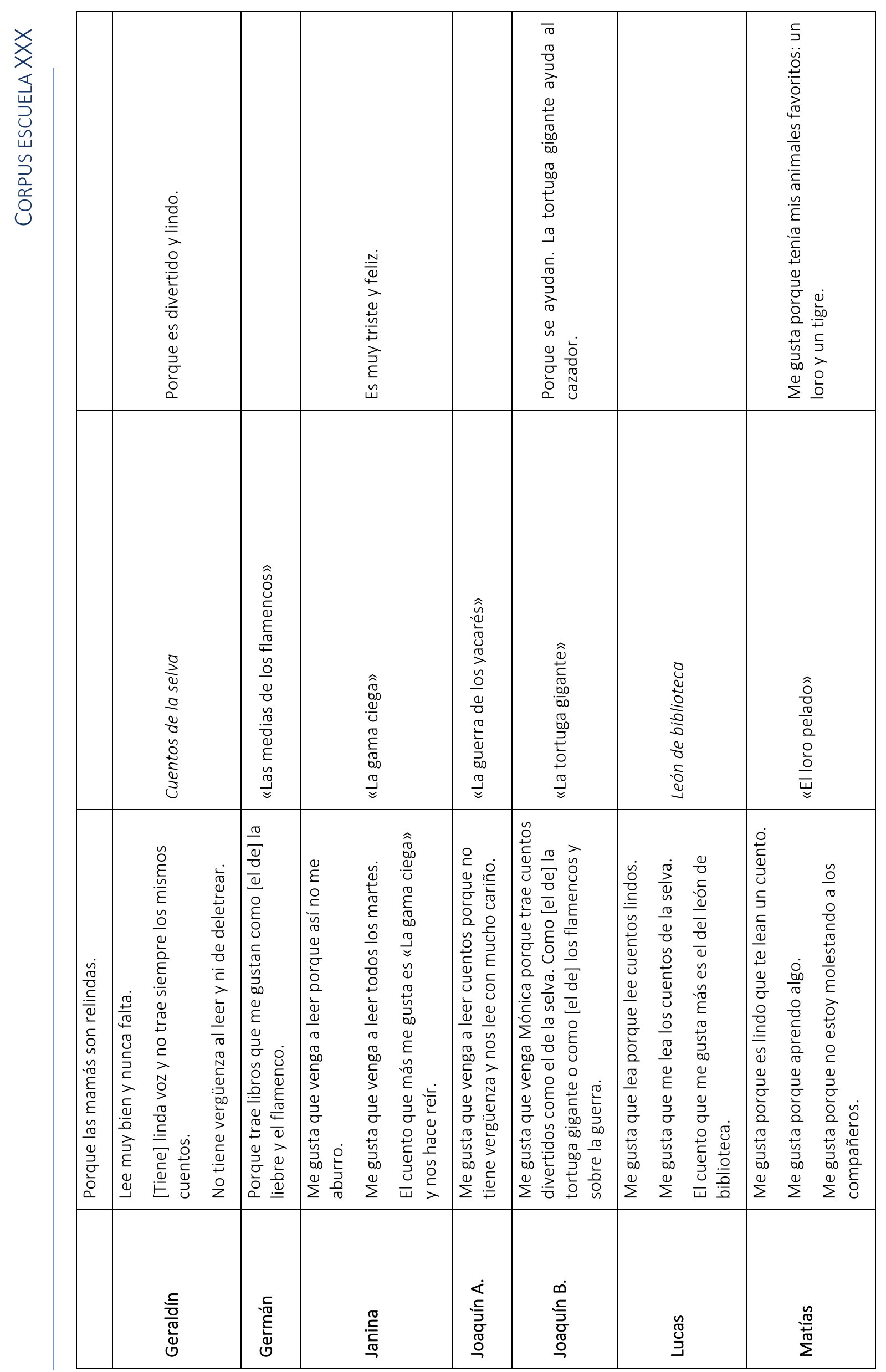




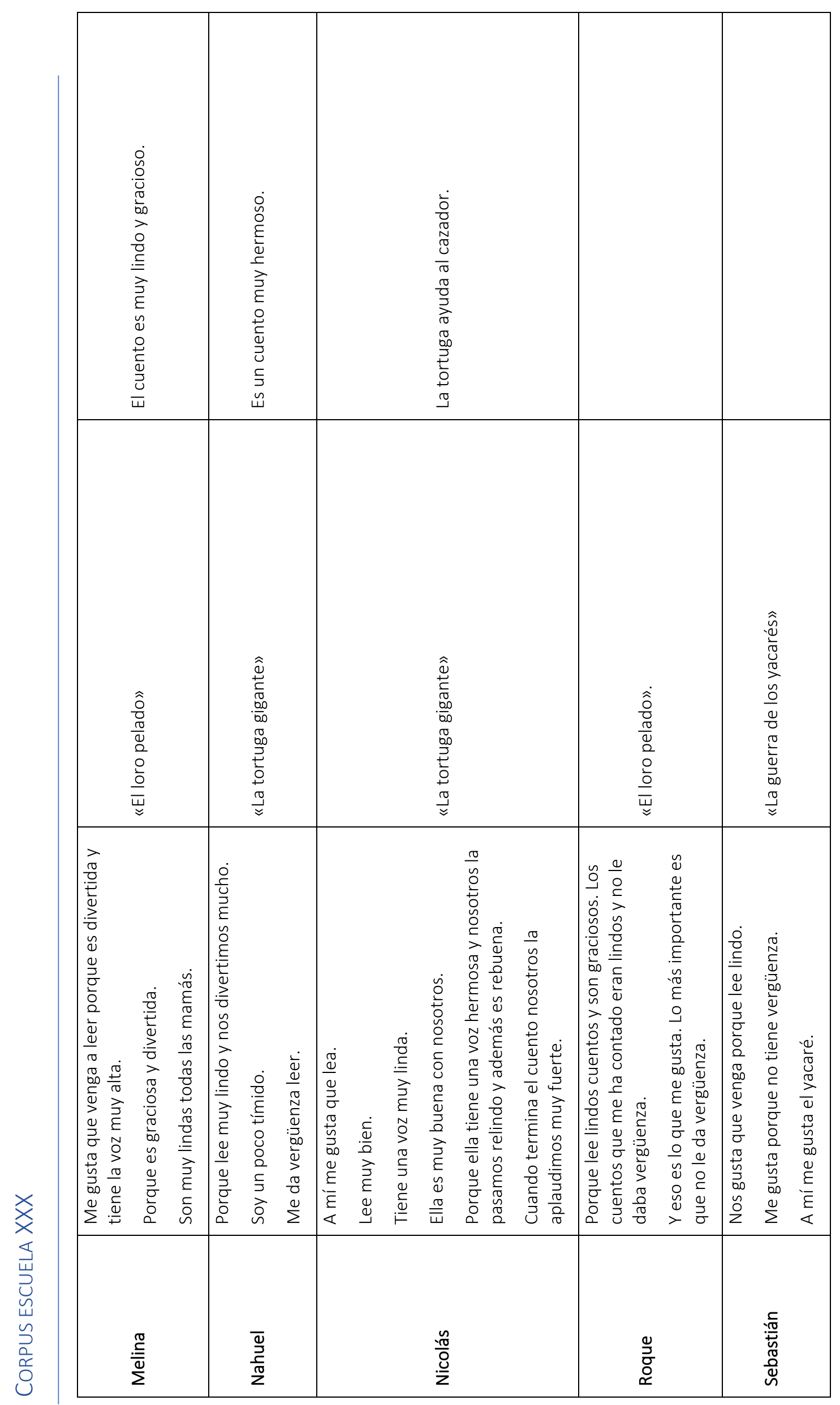




\subsection{Caso 4. Patricia}

\subsubsection{Entrevistas}

\subsubsection{Entrevista a Patricia}

Fecha y hora: $20.10 .2015,10.30$ horas

Lugar: comedor de la escuela

Participantes: Patricia, investigadora

(Nos saludamos y mientras prendo el grabador, que se había quedado sin pilas y tuve que reemplazarlas, le comento los propósitos de la entrevista.)

Sandra: entonces || son unas poquitas preguntas

Patricia: sí

Sandra: vamos a empezar || Patricia | ¿por qué decidiste vos integrarte al equipo comunitario?

Patricia: en realidad fue una propuesta que...- | yo | en primer lugar | tengo:: | amor por los niños || siempre que pude integrarme a algo en la escuela | siempre ...- | pudiendo dije que sí |leer me gusta | entonces | fue doble:: la alegría ¿no? | y:: vi respuesta en los chiquilines y entonces dije «bueno sí» || por eso más que nada | porque me gust...- | en primer lugar me gustan los niños | y siempre que haya algo para ayudar a los chiquilines y yo pueda | voy a decir que sí | y si se trata de lectura bueno más todavía ¿no?

Sandra: Patricia es tu segundo año ¿no?

Patricia: es el segundo año sí

Sandra: debe haber sido muy buena la experiencia para que vos decidieras continuar

Patricia: isí! isí! isí! | fue buena la experiencia | yo me sentí:: | alegre | feliz de hacerlo | y sentía::...- | lo mismo | que yo sentía | sentía que los chiquilines estaban viviendo || era un momento | ¿cómo te puedo explicar? || yo estaba dando lo mejor de mí | sentía que los chiquilines se daban cuenta de eso || y lo retribuí:: an | y llegamos a interactuar | más que nada con los grupos grandes el año pasado | llegamos a interactuar de una manera mágica || sí | sí || con quinto el año pasado me pasó eso | viste que los chiquilines | era como esperar el momento para interactuar para meterse en ese mundo lestaba leyendo Los fantasmas de la escuela que este año me lo pidieron de vuelta | y se creó eso

Sandra: imirá vos! ese es un dato buenísimo que vos das | porque generalmente | se piensa que los grandes pierden interés | por leer

Patricia: yo creo que hay que buscar || más que nada | me parece a mí | es tratar de...- | sin ponerme a la par porque soy una mujer de 44 años nunca puedo estar a la par de un niño de 10 o de 11 I pero buscar el interés ¿̇entendés? | no es lo que a mí me gustaría | que ellos leyeran | sino tratar de ver | por dónde van los (???) |qué es lo que está pasando por la cabecita de ellos | y esa es la manera de atraparlos | me parece

Sandra: los cuentos que vos les llevaste a leer a ellos ¿̇los elegís vos? 
Patricia: sí | Los fantasmas de la escuela me lo... | me lo propuso la maestra Sonia | y:: | bueno leímos un capítulo | y:: la respuesta fue maravillosa que llegamos a leer Los fantasmas de la escuela y Los fantasmas de la escuela pasaron de clase | me pidieron que me quedara | porque viste que rotamos todos los meses | y con quinto estuve como tres cuatro meses con ellos | sí | sí

Sandra: es impresionante porque si se logra eso...- | siempre está la idea cuando yo elegí tercer año era por el miedo de encontrarme con esa apatía de los chiquilines | y esto que vos decís cuestiona todo eso Patricia: claro

Sandra: entonces lo que venía ahora | es cómo vivís esas actividades de lectura

Patricia: con alegría | con alegría sí || es media que es una fiesta | es una fiesta

Sandra: yo cuando estuve con el Abuelo Sapo y con |la Cena elegante me di cuenta que esa pasión |ellos lo notaban

Patricia: es una fiesta es una fiesta

Sandra: ¿vos qué decís? | ¿para qué le puede servir a los niños que venga | no solo Patricia | sino el equipo comunitario a la escuela?

Patricia: los chiquilines bajan un cambio || bajan un cambio | tenés que atrapa::rlos | tenés que saluda::rlos | darles un tie::mpo porque no es todo mágico | no están | acostumbrados de repentes a la serenidad de la lectura | entonces darles sus tiempos saluda::rlos | ahí empiezan a prestar atención | empiezan a:: | a meterse estar...- | y yo pienso que eso les debe servir para todas las áreas ¿no? | porque es necesaria la concentració::n | yo pienso que sí que muy importante

Sandra: y ahora que hablamos ya de la concentración y de las áreas| también ¿vos considerás que le sirve al maestro?

Patricia: iay::! sí | claro | porque el maestro también lee [enf.]

Sandra: hay maestros incluso como Carmen y Amalia que se ponen como uno más del grupo | ellas disfrutan como sus niños

Patricia: sí | sí | pasa sí con muchas maestras

Sandra: y ahora | volviendo un poco a tu historia como mamá lectora de la escuela en estos dos años | ¿vos notás que fuiste cambiaste a::Igo a medida que fuiste agarrando experie::ncia?

Patricia: sí | sí | una se pone más canchera | y pasa en todo ¿no? | y también está que ahora los chiquilines ya me conocen | yo ya soy parte de la escuela || antes era...- | cuando entraba a un salón por primera vez era preguntarme quién era:: | porque ellos curiosean ¿no? | quién sos | ahora ya no | ahora ya viene Patricia o viene la mamá de Bautista || sí ahora estoy más canchera | ya los conozco | ya los reconozco || y ya | nos vemos en la calle | «¿̇y cómo est::ás?» | «ट y cómo te fue en la escuela?» | "y me fue bien en el carné» | se crea una amistad | con los chicos

Sandra: se crea un vínculo diferente

Patricia: un vínculo diferente 
Sandra: $<5>$ ¿alguna lectura que te haya...- | de todas las que has hecho que te haya impactado de una manera en particular | que te haya gustado? | ¿alguna que hayas dicho «no esta no me gustó»?

Patricia: no | no | que no me haya gustado no | lo que sí tuvo gran repercusión son Los fantasmas de la escuela | sí | esa estuvo...- | porque es...- | fue muy acertada la elección de Sonia | porque los chiquilines | tomaron la historia como propia || ellos se sentían | totalmente identificados [enf.]| es más | habían hasta planificado hasta hacer alguna actividad con el libro para la fiesta de fin de año | que no se pudo dar quizás este año sí

Sandra: capaz que sí

Patricia: | capaz que sí | podamos o pintar los muros como lo hicieron en el libro o algo de eso | vamos a ver | ojalá que se dé

Sandra: ahora que me hablás de eso el autor de ese cuento lo pueden invitar

Patricia: Ignacio Martínez es

Sandra: si lo invitás viene | capaz que viene

Patricia: ¿sí?

Sandra: sí | se engancha

Sandra: bueno y en el plano personal | ¿cuáles son tus lecturas favoritas?

Patricia: bueno yo ahora estoy leyendo algo que me...- | que me tiene así como:: | que lo leo | lo leo y no lo leo | estoy leyendo La chica /que soñaba con un bidón / de nafta / de gasolina y no me acuerdo | y es muy tormentoso | es muy tormentoso

Sandra: ¿'es una novela?

Patricia: sí | por lo general trato de leer | de todo un poco | de todo un poco $\mid$ \{(risas) menos libros de autoayuda\} || sí | leo de todo un poco leo de todo un poco | ahora estoy con eso de bueno lo dejo | pero no lo quiero dejar porque | uno no puede juzgar un libro hasta no terminarlo

Sandra: si te lleva a seguirlo leyendo

Patricia: sí

Sandra: <6> ya me dijiste que Los fantasmas de la escuela le había gustado mucho a los de quinto | ¿qué lecturas | si tuvieras que sintetizar en un género | les gusta más a los chiquilines? | a los de quinto | a los de tercero

Patricia: yo a los de quinto a los de quinto | a los de quinto le voy con libros con novelas | no les voy con cuentitos cortos | porque es una manera de dejarlos enganchados me parece a mí [enf.] | y los chiquitos se enganchan con cue::ntos | con mucha ilustració::n | pocas palabras y mucha ilustración

Sandra: ¿vos qué recordás || de::I día que leíste el Abuelo Sapo? | ¿te acordás?

Patricia: iay sí! [enf.] || estaba::n | como efervescentes || interactuaron | divinos se hicieron preguntas | disfrutaron la lectura | se divirtie::ron [enf.] || estuvo muy lindo | estuvo muy lindo sí

Sandra: ¿y de la otra lectura? | Una cena elegante? 
Patricia: itambié::n! | también estuvo linda | la del Abuelo Sapo me parece que fue más ¿no?

Sandra: ¿y qué observaste en las instancias de lectura en los niños?

Patricia: sí | había un grupo que era más efervescente que otro me parece | no me acuerdo si fue el de Amalia | ahora no me acuerdo | pero sí ellos se metieron en el cuento | interactuaron | hicieron preguntas y se rieron mucho también

Sandra: se rieron mucho | ¿y te parece que aprendieron a::Igo de esa lectura en particular?

Patricia: bueno eso | no lo podría juzgar | porque yo no volví | a la clase | no sé...- | por lo general pasa que | volvés dos semanas o algo así | y te dicen «jah porque te acordás!» | y lo comparan lo que leyendo con lo que les leíste antes | no te puedo decir si les quedó algo || me imagino que sí | me imagino que sí [enf.]

Sandra: ¿y el cuento que yo elegí que fue Una cena elegante | te parece que estuvo bien elegi::do?| o este cuento «mirá fue una porquería»

Patricia: ino! ino! ino! | bárbaro [enf.] | estaban ahí los chiquilines | si no ellos...- | vos te das cuenta | si a ellos no les interesa vos te das cuenta | o empiezan a charlar entre e::Ilos | o empiezan a ponerte cara de que me estoy durmie::ndo || yo no noté eso

Sandra: yo eso nunca lo noté con ninguna mamá que leyó | aunque:: | por ejemplo vos los notás que están callados pero siempre están atentos

Patricia: $<6>$

Sandra: vos me hablabas de que te gustaba mucho leer | ¿vos desde cuándo leés? | ¿̇en qué momento apareció la lectura en tu vida? =.....=

Patricia: $=\ldots . . .=i a:: \mathrm{h}$ ! siempre desde la adolescencia | yo me acuerdo que tenía 17 años || y:: |yo soy artesana | y entonces | yo trabajaba |iba al liceo de noche| y trabajaba para pagarme un curso de artesanías || y en la Casa de...- || la Empleada en la Ciudad Vieja | daban unos...- | daban unos cursos de artesanías y ahí me metí en un taller literario

Sandra: jah qué bueno!

Patricia: isí! yo tenía 17 años y mis amigas | me bromeaban porque yo era la...- | como la nieta | porque iban todas señoras mayores en aquella época no se leí::a mucholl y ahí fue que me enganché y me decían «ipero cómo vas a leer!» [enf.] I y yo me acuerdo que les decía «pero estamos leyendo Juana de Ibarbourou | «[enf.] pero no | vos tenés 17 años! pa pa pa» desde la adolescencia fue que me enganché Sandra: ¿̇y en la niñez | en la escue::la | en tu casa? $=\ldots . . .=$

Patricia: $=\ldots . . .=$ bueno de la escuela sí pero...- $\mid$ en mi casa mis padres no eran $\mid$ no no eran...- $\mid$ todas mis inquietudes fueron | después | sí después | leía en la escuela lo de la escuela | tenía cuentos en casa pero no era una cosa que fuera habitual || sí | sí sí

Sandra: iqué bueno! ¿̇y pudiste seguir manteniendo el hábito hasta ahora?

Patricia: isí! | isí! |! hubo...- | hubo épocas en que leía más | y épocas en las que leía menos | o porque Bautista era chi::co | viste que los tiempos...- | la lectura| no es para...- | está bueno leer en el ómnibus | pero está bueno sentarse en tu ca::sa || tranqui::la 
Sandra: tener tu momento

Patricia: sí

Sandra: <6> una cosa que | siempre me encantó en esta escuela | es el grupo de mamás lectoras que son maravillosas | y cuando vine a las reuniones vi lo que conversan cómo planifican | ¿cómo valorás esas reuniones?

Patricia: bien | bien || sí son un grupo fantástico | son fantásticas | están mu::y comprometidas [enf.] | una de las chiquilinas || yo no estoy mucho | pero una de las chiquilinas el martes se tuvo que retirar del grupo por cuestiones personales | Laura | y ella estaba angustiada de verdad [enf.]| y eso es...- | es noble [enf.] | es es...- | porque ella está | brindando su tiempo | ella podría estar ocupando esa media hora o una hora que le lleva ir y volver de la escuela | en otra actividad | y ella siente la pérdida [enf.] |y ella se sentía mal por no poder venir || es un grupo fantástico | [enf.] Janet que viene con su bebé | [enf.] vos te das cuenta que es una entrega || lo que recibís a cambio es la alegría de estar haciendo algo por los chiquilines | es un grupo fantástico [enf.]

Sandra: la verdad que se nota | es un grupo mu::y organizado | tienen mucha energía

Patricia: pasa con los maestros

Sandra: pasa con los maestros y pasa con los niños | se vive en todos los niveles | es maravilloso || bueno y si el año que viene está Biblioteca Solidaria ¿vas a seguir?

Patricia: y pienso que sí

Sandra: ¿̇y qué consejo le darías por ejemplo a un nuevo integrante?

Patricia: a::h que se deje llevar | que es fantástico que lo disfrute esto es un goce sí sí | no hay...- | no hay fórmulas | es entregarse nada más | no hay fórmulas | los chiquilines te van a guiar || yo apuesto cien por ciento a los chiquilines || sí no hay fórmulas secretas | es entregarse y disfrutarlo | si les gusta | ellos se dan cuenta | ellos se dan cuenta de todo

Sandra: ¿te acordás del Abuelo Sapo que discutían si era un monstruo si era otra cosa?

Patricia: \{(risas) sí sí\} | sí | sí | sí | se da

[Recordamos la discusión de los niños el día de la lectura de Los secretos de Abuelo Sapo.]

Patricia: sí sí | hay que dejarse llevar los chiquilines

Sandra: bueno Patricia imuchísimas gracias! | me parece que lo que hacen es fantástico 


\subsubsection{Entrevista a Amalia, maestra de tercer año B}

Fecha y hora: $14.10 .2015,09.00$ horas

Lugar: salón de tercer año A

Participantes: Carmen, investigadora

Sandra: bien || Amalia | la idea de esta entrevista | es | ampliar un poco el...- | complementar las observaciones que:: | que fuimos haciendo en el trabajo de campo | las observaciones a los mediadores | con la lectura | es eso | un complemento para esas observaciones

Amalia: \{mueve la cabeza [asiente]\}

Sandra: decime | ¿qué tal te resultó | que Patricia haya venido a tu clase | Patricia que fue la mamá que yo observé ¿verdad?

Amalia: positivo $=\ldots . . .=$

Sandra: $=\ldots . . .=$ Rosario y Patricia perdón | las dos

Amalia: divinas | realmente...- | bueno | dos personas distintas ¿no? | Patricia realmente le pone este toque:: | más de narradora || entonces | despierta la intriga en los guri::ses | hace las pausas para que ellos intervengan | se nota más madurez...- | tal vez... | a ver las dos divinas ¿no? | en Patricia se nota otra madurez | cuando lee | y bueno las dos | precioso realmente || me encantó | además yo sé que es difícil pararse frente a una clase | y empezar a leer | y ellas lo hacen realmente con mucha responsabilidad || y:: | y los chiquilines realmente lo disfrutan | porque vos ves que | cada martes cuando vienen | hasta el día de hoy | ellos || disfrutan la lectura | escuchan atienden

Sandra: ¿qué rescatás de esos momentos? | ¿algo en particular que rescates?

Amalia: bueno | que la mayoría de las veces por ejemplo | yo no tengo que intervenir | ellos están | atrapados porque quie::ren | porque les gusta | no es porque yo se lo imponga | o muchas veces que ellos...- | los niños en la escuela hacen cosas porque la maestra quiere | en ese momento ellos realmente...- | después de dos años de:: | ProLEE:: || lo aceptaron | lo tienen como parte |\{(risas) parte entretenida de la clase\} | lamentablemente es así

Sandra: ¿vos | por qué crees que sirve que ellas vengan a leer? || ¿las mamás lectoras?

Amalia: por varias cosas | sirve para que otras mamás se integren || porque:: | no son mamás de la clase | sin embargo ellos lo toman como:: mamás de la escuela | entonces | lo que sienten es que | son parte de la escuela || no son solo parte de la biblioteca | y sería deseable | divino | como yo les decía la otra vez a ellos | bueno que para el año 2016 se sumen otras mamás | y también lo bueno que vi fue la continuidad | desde marzo...- | desde abril que empezaron | nunca abandonaron | sie::mpre vinieron || y eso también es bueno || y bueno sería deseable que | que vieran la escuela un espacio abierto realmente | no solamente cuando hacemos una actividad para padres | o una actividad con padres | sino bueno | un espacio para padres

Sandra: ¿qué observás de distinto | por ejemplo cuando vienen las mamás a leer | que cuando vos leés? | si tuvieras que comparar lo bueno| y lo que | lo que tendría que ser distinto

(Un niño se acerca y le dice a Amalia: «ya terminé». Ambas le pedimos que espere un momento.)

Amalia: bu::eno | creo que tal vez cuando vienen las mamás ellos están más concentrados | cuando leo yo es un poco más jocoso |más...- | intervienen má::s | dicen algunas co::sas que de repente cuando 
vienen las madres no las dicen | o sea un chiste | conmigo | porque estamos más horas | no sé si más libertad | o ellos mismos....- | yo soy la maestra | y lo otro son las mamá | si bien respetan el trabajo de las madres || les gusta | la escuchan | se entretienen || yo creo que cuando estoy yo ellos le agregan el chiste ¿no?| eso de «es la maestra podemos hacer otras cosas»

Sandra: ¿vos decís que tienen más libertad contigo que con ellas?

Amalia: o de repente yo cuando están las mamás soy una censura |que cuando soy yo eso desaparece | uno se para en una esquina y los miras | entonces es que de una forma u otra | también censura ciertas cosas | que cuando vos está al frente | se las permitís | yo no quiero que molesten a las mamás | aunque sé que no lo van a hacer porque son divinos || pero cuando estoy yo...-- | porque sí sé cómo pararlos | tal vez les permito un chiste || que en otro momento no

Sandra: ¿si vos tuvieras que pensar | cuál sería la escena ideal de lectura:: | de las mamás? || ¿vos qué les pedirías a la mamá que hiciera? | un escenario ideal ¿no? | no el que observamos | sino el ideal | ¿qué les pedirías a ellos que hicieran? | ¿cómo tendrían | que responder ellos a:: | a esa mamá que lee Amalia: $<5>$ [piensa] me gustaría por ejemplo tener un espacio distinto | el tema...- | el famoso rincón de lectura | que no fueran la silla y la mesa | que ellos pudieran sentarse con otra libertad || un almohadón | una alfombra | no estar en su banco y su silla | poderlos sacar de este espacio | y después | sí abrir esa posibilidad ese espacio | a ver qué les parece | qué opinan | qué va a pasar | que se sientan un poco más libres de hacerlos participar y volver al cuento | esa intervención entre las dos partes || esa parte me parece que | hay que madurarla | por un tema de que es...- | un proyecto nuevo | porque a pesar de que lleve dos años sigue siendo un proyecto nuevo | entonces || creo que con el tiempo se puede lograr eso | a que bueno | el título y qué va a pasar | el tenerlos ahí y volver al cuento | esa parte más madura | pero bueno || como ideal ¿no?

Sandra: como ideal ¿no? | como para un futuro | y:: | por ejemplo | en los niños | ¿cómo te imaginás esa participación ideal?

Amalia: ah:: | compenetrada en el cuento | que se sientan atrap...- | como cuando uno les lee en casa | que vos de repente decís ta...- | yo tengo una | pero me siento a leerle | y ella interviene en el cuento | pero interviene libremente en el cuento | y lo sigue escuchando | entonces || creo que eso mismo se puede...- | es cierto | tal vez le estamos pidiendo mucho a la mamá lectora | pero bueno | si me dicen ideal | también lo quiero para mí

(Interrumpe una maestra y me pregunta si sé de algún título que conozca para regalarles a las mamás del equipo comunitario de lectura. Quedo en averiguarle en alguna librería del centro.)

Amalia: un ida y vuelta | y que los chiquilines se sientan | libres | no sé si no | en algún momento | que ellos mismos || tomen la posta de:: | de lectores

Sandra: ¿qué otra cosa se te ocurre | que tendrían que hacer las mamás cuando vienen a leer?

Amalia: en realidad se supone que la idea es fomentar el gusto por la lectura || ponerle alguna otra actividad de intervenir | tal vez no:: es lo correcto | pero sí de repente | decir este martes no leemos | este martes | hacemos algo con todo con lo que ya leímos | como para...- | cada tanto | una vez cada dos meses | cada ocho cuentos hacer una actividad de...- | ino importa! | una expresión que salga de...- 
| de la clase | o de to::dos | o algo plástico | no algo teórico | sino algo...- | decir bueno | «hemos leído esto» | y ponemos una cartelera | algo así para ir llevando un hilo ¿no? | tal vez

Sandra: bueno ahora acordate | esto fue hace mucho tiempo pero...- | estuvo la huelga en el medio | cuando vino Patricia a leer Una cena elegante | acordate de ese momento | ¿cómo viviste ese momento vos? | Patricia leyendo la Cena elegante |algo que te acue::rdes | tenía idea de hacerlo enseguida [la entrevista]

(Llegan los niños de su clase de Educación Física y Amalia les llama la atención <20>.)

Amalia: me encantó | por la modalidad de Patri::cia | el cuento estaba precio::so realmente || creo tal vez...- | tal vez ellos estaban muy inquie::tos y Patricia | no sé si estaba mal de la garga::nta o qué | me acuerdo que...- | el cuento me encantó | ella trabajó precioso el cuento | pero aun así le faltó algo má::s | yo creo que esta clase podría haberlo || no sé hasta dónde llegaron a entender el contenido del cuento | el tema

Sandra: vos comparalo con el Abuelo Sapo | ¿te acordás?

Amalia: cla::ro | creo que el Abuelo Sapo lo disfrutaron más | tal vez porque fue una lectura más sencilla | pero | la Cena elegante era un cuento muy...- | dentro de los cuentos de niños profu::ndo | tan precioso | yo creo que no llegaron a::I | al nudo del cuento | o porque son chicos | o porque ese no era...- | no era el mejor día de Patricia | estaba mal de la garganta le dolía la cabeza o algo | le costaba un poco | y ellos estaban dispersos |le daba risa la situación | entonces les costó traerlos un poco más |l yo he visto a Patricia a leer | precioso [enf.] | y ese cuento estaba hermoso | me encanta Patricia [enf.] | me encanta

Sandra: yo por ejemplo | disfruté mucho cuando leyó el Abuelo Sapo

Amalia: claro yo creo que ellos disfrutaron más | el Abuelo Sapo | aunque no era tan profundo |como La cena elegante || pero no sé si fue por un tema de edad o qué que no llegaron al | al nudo del cuento | a la moraleja | no la entendieron || sí ese día estaban muy inquie::tos

Sandra: ¿hay alguna parte del cuento que vos hayas notado | ese día que a ellos les interesó má::s?

Amalia: no | no:: | yo creo que bueno como todo | al principio estaban muy motivados | empezaron b::árbaro | después empezaron a dispersarse | y ahí fue cuando se perdieron | y por eso no llegaron a final | se perdieron | no entendieron la moraleja | se dispersaron en el medio | pero bueno | me encanta Sandra: ¿vos identificaste aprendizajes?

Amalia: yo creo que ese cuento tendría que volver a repetirse || ese cuento | en algún otro momento tendré que volver | tendré que leer

Sandra: vos me dijiste que estaba muy lindo el cuento | ¿te parece que el cuento estuvo bien elegido o fue un obstáculo para que ellos lo entendieran?

Amalia: realmente | me pareció que estaba muy bien elegido || todos los cuentos que han traído | realmente | son preciosos [enf.] | tienen un excelente contenido | ime encanta! | ime encanta! | el León de biblioteca espectacula::r| La manta | de las historias precioso realmente | diez puntos

(Aumenta el bullicio y apuramos la entrevista.) 
Sandra: y bueno para cerrar | vos pensás que el lugar que ocupa la lectura de cuentos | la de cuentos no de otras cosas en la escuela | ¿̇es e::I lugar que tiene que tener? | ¿tendría que tener má::s | más dedicación | o menos?

Amalia: creo que deberíamos tener || un día |está bárbaro que venga otra persona | |padre abuelo tío | otra persona | otra maestra de la escuela | (???) | pero creo que también tendríamos que reflotar el momento de leer ellos | que esa es la parte que no la tenemos | el año pasado cuando teníamos la Biblioteca Solidaria $=\ldots . .=$

Sandra: $=\ldots . . .=$ ¿ंeste año no funciona la biblioteca?

Amalia: no le quedó nada | la biblioteca se desarmó | hay algunos pocos libros allá arriba | y los libros buenos | los tiene Mariela en su biblioteca | que son los que les da a las mamás | todos los libros nue::vos buenos | la buena lectura | está en la biblioteca de Mariela | ¿si podemos pedirle a Mariela? | sí podemos pedirle a Mariela || pero no es la biblioteca

Sandra: no es ir allá a leer

Amalia: no es ir allá a leer | eso se | eso se desarmó

Sandra: iqué lástima!

Amalia: y sin embargo el año pasado eso se había implementado /o empezaban a leer un libro y lo seguían después

Sandra: iqué lástima! | icon el esfuerzo que hicieron! | era un esfuerzo importante

Amalia: lo bueno estaban cuando eran las dos escuelas juntas [unificada la biblioteca de la mañana y la de la tarde] | ahí había muchos cuentos

(Amalia solicita silencio a los niños.)

Sandra: ¿algo más que quieras agregar?

Amalia: me encantó | me gusta el proyecto ProLEE | creo que el año que viene hay que reflotar la biblioteca | no sé si empezar ahora a fin de año | a decir «bueno a ver qué tenemos | qué arreglamos y qué hacemos» | para que en marzo sea un comienzo | pero me parece que falta esa parte donde ellos leen | esa parte es fundamental

Sandra: sin libros no se puede leer

Amalia: como en la casa no hay

Sandra: ibueno muchas gracias Amalia!

Amalia: cualquier cosa Sandra que vengas me avisas

\subsubsection{Entrevista a los niños de tercer año $B$}

Fecha y hora: 29.09.2015, 09.00 horas

Lugar: patio interior central de la escuela

Participantes: Abel, Priscila, Michael, Iliana, Estiven, Axel 


\section{Abel}

Sandra: ¿hola Abel cómo estás?

Abel: bien

Sandra: esperá que no veo | me tengo que poner los lentes (busco la encuesta)

Abel: mi mamá me dice que haga la letra chica

Sandra: mamá te dice que hagas la letra chica | pero yo imirá! tengo que usar lentes porque no veo | entonces por eso...- | iestá bien! || yo porque no:: no puedo ver | ¿vos te acordás que yo te hice unas preguntas por escrito el otro día?

Abel: sí | qué nos leyó Patricia y qué nos pareció

Sandra: exacto | ¿̇y te acordás lo que vos pusiste?

Abel: no me acuerdo

Sandra: ¿no te acordás lo que pusiste? | ¿nada de nada?

Abel: \{mueve la cabeza [niega]\}

Sandra: bueno yo te voy a dar una:: idea | vos pusiste | «me gusta que venga a leer porque tiene los propios libros»

Abel: \{mueve la cabeza [asiente]\}

Sandra: ¿sí? | ¿y qué más?

Abel: que los libros son:: lindos

Sandra: ¿'son lindos? | ¿te gusta que te lean las mamás? | ¿te gusta que te lean las maestras | ¿tiene algo de especial que vengan las mamás?

Abel: $<6>$

Sandra: ¿tiene algo de especial?

Abel: sí

Sandra: ¿qué? | ¿a ver?

Abel: que los cuentos que leen son lindos

Sandra: muy bien ¿qué más? | vos escribiste cosas muy lindas

Abel: $<5>$

Sandra: ite olvidaste! || bueno no importa | ¿vos te acordás de algún libro que hayan leído las mamás y que haya gustado mucho?

Abel: «El loro pelado»

Sandra: «El loro pelado» | ¿`y por qué te gustó?

Abel: porque:: || era divertido

Sandra: era divertido | ¿y qué te acordás de ese día que leyó la mamá? 
Abel: que el loro se acercó a:: un animal y le sacó todas las plumas

Sandra: cierto || ¿̇y:: te acordás quién lo leyó?

Abel: no

Sandra: ¿qué mamá? || vinieron tres mamás a leer | la mamá de:: | Bautista | Patricia || Rosa::rio y después vino Mónica | ¿te acordás quién de ellas tres?

Abel: una que tenía un buzo violeta

Sandra: Mónica || ¿de lentes | como yo así? | Mónica

Abel: $\{$ mueve la cabeza [asiente]\}

Sandra: ¿y vos te acordás cuando Patricia vino a leerles un cuento que se llama Una cena elegante?

Abel: sí

Sandra: ¿qué te acordás de ese cuento?

Abel: creo que sí

Sandra: ¿ंeh?

Abel: creo que sí

Sandra: ¿qué te acordás?

Abel: $<5>$ no | no me acuerdo ahora

Sandra: ¿no te acordás nada en especial de ese cuento? | si te había gustado | si era divertido era triste Abel: era divertido

Sandra: si tenía un final feliz o un final triste

Abel: no me acuerdo

Sandra: ¿no? | bien | Abel y el año que viene cuando estés en cuarto ¿te va a gustar que vengan las mamás a leer de vuelta?

Abel: sí

Sandra: ¿̇y qué libros les pedirías que te leyeran?

Abel: «El loro pelado»

Sandra: ¿«El loro pelado de vuelta»?

Abel: sí

Sandra: ¿sí? | bueno muchas gracias Nahuel decile a Priscila

Abel: Abel

Sandra: ¿y qué te dije yo?

Abel: Nahuel

Sandra: bueno iperdón! | ¿le decís a Priscila? 
Priscila

Sandra: ihola! | Priscila ¿̇cómo andás? ¿̉ien?

Priscila: bien

Sandra: esperá que busco las preguntas | que ahora se me traspapelaron | ¿vos te acordás del otro día que yo les hice unas preguntas por escrito?

Priscila: sí

Sandra: ¿sí? | ¿te acordás que les pregunté:: qué pensaban de Patricia la mamá que viene a leer?

Priscila: sí

Sandra: ¿vos qué habías puesto? | ¿qué habías escrito?

Priscila: e:: h | me gusta sí

Sandra: ¿sí?

Priscila: me gusta sí | cuando vienen a leer

Sandra: sí yo te veo que levantás la ma::no y estás muy...- | muy atenta sie::mpre

Priscila: sí

Sandra: ¿te gusta que te lean?

Priscila: a mí me encanta | mi madre siempre en la noche me lee...- | me lee varios cuentos y:: | hay un cuento que me lee | quince...- | quince cuentos viste que tiene y entonces mi madre va leyendo ahí | y yo...- | y yo me duermo

Sandra: ¿te dormís con la lectura de tu mamá? iqué lindo! =....=

Priscila: $=\ldots . .=$ y cada vez que cierro los ojos me imagino que es realidad

Sandra: iqué lindo! | y vos pusiste acá | ¿por qué te gustaba que viniera...- | que vengan estas mamás a leer? | las mamás de...-

Priscila: porque:: me gusta mucho porque:: | porque:: | cuando leen siento que | están...- | es realidad | y te das cuenta cuando...- | cuando pasa un problema y el final

Sandra: muy bien | vos me pusiste acá que Patricia es divertí::da | que lee muy bien las mamás

Priscila: sí |leen muy bien

Sandra: ¿`y qué más?

Priscila: $<5>$

Sandra: ¿hay algo especial que tenga Patricia | cuando viene a leer? | ¿qué tiene?

Priscila: isí! | me gusta cuando dice «buen día» | y nosotros le decimos «hola» y toda la clase dice eso igual

Sandra: ¿y algo más que te acuerdes?

Priscila: no 
Sandra: ¿no? | ¿hay algún libro que te hayan leído | y te haya gustado mu::cho?

Priscila: sí el de La Bella Durmiente

Sandra: ¿sí? | ¿qué te hayan leído las mamás acá en la escuela?

Priscila: no I La Bella Durmiente me lo lee en mi casa mi madre

Sandra: jah! te lo lee mamá | pero no | yo te pregunto por los libros que leen las mamás que vienen acá

Priscila: «Las medias de los flamencos»

Sandra: «Las medias de los flamencos»| ¿quién lo leyó? ¿te acordás?

Priscila: <5> yo que...- || no me acuerdo | creo que lo leyó Patricia o...-

Sandra: ¿Patricia?

Priscila: Patricia fue que lo leyó

Sandra: ¿sí? | ¿y qué te acordás de ese cuento?

Priscila: que pasó un problema y un fina::I | que las víboras de coral | pensaban que:: | la lechuza agarró las me...- | le agarró las medias | y como los flamencos eran tan tontos entonces ta | le hicieron caso a la le...- | no le hicieron caso y ta| fueron corriendo a la fiesta | se pusieron las medias | y dijo la lechuza «no dejen de...- | de parar de bailar | porque si no:: |van a...- | van a sufrir»

Sandra: bien I ¿y por qué te había gustado ese cuento?

Priscila: porque es mi preferido porque | yo de chiquita cuando tenía cinco años | mi madre me lo lee mi madre me lo leía | y en cinco también |cuando...- | cuando yo estaba en nivel cinco

Sandra: pero es un cuento la::rgo

Priscila: sí | pero me gusta

Sandra: muy lardo | vos pusiste acá sí que es «Las medias de los flamencos es mi favorito» | ¿vos te acordás el día que | vino Patricia a leer un cuento que se llama Una cena elegante?

Priscila: isí! | jese también me gustó! | que la gallina | que:: el zorro miraba a ver si...- | para que salgan los cosos para comer | los pastitos ${ }^{15}$ | ese me gustó también || me gustó | ese no lo puse pero ta puse «Las medias de los flamencos»

Sandra: ¿te gustó mucho? ¿y por qué te gustó?

Priscila: porque hacía varias comi::das | y entonce::s | e::...l | el ani...- | el animal el zorro | le traía los pollos | a los...- | a lo::s | pollos ¿ंviste? | y entonces | iban...- | y lo engañaba y decía «iay! |trajo comida el tío» | y entonces | vuelve a casa | y la otra vez trajo...- | la otra vez trajo una torta mu::y grande | que...- [enf.] | creo que era de cinco...- | de cinco...- | más grande era $\mid$ entonces $\mid$ la...- $\mid$ la...- $\mid$ la...- $\mid$ el zorro | y la gallina | pensaban que era el tío | y ta | comían | el zorro dejaba en la puerta | y vigila::ba

${ }_{15}$ Parece referirse al Julieta, ¿qué plantaste? 
a ver si sale un pollo | para ver si sale:: | a ver si sale para cazarlo | pero al otro día ya vieron y ta | él quedó ahí | y salieron todos y le agradecieron a él ${ }^{16}$

Sandra: bueno muy bien

Priscila: pero la gallina se puso muy furiosa

Sandra: ¿muy furiosa?

Priscila: sí

Sandra: bueno Priscila || el año que vienen vas a estar en cuarto ¿no? | ¿te gustaría que vinieran las mamás de vuelta a leer?

Priscila: sí otra vez

Sandra: ¿y qué les pedirías que te leyeran?

Priscila: el de «Las medias de los flamencos otra ve::z» | e::m | ese que te estaba hablando de La cena elegante | El sapo tiene frío | El sapo tiene miedo digo | iperdón! y el otro que no me acuerdo qué era| ah sí | que era | el de la garra del tigre | ¿cómo se llamaba?

Sandra: ya sé cuál es | se llama Cuando el temible tigre

Priscila: sí ese también

Sandra: ¿y ese quién lo leyó?

Priscila: una gordita chiquitita

Sandra: Rosario

Priscila: iah! [enf.] Rosario esa y otro más que...- Blancanieves

Sandra: bueno muchas gracias Priscila | ¿podés decirle a Michael?

Priscila: sí

Sandra: ¿̇se porta bien Michael o más o menos?

Priscila: \{risas (se retira)\}

\section{Michael}

Sandra: acá Michael (Le indico dónde sentarse.)

(El niño se sienta a mi lado.)

Sandra: Michael | yo pensé que era Michael [/máikol/] || ¿cómo estás Michael? ¿bien? | ¿tenés ganas de hablar? I ¿o más o menos?

Michael: más o menos

Sandra: más o menos || te voy a hacer unas preguntas cortitas cortitas | que tienen que ver co::n | lo que escribieron el otro día por escrito ¿te acordás?

${ }^{16}$ Parece referirse a El estofado del lobo. 
Michael: \{mueve la cabeza [asiente]\}

Sandra: ¿vos te acordás que yo les preguntaba qué pensaban de cuando Patricia viene a leerles?

Michael: $\{$ mueve la cabeza [asiente]\}

Sandra: ¿vos qué escribiste?

Michael: $<8>$ no sé no me acuerdo

Sandra: ¿a ver? | pensá un poquito

Michael: es divertido | y por lo menos tenemos algo para...- | para leer | escuchar

Sandra: ¿algún cuento que haya leído| que te acuerdes?

Michael: «El loro pelado»

Sandra: ¿ «El loro pelado»? ¿qué te pareció ese libro?

Michael: es divertido y siempre que voy a la biblioteca lo leo

Sandra: ¿vas a la biblioteca?

Michael: \{mueve la cabeza [asiente]\}

Sandra: ¿y qué te acordás de «El loro pelado?

Michael: no sé porque:: | yo:: | tengo problemas de | pérdida de memoria

Sandra: i¿cómo vas a tener problemas tan jovencito?! | Michael | ¿vos te acordás cuando vino Patricia a leer un cuento a la clase? I ¿te acordás del cuento cuál era?

Michael: \{mueve la cabeza [asiente]\}

Sandra: ¿cuál era?

Michael: no | solo me acuerdo la del loro | ese

Sandra: ¿cuál?

Michael: la del loro

Sandra: ¿y cuando leyó Patricia Una cena elegante?

Michael: $\{$ mueve la cabeza [asiente]\}

Sandra: ¿qué te acordás de ese cuento?

Michael: de una cena elegante con velas y $\ldots-<10>$ y todas esas cosas

Sandra: imuy bien! || ¿y de otras mamás que hayan venido a leer? | ¿te acordás de algún otro cuento?

Michael: \{mueve la cabeza\} [niega]

Sandra: ¿no? ¿y el año que viene que vas a estar en cuarto? | ¿te...- | te gustaría que fueran las mamás a leer?

Michael: $\{$ mueve la cabeza [asiente]\}

Sandra: ¿sí? | ¿y qué les pedirías que te leyeran? 
Michel: no sé cualquier libro

Sandra: ¿cualquiera? | bueno imuy bien! | muchas gracias Michael | está pronto entonces | dale igracias!

Iliana

Sandra: ¿cómo andás Iliana? ¡buen día!

Iliana: ¡buen día!

Sandra: Iliana las preguntas que yo te voy a hacer son las que hice por escrito el otro día | ¿vos te acordás que yo les pregunté | qué pensaban de las mamás que vienen a leer? | ¿vos qué habías puesto? Iliana: puse:: que a mí me gusta que las mamás vengan

Sandra: ¿te gusta? | ¿por qué te gusta que Patricia venga? | acá pusiste $=\ldots . . .=$

Iliana: $=\ldots . . .=$ porque:: $\mid$ es buena y porque me gusta que me lean los cuentos

Sandra: y pusiste algo muy interesante | que son muy divertidas las mamás

Iliana: \{mueve la cabeza [asiente]\}

Sandra: ¿sí? || ¿'son más divertidas que las maestras?

Iliana: isí! \{mueve la cabeza riéndose [asiente]\}

Sandra: ¿un poquito?

Iliana: \{aunque el otro día Olga se cayó de la silla y se dobló la pata de la silla (risas)\}

Sandra: ¿quién es Olga?

Iliana: nuestra suplente

Sandra: iah! | la pobre suplente| justo viene a hacer la suplencia y se cae | pero bueno qué va a hacer Iliana: y casi que (???) porque yo me lastimé

Sandra: !ah! | pobre || Iliana| ¿vos te acordás cuando vino a leer Patricia a la clase?

Iliana: sí

Sandra: ¿qué cuento les leyó Patricia? | ¿te acordás quién es Patricia?

Iliana: e::h $<10>$

Sandra: ¿la mamá alta | que es mamá de Bautista de segundo?

Iliana: sí || creo que nos leyó Una cena elegante

Sandra: Una cena elegante | ¿y qué te acordás de ese cuento?

Iliana: era que:: | un mapache había hecho todo comida...- | en todo comida elegante || pero creo que era...- | y después todos los animales y se le comieron toda la comida

Sandra: imuy bien! | ¿y qué más te acordás | de ese día | que ella leyó?

Iliana: $<10>$ todos esos animales que:: hacía comida |pero...- | pero él no les daba por eso fueron y:: | para vengarse | se comieron la comida de él 
Sandra: la comida de él | ¿te había gustado ese libro?

Iliana: sí me encantó [enf.]

Sandra: ¿y qué te acordás de Patricia leyendo?

Iliana: que era muy divertida

Sandra: que era divertida | ies verdad! | es muy divertida leyendo || ¿̇algún otro cuento que hayas leído con las mamás

Iliana: «Los juguetes»

Sandra: «Los juguetes» $=\ldots . . .=$

\|liana: =..... puse también «me gustó»

Sandra: ¿con quién lo leíste?

Iliana: e::h | no me acuerdo el nombre porque no sé mucho eso

Sandra: Rosario

Iliana: jah! Rosario

Sandra: ¿sí? | ¿y qué te acordás de ese día que Rosario les leyó el cuento?

Iliana: era que una niña no quería cambiar una muñeca de trapo

Sandra: un cuento muy lindo || ¿y por qué te gustó especialmente e::se libro?

Iliana: porque:: me gustan los juguetes y || porque me gusta jugar

Sandra: ¿con muñecas de trapo?

Iliana: sí |l yo hago en mi casa

Sandra: ¿sí? | iah claro! | ipor eso te gustó tanto! || iqué lindo! <6> lliana una última pregunta | el año que viene | que vas a estar en cuarto | que van a venir | mamás de vuelta a leer | ¿te gustaría | que vinieran de vuelta?

Iliana: sí me gustaría que vinieran de vuelta

Sandra: ¿y qué les pedirías que te leyeran?

Iliana: un cuento lindo y divertido

Sandra: ¿sí? algún título en especial |algún tema en especial que te gusta

Iliana: no un cuentito divertido

Sandra: un cuentito divertido

Iliana: son los cuentos que me gustan esos

Sandra: bueno muchas gracias Iliana | le decís a Estiven que venga | ¿Estiven vino?

Iliana: sí

Sandra: ¿sí? | ¿se porta mal Estiven? 
Iliana: no hace los trabajos

Sandra: bueno decile que si terminó que venga | y si no que venga Allison ¿ta? | Estiven es un ratito

\section{Estiven}

Sandra: ¿Estiven?

Estiven: \{mueve la cabeza [asiente]\}

Sandra: ¿sí?

Sandra: Estiven | vos no escribiste nada el otro día | ¿qué pasó? | ¿no querías escribir?

Estiven: no | no sabía qué:: escribir

Sandra: ¿no sabías? | ¿y vos te acordás lo que yo te pregunté?

Estiven: no

Sandra: ¿te pregunté qué pensabas de Patricia | la mamá que viene a leer?

Estiven: sí

Sandra: ¿y qué habías pensado poner?

Estiven: ¿'sos maestra de apoyo?

Sandra: ¿eh?

Estiven: ¿ंvos sos maestra de apoyo?

Sandra: no no soy nada | soy una persona que pregunta nomás | Estiven vos que...- | qué te acordás qué habías pensado en ese momento? | ¿te gusta que te lean?

Estiven: sí

Sandra: ¿sí? | ¿las mamás? | ¿por qué?

Estiven: porque:: | me divierten

Sandra: ¿te divierten? |¿sí? | ¿y por qué más?

Estiven: $<10>$

Sandra: ¿algún otro motivo?

Estiven: \{mueve la cabeza [niega]\}

Sandra: ¿no?

Estiven: no | porque ta | solo me hace acordar a mi madre

Sandra: ¿cómo?

Estiven: me hace acordar a mi madre

Sandra: te hacen acordar a mamá | muy bien | Estiven | ¿y algún cuento que te:: | te haya::n | leído las mamás que te haya gustado? | si no te acordás el título ¿de qué se trataba?

Estiven: «La gama ciega» 
Sandra: te acordás entonces del cuento | ¿y por qué te gustó ese cuento?

Estiven: porque:: | era tipo una cebra no me acuerdo bien | y:: | y iba siempre a comer miel | y:: un día | fue...- | y al otro día fue también y la:: | la picaron toda en el ojo

Sandra: ¿y por qué te gustó ese cuento? || perdón! | no sé | ¿te gustó el cuento?

Estiven: isí me gustó sí!

Sandra: ¿`y por qué?

Estiven: porque tenía animales

Sandra: porque tenía animales | ¿y algún otro libro que te hayan leído?

Estiven: $<10>$

Sandra: ¿no?

Estiven: no no me acuerdo

Sandra: ¿vos te acordás un día que Patricia vino a leer a tu clase?

Estiven: sí

Sandra: ¿te acordás qué cuento leyó?

Estiven: no

Sandra: ¿no? | ¿un cuento que se llamaba | Una cena elegante?

Estiven: ia::h | isí!

Sandra: ¿sí? || ¿era divertido ese cuento?

Estiven: sí

Sandra: ¿por qué?

Estiven: porque::...- e::1...- | el animal no me acuerdo qué era | y siempre iba a todos lados | a ver si conseguía una...- | algo para comer

Sandra: cierto

Estiven: y:: cuando:: lo...- | cuando encontraba algo para comer lo...- | los ani...- | los veía a los animales | y los animales se les escapaban | y todos iban a la madriguera de él

Sandra: ite acordás muy bien! || ¿y te acordás de Patricia leyendo ese cuento?

Estiven: e::h || no

Sandra: ¿algo en especial de ese momento?

Estiven: no

Sandra: ¿no? | bueno y el año que viene cuando estén en cuarto ¿te gustaría que las mamás leyeran?

Estiven: \{mueve la cabeza [asiente]\}

Sandra: ¿sí? | ¿qué cuento les pedirías que te leyeran? 


\section{CORPUS ESCUELA XXX}

Estiven: Una cena elegante

Sandra: ¿el mismo? | ¿les pedirías ese mismo cuento?

Estiven: \{mueve la cabeza [asiente]\}

Sandra: bueno gracias | Estiven

Estiven: \{mueve la cabeza [asiente]\}

Axel

Sandra: Axel ¿cómo andás? ¿bien?

Axel: bien

Sandra: ¿todo bien? | bueno igracias por venir! || Axel las preguntas que te voy a hacer son...- |las que les hice el otro día por escrito y que vos habías contestado muy bien

Axel: sí

Sandra: ¿vos te acordás que yo te había preguntado qué pensabas de Patricia | la mamá que vino a leerles ¿te acordás?

Axel: sí

Sandra: ¿y vos qué habías puesto?

Axel: que me gustaba porque leía cuentos lindos

Sandra: bien | y escribiste más cosas

Axel: sí

Sandra: ¿por qué?

Axel: no sé:: | ¿de las maestras?=....=

Sandra: $=\ldots . . .-$ no no $\mid$ de la mamá que vino a leer

Axel: ¿̇a leer? | porque tiene linda voz porque:: || y porque las mamás nunca faltan | creo que escribí eso $<8>$

Sandra: ¿algún otro motivo que te acuerdes?

Axel: no

Sandra: ¿qué tiene de especial que las mamás vengan a leer?

Axel: que leen cuentos lindos || iy no me acuerdo más!

Sandra: bien ¿algún cuento que te haya gustado mucho que hayan leído?

Axel: el zorro y la mulita

Sandra: el zorro y la mulita |bien | ¿y por qué te acordás de ese cuento?

Axel: me gustó porque el zorro era muy va::go y la mulita trabajado::ra | y porque la mulita plantaba y ella se quedaba con lo de...- | la cosecha más buena y el zorro se queda con lo peor | todo eso Sandra: exacto || Axel | ¿y:: || te gustaba por qué? | ¿era divertido? ¿era triste? 
Axel: porque era divertido

Sandra: porque era divertido | era cómico || bien | ¿vos te acordás cuando vino a la clase a leer Patricia? | una vez leyó un libro que se llama | Los secretos de Abuelo Sapo | ¿te acordás?

Axel: no

Sandra: ¿y después leyó otro que se llama Una cena elegante?

Axel: sí esa sí

Sandra: ¿te acordás?

Axel: sí

Sandra: ¿qué te acordás de ese libro?

Axel: me acordé que:: ...- | ¿que era un mapache el de la...-?

Sandra: era un tejón

Axel: un tejón | que el tejón tenía comida | y:: no le gustaba siempre la misma | y quería comer algo bueno | y siempre que quería comer un animal pasaba algo || y ta | y después lo último me acuerdo cuando el caballo...- | cuando todos los animales que:: | se iban corriendo se metían pa' la cueva de él I y se comieron toda la comida

Sandra: cierto | ¿y qué te acordás de ese libro? | ¿te gustó? | ¿te había gustado? ¿te había aburrido?

Axel: no | me gustó

Sandra: ¿sí? ¿’por qué?

Axel: porque es así muy | cómico | muy muy...-

Sandra: era muy cómico jes verdad! | ¿y vos te acordás de Patricia leyendo ese libro?

Axel: no

Sandra: ¿no? | ¿nada? | imuy bien! | una última pregunta Axel | el año que viene van a estar en cuarto ¿no? I ¿a vos te gustaría que vinieran las mamás a leer?

Axel: sí

Sandra: ¿sí? | ¿siguieran viniendo? | ¿y qué les pedirías que leyeran?

Axel: El libro de la selva por ejemplo e::h || ¿cómo era este? | iesperá! | me olvidé El elefante | un libro que tengo en mi casa y:: | ia::hi y El traje nuevo del emperador

Sandra: ¿te gusta ese cuento?

Axel: sí

Sandra: bueno | entonces vamos a decirle que el año que viene les lean ese

Axel: ¿̇a quién llamo ahora?

Sandra: no ya terminé | igracias! 


\subsubsection{Sesiones de lectura de Patricia}

\subsubsection{Los secretos de Abuelo Sapo}

Pauta de sistematización de las observaciones de la sesión de lectura de Los secretos de Abuelo Sapo

\begin{tabular}{|c|c|c|c|}
\hline \multicolumn{4}{|c|}{ Escuela: XXX } \\
\hline \multicolumn{4}{|c|}{ Fecha y hora: $26.05 .2015,09: 30$} \\
\hline \multicolumn{4}{|c|}{ Contexto: la sesión de lectura se realizó en el salón de clase. } \\
\hline \multicolumn{4}{|c|}{ Grupo: $3 .^{\circ} \mathrm{B}$} \\
\hline \multicolumn{4}{|c|}{ Cantidad de niños presentes: 24} \\
\hline \multicolumn{4}{|c|}{ Otros presentes: maestra Amalia, investigadora } \\
\hline \multicolumn{4}{|c|}{$\begin{array}{l}\text { Les Secretos } \\
\text { de Abuelo Sapo }\end{array}$} \\
\hline \multicolumn{4}{|c|}{ Selección del libro: El libro fue recomendado por Mariela, la maestra referente del proyecto, a la mediadora. } \\
\hline \multicolumn{4}{|c|}{ Observaciones } \\
\hline \multicolumn{4}{|c|}{ Antes de iniciar la lectura } \\
\hline \multirow{11}{*}{$\begin{array}{l}\frac{\pi}{0} \\
\frac{0}{0} \\
\frac{\pi}{0} \\
\frac{\mathbb{Q}}{2}\end{array}$} & \multirow{2}{*}{$\begin{array}{l}\text { ¿Organiza el espacio de } \\
\text { lectura? }\end{array}$} & Sí & \\
\hline & & No $x$ & $\begin{array}{l}\text { Los niños se disponen en sus asientos tal como están } \\
\text { habitualmente. La maestra se dispone en su escritorio y yo } \\
\text { en una silla vacía al fondo del salón. }\end{array}$ \\
\hline & $\begin{array}{l}\text { ¿Dónde y cómo se ubica } \\
\text { para leer? }\end{array}$ & \multicolumn{2}{|c|}{$\begin{array}{l}\text { Inicia la lectura parada frente al grupo, de espaldas al pizarrón, pero luego } \\
\text { recorre el salón mostrando las ilustraciones, mientras lee. }\end{array}$} \\
\hline & ¿Realiza algún ritual de & Sí & \\
\hline & InIClO? & No $x$ & \\
\hline & ¿Realiza preguntas o & Sí x & Saluda a los niños y responde a sus comentarios. \\
\hline & comentarios? & No & \\
\hline & ¿Responde las preguntas o & Sí X & \\
\hline & comentarios de los niños? & No & \\
\hline & ¿Responde las preguntas o & Sí & \\
\hline & comentarios de la docente? & No $x$ & \\
\hline
\end{tabular}


Corpus ESCUELA XXX

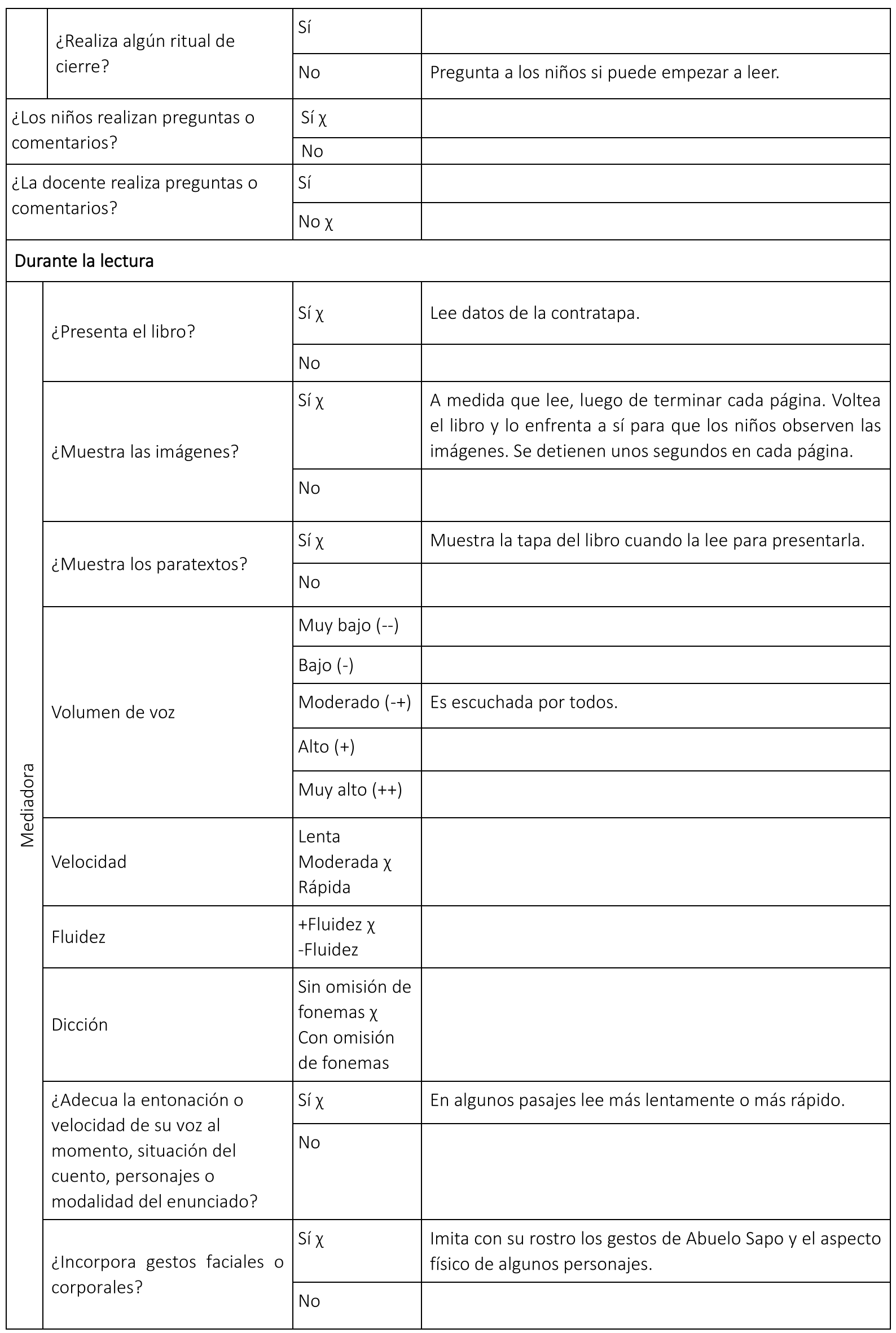




\section{CORPUS ESCUELA XXX}

\begin{tabular}{|c|c|c|c|}
\hline \multirow{2}{*}{\multicolumn{2}{|c|}{ Se desplaza mientras lee }} & Síx & \\
\hline & & No & \\
\hline \multirow{2}{*}{\multicolumn{2}{|c|}{$\begin{array}{l}\text { ¿Realiza preguntas o } \\
\text { comentarios? }\end{array}$}} & Sí $\chi$ & \\
\hline & & No & \\
\hline \multirow{2}{*}{\multicolumn{2}{|c|}{$\begin{array}{l}\text { ¿Responde preguntas o } \\
\text { comentarios de los niños? }\end{array}$}} & Sí X & \\
\hline & & No & \\
\hline \multirow{2}{*}{\multicolumn{2}{|c|}{$\begin{array}{l}\text { ¿Realiza algún ritual de } \\
\text { cierre? }\end{array}$}} & Sí & \\
\hline & & No $\chi$ & \\
\hline \multirow{2}{*}{\multicolumn{2}{|c|}{$\begin{array}{l}\text { ¿Los niños realizan preguntas o } \\
\text { comentarios? }\end{array}$}} & Sí & \multirow{2}{*}{ En forma espontánea. } \\
\hline & & No & \\
\hline \multirow{2}{*}{\multicolumn{2}{|c|}{$\begin{array}{l}\text { ¿La docente realiza preguntas o } \\
\text { comentarios? }\end{array}$}} & Sí & \\
\hline & & No $x$ & \\
\hline \multicolumn{4}{|c|}{ Después de la lectura } \\
\hline \multirow{8}{*}{$\begin{array}{l}\frac{0}{0} \\
\frac{0}{0} \\
\frac{.0}{0} \\
\frac{\Phi}{2}\end{array}$} & \multirow[t]{2}{*}{ ¿Realiza preguntas? } & Sí $x$ & \\
\hline & & No & \\
\hline & \multirow{2}{*}{$\begin{array}{l}\text { ¿Responde preguntas o } \\
\text { comentarios de los niños? }\end{array}$} & Sí & \\
\hline & & No $\chi$ & \\
\hline & \multirow{2}{*}{$\begin{array}{l}\text { ¿Responde preguntas o } \\
\text { comentarios de la docente? }\end{array}$} & Sí & \\
\hline & & No $\chi$ & \\
\hline & \multirow{2}{*}{$\begin{array}{l}\text { ¿Realiza algún ritual de } \\
\text { finalización? }\end{array}$} & Sí & \\
\hline & & No & $\begin{array}{l}\text { Se despide de los niños y le comenta que no sabe si } \\
\text { continuará leyendo la próxima semana. }\end{array}$ \\
\hline \multirow{2}{*}{\multicolumn{2}{|c|}{$\begin{array}{l}\text { ¿Los niños realizan preguntas o } \\
\text { comentarios? }\end{array}$}} & Sí & \\
\hline & & No $\chi$ & \\
\hline \multirow{2}{*}{\multicolumn{2}{|c|}{$\begin{array}{l}\text { ¿La docente realiza preguntas o } \\
\text { comentarios? }\end{array}$}} & Sí & \\
\hline & & No $\chi$ & \\
\hline \multicolumn{4}{|c|}{ Interacciones entre los actores } \\
\hline \multicolumn{2}{|c|}{$\begin{array}{l}\text { Actitud de la mediadora hacia los } \\
\text { niños }\end{array}$} & \multicolumn{2}{|c|}{ De complicidad y afecto. } \\
\hline \multicolumn{2}{|c|}{$\begin{array}{l}\text { Actitud de la docente hacia la } \\
\text { mediadora }\end{array}$} & \multicolumn{2}{|c|}{$\begin{array}{l}\text { Habilita la participación de la mediadora al iniciar la sesión de lectura. Se } \\
\text { involucra en la escucha del cuento con actitud cómplice. }\end{array}$} \\
\hline \multicolumn{2}{|c|}{$\begin{array}{l}\text { Actitud de los niños hacia la } \\
\text { mediadora }\end{array}$} & \multicolumn{2}{|c|}{$\begin{array}{l}\text { Están esperando con interés a la mediadora. Al llegar, suspenden la tarea } \\
\text { que están haciendo y se disponen a escuchar la lectura. } \\
\text { Escuchan con atención. Se compenetran con la historia leída. Participan en } \\
\text { forma espontánea y a veces, desordenada. Se muestran entusiasmados en } \\
\text { la conversación. }\end{array}$} \\
\hline \multicolumn{2}{|c|}{$\begin{array}{l}\text { Actitud de la mediadora hacia la } \\
\text { docente }\end{array}$} & \multicolumn{2}{|c|}{ De respeto y complicidad. } \\
\hline
\end{tabular}




\section{Transcripción de la sesión de lectura de Los secretos de Abuelo Sapo}

Patricia: ¿andan bien chiquilines?

Niño: bien con frío \

Patricia: con frío no ya pasó $\backslash \mid$ con frío $\backslash \mid$ ahora salimos al recreo $\backslash$

Niño: yo sigo con frío \

Patricia: ¿seguís con frío?

Niño: más frío \}

(Hablan de la venta de panchos ${ }^{17}$ y meriendas a la hora del recreo $<4>$.)

Patricia: ¿bueno vamos a empezar chiquilines?

Patricia: el librito que vamos a leer ho::y \\| se llama Los secretos de Abuelo Sapo \

Niño: ja::h!\

Patricia: ¿verdad? || de Keiko Kasza \| que es una escritora japonesa || es | escritora e ilustradora de sus propios cuentos $\backslash$ | nació en Japón pero vive actualmente en Estados Unidos con su esposo y sus hijos $\backslash$ || sus libros infantiles $\backslash$ | han cautivado al público infantil en toda Latinoamérica / || y se destacan especialmente entre otros $\backslash$ | de su género / | por presentar $\backslash$ | a un mismo tiempo $\backslash$ | historias divertidas $\backslash \mid$ y aleccionadoras $\backslash \|$ \{muestra la tapa del libro $<10>$ \} cuando Abuelo Sapo y Sapito van a caminar por el bosque \| Abuelo Sapo \le advierte a su nieto sobre los enemigos [aaa] hambrie::ntos / que podrían estar al acecho $\backslash \mid$ Sapito está preocupado $\backslash$ | pero su abuelo promete $\backslash$ | compartir con él sus secretos más especiales $\backslash$ | cuando de enfrentar $\backslash||$ a los predadores $\backslash$ | ya me está empezando a fallar la vista \| del bosque central \ique me olvidé de los lentes! \con esto de la bolsa me olvidé la cartera (alude a la bolsa que identifica a los mediadores de los ECL y en la cual llevan los libros) \\| lo que Sapito no se alcanza a imaginar es que él mismo $\backslash$ | tan pequeño e inexperto como es $\backslash \mid$ puede llegar a salvar a su abuelo de convertirse en un [aaa] sándwich de sapo $\backslash \|$ sándwich de sapo a esta hora $\backslash$ | yo me lo comería \| aunque fuera \| sándwich de lo que fuera \

Niño: !a::h qué asco! \

Patricia: yo me lo como \| ia mí qué me importa! \| un día Abuelo Sapo y Sapito / | salieron a caminar por el bosque \\| y ahí van ellos pa::nchos de la ma::no \\{recorre el salón de clase mostrando las ilustraciones $<15>\}$

Niño: viene un señor $\backslash$

Niño: iqué lindo! \

Patricia: ¿viene un señor? no sé si viene un señor $\ \mid$ vamos a ver si viene un señor / | \{muestra las ilustraciones $\langle 5\rangle$ \} ¿̇sabes Sapito? dijo Abuelo $\backslash \mid$ nuestro mundo / | está lleno de enemigos $\backslash \mid$ de enemigos hambrientos $\backslash \|$ ¿cómo nos podemos proteger Abuelo? preguntó Sapito \| bueno declaró abuelo $\backslash$ | voy a compartir contigo mis secretos $\backslash \|$ mi prim...- $\backslash \mid$ mi primer secreto / | es ser valiente $\backslash \|$ debes ser valiente $\backslash \mid$ al enfrentarte $\backslash \mid$ con un enemigo peligroso \{recorre el salón mostrando las ilustraciones $<15>\}$

\footnotetext{
${ }^{17}$ Salchichas.
} 
(Un niño de la primera fila se para constantemente; reclama ver las ilustraciones.)

Patricia: ¿̇í? \{continúa recorriendo el salón mostrando las ilustraciones $<10>$ \}

Niño: ja::h mirá! \| ilo vi mirá!\

Patricia: i¿qué::??! imuy bie::n! \

(Los niños se esfuerzan en mirar las ilustraciones.)

Niño: jencontré una pista!\

Patricia: iencontró una pista! imaravillo::so! \| porque a veces hay que...- $\backslash \mid$ que mirar un poquito más \| con atención no sé \| vamos a ver el cuento / || yo todavía no llegué a esa parte \| no sé lo que dice $\backslash \mid=\ldots . .=$

Niño: $=\ldots . . .=$ ¡la víbora! \

Patricia: ¿es una víbora decís vos?

Niño: isí! \

Patricia: vamo[s] a ver \

Niña: ¡la encontré! ila encontré! \

Patricia: en ese preciso momento / | apareció una culebra |

Niño: iqué te dije! \

Niño: es una especie de serbiente (sic) \

Niño: [enf.] es una serpiente \

Patricia: ihola sapos! siseó la culebra \| me los voy a comer de almuerzo \|| Sapito dio un alarido y corrió a esconderse $\backslash$ | pero:: \| Abuelo $\backslash$ | ¿estaba asustado? / \{recorre el salón mostrando las ilustraciones $<20>\}$

Niño: no $\backslash \mid$ se ve que no $\backslash$

Niño: iesperá!\

Niño: no estaba asustado \

Niño: isí::! \| estaba \

Niño: estaba medio ahí \

Niño: estaba asombrado \

Niño: yo corría ahí \

Patricia: ¿asombrado puede ser?

Niño: ¿̇a ver? | ino! solo se sorprendió \

Patricia: bueno ¿vamos a ver qué dice el cuento? || ini un poquito! \| icómeme si puedes! \| gritó ferozmente el abuelo \| quizás soy mucho más grande de lo que tú puedas tragar \| Abuelo tomó aire y se hizo cada vez más grande \|| pue::s \| tal vez otro día \| murmuró la culebra y se fue lentamente \{recorre el salón mostrando las ilustraciones $<15>$ \} 
Patricia: iy el sapo quedó \|| giga::nte! [enf.] \{hace el gesto con sus manos explicando cómo se hinchó el sapo\} \{recorre el salón mostrando las ilustraciones $<15>$ \}

(Un niño hace el gesto con su cuerpo imitando cómo se infló el sapo.)

Niño: ¿̇a ver? ¿a ver?

Niño: (???)

Niño: ¿ंqué culebra?

Patricia: así me van a quedar los ojos a mí por leer sin lentes $\backslash \mid$ como los de la culebra $\backslash$

Niño: jah! \| ¿tan brillosos?

Niño: ¡o::h!\

Patricia: así \\{continúa recorriendo el salón y mostrando las ilustraciones $<10>$ \} $\|$ ¿vieron todos? | Sapito saltó de los arbustos $\backslash \mid$ ioh abuelo! \| [enf.] fuiste tan valiente $\backslash \mid$ [enf.] estuviste maravilloso \} || Abuelo Sapo sonrió lleno de alegría \| igracias! \| le dijo \| pero algunos enemigos / | son demasiado grandes para espantarlos $\backslash \|$ mi segundo secreto / | es ser astuto \|| debes ser astuto / | al enfrentarte $\backslash \mid$ con un enemigo peligroso $\backslash$

Niño: ¿̇a ver?

Patricia: \{recorre el salón mostrando las ilustraciones $<15\}$

Niña: imirá! \|| [enf.] otra \

Niño: [enf.] otro animal\

Patricia: [enf. ] ¿otra?| ¿otro?

Niño: iah! [enf.] este encuentra todo $\backslash=\ldots . . .=$

Niño: $=\ldots . .=[$ enf.] es una tortuga \}

Patricia: ¿es una tortuga? | ¿te parece una tortuga?

Niño: [enf.] es gigante \

Niño: [enf.] este encuentra todo \{señala a su compañero\} totalmente de acuerdo que es una tortuga \} Patricia: ¿ंes una serpiente? ¿ंes una tortuga? | vamo[s] a ver $\backslash$ | a ver $\backslash$ (da tiempo para que los niños discutan las hipótesis sobre el próximo personaje $<15>$ )

Niño: ¿̇a ver? ¿̇a ver?

Niño: es una tortuga $\backslash \|$ es una tortuga totalmente $\backslash \|$ totalmente de acuerdo que es una tortuga $\backslash \mid$ por la forma de la boca $\backslash$

(Los niños piden ver las ilustraciones.)

Niño: [enf.] es una tortuga es una tortuga

Niño: ino! \| [enf.] no es una tortuga \

Niño: por la forma de la boca \} 
Niño: [enf.] es una tortuga \

Niño: no hay duda \

Niño: [enf.] no es una tortuga \

Niña: [enf.] una víbora \

Patricia: en ese preciso momento \| apareció \| una gran \tortuga \| voraz \\{recorre el salón mostrando las ilustraciones $<10>$ \}

Niños a coro: ia::h! \[sorpresa]

Niño: [enf.] tortuga tortuga \}

Niño: ite dije! ite dije! \| la forma de la boca era una tortuga \

Patricia: ihola sapos! \|| chasqueó la tortuga \\| [enf.] me los voy a comer de un bocado \\| ichas! \| ichas! \

Niño: i[es]pera! \tremenda tortuga \

Patricia: Sapito / | dio un alarido y corrió a esconderse \|| pero Abuelo \| ¿̇estaba asustado? \{recorre el salón mientras muestra las ilustraciones $<10>\}$

Niño: no \

Niña: no \

Niña: [enf.] ni un poquito \}

Patricia: [enf.] no era una tortuga / | era una tortuga voraz \\{recorre el salón mientras muestra las ilustraciones $<8>\}$

Niño: [enf.] se hinchó:: \| [enf.] se infló \}

Niños a coro: ino::!!

Niño: parece un dragón \

Niños a coro: [expresiones de sorpresa]

Niño: ¿a ver? ¿a ver? ¿a ver? ¿a ver?

Patricia: ¿a ver? ¿a ver? ¿a ver? \{risas\} || ¿̇a ver? ¿a ver? ¿̇a ver? / [imita al niño]

Niña: parece un hipopótamo\

Niño: [enf.] Sapito se fue saltando \\| se fue corriendo él \

Patricia: isí::! Sapito se va \

Niño: corriendo \}

Patricia: emprende el viaje enseguida Sapito \}

(Lentamente se apaga la discusión entre los niños.)

Patricia: ini un poquito! \|| ¿ंun bocado? | preguntó Abuelo \| ¿no prefieres un banquete? iclaro que sí! respondió la tortuga \| hace poco / | una apetitosa [enf.] culebra / | pasó por acá \| si te apresuras / | la puedes atrapar \| igracias por el consejo! dijo la tortuga \| y se fue rápido a cazar a la culebra \ 
Niño: iguau::! \

Niños a coro: [sorpresa] \

Niño: isi::! |es cierto \

Niño: ¿a ver? ¿̇a ver? ¿a ver? ¿a ver? ¿a ver si puedo encontrar algún bicho? /

Niño: jesperá!\

Niña: ino! [Se queja de la actitud de su compañero que dilata la lectura.]

Niño: [enf.] vi algo \

Patricia: ¿viste algo? se fue ahora \

Niño: un bicho \}

Niño: (???)

Niño: [enf.] debe ser Sapito \}

Patricia: [enf.] Sapito \capaz que es Sapito que está por ahí \| escondido \

Niño: ¿a ver? ¿a ver? ¿a ver?

Niño: [enf.] no está escondido \

Niño: ino! [enf.] no está escondido \

Patricia: bueno ¿ंvamos a seguir con el cuento a ver si está Sapito? \}

Niño: es solo pasto es solo pasto \}

Patricia: Sapito $\backslash \mid$ saltó de los arbustos $\backslash \mid$ \{recorre el salón mostrando las ilustraciones $<20>\} \backslash \mid$ io::h Abuelo! gritó [enf.] \| fuiste ta::n astuto! \| jestuviste maravilloso! \|| Abuelo Sapo sonrió lleno de alegría | igracias! le dijo \| ahora / | el tercer / | y último secreto \|| [aaa] pero antes de que pudie::ra decir otra palabra:: $\mid$ recorre el salón mostrando las ilustraciones $\langle 20>\}=\ldots . . .=$

Niño: $=\ldots . . .=$ apareció:: e:::...-।

Niño: [enf.] un lagarto $\backslash$

Niño: ino!】

Niño: (???)

Niño: [enf.] un puma $=\ldots . . .=$

Niño: $=\ldots . . .=$ ¿por qué no dejás que alguien también descubra el bicho?

Niño: $=\ldots . . .=$ [enf.] un puma

Niño: [enf.] un camaleón \

Niño: [enf.] los pumas son diferentes \}

Patricia: son diferentes los pumas sí \

Niño: [enf.] un puma $\backslash \mid$ se le ve la cola $\backslash$ 
Niño: [enf.] es un camaleón \

Niño: ja::h! él siempre tiene que descubrir todos los bichos \[enojado con su compañero.]

Patricia: (Intenta que los niños hagan silencio pero desiste inmediatamente.)

Niños a coro: (discuten acaloradamente)

Niño: [enf.] un camaleón un camaleón \

Patricia: ¿qué mi amor? / II (mira a un niño que no ha participado hasta el momento)

Niño: un dinosaurio \

Patricia: [enf.] un dinosaurio \

Niño: [enf.] un camaleón \

Niño: [enf.] debe ser un camaleón \

Niño: eso parece...- $\backslash$

Patricia: la cola de una rana \

Niño: isí! \

Niño: debe ser un camaleón \

Patricia: puede ser $\backslash$

Nino: un dinosaurio $\backslash$

Niño: eso es una culebrilla \}

Patricia: ¿será? | ¿vamos a ver si dice eso?

Niña: [enf.] es un camaleón \

Patricia: es un camaleón \es un dinosaurio \

Niño: [enf.] un dinosaurio \

Patricia: [aaa] un eno::rme \| eno::rme eno::rme eno::rme ${ }^{18}$ [enf.] \| monstruo apareció \}

Niña: ¿monstruo? | ¿monstruo?

Patricia: [enf.] monstruo:: \{recorre el salón mostrando las ilustraciones $<15>$ \}

Niño: ¿a ver?

Patricia: ihola sapos! / | rugió el monstruo \|| me los voy a comer a todos / | por diversión \\{recorre el salón mostrando las ilustraciones $<15>\}$

Niño: [enf.] es un dinosaurio \

Niño: [enf.] es un dinosaurio \

Patricia: es un monstruo $\backslash$ | es un monstruo $\backslash$ | exacto $\backslash||$ Sapito dio un alarido $\backslash$ y corrió a esconderse $\backslash$ | pero Abuelo \¿estaba asustado? / \{recorre el salón mostrando las ilustraciones] $<20>$ \}

\footnotetext{
${ }^{18}$ La palabra enorme no está reiterada en el texto.
} 
Niños a coro: ¡no::! \

Niño: no pero déjame que descubra \

Patricia: no sé vamos a mirar vamos a mirar $\backslash\{$ recorre el salón mostrando las ilustraciones $<15>\}$

Niño: ¿viste que era un dinosaurio?

Nino: [enf.] es un lobo es \

Niño: [enf.] ahora sí se asustó \

Patricia: [enf.] ahora sí se asustó \

Niño: es un lobo este $\backslash\{$ mirando a su compañero]

Niño: [enf.] es un lobo \}

Niño: [enf.] ahora sí se asustó ahora sí se asustó \}

Niño: [enf.] es un dinosaurio \

Niño: [enf.] ahora sí se asustó \

(Continúa la discusión acaloradamente.)

Patricia: es una mezcla \

Niño: [enf.] ahora sí se asustó $\backslash \mid$ es una mezcla de dinosaurio $\backslash \mid$ y mono $\backslash$

Patricia: ahí va \

(Finaliza la discusión y los niños hacen silencio espontáneamente.)

Patricia: isí! \| estaba asustado \| nunca en su vida había visto una criatura más espantosa \| intentó escapar $\backslash \mid$ pero el monstruo lo atrapó \{recorre el salón mostrando las ilustraciones $<20>$ \}

Niño: ¿a ver? / | permiso |

Niña: ahora sí \| que se pone bueno el cuento \

Nena: alguien dijo \|que había un...-\que había una tortuga \

Patricia: jah! vamos a seguir con el cuento \| capaz que sí que alguien dijo que había una tortuga \| nosotros no sabemos \¿ta? \| \{recorre el salón mostrando las ilustraciones $<15>$ \} ipobre sapo! \|| se va corriendo pero despavorido $\backslash \|$ Sapito $\backslash$ | estaba escondido entre los arbustos / temblando de miedo $\backslash$ $\|$ pero recordó los secretos de su abuelo $\backslash \|$ ser valiente $\mathrm{y}$ astuto $\backslash \mid=\ldots . .=$

Niños a coro: $=\ldots . . .=[$ enf.] ser valiente $y$ astuto (Al unísono con la mediadora.)

Patricia: $=\ldots . . .=$ ser valiente y astuto $\backslash \|$ vio unas bayas silvestres / | y decidió rápidamente lo que tenía que hacer $\backslash$ \{recorre el salón mostrando las ilustraciones $<10>$ \}

Niño: bichitos de luz \

Niño: ¿a ver? ¿̇a ver? ¿̇a ver? \

Niño: dejá que adivinemos otra vez \ 
Niños: unas mariquitas imirá! \{señala la ilustración a su compañero\}

Patricia: [enf.] unas mariquitas parecen sí

Nino:imirá! [enf.] aquí hay unas mariquitas \

Niño: las mariquitas se comen al gigante ese \

Patricia: ¿las mariquitas se comen al gigante? ¡u::h!\

Niño: iy no! \

Patricia: en un cuento todo puede pasar $\backslash$ ।

Niño: sí \es lo que iba a decir $\backslash \mid$ así que no es raro \|

Niño: imentira! \[desmiente a su compañero]

Patricia: Sapito le lan...- \|Sapito le lanzó las bayas al monstruo \|| las bayas se reventaron y le dejaron manchas rojas en las patas $\backslash$

Niña: iu::h! \

Patricia: el monstruo / | ni siquiera se dio cuenta \| estaba muy ocupado convirtiendo a Abue::lo / |en un sándwich [aaa] de $\backslash \mid$ sapo $=\ldots . . .=$

Niño: $=\ldots . . .=[$ enf.] bocadillo $\backslash \|$ un bocadillo $\backslash$

Patricia: [aaa] aquí está Sap::ito \| lanzando las ba::yas \| y acá están las patas del monstruo \| \{recorre el salón mostrando las ilustraciones $<20>\}$

Niño: ¿a ver? ¿a ver? ¿a ver? ¿a ver?

Niño: yo sabía qué iba a tener esa [mancha] roja ahí \

Patricia: ¿vos sabías? / | iqué bueno! \

Niño: [enf.] mirá cómo le quedan las patas medias rojas \

Patricia: medias rojas con manchitas rojas $\backslash$ | ¿allí ven las manchitas rojas? / \{recorre el salón mostrando las ilustraciones $<20>\}$

Niños a coro: ¡sí! \

Patricia: ¿sí? / | ¿ven todos? / \{muestra las ilustraciones mientras recorre el salón <15>\} ento::nces / $=\ldots . .=$

Niño: $=\ldots . .=$ no los mata $\backslash$

Patricia: Sapito salió de arbusto ${ }^{19}$ con gran valentía \| iAbuelo! grito \

Niño: ja::h!\

Patricia: [enf.] deja al monstruo \/i¿qué?! dijo el monstruo \| i¿qué?! / gritó el abuelo \

Niño: ino::! \

Niño: ja::h!;no::! \ya iba para dentro de la boca \

\footnotetext{
${ }^{19}$ En el libro se lee «de los arbustos»
} 
Niño: [enf.] no se lo come \

Patricia: este va a ser mi sándwich \| cuando llegue a casa \\{recorre el salón mostrando las ilustraciones $<15>\}$

Niños a coro: (comentan entusiasmados)

Patricia: [enf.] Abuelo $\backslash$ | dijo Sapito $\backslash \mid$ [aaa] no es muy amable de tu parte / | andar por ahí envenenando monstruos $\backslash$ | tu veneno ya está subiendo por las patas $\backslash$ | pronto tendrá manchas por toda la cola / | y luego morirá \

Niño: jah! piensa que está enfermo\

Patricia: ¿no te da vergüenza abuelo? / | el monstruo \| se miró las patas $\backslash$ | isocorro! isocorro! \| iestos sapos malvados me quieren envenenar! \\{recorre el saló mostrando las ilustraciones] $<10>\}$

Niño: ¿̇morirá?

Niña: no \

Niño: ¿̇o no morirá?

Niño: ino! XXX \| si le tiró una baya pensaba que $\backslash=\ldots . . .=$

Niño: $=\ldots . . .=$ próximo capítulo $\backslash$

Patricia: \{risas\} \{continúa mostrando las ilustraciones mientras recorre el salón $<15>$ \} el monstruo / | corrió tan rápido como pudo \| Abuelo y Sapito se abrazaron \| iuf! / | suspiró Abuelo \| estuve cerca $\backslash$ || isí! dijo Sapito \|bueno \| finalmente Abuelo \| ibueno! dijo finalmente Abuelo \| pero aún / no has escuchado mi tercer consejo \| ¿cuál es? / | preguntó Sapito? \{recorre el salón mostrando las ilustraciones $<20>$ \}

Niño: correr $\backslash$

Niño: salió corriendo \}

Niño: correr como un desacatado \

Patricia: \{risas\} [enf.] la cara de amor que tienen estos sapos \| ipor favor! \imirá! \|

Niño: es que se llevan bien \

Patricia: se llevan bie::n \| se quieren mucho \sí \\{recorre el salón mostrando las ilustraciones $<20>$ \} Abuelo está $\backslash \mid$ embelesado con su nieto \}

Niño: ¿̇y el mono?

Patricia: ¿y el mono (???)? =....=

Niño: $=\ldots . . .=y$ el mono $/ \mid$ por ser tan feo $\backslash \mid$ se va a correr pa todo $\backslash$

Patricia: mi tercer secreto es $\backslash \|$ declaró el abuelo $\backslash$ | en caso de emergencia / | estar seguro de tener un amigo con quién contar $\backslash \|$ Sapito $\backslash \mid$ [enf.] fuiste tan valiente $\backslash \mid$ [enf.] fuiste tan astuto $\backslash \mid$ [enf.] estuviste maravilloso \|| y esta vez fue Sapito \| quien sonrió \| lleno de alegría \

Niños a coro: $\{$ aplausos\} 
Patricia: ¿ustedes son astutos y valientes?

Niños a coro: isí! \

Niña: yo no \

Patricia: ¿cuando la ocasión lo amerita? / | ¿eh?

Niño: de vez en cuando \

Patricia: ¿de vez en cuando? | ¿por ejemplo?

Niño: iyo qué sé! \|<5>

Amalia: $\{$ risas $\}$

Niños a coro: (discuten)

Niño: cuando lo precise maestra (refiriéndose a la mediadora) \| cuando lo precise maestra \

Niños a coro: (???) (Continúan intercambiando entusiasmados.)

Niño: cuando lo precise maestra \

Amalia: [enf.] divino cuento:: \|| divino \| no lo conocía ese ¿eh? \| [enf.] divino cuento

Niño: yo tampoco \

Patricia: ¿les gustó::?

Niños a coro: isí!

(La maestra solicita silencio para que la mediadora se despida.)

Patricia: no sé si el martes que viene / | voy a seguir con ustedes / | o viene la otra mamá \| no sé \| en todo caso me encantó conocerlos / | y si no se da el martes que viene / | capaz que el mes que viene $\backslash$ | en algún momento vamos a coincidir $\backslash$ | en la escuela \¿eh? / | ¿sí?

Niño: iquedate vos! iquedate vos!

Niño: [enf.] otro cuento

Niños a coro: $\{$ aplausos\}

(Nos retiramos.) 


\subsubsection{Una cena elegante}

Pauta de sistematización de las observaciones de la sesión de lectura de Una cena elegante

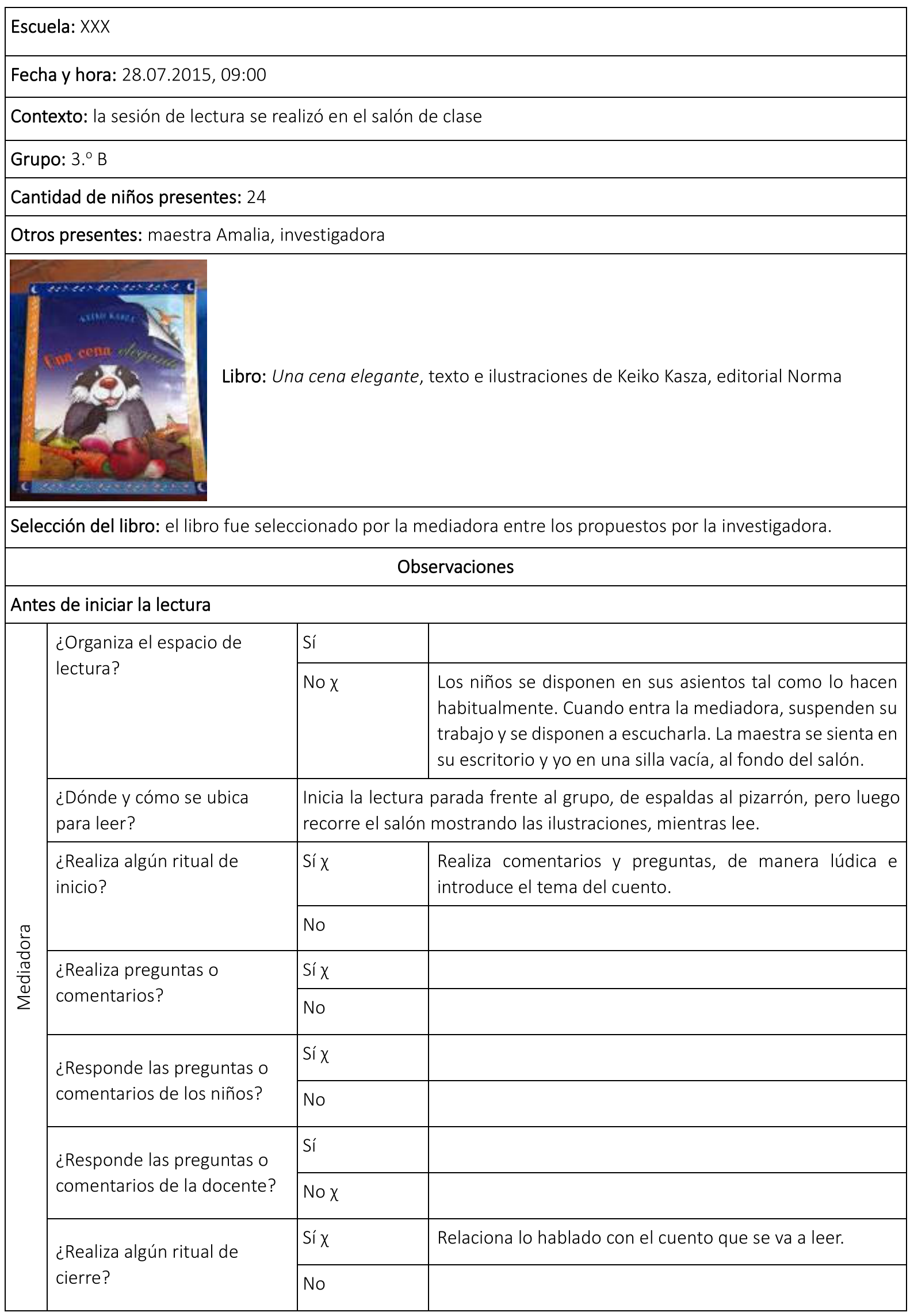




\section{CORPUS ESCUELA XXX}

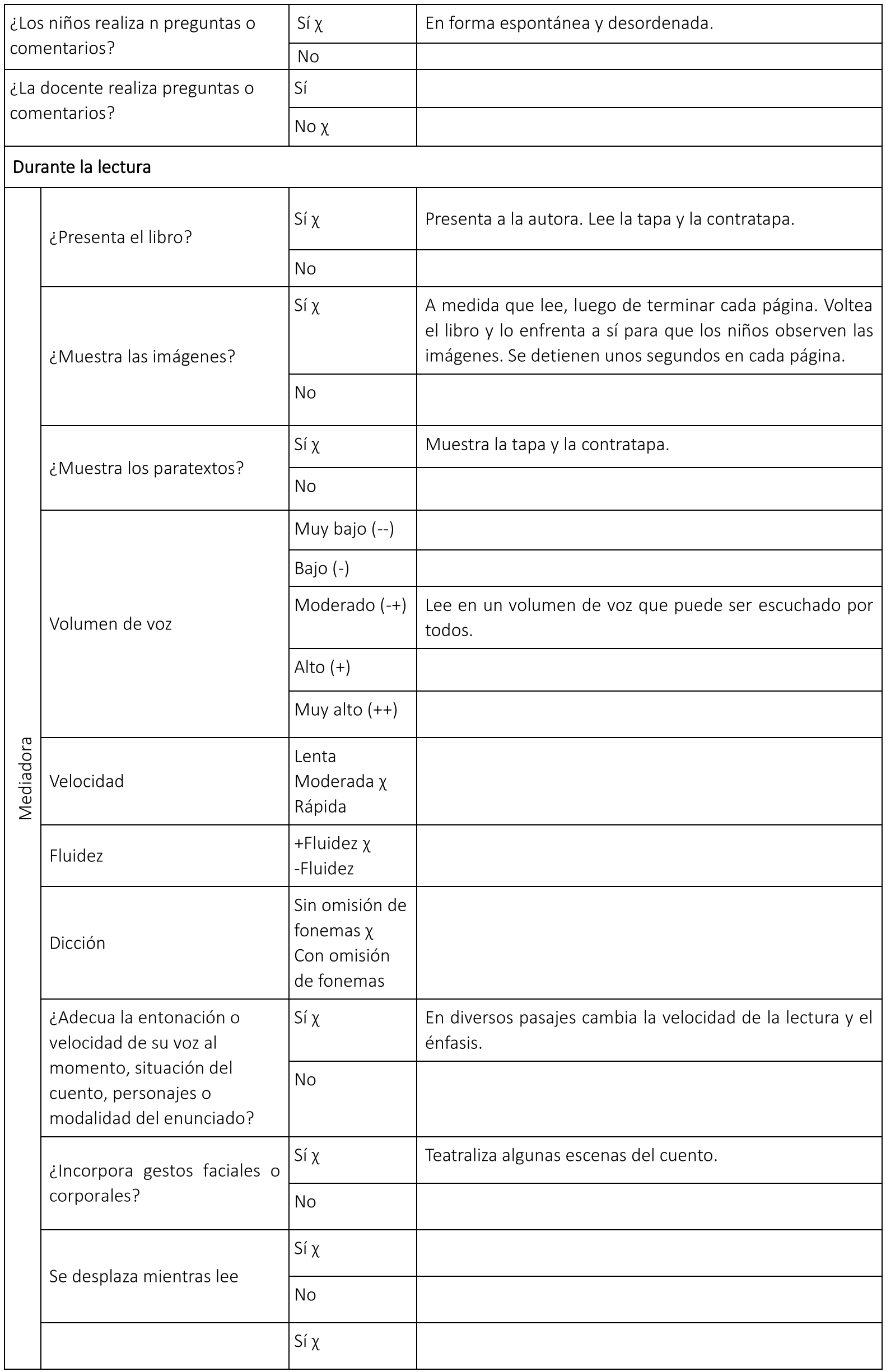


Corpus escuela XXX

\begin{tabular}{|c|c|c|c|}
\hline \multicolumn{2}{|c|}{$\begin{array}{l}\text { ¿Realiza preguntas o } \\
\text { comentarios? }\end{array}$} & No & \\
\hline \multirow{2}{*}{\multicolumn{2}{|c|}{$\begin{array}{l}\text { ¿Responde preguntas o } \\
\text { comentarios de los niños? }\end{array}$}} & Sí x & $\begin{array}{l}\text { Los niños comentan con entusiasmo, pero en forma } \\
\text { desordenada. }\end{array}$ \\
\hline & & No & \\
\hline \multirow{2}{*}{\multicolumn{2}{|c|}{$\begin{array}{l}\text { ¿Realiza algún ritual de } \\
\text { cierre? }\end{array}$}} & Síx & Cierra la lectura con «Colorín colorado». \\
\hline & & No & \\
\hline \multirow{2}{*}{\multicolumn{2}{|c|}{$\begin{array}{l}\text { ¿Los niños realizan preguntas o } \\
\text { comentarios? }\end{array}$}} & Síx & \multirow[t]{2}{*}{ En forma espontánea y desordenada. } \\
\hline & & No & \\
\hline \multirow{2}{*}{\multicolumn{2}{|c|}{$\begin{array}{l}\text { ¿La docente realiza preguntas } 0 \\
\text { comentarios? }\end{array}$}} & Sí & \\
\hline & & No $x$ & \\
\hline \multicolumn{4}{|c|}{ Después de la lectura } \\
\hline & \multirow[t]{2}{*}{ ¿Realiza preguntas? } & Síx & \\
\hline & & No & \\
\hline & \multirow{2}{*}{$\begin{array}{l}\text { ¿Responde preguntas o } \\
\text { comentarios de los niños? }\end{array}$} & Síx & \\
\hline & & No & \\
\hline & \multirow{2}{*}{$\begin{array}{l}\text { ¿Responde preguntas o } \\
\text { comentarios de la docente? }\end{array}$} & Sí & \\
\hline & & No $x$ & \\
\hline & \multirow{2}{*}{$\begin{array}{l}\text { ¿Realiza algún ritual de } \\
\text { finalización? }\end{array}$} & Sí & \\
\hline & & No & Consulta a los niños si le gustó el cuento. \\
\hline \multirow{2}{*}{\multicolumn{2}{|c|}{$\begin{array}{l}\text { ¿Los niños realiza n preguntas o } \\
\text { comentarios? }\end{array}$}} & Sí X & Le responden a la mediadora. \\
\hline & & No & \\
\hline \multirow{2}{*}{\multicolumn{2}{|c|}{$\begin{array}{l}\text { ¿La docente realiza preguntas o } \\
\text { comentarios? }\end{array}$}} & Sí & \\
\hline & & No $x$ & \\
\hline \multicolumn{4}{|c|}{ Interacciones entre los actores } \\
\hline \multicolumn{2}{|c|}{$\begin{array}{l}\text { Actitud de la mediadora hacia los } \\
\text { niños }\end{array}$} & \multicolumn{2}{|c|}{$\begin{array}{l}\text { Se hace cómplice de los niños. Debe ponerles límites en determinados } \\
\text { momentos de la sesión. }\end{array}$} \\
\hline \multicolumn{2}{|c|}{$\begin{array}{l}\text { Actitud de la docente hacia la } \\
\text { mediadora }\end{array}$} & \multicolumn{2}{|c|}{$\begin{array}{l}\text { De complicidad y lúdica con la mediadora y la lectura. No establece límites } \\
\text { a los niños. }\end{array}$} \\
\hline \multicolumn{2}{|c|}{$\begin{array}{l}\text { Actitud de los niños hacia la } \\
\text { mediadora }\end{array}$} & \multicolumn{2}{|c|}{$\begin{array}{l}\text { Se compenetran con la historia y participan con entusiasmo, aunque } \\
\text { muchas veces se desordenan. }\end{array}$} \\
\hline \multicolumn{2}{|c|}{$\begin{array}{l}\text { Actitud de la mediadora hacia la } \\
\text { docente }\end{array}$} & \multicolumn{2}{|c|}{ De respeto y complicidad. } \\
\hline
\end{tabular}


Transcripción de la sesión de lectura de Una cena elegante

Patricia: bueno ¿cómo están chiquilines?

Niños a coro: ibie::n! \

Patricia: ¿vamos a leer?

Niño: (???)

Patricia: vamos a hacer sile:: ncio $\backslash$ | ¿se acuerdan de mi nombre?

Niña: Patricia \

Patricia: Patricia \

(La mediadora espera a que los niños hagan silencio para comenzar a leer $<30>$.)

Patricia: iqué li::ndo!\

Niño: iqué lindo!

Patricia: <10> ¿quién tiene hambre?

Niños a coro: iyo!

Patricia: bueno vamos a hablar de una cena elegante $\backslash$ (???)

Niño: iah no! \[enf.] me va a venir más hambre \

Patricia: ¿cómo se imaginan una cena elegante ustedes?

Niño: [enf.] no escucho \si no me dejan pasar no escucho \

Niño: una cena elegante yo $\backslash=\ldots . . .=$

Patricia: $=\ldots . .=$ ¿cómo te imaginás vos una cena elegante $?$ ¿vos?

Niña: con velas \}

Patricia: [enf.] con velas \¿vos?

Niños a coro: (Discuten en forma desordenada.)

Patricia: [enf.] con velas \iqué lindo!

Niño: y copas \

Patricia: [enf.] y co::pas \

Niños a coro: (Discuten en forma desordenada.)

Patricia: bueno pero esta $\backslash=\ldots . .=$

Niño: $=\ldots . . .=$ [enf.] no quie::ro comer ahora $\backslash$

Patricia: ¿no querés comer? bueno no comas \

Niño: quiero comer a las diez \a las diez \a la hora del recreo \

Patricia: esta cena elegante es un poco $\backslash \mid$ especial $\backslash \mid$ ¿verdad?

Niño: porque si no me va a venir más hambre \} 
(La mediadora espera que los niños hagan silencio.)

Patricia: es una historia que nos cuenta \

Niño: isilencio!

Patricia: isilencio! \| \{recorre el salón mostrando la tapa del libro $<20>\}$ es una historia que nos cuenta Keiko Kasza / \{continúa recorriendo el salón mostrando la tapa del libro $<25>$ \} de una cena elegante \}

Niño: ¿qué es eso?

Niño: un quis \

Niño: ieso es cualquiera! [despectivo]

Niña: Una cena elegante \(Lee la tapa del libro.)

Niño: un mapache \

(Continúa la discusión desordenada.)

Niño: [enf.] XXX \XXX\vamos a (???) y le digo \poneme pollo todo \

Niño: [enf.] un perro\

Niño: [enf.] un oso \

Niño: [enf.] un koala \

Niño: [enf.] se está yendo \

Niño: [enf.] un mapache $\backslash$

Niño: [enf.] es un mapache $\backslash$

Niño: [enf.] eso es un mapache \

Niña: parece un mapache \

Niño: [enf.] un mapache $\backslash$

(Los niños continúan discutiendo desordenadamente.)

Patricia: bueno vamos...- $\backslash \mid$ vamos a leer porque si no se nos va la media hora $\backslash$

Niño: isilencio!\

Niño: ¡silencio! \

Niño: isile::ncio! \

(La mediadora espera que los niños hagan silencio para comenzar a leer.)

Patricia: saben que (???) después tengo que levantar mucho la voz y después...- \| Tejón mira las manzanas las raí::ces y los gusanos almacenados en su guarida \ | pero se muere por una cena sofisticada $\backslash$ || persigue / | y por poco agarra \| los ingredientes principales de tres platos potenciales $\backslash$ || taco de topo \hamburguesa [aaa] de rata \

Niño: jah! 
Patricia: y banana split / de conejo \

Niños a coro: jag::!

Patricia: después de cada persecución / | los animalitos escapan y se esconden en un agujero cercano $\backslash$ | cuando Tejón vuelve a su guarida / | encuentra una nota de agradecimiento de sus tres visitantes \ | bla bla bla bla no vamos a seguir leyendo esto / | y después dice una reseña sobre Keiko Kasza que es una escritora e ilustradora de sus...- / | de cuentos de niños / | esto ya lo contamos la vez pasada porque yo cuando vine les leí un cuento de esta misma autora ¿se acuerdan?

Nino: isí! \estaba el propio ese \

Patricia: que nació en Japó::n / | bla bla bla \vamos derecho al cuento \

Niño: bla bla como dice $\backslash$

Patricia: bla bla bla bla \\| Una cena elegante $\backslash\{$ recorre el salón mientras muestra las ilustraciones $<10>$ \} la madriguera de Tejón estaba lle::na de comida \| pero él no estaba contento \| manzanas / | lombrices / | y raíces \lo mismo de siempre suspiró \| quisiera comer una cena elegante \

Niña: jah! \\{suspira\}

Niño: ¿̇a ver?

Niño: [enf.] me dio hambre \

Niño: ¿qué es eso que le está poniendo?

Niño: ¿viste que no era un mapache?

Niño: [enf.] no es un mapa::che \

Patricia: [enf.] es un tejón \

Niña: [enf.] ese es XXX

Patricia: iqué payaso que sos! \\{recorre el salón mientras muestra las ilustraciones $<20>\}$

Niños a coro: $\{$ risas $\}$

Niño: el tejón dijo ja comer!\

Niños a coro: (???)

Patricia: entonces $\backslash$ | Tejón salió de su madriguera a rastras / | y se puso ávido / | a buscar su cena elegante $\backslash\{$ recorre el salón mientras muestra las ilustraciones $<15>\}$

Niño: salió el tejón a buscar la comida \

Niña: no eso es un topo \

Patricia: [enf.] es un tejón \\{continúa recorriendo el salón mientras muestra las ilustraciones $<20>$ \}

Niño: tiene un montón de comida \

Niños a coro: (Discuten en forma desordenada.)

Niña: [enf.] vos discutís y es un tejón y punto \}

Niño: era XXX 
Patricia: muy pronto:: \|| muy pronto:: \|| Tejón / | espió a un topo que pasaba caminando \

Niño: ¿camina el topo?

Niño: ¿qué es un topo?

Niño: un topo es XXX

Niños a coro: \{risas\}

Patricia: im::! pensó $\backslash||$ [enf.] ¿qué tal un taco de topo con salsa pica::nte? / \{recorre el salón mostrando las ilustraciones $<20>\}$

Niño: iay! \

Niño: iqué rico! picantel

Patricia: [enf.] eso sí que sería una cena elegante \}

Niño: [enf.] sí es muy elegante [con ironía] \}

Niño: [enf.] el topo

Niño: [enf.] mirá lo que es el topo y mirá lo que es eso \

Niños a coro: (Discuten en forma desordenada.)

Patricia: [enf.] un taco de topo $\backslash \mid$ con salsa picante [enf.] $\backslash$

Niña: ipobrecito!

Niño: que corra el topo \

Niños a coro: (Discuten en forma desordenada.)

Patricia: se lanzó a agarrar al topo \/ pero este era demasiado escurridizo / | y resbalaba que se resbaló de las manos de Tejón \| luego se escabulló \|[ac.] lo más rápido que pudo \\{recorre el salón mostrando las ilustraciones $<20>\}$

Niño: [enf.] qué topo una miniatura \}

Niña: ison tan li:ndos!\

Niño: [enf.] era así \}

Niños a coro: (Discuten en forma desordenada.)

Patricia: [enf.] es un to::po \ipero qué manera de discutir el libro! | [enf.] esto es un topo \| y esto es el tejón \

Niño: [enf.] el tejón es como un gorila ${ }^{20} \backslash$

Niños a coro: (Discuten en forma desordenada.)

Patricia: ¿ven ahí chiquilines? ¿sí? / \{recorre el salón mostrando las ilustraciones <10>\}

Niño: parece un ratón \

20 Las ilustraciones del cuento no mantienen las proporciones. 
Niño: [enf.] es verdad es un topo!\

Niño: parece un (???)\

Patricia: y encontró un lugar perfecto para esconderse \}

Niña: buscalo \

Patricia: Tejón quedó un poco des...- | desilusionado / | pero no por mucho tiempo \| pues muy pronto / | espió una rata que pasaba caminando |

Niños a coro: ia::g!\

Niño: iqué asco! \

Patricia: ¡m::! pensó \

Niño: eso es muy (???)\

Niña: ies horrible! \

Niño: y todavía no agarró nada \

Niña: iay! [enf.] qué asco \}

Patricia: ¿qué tal una hamburguesa de rata cubierta con salsa de queso? | eso sí sería una cena elegante / $\{$ recorre el salón mostrando las ilustraciones $<20>\}$

Niños a coro: (Discuten en forma desordenada mientras la mediadora muestra las ilustraciones $<30>$. Esta pide silencio para proseguir la lectura.)

Patricia: se lanzó a agarrar la rata \

Niño: pero se le escapó \| se le escapó \

Patricia: iah! yo no puedo leer así / (Espera a que los niños hagan silencio.)

Patricia: se lanzó a agarrar la rata \| pero esta se zarandeaba demasiado / | y sacude que se sacudió de las manos de Tejón \| luego se escabulló / | lo más rápido que pudo \

Niño: ¿̇a ver?

Niño: iay no! \

Niño: [enf.] otra vez \

Niño: [enf.] está fallando \

Niño: jah sí::!\

Niño: allá afuera entró e::I ¿̇ómo era? =.....=

Niños a coro: (???) \(Le responden a su compañero.)

Niño: entró pa la cueva de::I Tejón \y ahora entra la rata \

Niño: [enf.] estaba encima de la rata \}

Patricia: y encontró un lugar perfecto para esconderse \}

Nino: ja::h! \ 
Niño: ¿dónde?

Patricia: otra vez Tejón / | quedó un poco desilusionado \| pero no por mucho tiempo pues pronto espió un conejo que pasaba caminando \\{recorre el salón mientras muestra las ilustraciones $<20>\}$

Niños a coro: (Discuten en forma desordenada mientras la mediadora muestra las ilustraciones.)

Niños a coro: [Expresan pena.]

Niño: ipobre! \

Niño: [enf.] un estofado de conejo \|| [enf.] un estofado de conejo \

(La maestra pide silencio.)

Patricia: [enf.] vamos a hacer silencio chiquilines $\backslash$ para poder leer $\backslash$ (La mediadora espera que los niños se tranquilicen para continuar $<15>$.)

Niño: [enf.] un estofado de conejo \

Patricia: im::! im::! pensó [enf.] \/ ¿qué tal un banana split / | de conejo cubierto con salsa de chocolate caliente?

Niños a coro: [expresiones de asco]

Niña: ique horrible! \

Patricia: ieso sí que sería una cena elegante ¿eh?! \{recorre el salón mostrando las ilustraciones $<20>\}$

Niño: ¿̇a ver?

Niño: [enf.] ¿̇a ver la rata?

Niña: elegante / (???)

Niño: y allá está el ratón con el topo \

Niños a coro: (Discuten en forma desordenada mientras la mediadora muestra las ilustraciones $<20>$.]

Patricia: se lanzó a agarrar al conejo / | pero este era demasiado veloz / | y brinca que brincó de las manos de tejón $\backslash \|$ luego se fue saltando lo más rápido que pudo \\{recorre el salón mientras muestra las ilustraciones $<20>\}$

Niño: ¿es el ratón o el topo?

Patricia: es el conejo \

Niños a coro: (Discuten en forma desordenada mientras la mediadora muestra las ilustraciones $<30>$.] Niño: y allá está el ratón con el topo \

Niño: mae [enf.] la cena que se hace el topo \e::I tejón iperdón! \

Patricia: [enf.] y encontró un lugar perfecto para esconderse \}

Niña: [enf.] sí claro maestra \}

Patricia: ipobre Tejón! \había perdido tres cenas seguidas \| y ahora tenía mu::cha mu::cha hambre \ || y gritó \[enf.] tengo ta::nta hambre que me podría comer un caballo \ 
Niña: ¿en serio? \{recorre el salón mostrando las ilustraciones $<20>$ \}

Niños a coro: (Opinan en forma desordenada mientras la mediadora muestra las ilustraciones <20.)

Niño: ipero qué cena!\

Niño: [enf.] están todos juntos ahí adentro \

Niño: [enf.] pero qué cena \

Niño: isilencio!\

Niña: ¿quién gritó?

(La mediadora espera que los niños hagan silencio para continuar la lectura.)

Patricia: iah! sí \|| dijo una voz malgeniada \| Tejón / | no podía creer su mala suerte \| justo allí \ | mirándolo con sarna ${ }^{21}$ desde su altura / | había un eno::rme caballo con cara de bravucón \[enf.]

Niño: ¿̇a ver?

Patricia: \[enf.] ¿tú? \¿comerme que a mí? \se burló el caballo \[enf.] no creo \\{recorre el salón mostrando las ilustraciones $<20>\}$

Niños: ¿̇a ver?

Niño: ipa! [enf.] mirá lo que es el caballo son terribles \

Niño: ¿qué tiene ahí?

Niños a coro: (Discuten en forma desordenada mientras la mediadora muestra las ilustraciones $\langle 20\rangle$.)

Niño: ipa! [enf.] mirá lo que es el caballo\

Niño: una vez (???)

Patricia: isí! \

Niño: (???)

Patricia: iy ahora largo y deja de molestarme! \| y con eso el caballo lo mandó a::Ito [enf.] \| muy por el aire de una sola patada $\backslash\{$ recorre el salón mostrando las ilustraciones $<20>\}$

Niños a coro: (Discuten en forma desordenada mientras la mediadora muestra las ilustraciones.)

Niño: ifua::!

Niño: y tiene la maquinita $\backslash \mid$ de la... | la cosa esa $\backslash$

Niño: le comieron toda la cena \

Niño: ¡basta de comida!\

Patricia: Tejón voló $\backslash \mid$ y voló $\backslash \mid$ y voló un poco más $\backslash=\ldots . . .=$

Niños a coro: $=\ldots . . .=$ voló $\backslash$

Niño: ipah!\

21 Se lee «sorna». 
Niño: manivela \

Niño: manivela \| manivela \

Patricia: hasta que $\backslash||$ itun! itun! \| aterri...-

Niña: iqué feo! \

Patricia: aterrizó exactamente / donde había comenzado \|en su propia madriguera \| imenos mal! / | illegué a casa! \| exclamó Tejón \| para qué quiero una cena elegante de todas formas $\backslash$ | tengo bastante / buena comida aquí mismo \\{recorre el salón mostrando las ilustraciones $<20>$ \}

Niños a coro: [expresiones de sorpresa]

Niño: iqué sabandijas!\

Niño: [enf.] se comieron todo $\backslash$

Niño: [enf.] y se fueron desapareciendo \}

Niña: [enf.] y se fueron escapando \

Niño: [enf.] y se fueron escapando y se comieron todo! \

Niño: [enf.] se le escaparon los sabandijas \

Niño: [enf.] se comieron todo \

Niña: [enf.] qué porquerías \

Patricia: [enf.] pero Tejón se equivocaba \|| toda su comida / | había desaparecido \

Niños: [expresiones de sorpresa]

Patricia: en su lugar \| lo único que encontró / | fue una nota que decía:: \{recorre el salón mostrando las ilustraciones $<20>\}$

(Los niños intentan leer la nota y hacen silencio.)

Niña: ¿qué decía?

Niña: igracia::s! \

Niña: gracias por tu paciencia \

Niña: gracias por tu comida \}

Niño: (???)

Patricia: apreciado quienquiera que viva acá \| aquí \| lamentamos haber entrado sin invitación / | pero nos perseguía un tejón espantoso y no teníamos / | dónde más escondernos \| las manza::nas \| lombri:: ces $\backslash \mid$ y raí::ces $\backslash$

Niño: jagh!

Patricia: estaban deliciosas $\backslash||$ igracias $\backslash \mid$ por una cena $\backslash \mid$ tan elegante! \

Niño: iguag! \ 
Niña: y era del Tejón \

Niño: (???)

Niño: ahora se entreveraron los colores que tenían (???)

Patricia: y acá están \\{recorre el salón mostrando las ilustraciones $<20>\}$

Niño: los tres personajes $\backslash$

Niña: cuatro \}

Niños a coro: (comentan desordenados $<10>)$

Patricia: y colorín colorado \

Niños a coro: este cuento se ha acabado \{aplausos\}

Patricia: ¿a alguno le pasó una vez así? / | que tenemos algo en casa / | y queremos algo más \y no nos damos cuenta que en casa tenemos lo que necesitamos / | ¿sí? \| nos pasa a veces ¿no?

Niño: mi padre se pensó que faltaba algo pero...-\

Patricia: y después a llorar al cuartito \|| se pierde y no valoramos (???)

(Los niños continúan comentando en forma desordenada.)

Patricia: claro la cena elegante la tenemos \¿̇les gustó chiquilines?

Niños a coro: isí::!

Patricia: $\{$ ¿̇í? (risas)\}

Amalia: (Le hace preguntas a un niño ???)

Patricia: y ahora yo voy a tener un desayuno 


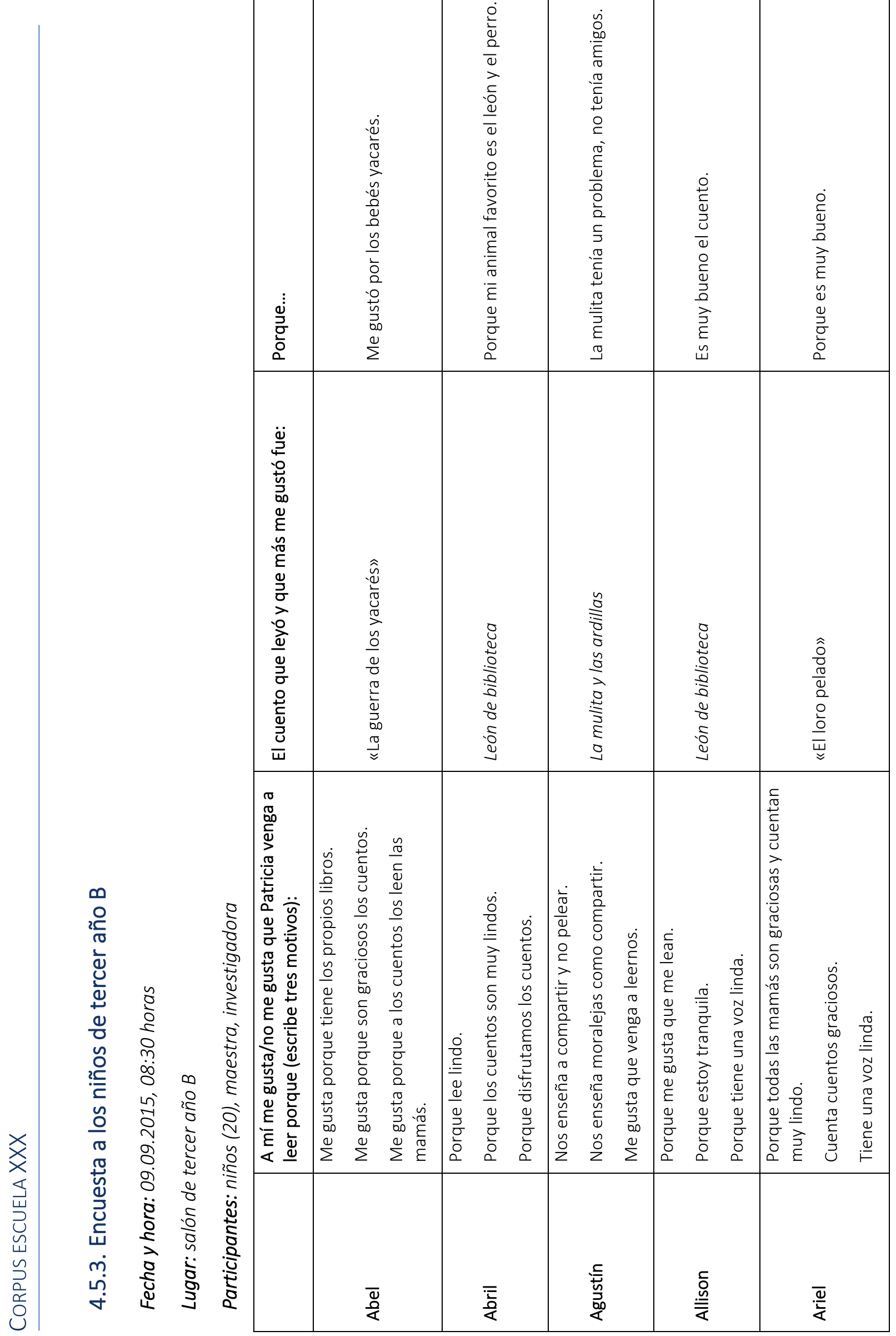




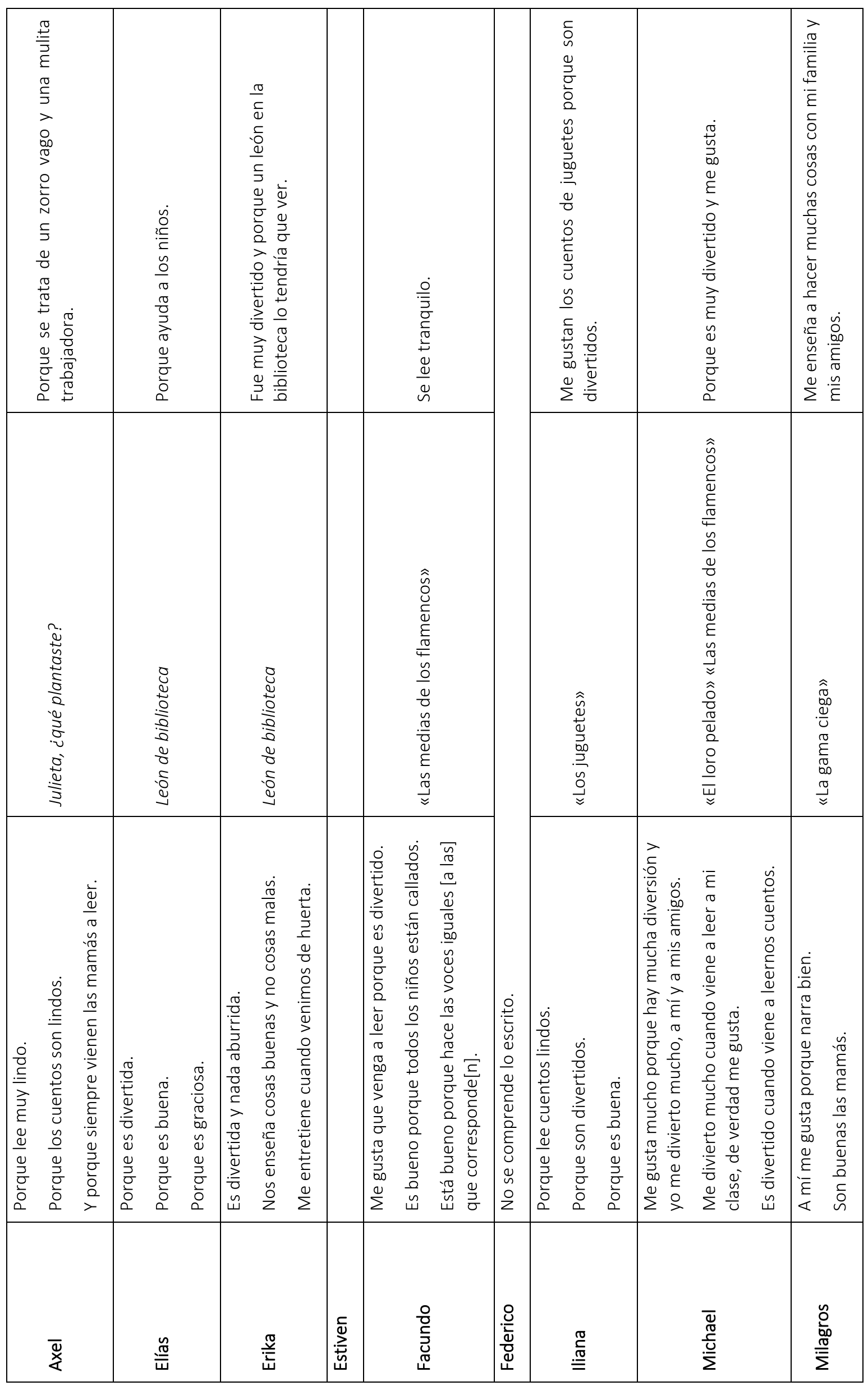


ฟ

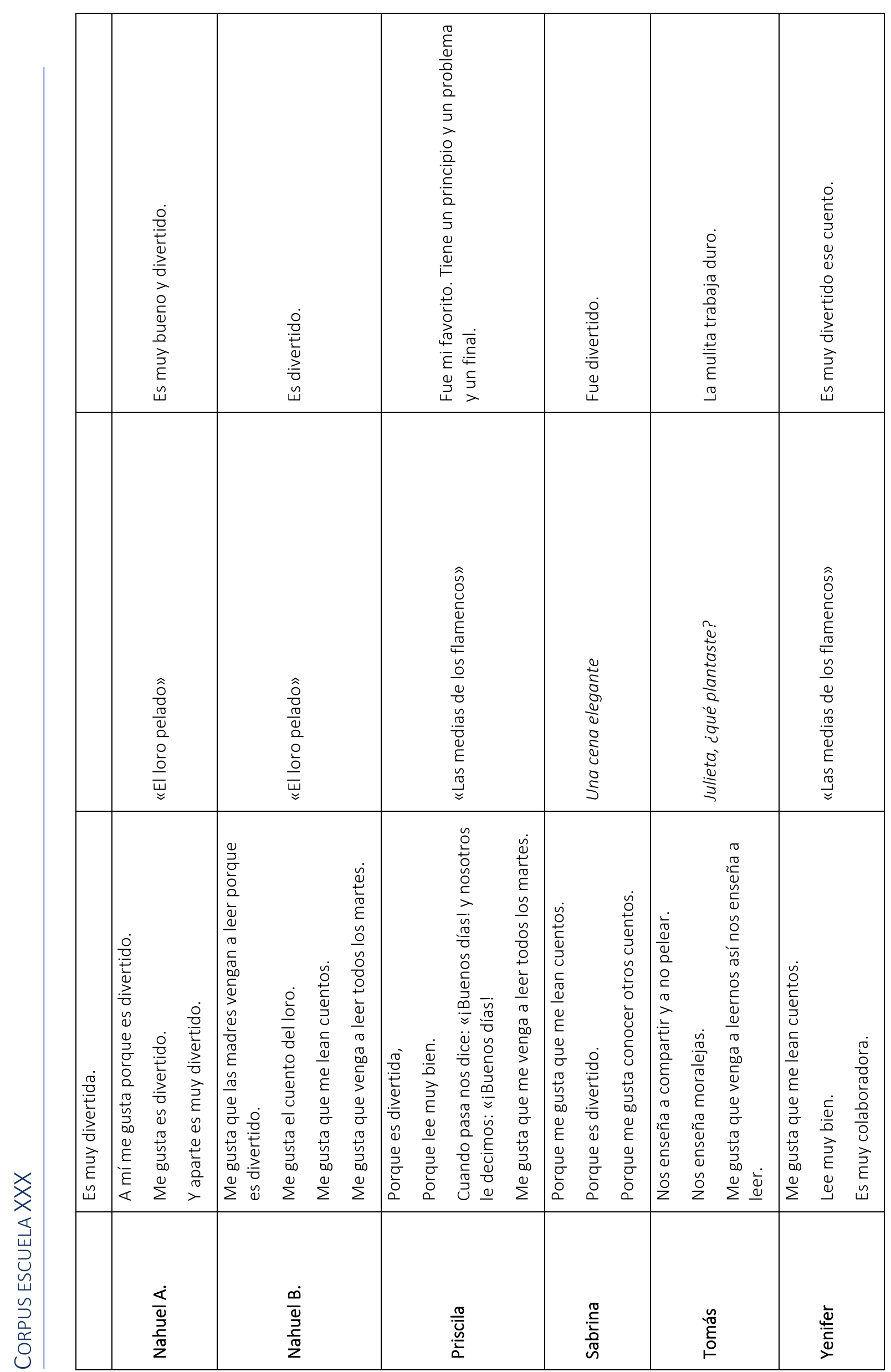




\section{DIARIO DE TRABAJO DE CAMPO}

\section{Lunes 27 de abril}

Llego a la escuela XX a comienzo del turno, tal como habíamos convenido por teléfono, pero debo esperar a María, la directora de la escuela XX, unos 30 minutos pues está atendiendo a un grupo de primer año, por ausencia de la maestra.

María se muestra amable. Le explico el tema de mi tesis, el problema a investigar y solicito su autorización para hacer el trabajo de campo en su escuela y grabar las sesiones de lectura. A cambio, me solicita que realice algún taller con las maestras, a lo que accedo con gusto, pero le indico que prefiero terminar primero el trabajo de campo.

La directora comenta que esa semana (del 27 al 30 de abril) se convocará a los integrantes del equipo comunitario 2014 para comenzar a organizar el trabajo en 2015. Informa además que las dos maestras de tercer año serán referentes: continúa en este rol la maestra Noelia y colaborará con ella la maestra Inés. Solicito que les consulte a ambas si están de acuerdo que realice el trabajo de campo en su escuela y en sus clases. No registro audios de esta entrevista.

\section{Jueves 30 de abril}

Concurro a la escuela XX, a la reunión de conformación del equipo comunitario de lectura. Esta se realiza en la sala de lectura de 08.00 a0 9.00 horas.

La sala está siendo acondicionada para su funcionamiento. Algunos libros están dispersos sobre una mesa, otros están aún en cajas de cartón.

Asisten dos madres (Carla y Sandra) y dos abuelos (Omar y Graciela), todos ellos participaron del equipo comunitario en 2014. Se encuentran presentes además las dos maestras referentes y dos jóvenes estudiantes magisteriales. Los participantes nos sentamos en ronda. La conversación se establece con fluidez.

Los integrantes del equipo comunitario cuentan su experiencia durante 2014 y comentan en qué clases prefieren leer.

Los dos abuelos destacan como muy positivo el intercambio que se da con los niños después de la lectura.

Una mamá (Sandra) indica que no quiere concurrir a leer a quinto y sexto año porque los niños no prestan atención al mediador y las maestras no apoyan la tarea. Refiere incluso a que en una ocasión se retiró antes de terminar la lectura porque los niños no la escuchaban ${ }^{22}$.

Carla comenta de las dificultades al leer (se encuentra en tratamiento con el fonoaudiólogo porque en ocasiones se queda sin voz), pero manifiesta su voluntad de continuar leyéndole a los niños mientras pueda hacerlo.

Las maestras muestran a los mediadores el espacio acondicionado para la sala de lectura y les comentan la intención de realizar actividades allí durante el año.

\footnotetext{
${ }^{22}$ Esta madre no continuó participando en el equipo comunitario de lectura.
} 
Los mediadores toman contacto con la colección de libros de la escuela y organizan la convocatoria y bienvenida del equipo 2015 para la semana previa al Día del Libro ${ }^{23}$.

Al finalizar la reunión, me presento, explico por qué estoy allí y solicito autorización para realizar el trabajo de campo en la escuela. Comento que voy a presenciar las reuniones del equipo comunitario, alguna de las sesiones de lectura de los maestros y mediadores de tercer año y que en algún momento les voy a solicitar que lean un libro (al momento no tengo pensado cuál o cuáles pueden ser), pero con su aval y autorización. No registro los audios de esta reunión.

\section{Jueves 14 de mayo}

Concurro a la primera reunión del equipo comunitario 2015 de la escuela XX.

Participan seis mediadores: tres de ellos (abuelo Omar, abuela Graciela y una mamá, Carla) permanecen desde 2014. Se suman tres jóvenes mamás: Carolina, Elsa, quien concurre con su niña de 2 años, y Leticia. Están presentes las maestras referentes, Inés y Noelia.

Explico a las nuevas integrantes el porqué de mi presencia y solicito autorización para grabar la conversación.

La reunión se efectúa en el salón de la maestra Inés a las 8.00 (hora de comienzo del turno), pues la sala de lectura está siendo utilizada por la profesora de Arte. Al comenzar, solicito autorización para grabar lo que se converse.

Nos ubicamos en ronda alrededor de las mesas de los niños. Las maestras han dispuestos los libros sobre la mesa, los entregados por Biblioteca Solidaria y otros más que pertenecen al acervo de la escuela.

Mientras se desarrolla la reunión y los adultos conversan, la niña de Elsa hojea los libros que están sobre la mesa mientras los adultos conversan.

Se organiza el cronograma de lecturas para las próximas semanas y acuerdan los grupos a los cuales cada uno concurrirá a leer: Omar leerá en sexto y en tercero A, el grupo de su nieta; Graciela en los cuartos, donde se encuentra su nieto y en los quintos años; Leticia leerá en Inicial 4 y primero A, las clases de sus hijos; Elsa y Carolina en los demás grupos de Inicial, primero B y segundos años; Carla lo hará en tercero $\mathrm{B}$.

\section{Viernes 22 de mayo}

Concurro a la escuela XXX a entrevistarme con Rosa, la directora de este centro, a las 8:00 (comienzo del turno), para explicarle mi investigación (propósitos, desarrollo, etc.) para que considere su aval a mi presencia en la escuela. Habíamos coordinado mi visita unos días antes por teléfono (me había costado un poco conseguir que me recibiera) y Rosa me está esperando. La maestra referente del año 2014 fue nuestro nexo. La directora se muestra amable; a pesar de que la noto recelosa, me da su autorización para la investigación. No registro el audio de esta entrevista por ser la inicial. Luego de la conversación, me solicita ayuda luego de que termine el trabajo de campo, para seleccionar los libros para una compra que realizará la escuela y me conduce al salón de la maestra referente 2015, Mariela (maestra

\footnotetext{
${ }^{23}$ El Día del Libro se conmemora el 26 de mayo, día en que se fundó la primera biblioteca pública en Uruguay.
} 
integrador $\left.{ }^{24}\right)$. Allí están reunidas algunas mamás del equipo comunitario de lectura esperándome: Patricia, Andrea, Rosario, Mónica y Angélica. Las dos primeras están en el equipo desde 2014. Son aproximadamente las 9.30 y estas madres ya han terminado sus lecturas. A medida que las demás terminan, se van acercando al salón de Mariela.

Les comento mi tesis y pido la autorización de todas ellas para hacer mi investigación. Les comento que voy a acompañar a las mediadoras que irán a leer en tercer año, a presenciar sus sesiones de lectura y registrar los audios de estas. Las mamás me escuchan con atención y se muestran muy amables. Percibo un muy buen vínculo entre ellas y con Mariela, de confianza y cercanía. La maestra referente me comenta que las mamás lectoras rotan por los grupos cada dos meses y, de acuerdo con el cronograma de la escuela, en los terceros años leerán Patricia, Rosario y Mónica. Converso con ellas tres, específicamente, y les solicito su autorización para seguirlas cuando concurran a leer a estos grupos. Parecen además tener su trabajo muy organizado y la dinámica de funcionamiento del equipo muy incorporada.

A las 10, hora del recreo, salgo al patio de recreo junto con Mariela quien me invita con un café. Allí me encuentro con Rocío, la maestra referente de 2014. Rocío me presenta a sus compañeras, entre ellas a Carmen y a Amalia, maestras de tercer año. Tengo el gran gusto de encontrarme con Amalia después de 20 años, ya que ella había sido mi compañera en el último año de práctica docente, cuando éramos estudiantes de Magisterio. En este ámbito informal me presento a las maestras de la escuela y les comento de mi investigación (aunque Rocío me había dicho que ya les había mencionado de mi interés en hacer el trabajo de campo en la escuela, en una de sus salas docentes).

Necesito el aval y la confianza de Carmen y de Amalia, por lo que solicito su autorización, y les explico que, si me autorizan, voy a acompañar a Patricia y a las demás mediadoras a leer a sus clases. Ambas maestras se muestran muy amables.

Finalmente, al terminar el recreo, voy al salón de Carmen primero, y después al de Amalia, para presentarme a los niños, comentarles que me van a ver acompañando a las mamás que van a leer y pedirles también su autorización.

\section{Martes 26 de mayo}

Concurro a la escuela XX para presenciar la primera actividad de Carla, la mediadora, mamá de Martín, alumno de tercer año A, en tercer año B. Al llegar, encuentro a la escuela en pleno festejo de la Semana del Libro (en Uruguay el Día del Libro se celebra el 26 de mayo en conmemoración de la efeméride de la fundación de la primera biblioteca pública). Todo el local escolar está ambientado para la ocasión. Me informa la directora que durante la semana todos los grupos han realizado talleres de lectura u otras actividades con amplia convocatoria a las familias.

En el salón, los niños esperan a Carla. La maestra la presenta como «la mamá de...» y explica que va a concurrir a leer como el año anterior. Me presenta también a mí y les comenta a los niños que voy a venir a acompañar a Carla cuando ella lea.

Hoy está presente, además, una estudiante de Magisterio que hace su práctica docente en este grupo. Me ubico junto con ella a la izquierda del salón. La maestra se sienta en una de las mesas de los niños, en el fondo del salón. La lectura que la mediadora preparó para esta sesión, a sugerencia de la maestra

${ }^{24}$ Esta maestra trabaja en forma personalizada con algunos niños de diferentes clases. 
en la última reunión del equipo comunitario es Aventuras y desventuras de Casiperro del Hambre, novela breve organizada en capítulos, de Graciela Montes.

Los niños se quedan en sus mesas mientras que Carla se ubica enfrente a la clase, sentada en una silla más alta. Luego de presentar el libro y a su autora, procede a leer el primer capítulo.

Lee en voz muy baja, pero de forma expresiva. La temática parece interesar a los niños que se ríen o sonríen frente a algunos pasajes del texto. El libro tiene muy pocas imágenes, en blanco y negro, y los niños solicitan verlas. La mediadora las muestra y comenta a medida que aparecen en el texto.

La actitud de los niños es de escucha pasiva, no preguntan ni comentan. Al finalizar la lectura, la mediadora no promueve instancias de intercambio con los niños. Los niños aplauden; la maestra agradece a Carla el haber asistido a leer.

El libro seleccionado es extenso, y al no tener imágenes no promueva el intercambio.

Luego de finalizar su sesión, me retiro del salón con esta mamá lectora. Juntas nos dirigimos, conversando, a la parada de ómnibus. Yo esperaré al que me trasladará a la escuela XXX. Llego a esta unos minutos antes de las 9:00. Patricia me está esperando en el salón de Mariela. Antes de llegar yo a la escuela ha ido a leer a los quintos años. El cuento que ha tomado, por sugerencia de la maestra referente es Los secretos de Abuelo Sapo (uno de los libros que llegó recientemente a la escuela con la colección de Biblioteca Solidaria).

Entramos juntas al salón de Carmen; maestra y niños aguardan con expectativa la llegada de la mediadora. Patricia saluda a los niños; todos la conocen como la mamá de Bautista (alumno de segundo año de la escuela). La mediadora se observa distendida, mientras lee camina por el salón y muestra las imágenes del libro. El entusiasmo inicial de los niños no decae mientras dura la lectura.

Luego de finalizar la sesión en tercero A nos dirigimos con Patricia a tercer año B de la maestra Amalia. También la esperan aquí los niños y se muestran muy entusiasmados con la lectura. La mediadora se desempeña en forma muy similar que en tercero A, pero al ser el salón de clases más grande no llega a recorrerlo todo. De igual manera, se asegura de que todos los niños observen las imágenes y ellos así se lo exigen. Al finalizar la lectura, los niños aplauden a la mediadora.

Antes de retirarnos, Amalia le solicita a Patricia que para la próxima sesión lea «La chacra» de Morosoli. Al salir del salón vuelvo a agradecer a esta mamá su disposición para dejarme acompañarla. Nos despedimos de Mariela y salimos juntas de la escuela.

\section{Lunes 1 de junio}

Concurro a la escuela XX donde Carla me espera, a las 08.00, en la puerta del salón de Noelia para entrar a leer. Cuando ingresamos, la maestra y los niños están esperando a la mediadora. Saludamos y Carla continúa con el segundo capítulo de Aventuras y desventuras de Casiperro del Hambre. Los niños y los adultos nos disponemos como en la sesión anterior.

Los niños escuchan desde sus asientos, sin formular preguntas ni comentarios. La maestra se sienta en una mesa, junto con los niños. En una ocasión Interviene con un gesto para solicitar a la mediadora que muestre las imágenes. Los niños no realizan preguntas y comentarios durante la lectura. Solo se observan inquietos cuando se muestran las escasas imágenes del cuento. 
Al igual que en la sesión anterior, la mediadora no promueve instancias de intercambio con los niños posteriores a la lectura.

\section{Martes 2 de junio}

Llego a la escuela a las 09.00. Hoy comienza a leer en esta clase una nueva mediadora, Rosario, mamá de un niño de quinto año, quien me está esperando en el salón de Mariela para ir a leer. No tenía presente que hoy rotarían las madres lectoras (a pesar de que la maestra referente me había informado de esta dinámica de rotación). Rosario tiene preparada la lectura solicitada por la maestra de tercero $B$ a Patricia la semana anterior, así que la recorrida empieza en el salón de Amalia. Cuando entramos con Rosario, los niños comienzan a aplaudir. Yo me ubico en el fondo del salón sentada en una mesa individual de los niños.

Mientras Rosario lee «La chacra», permanece de pie frente al salón. El relato es muy breve y las ilustraciones no son muy llamativas; los niños se muestran poco interesados en la lectura y casi no participan durante la sesión. Algunos dibujan en sus cuadernos mientras la mediadora lee; en los asientos frente al pizarrón dos niños se ponen a conversar en mitad de la lectura, lo que hace que la maestra les llame la atención. A pesar de ello, cuando la mediadora termina de leer, le piden otro relato y ella les lee «Los juguetes», pero sin diferencias en la respuesta. Al terminar de leer, los niños aplauden otra vez a Rosario; la maestra retoma el relato leído y lo relaciona con la biografía de su autor, Juan José Morosoli.

Nos despedimos y nos dirigimos al salón de Carmen. Los niños están esperando con interés a la mediadora y la reciben con expresiones de alegría. Al igual que en tercero B, Rosario se ubica parada frente al salón y yo me siento en el fondo, en un banco doble (vareliano), de los antiguos. La lectura de «La chacra» tampoco aquí genera entusiasmo.

Al finalizar la sesión, los niños aplauden a la mediadora; nos despedimos y la maestra se queda comentando la lectura con los niños. Pasamos con Rosario por el salón de Mariela; yo saludo a ambas y la mamá se queda a coordinar con la referente los detalles de la próxima semana.

\section{Miércoles 3 de junio}

Asisto a la tercera reunión del equipo comunitario de la escuela XX que se realiza en el pasillo al lado de los baños, ya que la sala de lectura se está usando para las actividades de Arte. Todos los presentes permanecemos con los abrigos puestos pues está frío y en este sitio no hay calefacción. Lidera la reunión la maestra Inés. Noelia no se encuentra presente pues no tiene con quién dejar a sus niños. La reunión estaba inicialmente prevista para el 11 de junio, pero debió adelantarse a causa de un paro docente previsto para esa fecha. Asisten Graciela (abuela), Elsa (con su niña) y Leticia. Inés informa que Omar está enfermo y que ha dejado de concurrir a leer. Las otras tres madres no asistieron y desconozco el motivo de su ausencia, pero debió ser porque el adelanto de la convocatoria hizo que no pudieran concurrir.

El motivo de la reunión es organizar el trabajo de los mediadores en lo que resta del mes de junio. La abuela Graciela además cuenta su experiencia de lectura en sus grupos con gran entusiasmo. Los presentes escogen los libros, que se encuentran esta vez depositados en una caja; Inés solo interviene para sugerir lecturas o aclarar dudas, a solicitud de los mediadores, pero no impone su selección. 
Al modo de cierre, la maestra referente lee La línea, de Beatriz Doumere y Ayax Barnes (1975, Ediciones del Eclipse).

\section{Miércoles 10 de junio}

Concurro a la escuela XX a comienzo del turno, a la sesión de lectura de Carla, tal como habíamos acordado la semana anterior; esperaba encontrar a la mediadora, pero en su lugar encuentro a Tatiana, mamá de una niña de la clase. Cuando llego, la lectura ya ha comenzado. Esta mamá, que es maestra, no integra el equipo comunitario de lectura, concurre por única vez a leer. El libro leído en esta ocasión ha sido elegido por ella: El mayor tesoro, de Arcadio Lobato (Ediciones SM). Mientras lee, esta mamá recorre el salón de clases mostrando las imágenes luego de leer cada página. Los niños la siguen atentos. Mientras lee, realiza preguntas, muestra las imágenes y responde a los comentarios de los niños.

Al finalizar la lectura, los niños aplauden a Tatiana. Luego, antes de retirarnos, converso brevemente con ella quien me cuenta que concurrió a leer a solicitud de su hija, pues se lo había prometido y que por motivos laborales no podría ir a leer otro día. Desconozco el motivo de la ausencia de Carla; no sé si no ha asistido por decisión propia o de la maestra. Le consulto entonces a Noelia qué ha sucedido con esta mediadora y la maestra me informa que está enferma, que por ese motivo no ha podido concurrir.

\section{Martes 16 de junio}

Llego a la escuela XXX a las 8.30 horas y me encuentro con Rosario quien me está esperando. Entramos juntas al salón de Carmen y los niños la reciben igual que la vez anterior: con aplausos. Me ubico en el fondo del salón y la mediadora comienza a leer el cuento El miedo a la luz mala, de Verónica Leite. Para leer, se ubica parada frente a la clase, de espaldas al pizarrón. Los niños escuchan la lectura en silencio; un niño sentado cerca de mí pinta en su cuaderno.

Mientras lee, Rosario hace pocos comentarios. Al terminar, todos la aplauden nuevamente, con entusiasmo. Luego, la maestra comienza el comentario del cuento. Al final, luego de despedirnos, vamos al salón de Amalia. Los niños reciben con gritos y aplausos a la mediadora. Parece que la están esperando con ansias. Rosario repite su ubicación. Yo me siento en un banco vacío en el fondo del salón. Los niños escuchan la lectura con mucha atención y, como la mediadora no se desplaza por el salón, algunos se levantan de sus asientos para ir a ver las imágenes (el visionado de las imágenes es muy demandado por los niños). Al igual que en el grupo anterior, Rosario hace pocos comentarios mientras lee el cuento. Cuando termina de leer pregunta: «¿Les gustó el cuento?», a modo de cierre. Los niños la despiden con aplausos y nos retiramos del salón.

\section{Jueves 18 de junio}

Concurro a la escuela XX las 08.00 a la cuarta reunión del equipo comunitario de lectura. Como es habitual, la reunión se realiza al comienzo del turno, esta vez en el salón de Noelia mientras sus niños se encuentran en la clase de Educación Física. A pesar de que todos los mediadores habían sido convocados el día anterior mediante mensajes de texto, asistieron únicamente Omar (para mi alivio), Carla y Cecilia; esta última se integra hoy al equipo 2015, aunque ya había participado en este en 2014. Omar vuelve a su tarea como mediador. Todos nos alegramos de que ya esté mejor de salud y haya podido volver a leer a la escuela (especialmente yo, que veía peligrar mi trabajo de campo). 
El día está nublado y bastante frío y está anunciada lluvia en el correr del día; tal vez sea este el motivo de la menguada concurrencia a la reunión.

La escuela se apronta además para celebrar mañana la fecha patria de homenaje a José Artigas y a la bandera nacional, por eso se vivencia en el día de hoy un movimiento inusual: traslado de niños de un sitio a otro, ensayos de danzas, etc.

En la reunión de hoy el equipo organiza su cronograma de lecturas para el resto del mes y cada mediador selecciona los libros que va a leer. En la mesa hay unos cuantos ejemplares, entre ellos Veinte mentiras de verdad, de José María Obaldía, algunos títulos de Susana Olaondo y Un puñado de semillas de Mónica Hughes. Luego de finalizada la reunión, cuando los niños de Noelia regresaran a su salón, a las 9.00, me dirijo con Omar al salón de Inés para la lectura de Un puñado de semillas. No había podido conversar con él hasta el momento para solicitarle si podía acompañarlo a su sesión ese día, pero él accede con mucho gusto a mi solicitud.

El salón de tercero A es amplio y luminoso. Sus ventanales dan hacia el parque. Es curioso observar que cuenta con dos pizarrones ubicados en paredes diferentes que permiten a la maestra cambiar la disposición del mobiliario y de los niños. En resto de las paredes se disponen algunas carteleras y en las esquinas del salón algunos cajones de madera pintados de colores (con colaboración de los padres, me comenta la maestra) donde colocan los libros de la biblioteca de aula. Cuando esta funciona, los niños se encargan de sacarlos del armario donde se guardan y organizarlos en los estantes, ya que el salón es compartido en el turno vespertino con otra escuela.

Cuando Omar llega, los niños terminan de acomodarse; la maestra pide silencio pues aún se encuentran un poco inquietos. Este abuelo vuelve hoy a leer en esta clase luego de haber estado sin venir unos cuantos días por problemas de salud.

Paulatinamente, se tranquilizan y comienzan a escuchar con atención. Antes de iniciar la actividad, la maestra les quita unas pelotitas de papel a dos niños que están jugando.

Los niños se sientan en el piso, en semicírculo, en medio de la ronda de mesas, próximos al mediador, quien se sienta en una silla pequeña frente a ellos. La maestra, la estudiante magisterial y yo nos ubicamos a la derecha, por fuera de la ronda.

Explico a los niños el porqué de mi presencia en el salón y les pido autorización para observarlos y grabar el audio de la sesión.

Omar comienza leyendo la contratapa del libro Un puñado de semillas. El cuento le fue sugerido por la maestra. Este libro llegó a la escuela en 2014, con la selección de Biblioteca Solidaria. Algunos niños ya conocían el cuento pues lo habían escuchado leer en el curso anterior.

El mediador realiza una lectura expresiva, en un tono de voz adecuado que todos pueden escuchar. Durante la lectura, los niños participan espontáneamente, pero en orden. Tanto Omar como la maestra dejan participar a los niños. Las intervenciones de esta última, mientras Omar lee, se limitan a mantener el orden de la clase y a controlar el comportamiento de los niños. Al finalizar la lectura y comentario de Omar, ella retoma la conversación con sus alumnos, y el mediador y yo nos retiramos.

Me despido de Omar y le agradezco por haberme dejado participar de su sesión. Me encuentro con Carla 09:30, frente a la dirección de la escuela, quien me está esperando para ir al salón de tercer año B. 
Carla leerá hoy el tercer capítulo de Aventuras y desventuras de Casiperro del hambre. Las escenas de lectura observadas en las sesiones anteriores se repiten. La mediadora se ubica sentada frente a la clase; lee en voz muy baja, pero con expresión. No genera interacciones con los niños. Yo me ubico en el fondo del salón. Los niños no participan, pero solicitan que se les muestren las pocas imágenes del texto.

Noelia, la maestra, se ubica en una mesa junto con los niños; en determinado momento interrumpe la lectura de la mediadora y se levanta para pedir a un niño que se mantenga en silencio.

Al finalizar la sesión, los niños aplauden como en las ocasiones anteriores.

La mediadora y yo nos despedimos de los niños y de la maestra quien sale del salón junto con nosotras. Fuera del salón, la maestra le pide a Carla si en lugar de leer puede grabar un CD para la próxima semana con la lectura del cuarto capítulo de la novela, ya que al leer en un volumen tan bajo, muchos niños no pueden escucharla. Carla no le responde, parece no haber recibido esta solicitud con agrado.

Salimos de la escuela con Carla caminando hacia la avenida a tomar el ómnibus; la mediadora me comenta, bastante molesta que no está dispuesta a grabar el audio y que se lo va a comunicar a la maestra, que si esta se lo vuelve a solicitar, no va a concurrir nuevamente a leer.

\section{Martes 14 de julio}

Asisto a las 8.00 horas a la segunda reunión del equipo comunitario de lectura de la escuela XXX. La temática es variada: evaluar la jornada de presentación del equipo, realizada en mayo, informar sobre los títulos leídos hasta el momento por las mediadoras, planificar la tercera y última rotación del año, desde agosto en adelante, y planificar el regalo que las madres le harán a los niños en el Día del Niño a celebrarse próximamente. Están presentes, al comienzo, Mariela, la maestra referente, Andrea A., Rosario, Mónica, Margareth, Laura y Janet, con su bebé de pocos meses en el cochecito. Janet, mamá de un exalumno de la escuela, y Andrea A. son las participantes más elocuentes. Ambas, además, están en el equipo desde 2014. La reunión transcurre en un clima muy distendido.

Entre lo que concierne a la tarea que desarrollan las mediadoras, se intercalan comentarios diversos sobre la sociedad, los hijos, la familia. Las mamás se sienten libres de hacer sus comentarios. La maestra referente, si bien introduce los temas a considerar y ordena la reunión cuando las madres se dispersan, es respetuosa de los comentarios de aquellas. Asume un rol de coordinadora, más que de directora de la reunión. En todo momento incentiva al equipo y destaca la importancia de su presencia en la escuela. Cuando la reunión ya está avanzada, llega Patricia de leer en sexto año. Las demás mediadoras la saludan amistosamente.

Al finalizar la reunión me quedo con Patricia y Rosario unos minutos a presentarles los libros que les propongo leer en tercer año y les comento el criterio por el cual los elegí: La manta de las historias de Ferida Wolf y Harriet May Savitz, ilustraciones de Elena Odriozola; Una cena elegante, El día de campo de Don Chancho y iNo te rías, Pepe!, de Keiko Kasza; Feroz...! Feroz!, de Liliana Cinetto, ilustraciones de Poly Bernatene; La abuelita de arriba y la abuelita de abajo, de Tomy de Paola. A Patricia le comento que Una cena elegante es de Keiko Kasza, la autora de Los secretos de Abuelo Sapo. Ella recuerda entusiasmada la lectura de este cuento: «iQué lindo que estuvo!». Les solicito que se los lleven, los lean en su casa y que la próxima vez que nos veamos me den su opinión sobre ellos. Ambas mediadoras aceptan gustosas. 
Luego las tres nos dirigimos a la biblioteca de la escuela, adonde fue el resto del grupo al terminar la reunión. Yo no la conocía hasta el momento. La biblioteca se ubica en el entrepiso de la escuela, contigua al salón en donde se imparten las clases de Inglés por videoconferencias. Encuentro el lugar abandonado y desordenado. El año anterior este espacio había sido acondicionado por los padres de la escuela, quienes habían rescatado una pieza utilizada para depósito.

A las 10:00 toca el timbre del recreo y con Rosario nos dirigimos al patio donde encontramos a Rocío, Mariela y Amalia.

A las 10:30, nos dirigimos al salón de tercero A. Rosario le ha pedido a Mariela un libro de su biblioteca para leer en el día de hoy: Cuando el temible tigre (Virginia Brown, ilustraciones de Matías Acosta, editorial Banda Oriental). No tengo claro si ya conocía esa lectura de antes.

Cuando entramos al salón de la maestra Carmen, al finalizar el recreo, los niños todavía se están acomodando en sus asientos, así que debemos esperar que terminen de ubicarse. Mientras tanto, la maestra nos comenta con tristeza que fue a buscar un libro a la biblioteca escolar y la encontró «media pobre». Les dice a los niños que como hay muchas clases de paseo, luego podrán subir a leer: «Este cuento que va a leer la mamá después lo pueden encontrar en la biblioteca ustedes lo escuchan y después lo pueden leer soli::tos en la biblioteca».

Rosario lee parada, frente al grupo, y yo me ubico en el fondo del salón, igual que las veces anteriores. La mediadora parece que conoce el libro y que le gusta mucho. Noto en su lectura mayor expresividad que en ocasiones anteriores y que contagia el entusiasmo y su agrado a los niños.

Los niños quedan muy inquietos al terminar de leer el cuento. La mediadora y yo nos retiramos del salón pasadas las 11:00, y como el turno finaliza a las 12:00, Rosario no concurre a leer a tercero B.

\section{Lunes 20 de julio}

Al regreso de las vacaciones de invierno, que se extendieron entre el 29 de junio y el 3 de julio, el equipo comunitario de lectura XX ha vuelto a ser convocado. La reunión se realiza en el salón de Inés mientras sus niños están en la clase de Educación Física. Están presentes ambas maestras referentes, Leticia, Cecilia, Graciela y Omar. Ignoro por qué no ha asistido Elsa. Noelia comenta que Carla está con problemas con su voz y no volverá a leer a su grupo. Su lugar va a ser ocupado de aquí en adelante por Cecilia.

La reunión transcurre con los intercambios habituales sobre las experiencias de los mediadores. Graciela comenta con los presentes que ella ha escrito algunos libros de poemas. Presentó algunos en concursos literarios y por uno de ellos obtuvo el primer premio. Esta faceta de la abuela lectora era desconocida para nosotros. La felicitamos y las maestras le solicitan que para la próxima reunión traiga algunos de sus poemas para leer.

Llevo a la reunión algunos posibles títulos que seleccioné para mi investigación. Les comento además el criterio por el cual los elegí: Feroz... iFeroz! (Liliana Cinetto), La abuelita de arriba y la abuelita de abajo (Tomie de Paola), No te rías, Pepe, El día de campo de don Chancho, Una cena elegante (Keiko Kasza) y La manta de las historias (Ferida Wolff y Harriet May Savitz). Se los entrego a Omar para que se los lleve, me dé su opinión y en caso de que no haya inconveniente, acordemos, la próxima vez que nos veamos, el día en que lo leerá. 
Los mediadores presentes se distribuyen los grupos y las lecturas: Graciela continuará leyendo en los grupos de cuarto y quinto, Cecilia lo hará en segundo A y en tercero B, Leticia en primero y segundo, Omar en los sextos y en tercero A. Eligen además los libros que van a leer. Noelia le sugiere a Cecilia leer en su grupo Un puñado de semillas; Leticia se lleva Diógenes no quiere ser ratón de Sergio López Suárez (editorial Banda Oriental); Omar busca el ejemplar de Cuentos de la selva para leer en tercero A, pero no lo encuentra en la caja de los libros. Inés se compromete a buscárselo en los próximos días.

Converso con Cecilia y Omar y les pido su permiso para estar presente en sus próximas sesiones de lectura que serán el jueves 30 de julio.

\section{Martes 21 de julio}

Llego a la escuela XXX a las 8:15 donde me espera Rosario para leer León de biblioteca, de Michelle Knudsen, ilustrado por Kevin Hawkes (editorial Ekaré).

Cuando con Rosario entramos al salón de tercero B, los niños aplauden. Cuando la mediadora presenta el libro, un niño que se llama Michelle, como la autora, se ríe al escuchar su nombre y comenta: «¿Por qué no me lo dan pa mí?», refiriéndose al libro. Todos hacen silencio para escuchar la lectura. Durante la misma, los comentarios de los niños son escasos. La maestra Amalia, quien se sienta junto a los niños en una mesa en el fondo del salón, participa atenta y comenta a la par de los niños, aunque también está atenta a estos. Al retirarnos del salón de tercero B, los niños aplauden a Rosario.

Luego de terminar en tercer año B, nos dirigimos a tercer año A. Al ingresar al salón la escena se repite: los niños aplauden, igual que al retirarnos. En esta clase, la participación de los niños durante la lectura es también acotada. La maestra Carla no interviene.

Al finalizar las sesiones, esperamos juntas a Patricia quien está leyendo en sexto para conversar sobre los libros que le entregué y me dé su opinión. Acordamos que el próximo martes 28 Patricia leerá Una cena elegante en tercer año B. Le explico a Rosario que le pediré a ella que más adelante lea otro libro.

\section{Martes 28 de julio}

Me encuentro con Patricia unos minutos antes de 09.00 para acompañarla a tercer año B donde leerá Una cena elegante de Keiko Kasza, (editorial Norma). Ingresamos juntas al salón. Ha pasado un tiempo desde la última lectura de esta mamá en este grupo, y a pesar de que los niños ya la conocen no demuestran entusiasmo cuando entra. Luego de saludarlos y a la maestra, quien siempre recibe a las mediadoras con optimismo, me ubico en el fondo del salón, en un banco doble.

Los niños están un poco inquietos y la mediadora tarda unos minutos en que hagan silencio para comenzar a leer. Toda la lectura fue dificultosa para Patricia ya que los niños estuvieron bastante dispersos y en varios momentos tuvo que detenerse para tranquilizarlos.

Patricia repite luego la lectura en la clase de Carla. Entramos juntas con la mediadora a la clase y los niños parecen no recordarla. En este grupo la participación de los niños es más ordenada y menos entusiasta que en el tercero $B$. 


\section{Jueves 30 de julio}

Al llegar a la escuela al comienzo del turno (8:00 horas), me encuentro con Omar y Cecilia en el recibidor de la escuela. Omar nos convida con mate y mientras esperamos que se haga la hora para concurrir al salón me preguntan sobre mi tesis: de qué trata, cuándo debo presentarla, por qué elegí el tema. Parece estar interesado en lo que le explico. Los mediadores me devuelven los libros que llevaron en la reunión pasada, les consulto su opinión sobre ellos. Con el aval de Omar, acordamos que en la sesión del 5 de agosto leerá La manta de las historias, y a Cecilia le pido que lea Una cena elegante, quien también se muestra dispuesta.

A las 08.30 entramos con la mediadora al salón de tercer año B. Me llama mucho la atención que Noelia no la presente a los niños. La maestra se cambia de lugar y se ubica en una de las mesas de los niños junto a una pila de cuadernos para corregir. Me ubico en el escritorio en un ángulo del salón junto a la estudiante de Magisterio que hace su práctica en esta clase. Para esta ocasión Cecilia ha preparado, a solicitud de la maestra, Un puñado de semillas. Cuando presenta el cuento, un niño, lan, interrumpe la lectura para decirle que ya lo había escuchado en otra oportunidad. La maestra, ante la insistencia del niño, lo rezonga varías veces: le dice que solo debe escuchar y no debe comentar nada. Esta situación se vive con tensión, por lo menos para mí, y creo que también para la mediadora. Cecilia recién puede comenzar a leer cuando lan accede a la solicitud de la maestra y hace silencio. Noelia corrige cuadernos mientras Cecilia lee y no vuelve a interrumpir la lectura.

Al terminar, Noelia intercambia algunas palabras con Cecilia acerca de cómo van a continuar sus lecturas en este grupo. Yo me mantengo un poco alejada de la conversación y espero a Cecilia en la puerta del salón.

Antes de retirarnos, un niño se acerca a la mamá lectora y le dice: «iLeés muy lindo!»».

Nos retiramos del salón, me despido de los niños y, afuera, de la mediadora. Le agradezco que me haya dejado acompañarla a leer. Omar está esperando en el banco del recibidor que los niños de tercero $A$ regresen de la clase de Educación Física. Nos quedamos allí unos minutos y al regreso de los niños, a las 09.00, nos dirigimos al salón.

Los niños se acomodan en el piso a medida que terminan de prenderse las túnicas, algunos beben el agua de sus botellas. Están muy agitados. Pero luego de que todos se sientan, Omar les pide que se paren nuevamente, que salten un momento y vuelvan a sentarse. Los niños lo obedecen extrañados y entusiasmados; luego de finalizado este ritual, vuelven a la calma. La maestra se sienta en el lugar de uno de los niños - ha quedado perpleja ante la solicitud del abuelo-, y mientras escucha el cuento corrige cuadernos. Yo me ubico en un ángulo del salón. No está presente esta vez la estudiante de Magisterio.

En esta oportunidad, Omar les lee «La abeja haragana» (Cuentos de la selva), de Horacio Quiroga, uno de sus autores favoritos. Este cuento fue elegido por él. Al finalizar la lectura, antes de retirarnos del salón, unos niños se le acercan y lo abrazan. Me despido y le agradezco haberme dejado estar presente en esa sesión. Omar se dirige a leer al salón de sexto año.

\section{Martes 4 de agosto}

Concurro a la escuela XXX a comienzos del turno a presenciar las sesiones de lectura en tercer año A y B. Allí me entero de que Rosario no vendrá a leer hoy por motivos laborales (había avisado a la maestra 
que no concurriría). Cubre su lugar Mónica, otra mamá del equipo lector, quien a solicitud de la maestra leerá «El loro pelado» y «La guerra de los yacarés», de los Cuentos de la selva de Horacio Quiroga.

Acompaño a Mónica a los dos terceros. Los niños no se extrañan de que Rosario no vaya, pero no reciben a Mónica de la misma manera que a ella.

Mónica lee con voz muy baja, con timidez y sin expresividad, y mientras ella lee, los niños permanecen en silencio absoluto.

Antes de retirarme de la escuela, le solicito a Mariela el contacto de Rosario ya que debo pedirle que lea La manta de las historias en el grupo de Carmen. Le dejo un ejemplar del libro a la maestra referente y le pido que se lo entregue, cuando pueda, a Rosario.

\section{Martes 11 de agosto}

Me encuentro con Rosario al comienzo del turno. La semana anterior le pregunté por teléfono si podía concurrir a leer La manta de las historias (libro que dejé en la escuela) y ella accedió. También se lo solicité a Carmen.

Ingresamos juntas al salón de tercero A y los niños la reciben con alegría y la aplauden. Me ubico como siempre en el fondo del salón y Rosario de espaldas al pizarrón, enfrentada a los niños.

Al terminar la lectura, la maestra interrumpe a la mediadora para iniciar el comentario del cuento, pero en cuanto surge la oportunidad, Rosario «retoma la posta».

Luego de finalizar esta lectura, acompaño a esta mamá a la clase de la maestra Amalia donde también lee La manta de las historias.

\section{Miércoles 12 de agosto}

Concurro a la escuela XX al comienzo del turno, hoy es el día en que Cecilia y Omar leerán los libros que les solicité, pues el miércoles pasado ( 5 de agosto) hubo paro docente. Habíamos quedado en que a las 08.30 Omar leerá La manta de las historias en tercero A y Cecilia, a las 09.30 en tercero B Una cena elegante.

Al llegar a la escuela, Omar ya se encuentra esperándome. Aguardamos unos diez minutos a que ingresen los niños al salón y se acomoden. Cuando entramos, Inés se ha puesto a trabajar en matemática y debemos aguardar a que termine aproximadamente 15 minutos más. Nos ubicamos en una esquina en el fondo del salón para interrumpir lo menos posible, aunque la presencia de Omar causa expectativa en los niños que apenas lo ven comienzan a saludarlo.

Al iniciar, Omar repite el mismo ritual que observé el día que leyó «La abeja haragana». Durante toda la sesión de hoy los niños se muestran bastante inquietos: conversan entre ellos y se distraen con frecuencia. Debe ser por este motivo que el abuelo se apura a concluir su sesión. Al finalizar esta, salgo de la clase junto con él. Nos despedimos, le agradezco la lectura y me entrega el libro que le solicité leer. Cecilia me está esperando en el hall de la escuela para concurrir a leer a tercero B.

Nos dirigimos ambas al salón, le anunciamos a Noelia que ya estamos y ella nos invita a pasar. Los niños y la maestra están esperando a la mediadora por lo que al ingresar se disponen inmediatamente a escuchar a Cecilia. Ella se encuentra bastante resfriada. Empieza a leer muy tímidamente, pero la 
respuesta de los niños le hace tomar confianza y se compenetra en la lectura, al punto que en algunos pasajes se anima a modular la voz de los personajes. Al terminar me comenta reiteradamente: «Lindo libro este», por lo que deduzco que disfrutó de la lectura.

Al concluir la sesión, me retiro del salón junto con la mediadora; ella sabe que lo observado va a ser usado en mi tesis y me pregunta preocupada cómo estuvo. La felicito por su lectura y le agradezco el haberme dejado estar presente. Me devuelve el ejemplar que le había prestado y luego de que se va, yo me instalo en el banco del hall de entrada a esperar la hora del recreo para poder conversar con las maestras sobre cómo seguirá el trabajo de campo.

Inés me comenta que ella se irá de viaje a mediados de setiembre y va a estar un mes ausente, por lo que me interesa poder acordar con ella su entrevista, las de los niños y la encuesta, antes de que ella se vaya (a su regreso, la escuela estará realizando las evaluaciones finales y comenzando los preparativos de la fiesta de fin de cursos).

\section{Miércoles 2 de setiembre}

Concurro a la escuela XX a comienzos del turno a realizar la encuesta a los niños de los terceros A y B, tal como lo había acordado con las maestras.

Me dirijo primero al salón de Inés, pero cuando llego a la clase, debo aguardar unos minutos a que ella termine de conversar con sus niños. Cuando la maestra me habilita, les reparto a los niños las hojitas de la encuesta (que entrego fotocopiada) la leemos juntos y la explico. Me encuentro que los niños participan con agrado. Luego de consultarlos a todos si entregaron la hoja, me retiro del salón.

Me dirijo luego al salón de Noelia, y repito el procedimiento.

\section{Miércoles 9 de setiembre}

Realizo las encuestas a los niños de tercer año A y B de la escuela XXX.

A comienzo de turno concurro al salón de Amalia. Les reparto las hojitas de la encuesta a los niños, luego les explico las preguntas y les comento que la encuesta es voluntaria. Un solo niño, Estiven, me devuelve la hoja en blanco.

A las 9:30 me dirijo a la clase de Carmen para entrevistar a sus niños y repito el procedimiento, todos los niños presentes esta vez completan la encuesta.

\section{Viernes 11 de setiembre}

Concurro a comienzo del turno, tal como había acordado la semana anterior con la maestra por mensaje de texto. El día está lluvioso y ha faltado algún niño (asisten 19 niños) pero ya estamos en setiembre y no quiero postergar el cronograma del trabajo de campo, pues dentro de unos días Inés viajará. Al llegar, debo recordarle a la maestra el porqué he ido ese día, pues no lo tiene presente.

Antes de iniciar, comento a los niños para qué he venido y cómo se van a realizar las entrevistas; les digo además que esta instancia es voluntaria. Escribo en el pizarrón los nombres de quienes voy a entrevistar, que concurrirán en forma individual a la entrevista, mientras la maestra continúa trabajando en el salón.

Me acomodo en el recodo del pasillo que da al baño de los varones, a escasos metros del salón de clases. Es el sitio más tranquilo y menos transitado a esa hora en la escuela, aunque en un momento durante 
la entrevista de Zoe el audio se escucha con dificultad por el desplazamiento de los niños de quinto año que regresan a su salón luego de una clase especial.

En este sitio se han realizado en alguna oportunidad las reuniones del equipo comunitario de lectura.

Entrevisto en total a siete niños. Comienzo con Zoe, quien en las respuestas por escrito manifestó que le gusta que los mediadores fueran a leer a la clase, «pero no mucho». Es una niña muy tímida que no se muestra muy colaboradora. Para romper el hielo le pregunto sobre la actividad del día anterior con los niños de la escuela rural en la que participaron los niños de los terceros años. No logro que se anime, pero de todos modos responde.

Continúo con Iván. Cuando iniciamos la entrevista me pregunta por qué lo estoy apartando de la clase, si es por algo mal que hizo «el otro día» a lo que le respondo: «No, Iván. ¿Qué es lo que tú podrías haber hecho mal?». El niño se ríe. Comenzamos bien. Es muy elocuente, al responder gesticula y mueve sus brazos con vehemencia.

Iván es un niño «inquieto», que se dispersa con frecuencia durante las sesiones de lectura de Omar. Sin embargo, en la de "La abeja haragana», luego de que Omar terminó de leer, se paró y lo abrazó espontáneamente. La maestra, por otra parte, me sugirió muy especialmente que entrevistara a este niño porque su actitud hacia la lectura había cambiado: se mostraba más receptivo e incluso estaba yendo a leer a las clases de los niños más pequeños.

Es el turno de Yasmila quien siempre se ha mostrado muy participativa y ha intervenido con acierto en las sesiones de Omar. Mi intención era entrevistar a Anshie, pero hoy no ha venido a la escuela, por lo que decido sustituirla.

Luego sigue Martín. En las sesiones de lectura se ha mostrado inquieto, pero ha seguido con atención la lectura del abuelo y ha realizado comentarios acertados. La mamá de Martín, Carla, participó como lectora en el grupo de tercer año B e integró el equipo comunitario desde 2014. El niño se muestra muy dispuesto a colaborar y se observa muy elocuente tanto en el diálogo como en sus gestos. Mientras lo espero, comienza a sonar una música que proviene del salón y debemos cerrar la gran puerta metálica que separa el rincón donde estamos haciendo las entrevistas del resto del pasillo.

A continuación, llamo a Sofía, quien también se destaca en las sesiones de lectura. Participa en forma elocuente de la entrevista; se muestra muy colaboradora.

Luego continúan Franco y Facundo, este último se muestra bastante reticente, y en ocasiones molesto frente a mis preguntas.

\section{Miércoles 16 de setiembre}

Realizo la entrevista a los niños de tercer año B de la escuela XX. El tiempo ha mejorado y hoy, por suerte la asistencia es casi total. Me interesa profundizar en las respuestas de algunos niños que en la encuesta han opinado en forma genérica, y también en la opinión de Agustín, quien manifestó que algunas veces se aburría durante las sesiones de esta mediadora.

Al llegar a la clase de Noelia, les explico a los niños cuál será el procedimiento y anoto en el pizarrón los nombres de quienes voy a entrevistar. 
Comienzo entonces por Agustín, quien se muestra muy poco colaborador. Este niño deja unas cuantas preguntas sin responder, pero aunque sea, logro que explicite por qué se aburre durante las lecturas.

Continúo con Facundo B., quien ha pesar de que es bastante elocuente en la clase, no parece estar dispuesto tampoco a colaborar con la entrevista.

A continuación, es el turno de Marylin. Esta es una de las niñas más participativas de la clase, durante las sesiones de Cecilia. La niña habla muy bajito y tengo que pedirle al comienzo de la entrevista que levante la voz, pues no la escucho. Marylin se muestra muy colaboradora y recuerda muy bien los cuentos leídos, tanto por Cecilia como por Carla y otra mamá que vino a leer solo en una oportunidad.

Luego es el turno de Milena a quien en las lecturas de Cecilia la he observado atenta e interesada, pero en la encuesta pareció no recordar a esta mamá. Participa también con timidez, pero con agrado.

Prosigo a entrevistar a Abril, quien se muestra muy elocuente, venciendo su timidez inicial, y finalizo con Emiliano, quien se muestra muy colaborador.

\section{Martes 29 de setiembre}

Concurro a la escuela XXX a las 8:00, a comienzos del turno, para entrevistar a los niños de tercer año B de la maestra Amalia, un momento antes de que llegue Mónica, la mediadora que ha sustituido a Rosario.

Cuando llego, la maestra y los niños ya me están esperando, pues había acordado la entrevista unos días antes.

Explico a los niños qué les voy a preguntar y les comunico que la entrevista será para quien quiera hacerla. iTodos quieren participar!, entonces escribo en el pizarrón el listado de niños a quienes voy a entrevistar, para no generarles expectativas y les comento que serán solo algunos, pues en unos momentos llegará Mónica a leerles.

Comienzo por entrevistar a Abel, un niño muy tímido. Su timidez se refleja también en la escritura pues apenas puedo leer lo que escribió en la encuesta que les realicé unos días antes.

Continúo con Priscila, que se ha mostrado muy atenta y entusiasta tanto en las sesiones de lectura de Rosario como de Patricia. Es una niña muy elocuente y participativa.

A continuación, entrevisto a Michael quien también se muestra tímido, a pesar de que en la encuesta ha desarrollado sus opiniones.

Cuando le toca el turno a lliana, viene sonriente. Parece que tiene muchas ganas de hablar. Es una de las niñas que se ha destacado con su participación en las sesiones de lectura.

Luego continúo con Estiven, porque entregó la hoja en blanco y finalizo con Axel, quien se destacó en con su participación en las sesiones de lectura. El niño se muestra muy colaborador y participa de la entrevista con elocuencia.

\section{Jueves 1 de octubre}

Hoy es el día en que finalizaré las entrevistas a los niños, por lo que concurro a la escuela XXX a visitar al grupo de Carmen (tercer año A). El día se presenta muy lindo, la temperatura es la de un día primaveral, muy agradable. 
Al llegar, los niños y la maestra me están esperando. Como las veces anteriores, les explico a los niños qué vamos a hacer y anoto los nombres de quienes participarán en el pizarrón, para no generarles expectativas.

Realizo las entrevistas en el patio interior de la escuela, por lo que no puedo evitar los desplazamientos de los niños de otras clases, yendo y viniendo de sus diversas actividades. En algunos momentos, debo interrumpir la conversación, pues hoy es día de clases de Inglés y llegan los niños de la escuela que funciona a contraturno.

Comienzo entrevistando a Joaquín, quien se muestra muy colaborador, pero parece más interesado en contar sobre su práctica de fútbol (que, al parecer, fue ayer).

Sigue Facundo, quien se ha mostrado muy elocuente durante las lecturas de las mediadoras. Como la maestra me informó que es un niño diagnosticado con TDA, y lo había observado muy ansioso por participar, no lo hago esperar. Facundo habla muy fluidamente, pero me asombro de que no recuerda mucho de las instancias de lectura con Rosario.

A continuación es el turno de Agustín, otro de los niños que en las sesiones de lectura se mostró muy participativo, pero no así en la entrevista, pues se observa inhibido.

Luego, sigo entrevistando a Janina, también muy tímida; a Abigail, muy colaboradora y elocuente y finalizo con Fiorella.

Pregunto varias veces por el niño que firma la encuesta como «Nicolás», pero ninguno de sus compañeros lo conoce, lo que me llama la atención.

Al finalizar las entrevistas acompaño a Fiorella al salón y le solicito a Carmen que reconozca la letra de esa encuesta. «iDiego!», dice la maestra. Le pregunto al niño con curiosidad por qué firmó como Nicolás. Me dice que no quiere ser entrevistado a lo que le respondo que se quede tranquilo que no le voy a hacer preguntas, si él no quiere.

\section{Miércoles 8 de octubre}

Regreso a la escuela XX, luego de las vacaciones de primavera. Hace unos días me puse en contacto con Noelia para coordinar con ella su entrevista, durante el horario de la clase de Educación Física, momento en que está liberada de atender a sus niños, pero por ausencia de una de sus colegas, debe hacerse cargo del grupo de segundo. La conversación transcurre, por lo tanto, dentro del salón de clases con unos cuantos niños alrededor y con un clima bastante ruidoso. De todas maneras, Noelia se muestra muy elocuente y dispuesta a colaborar.

Antes de retirarme, le solicito a Noelia me proporcione las fechas y títulos que leyó Cecilia en su clase y los contactos personales de Cecilia y Omar para coordinar con ellos el momento de la entrevista, ya que luego de los paros docentes, el equipo comunitario no ha retomado su tarea en esta escuela.

\section{Miércoles 14 de octubre}

Concurro a la escuela XXX a entrevistarme con Carmen y Amalia, aprovechando los horarios en que los niños concurren a sus clases de Educación Física. Las maestras me estaban esperando para la entrevista. 
No hay niños en la clase de Carmen, y solo algunos que no pudieron concurrir a hacer gimnasia en la de Amalia, así que puedo conversar con tranquilidad con ambas maestras, hasta el regreso de los niños.

\section{Martes 20 de octubre}

Gracias a la gestión de Mariela, coordiné la entrevista con Patricia para hoy, luego de que ella termine de leer a los niños. Llego a la escuela a la hora del recreo, y luego de una breve reunión con las maestras y las mediadoras en el patio de la escuela, nos dirigimos con Patricia al comedor en donde las auxiliares de la cocina nos convidan con un café.

No quiero abusar del tiempo de Patricia, pues la noto apurada, pero luego de que comenzamos a hablar ella se muestra dispuesta y participa con entusiasmo.

\section{Jueves 5 de noviembre}

Me encuentro con Rosario en la escuela XXX, quien ha venido especialmente para la entrevista, ya que el martes no concurrió a leer porque debía trabajar, Coordinamos la entrevista por Wathsapp, para luego de que finalice el horario del recreo escolar. La mediadora aceptó gustosa venir especialmente a la escuela para ser entrevistada. Rosario llega unos minutos antes de finalizar el recreo. Nos encontramos en la puerta de la escuela y nos dirigimos al comedor. La mediadora es conocida del personal de la cocina por lo que ella misma prepara el café para ambas, con confianza.

\section{Martes 17 de noviembre}

Me encuentro en el recibidor de la escuela con Omar, el abuelo lector, al inicio del turno. La semana anterior lo contacté por teléfono (la maestra Inés me proporcionó su celular) y quedamos en encontrarnos a las 08.00 horas en el local escolar.

Hasta la fecha, desde julio, no se ha vuelto a reunir el equipo comunitario de la escuela XX, y desde agosto tampoco los mediadores han retomado las sesiones de lectura, debido al conflicto de la enseñanza.

Llego sobre la hora y Omar ya me está esperando en el hall de la escuela. Siempre se ha mostrado muy amable y dispuesto a colaborar con la investigación pues su hija más chica se recibió hace muy poco de maestra.

Solicito a la secretaria de la escuela un lugar en la secretaría para hacer la entrevista. Nos acomodamos allí, lejos del ruido del comienzo de la jornada (niños que se retrasan al entrar, padres que se entrevistan con las maestras, profesor de Educación Física, niños que van y vienen, la música de las clases que ya están preparando sus actuaciones para la fiesta de fin de cursos).

Explico a Omar que ya estoy finalizando el trabajo de campo y el motivo de mi entrevista (complementar las observaciones realizadas durante las sesiones de lectura). Comentamos también del tiempo que pasó desde la última lectura en la clase de Inés, de la pena de no haber continuado el proyecto en la escuela (interrumpido por el conflicto de la enseñanza), del conflicto...

Enciendo el grabador y solicito autorización al abuelo para registrar el audio de la entrevista...

\section{Lunes 19 de noviembre}

Finalmente, pude coordinar con Inés para hacerle su entrevista. La maestra ha regresado de su viaje y se ha reintegrado a trabajar hace algunas semanas. Entremedio ha transcurrido el conflicto de la enseñanza, con la suspensión de más de algunos días de clase y el viaje. Quedamos con Inés en que la 
entrevistaría en el horario en que sus alumnos van a la clase de Educación Física. Llego a la escuela a las 8.00 y voy a su salón. Mientras los niños se aprontan para su clase, hablamos distendidamente sobre su viaje, los lugares visitados... Luego de que los niños se van, le recuerdo cuál es el propósito de mi investigación. El tiempo de las clases de Educación Física es utilizado por las maestras para las tareas de corrección o coordinación, y a esta altura del curso, ese tiempo es muy valioso por lo que agradezco especialmente a Inés, entonces, que me reciba.

Quedan escasos días para la finalización de cursos y en las escuelas están comenzando las evaluaciones y los ensayos para la fiesta de fin de cursos.

Inés se muestra muy receptiva y dispuesta a dar información. La entrevista transcurre en un clima agradable y finaliza incluso luego de que los niños regresan al salón.

\section{Miércoles 25 de noviembre}

Entrevisto a Cecilia en la escuela XX. Concurro a la escuela a las 8:00, pero debo esperar hasta las 8.45 a que la mediadora, junto con otros padres, despidan a sus hijos que se va al paseo de fin de año. Mientras la espera, converso con Cecilia y, Carla, la mamá lectora, quien comenzó el año leyendo en tercero B y luego abandonó. Cecilia informa que fue convocada para la reunión final del próximo lunes. Carla se muestra molesta porque ella no fue avisada, y manifiesta su voluntad de concurrir.

Aprovechamos que los grupos de tercero se han ido, para usar uno de los salones libres para hacer la entrevista.

Cecilia está acompañada de su esposo, Walter, quien también estaba presente para despedir a su hija. Este cuenta que integró el equipo comunitario de lectura en 2014, pero este año por su agenda laboral no pudo hacerlo. Comenta de su experiencia leyendo, que le había gustado la tarea y que espera volver a realizarla si su trabajo se lo permite.

Agradezco la presencia de ambos antes de comenzar, les cuento brevemente de qué se trata la entrevista y les pido permiso para grabar. Cecilia se muestra muy amable y dispuesta a colaborar, Walter no participa.

\section{Viernes 27 de noviembre}

A las 8.00 horas, entrevisto a María, directora de la escuela XX. Concurro al inicio del turno, tal como habíamos acordado el día anterior. Me costó bastante encontrar un tiempo para hacer la entrevista debido a que ya estamos a escasos días de la finalización de cursos. Mientras la espero, observo el movimiento habitual de los niños que se desplazan a diversas actividades.

La directora me espera en su oficina. Me recibe muy amablemente y dispuesta a conversar. Hablamos distendidamente sobre el trabajo del final de cursos y sobre estos últimos días del año lectivo.

Al finalizar la entrevista, luego de agradecer el tiempo que me dedicó, le recuerdo lo que me solicitó al inicio del trabajo de campo y me pongo a disposición de la escuela para participar de una sala docente cuando me lo soliciten. 


\section{Lunes 30 de noviembre}

Se realiza en la escuela XX, a las 8:00 horas, la última reunión del equipo comunitario de lectura. Asisten Graciela (abuela), Carla (mamá), Walter (esposo de Cecilia que concurre porque esta se olvidó de la convocatoria) y las dos maestras referentes: Noelia e Inés. Presencio la reunión hasta 8.30, luego me retiro porque el propósito de esta instancia es realizar una evaluación y considero que no debo estar presente. Me quedo solo unos minutos pues quiero despedirme de todos los integrantes del equipo comunitario y agradecerles especialmente el haberme dejado hacer el trabajo de campo en la escuela, junto a ellos. Realmente me siento muy agradecida hacia ellos y que me ha servido de mucho todo lo que he podido vivenciar en el transcurso del trabajo de campo. Dejo para la biblioteca de la escuela los ejemplares de Una cena elegante y La manta de las historias y un obsequio para el equipo comunitario de lectura.

\section{Viernes 4 de diciembre}

Estamos ya en diciembre y en muy pocos días estarán finalizando las clases. En las escuelas ya están aprontándose para los actos de clausura de cursos y los ánimos de todos no son los mismos que antes. Para poder entrevistar hoy a Rosa, debí llamarla en tres oportunidades, pero finalmente accedió gustosa a la entrevista y pudo hacerse de un momento para dedicarlo a esta.

Luego de entrevistar a Rosa, converso con Mariela, quien siempre se ha mostrado muy colaboradora conmigo. Dejo en la escuela los ejemplares Una cena elegante y La manta de las historias y un presente para el equipo comunitario. 


\title{
6. CARTA DE SOLICITUd AL CEIP PARA LA REALIZACIÓN DEL TRABAJO DE CAMPO
}

Montevideo, 6 de jullo de 2015

\author{
Administración Nacional de Educación Pública \\ Consejo de Educación Inicial y Primaric \\ Señora Directora Gencral \\ Mag. Irupé Buzzetti \\ Estimada sefiora:
}

Me dirijo a usted para solicitar, a traves de su persona, la autorización del Consejo de Educación Inicial y Primaria a realizar el trabajo de campo correspondiente a mi tesis final de la Maestría en Escritura y Alfabetización de la Universidad Nacional de La Plata: Aportes del equipo comunitario de lectura a los aprendizajes lectores de las escolares uruguayos. Estudio de casa de lo Biblioteca Solidario.

Esta tesis tiene como objetivo investigar la incidencia del proyecto Biblioteca Solidaria en las escuelas de Uruguay donde se desarrolla a través de un estudio de caso en dos escuelas públicas de Montevideo que participan del mismo desde 2014 y que otorga amplio protagonismo a los equipos comunitarios de lectura. Concretamente, se pretende investigar cuál es la contribución específica de los mediadores de los equipos comunitarios de lectura cn la formación de los nifíos como lectores en las instancias de lectura de cuentos $\gamma$ discusión sobre la leído. Las escuelas seleccionadas para realizar la investigación son la nro. 23. Tomás Claramunt, y la nro. 303, OEA.

Como usted ya sabe, Biblioteca Solidaria constituye un proyecto desarrollado por el Programa de Lectura y Escritura en Español del Consejo Directivo Central de la Adrninistración Nacional de Educación Pública en el que participan 416 escuelas públicas de todo el pais. Durante la fase ce impiementación del proyecto (2014) se realizỏ un seguimiento ${ }^{1}$ en el cual se constató el papel fundamental de los equipos comunitarios de lectura en el aurnento de las instancias de lectura en el ámbito escolar y en la generación del gusto por la lectura. Sobre esta base, esta investigación intentará generar conocimiento sobre la incidencia de los mediadores de los equipos comunitarios y su posible contribución en la formación de los niños como lectores, a

${ }^{1}$ El seguimiento fue realizado par PmL FE con el apoyo de la empresa española Neturity y de la División de Investigación, Evaluación y Estadistica de la ANEF (Uiruguay). El iniome final se recopila en el documento Bibjicteca Solidaria en primera persona. 
los efectos de brindar argumentos que avalen o desestimen la extensión del proyecto. La intervención de los mediadores de los equipos comunitarios de lectura, en forma sistemática, en la institución educativa y en el aula aportará una singular relación con la lectura y los libros que se evidenciará en la manera de leer, de generar el ambiente de lectura $\gamma$ los espacios de diálogo y discusión sobre lo leido por parte de los nin̄os. Esta intervención posee una impronta particular, diferente a la que realiza el maestro desde sus prácticas de enseñanza.

El propósito cnunciado más arriba interesa particularmente a quien desarrollará ecta investigación por ser maestra de coducación primaria, efectiva desde 1995, por su vinculación laboral can el Programa de Lectura y Escritura en Español y también por el hecho de que el proyccto investigado se halla inserto en la política educativa pública.

Adjunto a esta solicitud el proyecto de investigación presentado ante el Comité Evaluador de la Maestría en Escritura y Alfabetizaciún de la Universidad Nacional de La Plata y las cartas de aval de mi directora de tesis, Dra. Ana Maria Margallo (Departamento de Didáctica de la Ulengua i la Literatura, de la Universidad Autónoma de Barcelona) y de mi codirectora, Mag. María Noel Guidali (Universidad Nacional de La Plata).

Quedo a la espera de la respucsta del Consejo de Educación Inicial y Primaria y aprovecho la ocasión para hacerle llegar mis atentos saludos.

Mtra. Sandra Mosca

C. 1. $1.682 .933-1$

FC. 23990

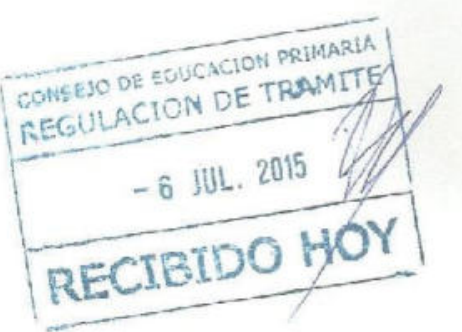




\section{RESOLUCIÓN DEL CEIP}

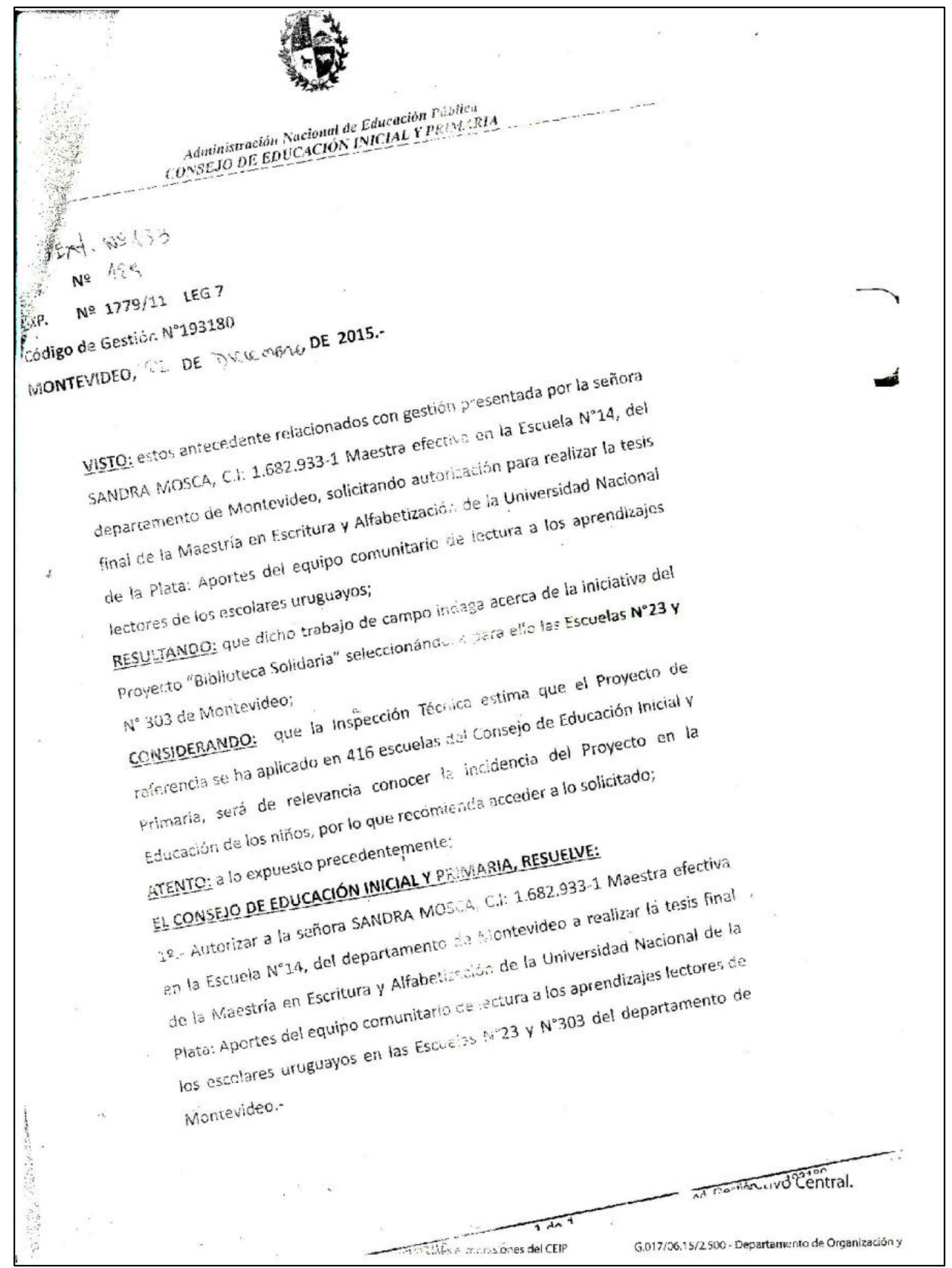




\section{Carta de aval de la Dra. Ana María Margallo}

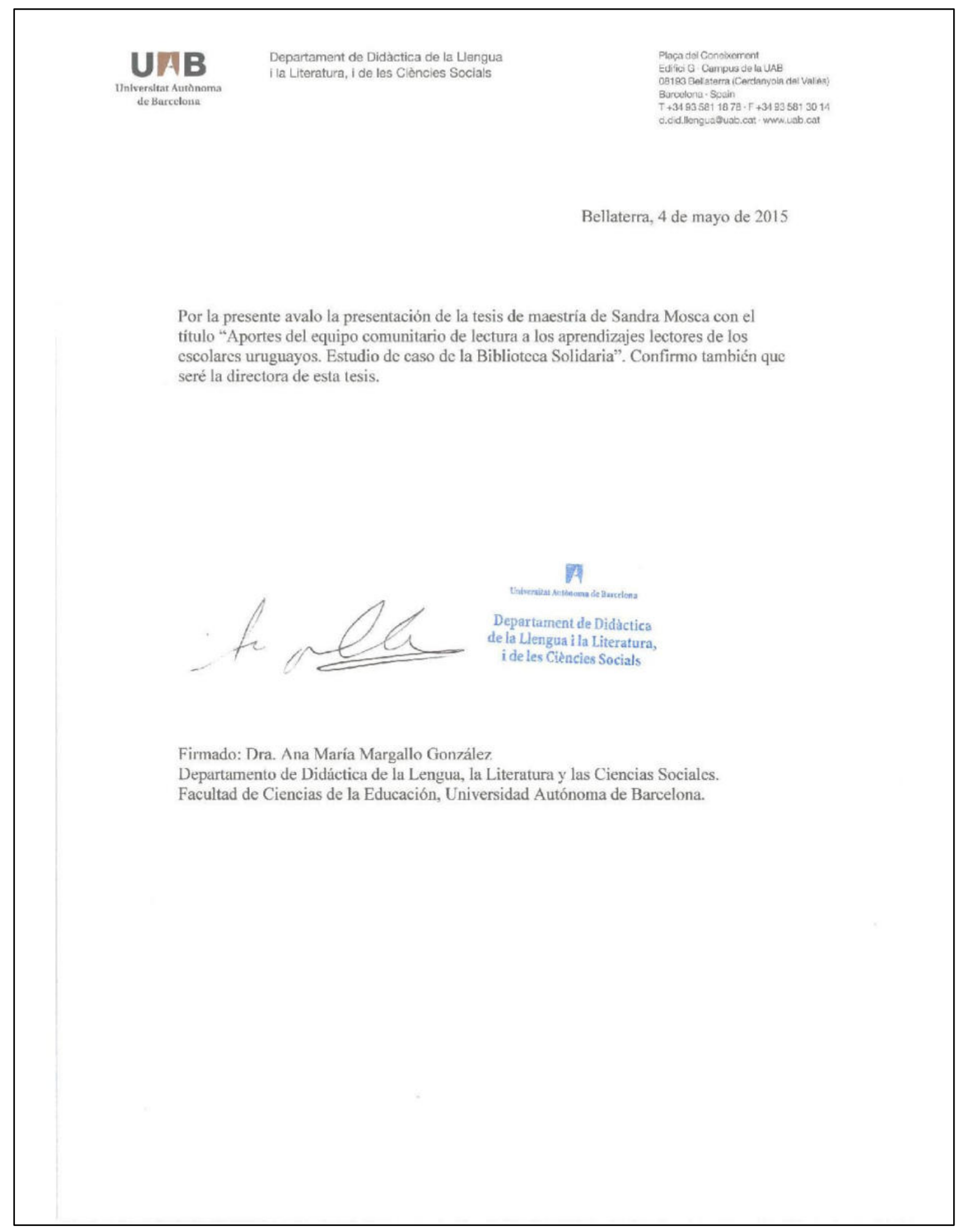


9. Carta de aval de la Mag. María Noel Guidali

Paysandú, 26 de mayo de 2015

\section{Comité Asesor de la}

Maestría en Escritura y Alfabetización

Universidad Nacional de La Plata

Presente.

De mi mayor consideración.

Me dirijo a ustedes a fin de manifestar mi aceptación de la Codirección del Proyecto de tesis denominado Aportes del equipo comunitario de lectura a los aprendizajes lectores de los escolares uruguayos. Estudio de caso de la Biblioteca Solidaria, presentado por la maestranda Sandra Mosca Mantel.

Sin otro particular, los saludo muy cordialmente,

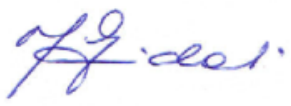

Mg. María Noel GuidaliLeunda 